\title{
An elemental and isotopic investigation of Quaternary silicic Taupo Volcanic Zone tephras from ODP Site 1123: chronostratigraphic and petrogenetic applications.
}

\author{
Aidan Stuart Robert Allan
}

A thesis submitted in partial fulfilment of the requirements for the degree of Masters of Science with Honours in Geology, Victoria University of Wellington, October 2008 


\section{ABSTRACT}

This thesis presents a chemical and isotopic investigation of well-dated silicic tephra layers sourced from the Taupo Volcanic Zone (TVZ), central North Island, New Zealand, that were recovered from deep ocean sediment cores at Ocean Drilling Program Site 1123 (4147.16’S, 171²9.94’W; 3290 m water depth), located approximately $1000 \mathrm{~km}$ east of the TVZ. The relative quiescence of the deep ocean sedimentary setting, the continuous supply of biogenic and terrigenous sediment and the favourable location of Site 1123 close to the main TVZ ash dispersal path have resulted in an extensive TVZ tephra record (70 Quaternary tephra layers preserved in 3 sediment cores) at Site 1123. This record extends and compliments the onshore record of silicic TVZ volcanism which has been obscured by erosion of nonconsolidated volcanic material and burial of older units by younger volcanic deposits. The Site 1123 cores comprise an important paleo-oceanographic record for the Southwest Pacific Ocean and as a result of previous paleo-environmental studies, the Site 1123 tephras have been assigned orbitally tuned stable isotope ages that are more precise than is currently possible by any radiometric dating techniques. These features of the Site 1123 tephra record highlight its potential to be established as a type section for Quaternary tephrochronological studies in the New Zealand region. In addition, the continuous stratigraphy and precise age control of these tephras enables the Site 1123 record to be used as a petrogenetic archive to investigate changes in chemical and isotopic composition of these tephras that may be related to changes in the petrogenesis of TVZ silicic magmas during the last $\sim 1.65 \mathrm{Ma}$.

This thesis establishes major and trace element chemical 'fingerprints' for the Site 1123 tephras using traditional (electron probe microanalysis) and novel (laser ablation inductively coupled plasma mass spectrometry) in situ geochemical techniques. Trace element fingerprints are demonstrated to provide a more precise means of correlating and distinguishing between tephras with essentially identical major element chemistries. These fingerprints are used to refine the original Site 1123 composite stratigraphy and age model and identify a section of repeated sediments in the Site 1123 cores that have introduced a significant error into the original composite stratigraphy and age model for the interval 1.1 to $1.4 \mathrm{Ma}$. Correlation of the tephra layers between the 3 sediment cores (1123A, B and C) 
establishes that $~ 37-38$ individual tephra units are recorded with ages ranging from $1.655 \mathrm{Ma}$ to $27.1 \mathrm{ka}$. Approximately $50 \%$ of the eruptive units and cumulative tephra thickness at the site were recorded during the first $~ 150$ ka of silicic TVZ volcanism (1.65 to $1.50 \mathrm{Ma}$ ). The fragmentary onshore record does not preserve clear evidence for this early period of hyperactivity.

Four broad silicic melt types are identified on the basis of chemistry and eruptive age. Trace element indices of fractional crystallisation suggests the origin of the four melt types is primarily due to differential degrees of fractional crystallisation of accessory zircon, hydrous mineral phases and Fe-Ti oxides. Sr-Nd-Pb isotopic compositions of 13 representative Site 1123 tephras cannot be generated using traditional models in which Torlesse meta-sedimentary rocks are the sole contaminant of mafic magmas. Instead the data support a model in which ascending TVZ basalts assimilate crustal rocks of both meta-greywacke terranes: firstly up to $15 \%$ of Waipapa crust is assimilated at depth, followed by assimilation of between 20 and $45 \%$ Torlesse crust at shallower levels. In this model the majority of Site 1123 tephras indicate a remarkably uniform amount of crust ( 35\%) with the most evolved sample requiring $45 \%$ crustal contribution. However, extensive fractional crystallisation (55-85\%) is required to have accompanied crustal assimilation in order to drive the relatively low $\mathrm{SiO}_{2}$ compositions of these contaminated mafic magmas $\left(\mathrm{SiO}_{2}=53-58 \mathrm{wt} \%\right.$ after crustal contamination) to the high $\mathrm{SiO}_{2}$ rhyolite (74-78 wt\%) compositions of the Site 1123 tephras. The large crustal contributions to TVZ silicic magmas (35-45\%) implied by these data are high compared to large volume silicic magmas from different settings (e.g. Yemen-Ethiopia; Long Valley, USA), a feature that likely reflects the thin crust and high thermal flux into the continental crust beneath the TVZ. 


\section{TABLE OF CONTENTS}

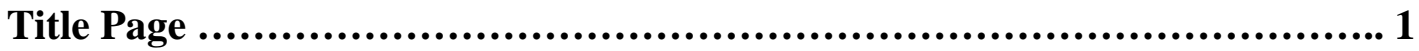

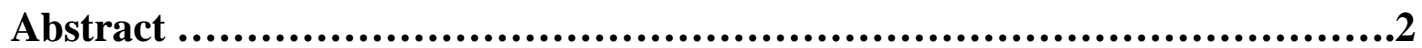

Table of contents................................................................ 4

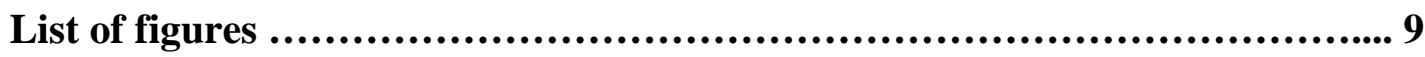

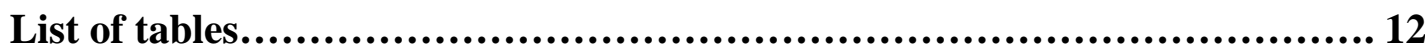

Acknowledgements ........................................................ 14

Chapter One: Introduction .................................................. 15

Chapter Two: Chronostratigraphic Applications .............................. 34

Chapter Three: Petrogenetic Applications ................................... 81

Chapter Four: Synthesis and Conclusions .................................. 117

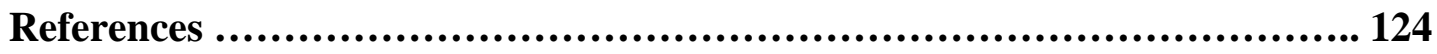

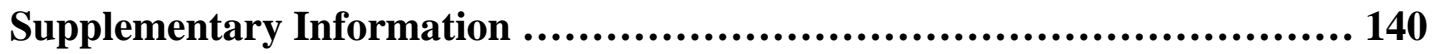

Appendix One: Sample list and original composite record tie-points ........ 141

Appendix Two: Analytical Techniques .................................... 145

Appendix Three: Major element data $\ldots \ldots \ldots \ldots \ldots \ldots \ldots \ldots \ldots \ldots \ldots \ldots \ldots \ldots \ldots \ldots \ldots . \ldots \ldots \ldots \ldots$

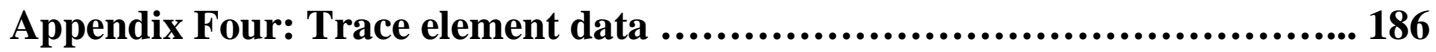

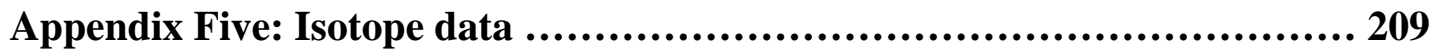

Appendix Six: Full major and trace element dataset ........................ CD 


\section{CHAPTER ONE: INTRODUCTION}

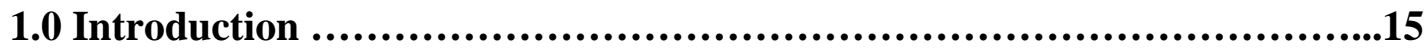

1.1 Research objectives of this thesis ................................17

2.0 Chronostratigraphic applications: using tephrochronology of Site 1123 to reconstruct the Quaternary TVZ eruptive history

2.1 ODP Site 1123: a potential type section for tephrochronology in the New

Zealand region?

2.2 Trace element fingerprinting: a means of recognising and correlating Site 1123 tephras

2.3 A rigorous evaluation of the Quaternary Site 1123 composite record and age model .25

3.0 Petrogenetic applications: insights into silicic magma generation from glass shard trace element and isotopic data ...................................27

3.1 Types of data used for petrogenetic modelling of TVZ volcanic rocks: a limiting factor?

3.2 The application of tephra geochemistry to TVZ rhyolite petrogenesis: new insights from ODP Site 1123 tephras?

4.0 Summary and structure of this thesis

\section{CHAPTER TWO: CHRONOSTRATIGRAPHIC APPLICATIONS}

Reconstructing the Quaternary evolution of the world's most active silicic volcanic system: insights from an 1.65 Ma deep ocean tephra record sourced from Taupo Volcanic Zone, New Zealand

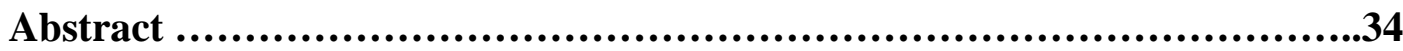

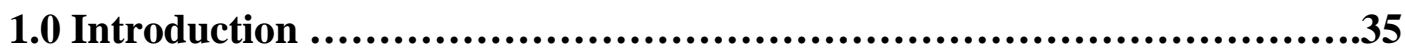

2.0 Regional Background to ODP Site 1123 tephra layers ....................38

3.0 Analytical Techniques ..................................................39

3.1 Sample preparation ..........................................39 
3.2 Electron probe microanalysis (EPMA) .40

3.3 Laser ablation inductively coupled plasma mass spectrometry (LA-ICPMS)

3.4 Precision and accuracy of major and trace element data .42

4.0 Results 45

4.1 Major element data .45

4.2 Trace element data . .47

4.3 Key Quaternary Site 1123 tephra layers ............................50

\subsection{Discussion} .51

5.1 Tephra trace element 'fingerprinting' as a chronostratigraphic tool ....51

5.2 Establishing isochronous tephra tie-lines between 1123A, 1123B and $1123 \mathrm{C}$ .56

5.3. Identification of repeated sections in the 1123A and 1123C cores .....58

5.4 Re-evaluating the Site 1123 composite stratigraphy and age model ....59

5.5 A revised composite stratigraphy for Site 1123 .65

5.6. Frequency of TVZ silicic eruptions in the last $1.65 \mathrm{Ma}$ 69

5.7 Deposition and preservation potential of deep-marine tephras .71

6.0 Conclusions .74

References .76

\section{Chapter Three: Petrogenetic Applications}

Re-examining the petrogenesis of silicic magmas from the world's most active silicic volcanic system: an elemental and Sr-Nd-Pb isotopic study of an 1.65 Ma deep ocean tephra record sourced from Taupo Volcanic Zone, New Zealand

Abstract 
2.1 Sample preparation $\ldots \ldots \ldots \ldots \ldots \ldots \ldots \ldots \ldots \ldots \ldots \ldots \ldots \ldots \ldots \ldots \ldots . \ldots \ldots 7$

2.2 Chemical separation of $\mathrm{Pb}, \mathrm{Sr}$ and $\mathrm{Nd}$...........................88

$2.3 \mathrm{~Pb}, \mathrm{Sr}$ and $\mathrm{Nd}$ isotopic analyses $\ldots \ldots \ldots \ldots \ldots \ldots \ldots \ldots \ldots \ldots \ldots \ldots \ldots . \ldots \ldots$

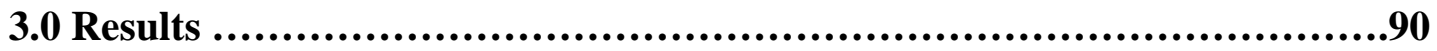

3.1 Major and trace element glass chemistry of Site 1123 tephras ..........90

3.2 Pb-Sr-Nd isotopic data for Site 1123 tephras ..........................96

4.0 Discussion ...........................................................101

4.1 Nature, origins and preservation of trace element heterogeneity in the melt phase of pre-eruptive silicic melt bodies ..........................101

4.2 Origins of the four broad silicic melt ypes represented by Site 1123

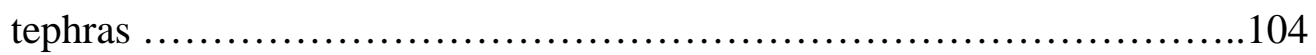

4.3 Isotopic constraints on the origins of silicic melts from the Taupo Volcanic Zone 107

4.4 Petrogenesis of the Taupo Volcanic Zone silicic large igneous province in a global context

\section{CHAPTER FOUR: SYNTHESIS AND CONCLUSIONS}

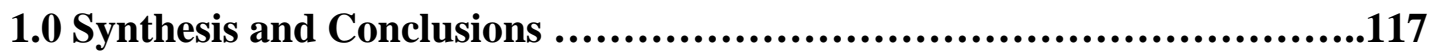

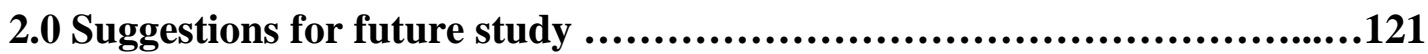

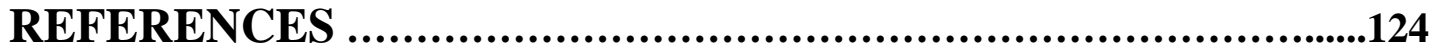

\section{SUPPLEMENTARY INFORMATION}

APPENDIX ONE: Sample list and original composite record tie-points .141 


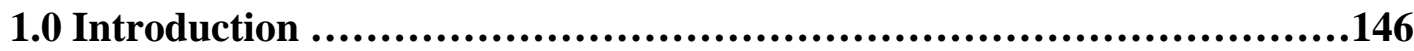

1.1 Microanalytical techniques .....................................146

1.1.1 Sample preparation ...................................146

1.1.2 Electron probe microanalysis (EPMA) ..................148

1.1.3 Laser ablation inductively couped plasma mass spectrometry

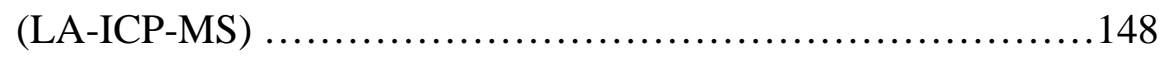

1.1.4 Precision and accuracy of major and trace element data ......156

1.1.5 Comparison to existing LA-ICP-MS trace element data of

TVZ tephras ................................................157

2.0 Isotopic analysis by multi-collector (MC-) ICP-MS ......................167

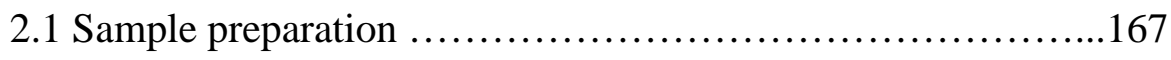

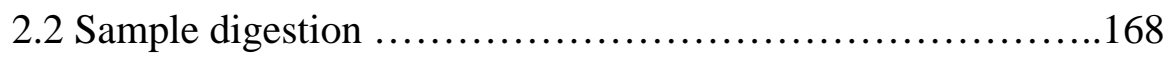

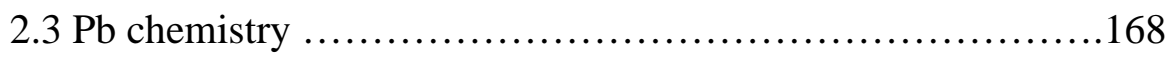

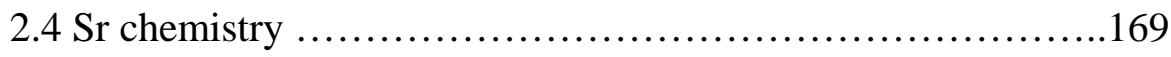

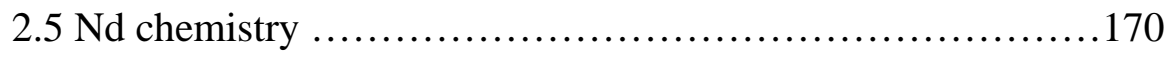

2.6 Isotopic analyses and standards $\ldots \ldots \ldots \ldots \ldots \ldots \ldots \ldots \ldots \ldots \ldots \ldots \ldots$

APPENDIX THREE: Major element data $\ldots . . \ldots \ldots \ldots \ldots \ldots \ldots \ldots \ldots \ldots \ldots \ldots \ldots \ldots \ldots \ldots . . . \ldots 174$

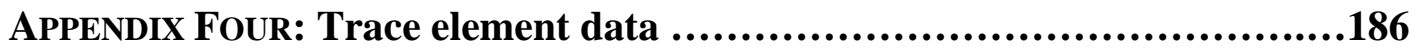

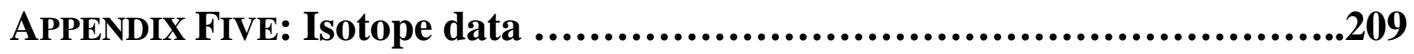

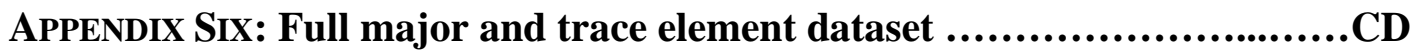




\section{LIST OF FIGURES}

\section{CHAPTER ONE: INTRODUCTION}

1-1 Map showing the volcanic, structural and geological features of the Taupo Volcanic Zone and central North Island .....................................15

1-2 Time-volume-source relationships of silicic TVZ eruptions associated with caldera collapse ...........................................................

1-3 New Zealand oceanic setting and location of ODP Leg 181 drilling sites.......18

1-4 Photo of a typical tephra-bearing sediment core from Site 1123 ..............20

1-5 Back-scattered electron images of volcanic glass shards ....................23

1-6 Summary of the data used to construct the original (0.0 to $1.7 \mathrm{Ma}$ ) Site 1123

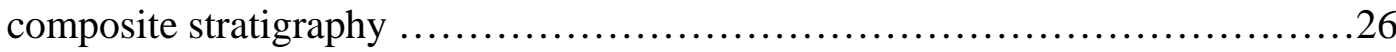

1-7 Comparison of the 0.0 to 1.7 Ma portion of the orbitally tuned oxygen isotope stratigraphies of Site 1123 and 849 (equatorial Pacific) ........................27

\section{Chapter Two: CHRonostratigraphic APPlications}

2-1 Location map showing the TVZ, Site 1123 and the other tephra-bearing sites

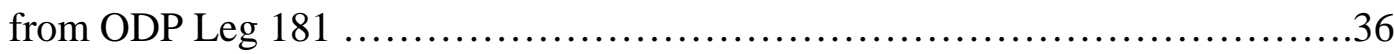

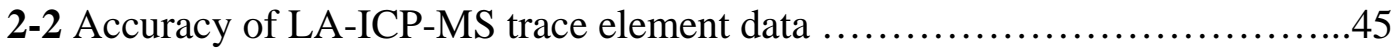

2-3 Total alkalis versus silica plot of Quaternary Site 1123 tephras ..............46

2-4 Bivariate plots of selected major element data for Site 1123 tephras .........48

2-5 Bivariate plots of selected trace element data for Site 1123 tephras ..........49

2-6 Bivariate plots of selected geochemical data for Site 1123 tephras correlated to previously documented onshore TVZ tephras .55

2-7 Bivariate plots of selected major and trace element data for the Kawakawa and Omataroa tephras demonstrating the discriminating power of single shard trace element data 
2-8 Stratigraphic columns demonstrating the tephra tie-lines established in this thesis .60

2-9 $\mathrm{Ba} / \mathrm{Sr}$ versus $\mathrm{Zr} / \mathrm{Y}$ plots for repeated tephras .62

2-10 Summary of the original Site 1123 composite stratigraphy for the period $\sim 0.45$ to $2.0 \mathrm{Ma}$ .64

2-11 Revised Site 1123 composite stratigraphy ( 0.0 to $1.7 \mathrm{Ma}$ ) based upon the tephra correlations established in this study

2-12 Cumulative thickness of Quaternary Site 1123 tephras plotted against time (Ma)

\section{Chapter Three: Petrogenetic Applications}

3-1 Maps showing the location of the TVZ and Site 1123 ......................84

3-2 Summary of the revised Site 1123 composite stratigraphy $\ldots \ldots \ldots \ldots \ldots \ldots \ldots . . .66$

3-3 Bivariate plots of selected major element data demonstrating the four silicic melt types of the Site 1123 tephras

3-4 Bivariate plots of selected trace element data (individual analyses) demonstrating the four silicic melt types of the Site 1123 tephras .95

3-5 Bivariate plots of selected trace element data (mean compositions) demonstrating the four silicic melt types of the Site 1123 tephras ..............................96

3-6 Primitive mantle normalised trace element profiles of Site 1123 tephras and their silicic melt types .97

3-7 Comparison of the Sr-Nd-Pb isotopic compositions of Site 1123 tephras with whole rock isotopic data for silicic TVZ rocks .98

3-8 Sr-Nd-Pb isotopic compositions of representative Site 1123 tephras .99

3-9 Bivariate trace element and trace element ratios plots demonstrating the chemical heterogeneity of Site 1123 tephras

3-10 Bivariate plots of trace element fractionation indices 105

3-11 Bulk mixing models of Sr-Nd-Pb isotope data .109 
3-12 Fractional crystallisation of crustally contaminated mafic magmas

3-13 Schematic cross section of the crust beneath the TVZ

\section{SUPPLEMENTARY INFORMATION}

\section{APPENDX TWO: Analytical Techniques}

Plate 1a Glass shards mounted in a 'half-moon’ epoxy resin mount

Plate 1b Layout of laser ablation chamber during trace element analysis

A2-1 Measured major element composition of ATHO-G normalised to reference values

A2-2 Measured trace element composition of ATHO-G normalised to reference values

A2-3 Primitive mantle normalised multi-element diagram for the $~ 1$ Ma Lower Te Muna (Potaka) Tephra 160 


\section{LIST OF TABLES}

\section{CHAPTER TWO: CHRONOSTATIGRAPHIC APPLICATIONS}

2-1 Analytical and instrument conditions during LA-ICP-MS analysis .43

2-2 Mean major and trace element glass compositions of representative Site 1123 tephras .52

\section{CHAPTER THREE: PETROGENETIC APPLICATIONS}

3-1 Major element data of representative Site 1123 tephras ......................92

3-2 Trace element data of representative Site 1123 tephras .....................93

3-3 Sr-Nd-Pb isotopic data of representative Site 1123 tephras ..................100

\section{SUPPLEMENTARY INFORMATION}

APPENDIX ONE: Sample list and original composite record tie-points

A1-1 Sample list ................................................... 142

A1-2 Original tie-points for the Site 1123 composite stratigraphy ................144

\section{APPENDIX Two: Analytical Techniques}

A2-1 Precision and accuracy of electron probe microanalysis major element data

A2-2 Major element reference values and uncertainties for the glass standards VGA99 and ATHO-G

A2-3 Precision and accuracy of laser ablation inductively coupled plasma mass spectrometry trace element data

A2-4 Comparison of EPMA major element data for the $~ 1$ Ma Lower Te Muna (Potaka) Tephra

A2-5 Comparison of LA-ICP-MS trace element data for the ca. 1 Ma Lower Te Muna (Potaka) Tephra 
A2-6 Reference values adopted for NIST612 (calibration standard) .165

A2-7 Certified reference values of ATHO-G (secondary standard) 166

\section{APPENDIX THREE: Major element data}

A3-1 Mean major element composition of Site 1123 and onshore tephras analysed in this thesis

\section{APPENDIX FouR: Trace element data}

A4-1 Mean trace element composition of Site 1123 and onshore tephras analysed in this thesis

\section{APPENDIX FIVE: Isotope data}

A5-1 Sr-Nd-Pb isotopic compositions of representative Site 1123 tephras. .210

\section{APPENDIX Six: Full major and trace element dataset}

A6-1 Tephra tie-lines between the Site 1123A, B and C sediment cores CD 


\section{ACKNOWLEDGEMENTS}

I would like to thank my three supervisors, Prof. Joel Baker, Prof. Lionel Carter and Dr Richard Wysoczanski, all of whom have been very generous with their time (and patience) throughout this thesis. Your constructive feedback and enthusiasm for this research have been fantastic. I am extremely grateful to Joel Baker for his invaluable support throughout this thesis, but in particular towards its conclusion, when the early birth of my little boy necessitated a rapid turn around during the final editing stages.

Brent Alloway, Lionel Carter and colleagues laid the foundation for this thesis following their preliminary investigations into the Site 1123 tephras. Brent also provided a number of glass separates for the tephras (which saved me a lot of time sieving!) and allowed me to have access to his unpublished age data that has proved invaluable during this research. Phil Shane, John Carter and Sam 'Boots' Nowland also provided some of the onshore tephra samples analysed in this study.

Prof. Colin Wilson and another anonymous reviewer provided thoughtful and constructive journal reviews of Chapter 2 of this thesis which was submitted, and has been accepted, for publication in Quaternary Science Reviews.

I would like to thank a number of staff and students of the Victoria University geology department who have helped out in various ways: John Patterson (for help during electron microprobe work), Stewart Bush (useful support and advice during sample preparation), Monica Handler (for helping with chemical separation of Sr, Nd and $\mathrm{Pb}$ in the ultra-clean lab), Warren Dickenson (for taking me under your wing during those early days in the ultra-clean lab), Tim Naish (for the helpful discussions regarding the tephras of the Wanganui Basin), Mike Hannah, Julie Vry, Dene Carroll, Cliff Atkins, Richard Wysoczanski (for hiring me as a tutor for various courses), Jill Ruthven (for hunting down those impossible to find papers), and Martin Schiller, Kate Saunders and Sophie Barton (for assisting in setting up the LA-ICPMS technique). A special thank you to my office buddies - Alex, Evie and Matt thanks for being a constant source of entertainment and for relieving boredom during those long and unproductive days. To Susanna, Netty, Julse, Evie, John, Dhiresh, Chris, 'Boots', 'George', Kim, Martin, Thor, Hannu, Gretch, Matt and anyone else I've inadvertently forgotten - thank you all for your friendship and for making uni life so much fun.

To my parents, Carol and Rodney Allan, and parents 'in law', Eddie and Sue Marr, thank you for continued love and support (both moral and financial!) throughout my studies. To my gorgeous daughter Mica - Daddy will have more time to play now! and my brand new little boy Eddie, who arrived just in time to make the acknowledgements section, I love you both.

And finally, to Julene. Your love and constant inspiration have kept me going throughout. I could not have done this without you. Thank you. 


\section{CHAPTER ONE: INTRODUCTION}

\subsection{Introduction}

The NNE-trending Taupo Volcanic Zone (TVZ), central North Island, New Zealand, is an active ca. $2 \mathrm{Myr}$ - old rifted continental arc related to the westward subduction of the Pacific Plate beneath the Australian Plate (Fig. 1-1). Throughout the Quaternary the TVZ has been the most frequently erupting and productive rhyolitic centre in the world (Houghton et al., 1995; Wilson et al., 1995). Initiation of TVZ volcanism was marked by the onset of andesitic magmatism at ca. $2 \mathrm{Ma}$ (Wilson et al., 1995). However, since ca. 1.6 Ma the region has been dominated by largevolume rhyolitic magmatism, comprising $\geq 90 \%\left(\geq 15000 \mathrm{~km}^{3}\right)$ of erupted magma with the remainder comprising andesite and minor $(<1 \%)$ basalt and dacite eruptives (Wilson et al., 1995). Since this time, preserved onland volcanic deposits indicate that there have been at least 34 caldera forming eruptions (Houghton et al., 1995) from eight prominent rhyolitic caldera centres in the central TVZ (Figs. 1-1 and 1-2). Explosive volcanism from these centres has resulted in the deposition of widespread

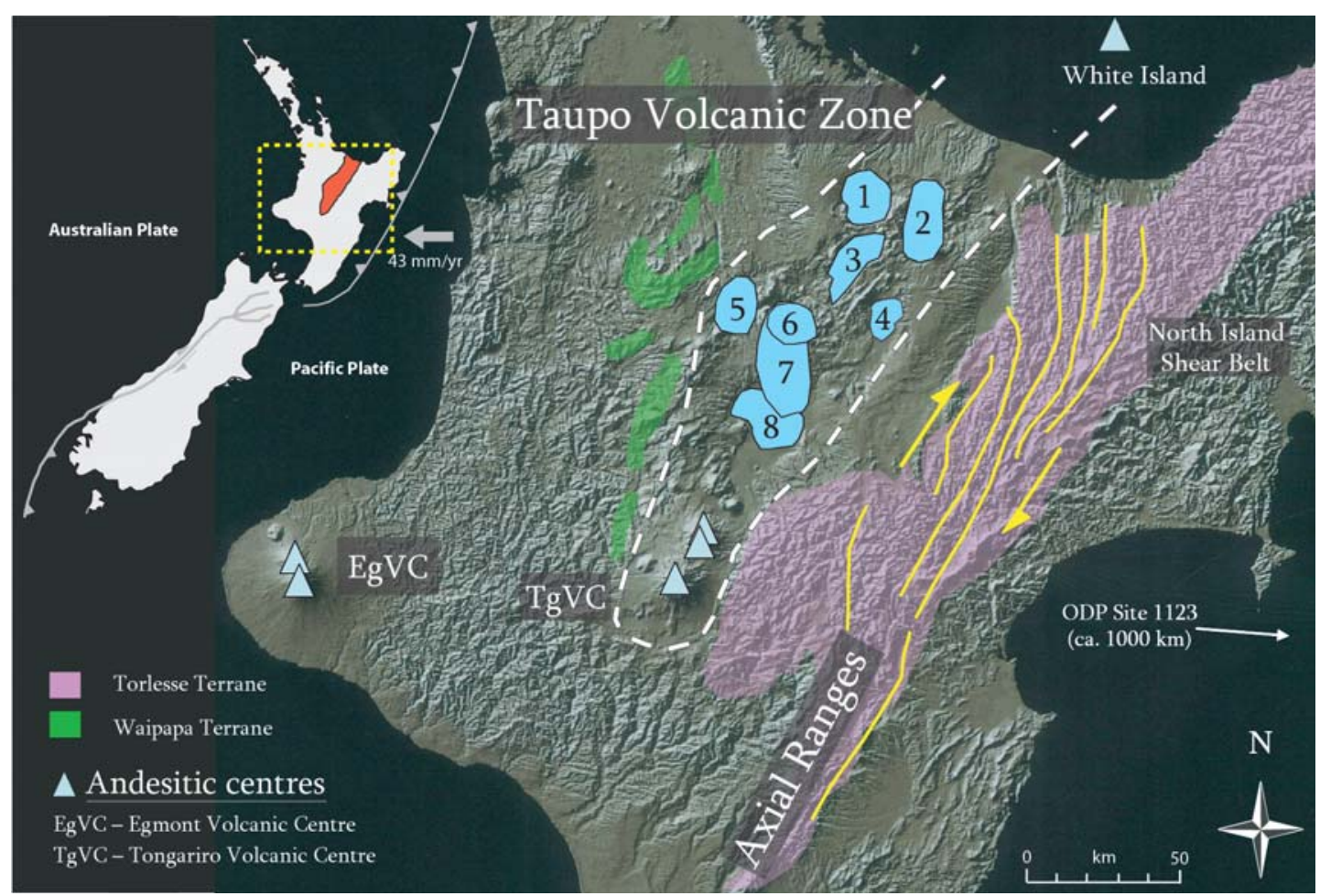

Figure 1-1. Map of the central North Island, New Zealand, showing the extent of the TVZ (dashed line) and significant volcanic, structural and basement terrane features. Numbered blue ellipses denote caldera boundaries: 1 Rotorua, 2 Okataina, 3 Kapenga, 4 Reporoa, 5 Mangakino, 6 Ohakuri, 7 Whakamaru, 8 Taupo (after Wilson et al., 1995). North Island Shear Belt and basement terrane boundaries from Graham et al. (1995). Inset: New Zealand onshore and offshore plate boundary. Digital elevation model developed by Rob Davies. C GeographX June 2000 
pyroclastic flow (ignimbrite) and fall (tephra) deposits throughout the central North Island and its offshore environs.

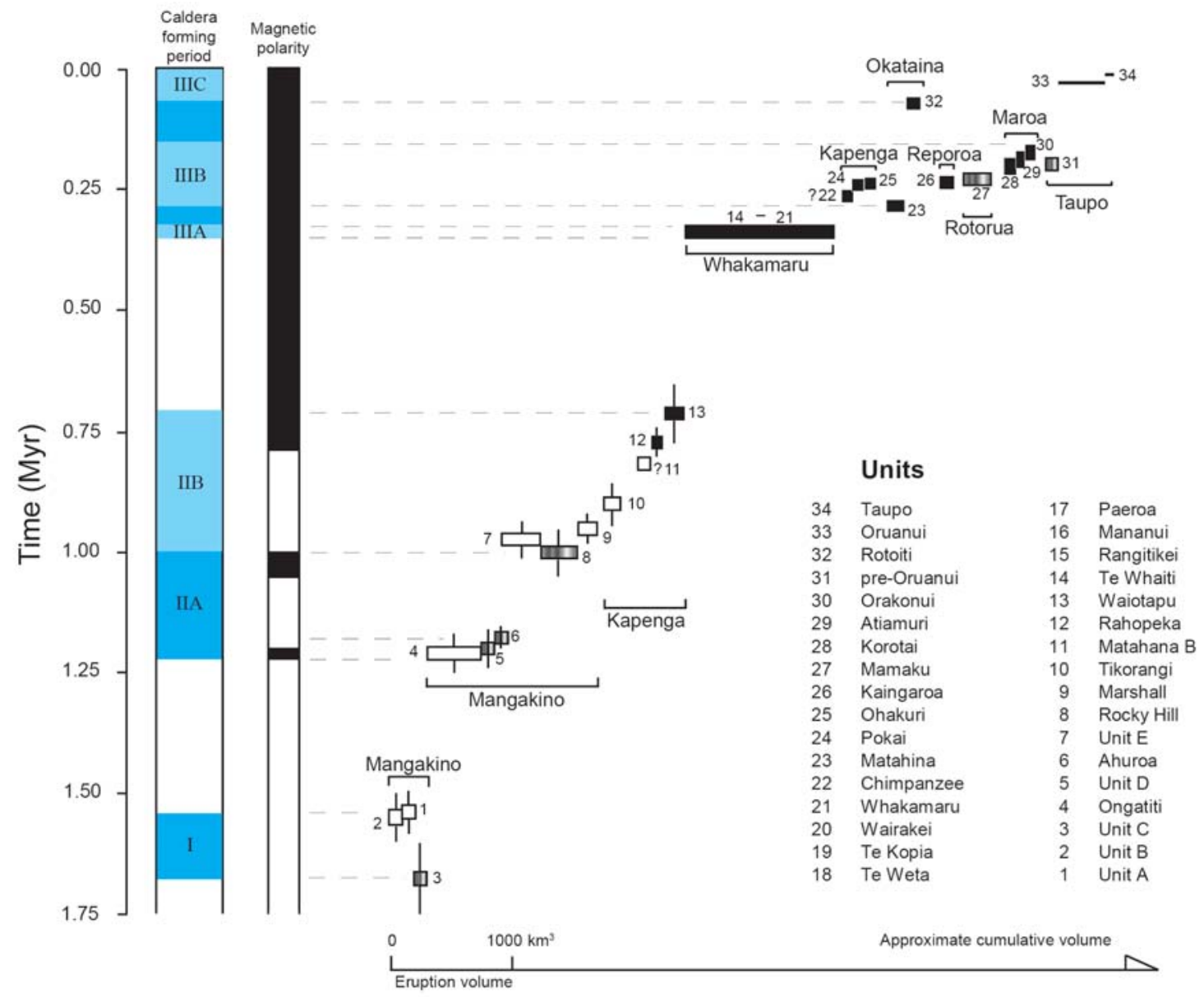

Figure 1-2. Summary diagram of time-volume-source relationships of the 34 major caldera-forming ignimbrites in the central TVZ (after Houghton et al., 1995). Width of symbols is proportional to the dense-rock-equivalent volume of each unit. Units are shaded according to magnetic polarity (black = normal; white = reversed; graded black to white $=$ transitional). Horizontal axis represents approximate cumulative volume.

These deposits have been widely utilised by Earth scientists in three broad areas of TVZ research: (1) to reconstruct the eruptive history of the TVZ (e.g. Houghton et al., 1995; Wilson et al., 1995), (2) the use of tephra deposits to provide chronostratigraphic markers which provide relative and absolute age constraints for sedimentary records and, when able to be geochemically fingerprinted, enable the correlation and synchronisation of distal stratigraphic records (e.g. Seward, 1974;

Froggatt and Lowe, 1990; Shane et al., 1995, 1996 and 2003; Shane, 2000; Schulmeister et al. 2001; Alloway et al., 2004 and 2006; Pillans et al., 2005; Lowe et al., 2008), and (3) chemical and isotopic studies of these deposits have been used to 
provide insights into the origins of voluminous rhyolite magmas (e.g. Blattner and Reid, 1983; Reid, 1983; Wilson et al., 1984; Conrad et al., 1988; Graham et al., 1992 and 1995; McCulloch et al., 1994; Sutton et al., 1995; Wilson et al., 2006). This thesis presents new high quality geochemical and isotopic data for a series of welldated Quaternary tephra deposits to provide new insights into these three broad aspects of TVZ research.

\subsection{Research objectives of this thesis}

This thesis presents a chemical and isotopic investigation of 70 Quaternary TVZderived silicic tephra deposits recovered from Ocean Drilling Program (ODP) Site 1123, located ca. $1000 \mathrm{~km}$ east of the TVZ (Fig. 1-3). The major and trace element chemistry of single glass shards from each tephra deposit were measured using microanalytical geochemical techniques (electron probe microanalysis, EPMA; laser ablation inductively coupled plasma mass spectrometry, LA-ICP-MS). $\mathrm{Sr}, \mathrm{Nd}$ and $\mathrm{Pb}$ isotopic compositions of 13 Site 1123 tephras representative of the main melt types identified by major and trace element chemistry were also measured by multicollector inductively coupled plasma mass spectrometry (MC-ICP-MS). The resulting dataset is used to provide insights into the three fields of TVZ research outlined above.

The first application of this dataset explores the use of these tephras as chronostratigraphic, time-parallel, marker horizons with the ultimate aims being to reconstruct a more complete eruptive history of the TVZ and to establish Site 1123 as a type section for Quaternary tephrochronologic studies in the New Zealand region. In doing so the fingerprinting potential of single shard trace element data and the potential of this relatively new technique to enhance future tephrochronologic studies is investigated.

The second application of this dataset aims to provide a new perspective on the controversy surrounding the petrogenesis of TVZ rhyolites; i.e. whether they represent predominantly new additions to the crust (derived by differentiation of mantle-derived basalts) or are the products of recycled continental crust (formed by melting/assimilation of crustal lithologies). While geochemical and isotopic data 


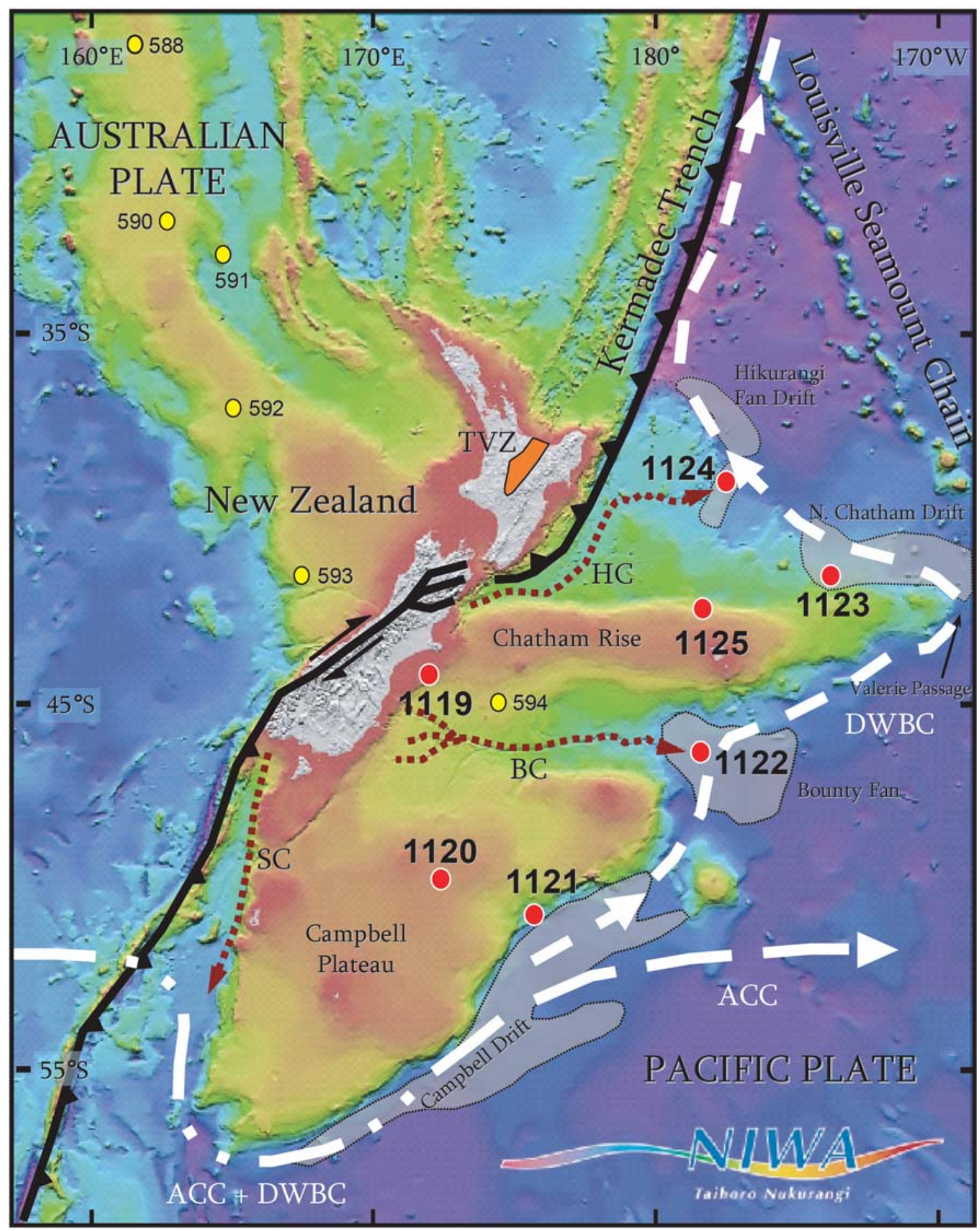

Figure 1-3. Location of ODP Leg 181 drill core sites. Also depicted is the Australian - Pacific plate boundary and the relevant submarine channel systems (SC, Solander Channel; BC, Bounty Channel; HC, Hikurangi Channel), bathymetric features, sediment masses and deep-ocean currents (ACC, Antarctic Circumpolar Current; DWBC, Deep Western Boundary Current) that form the framework of the ENZOSS model of Carter et al. (1996). Drill core sites from DSDP Leg 90, recovered during 1982-83, are marked by yellow circles. Only four sites from DSDP Leg 90 (591-594) preserved Quaternary rhyolitic tephras sourced from the TVZ which, when correlated between the different sites, correspond to no more than five eruptive events (Nelson et al., 1986). The greater number of Quaternary rhyolitic TVZ eruptions recorded in ODP Leg 181 sediment cores ( 100 events; Alloway et al., 2005) compared to that of DSDP Leg 90 is probably due to the more favourable location of the ODP sites to the east and southeast of the TVZ where ash dispersal is favoured by the prevailing westerly winds. Map copyright CANZ, 1996. Undersea New Zealand 1:4,000,000 $2^{\text {nd }}$ Edition. NZ Oceanographic Institute Miscellaneous Series 74. 
obtained from bulk analyses of TVZ volcanic rocks have been widely applied to understanding the processes of TVZ silicic magma generation (e.g. Blattner and Reid, 1982; Reid, 1983; Conrad et al., 1988; Graham et al., 1992 and 1995;

McCulloch et al., 1994), tephras have rarely been used for this purpose. Single shard trace element data measured by LA-ICP-MS and new high precision isotopic data measured by MC-ICP-MS may provide a new perspective into this field of research. Background information to these two contrasting research objectives is discussed below.

\subsection{Chronostratigraphic applications: using tephrochronology of Site 1123 to reconstruct the Quaternary TVZ eruptive history}

The history of explosive, large-volume rhyolitic volcanism from the TVZ has primarily been reconstructed from terrestrial records. However, the combined effects of tectonism, preferential erosion of non-welded ignimbrites and airfall deposits, and the burial of older units by successive volcanic eruptions (particularly from the $\sim 340$ ka Whakamaru-group ignimbrites) have resulted in a fragmentary terrestrial record (Wilson, 1991; Wilson et al., 1995; Shane, 2000; Carter et al., 2004). As a result only TVZ volcanic deposits younger than $\sim 65$ kyr may be considered to have been preserved and studied in any great detail (Wilson et al., 1995). Therefore, the greatest potential for reconstructing a reliable chronology and more complete history for the oldest sections (pre-340 kyr) of the TVZ is to study tephra deposits in well-dated, high resolution sedimentary records. Deep ocean Quaternary sediment cores are ideal for this purpose because: (1) they typically provide continuous records of sedimentation with temporal resolution at the sub-millennial scale for millions of years, (2) a continuous sedimentary record should provide unequivocal stratigraphic relationships and relative age information between tephras closely spaced in time, (3) deep ocean tephras are less susceptible to erosion, reworking or redeposition due to vigorous climate, wave and storm current action, tides, and fluvial contamination which can plague terrestrial, lacustrine, riverine and shallow marine records, (4) paleomagnetic and stable isotope chronologies are able to be constructed yielding age control for tephras that may be superior to available radiometric dating 
techniques, and (5) tephras can potentially be correlated to onshore TVZ deposits on the basis of geochemical fingerprints.

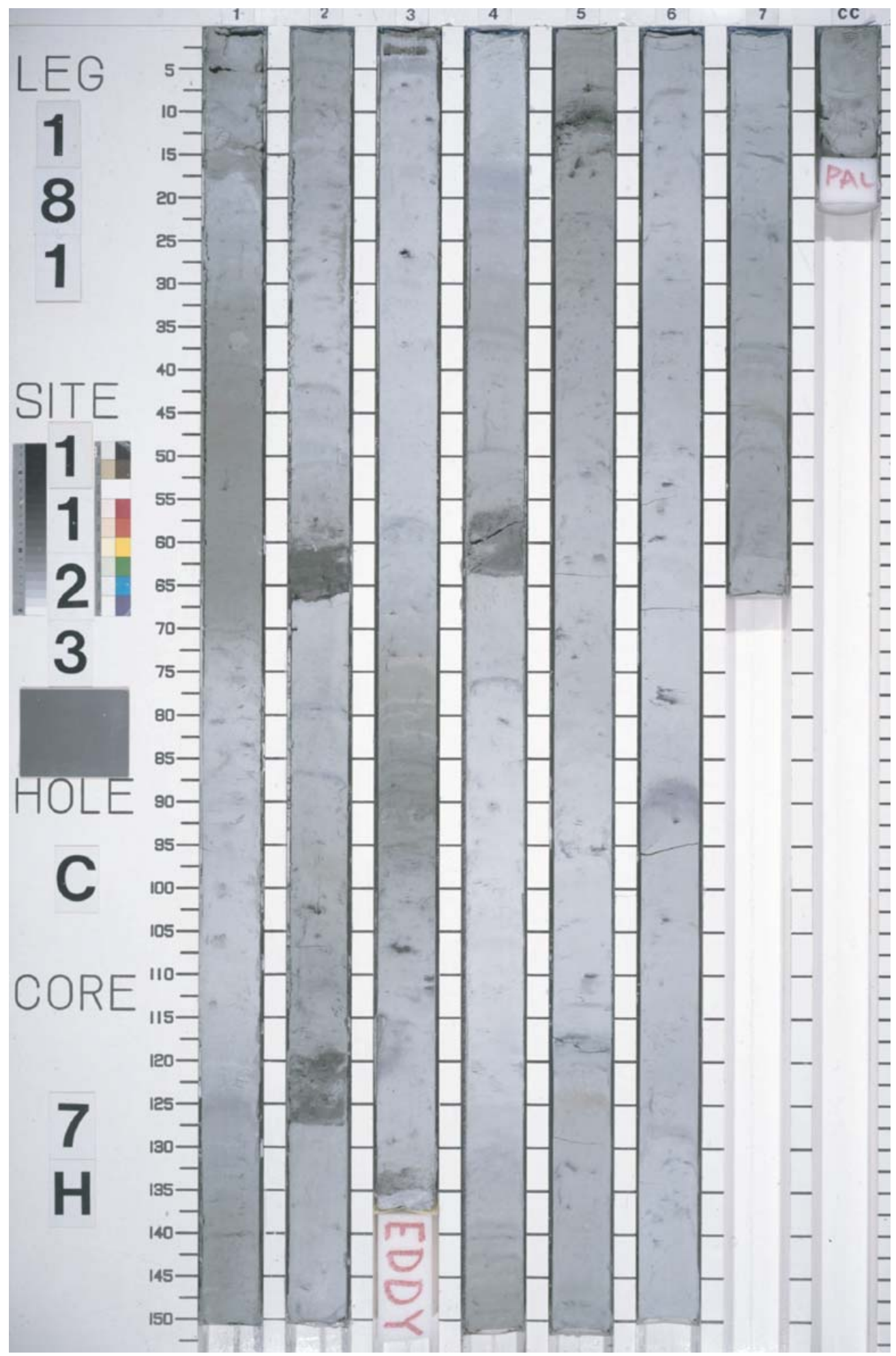

Figure 1-4. Pinkish-grey tephra layers (which appear as dark-coloured layers) within green to pink foraminiferbearing nannofossil ooze (1123C-7H, 55.6 - $66.0 \mathrm{mbsf})$. Tephra layers generally have sharp bases, exhibit normal grading and bioturbated tops. (Photo: Shipboard Scientific Party, 1999). 
The discovery of an extensive Quaternary TVZ tephra record in deep ocean sediment cores from Sites 1122, 1123, 1124 and 1125 of ODP Leg 181 (Fig. 1-3) has provided the impetus for reconstructing a more complete, chronologically constrained, history of large volume rhyolitic eruptions from the TVZ (e.g. Carter et al., 2003, 2004; Alloway et al., 2005). This thesis focuses on the well-dated Quaternary TVZ tephra record recovered from Site 1123

\subsection{ODP Site 1123: a potential type section for tephrochronology in the New}

\section{Zealand region?}

ODP Site 1123 is located $\sim 1000 \mathrm{~km}$ offshore to the east of New Zealand $\left(41^{\circ} 47.16^{\prime} \mathrm{S}, 171^{\circ} 29.94^{\prime} \mathrm{W}\right)$ at $3290 \mathrm{~m}$ water depth (Fig. 1-3). Drilling at the site in September 1998 penetrated the North Chatham Drift sediment mass deposited in response to the deceleration of the Deep Western Boundary Current (DWBC) as it passes through the Valerie Passage (Carter et al., 1996; Hall et al., 2002). Three sediment cores (1123A, B and C) were recovered yielding a continuous record of sedimentation under the influence of the DWBC for the last $\sim 20 \mathrm{Myr}$ (Shipboard Scientific Party, 1999). Preserved within the three Site 1123 sediment cores are 108 tephra layers which document $\sim 12 \mathrm{Myr}$ of (almost exclusively) rhyolitic volcanism from the presently active TVZ (Pleistocene) and the extinct Coromandel Volcanic Zone (CVZ; middle Miocene to Pliocene) (Alloway, unpublished data). In the Quaternary section of the Site 1123 record, which is the focus of this thesis, 70 macroscopic TVZ-derived tephra deposits $(\sim 0.02-1.65 \mathrm{Ma})$ were recovered in the 3 cores (Fig. 1-4; also see Appendix 1). A lack of suitable material for all but a handful of Site 1123 tephras precludes direct dating by accurate and precise radiometric methods (e.g. K-rich mineral phases for K-Ar or ${ }^{40} \mathrm{Ar} /{ }^{39} \mathrm{Ar}$ dating), and $90 \%$ of the tephras are outside the range of ${ }^{14} \mathrm{C}$ dating. Volcanic glass shards are abundant and suitable for dating by the isothermal plateau fission track (ITPFT) method (Westgate, 1989). However, this technique is associated with large uncertainties $( \pm 10 \%$ to $<20 \%$ for samples $1-2$ Ma based on 4 ITPFT ages presented in Alloway et al., 2005; 2 sd relative). A comprehensive $~ 3$ Myr stable isotope stratigraphy for the Site 1123 composite record was established by Hall et al. (2001) and Harris (2002) and, subsequently, the 70 Quaternary tephra layers have 
each been assigned orbitally tuned age estimates based on their position within the composite oxygen isotope stratigraphy (see Appendix 1; Alloway et al., 2005; Alloway, unpublished data). Although this is an indirect method of dating, this technique generally yields more accurate and precise ages $( \pm 1.2-2.5 \mathrm{kyr}$; Hall et al., 2001) for these tephras than is conceivably possible by any radiometric dating techniques.

The large number of tephras and their well constrained ages makes the Site 1123 record an ideal type section for tephrochronology studies in the New Zealand region. However, for Site 1123 to be accepted as a type section for this purpose first requires: (1) a means of recognising and correlating these tephras amongst the three Site 1123 sediment cores and to other sedimentary records, and (2) a rigorous evaluation of the Site 1123 composite stratigraphy and age model.

\subsection{Trace element fingerprinting: a means of recognising and correlating Site 1123 tephras?}

The most common technique for distinguishing between tephras and correlating tephra deposits over large distances is to compare a major element 'fingerprint' of single glass shards measured by electron probe microanalysis (EPMA). Previous workers on Site 1123 tephras (Carter et al., 2003 and 2004; Alloway et al., 2005) have used this technique to correlate five Quaternary tephras from Site 1123 to five onshore TVZ deposits; the Kawakawa (26.5 ka), Omataroa ( $33 \mathrm{ka})$, Kidnappers B ( $\sim 0.99 \mathrm{Ma})$, Potaka ( 1.0 Ma) and Ototoka $(\sim 1.65 \mathrm{Ma})$ tephras. Alloway et al. (2005) commented, however, that several tephras with very similar major element chemistries precluded the establishment of unequivocal tephra correlations for the early Quaternary section of the Site 1123 record. This inherent limitation in major element fingerprinting of tephras is due to the inability of the EPMA technique to resolve small differences in the concentration of minor elements (e.g. $\mathrm{TiO}_{2}, \mathrm{MgO}$, $\mathrm{MnO}, \mathrm{Cl})$ and the common lack of significant major element variability in suites of related rhyolitic tephras (e.g. Pearce et al., 2007). Trace element abundances in the residual melt of an evolving magma vary more widely as a result of magma differentiation processes such as fractional crystallisation and assimilation of continental crust. For example, zirconium ( $\mathrm{Zr}$ ) occurs in trace amounts (ppm levels) in all magmas but forms a major constituent of the accessory mineral zircon 

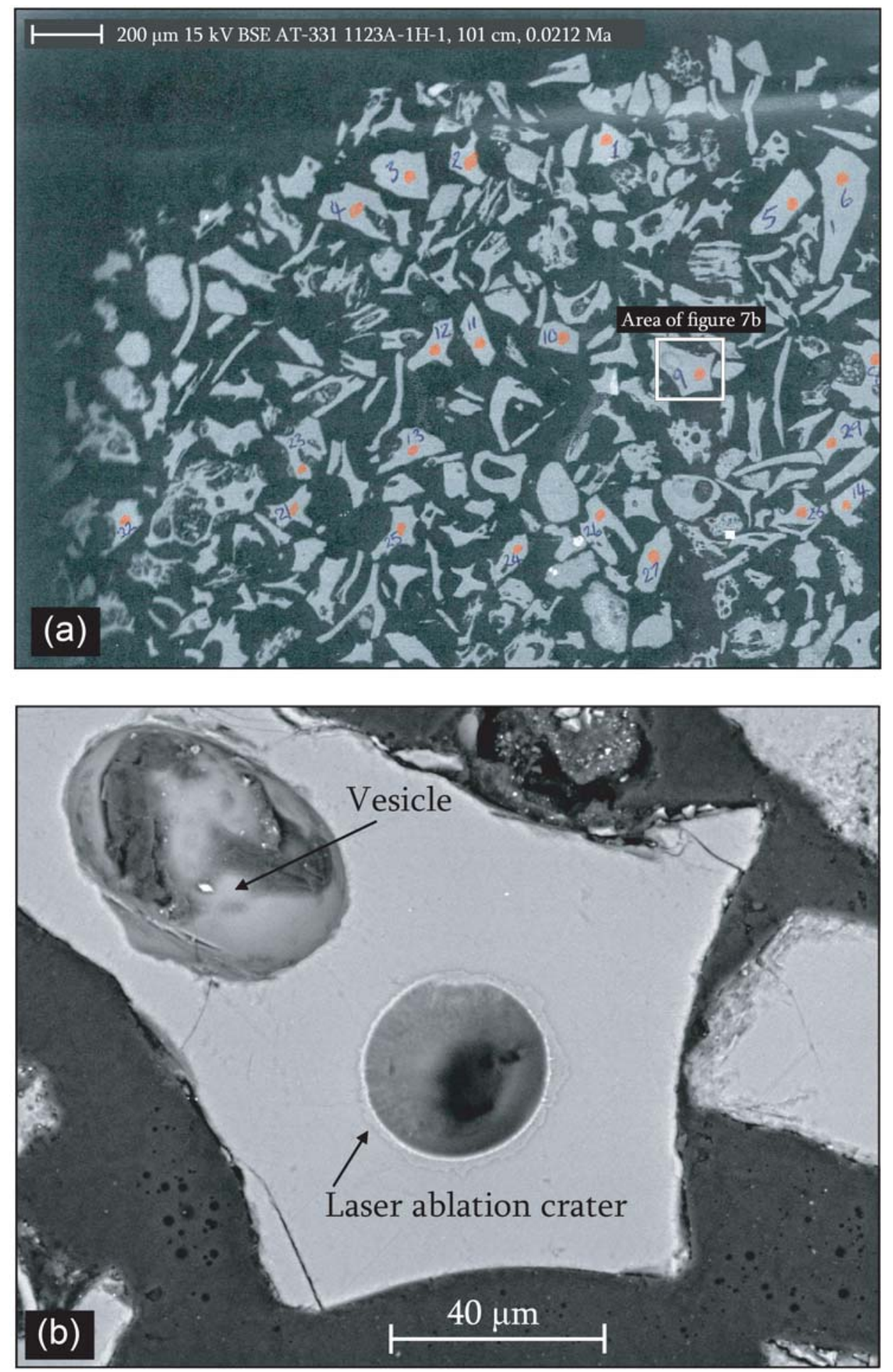

Figure 1-5. Back-scattered electron images (BSE) of (a) individual glass shards during major element characterisation by EPMA and, (b) a $\sim 35 \mu \mathrm{m}$ ablation crater generated during trace element analysis of $a \sim 150 \mu \mathrm{m}$ glass shard by LA-ICP-MS. During major element characterisation by EPMA each glass shard analysed is marked on the BSE image so that it can be relocated for trace element analysis using LA-ICP-MS. The CaO content of an individual glass shard measured by EPMA, and the count rate for the minor isotope ${ }^{43} \mathrm{Ca}$ obtained on the same glass shard during LA-ICP-MS analysis are used to calculate the trace element composition of that glass shard (see Appendix 2). 
(typically $\sim 68$ wt. $\% \mathrm{ZrO}_{2}$ ). Therefore only minute degrees of zircon fractionation $(<<1 \%)$ are required to dramatically reduce the concentration of $\mathrm{Zr}$ in the residual melt. For this reason trace element fingerprinting of glass from tephra deposits may provide a more robust means of correlating tephras that exhibit essentially identical major element chemistries.

Bulk geochemical techniques are considered unsuitable for characterising tephras due to problems associated with phenocryst and detrital mineral contamination (Hunt and Hill, 2001), limiting the usefulness of traditionally applied bulk trace element techniques such as X-ray fluorescence (XRF) and instrumental neutron activation analysis (INAA) (e.g. Dunbar et al., 1989; Shane, 1994; Shane et al., 1995) for correlating tephras. For example, incorporation of a single zircon crystal in a bulk tephra analysis would yield much higher concentrations for $\mathrm{Zr}$ (and $\mathrm{Hf}$ and heavy rare earth elements) than would be produced for a duplicate analysis of the same tephra that did not incorporate that zircon crystal.

Recent developments in analytical methods (e.g. LA-ICP-MS) have led to an increasing number of tephra correlation studies utilising the trace element geochemistry of individual shards of volcanic glass from tephra deposits (e.g. Pearce et al., 1996, 1999, 2002, 2004, 2007, 2008; Bryant et al., 1999; Ukstins Peate et al., 2003 and 2008; Harangi et al., 2005). In LA-ICP-MS, the trace element concentration of glass shards is calculated by reference to count rates obtained from a standard with a known trace element composition, followed by a secondary correction to a major element (the internal standard) monitored during the LA-ICPMS analysis (Pearce et al., 1996, 2007). Thus, for the LA-ICP-MS trace element technique to be employed the glass shards must first be characterised by EPMA so that a major element can be used as an internal standard, and each individual glass shard analysed by EPMA must later be re-analysed by LA-ICP-MS (Fig. 1-5). The LA-ICP-MS technique (see Appendix 2) is less susceptible to contamination (compared to bulk analytical techniques) from associated minerals because the analyst determines the position of the laser beam on the sample. In the case of accidental contamination (e.g. penetration of a phenocryst beneath the glass shard), inspection of the time-resolved data enables the analyst to identify the exact point in time when the contamination occurred. The analyst then has the option of discarding the analysis entirely or using only the data that was acquired prior to ablation of the 
phenocryst (Harangi et al., 2005). In addition, it is only by using microanalytical techniques such as EPMA and LA-ICP-MS, that the existence of multiple glass shard populations can be identified. These multiple compositional populations may reflect either a real magmatic signal, perhaps related to late-stage injection of a new batch of magma prior to eruption, or a post-depositional artefact resulting from sedimentary reworking of two or more tephra deposits.

Previous applications of single shard trace element data measured by LA-ICP-MS have demonstrated that it can provide a reliable means of distinguishing between tephras of similar major element chemistry and correlating them over large $\left(\sim 10^{3}\right.$ km) distances (e.g. Pearce et al., 1996, 1999, 2002, 2004, 2007, 2008; Bryant et al., 1999; Ukstins Peate et al., 2003 and 2008; Harangi et al., 2005).

In this thesis, the LA-ICP-MS technique is used to measure the trace element composition of all 70 Quaternary Site 1123 tephra layers. This dataset is used to assess whether tephras with effectively identical major element chemistry can be routinely distinguished on the basis of a trace element fingerprint. The trace element chemistry of selected onshore TVZ tephras has also been measured in an attempt to confirm the correlation of some of the previously identified Site 1123 tephras (e.g. Kawakawa Tephra; Alloway et al., 2005).

\subsection{A rigorous evaluation of the Quaternary Site 1123 composite record and age model}

Acceptance of the Site 1123 record as a type section for tephrochronology in the New Zealand region requires a rigorous evaluation of its composite stratigraphy and age model. The initial Quaternary Site 1123 composite stratigraphy was created by comparing and correlating distinctive magnetic susceptibility and light reflectance profiles between the 1123A, B and C cores, and first order age control was achieved by the identification of key paleomagnetic boundaries (Fig. 1-6 and Appendix 1) (Shipboard Scientific Party, 1999). Age control was enhanced by graphically correlating the composite light reflectance profile to the stable isotope record from ODP Site 846/849. This initial composite age model (Shipboard Scientific Party, 1999) was later refined and enhanced following stable isotopic (carbon and oxygen) analysis of benthic foraminifera at $5-10 \mathrm{~cm}$ intervals (Hall et al., 2001; Harris, 2002). Tuning of the Site 1123 stable isotope record to the ODP Site $849 \delta^{18}$ O record 

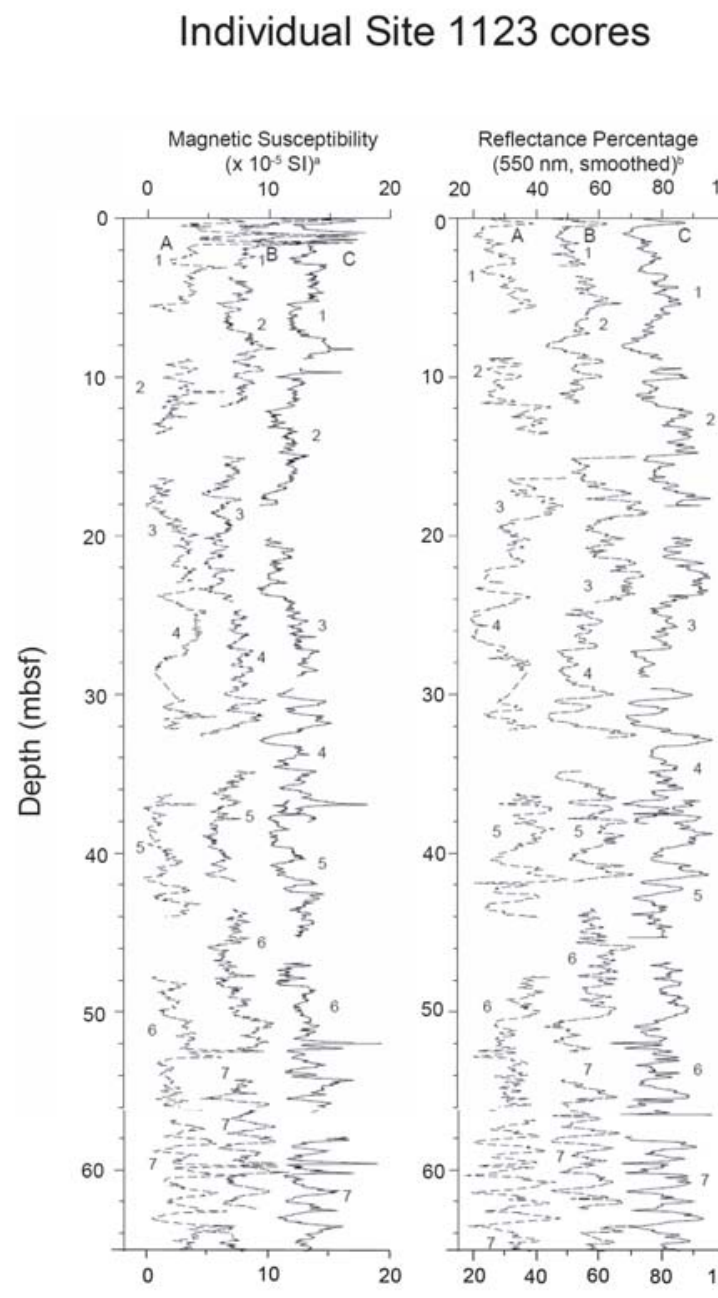

Site 1123 Composite Record

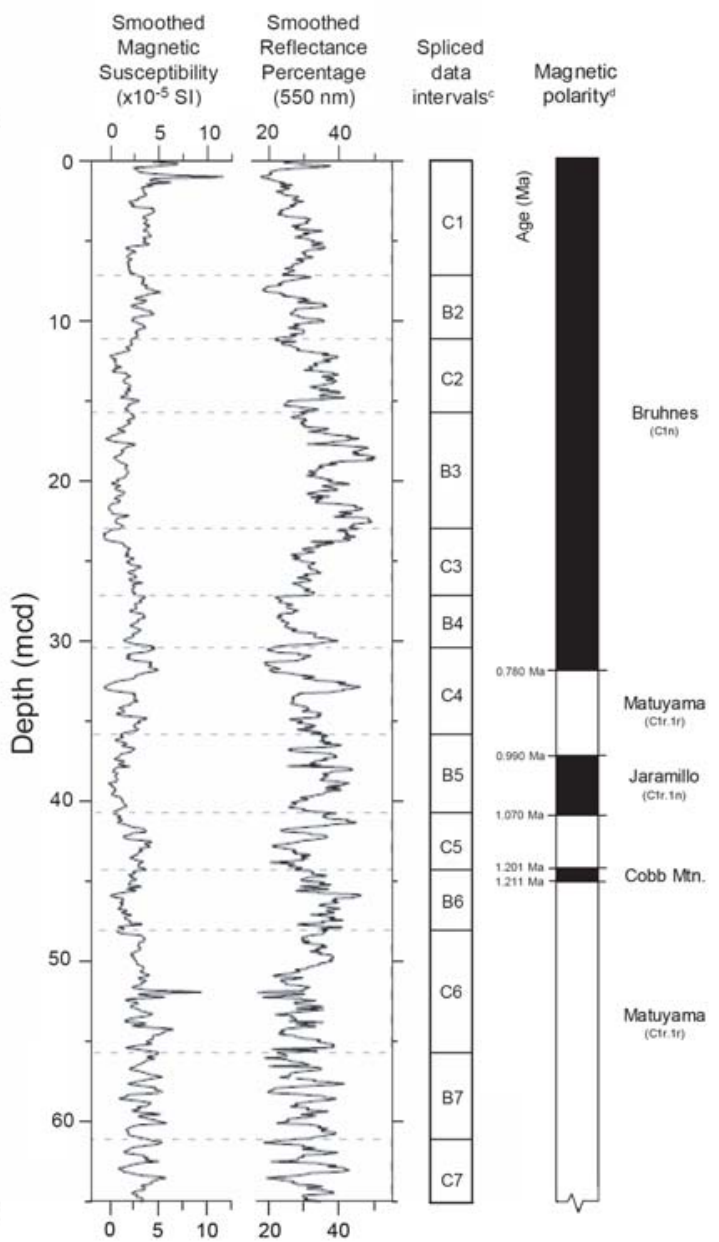

Figure 1-6. Summary of the portion of the Site 1123 composite stratigraphy that contains Quaternary TVZ tephras $(0.00-1.65 \mathrm{Myr})$. Distinctive features from the magnetic susceptibility and light reflectance profiles of $1123 \mathrm{~A}, \mathrm{~B}$ and $\mathrm{C}$ were correlated and spliced into a single composite profile. ${ }^{a} \mathrm{~B}$ and $\mathrm{C}$ core data offset by $5 \times 10^{-5}$ and $10 \times 10^{-5}$ respectively. ${ }^{b} \mathrm{~B}$ and $\mathrm{C}$ core data offset by $25 \%$ and $50 \%$ respectively. ${ }^{\mathrm{c}}$ The spliced composite record was constructed from the B and C cores only. ${ }^{d}$ Magnetic polarity record for the entire Quaternary record is constrained solely by data from the C core. Modified from Shipboard Scientific Party (1999).

(equatorial Pacific; Mix et al., 1995) yielded an orbitally tuned composite stable isotope age model that extends from $0.0-3.0 \mathrm{Ma}$ with a temporal resolution of \pm 1.2 $-2.5 \mathrm{kyr}$ (Hall et al., 2001). The section of the oxygen isotope age model that constrains the ages of the Quaternary TVZ tephras investigated in this thesis is shown in Figure 1-7.

While previous authors have attempted to correlate Site 1123 tephras to onshore TVZ deposits (Carter et al., 2003 and 2004; Alloway et al., 2005), to date there has been no attempt to correlate these tephras between the three Site 1123 sediment cores. Correlating these tephras between the three cores would allow for an 
independent and critical evaluation of the composite stratigraphy and age model, the results of which would serve to enhance the quality and reliability of the Site 1123 record as a type section for tephrochronology in the New Zealand region.

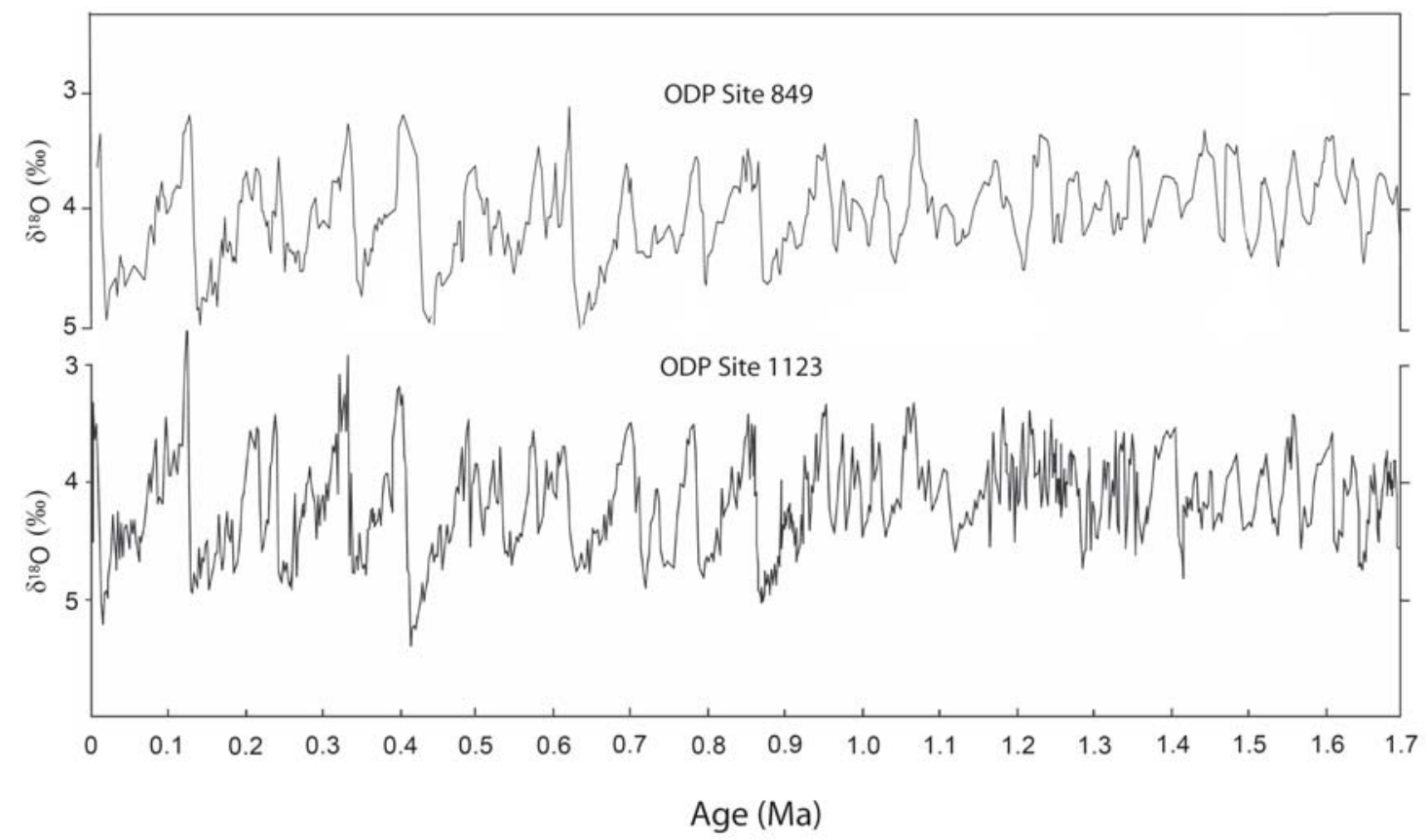

Figure 1-7. Summary of the $0.00-1.70 \mathrm{Myr}$ section of the Site 1123 composite oxygen isotope stratigraphy. The $\delta^{18} \mathrm{O}$ curve from ODP Site 849 (equatorial Pacific; Mix et al., 1995) that was used to tune the Site 1123 curve is shown for reference.

\subsection{Petrogenetic applications: insights into silicic magma generation from glass shard trace element and isotopic data}

The large proportion of erupted rhyolite magma ( $>90 \%)$ compared to more mafic compositions makes the TVZ an ideal setting to study the generation of large-volume silicic (particularly rhyolitic) magmas. However, the various sources and interaction of magmatic processes that have led to the generation of TVZ rhyolite magmas have proved problematic for TVZ researchers to decipher. Geochemical studies have shed some light on these issues (e.g. Blattner and Reid, 1983; Reid, 1983; Conrad et al., 1988; Graham et al., 1992 and 1995; McCulloch et al., 1994) yet these processes are still poorly understood. From a theoretical standpoint, rhyolitic magmas may represent the final product of one of two end-member models: extreme fractional crystallisation of a mafic, mantle-derived magma or melting of continental crust. A 
third, and perhaps more realistic, model termed assimilation - fractional crystallisation, or AFC, takes into account the effects of simultaneous fractional crystallisation in a magma chamber and assimilation of the surrounding wall-rock (De Paolo, 1981).

End-member models of fractional crystallisation and crustal melting have been dismissed as the sole processes operating to form TVZ rhyolites on the basis of chemical and isotopic data (e.g. Blattner and Reid, 1983; Reid, 1983; Conrad et al., 1988; Graham et al., 1992 and 1995; McCulloch et al., 1994). Reid (1983) showed that extreme (up to 90\%) fractionation of TVZ high-alumina basalt (HAB) and andesites can generate residual magmas with rhyolitic compositions but the modelled compositions were inconsistent with the observed trace element and rare earth element (REE) compositions of TVZ rhyolites. Similarly, whole sale melting of continental crust (Torlesse and Waipapa meta-greywacke; Fig. 1-1) has been eliminated as the sole source of TVZ rhyolites on isotopic grounds (Graham et al., 1995). The Torlesse meta-greywackes are isotopically distinct ( $\mathrm{Sr}, \mathrm{Nd}, \mathrm{Pb}, \mathrm{O})$ from the rhyolites, and, whereas Waipapa meta-greywackes are isotopically more similar to the rhyolites, the degree of overlap (particularly for $\delta^{18} \mathrm{O}$ ) is slight (Graham et al., 1992; 1995). Combining the effects of fractional crystallisation and crustal contamination through AFC modelling has generally resulted in a more satisfactory explanation of the chemical and isotopic features of the rhyolites, indicating a relationship through fractionation of high-alumina basalt (Kakuki Basalt) and assimilation of Torlesse metasedimentary crust (e.g. Graham et al., 1992; McCulloch et al., 1994). The involvement of continental crust suggested by isotopic data is also consistent with the recent discovery of rare Mesozoic ( $\sim 92-340 \mathrm{Ma})$ resorbed zircon cores in the $\sim 1.2 \mathrm{Ma}$ Ongatiti (Brown and Smith, 2004) and the $\sim 26.5$ ka Oruanui ignimbrites (Charlier et al., 2005). Although these AFC models are considered 'internally consistent within the associated errors' (Graham et al., 1995), they fail to explain the apparent absence of the corresponding large volumes $\left(>100,000 \mathrm{~km}^{3}\right)$ of basalt required to evolve by crystal fractionation to generate the observed volumes of erupted rhyolite $\left(\sim 15,000 \mathrm{~km}^{3}\right.$; Graham et al., 1995).

The strong isotopic $\left(\mathrm{Pb}, \mathrm{Sr}\right.$ and $\left.\delta^{18} \mathrm{O}\right)$ similarities between TVZ rhyolites and andesites led Graham et al. (1992) to suggest that all TVZ rhyolite compositions could potentially be generated by remelting of early andesites buried beneath the TVZ, requiring only small degrees of contamination by a more radiogenic 
component, assumed to be Torlesse metasedimentary crust. However, the extent and composition of these buried andesites are presently poorly constrained (e.g. Browne et al., 1992) and are a significant limitation for this model (Graham et al., 1992 and 1995).

\subsection{Types of data used for petrogenetic modelling of TVZ volcanic rocks: a limiting} factor?

The vast majority of trace element and isotopic data that have been used to examine the petrogenesis of TVZ volcanic rocks has been acquired through bulk geochemical techniques (thermal ionisation mass spectrometry [TIMS], XRF, INAA, solution ICP-MS) on powdered whole rock samples (i.e. whole rock geochemical data). Implicit in the use of whole rock isotopic data for petrogenetic modelling however is the assumption that volcanic rocks are isotopically homogeneous at the scale of minerals (Davidson et al., 2007).

Improvements in microanalytical technologies now permit trace element and isotopic fingerprinting on the scale of single crystals (e.g. sensitive high resolution ion microprobe [SHRIMP], LA-ICP-MS, secondary ionisation mass spectrometry [SIMS], LA-MC-ICP-MS). Recent applications of these techniques have demonstrated that igneous phenocrysts are rarely in isotopic equilibrium with the host groundmass and imply the mingling of material (magmas, crystals and xenolithic material) from diverse sources (Price et al., 2005; Davidson et al., 2001 and 2007; Morgan et al., 2007, Charlier et al., 2007 and 2008). These findings suggest that the whole rock isotopic data that has previously been applied to petrogenetic modelling of TVZ volcanic rocks may in fact mask the potentially complex pathways by which TVZ rhyolites evolve (e.g. Charlier et al., 2008). Therefore, representative chemical and isotopic characterisation of volcanic rocks may only be possible if the individual components of volcanic rocks (i.e., juvenile glass, melt inclusions and individual regions of zoned igneous minerals) are targeted through the application of microanalytical techniques. Such an approach then allows for each component of a magma to be viewed in isolation and may reveal complexities hitherto masked or 'averaged out' by whole rock geochemical techniques (e.g. Charlier et al., 2008).

The deposits from the $\sim 26.5 \mathrm{ka}$ Oruanui eruption from Taupo caldera $\left(\sim 500 \mathrm{~km}^{3}\right.$ magma) have been extensively characterised by new high precision, high spatial 
resolution, microanalytical techniques. These studies include U-Pb and U-Th dating of single zircon crystals from the Oruanui and other magmas erupted from Taupo caldera (Charlier et al., 2005), in-situ analysis of major, trace and volatile elements from melt inclusions (Liu et al., 2006), and detailed major element and ${ }^{87} \mathrm{Sr} /{ }^{86} \mathrm{Sr}$ isotopic traverses of complexly zoned plagioclase crystals (Charlier et al., 2008). When viewed in context with detailed petrographic, geochemical and field studies of the pre- and post-Oruanui eruptions from Taupo caldera (Sutton et al., 1995; Wilson, 2001 and 2006) these studies have shown that the Oruanui magma chamber was an open system, rapidly assembled over a period of $\sim 40 \mathrm{kyr}$ and that it received significant contributions from crustally contaminated mafic magmas, partly-melted intermediate-composition igneous intrusions and greywacke melts. The open system behaviour and rapid assembly ( $40 \mathrm{kyr}$ ) of the Oruanui magma system, implied by the above research, contrasts strongly with petrogenetic models that have been proposed for many silicic volcanic systems (e.g. Bishop Tuff, western USA) which, despite local complexities, are generally considered to have assembled over periods of $10^{4}-10^{5} \mathrm{yr}^{-1}$ or more, and evolved primarily by closed system fractional crystallisation in and above crystal mush zones with minimal interactions with surrounding country rock (Reagan et al., 2003; Christiansen, 2005; Hildreth and Wilson, 2007; Charlier et al., 2008). Such studies also highlight the importance and potential of microanalytical geochemical data in advancing our understanding of rhyolite magma generation in the TVZ.

\subsection{The application of tephra geochemistry to TVZ rhyolite petrogenesis: new} insights from ODP Site 1123 tephras?

Published trace element data for TVZ tephras are rare (e.g. Dunbar et al., 1989; Shane, 1994; Shane et al., 1995) and where available have typically been determined by bulk analytical techniques (e.g. XRF, INAA). The same problems that inhibit the use of bulk trace element techniques for tephra correlation studies (see section 2.2) also limit their usefulness for petrogenetic applications.

While the primary focus of tephra LA-ICP-MS trace element data has traditionally been to address the issues of tephra fingerprinting and correlation, some authors have also used these datasets to investigate the petrogenesis of the magmas (e.g. Harangi et al., 2005; Bryant et al., 1999; Ukstins Peate et al., 2003 and 2008; Pearce et al., 
2002 and 2008). Many of these studies have documented the existence of significant, small scale trace element heterogeneity between individual glass shards from single eruptive events (e.g. Pearce et al., 2002 and 2008; Ukstins Peate et al., 2003 and 2008). When intra-tephra trace element heterogeneity is demonstrated to be greater than the analytical uncertainties (generally achieved by reference to analyses of a homogenous reference material) such variations can be attributed to real compositional gradients in the magma chamber prior to eruption. Therefore, single shard trace element data can be thought of as providing 'snapshots-in-time' of an evolving residual melt and may document processes such as mixing of two or more discrete batches of magma or the crystallisation of phenocryst and accessory mineral phases (e.g. Pearce et al., 2002).

The single shard trace element data for the 70 Quaternary Site 1123 tephras investigated in this thesis provides new insights into the petrogenesis of TVZ rhyolites. By only analysing glass shards (the residual melt of the evolving magmas), this trace element dataset is not compromised the incorporation of phenocrysts (see section 3.2). Hence, variations within the trace element data of individual tephras presented here (when greater than analytical uncertainties) reflect real magmatic processes (e.g. fractional crystallisation, crustal melting/assimilation, magma mixing).

To compliment the LA-ICP-MS trace element data, 13 Site 1123 tephras representative of four distinct magma-types revealed by major and trace element data have been selected for radiogenic isotope analysis $(\mathrm{Sr}, \mathrm{Nd}, \mathrm{Pb})$ by multi-collector ICP-MS (a bulk geochemical technique). While isotopic ratios are not fractionated by melting and crystallisation processes (Faure, 1986; Dicken, 2005) the incorporation of phenocrysts with multi-stage crystallisation histories (e.g. Charlier et al., 2008) into a bulk analysis (e.g. MC-ICP-MS) will influence the isotopic data. However, by virtue of their distance from source $(\sim 1000 \mathrm{~km})$, the Site 1123 tephras are typically crystal poor and glass shards typically comprise $>95 \%$ of igneous material. The tephras selected for isotopic analysis contained only minor amounts of igneous minerals (typically $\sim 0.1 \%$ to $1 \%$ with a single sample comprising $\sim 4 \%$ ), ensuring the influence of multi-history crystals on the 'final isotopic composition' is minimal. 


\subsection{Summary and structure of this thesis.}

In summary, the following attributes make the Site 1123 tephra record ideal for investigating the eruptive history of the TVZ, establishing it as a type section for tephrochronology and providing new insights into the petrogenesis of silicic TVZ magmas:

(1) The record spans the entire $\sim 1.65 \mathrm{Myr}$ history of TVZ rhyolitic volcanism and is tied to a high resolution palaeoclimatic record with orbitally tuned stable isotope age control.

(2) The long and apparently continuous Site 1123 stratigraphy enables a more complete, continuous history of silicic TVZ volcanism to be pieced together.

(3) The three Site 1123 sediment cores (A, B and C) offer the opportunity to rigorously evaluate the composite record and age model.

(4) The Site 1123 tephras contain abundant fresh glass shards which are ideal for geochemical analysis.

The objectives of this thesis are threefold. Firstly, to assess the ability of single shard trace element data to distinguish between TVZ tephras with effectively identical major element chemistries. Secondly, to evaluate and refine the stratigraphy of the Site 1123 tephra record to establish it as a type section for tephrochronology studies in the New Zealand region and reconstruct a more complete history of large-volume rhyolitic eruptions from the TVZ. Finally, to provide new insights into the petrogenesis of large-volume TVZ silicic magmas.

This thesis comprises four chapters and five appendices with the following structure:

Chapter One: Introduction

Chapter Two: Chronostratigraphic applications

"Reconstructing the Quaternary evolution of the world's most active silicic volcanic system: insights from an 1.65 Myr deep ocean tephra record sourced from Taupo Volcanic Zone, New Zealand.” 
This chapter has been submitted, and subsequently accepted, for publication in the journal Quaternary Science Reviews. As such, this chapter is written and structured in the style of this journal.

Chapter Three: Petrogenetic applications

"Re-examining the petrogenesis of silicic magmas from the world's most active silicic volcanic system: an elemental and Sr-Nd-Pb isotopic study of an $~ 1.65 \mathrm{Ma}$ deep ocean tephra record sourced from Taupo Volcanic Zone, New Zealand” This chapter will be submitted as a research and review paper to the Journal of Petrology in November 2008. As such, it is written and structured in the style of this journal.

Chapter Four: Synthesis and conclusions

\section{Supplementary Information}

Appendix One: Sample list and original Site 1123 composite record tie-points Appendix Two: Analytical techniques

Appendix Three: Major element data

Appendix Four: Trace element

Appendix Five: Isotopic data

Appendix Six: Full major and trace element dataset and details of revised composite stratigraphy tie-lines (CD) 


\title{
CHAPTER TWO: \\ CHRONOSTRATIGRAPHIC APPLICATIONS
}

\author{
Reconstructing the Quaternary evolution of the world's most active silicic volcanic \\ system: insights from a $\sim 1.65 \mathrm{Ma}$ deep ocean tephra record sourced from Taupo \\ Volcanic Zone, New Zealand
}

Note: this chapter has been submitted, and subsequently accepted, for publication in the journal Quaternary Science Reviews (doi: 10.1016/j.quascirev.2008.09.003)

\begin{abstract}
The Taupo Volcanic Zone (TVZ), central North Island, New Zealand, is the most frequently active Quaternary rhyolitic system in the world. Silicic tephras recovered from Ocean Drilling Programme Site 1123 (41 ${ }^{\circ} 47.16^{\prime}$ S, $171^{\circ} 29.94^{\prime} \mathrm{W}$; $3290 \mathrm{~m}$ water depth) in the southwest Pacific Ocean provide a well-dated record of explosive TVZ volcanism since $\sim 1.65 \mathrm{Ma}$. We present major, minor and trace element data for 70 Quaternary tephra layers from Site 1123 determined by electron probe microanalysis (1314 analyses) and laser ablation inductively coupled plasma mass spectrometry (654 analyses). Trace element data allow for the discrimination of different tephras with similar major element chemistries and the establishment of isochronous tie-lines between three sediment cores (1123A, B and C) recovered from Site 1123. These tephra tie-lines are used to evaluate the stratigraphy and orbitally tuned stable isotope age model of the Site 1123 composite record. Trace element fingerprinting of tephras identifies $\sim 4.5 \mathrm{~m}$ and $\sim 7.9 \mathrm{~m}$ thick sections of repeated sediments in 1123A (49.0 - 53.5 mbsf [metres below seafloor]) and 1123C (48.1 - $56.0 \mathrm{mbsf}$ ), respectively. These previously unrecognised repeated sections have resulted in significant errors in the Site 1123 composite stratigraphy and age model for the interval $1.15-1.38 \mathrm{Ma}$ and can explain the poor correspondence between $\delta^{18} \mathrm{O}$ profiles for Site 1123 and Site 849 (equatorial Pacific) during this interval.

The revised composite stratigraphy for Site 1123 shows that the 70 tephra layers, when correlated between cores, correspond to $\sim 37-38$ individual eruptive events (tephras), seven of which can be correlated to onshore TVZ deposits. The frequency of large-volume TVZ-derived silicic eruptions, as recorded by the deposition of tephras at Site 1123, has not been uniform through time. Rather it has been typified by short periods (25-50 ka) of intense activity bracketed by longer periods (100-130 ka) of quiescence. The most active period (at least 1 event per $7 \mathrm{ka}$ ) occurred between $\sim 1.53-1.66 \mathrm{Ma}$, corresponding to the first $\sim 130 \mathrm{ka}$ of TVZ rhyolitic magmatism. Since $1.2 \mathrm{Ma}, \sim 80 \%$ of tephras preserved at Site 1123 and the more proximal Site 1124 were erupted and deposited during transitions to glacial periods or full glacial lowstands. This feature may reflect either enhanced atmospheric transport of volcanic ash to these sites (up to $1000 \mathrm{~km}$ from source) during glacial conditions or, more speculatively, that these events are triggered by changes in crustal stress accumulation associated with large amplitude sea level changes.

Only 8 of the $\sim 37-38$ Site 1123 tephra units $(\sim 20 \%)$ can be found in all three cores, and 22 tephra units $(\sim 60 \%)$ are only present in one of the three cores. Whether a tephra is preserved in all three cores does not have any direct relationship to eruptive volume. Instead it is postulated that tephra preservation at Site 1123 is 'patchy' and influenced by the vigorous nature of their deposition to the deep ocean floor as vertical density currents. At this site, at least 5 cores would need to have been drilled within a proximity of 10's to 100's of metres of each other to yield a $>99 \%$ chance of recovering all the silicic tephras deposited on the ocean surface above it in the past $1.65 \mathrm{Ma}$.
\end{abstract}




\subsection{Introduction}

The Taupo Volcanic Zone (TVZ) is an active, ca. 2 Ma old, rifted continental arc associated with the westward subduction of the Pacific Plate beneath the central North Island, New Zealand (Fig. 2-1). It is considered the most productive centre of Quaternary rhyolitic volcanism in world, and is estimated to have erupted $\geq 15000$ $\mathrm{km}^{3}$ of rhyolitic magma throughout the Quaternary (Wilson et al., 1995a). Since the inception of rhyolitic magmatism at ca. $1.65 \mathrm{Ma}$, at least 34 caldera-forming eruptions have occurred from eight prominent rhyolitic caldera centres (Houghton et al., 1995). These explosive silicic eruptions have resulted in the deposition of widespread pyroclastic flow (ignimbrite) and fall (tephra) deposits throughout the central North Island and its offshore environs.

Attempts to reconstruct a complete Quaternary volcanic history of the TVZ are hindered by two factors: (1) the low resolution of most dating techniques compared to the young age and frequency of the eruptive events and; (2) the fragmentary nature of the onland terrestrial TVZ record. Absolute dating of large-volume TVZ rhyolites is largely based upon radiometric dating techniques (e.g. ${ }^{14} \mathrm{C}, \mathrm{K}-\mathrm{Ar},{ }^{40} \mathrm{Ar}-{ }^{39} \mathrm{Ar}-$ where appropriate material is available) and glass isothermal plateau fission track (ITPFT) dating of material from terrestrial ignimbrite and tephra deposits. These dating techniques can result in ambiguous, overlapping (within statistical errors) age determinations between units and generally lack the temporal resolution required to link these eruptive episodes to high resolution paleoclimate information in the marine sedimentary rock record. Additionally, only the products of the youngest TVZ eruptions $(<65 \mathrm{ka})$ have been well preserved and studied in any great detail (Wilson et al., 1995a). Older units and, in particular, those that pre-date the $\sim 350 \mathrm{ka}$ Whakamaru group ignimbrites, are poorly preserved in the terrestrial record owing to erosion or destruction and burial by younger volcanic deposits. Thus, the greatest potential for constructing a reliable chronology and more complete history for the oldest sections (pre-350 ka) of the TVZ is to study tephra deposits preserved in welldated, high resolution, marine sedimentary records.

The recovery of an extensive TVZ-sourced silicic tephra record from Ocean Drilling Programme (ODP) Leg 181 has provided the impetus for reconstructing a complete, 


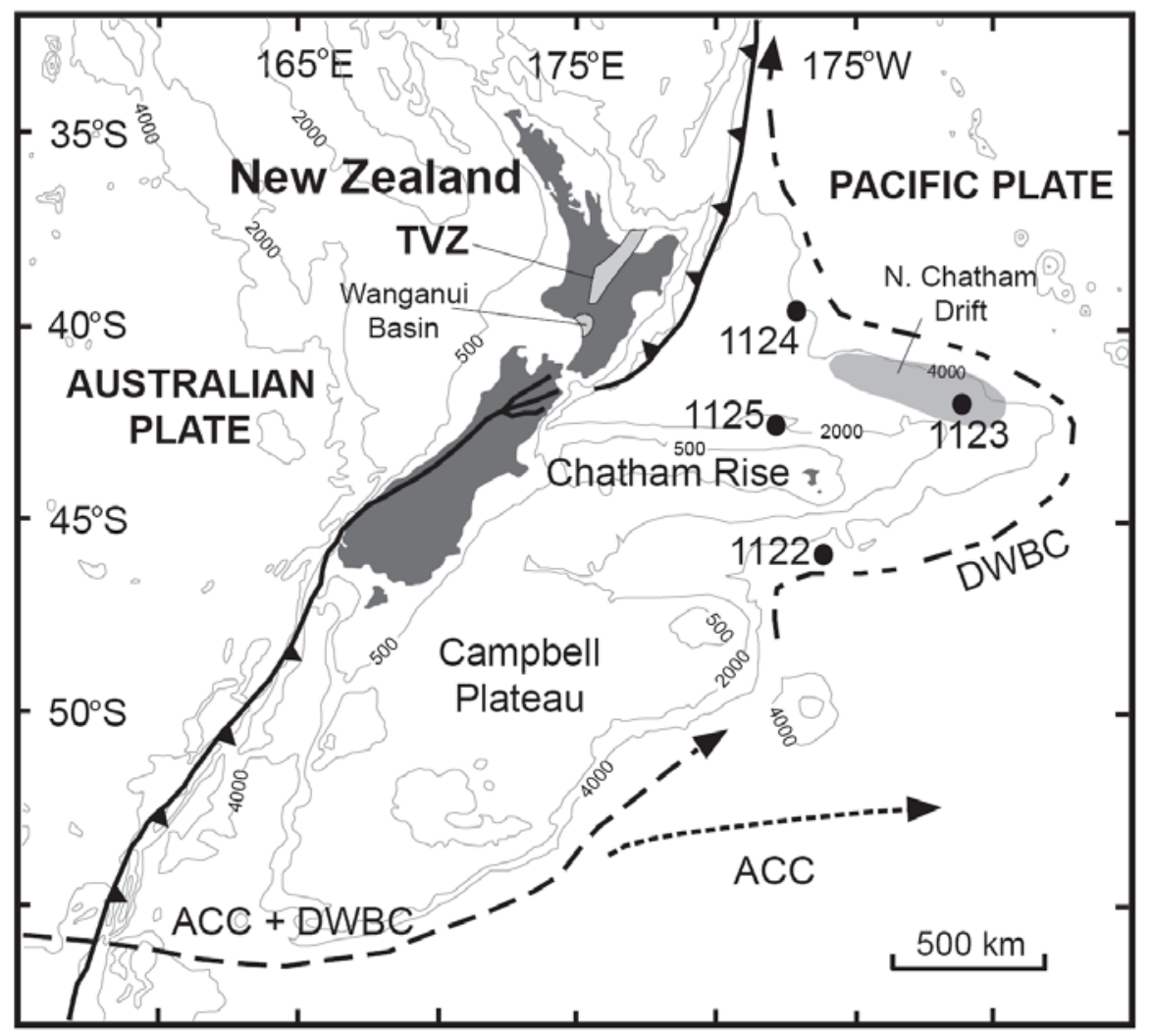

Figure 2-1. Location of ODP Site $1123\left(41^{\circ} 47.16^{\prime} \mathrm{S}, 171^{\circ} 29.94^{\prime} \mathrm{W} ; 3290 \mathrm{~m}\right.$ water depth) and Taupo Volcanic Zone (TVZ). Sediment cores from Sites 1122, 1124, and 1125 also recovered tephras originating from TVZ (Alloway et al., 2005). Also shown are the generalised deep ocean current regimes (ACC, Antarctic Circumpolar Current; DWBC, Deep Western Boundary Current) and the onshore/offshore New Zealand plate boundary. Depth contours are in metres. Modified from Weedon and Hall (2004).

chronologically constrained, eruptive history to complement the fragmentary onland TVZ record (e.g. Carter et al., 2003; Alloway et al., 2005). The chronology of the Site 1123 (Fig. 2-1) composite record is tightly constrained by a combination of magnetostratigraphy and orbitally tuned stable isotope data making it an important paleo-climatic and -oceanographic record for the southwest Pacific region (e.g. Hall et al., 2001; Fenner and Stefano, 2004; Mildenhall et al., 2004; Weedon and Hall, 2004). At Site 1123, ca. 70 TVZ-sourced Quaternary tephra layers (0.02-1.65 Ma) were recovered and assigned preliminary ages from the composite benthic oxygen isotope stratigraphy (Alloway et al., 2005; Brent Alloway, unpublished data). Age control on these tephra layers is generally greater than is possible by current radiometric dating techniques (e.g. isothermal plateau fission track [ITPFT] glass ages). However, the resolution of the oxygen isotope stratigraphy is not likely to provide more reliable ages for the youngest section of the record $(<\sim 50 \mathrm{ka})$ than is possible from ${ }^{14} \mathrm{C}$ dating of onland correlatives, although this only affects 6 of the 70 
studied tephra layers. To date, however, there has been no attempt to correlate tephra layers between the three cores at Site 1123 (1123A, 1123B and 1123C), which would enable an independent evaluation of the 'splice' used to construct the composite record and oxygen isotope age model of Site 1123 and a more complete history of explosive silicic volcanism from the TVZ to be constructed.

The most common geochemical technique applied to tephra correlation is electron probe microanalysis (EPMA), which provides a major element 'fingerprint' of individual shards of volcanic glass. However, in some cases, the major element variations for a suite of tephras may be too small to enable unequivocal correlations to be made. Alloway et al. (2005) presented major element (EPMA) compositions for ca. 50 Quaternary Site 1123 tephra layers and correlated a small number of these to onshore TVZ deposits. They noted, however, that particularly for the early Quaternary section of the record, there were too many tephra layers with similar major element compositions to enable unambiguous correlations to be proposed. The abundances of trace elements in magmas are more greatly affected by magmatic processes than major element concentrations. For example, fractional crystallisation can result in significant changes in a magma's trace element concentrations and yet may have a very limited influence on its major element composition (e.g. Hildreth, 1979; Mahood and Hildreth, 1983). Thus, trace element fingerprinting of tephra layers may allow the identification of different tephras with very similar major element chemistry, permitting more precise tephra correlations to be established. Recent developments in analytical methods (e.g. laser ablation inductively coupled plasma mass spectrometry, LA-ICP-MS) have led to an increasing number of tephra correlation studies utilising single shard trace element geochemistry (e.g. Pearce et al., 1996, 1999, 2002, 2004, 2007, 2008; Bryant et al., 1999; Ukstins Peate et al., 2003, 2008; Harangi et al., 2005). The LA-ICP-MS technique has a spatial resolution of tens of microns and can be used to rapidly ( $\sim 5$ min including standard and background data acquisition) determine the abundance of more than 30 minor and trace elements in solid samples.

Here we present new major (EPMA, 1314 analyses) and trace element (LA-ICP-MS, 654 analyses) data for 70 macroscopic Quaternary tephra layers from ODP Site 1123. We use this geochemical dataset to: (1) assess the utility of trace element data to distinguish between tephras with very limited major element variations; (2) establish 
isochronous tephra tie-lines between cores 1123A, 1123B and 1123C, and critically review the Site 1123 composite stratigraphy and orbitally tuned oxygen isotope age model; (3) evaluate and review the timing and frequency of Quaternary explosive silicic eruptions from the TVZ; and (4) assess the preservation potential of deep marine tephras and the applicability of the isopach technique for estimating eruption volumes using tephras from the deep ocean.

\subsection{Regional Background to ODP Site 1123 tephra layers}

Seven sites were drilled during ODP Leg 181 in the southwest Pacific Ocean with the objective of studying the paleo-hydrography, paleo-climatology, micropaleontology and sedimentation history of thick, fine-grained, sediment masses deposited under the influence of the Antarctic Circumpolar Current (ACC) and Deep Western Boundary Current (DWBC) systems (Fig. 2-1) (Shipboard Scientific Party, 1999). Terrigenous sediment eroded from the New Zealand landmass is delivered to the deep ocean east of New Zealand via submarine channel systems (e.g. Solander, Bounty and Hikurangi) where it is entrained and dispersed northwards by the DWBC (Carter et al., 1996). As the DWBC slows, large sediment drifts accumulate (e.g. North Chatham Drift at Site 1123, Fig. 2-1). Throughout the Quaternary, clouds of volcanic ash produced by explosive eruptions from the TVZ have been dispersed by the prevailing vigorous westerly wind system and deposited as tephra layers on the deep ocean floor east of New Zealand (ODP Sites 1122, 1123, 1124, 1125; Carter et al., 2003) and less frequently to the west (DSDP Leg 90; Nelson et al., 1986) and north (Pillans and Wright, 1992).

The extensive record of explosive TVZ silicic volcanism recovered at Sites 1123 and 1124 (and to a lesser extent Sites 1122 and 1125), when coupled with the onshore record, should allow a relatively complete, chronologically constrained, Quaternary history for the TVZ to be established (e.g. Alloway et al., 2004, 2005; Carter et al., 2004; Pillans et al., 2005). The age model for Site 1123 is underpinned by key magnetic polarity horizons (Shipboard Scientific Party, 1999) and rigorously defined by orbitally tuned stable isotopic data from benthic foraminifera (Hall et al., 2001; Harris, 2002). The orbitally tuned age control on these tephra layers provides a rare 
opportunity to place the timing of these large silicic eruptions within the context of highly resolved paleo-climatic and paleo-oceanographic records. As such, the Site 1123 tephra record forms a vital chronostratigraphic framework for reconstructing the volcanic history of the TVZ and also for correlating between fragmentary Quaternary sedimentary sequences used in paleo-environmental studies elsewhere in the southwest Pacific region.

The tephra record at Site 1123 extends as far back as $\sim 12 \mathrm{Ma}$ (Carter et al., 2003). However, this study focuses on the Quaternary section of the record (present to 1.81 Ma) from which 70 macroscopic tephra layers were recovered from the three cores drilled at this site (1123A, B and C). The tephra layers are typically pinkish-grey to light pinkish-grey (5YR 5/1 to 5YR 7/1; Munsell colours) and are characterised by sharp bases, fining upwards textures and bioturbated tops (Carter et al., 2003), but occasionally occur in lenses, infilled burrows, or have been slightly rotated as a result of piston coring processes (Shipboard Scientific Party, 1999). The thickness of individual tephra layers range from 0.3 to $10 \mathrm{~cm}$ with a mean thickness of $3.7 \mathrm{~cm}$. Due to the significant distance from eruption source, these distal tephra deposits are typically fine grained. The average size of glass shards varied between ca. $30-100$ $\mu \mathrm{m}$, which although small, is well within the spatial resolution of EPMA and modern LA-ICP-MS techniques (Pearce et al., 2007).

\subsection{Analytical Techniques}

\subsection{Sample preparation}

Volcanic glass was separated from bulk tephra samples and mounted in epoxy resin blocks for geochemical characterisation by EPMA (major elements) and LA-ICP-MS (trace elements). About 50 tephra layers analysed in this study were provided by Brent Alloway and are allocated the same sample numbers as in Alloway et al. (2005). All other samples analysed in this study were obtained from the Integrated Ocean Drilling Program's Gulf Coast Repository (Texas, USA). These samples were rinsed through a $33 \mu \mathrm{m}$ nylon mesh to remove excess mud. This produced a residue of $80-95 \%$ volcanic glass shards with the remainder comprising feldspar and mafic 
igneous minerals, and carbonate microfossils. The separated glass was then rinsed and decanted several times in ultra-clean water $(>18.2 \mathrm{M} \Omega)$ and left to dry at $50^{\circ} \mathrm{C}$ for 2-3 days. Only one sample was mounted in each epoxy block to avoid the possibility of inter-sample contamination during preparation. The epoxy blocks were ground down using 400 - 4000 grit silicon carbide paper to expose the glass shards and then polished using $1 \mu \mathrm{m}$ liquid diamond suspension. A $25 \mathrm{~nm}$ carbon coating was applied to each sample prior to major element characterisation by EPMA, but then was removed prior to LA-ICP-MS analysis.

\subsection{Electron probe microanalysis (EPMA)}

The major element composition $\left(\mathrm{SiO}_{2}, \mathrm{TiO}_{2}, \mathrm{Al}_{2} \mathrm{O}_{3}, \mathrm{FeO}, \mathrm{MnO}, \mathrm{MgO}, \mathrm{CaO}, \mathrm{Na}_{2} \mathrm{O}\right.$, $\mathrm{K}_{2} \mathrm{O}$ and $\mathrm{Cl}$ ) of glass shards was determined using a JEOL 733 Superprobe equipped with three wavelength dispersive spectrometers at Victoria University of Wellington, New Zealand. Major element concentrations were determined using the ZAF correction method. Analyses were performed using an accelerating voltage of $15 \mathrm{kV}$ under a static electron beam operating at $8 \mathrm{nA}$. The electron beam was defocused to $20 \mu \mathrm{m}$ and $\mathrm{Na}_{2} \mathrm{O}$ and $\mathrm{K}_{2} \mathrm{O}$ were determined first during each run to minimise the effects of alkali loss resulting from electron beam heating and damage to the glass matrix. All analyses were normalised to $100 \%$ to enable comparison of tephras that may have experienced varying degrees of secondary hydration. The instrument was calibrated daily using a series of natural and synthetic standards: Al, Ti, Fe, Mn and $\mathrm{Mg}$ - synthetic element oxides; $\mathrm{Si}$ and $\mathrm{Ca}$ - wollastonite; $\mathrm{Na}$ - jadeite; $\mathrm{K}$ orthoclase; $\mathrm{Cl}$ - sodalite. The homogeneous reference glasses VG-A99 (basaltic) and ATHO-G (rhyolitic) were analysed between samples to monitor any spectrometer drift and the precision and accuracy of the major element data. Table A2-1 in the supplementary information summarises the precision and accuracy of the EPMA data reported in this study. A back-scattered electron image of each sample was taken during major element characterisation so that each individual glass shard measured by EPMA could later be analysed for trace elements by LA-ICP-MS.

\subsection{Laser ablation inductively coupled plasma mass spectrometry (LA-ICP-MS)}

The trace element composition of single shards of volcanic glass was determined using a New Wave deep UV (193 nm solid state) laser ablation system coupled to an 
Agilent 7500CS ICP-MS at Victoria University of Wellington, New Zealand. Typically thirty-eight minor and trace elements were determined by LA-ICP-MS: Mg, Ti, V, Cr, Mn, Ni, Co, Cu, Zn, Ga, Rb, Sr, Y, Zr, Nb, Mo, Cs, Ba, La, Ce, Pr, Nd, Sm, Eu, Gd, Tb, Dy, Ho, Er, Tm, Yb, Lu, Hf, Ta, W, Pb, Th and U. All data were acquired as static spot analyses using a laser beam diameter of 25 or $35 \mu \mathrm{m}$. Helium was used as a carrier gas to more efficiently transfer the sample aerosol from the ablation chamber to the ICP-MS and this provided a 2-3 fold increase in signal intensity and a reduction in background intensity across the entire mass range (cf. Eggins et al., 1998) as compared to using argon. A summary of LA-ICP-MS analytical parameters is presented in Table 2-1.

The LA-ICP-MS data acquisition technique employed here follows that of Pearce et al. (1996) where a minor isotope of a major element (here ${ }^{43} \mathrm{Ca}$ ), previously determined by EPMA, is included in the ICP-MS analysis and used as an internal standard. Analyses of the sample are bracketed by analyses of a reference material (e.g. NIST 612) so that (after corrections for backgrounds) the trace element concentration of element $\mathrm{x}$ in a tephra glass shard is determined by the relationships:

$$
\begin{gathered}
\mathrm{C}_{\text {tephra }}^{\mathrm{CaO}, \text { ICP-MS }}=\mathrm{C}_{\text {std }}^{\mathrm{Caa}} \times\left(\mathrm{CPS}_{\text {tephra }}^{\mathrm{Ca}} / \mathrm{CPS}_{\text {std }}^{\mathrm{Ca}}\right) \\
\mathrm{C}_{\text {tephra }}^{\mathrm{x}, \mathrm{ICP}-\mathrm{MS}}=\mathrm{C}_{\text {std }}^{\mathrm{x}} \times\left(\mathrm{C}_{\text {tephra }}^{\mathrm{CaO}, \mathrm{PPM}} / \mathrm{C}_{\text {tephra }}^{\mathrm{Caa}, \mathrm{ICP}-\mathrm{MS}}\right) \times\left(\mathrm{CPS}_{\text {tephra }}^{\mathrm{x}} / \mathrm{CPS}_{\text {std }}^{\mathrm{x}}\right)
\end{gathered}
$$

$\mathrm{C}_{\text {tephra }}^{\text {Cao,ICP-MS }}, \mathrm{C}_{\text {tephra }}^{\mathrm{CaO}, \mathrm{EPMA}}=$ concentration of Ca determined by LA-ICP-MS or EPMA $\mathrm{C}_{\text {std }}^{\mathrm{caO}}=$ reference $\mathrm{CaO}$ concentration of the NIST612 standard $\mathrm{CPS}_{\text {tephra }}^{\mathrm{Ca}}, \mathrm{CPS}_{\text {std }}^{\mathrm{Ca}}=$ counts per second obtained on ${ }^{43} \mathrm{Ca}$ whilst ablating the tephra glass shard (tephra) or standard (std)

$\mathrm{C}_{\text {tephra }}^{\mathrm{x}, \mathrm{ICP}}=$ concentration of element $\mathrm{x}$ determined by LA-ICP-MS

$\mathrm{C}_{\mathrm{std}}^{\mathrm{x}}=$ reference concentration of element $\mathrm{x}$ in the standard NIST612

$\mathrm{CPS}_{\text {tephra }}^{\mathrm{x}}, \mathrm{CPS}_{\text {std }}^{\mathrm{x}}=$ counts per second obtained on an isotope of element $\mathrm{x}$ whilst ablating the tephra glass shard (tephra) or standard (std)

In order for this method to accurately determine the trace element abundances in the sample, it is ideal for the calibration standard (reference material) to have a matrix composition similar to that of the sample. A poor choice of calibration standard may produce differential elemental fractionation in the standard and sample (matrix effects) during the analysis resulting in inaccurate data. The exact causes of 
elemental fractionation during LA-ICP-MS analyses and the location at which this occurs have been widely studied and variously attributed to either the laser ablation process itself, aerosol transport processes and incomplete ionisation of large particles

within the plasma, or various combinations thereof (e.g. Eggins et al., 1998; Guillong and Günther, 2002; Rodushkin et al., 2002; Horn and Günther, 2003; Kroslakova and Günther, 2007).

Tests have shown that NIST612 is suitably matrix-matched for the analysis of rhyolite glasses (see section 3.4) and thus we use NIST612 $\left(\mathrm{SiO}_{2}=71.9 \mathrm{wt} \%\right)$ as the calibration standard for calculating all trace element abundances of the rhyolitic glasses analysed in this study. Between 3 and 5 spot analyses of the MPI-DING rhyolite glass standard (ATHO-G; $\mathrm{SiO}_{2}=75.6 \mathrm{wt} \%$ ) were performed at least once a day during sample data acquisition to monitor the precision and accuracy of the trace element data for the Site 1123 tephra samples (see Table A2-3 in the supplementary information). All analyte isotopes (Table 2-1) were chosen so that they were least affected by potential direct, oxide and doubly-charged interferences, and $\mathrm{ThO}+/ \mathrm{Th}+$ was maintained at $<2 \%$ for all analyses (typically $<1 \%$ ). Data acquired for every element from all LA-ICP-MS analyses in this dataset have been screened to remove analyses that were compromised by the accidental ablation of micro-phenocrysts below the glass surface (e.g. Harangi et al., 2005) to ensure that only data corresponding to pure glass shard material was integrated when calculating trace element abundances.

\subsection{Precision and accuracy of major and trace element data}

The precision and accuracy of both analytical techniques is briefly discussed here by reference to the glass standards analysed in this study (Tables A2-1 and A2-3). The basaltic glass VG-A99 yielded major element concentrations that, with the exception of $\mathrm{MnO}$, agreed to within $\pm 4 \%$ of the recommended reference values (Jarosewich et al., 1979). The rhyolitic glass ATHO-G reproduced to within $\pm 6 \%$ of the preferred reference values (Jochum et al., 2006) with the exception of the low concentration elements $\mathrm{MgO}(+12 \%), \mathrm{MnO}(+35 \%)$ and $\mathrm{Cl}(-50 \%)$. However, $\mathrm{Mg}$ and $\mathrm{Mn}$ concentrations of the glasses were also determined by LA-ICP-MS at much greater precision and accuracy than the EPMA measurements. The day-to-day precision of 
Table 2-1. $\quad$ Laser ablation inductively coupled plasma mass spectrometry (LA-ICP-MS): instrumental and analytical conditions

\section{Laser ablation}

Laser ablation system

Ablation mode

Spot size

Repetition rate

Laser power

Dwell time

\section{ICP-MS}

ICP-MS system

Acquisition mode

Detection mode

\section{Standards and Calibration}

Calibration standard

Secondary standard

Internal standard

\section{Method}

Background acquisition

Sample/standard data acquisition

Washout time

Measured isotopes

Integration time
New Wave 193 nm (deep UV) solid state

Static spot analyses

25 or $35 \mu \mathrm{m}$ (predominantly $35 \mu \mathrm{m}$ )

$5 \mathrm{~Hz}$

$0.4-0.6 \mathrm{~J} / \mathrm{cm}^{2}$

$5 \mathrm{~s}$

Agilent 7500CS

Peak hopping

Pulse counting

NIST612

MPI-DING ATHO-G (Icelandic rhyolite)

${ }^{43} \mathrm{Ca}$

$60 \mathrm{~s}$

$60 \mathrm{~s}$

$60 \mathrm{~s}$

${ }^{24} \mathrm{Mg},{ }^{43} \mathrm{Ca},{ }^{47} \mathrm{Ti},{ }^{51} \mathrm{~V},{ }^{53} \mathrm{Cr},{ }^{55} \mathrm{Mn},{ }^{59} \mathrm{Co},{ }^{60} \mathrm{Ni},{ }^{63} \mathrm{Cu},{ }^{66} \mathrm{Zn},{ }^{71} \mathrm{Ga}$, ${ }^{85} \mathrm{Rb},{ }^{88} \mathrm{Sr},{ }^{89} \mathrm{Y},{ }^{90} \mathrm{Zr},{ }^{93} \mathrm{Nb},{ }^{95} \mathrm{Mo},{ }^{133} \mathrm{Cs},{ }^{138} \mathrm{Ba},{ }^{139} \mathrm{La},{ }^{140} \mathrm{Ce}$, ${ }^{141} \mathrm{Pr},{ }^{146} \mathrm{Nd},{ }^{147} \mathrm{Sm},{ }^{153} \mathrm{Eu},{ }^{157} \mathrm{Gd},{ }^{159} \mathrm{~Tb},{ }^{163} \mathrm{Dy},{ }^{165} \mathrm{Ho},{ }^{166} \mathrm{Er}$, ${ }^{169} \mathrm{Tm},{ }^{172} \mathrm{Yb},{ }^{175} \mathrm{Lu},{ }^{178} \mathrm{Hf},{ }^{181} \mathrm{Ta},{ }^{182} \mathrm{~W},{ }^{208} \mathrm{~Pb},{ }^{232} \mathrm{Th},{ }^{238} \mathrm{U}$

${ }^{47} \mathrm{Ti},{ }^{95} \mathrm{Mo},{ }^{133} \mathrm{Cs}$ and from ${ }^{146} \mathrm{Nd}$ to ${ }^{238} \mathrm{U}=20 \mathrm{~ms}$

All others $=10 \mathrm{~ms}$

NIST612

Rastering $(2 \mu \mathrm{m} / \mathrm{s})$ beneath a $35 \mu \mathrm{m}$ spot

${ }^{43} \mathrm{Ca},{ }^{89} \mathrm{Y},{ }^{140} \mathrm{Ce},{ }^{208} \mathrm{~Pb}$ (\% RSD for each isotope typically $<5 \%$ )

Typically $<<1000 \mathrm{cps}$, always $<2000 \mathrm{cps}$

(ca. 1\% of NIST612 signal and ca. $10-15 \%$ of sample signal)

$\mathrm{ThO}+/ \mathrm{Th}+$ typically $<1 \%$, always $<2 \%$

$0.83-0.90 \mathrm{~L} / \mathrm{min}$

$77-90 \%$

$1500 \mathrm{~W}$

$1.72 \mathrm{~V}$

$4 \mathrm{~mm}$ 
EPMA measurements based on repeated analyses $(\mathrm{n}=29)$ of ATHO-G were: $\mathrm{SiO}_{2},<$ $\pm 2 \% ; \mathrm{Al}_{2} \mathrm{O}_{3},< \pm 4 \% ; \mathrm{CaO}, \mathrm{FeO}, \mathrm{K}_{2} \mathrm{O}$ and $\mathrm{Na}_{2} \mathrm{O}, \pm 8-15 \% ; \mathrm{TiO}_{2} \pm 30 \% ; \mathrm{MgO}$, $\mathrm{MnO}$, and $\mathrm{Cl} \pm 50-90 \%$ (\% 2 sd relative)

The rhyolitic glass standard ATHO-G was also repeatedly measured by LA-ICP-MS to monitor the accuracy and precision of the trace element data acquired throughout this study. The mean ( $\mathrm{n}=91)$ abundances of Ti, Mn, Zn, Rb, Sr, Y, Zr, Nb, Ba, La, Ce, Pr, Nd, Sm, Eu, Gd, Tb, Dy, Ho, Er, Tm, Yb, Lu, Hf, Ta, W, Pb, Th and U are within \pm ca. $5 \%$ of the recommended values (Jochum et al., 2006) (Fig. 2-2). The mean values determined for $\mathrm{V}$ and $\mathrm{Cu}$ are ca. 10\% lower than the Jochum et al. (2006) values, whereas $\mathrm{Cr}$, Ga, Mo and Cs are lower by ca. $15-20 \%$, and $\mathrm{Mg}$ is higher by ca. $15 \%$. The values of Co and Ni were significantly lower than preferred values (Jochum et al., 2006) by ca. 40-50\%. The deviations from the recommended values for these relatively low concentration elements $(\mathrm{Mg}, \mathrm{V}, \mathrm{Cr}, \mathrm{Co}, \mathrm{Ni}, \mathrm{Cu}, \mathrm{Ga}$, Mo, Cs) may be due to a number of factors: (a) the reference values for these elements in either ATHO-G or NIST612 (calibration standard) may be incorrect and poorly constrained; (b) mass interferences on the analyte isotopes in the NIST612 standard may be resulting in inaccurate data, (c) the signal intensity for an element may be small compared to background intensity (e.g. Co, Ni). For example, a significant part of the discrepancy $(\sim 17 \%)$ between the mean $\mathrm{Mg}$ concentration determined for ATHO-G and the recommended value (Jochum et al., 2006) is likely to be due to the utilised reference concentration of $\mathrm{Mg}$ in NIST612, which has a large uncertainty (77 \pm 30 ppm, Pearce et al., 1997), being 10-20\% too high. The day-today precision of LA-ICP-MS trace element data was typically \pm ca. 6\% (2 sd relative) for most elements of interest $(\mathrm{Mg}, \mathrm{Ti}, \mathrm{Mn}, \mathrm{Ga}, \mathrm{Rb}, \mathrm{Sr}, \mathrm{Y}, \mathrm{Zr}, \mathrm{Nb}, \mathrm{Ba}$, rare earth elements [REE], Hf, Ta, $\mathrm{Pb}, \mathrm{Th}, \mathrm{U})$. The reproducibility of low concentration elements (e.g. V, Ni, Cr, Co, Cu, Cs, Mo, W) and volatile elements (e.g. Zn) varied more widely (V, Cs and $\mathrm{W}$ typically $10-15 \%$; Ni, Cu, Co, and Mo typically $15-30 \%$; Cr typically $\sim 80 \%$ ) from day-to-day and these elements were generally not used for the correlation of the tephra layers. 


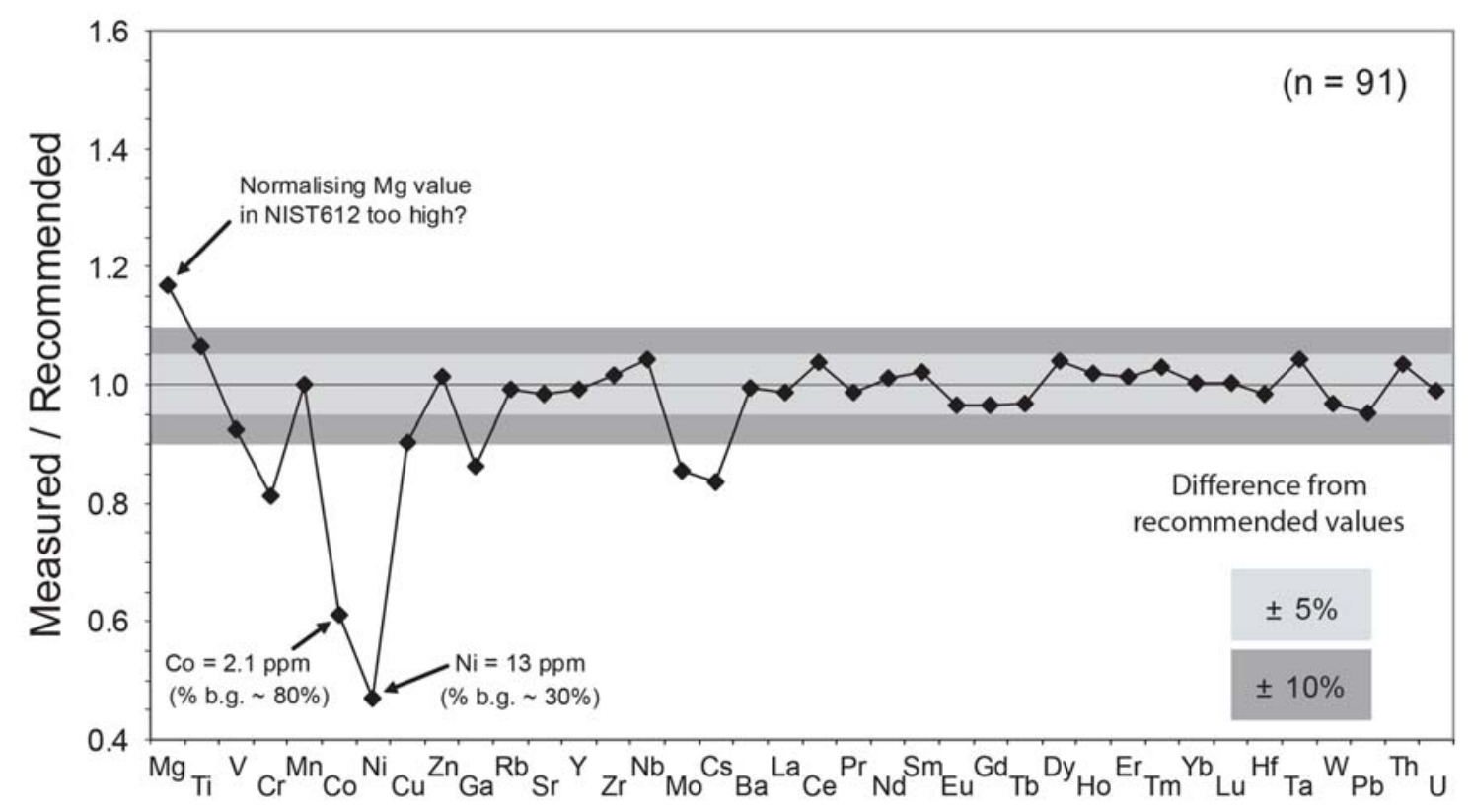

Figure 2-2. Normalised trace element data for the rhyolitic glass standard ATHO-G measured by LA-ICP-MS. Data represents the mean values ( $n=91,35 \mu$ m spot analyses) normalised to the recommended values (Jochum et al., 2006). Of the 38 minor and trace elements measured, 28 are accurate to within ca. $\pm 5 \%$ of the recommended reference values. The parameter \% b.g. is the percentage of total signal for an element that is made up from background (the gas blank) during a typical analysis of ATHO-G.

\subsection{Results}

\subsection{Major element data}

The mean major element compositions of glass shards from the tephra layers are presented in Table A3-1 (supplementary information). Where multiple geochemical glass populations were identified in a single tephra deposit a separate mean has been calculated for each population. All major element data have been normalised to $100 \%$ on an anhydrous basis. Mean analytical totals for individual samples typically varied from $93-97 \%$. Individual analyses that totalled $<91 \%$ were rejected. An exception to this was sample AT-382 (1123B-7H-5, $75.5 \mathrm{~cm})$, which was very hydrated and all shards returned totals ranging from $89.0-93.5 \%$. All the tephras analysed here fall within the rhyolite field on a total alkalis-silica (TAS) classification diagram (Fig. 2-3). Five samples contained one or two andesitic shards. However, out of 1314 major element analyses of glass shards only 7 andesitic shards were found. These andesitic shards are not incorporated in the mean compositions presented in Table A3-1 or shown on Fig. 2-3. 


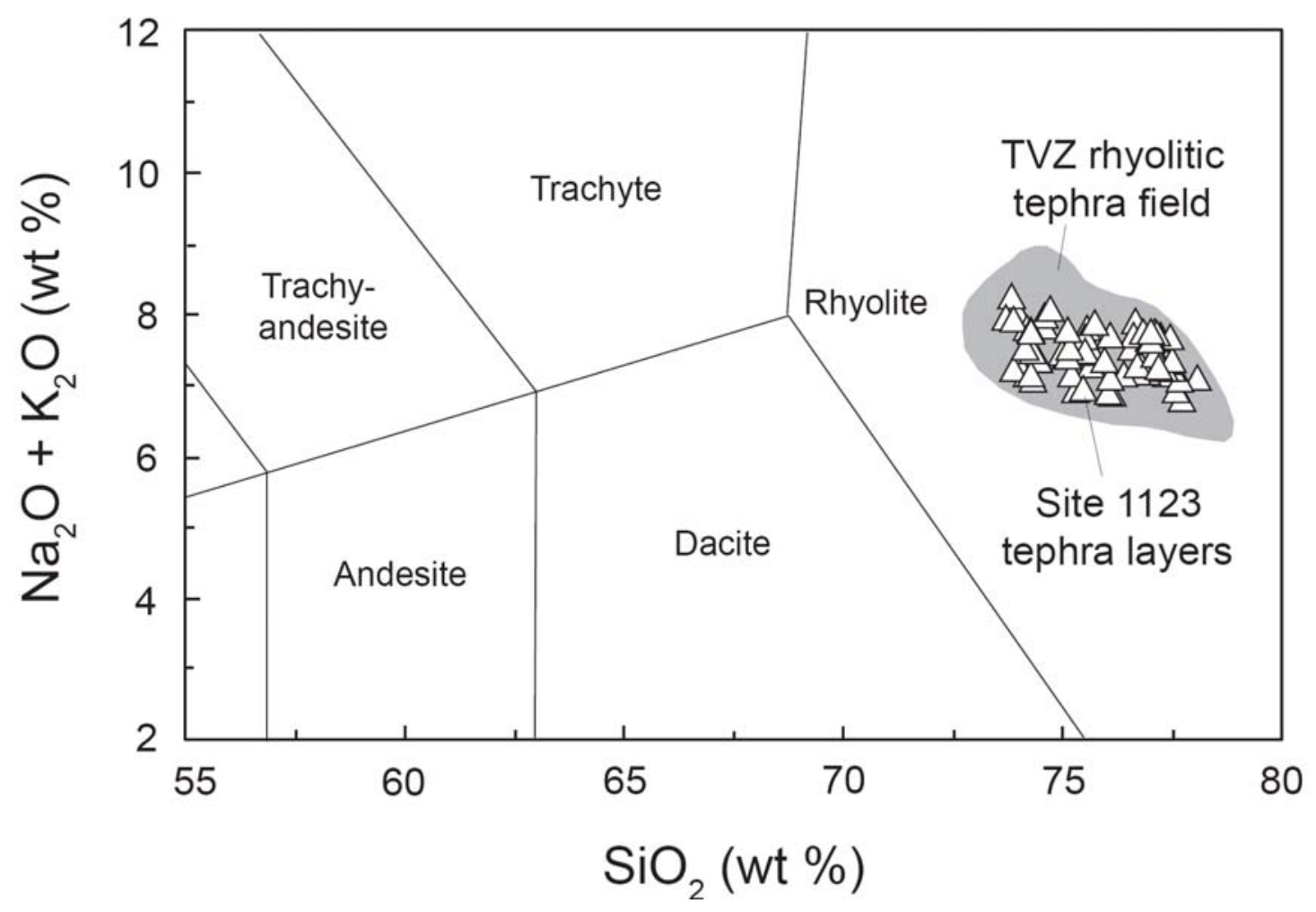

Figure 2-3. Total alkalis $\left(\mathrm{Na}_{2} \mathrm{O}+\mathrm{K}_{2} \mathrm{O}\right)$ versus silica $\left(\mathrm{SiO}_{2}\right)$ diagram of Site 1123 tephras. All Site 1123 tephra layers have rhyolitic compositions using the classification scheme of Le Maitre (1984).

Major element data for Site 1123 tephras reveal broad trends in silicic geochemistry throughout the Quaternary evolution of the TVZ. Selected major and minor element data determined by EPMA are shown to illustrate these trends (Fig. 2-4). (Note: several tephra layers were found to be repeated in the $1123 \mathrm{~A}$ and $\mathrm{C}$ cores as discussed later in section 5.3; data from these repeated tephras are not included in Fig. 2-4). The tephras are separated into four groups based on stratigraphic position that correspond to the approximate age ranges shown in the legend of Figure 2-4a. These groups appear to comprise four broad silicic melt types (Fig. 2-4). The dominant compositional fields of three of these melt types are marked by grey shading (Fig. 2-4). Although these melt types do have some overlapping compositions, each of these three types can be distinguished on the basis of eruption time and major element chemistry. The oldest melt type (ca. $1.40-1.65 \mathrm{Ma} ; 56-65$ mbsf [metres below seafloor]) is characterised by tephras that have less evolved compositions (lower $\mathrm{SiO}_{2}$, higher $\mathrm{FeO}_{\mathrm{t}}$ ) when compared to the youngest melt type $(<$ ca. $0.85 \mathrm{Ma} ;<34 \mathrm{mbsf}$ ). However, an exception to this is a number of low $\mathrm{Ti}$ 
samples (ca. $1.60 \mathrm{Ma}$ ) that have chemistry unlike other tephra layers deposited at Site 1123 during the same time period (ca. $1.40-1.65 \mathrm{Ma}$ ) or at anytime in the Quaternary, and are therefore grouped separately. These evolved, low Ti, samples are characterised by high $\mathrm{SiO}_{2}$ and $\mathrm{K}_{2} \mathrm{O}$ and low $\mathrm{TiO}_{2}, \mathrm{MgO}, \mathrm{FeO}_{\mathrm{t}}$ and $\mathrm{CaO}$ (Fig. 2-4 and Table A3-1). The remaining group (ca. 0.85 - $1.40 \mathrm{Ma}$; 34-56 mbsf) contains compositions that overlap the other two groups that pre- and post-date this eruption interval, but also includes a fourth melt type that is characterised by higher $\mathrm{CaO}$ and $\mathrm{TiO}_{2}$ at a given $\mathrm{SiO}_{2}$, and higher $\mathrm{MgO}$ and $\mathrm{CaO}$ at a given $\mathrm{FeO}_{\mathrm{t}}$ than the pre-1.40 $\mathrm{Ma}$ and post-0.85 Ma tephras.

\subsection{Trace element data}

The mean trace element compositions of glass shards from the tephra layers are presented in Table A4-1 (supplementary information). Trace element data were not obtained for every glass shard analysed by EPMA due to occasional problems with partial or complete shattering of glass shards or penetration of compositional boundaries during analyses.

The broad temporal trends in TVZ silicic geochemistry that are revealed by major element data (Fig. 2-4) are also evident in the trace element data (Fig. 2-5). The oldest Site 1123 tephras (ca. 1.40 - 1.65 Ma group) are again characterised by shards with less evolved compositions (e.g. higher $\mathrm{Zr}$ ) compared to the youngest tephras (< ca. $0.85 \mathrm{Ma}$ group). Trace element data further highlight the significantly different chemistry of the low Ti samples (ca. 1.60 Ma) compared to other Site 1123 tephra layers deposited during the same time period (ca. $1.40-1.65 \mathrm{Ma}$ ) and all the other Quaternary Site 1123 tephra layers. The same four melt groups defined by major element data (Fig. 2-4) are also reflected in trace element data (Fig. 2-5). On some plots (Fig. 2-5a, b, e, g) only three of these groups are readily distinguished, whereas other plots (Fig. 2-5c, d, f, h) clearly demonstrate the presence of the four melt types. Despite revealing the same four melt types as were shown by major element data, the trace element data indicate a more complex petrogenetic story. This is typified by 

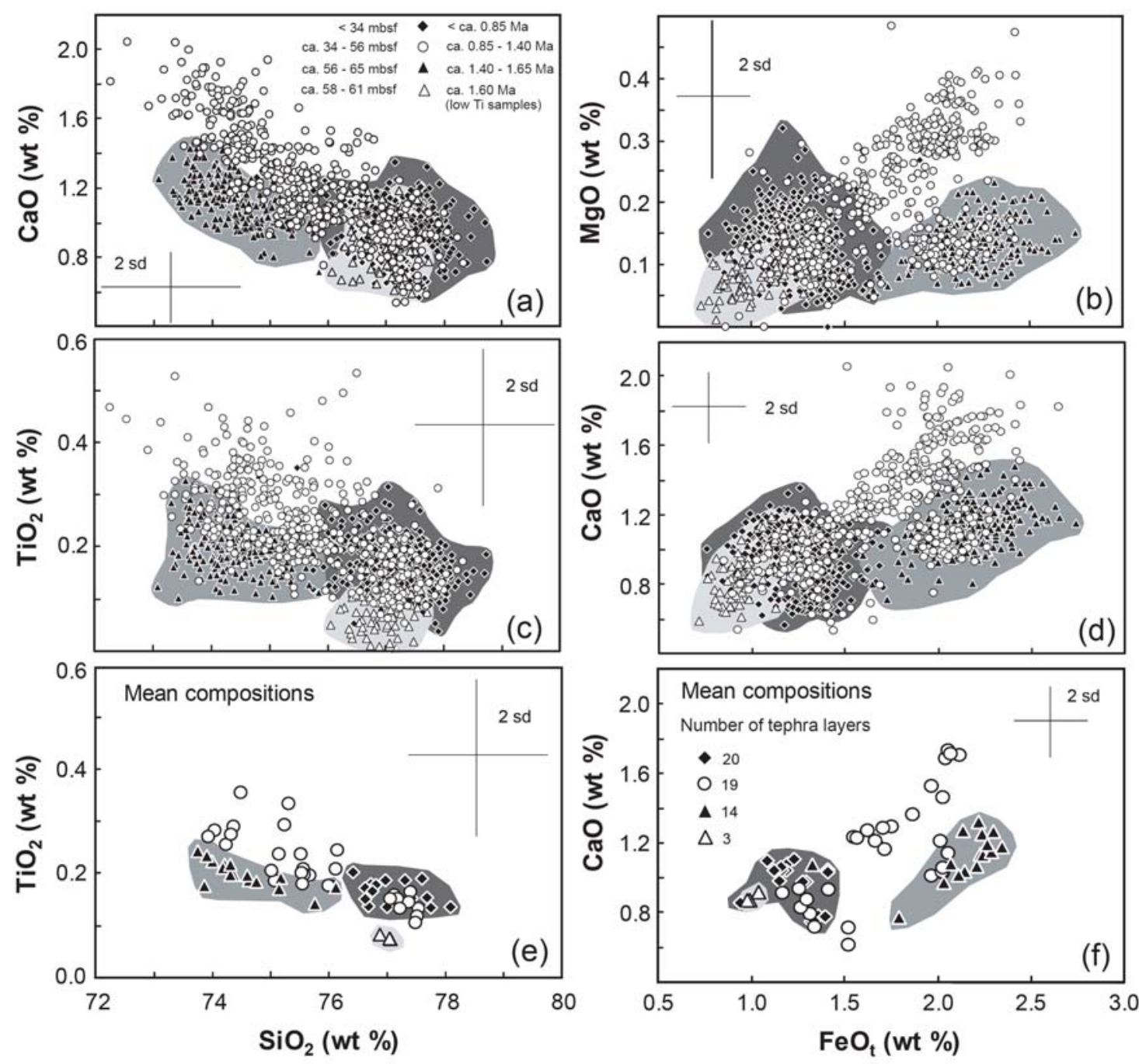

Figure 2-4. Selected major and minor element data for Site 1123 tephra layers. For a-d each symbol represents an individual analysis by EMPA $(n=948$; repeated tephra layers from the disturbed sections in $1123 \mathrm{~A}$ and $\mathrm{C}$ cores are omitted - see section 5.3). For e \& f each symbols represents the mean composition of each tephra layer.

Groupings are based on depths within the three sediment cores: < $34 \mathrm{mbsf}$, filled diamonds; ca. $34-56 \mathrm{mbsf}$, open circles; ca. 56 - 65 mbsf, filled triangles. Low Ti samples (ca. 58 - 61 mbsf, open triangles) are chemically distinct to the $56-65$ mbsf group and are therefore grouped separately. Shaded fields are shown to illustrate the dominant compositions for the < 34 mbsf (dark grey), ca. 56 - 65 mbsf (medium grey) and low Ti (light grey) groupings. (a) $\mathrm{CaO}$ versus $\mathrm{SiO}_{2}$ (wt\%), (b) $\mathrm{MgO}$ versus $\mathrm{FeO}_{\mathrm{t}}$ (wt\%), (c) $\mathrm{TiO}_{2}$ versus $\mathrm{SiO}_{2}$ (wt\%), (d) $\mathrm{CaO}$ versus $\mathrm{FeO}$ (wt\%), (e) mean $\mathrm{TiO}_{2}$ versus $\mathrm{SiO}_{2}$ (wt\%), (f) mean $\mathrm{CaO}$ versus $\mathrm{FeO}_{\mathrm{t}}(\mathrm{wt} \%$ ).

the plot of Y/Th versus $\mathrm{Zr}$ (Fig. 2-5e, g), in which the youngest group of tephras $(<$ $0.85 \mathrm{Ma}$ ) are clearly separated into at least three further distinct subgroups. The mean major and trace element composition of tephra layers representative of each melt type are presented in Table 2-2. All individual tephra layers exhibit at least a small degree of trace element variation among different glass shards from a single sample that is greater than the analytical uncertainties of the method (ca. $\pm 5 \%$ ), even though many of these samples would be considered compositionally homogeneous on the basis of EPMA data alone. For example, tephra layer AT-331 has Rb that varies from ca. 105 to $165 \mathrm{ppm}$. These trace element variations most likely reflect small-scale 

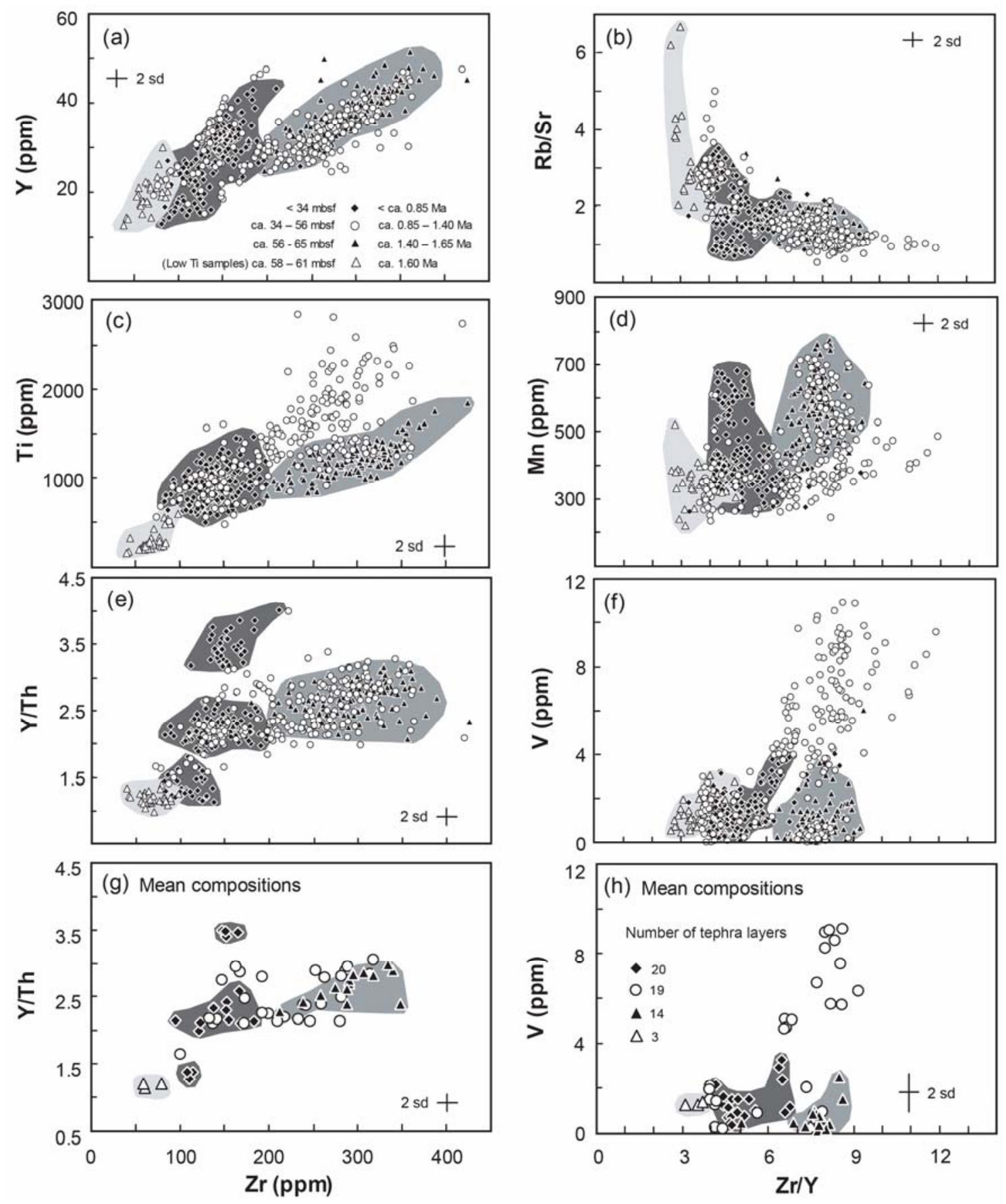

Figure 2-5. Selected minor and trace element data for Site 1123 tephras. For a-f each symbol represents an individual analysis by LA-ICP-MS ( $n=540$; repeated tephra layers from the disturbed sections in 1123A and C cores are omitted - see section 5.3). For $g \& h$ each symbol represents the mean composition of each tephra layer. Shaded fields and groupings are as described in Fig. 2-4. (a) $Y$ versus $Z r$ (ppm), (b) Rb/Sr versus $Z r / Y$, (c) Ti versus $\mathrm{Zr}(\mathrm{ppm})$, (d) Mn (ppm) versus $\mathrm{Zr} / \mathrm{Y}$, (e) Y/Th versus $\mathrm{Zr}(\mathrm{ppm})$, (f) $\mathrm{V}$ (ppm) versus $\mathrm{Zr} / \mathrm{Y}$, (g), mean $\mathrm{Y} / \mathrm{Th}$ versus $\mathrm{Zr}$ (ppm), (h) mean $V$ (ppm) versus $\mathrm{Zr} / Y$.

compositional variations in magma chambers prior to eruption. Individual tephra layers that exhibit marked major element heterogeneity, as might be expected, also exhibit the strongest variations in trace element concentrations. For example, the $\mathrm{FeO}$ 
and $\mathrm{CaO}$ concentrations in individual shards from tephra layer AT-402 range from 0.70 to $1.31 \mathrm{wt} \%$ and 0.59 to $1.22 \mathrm{wt} \%$ respectively. Individual shards from the same sample have a range in $\mathrm{Sr}$ concentrations from 16.5 to $89.1 \mathrm{ppm}$ (over a factor of 5), Ba from 144 to $941 \mathrm{ppm}$ (over a factor of 6) and $\mathrm{Eu}$ from 0.14 to 0.76 (over a factor of 5).

\subsection{Key Quaternary Site 1123 tephra layers}

Alloway et al. (2005) used major element glass chemistry to correlate a number of Site 1123 tephras to five well-known TVZ tephras. The 'named' tephras identified by Alloway et al. (2005) were the Kawakawa, Omataroa, Kidnappers B, Potaka and Ototoka tephras. Major and trace element data obtained in this study support these correlations with two exceptions: (1) the Kidnappers B Tephra, and (2) the Ototoka Tephra. The Kidnappers B Tephra was first named and described by Black (1992) for a tuff sequence occurring in the coastal cliffs of Cape Kidnappers, southern Hawkes Bay, New Zealand. The major element glass composition of the Kidnappers B Tephra reported by Black (1992) and Shane et al. (1996), was uniform within analytical error. For example, the $\mathrm{FeO}$ and $\mathrm{CaO}$ contents in the Kidnappers $\mathrm{B}$ Tephra of Black (1992) varied by ca. $\pm 10 \%$ ( 2 sd relative). However, the two Site 1123 tephra layers (AT-273, AT-377) that Alloway et al. (2005) correlated to the Kidnappers B Tephra show significant heterogeneity in their major element compositions, with the $\mathrm{FeO}$ and $\mathrm{CaO}$ contents varying by ca. $\pm 30 \%$ ( 2 sd relative). The Ototoka Tephra has been identified in shallow-marine sediments and correlated between several localities in the Wanganui Basin, New Zealand, on the basis of indistinguishable major element glass chemistry (Pillans et al., 2005). Data obtained here for the three Site 1123 tephra layers (AT-271, AT-375, AT-344) proposed by Alloway et al. (2005) to be correlatives of the Ototoka Tephra, are compositionally offset (e.g. all samples have lower $\mathrm{FeO}_{\mathrm{t}}$ ) in comparison to the published compositions of the Ototoka Tephra in the Wanganui Basin (Pillans et al., 2005). In this study, 19 tephra layers from the three Site 1123 sediment cores (A, B and C) are correlated to 7-8 onshore TVZ-derived tephra deposits. The tephras identified here are: Kawakawa Tephra (AT-331), Omataroa Tephra (AT-332, AT-376, A-9, A10), Rotoehu Tephra (A-11), Potaka Tephra (AT-338), correlative(s) to the Unit D and/or Ahuroa eruptions (AT-378, AT-379, AT-380), correlative to AT-362 of 
Pillans et al. (2005) preserved in the Wanganui Basin (A-19, AT-385, A-18), and Mangapipi Tephra (AT-274, AT-408, CN, AT-400, AT-374, AT-339). Due to a sparsity of existing single shard trace element data for onland New Zealand tephras, the majority of these 'named' Site 1123 tephras have been identified on the basis of major element chemistry (Fig. 2-6) and additional constraints provided by magnetic polarity and stratigraphic relationships. However, the correlation of Site 1123 tephras to the Kawakawa, Rotoehu and Potaka tephras are also verified here by comparison of single shard trace element chemistry to onshore correlatives analysed in this study (Fig. 2-6).

The published ages of the tephras at Site 1123 (Alloway et al., 2005; Pillans et al., 2005) have been assigned on the basis of their position within the Site 1123 composite benthic oxygen isotope stratigraphy (Hall et al., 2001; Harris, 2002). The composite stratigraphy and, hence, the composite age model and ages assigned to the Site 1123 tephras, are re-evaluated in section 5.4.

\subsection{Discussion}

\subsection{Tephra trace element 'fingerprinting' as a chronostratigraphic tool}

The concentrations of trace elements in magmas are more strongly affected by magma differentiation processes (fractional crystallisation and assimilation of continental crust) and source processes (mantle heterogeneity and variable degrees of partial melting) than major elements. For example, only $0.05 \%$ fractionation of zircon in a rhyolitic melt with $300 \mathrm{ppm} \mathrm{Zr}$ would reduce the concentration of $\mathrm{Zr}$ in the residual melt by almost $50 \%$. Thus, trace elements may potentially provide a more sensitive geochemical fingerprint for tephras than major elements. Major and trace element data acquired for two late Quaternary TVZ tephras recovered from Site 1123 can be used to demonstrate that this is the case (Fig. 2-7). A plot of $\mathrm{CaO}$ versus $\mathrm{FeO}_{\mathrm{t}}$ (and data from Table A3-1) illustrates the complete major element compositional overlap for the Kawakawa ( $27.1 \mathrm{ka}$; Lowe et al., 2008) and Omataroa ( 31.6 ka; Shane et al., 2006) tephras recovered from Site 1123 (Fig. 27a). In contrast, the $\mathrm{Rb}$ and $\mathrm{Ba}$ abundances of glass shards from these same two tephras are quite different (Fig. 2-7b). The tephra layer A-9 overlies layer A-10 by 
Table 2-2 Major and trace element compositions of representative Site 1123 tephras

\begin{tabular}{|c|c|c|c|c|c|c|c|c|c|c|c|c|c|c|c|c|}
\hline $\begin{array}{l}\text { Sample no. } \\
\text { Sample } \\
\text { details a }\end{array}$ & \multicolumn{2}{|c|}{$\begin{array}{l}\text { AT-331 } \\
1123 \mathrm{~A}-1 \mathrm{H}-1\end{array}$} & \multicolumn{2}{|c|}{$\begin{array}{l}\text { AT-272 } \\
1123 \mathrm{~A}-2 \mathrm{H}-6\end{array}$} & \multicolumn{2}{|c|}{$\begin{array}{l}\text { AT-396 } \\
1123 \mathrm{C}-4 \mathrm{H}-6\end{array}$} & \multicolumn{2}{|c|}{$\begin{array}{l}\mathbf{A - 1 4} \\
1123 \mathrm{C}-5 \mathrm{H}-1\end{array}$} & \multicolumn{2}{|c|}{$\begin{array}{l}\text { AT-408 } \\
1123 \mathrm{C}-7 \mathrm{H}-2\end{array}$} & \multicolumn{2}{|c|}{$\begin{array}{l}\text { A-22 } \\
1123 \text { C-7H-4 }\end{array}$} & \multicolumn{2}{|c|}{$\begin{array}{l}\text { AT-343 } \\
1123 \mathrm{~A}-7 \mathrm{H}-4\end{array}$} & \multicolumn{2}{|c|}{$\begin{array}{l}\text { CO } \\
1123 \mathrm{~B}-7 \mathrm{H}-6\end{array}$} \\
\hline Base $^{b}$ & \multicolumn{2}{|c|}{$101 \mathrm{~cm}$} & \multicolumn{2}{|c|}{$70 \mathrm{~cm}$} & \multicolumn{2}{|c|}{$73 \mathrm{~cm}$} & \multicolumn{2}{|c|}{$93 \mathrm{~cm}$} & \multicolumn{2}{|c|}{$127 \mathrm{~cm}$} & \multicolumn{2}{|c|}{$63 \mathrm{~cm}$} & \multicolumn{2}{|c|}{$112 \mathrm{~cm}$} & \multicolumn{2}{|c|}{$15.5 \mathrm{~cm}$} \\
\hline $\mathrm{mbsf}^{\mathrm{c}}$ & \multicolumn{2}{|c|}{$1.01 \mathrm{~m}$} & \multicolumn{2}{|c|}{$14.3 \mathrm{~m}$} & \multicolumn{2}{|c|}{$36.23 \mathrm{~m}$} & \multicolumn{2}{|c|}{$38.43 \mathrm{~m}$} & \multicolumn{2}{|c|}{$59.27 \mathrm{~m}$} & \multicolumn{2}{|c|}{$61.63 \mathrm{~m}$} & 59.22 & & 58.56 & \\
\hline Group $^{d}$ & $<$ ca. & $0.85 \mathrm{Ma}$ & $<$ ca. & $0.85 \mathrm{Ma}$ & $\begin{array}{l}\text { ca. } 0.8 \\
\mathrm{Ma}\end{array}$ & $85-1.40$ & $\begin{array}{l}\text { ca. } 0.8 \\
\mathrm{Ma}\end{array}$ & $35-1.40$ & $\begin{array}{l}\text { ca. } 1.4 \\
\mathrm{Ma}\end{array}$ & $40-1.65$ & $\begin{array}{l}\text { ca. } 1 .{ }^{\circ} \\
\mathrm{Ma}\end{array}$ & $0-1.65$ & $\begin{array}{l}\text { ca. } 1.6 \\
\text { (low } 1\end{array}$ & $\begin{array}{l}50 \mathrm{Ma} \\
\text { ii) }\end{array}$ & $\begin{array}{l}\text { ca. } 1 .( \\
\text { Ti) }\end{array}$ & $0 \mathrm{Ma}$ (low \\
\hline EPMA & Mean & $2 s d^{\mathrm{h}}$ & & & & & & & & & & & & & & \\
\hline$n^{e}$ & 62 & & 15 & & 36 & & 24 & & 18 & & 17 & & 31 & & 26 & \\
\hline $\mathrm{SiO}_{2}$ (wt. \%) & 77.4 & 0.84 & 77.8 & 1.02 & 74.5 & 2.51 & 75.1 & 1.92 & 74.4 & 0.66 & 74.3 & 0.63 & 76.9 & 0.78 & 77.1 & 0.76 \\
\hline $\mathrm{TiO}_{2}$ & 0.15 & 0.07 & 0.14 & 0.07 & 0.36 & 0.21 & 0.24 & 0.10 & 0.20 & 0.09 & 0.20 & 0.09 & 0.08 & 0.08 & 0.08 & 0.08 \\
\hline $\mathrm{Al}_{2} \mathbf{O}_{3}$ & 12.6 & 0.45 & 12.5 & 0.44 & 13.7 & 0.99 & 13.7 & 0.96 & 14.0 & 0.32 & 13.7 & 0.34 & 13.1 & 0.57 & 13.0 & 0.33 \\
\hline $\mathrm{FeO}_{\mathrm{t}}{ }^{\mathrm{f}}$ & 1.19 & 0.25 & 1.29 & 0.27 & 2.03 & 0.81 & 1.71 & 0.48 & 2.34 & 0.29 & 2.26 & 0.32 & 0.99 & 0.25 & 1.04 & 0.28 \\
\hline MnO & 0.10 & 0.11 & 0.11 & 0.13 & 0.12 & 0.12 & 0.10 & 0.08 & 0.13 & 0.08 & 0.14 & 0.10 & 0.10 & 0.10 & 0.09 & 0.11 \\
\hline MgO & 0.14 & 0.05 & 0.27 & 0.37 & 0.33 & 0.28 & 0.24 & 0.13 & 0.13 & 0.04 & 0.15 & 0.06 & 0.09 & 0.06 & 0.08 & 0.05 \\
\hline $\mathrm{CaO}$ & 1.08 & 0.17 & 0.98 & 0.20 & 1.46 & 0.51 & 1.29 & 0.42 & 1.18 & 0.14 & 1.19 & 0.17 & 0.87 & 0.34 & 0.92 & 0.31 \\
\hline $\mathrm{Na}_{2} \mathrm{O}$ & 4.06 & 0.50 & 3.53 & 0.84 & 4.21 & 0.79 & 3.97 & 0.37 & 4.17 & 0.53 & 4.37 & 0.15 & 3.46 & 0.40 & 3.58 & 0.37 \\
\hline $\mathbf{K}_{2} \mathbf{O}$ & 3.08 & 0.33 & 3.26 & 0.29 & 3.14 & 0.64 & 3.42 & 0.35 & 3.29 & 0.32 & 3.41 & 0.24 & 4.28 & 0.93 & 4.04 & 0.73 \\
\hline $\mathrm{Cl}$ & 0.21 & 0.08 & 0.19 & 0.05 & 0.20 & 0.06 & 0.20 & 0.08 & 0.21 & 0.08 & 0.21 & 0.06 & 0.14 & 0.05 & 0.16 & 0.06 \\
\hline Total $^{\mathrm{g}}$ & 94.70 & 3.98 & 94.73 & 2.02 & 94.98 & 2.48 & 96.47 & 3.68 & 93.88 & 2.45 & 94.88 & 1.95 & 94.05 & 2.73 & 95.29 & 1.52 \\
\hline LA-ICP-MS & & & & & & & & & & & & & & & & \\
\hline & 8 & & 13 & & 23 & & 13 & & 10 & & 11 & & 9 & & 13 & \\
\hline Mg (ppm) & 991 & 142 & 798 & 253 & 2264 & 1582 & 1739 & 1010 & 1014 & 210 & 1055 & 329 & 516 & 365 & 690 & 559 \\
\hline $\mathrm{Ti}$ & 911 & 171 & 916 & 260 & 2164 & 1270 & 1529 & 696 & 1394 & 251 & 1112 & 237 & 279 & 255 & 365 & 270 \\
\hline V & 1.51 & 1.12 & 0.77 & 0.40 & 7.55 & 15.1 & 5.71 & 4.35 & 0.36 & 0.53 & 0.86 & 0.81 & 1.25 & 1.50 & 1.38 & 1.40 \\
\hline $\mathrm{Cr}$ & 3.18 & 7.25 & 1.57 & 2.77 & 3.06 & 9.24 & 1.67 & 4.35 & 1.02 & 1.66 & 1.38 & 2.43 & 0.68 & 1.69 & 4.25 & 9.64 \\
\hline Mn & 419 & 86.3 & 367 & 92.3 & 511 & 139 & 383 & 111 & 678 & 102 & 531 & 98.0 & 311 & 86.6 & 352 & 67.5 \\
\hline Co & 0.65 & 0.34 & 0.53 & 0.33 & 1.23 & 1.74 & 1.49 & 0.97 & 0.62 & 0.61 & 0.78 & 0.60 & 0.48 & 0.42 & 0.85 & 1.22 \\
\hline $\mathrm{Ni}$ & 0.41 & 0.74 & 0.39 & 0.63 & 0.99 & 1.72 & 2.49 & 4.63 & 0.63 & 2.09 & 2.82 & 4.08 & 2.27 & 4.19 & 4.23 & 8.33 \\
\hline $\mathbf{C u}$ & 2.64 & 1.88 & 2.32 & 0.50 & 2.73 & 1.87 & 6.60 & 8.00 & 2.89 & 1.11 & 13.7 & 15.1 & 3.26 & 2.55 & 5.42 & 8.23 \\
\hline Zn & 45.5 & 23.8 & 40.1 & 27.0 & 33.5 & 35.9 & 44.5 & 18.5 & 70.1 & 42.0 & 45.6 & 26.2 & 17.9 & 12.7 & 23.9 & 16.4 \\
\hline Ga & 14.7 & 5.89 & 14.0 & 4.33 & 14.3 & 4.90 & 16.0 & 3.08 & 18.0 & 2.88 & 16.4 & 2.69 & 11.1 & 3.32 & 13.3 & 3.35 \\
\hline $\mathbf{R b}$ & 126 & 41.8 & 123 & 38.3 & 100 & 36.7 & 133 & 24.4 & 116 & 20.0 & 131 & 25.6 & 139 & 48.0 & 154 & 30.3 \\
\hline $\mathrm{Sr}$ & 84.5 & 14.7 & 77.7 & 18.8 & 103 & 23.9 & 102 & 48.2 & 89.7 & 8.98 & 95.3 & 25.1 & 55.2 & 33.2 & 60.8 & 37.3 \\
\hline $\mathbf{Y}$ & 22.7 & 3.65 & 30.3 & 6.15 & 33.1 & 9.16 & 27.2 & 6.30 & 42.9 & 6.48 & 38.2 & 8.30 & 17.3 & 4.70 & 21.5 & 4.54 \\
\hline $\mathrm{Zr}$ & 121 & 15.0 & 155 & 44.1 & 282 & 71.4 & 233 & 113 & 334 & 53.3 & 288 & 60.7 & 60.6 & 21.8 & 79.3 & 19.0 \\
\hline Nb & 7.62 & 2.15 & 10.1 & 3.12 & 10.6 & 2.74 & 9.62 & 1.94 & 13.0 & 2.29 & 11.8 & 2.14 & 4.85 & 2.19 & 5.95 & 1.23 \\
\hline Mo & 1.74 & 1.97 & 1.49 & 0.42 & 1.34 & 0.76 & 3.89 & 5.07 & 2.17 & 0.84 & 1.90 & 0.67 & 0.98 & 0.42 & 1.27 & 0.87 \\
\hline Cs & 6.37 & 2.06 & 5.04 & 1.65 & 4.79 & 1.84 & 6.15 & 1.23 & 6.30 & 1.03 & 6.75 & 1.29 & 8.44 & 3.72 & 9.23 & 2.00 \\
\hline Ва & 663 & 202 & 791 & 195 & 698 & 172 & 812 & 132 & 814 & 104 & 827 & 152 & 636 & 219 & 695 & 301 \\
\hline La & 21.8 & 5.09 & 27.5 & 5.77 & 25.3 & 6.22 & 27.1 & 5.49 & 31.4 & 4.63 & 31.6 & 6.54 & 20.8 & 7.17 & 25.1 & 8.43 \\
\hline
\end{tabular}




\section{Table 2-2 continued}

\begin{tabular}{|c|c|c|c|c|c|c|c|c|c|c|c|c|c|c|c|c|}
\hline \multirow{2}{*}{$\begin{array}{l}\text { Sample no. } \\
\mathrm{Ce}\end{array}$} & \multicolumn{2}{|c|}{ AT-331 } & \multicolumn{2}{|c|}{ AT-272 } & \multicolumn{2}{|c|}{ AT-396 } & \multicolumn{2}{|l|}{ A-14 } & \multicolumn{2}{|c|}{ AT-408 } & \multicolumn{2}{|l|}{ A-22 } & \multicolumn{2}{|c|}{ AT-343 } & \multicolumn{2}{|l|}{ CO } \\
\hline & 46.9 & 15.3 & 53.3 & 16.2 & 49.2 & 13.7 & 59.9 & 11.2 & 67.6 & 10.4 & 66.1 & 12.9 & 41.8 & 13.1 & 47.6 & 14.4 \\
\hline Pr & 4.80 & 1.04 & 5.98 & 1.48 & 5.84 & 1.37 & 6.46 & 1.25 & 7.65 & 1.24 & 7.24 & 1.28 & 4.12 & 1.27 & 4.80 & 1.10 \\
\hline Nd & 17.6 & 4.78 & 24.0 & 5.45 & 24.4 & 5.34 & 24.7 & 5.64 & 32.9 & 5.16 & 30.2 & 5.92 & 15.1 & 5.24 & 17.9 & 4.35 \\
\hline Sm & 3.46 & 0.64 & 4.82 & 1.33 & 5.32 & 1.75 & 5.12 & 1.18 & 7.02 & 1.22 & 6.56 & 1.41 & 2.83 & 0.70 & 3.29 & 0.77 \\
\hline Eu & 0.63 & 0.22 & 0.76 & 0.21 & 1.02 & 0.30 & 0.89 & 0.38 & 1.17 & 0.19 & 1.05 & 0.32 & 0.28 & 0.13 & 0.33 & 0.22 \\
\hline Gd & 3.22 & 1.51 & 4.89 & 1.37 & 5.34 & 1.61 & 4.44 & 0.86 & 6.97 & 1.62 & 6.37 & 1.18 & 2.47 & 0.89 & 2.95 & 0.92 \\
\hline Tb & 0.56 & 0.19 & 0.76 & 0.16 & 0.88 & 0.26 & 0.70 & 0.13 & 1.09 & 0.18 & 1.01 & 0.22 & 0.40 & 0.11 & 0.47 & 0.13 \\
\hline Dy & 3.70 & 0.90 & 5.25 & 1.22 & 5.83 & 1.92 & 4.90 & 1.35 & 7.69 & 1.53 & 6.52 & 1.57 & 2.68 & 0.81 & 3.26 & 0.71 \\
\hline Но & 0.79 & 0.28 & 1.08 & 0.27 & 1.26 & 0.28 & 0.99 & 0.23 & 1.55 & 0.32 & 1.38 & 0.33 & 0.58 & 0.19 & 0.67 & 0.22 \\
\hline Er & 2.25 & 0.60 & 3.31 & 0.77 & 3.54 & 1.09 & 2.92 & 0.80 & 4.73 & 0.96 & 4.09 & 0.84 & 1.85 & 0.57 & 2.16 & 0.54 \\
\hline Tm & 0.38 & 0.16 & 0.48 & 0.09 & 0.57 & 0.16 & 0.46 & 0.09 & 0.69 & 0.15 & 0.63 & 0.14 & 0.28 & 0.12 & 0.34 & 0.15 \\
\hline Yb & 2.69 & 0.47 & 3.38 & 0.60 & 3.82 & 1.00 & 3.20 & 0.73 & 4.92 & 1.05 & 4.02 & 0.98 & 2.16 & 0.68 & 2.36 & 0.71 \\
\hline Lu & 0.39 & 0.14 & 0.52 & 0.14 & 0.59 & 0.20 & 0.48 & 0.12 & 0.73 & 0.15 & 0.65 & 0.14 & 0.32 & 0.11 & 0.38 & 0.15 \\
\hline Hf & 3.26 & 1.17 & 4.87 & 0.73 & 7.01 & 2.28 & 5.85 & 1.99 & 8.37 & 1.54 & 7.30 & 1.50 & 2.31 & 0.62 & 2.82 & 0.73 \\
\hline Та & 0.73 & 0.19 & 0.93 & 0.23 & 0.80 & 0.27 & 0.75 & 0.15 & 0.98 & 0.14 & 0.87 & 0.16 & 0.71 & 0.38 & 0.86 & 0.17 \\
\hline W & 1.64 & 0.76 & 1.68 & 0.58 & 1.13 & 0.70 & 1.64 & 0.40 & 1.52 & 0.38 & 1.46 & 0.25 & 2.09 & 0.85 & 2.05 & 0.55 \\
\hline $\mathbf{P b}$ & 15.2 & 4.56 & 18.9 & 6.47 & 15.3 & 5.74 & 20.0 & 4.67 & 20.7 & 3.37 & 20.6 & 2.85 & 17.9 & 4.96 & 20.6 & 3.83 \\
\hline Th & 11.4 & 2.32 & 14.1 & 2.96 & 11.8 & 3.35 & 12.6 & 2.71 & 14.4 & 2.33 & 14.6 & 2.33 & 15.2 & 4.69 & 18.0 & 2.18 \\
\hline $\mathbf{U}$ & 2.77 & 0.75 & 2.94 & 0.93 & 2.34 & 0.92 & 3.25 & 0.65 & 3.08 & 0.54 & 3.22 & 0.56 & 3.46 & 1.44 & 3.65 & 0.83 \\
\hline $\mathrm{Rb} / \mathrm{Sr}$ & 1.50 & 0.44 & 1.60 & 0.66 & 0.98 & 0.38 & 1.39 & 0.88 & 1.29 & 0.17 & 1.39 & 0.42 & 2.81 & 2.84 & 2.86 & 2.65 \\
\hline $\mathrm{Zr} / \mathrm{Th}$ & 10.7 & 1.73 & 11.2 & 4.34 & 24.1 & 4.03 & 18.7 & 9.44 & 23.2 & 1.52 & 19.7 & 3.52 & 4.03 & 1.47 & 4.41 & 1.02 \\
\hline $\mathbf{E u} / \mathbf{E u}^{*}{ }^{i}$ & 0.58 & 0.20 & 0.48 & 0.11 & 0.59 & 0.17 & 0.57 & 0.17 & 0.51 & 0.12 & 0.49 & 0.10 & 0.33 & 0.12 & 0.33 & 0.20 \\
\hline $\mathrm{Rb} / \mathrm{Sm}$ & 36.5 & 8.78 & 25.5 & 6.15 & 19.3 & 9.16 & 26.1 & 5.25 & 16.6 & 2.56 & 20.1 & 3.16 & 49.1 & 13.0 & 47.5 & 13.7 \\
\hline $\mathbf{Z r} / \mathbf{Y}$ & 5.35 & 0.69 & 5.17 & 1.96 & 8.54 & 0.93 & 8.58 & 3.75 & 7.80 & 0.53 & 7.56 & 1.32 & 3.54 & 1.46 & 3.71 & 1.01 \\
\hline $\mathrm{Ba} / \mathrm{Sr}$ & 7.83 & 1.77 & 10.3 & 3.47 & 6.81 & 1.73 & 8.46 & 4.83 & 9.08 & 0.75 & 8.78 & 2.32 & 12.3 & 7.90 & 11.8 & 4.71 \\
\hline
\end{tabular}

a $1123 \mathrm{~A}-1 \mathrm{H}-1=$ Site 1123 , hole $\mathrm{A}$, core type $(\mathrm{H}=$ hydraulic piston core $)$, section 1

${ }^{\mathrm{b}}$ Depth to base of tephra $(\mathrm{cm})$ in the relevant section

${ }^{c}$ Depth to base of tephra in metres below seafloor in the corresponding hole

${ }^{\mathrm{d}}$ Groupings based on melt types represented in Figs. 2-4 and 2-5

e Number of analyses

${ }^{\mathrm{f}}$ All iron as $\mathrm{FeO}$

${ }^{\mathrm{g}}$ Mean total of original EPMA analyses

\pm 2 standard deviations in wt. $\%$ or ppm

${ }^{\mathrm{i}} \mathrm{Eu} / \mathrm{Eu}^{*}=\left(\mathrm{Eu}_{\mathrm{N}}^{2} /\left(\mathrm{Sm}_{\mathrm{N}} \mathrm{x} \mathrm{Gd}_{\mathrm{N}}\right)\right){ }^{0.5}$, where $\mathrm{Eu}_{\mathrm{N}}, \mathrm{Sm}_{\mathrm{N}}$ and $\mathrm{Gd}_{\mathrm{N}}$ are the measured values of $\mathrm{Eu}, \mathrm{Sm}$ and $\mathrm{Gd}$ normalised to chondritic abundances 
$18 \mathrm{~cm}$ in the $1123 \mathrm{C}$ core, and on the basis of major element data alone one would potentially correlate the uppermost tephra layer in 1123A (AT-331 - Kawakawa Tephra) with the uppermost tephra layer in 1123C (A-9). However, the trace element data (Fig. 2-7b, c; Table A4-1) clearly show that AT-331 and A-9 are chemically distinct and that A-9 is compositionally indistinguishable from the underlying Omataroa Tephra (A-10). Site 1123C core logging notes (Shipboard Scientific Party, 1999) indicate that sample A-9 is an tephra lens that was thought to have been displaced up-core by $\sim 23 \mathrm{~cm}$ as a result of piston coring processes, confirming that samples A-9 and A-10 are the same tephra despite their adjacent positions within the same core.

Given their similar major element chemistry and age, there is considerable potential for misidentifying the Kawakawa and Omatoroa tephras in high resolution, late Quaternary climate reconstructions in New Zealand where the field and stratigraphic age control on the tephra is poor (e.g. Almond et al., 2007; Newnham et al., 2007; Lowe et al., 2008). It is important to note that the Kawakawa and Omataroa tephras preserved at Site 1123 are also able to be distinguished on the basis of colour. Here, as well as at Sites 1124 and 1125 (Alloway et al., 2005), the Omataroa Tephra characteristically grades from a white base (5YR 8/1) into a pinkish grey top (5YR7/2). While this distinctive colouring may be relied upon for identification where these tephras are preserved as macroscopic deposits (e.g. Leg 181 cores), difficulties arise when trying to distinguish between microscopic deposits (or cryptotephras) where the distinguishing colour banding is not preserved. However, the clear trace element distinction between these two tephras that is shown here to be possible using the single shard LA-ICP-MS technique highlights the usefulness of this method to discriminate between tephras with effectively indistinguishable major element glass chemistry where no other means of discrimination are available.

Variations in trace element abundances within individual tephras (e.g. Fig. 2-7b) are greater than the analytical uncertainty of the LA-ICP-MS method (ca. $\pm 5 \%$ ), and might reflect small-scale chemical variability in the melt prior to eruption. However, it is important to consider whether these variations and, in particular, positive covariations between element concentrations may potentially have been introduced by the internal $\left({ }^{43} \mathrm{Ca}\right)$ normalisation process (i.e. be an analytical artefact), resulting from the uncertainty of $\mathrm{CaO}(\mathrm{wt} \%)$ measurements in relatively low-Ca rhyolitic glass 

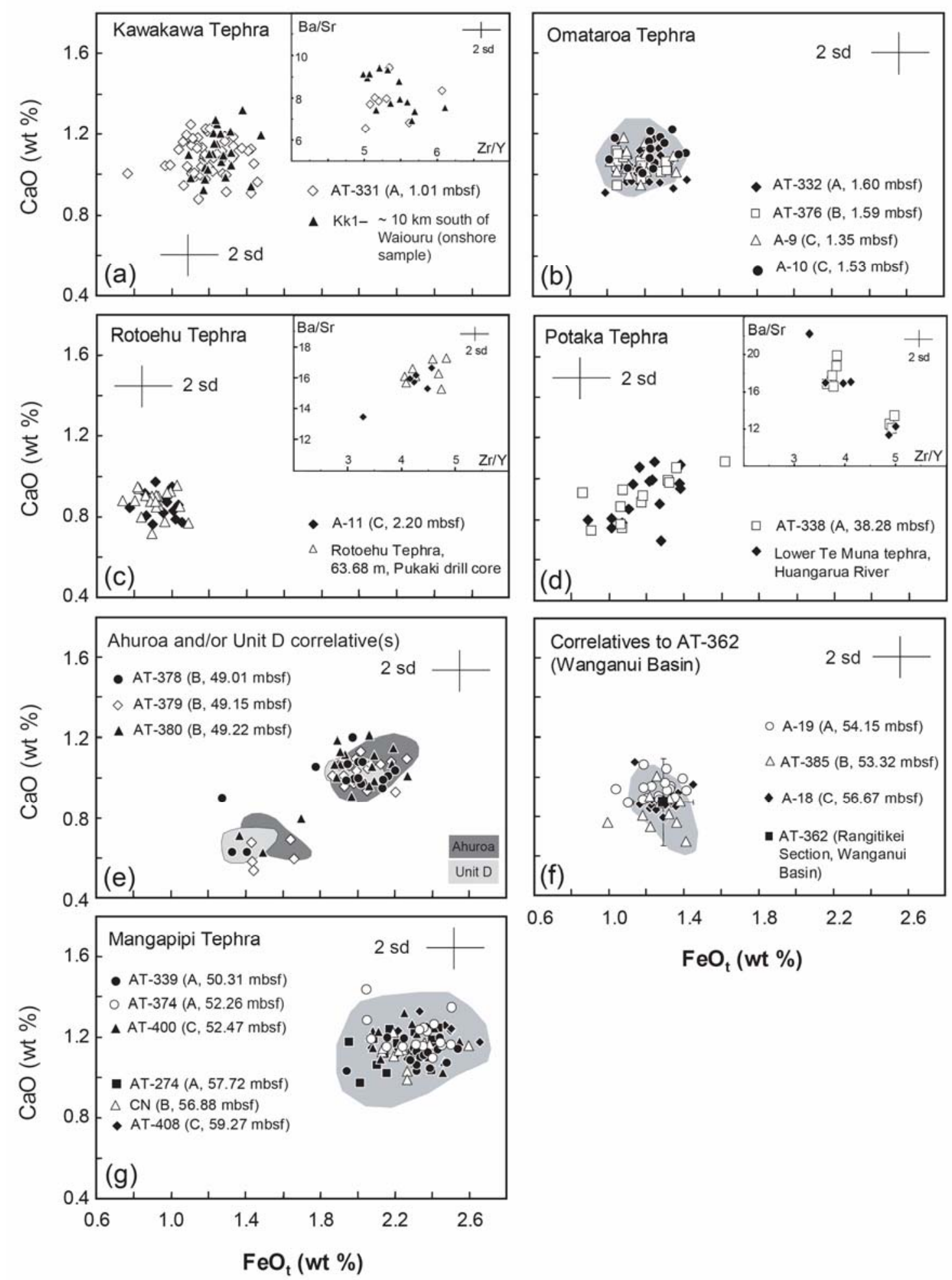

$\mathrm{FeO}_{\mathrm{t}}(\mathrm{wt} \%)$

Figure 2-6. Plots of $\mathrm{CaO}$ versus $\mathrm{FeO}_{\mathrm{t}}(\mathrm{wt} \%)$ for Site 1123 tephras correlated to previously documented onland TVZ tephra deposits. Where applicable the compositional field for tephras (onland samples) are illustrated by grey shading. (a) Kawakawa Tephra; (b) Omataroa Tephra, compositional field of onland correlatives from Alloway et al. (2005); (c) Rotoehu Tephra; (d) Potaka Tephra; (e) Ahuroa and/or Unit D tephra correlatives, compositional fields from Black et al. (1996); (f) correlatives to tephra AT-362 from the Rangatikei Section, Wanganui Basin, compositional field from Pillans et al. (2005); (g) Mangapipi Tephra, compositional field from Pillans et al. (2005). The correlation of Site 1123 tephras to the Kawakawa, Rotoehu and Potaka tephras are confirmed here by comparison of trace element data of analysed onland tephra samples as illustrated by inset plots of $\mathrm{Ba} / \mathrm{Sr}$ versus $\mathrm{Zr} / \mathrm{Y}$. 
determined by EPMA $( \pm 8 \%, 2$ sd relative $)$. The possibility that this is the case can be excluded in two ways. Firstly, plots of compatible elements (e.g., Sr, Zr) against incompatible elements (e.g., Rb) do not show the positive co-variations as would be expected if these trends were an analytical artefact. Secondly, because trace element ratios are insensitive to the internal normalisation process, the compositional spread in Figure 2-7c $(\mathrm{Rb} / \mathrm{Sm}$ vs $\mathrm{Ba} / \mathrm{Th})$ also demonstrates that the trace element variations are not solely an analytical artefact but actually reflect real, small-scale, chemical heterogeneity in the melt immediately prior to eruption. The ability to identify such chemical variability not only yields important information about the processes responsible for the chemical variability in the melts from which these tephras were derived, but, importantly for this study, provides additional fingerprinting criteria when establishing (or eliminating) a possible correlation between two tephra layers.

\subsection{Establishing isochronous tephra tie-lines between 1123A, 1123B and 1123C}

Due to the rapid deposition of tephras in deep marine settings (cf. Manville and Wilson, 2004), tephra correlations can be used to establish isochronous tie-lines between the three Site 1123 cores. These tephra tie-lines can then be compared against the original tie-lines used to construct the Site 1123 composite record (based on comparison of down-core magnetic susceptibility and light reflectance profiles). Once established, these tephra correlations allow a critical evaluation of the Site 1123 composite stratigraphy to be made.

On average, 9 shards yielded trace element data for each tephra (with a single glass population). Considering the significant small-scale chemical heterogeneity shown here (Figs. 2-7b,c) and reported in many LA-ICP-MS studies on volcanic glass from tephra deposits (e.g. Pearce et al., 2002, 2008; Ukstins Peate et al., 2008), it is unlikely that a comparison of the mean trace element composition of each sample is the best approach to reliably compare and correlate the tephra layers in this dataset. Therefore, the approach taken here was to closely examine a number of bivariate trace element abundance and trace element ratio plots to assess the degree of compositional overlap (e.g. Figs. 2-7b,c).

All tephra correlations were established following scrutiny of single shard major and trace element data as well as constraints provided by stratigraphic relationships and 

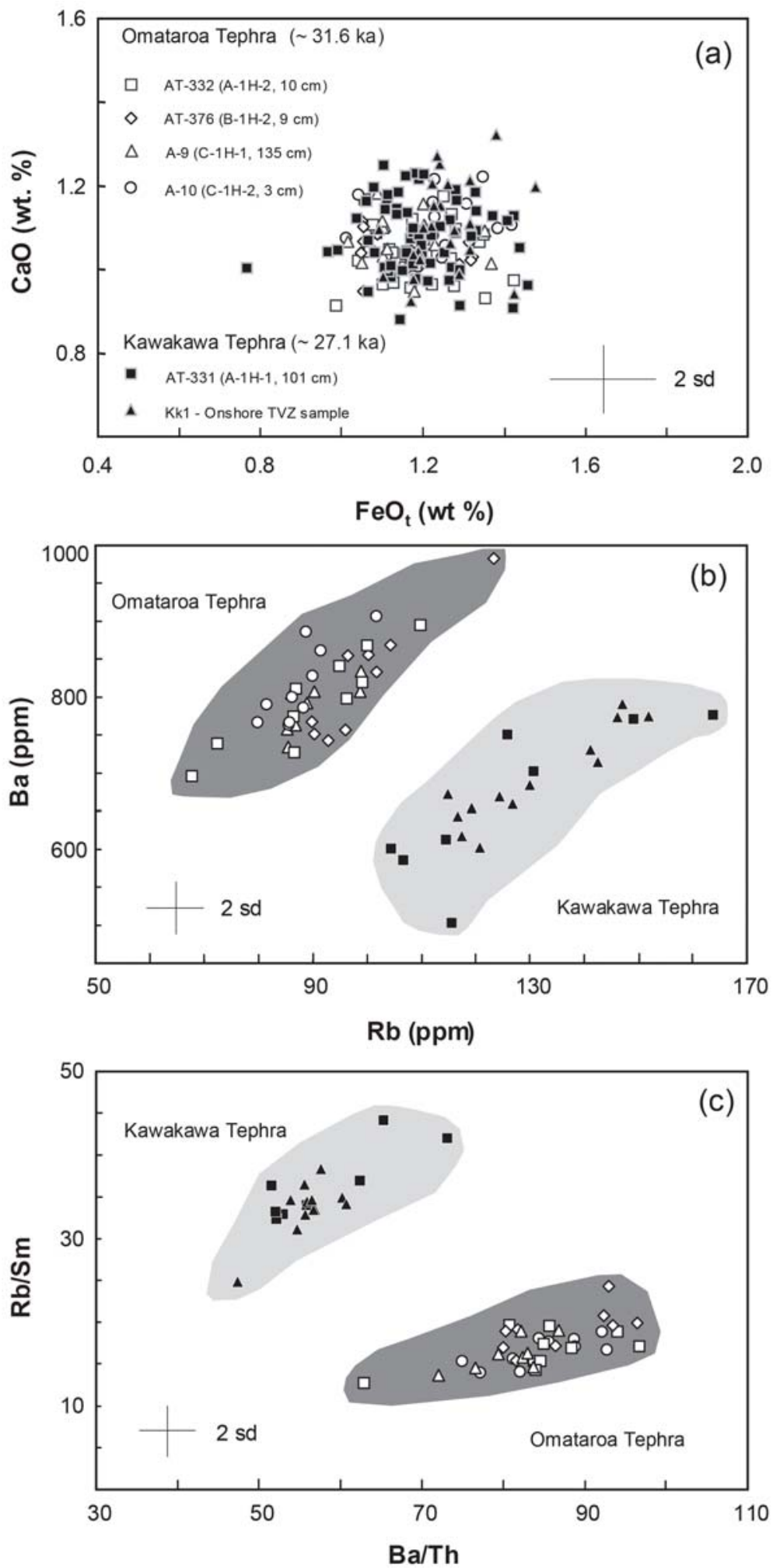

Figure 2-7. Data for selected major and trace elements for glass shards from the Omataroa (31.6 ka) and Kawakawa (27.1 ka) tephras from Site 1123. Also shown are data for a sample of the Kawakawa Tephra (Kk1) collected from the onshore TVZ (Irirangi Section, $\sim 10 \mathrm{~km}$ south of Waiouru, provided by J.A. Carter). Sample details: A-1H-2, $10 \mathrm{~cm}$ corresponds to a sample taken from Site 1123, hole A, core 1, type $\mathrm{H}$ (hydraulic piston), section 2 and the depth $(10 \mathrm{~cm})$ to the base of tephra within the section. (a) $\mathrm{CaO}$ versus $\mathrm{FeO}_{\mathrm{t}}(\mathrm{wt} \%)$. (b) $\mathrm{Ba}$ versus $\mathrm{Rb}$ abundances (ppm). (c) Rb/Sm versus Ba/Th. Grey shaded fields are for clarity only. 
paleomagnetic boundaries (Fig. 2-8). The most useful geochemical parameters for correlating and distinguishing between the Site 1123 tephras were found to be the abundances of $\mathrm{Rb}, \mathrm{Ba}, \mathrm{Sr}, \mathrm{Y}, \mathrm{Zr}, \mathrm{Hf}, \mathrm{Mg}, \mathrm{Mn}$ and $\mathrm{Ti}$ and trace element ratios such as $\mathrm{Rb} / \mathrm{Sr}, \mathrm{Ba} / \mathrm{Sr}, \mathrm{Zr} / \mathrm{Y}, \mathrm{Y} / \mathrm{Th}, \mathrm{Ba} / \mathrm{Th}$ and $\mathrm{Rb} / \mathrm{Sm}$.

\subsection{Identification of repeated sections in the $1123 \mathrm{~A}$ and $1123 \mathrm{C}$ cores}

The robust geochemical fingerprints provided by single shard trace element geochemistry show that parts of the core are, in fact, repeated. These repeated sections are identified by the reappearance of several tephras in parts of the $1123 \mathrm{~A}$ and $\mathrm{C}$ cores (Fig. 2-9).

The repeated section in 1123A occurs between $\sim 49.0$ and $\sim 53.5 \mathrm{mbsf}$ and is recognised by the reappearance of the Mangapipi Tephra (AT-374 and AT-339 at $52.26 \mathrm{mbsf}$ and $50.31 \mathrm{mbsf}$, respectively) and 'low Ti' tephra (A-17 and AT-340 at $53.26 \mathrm{mbsf}$ and $52.87 \mathrm{mbsf}$, respectively). The Mangapipi Tephra is also found in $1123 \mathrm{~A}$ at $57.72 \mathrm{mbsf}$ (AT-274; Fig. 2-8) in what is interpreted to be its undisturbed position due to the good agreement between the Site 1123 orbitally tuned oxygen isotope age of $1.554 \mathrm{Ma}$ (Brent Alloway, unpublished data) and the astronomically tuned age of 1.54 Ma for the Mangapipi Tephra from the Wanganui Basin, North Island, New Zealand (Pillans et al., 2005). The 'low Ti' tephra is also found in what is interpreted as its undisturbed stratigraphic position at $59.22 \mathrm{mbsf}(\mathrm{AT}-343)$ in 1123A (Fig. 2-8).

The repeated section in $1123 \mathrm{C}$ occurs between $\sim 48.1$ and $\sim 56.0$ mbsf. Here, the repeated sediments again contain the 'low Ti' tephra (AT-402 at $53.92 \mathrm{mbsf}$ ) and Mangapipi Tephra (AT-400 at $52.47 \mathrm{mbsf}$ ) as well as what we refer to as the 'Overlying Mangapipi' tephra (AT-399 at 52.15 mbsf). The 'low Ti'(A-21), Mangapipi (AT-408) and 'Overlying Mangapipi' (AT-407) tephras all occur further down core at 60.85, 59.27 and 58.67 mbsf, respectively, in what is interpreted as their undisturbed stratigraphic positions (Fig. 2-8). This is again supported by the good agreement between the orbitally tuned age for AT-408 (Mangapipi Tephra in $1123 \mathrm{C}$ ) of $1.551 \mathrm{Ma}$ (Brent Alloway, unpublished data) and the 1.54 Ma age of the Mangapipi Tephra from the Wanganui Basin (Pillans et al., 2005). 
The estimated base of the repeated sections in $1123 \mathrm{~A}$ and $1123 \mathrm{C}$ occurs about $0.6 \mathrm{~m}$ above the correlated tephra layers A-19 (1123A) and A-18 (1123C). These tephra layers can also be correlated with AT-385 in 1123B. The estimated lower limit of the repeated sections is placed above these samples because this tephra unit can be correlated across all three cores and is not repeated up-section in any of the three cores.

The process responsible for producing the repeated sections in $1123 \mathrm{~A}$ and $1123 \mathrm{C}$ is unclear. The most likely, and favoured, explanation is that the sediments were repeated due to a localised sedimentary slide that essentially moved a coherent body of sediment with minimal internal deformation and redeposited the tephras in the same stratigraphic order as they were deposited at Sites 1123A and C. The inferred sedimentary slide must have been localised because there is no evidence for a repeated section in $1123 \mathrm{~B}$, situated within a few hundred metres of $1123 \mathrm{~A}$ and $1123 \mathrm{C}$.

\subsection{Re-evaluating the Site 1123 composite stratigraphy and stable isotope age model}

The repeated sections identified in 1123A and 1123C suggest the early Quaternary composite record may have incorrectly assigned ages to the tephras, which were based primarily upon the composite benthic oxygen isotope curve established by Hall et al. (2001; section 0.0 - 1.2 Ma) and Harris (2002; section 1.2 - 3.0 Ma). In order to assess this possibility, we examined the correspondence between the original composite splice tie-lines (Shipboard Scientific Party, 1999) with those established here on the basis of tephra correlations between the three cores.

The original splice tie-lines (Fig. 2-8) were established by correlating distinctive magnetic susceptibility and light reflectance properties between 1123B and 1123C Shipboard Scientific Party, 1999). Between 0-41 mbsf and $~ 53-65$ mbsf there is a good correspondence between the two sets of tie-lines with our tephra correlations being parallel to the original splice tie-lines. However, the tie-line established here by the correlation of tephras AT-397 (1123C) and CP (1123B) directly cross-cuts two of the original splice tie-lines. The discrepancy between the tie-lines is due to the previously unrecognised repetition of the section in $1123 \mathrm{C}$. 


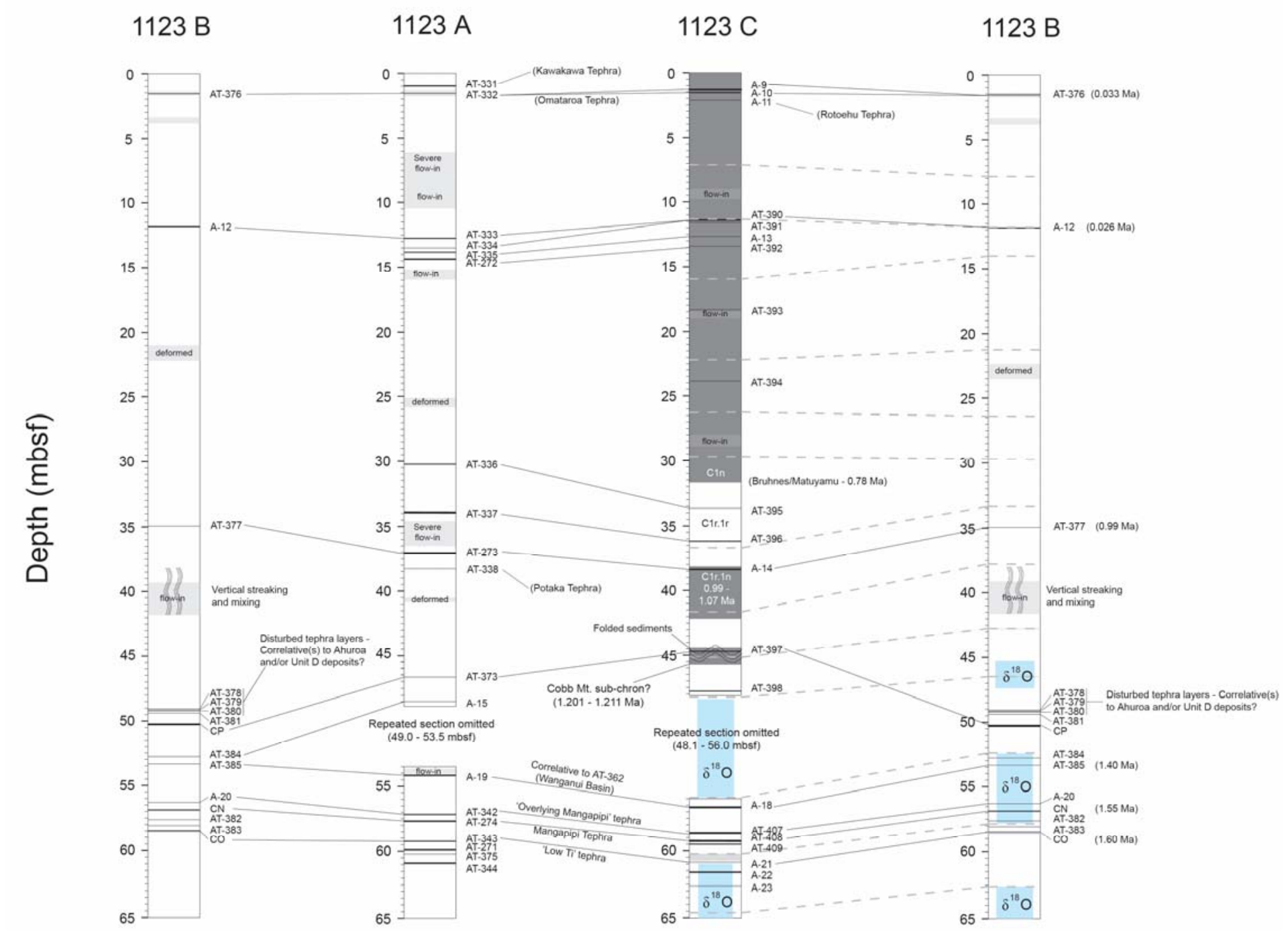


Figure 2-8. Stratigraphic columns illustrating the isochronous tephra layer tie-lines (solid lines) established between the three Site 1123 sediment cores (A, B and C). 1123B is shown twice (at the far left and right of the figure) to allow a clearer comparison with the tephra layers in 1123A and 1123C. Sections are omitted between $49.0-53.5$ mbsf in 1123A and $48.1-56.0$ mbsf in 1123C following the identification of a repeated section (see section 5.3). The original composite record tie-lines established between 1123B and 1123 C (Shipboard Scientific Party, 1999) are shown as heavy dashed lines. Note that the tephra tie-lines agree well with those of the original composite record between $0-44$ mbsf and 53 - 65 mbsf. However the tephra tie-line between AT-397 (1123C) and CP (1123B) directly cuts across two of the original splice tie-lines. Also shown are the early Quaternary sections of $1123 \mathrm{~B}$ and $1123 \mathrm{C}$ that were sampled for oxygen isotope analysis (light grey shading and annotated) of benthic foraminifera (Harris, 2002). Areas of disturbed sediment (e.g. flow-in, folding) are annotated throughout. The paleomagnetic intervals identified in 1123C were used during construction of the original composite record. Note, however, that the section interpreted to represent the Cobb Mountain sub-chron (Shipboard Scientific Party, 1999) coincides precisely with the section of folded sediments in 1123C. This observation, and the conspicuous absence of the Cobb Mountain reversal in the paleomagnetic profiles of $1123 \mathrm{~A}$ and $1123 \mathrm{~B}$ (data available at http://iodp.tamu.edu/janusweb/paleomag/cryomag.shtml), questions whether this sub-chron is really present at Site 1123.

Comparison of $\delta^{18} \mathrm{O}$ profiles from ODP Sites 1123 and 849 (equatorial Pacific) for 0.45 - 2.0 Ma shows a close correlation (Fig. 2-10). However, between ca. $1.15-$ 1.38 Ma the correlation between the two records is poor. During this period, the Site 1123 record does not match any of the clearly defined $\delta^{18} \mathrm{O}$ minima and maxima of the Site 849 record (Fig. 2-10). The orbitally tuned oxygen isotope age assigned to tephra AT-397 is $1.167 \mathrm{Ma}$ (Alloway et al., 2005). When shown in the context of the $\delta^{18} \mathrm{O}$ records in Figure 2-10, this tephra layer falls at the very 'top' of the disturbed section of the Site $1123 \delta^{18} \mathrm{O}$ curve. The two correlatives of AT-397 established here on the basis of trace element chemistry, AT-373 (1123A) and CP (1123B), have been assigned ages of 1.268 Ma and 1.351 Ma respectively (Brent Alloway, unpublished data). Again these fall within the disturbed section of the Site 1123 oxygen isotope record. These three tephra layers from 1123A, B and C, the trace element chemistry of which identifies them as being the same tephra unit (i.e. a single eruptive event), are separated in the original composite record by $\sim 9 \mathrm{mcd}$ (metres composite depth), meaning their corresponding orbitally tuned age estimates are offset by up to $\sim 180$ ka.

In this study, tephra layers A-19 (1123A), AT-385 (1123B) and A-18 (1123C), are tentatively correlated with sample AT-362 from the Rangitikei Section of the Wanganui Basin, New Zealand (Fig. 2-6f). These correlated tephra layers, which are only found once in each core, provide a continuous horizon at Site 1123 suggesting that tephra layers below this horizon are undisturbed. The $\delta^{18} \mathrm{O}$ age for each of these samples at Site 1123 is ca. $1.40 \mathrm{Ma}$ (Brent Alloway, unpublished data). An age was not presented for sample AT-362 in Pillans et al. (2005), but an approximate age of ca. 1.35 $\mathrm{Ma}$ is interpolated here based on its position between Sequences 28 and 29 in the orbitally tuned sequence stratigraphy at Wanganui Basin (Pillans et al., 2005). 

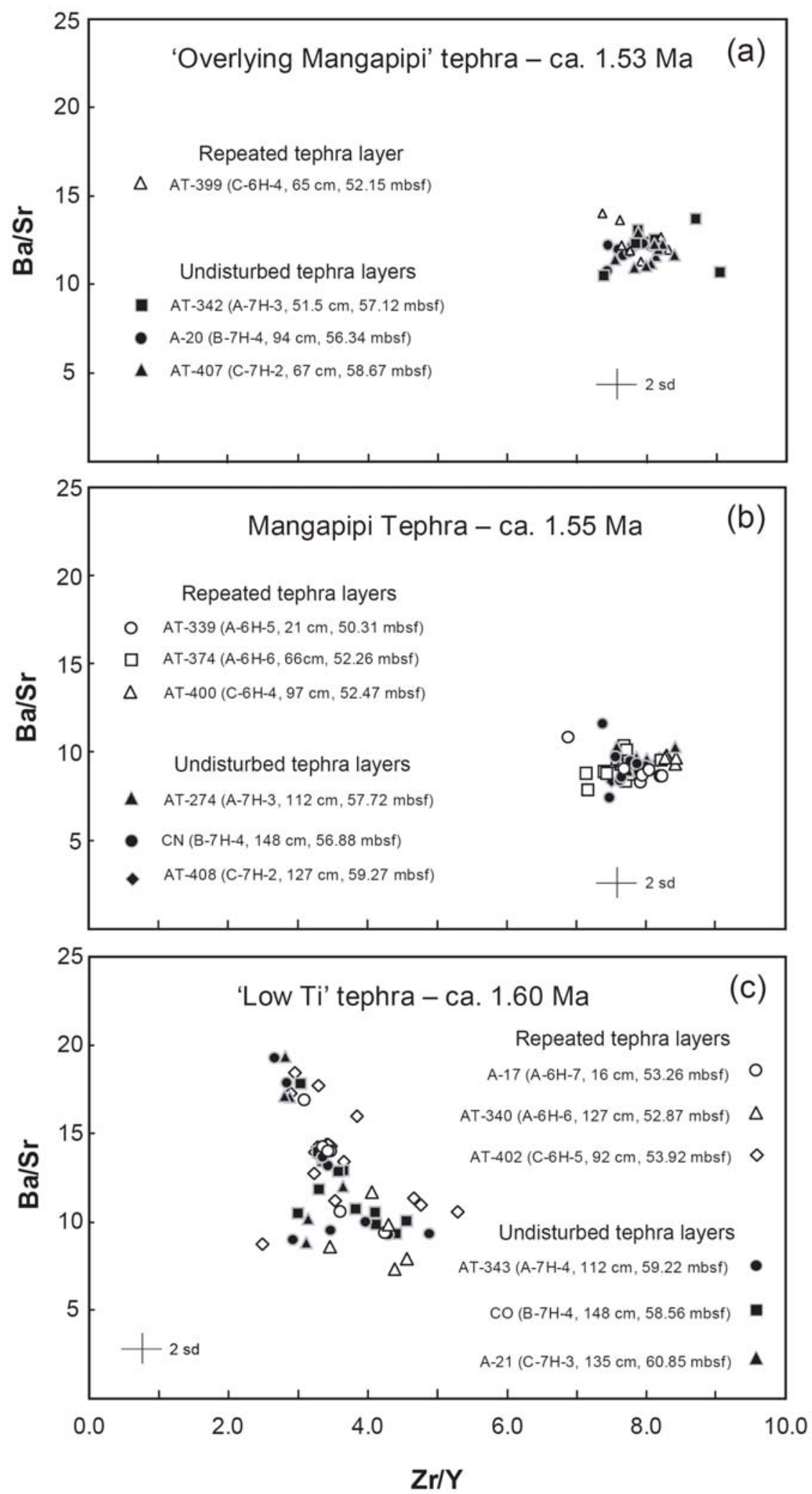

Figure 2-9. An example of the trace element fingerprints used to identify repeated sections in the Site 1123 cores (see text for discussion). $\mathrm{Zr} / \mathrm{Y}$ and Ba/Sr ratios of the (a)'Overlying Mangapipi', (b) Mangapipi and (c) 'low Ti' tephras are shown, with the solid symbols indicating the samples that are interpreted to be in the correct stratigraphic position, and the open symbols indicating samples from the repeated section. The sample details are as described in Fig. 2-7, but here also include the depth to the base of each tephra in mbsf. 
This interpolated age is within $50 \mathrm{ka}$ of the $\delta^{18} \mathrm{O}$-based age for the Site 1123 samples. Notably, these correlated tephras occur outside the section of the Site $1123 \delta^{18} \mathrm{O}$ curve that shows a poor match with the Site 849 record (Fig. 2-10), and show a good correspondence with the original splice tie-lines shown in Figure 2-8.

On the basis of the inferred isochronous tephra tie-lines established in this study, we suggest that any tephras that have been previously assigned ages from the Site 1123 $\delta^{18} \mathrm{O}$ curve between ca. $1.10-1.38 \mathrm{Ma}$ have unreliable ages. This means that approximately 12 tephra layers within the composite record, which when correlated between the three cores, corresponds to $\sim 5-6$ individual tephra eruptive units, do not have accurate age constraints. Three closely spaced (within $21 \mathrm{~cm}$ ) samples from 1123B, which occur either as tephra lenses (AT-378, AT-380) or a discrete tephra layer with a deformed base (AT-379), are tentatively identified as reworked correlatives to the Unit D and/or Ahuroa Ignimbrite-forming eruption(s) on the basis of their characteristic bimodal major element chemistry. The major element chemistry of these layers is indistinguishable from the Unit D and Ahuroa glass chemistry reported by Black et al. (1996) (Fig. 2-6). Trace element chemistry was unable to resolve whether these three layers correspond to one or both eruptive events. The ca. 1.32 Ma age assigned to these layers (Brent Alloway, unpublished data) falls within the disturbed section of the composite age model and is therefore considered unreliable. High quality ${ }^{40} \mathrm{Ar}-{ }^{39} \mathrm{Ar}$ ages of $1.18 \pm 0.02 \mathrm{Ma}$ (Briggs et al., 1993 ) and 1.20 $\pm 0.04 \mathrm{Ma}$ (Houghton et al., 1995) have been obtained for the stratigraphically older Unit D deposits and ages of $1.19 \pm 0.03 \mathrm{Ma}$ and $1.18 \pm 0.02$ Ma (Houghton et al. [1995] and Briggs et al. [1993], respectively) have been reported for the Ahuroa Ignimbrite. The correlation of these tephra layers to the Unit $\mathrm{D}$ and/or Ahuroa eruptive units, although not yet verified by comparison to the trace element chemistry of onland correlatives, provides some level of age control for the portion of the Site 1123 composite age model compromised by the repeated sections in $1123 \mathrm{~A}$ and $1123 \mathrm{C}$.

The early Quaternary sections of 1123B and 1123C that were sampled for benthic foraminiferal oxygen isotope analysis (Harris, 2002) are shown in Figure 2-8 (dark grey shading). It is important to note that $1123 \mathrm{C}$ was sampled between 48.25 to 55.95 mbsf (Harris, 2002). This entire segment corresponds to the section of the $1123 \mathrm{C}$ core that is shown here to contain repeated tephras and is almost certainly the 


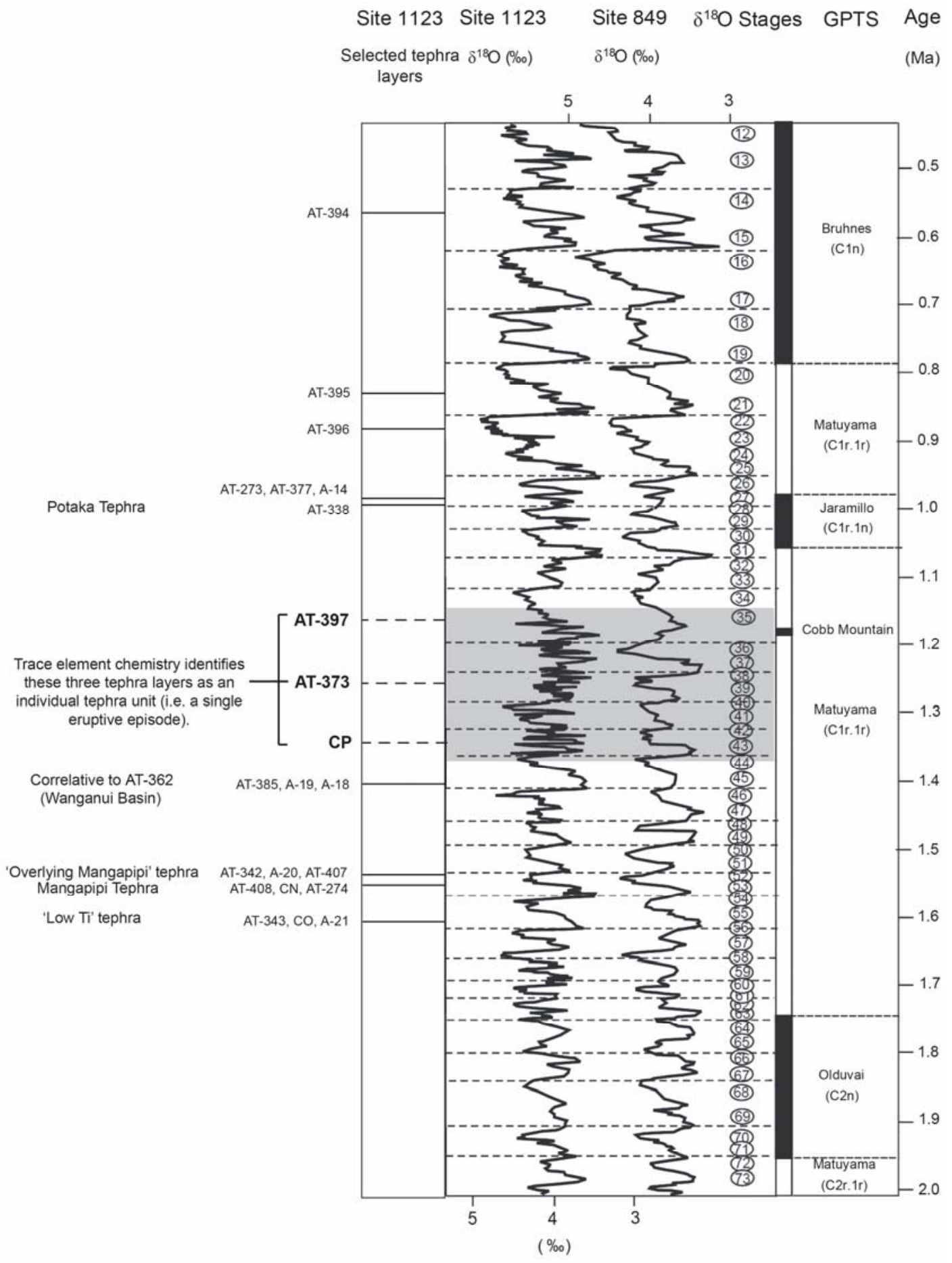

Figure 2-10. Summary of the $\sim 0.4-2.0$ Ma section of the Site 1123 composite oxygen isotope curve compared to that from Site 849 (equatorial Pacific; Mix et al., 1995) (modified from Pillans et al., 2005). The two records mostly show a good correspondence, however, the Site $1123 \delta^{18} \mathrm{O}$ curve shows a significant departure from the Site 849 $\delta^{18} \mathrm{O}$ curve between ca. $1.15-1.38 \mathrm{Ma}$ (shaded region). Only selected Site 1123 tephra layers are shown for illustrative purposes. Three tephra layers that are correlated between all three Site 1123 cores (i.e. a single tephra eruptive unit) are offset in this original composite record by up to $9 \mathrm{~m}$, corresponding to an age difference of $\sim 180$ $\mathrm{ka}$, demonstrating that significant errors have been introduced into the composite stratigraphy and age model as a result of the repeated sections in $1123 \mathrm{~A}$ and $\mathrm{C}$. The Site $1123 \delta^{18} \mathrm{O}$ curve departs from the Site 849 record during the $1.15-1.38 \mathrm{Ma}$ period because this part of the curve is constrained by oxygen isotope data obtained from benthic foraminifera sampled from within the repeated section in $1123 \mathrm{C}$ (see Fig. 2-8). The $\delta^{18} \mathrm{O}$ curves are well matched prior to $\sim 1.4 \mathrm{Ma}$ because this section of the record is constrained by oxygen isotopic data from sections of the composite record that are not compromised by the repeated section in 1123C (see Fig. 2-8). GPTS geomagnetic polarity time scale. 
reason for the significant departure between the $\delta^{18} \mathrm{O}$ records for Sites 1123 and 849 between ca. $1.15-1.38 \mathrm{Ma}$. Given there is no evidence from this study to suggest that the inferred sedimentary slide that caused the repeated sections in $1123 \mathrm{~A}$ and $1123 \mathrm{C}$ has compromised the stratigraphy of the 1123B core, an 'intact' and complete Quaternary $\delta^{18} \mathrm{O}$ record for Site 1123 could be recovered, provided sampling is restricted to $1123 \mathrm{~B}$ between $\sim 41.0-54.0 \mathrm{mbsf}$.

\subsection{A revised composite stratigraphy for Site 1123}

The revised composite record for Site 1123 presented here is based on the tephra correlations between the three cores (Fig. 2-11; Table A6-1). Seven Site 1123 tephras are correlated to onland TVZ deposits (Fig. 2-6) - the Kawakawa, Omataroa, Rotoehu, Potaka, Unit D and/or Ahuroa and Mangapipi tephras, and correlatives to sample AT-362 from the Wanganui Basin (Pillans et al., 2005). The orbitally tuned age estimates for these Site 1123 tephras (where reliable - see section 5.4) are generally in close agreement with previous radiometric or astronomically tuned age determinations as summarised in Figure 2-11. Two exceptions to this are the age estimates provided for the late Quaternary Kawakawa and Rotoehu tephras. At present the most reliable age for the Kawakawa Tephra is considered to be a pooled radiocarbon age of $22590 \pm 230{ }^{14} \mathrm{C}$ yr BP (corresponding to a calibrated age of $27.1 \mathrm{ka}$; Lowe et al., 2008) determined on small carbonised wood fragments embedded within the associated Oruanui Ignimbrite (Wilson et al., 1988). The Site 1123 orbitally tuned age estimate of 21.2 ka reported by Alloway et al. (2005) is considerably younger than this presently accepted age. However, several lines of evidence suggest this orbitally tuned age for the Kawakawa Tephra is unreliable and should be abandoned. Firstly, the oxygen isotope data used to define the age of the tephra did not come from the same sediments that actually contain the tephra (i.e. no oxygen isotopic data was derived from 1123A). If the upper section of $1123 \mathrm{~A}$ was not completely recovered (e.g. the core barrel had indented the seabed prior to firing) then an orbitally tuned age, based on the assumption of a 1:1 age-depth relationship between the uppermost sections of the three sediment cores, is invalid. Subsequent splicing into the oxygen isotope stratigraphy would, in this scenario, result in a younger age for the tephra. Secondly, the oxygen isotope sampling resolution may have been too coarse to resolve an accurate age as there are only 12 individual 
oxygen isotope data points to constrain the $0.0-22.4$ ka period (I. Hall, unpublished data). Finally, the tephra layer has been dispersed due to heavy bioturbation (Shipboard Scientific Party, 1999) making its use as an isochron at Site 1123 questionable. An orbitally tuned age estimate of $\sim 26 \mathrm{ka}$ was presented by Lean and McCave (1998) for the Kawakawa Tephra recovered from the Site 1123 survey core, CHAT-1K $\left(41^{\circ} 35^{\prime} \mathrm{S}, 171^{\circ} 30^{\prime} \mathrm{W}\right)$. This age estimate is considered more reliable because; (1) CHAT-1K was a kasten core, a type of core specifically designed to recover the sediment-water interface, (2) in contrast to the Site 1123 age estimate, the oxygen isotope data used to infer the age of the Kawakawa Tephra was obtained from samples taken from the same sediment core in which the tephra was recovered, (3) the sampling resolution $(4 \mathrm{~cm})$ was almost double that of the uppermost section of Site 1123, and (4) the $\sim 26 \mathrm{ka}$ age is consistent with the (calibrated) accepted age of $\sim 27097 \pm 957$ years ( $2 \mathrm{sd}$ ) (Lowe et al. 2008).

The age of the Rotoehu Tephra is controversial with published age estimates ranging between $\sim 35$ and $71 \mathrm{ka}$ (Wilson et al., 2007). The orbitally tuned age estimate of the Rotoehu Tephra at Site 1123 is $45.1 \mathrm{ka}$. This age is consistent with those determined by luminescence methods and age estimates inferred from extrapolated sedimentation rates in paleo-lake records which routinely indicate an age of $\sim 45-50$ ka (e.g. Lian and Shane, 2000; Shulmeister et al., 2001; Shane and Sandiford, 2003). However, radiometric ages $\left(\mathrm{K}-\mathrm{Ar},{ }^{40} \mathrm{Ar} /{ }^{39} \mathrm{Ar}\right)$ for lava flows bracketing the Rotoehu Tephra seem to constrain a maximum age for the tephra of $64 \pm 8 \mathrm{ka}$ (Wilson et al., $1992 ; 2 \mathrm{sd}$ ) and a minimum age of $58.1 \pm 2.2 \mathrm{ka}$ (Wilson et al., 2007; $2 \mathrm{sd}$ ). Although the Site 1123 age is consistent with some of the younger ages suggested for the Rotoehu Tephra, we urge caution when adopting this age because its accuracy is limited by the relatively coarse sampling resolution of the oxygen isotope curve and/or issues surrounding incomplete recovery of the seabed.

We note, however, that despite the discrepant ages for the Kawakawa and Rotoehu tephras at Site 1123 , the orbitally tuned age estimate for the Omataroa Tephra $(\sim 33$ $\mathrm{ka}$; Alloway et al., 2005) is in close agreement to ${ }^{14} \mathrm{C}$ age determinations for onshore correlatives of the Omataroa Tephra ( $31.6 \mathrm{ka}$; Shane et al., 2006) and on foraminifera underlying the Omataroa Tephra at Site 1123 (31.7 ka; Alloway et al., 2005). 


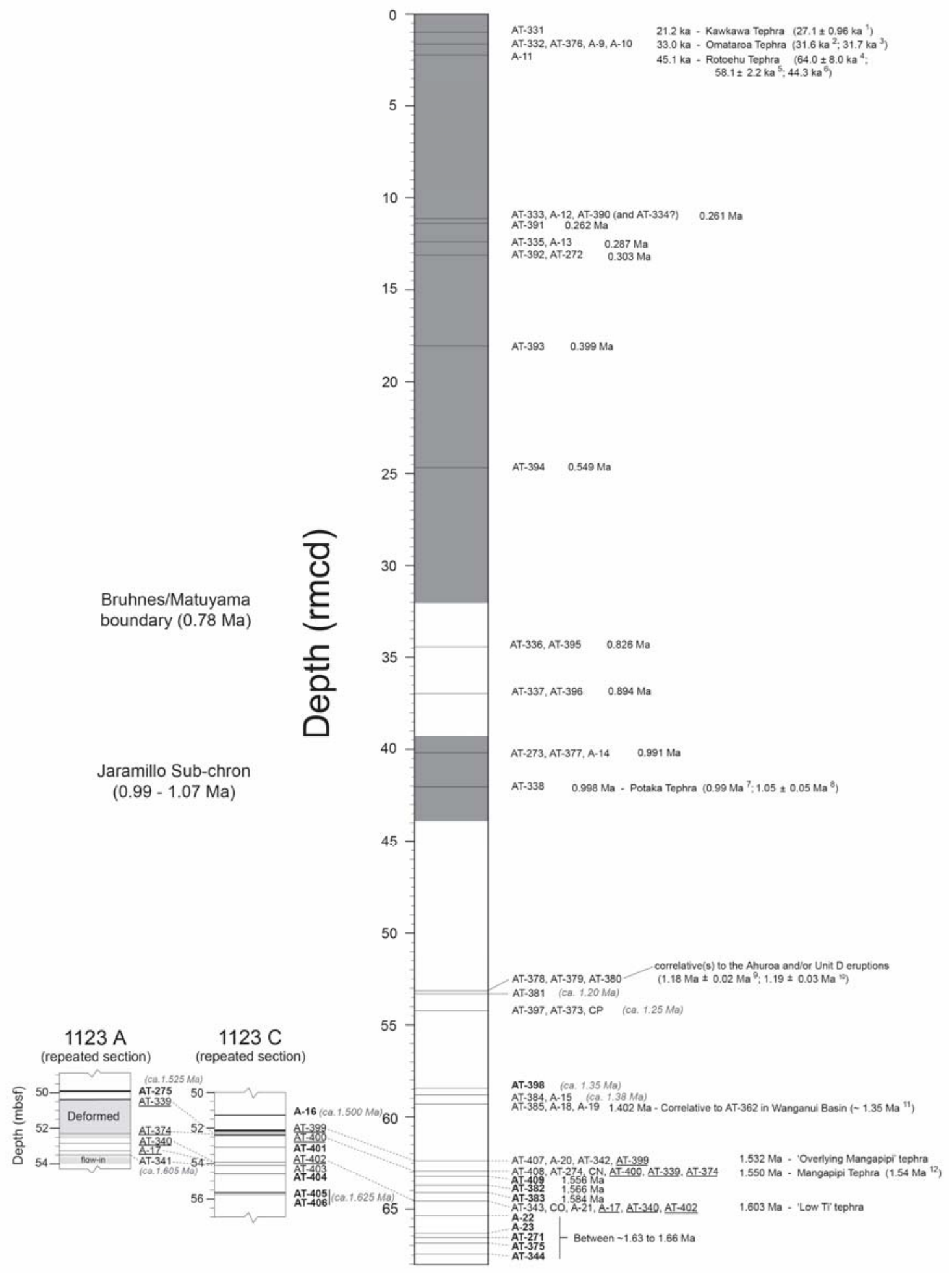

Figure 2-11. A revised composite Quaternary stratigraphy for Site 1123. Revised metres composite depth (rmcd) were calculated using the offsets from Shipboard Scientific Party (1999) and the later revision in Harris (2002). Tephra ages are from the orbitally tuned Site 1123 oxygen isotope age model unless indicated otherwise (note the change in age units below $3 \mathrm{rmcd}$ ). Tephras which fall within the disturbed section of the Site 1123 age model are assigned provisional ages (italicised) based on their stratigraphic position and proximity to the reliably dated tephras. Throughout the record, the age (where appropriate) and composite depth for tephras that have been correlated between cores are attributed to samples from 1123B because of the absence of a repeated section in this core. For tephras correlated between 1123A and C (and absent in B), the age and composite depth of the 1123C 
sample is preferred because $1123 \mathrm{C}$ is additionally constrained by magnetostratigraphy. The repeated sections from $1123 \mathrm{~A}$ and $\mathrm{C}$ are shown to the side with tie-lines to illustrate which of these tephras can be reliably correlated between $1123 \mathrm{~A}$ and $1123 \mathrm{C}$ and spliced into the revised composite record (underlined samples). Because some tephras occur in only one of the three cores, some tephras lack the necessary stratigraphic control to be unambiguously spliced into the revised composite record (indicated by bold type). (References: ${ }^{1}$ Lowe et al., 2008 calibrated ${ }^{14} \mathrm{C}$ age $[2 \sigma]$ of Wilson et al., 1988; ${ }^{2}$ Shane et al. 2006 - calibrated pooled ${ }^{14} \mathrm{C}$ age; ${ }^{3}$ Alloway et al., 2005 - calibrated ${ }^{14} \mathrm{C}$ age on Site 1123 foraminifera in sediments underlying the Omataroa Tephra; ${ }^{4}$ Wilson et al., $1992-$ $\mathrm{K}-\mathrm{Ar}$ age of a lava flow underlying the Rotoehu Tephra [maximum age; 20]; ${ }^{5}$ Wilson et al., $2007-{ }^{40} \mathrm{Ar}-{ }^{39} \mathrm{Ar}$ age of a lava flow overlying the Rotoehu Tephra [minimum age; 2б]; ${ }^{6}$ Shane and Sandiford, 2003 - interpolated from sedimentation rate; ${ }^{7}$ Pillans et al., 2005 - astronomically tuned age estimate; ${ }^{8}$ Alloway et al., $1993-$ glass-ITPFT age $(1 \sigma) ;{ }^{9}$ Briggs et al., $1993-{ }^{40} \mathrm{Ar}-{ }^{39} \mathrm{Ar}$ age, Ahuroa Ignimbrite; ${ }^{10}$ Houghton et al., $1995-{ }^{40} \mathrm{Ar}-{ }^{39} \mathrm{Ar}$ age of Unit D Ignimbrite; ${ }^{11}$ Age interpolated here based on position in astronomically tuned sedimentary record at Wanganui Basin (after Pillans et al., 2005); ${ }^{12}$ Pillans et al., 2005 - astronomically tuned age estimate.)

Apart from the identification of the repeated sections in 1123A and $\mathrm{C}$, and the resulting errors in the composite age model, only relatively minor revisions are made to the remainder of the original composite record. For example, the tephra layers AT336 and AT-337 (1123A) were originally spliced into the composite record in a period of normal magnetic polarity and assigned ages of 0.64 and $0.75 \mathrm{Ma}$, respectively. Trace element chemistry shows that these two tephras correlate to AT395 and AT-396 respectively (1123C) which fall within in a period of reversed polarity and were assigned ages of 0.83 and $0.89 \mathrm{Ma}$, respectively. The composite depths and ages assigned to the 1123C tephras (AT-395 and AT-396) are preferred because $1123 \mathrm{C}$ is the only core to be constrained by paleomagnetic data for the whole of the Quaternary section of the record (Shipboard Scientific Party, 1999). It is not possible to unequivocally splice all 70 tephra layers into the revised composite record owing to a lack of stratigraphic control for tephras that only occur in one of the three cores. In Figure 2-11, the repeated sections from 1123A and $1123 \mathrm{C}$ are shown separately (depths in mbsf). The tephras within the repeated sections that can be reliably spliced into the revised composite record ('low Ti', Mangapipi and 'Overlying Mangapipi') are illustrated by tie-lines. Because there is not a one-to-one match between the tephras in the repeated sections and the 'in-situ' sections, many tephras from the repeated sections cannot be unambiguously spliced into the composite record (e.g. should AT-401 be placed above or below AT-382?). Similarly, as a result of the estimated location of the base of the repeated section in 1123C, samples AT-403, AT-404, AT-405 and AT406 (1123C) are by implication assumed to be stratigraphically older than the 'low Ti' tephra (AT-402). As correlatives of these tephras do not appear anywhere else in the record, this assumption is unable to be verified. Should a similar study be undertaken for the extensive tephra record recovered from ODP Site $1124(\sim 300 \mathrm{~km}$ northwest of Site 
1123), which is more proximal to the eruptive centres in the TVZ, then establishing tephra correlations between the two sites may enable these tephras to be correctly spliced into the revised Site 1123 record.

\subsection{Frequency of explosive large-volume TVZ silicic eruptions in the last $1.65 \mathrm{Ma}$}

The tephra record at Site 1123, by virtue of distance from the TVZ (ca. $1000 \mathrm{~km}$ ), is likely to record only very explosive and/or large eruptions. Nevertheless, because the onland TVZ record is largely fragmented due to erosion and burial and destruction by younger volcanic activity, the Site 1123 record, together with those of 1122, 1124 and 1125 , represent one of the most complete records of explosive silicic volcanism from the TVZ.

This study establishes that the 70 macroscopic Quaternary tephras layers recovered from the A, B and C cores at Site 1123 correspond to 37-38 individual tephra units/eruptive events. For the entire Quaternary tephra record $(\sim 1.65 \mathrm{Ma})$ this constitutes an eruptive frequency of at least 1 every $44 \mathrm{ka}$. Inspection of the revised composite record (Figs. 2-11 and 2-12), however, shows that the frequency of tephra deposition at Site 1123 has not been constant throughout the evolution of the TVZ. Parts of the composite record (e.g. 0-3 rmcd [revised metres composite depth], 11-14 rmcd, 53-55 rmcd, 58-60 rmcd) contain a number of tephras deposited over relatively short periods of time (ca. $25-50 \mathrm{ka}$ ). Where accurate age constraints are available, it is notable that these tightly clustered groups of tephras are generally preceded (and followed) by relatively long periods of quiescence (typically 100 - $130 \mathrm{ka}$ or longer). In contrast, from $\sim 18$ to $43 \mathrm{rmcd}$, where only 6 tephra units were recovered, the temporal separation of these units is generally more uniform. Strikingly, between ca. 62-68 rmcd, at least 18 tephra eruptive units are preserved within a period of $<130$ ka. At this time (ca. $1.66-1.53 \mathrm{Ma}$ ), when the TVZ was in its infancy, the frequency of large-volume silicic eruptions as recorded at Site 1123, was at least 1 every $7 \mathrm{ka}$. That higher frequency cannot be attributed to the site being closer to the source volcanoes because Neogene plate tectonic reconstructions of the Australian-Pacific plate boundary (King, 2000) show that at ca. 1.6 Ma Site 1123 was further away from the TVZ than the present day. This early phase of activity is further emphasised in Figure 2-12 showing that 50\% of the Quaternary tephra eruptive units (and 
preserved thicknesses) were erupted during the first $\sim 250 \mathrm{ka}$ of silicic activity. The fragmentary terrestrial record of old ( $>350 \mathrm{ka}) \mathrm{TVZ}$ rhyolitic volcanic activity, particularly from the Mangakino caldera (e.g. Wilson, 1986; Houghton et al., 1995), offers limited insights into this period of intense silicic eruptive activity.

One interesting aspect of the Site 1123 tephra record relates to the timing of these TVZ eruptions with respect to glacial-interglacial cycles in the past 1.2 Ma.

Approximately $80 \%$ of the post-1.2 Ma eruptive events preserved as tephra layers at Site 1123, and those recovered from 1124C (graphically tuned to the Site 1123 oxygen isotope stratigraphy - Alloway, unpublished data), occurred during glacial periods. (The glacial-interglacial boundary is defined here as the half-way point between $\delta^{18} \mathrm{O}$ minima and maxima for each climate cycle meaning that $\sim 60 \%$ of the last 1.2 $\mathrm{Ma}$ is defined as a glacial period). This may reflect that the transport of ash material from explosive silicic eruptions in the TVZ to Sites 1123 and 1124, and subsequent preservation, was favoured during glacial times when intensified atmospheric circulation may have assisted eastward atmospheric transport of the erupted material. Alternatively, perhaps eustatic unloading of the New Zealand microcontinent during glacial transitions, associated with the onset of large amplitude sea-level changes since the Mid-Pleistocene Transition, has significantly influenced the timing of eruptions from shallow silicic magma chambers in the TVZ. The idea of a causal link between changing sea level and the triggering of volcanic eruptions has been postulated before. For example, McNutt and Beavan (1987) and Mason et al. (2004) have documented statistically significant links between annual variations in regional sea level and the timing of historical eruptions from Pacific Rim volcanoes. Stress accumulation caused by surface mass redistribution (falling sea level) during glaciation (Nakada and Yokose, 1992) has also been invoked as a possible trigger for periods of enhanced volcanic productivity during the Quaternary (e.g. Rampino et al., 1979; Paterne et al., 1990; McGuire et al., 1997). However, it seems unlikely that ca. $100 \mathrm{~m}$ of sea level change around the New Zealand microcontinent could influence the dynamics of magma bodies at $4-8 \mathrm{~km}$ depth given the relatively small stress change $(<1 \%)$ associated with $100 \mathrm{~m}$ of sea level change. A study of the Quaternary tephra record from marine sediment cores more proximal to the TVZ would be useful in distinguishing these hypotheses. 


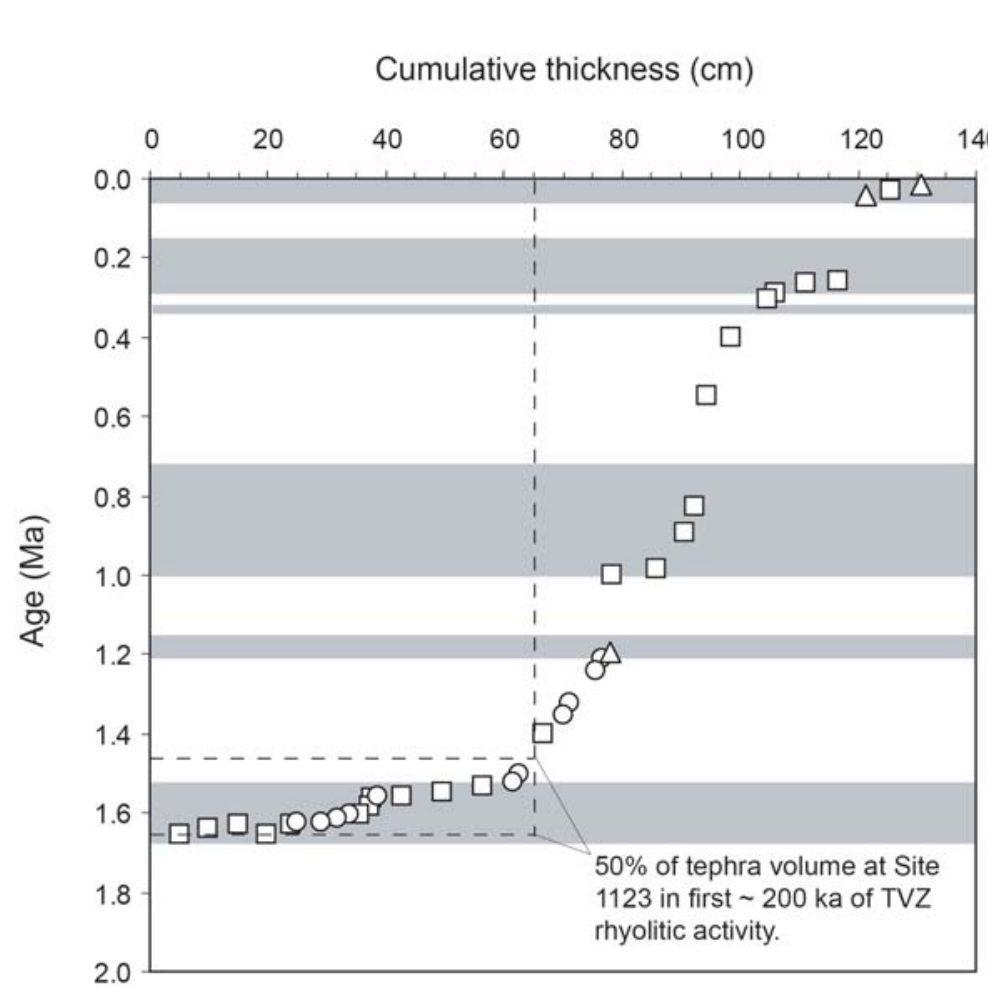

Site 1123 tephra record

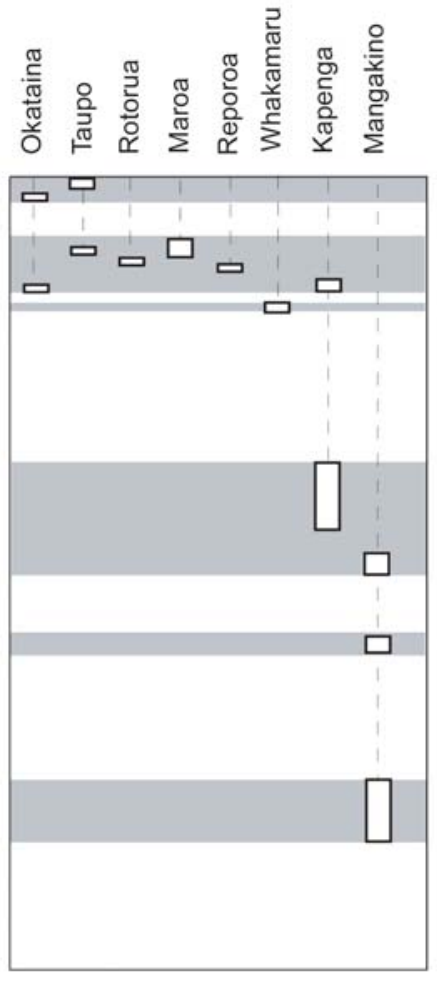

Terrestrial record - caldera collapse episodes

Figure 2-12. Cumulative thickness $(\mathrm{cm})$ of the 37 TVZ-derived tephra eruptive units at Site 1123 plotted against time (Ma). Thicknesses of individual tephra eruptive units represent the mean thickness of each unit correlated between cores. Square symbols indicate orbitally tuned ages, circles indicate interpolated ages for tephras within the disturbed section of the composite age model and triangle symbols denote the age of an onland correlative. Note $50 \%$ of the total tephra thickness was produced in the first $\sim 200$ ka. Also shown are the known periods of activity for the eight caldera centres within the central TVZ (after Houghton et al., 1995). Dashed lines are for clarity only and do not imply any continuity of the caldera systems. A significant number of large eruptions are recorded at Site 1123 for which there is no evidence in the terrestrial ignimbrite stratigraphy.

\subsection{Deposition and preservation potential of deep-marine tephras}

The most common method of estimating eruption volumes is to construct isopach maps of air fall deposits, inferring a direct relationship between the thickness and distance of a tephra from its source to the size of the eruption (e.g. Froggatt, 1982; Pyle, 1989, 1995; Fierstein and Nathenson, 1992). However, the thickness of tephras correlated between the three sediment cores at Site 1123 is often, though not always, inconsistent. For example, the thickness of the correlated tephra layers A-19 (1123A), AT-385 (1123B) and A-18 (1123C) varies from $2 \mathrm{~cm}$ to $8 \mathrm{~cm}$. This observation, and previous work by Manville and Wilson (2004), would suggest that the isopach technique is unreliable when applied to tephras in deep ocean settings. Manville and Wilson (2004) examined the processes involved in the deposition of 
marine tephras, challenging the theory that glass shards settle from the ocean surface to the seafloor following Stokes Law. The 1991 Pinatubo eruption and resulting marine tephra was used as an example to highlight inconsistencies in this theory. Following Stokes Law, Manville and Wilson (2004) calculated that individually settling glass shards $(<32 \mu \mathrm{m})$ would take months to decades to reach the deep ocean floor. However, the 1991 Pinatubo tephra was collected in deep ocean samplers (> $3700 \mathrm{~m}$ water depth) only three days after the eruption (Weisner et al., 1995). Using laboratory experiments to simulate a heavy ash fall on the ocean surface, Manville and Wilson (2004) showed that gravitational instabilities would form beneath the ocean surface leading to the rapid deposition of the tephra via vertical density currents. Upon reaching the ocean floor lateral density flows formed and flowed around the seafloor topography, influencing properties such as grain size distribution and tephra thickness. As a result, Manville and Wilson (2004) concluded that the use of grain size distribution and tephra thickness from marine tephras could not be relied upon to elucidate characteristics about the source eruptions, such as eruptive volume, in the same way that they are commonly applied to terrestrial deposits. The variable thickness of the correlated tephras between the three cores at Site 1123 is entirely consistent with the conclusions of Manville and Wilson (2004). It is notable that out of the $\sim 37-38$ tephra eruptive units recognised in the revised composite record at Site 1123, only 8 are identified in all three Site 1123 sediment cores. Furthermore, the potential for a tephra to be preserved in all three records does not seem to have any direct relationship to eruption size. For example, the Kawakawa and Rotoehu tephras originate from the Oruanui $\left(\sim 530 \mathrm{~km}^{3}{ }_{\text {magma }}\right)$ and Rotoiti ( $>\sim 120 \mathrm{~km}^{3}$ magma) eruptions, respectively, which are the largest eruptions to occur in the last ca. $230 \mathrm{ka}$ of TVZ history (Wilson et al., 2007). Despite the large size of their parental eruptions, these tephras were only recovered in one of the three Site 1123 cores (Figure 2-8). In contrast, the Omataroa Tephra, sourced from a comparatively small $\left(\sim 4.1 \mathrm{~km}^{3}{ }_{\text {magma }}\right.$; Smith et al., 2005$)$ eruption from Okataina volcano, is present in all three cores as 3 to $5 \mathrm{~cm}$ thick layers.

Two other aspects of the (non-) preservation of TVZ tephras in the Site 1123 record are important to note. Firstly, the Potaka Tephra is one of the most widespread Quaternary tephras in the New Zealand region (Shane, 1994) and has been linked to the Kidnappers eruption with an estimated bulk volume of the ignimbrite alone of $>$ 
$450 \mathrm{~km}^{3}$ (Wilson et al., 1995b). However, at Site 1123 the Potaka Tephra is only present in one core (1123A) as a very thin $(5 \mathrm{~mm})$ layer. Secondly, the Rangitawa Tephra (previously Mt Curl Tephra), which is related to the $\left(>1000 \mathrm{~km}^{3}\right.$ magma) Whakamaru group ignimbrites (Brown et al.,1998), the single largest known eruptive episode from the TVZ, is entirely absent from the Site 1123 record.

The results of Manville and Wilson (2004) provide one possible explanation for the seemingly random preservation potential of these tephras. The conspicuous absence of the Rangitawa Tephra probably does not reflect that this tephra was never dispersed as far as Site 1123, an assertion supported by the identification of the Rangitawa Tephra in deep ocean sediment cores located several hundred kilometres to the northeast and southeast of Site 1123 (Froggatt et al., 1986; Shane and Froggatt, 1991). Rather, owing to the vigorous nature of tephra deposition in the deep ocean (Manville and Wilson, 2004), and interactions with paleo-seafloor topography at the time of deposition, the Rangitawa Tephra could be 'patchily' preserved at Site 1123 and simply may not have been sampled in any of the three sediment cores. Similarly, this could explain why tephras originating from some of the largest known TVZ eruptions (such as the Kawakawa, Rotoehu and Potaka tephras) were only recovered in one out of three cores, yet smaller eruptive units, such as the Omataroa Tephra, were recovered in all three. In addition, it is possible that sea state has a significant influence on the preservation of tephra deposits in deep ocean sediments. For example, one might expect that an ash fall deposited during stormy open sea conditions may be more vigorously mixed as it descends to the ocean floor, resulting in a more uniform preservation, whereas during calm ocean conditions the ash 'crust' that forms on the ocean surface (cf. Manville and Wilson, 2004) give way to gravitational instability resulting in patchy preservation.

Despite the retrieval of three cores in close proximity (within a few hundred metres) at Site 1123, a maximum of 22 out of $\sim 37$ individual tephra eruptive units at Site 1123 are preserved in one core. This means that the probability $(\mathrm{P})$ of recovering a tephra in one of the three cores is only approximately $\mathrm{P}=0.60$. Therefore, the probability that a tephra is present at Site 1123, but was not recovered in any of the three cores (as is postulated for the Rangitawa Tephra), can be approximated as $\mathrm{P}=$ $0.40^{3}$ or, $\sim 0.064$. Although simplified, this statistical approach suggests that only $~$ $93 \%$ of all tephras present at Site 1123 may have been recovered by the three 
sediment cores. In order to recover $>99 \%\left(\mathrm{P}=1.0-0.4^{5}\right)$ of all tephras at this site at least 5 cores would need to have been retrieved. Whilst these statistics are likely sitespecific, on this basis it may be considered that any deep ocean sediment drilling project that has the potential for tephrochronological age control should comprise multiple cores in close proximity to provide a greater chance of retrieving all or most of the tephras present at any given site; although this recommendation should be considered with respect to the large cost of recovering multiple deep ocean drill cores. As this study has shown, the LA-ICP-MS technique of fingerprinting individual glass shards of tephras using trace element data then provides a robust method of correlating between these cores to construct a composite record in conjunction with other stratigraphic techniques.

\section{Conclusions}

New single shard major and trace element data for 70 Quaternary silicic tephra layers recovered from ODP Site 1123 has shown that:

(1) LA-ICP-MS trace element data can clearly distinguish between individual tephra eruptive units that have effectively identical major element glass chemistries.

(2) Two previously unidentified repeated sections of the core in $1123 \mathrm{~A}(\sim 4.5 \mathrm{~m}$ thick) and $1123 \mathrm{C}$ ( $7.9 \mathrm{~m}$ thick) are recognised, and may have been caused by a localised sedimentary slide. These repeated sections were unable to be resolved by visual inspections of the sediment cores or from the major element glass fingerprints of the repeated tephras, and highlight the potential for the use of trace elements by the LA-ICP-MS technique to refine the construction of composite marine stratigraphic records when tephras are available for analysis.

(3) Isochronous tephra tie-lines established between cores (1123A, B and C) allow critical evaluation of the original composite record. The previously unrecognised repeated sections in $1123 \mathrm{~A}$ and $1123 \mathrm{C}$ led to a significant error in the original composite stratigraphy and oxygen isotope age model between ca. 1.15 and 1.38 Ma. Thus, the previously reported Quaternary Site 1123 composite oxygen isotope age model is only reliable for the periods 0.0 to $1.15 \mathrm{Ma}$ and 1.40 to $1.81 \mathrm{Ma}$. The lack of evidence for repeated stratigraphy in $1123 \mathrm{~B}$ means that construction of a complete 
Quaternary oxygen isotope record for this site is possible, but only if sampling is restricted to 1123B from 41.0 - 54.0 mbsf.

(4) The eruptive frequency of explosive TVZ-derived silicic eruptions, as recorded by the deposition of $\sim 37$ tephra units at Site 1123, has not been constant throughout the evolution of the TVZ. It has generally been characterised by short periods (25-50 ka) of intense activity bracketed by longer periods (100-130 ka or longer) of quiescence. The most active period of tephra deposition at Site 1123 (at least 1 every $7 \mathrm{ka}$ ) occurred from $1.53-1.66 \mathrm{Ma}$, corresponding to the first $\sim 130 \mathrm{ka}$ of silicic volcanism in the TVZ.

(5) Tephras preserved at Sites 1123 and 1124 after the mid-Pleistocene transition (post-1 Ma) and onset of 100 ka climate cycles were predominantly erupted and deposited within, or during the transition into glacial periods. This may reflect stronger atmospheric winds during glacial periods that more effectively delivered tephra material to the ocean surface above Site 1123 or, more speculatively, a eustatic unloading effect on the emptying of large shallow-level magma chambers from the New Zealand microcontinent during periods of lowering or low sea-level. (6) Significant variations in the thicknesses of individual tephra eruptive units correlated between the Site 1123 sediment cores, and the irregular occurrence of most tephras in the three cores, support the findings of Manville and Wilson (2004) that the physical properties of deep marine tephras (e.g. thickness, grain size) are strongly influenced by the mode of deposition (vertical density currents). Thus, the isopach technique for estimating eruption volumes based on the thickness of tephra deposits is unreliable when applied to deep ocean tephras. 


\section{References}

Alloway, B.V., Pillans, B.J., Sandhu, A.S., Westgate, J.A., 1993. Revision of marine chronology in Wanganui Basin, New Zealand, based on isothermal plateau fission-track dating of tephra horizons. Sedimentary Geology 82, 299-310.

Alloway, B., Westgate, J., Pillans, B., Pearce, N., Newnham, R., Byrami, M., Aarburg, S., 2004. Stratigraphy, age and correlation of middle Pleistocene silicic tephras in the Auckland region, New Zealand - a prolific distal record of Taupo Volcanic Zone volcanism. New Zealand Journal of Geology and Geophysics 47, 447-479.

Alloway, B.V., Pillans, B.J., Carter, L., Naish, T.R., Westgate, J.A., 2005. Onshore-offshore correlation of Pleistocene rhyolitic eruptions from New Zealand: implications for TVZ eruptive history and paleoenvironmental construction. Quaternary Science Reviews 24, 1601-1622.

Almond, P.C., Shanhun, F.L., Rieser, U., Shulmeister, J., 2007. An OSL, radiocarbon and tephraisochron based chronology for Birdlings Flat loess at Ahuriri Quarry, Banks Peninsula, Canterbury, New Zealand. Quaternary Geochronology 2, 4-8.

Black, T.M., 1992. Chronology of the Middle Pleistocene Kidnappers Group, New Zealand and correlation to global oxygen isotope stratigraphy. Earth and Planetary Science Letters 109, 573-584.

Black, T.M., Shane, P.A.R., Westgate, J.A., 1996. Chronological and paleomagnetic constraints on widespread ignimbrites of the Taupo Volcanic Zone, New Zealand. Bulletin of Volcanology 58, 226-238.

Briggs, R.M., Gifford, M.G., Moyle, A.R., Taylor, S.R., Norman, M.D., Houghton, B.F., Wilson, C.J.N., 1993. Geochemical zoning and eruptive mixing in ignimbrites from Mangakino volcano, Taupo Volcanic Zone, New Zealand. Journal of Volcanology and Geothermal Research 56, 175-203.

Brown, S.J.A., Wilson, C.J.N., Cole, J.W., Wooden, J., 1998. The Whakamaru group ignimbrites, Taupo Volcanic Zone, New Zealand: evidence for reverse tapping of a zoned silicic magmatic system. Journal of Volcanology and Geothermal Research 84, 1-37.

Bryant, C.J., Arculus, R.J., Eggins, S.M., 1999. Laser ablation-inductively coupled plasma-mass spectrometry and tephras: A new approach to understanding arc-magma genesis. Geology 27, 1119-1122.

Carter, L., Carter, R.M., McCave, I.N., Gamble, J., 1996. Regional sediment recycling in the abyssal Southwest Pacific Ocean. Geology 24, 735-738.

Carter, L., Alloway, B., Shane, P., Hall, I.R., Harris, S.E., Westgate, J.A., 2003. Demise of one volcanic zone and birth of another - A 12 m.y. marine record of major rhyolitic eruptions from New Zealand. Geology 31, 493-496.

Carter, L., Alloway, B., Shane, P., Westgate, J., 2004. Deep-ocean record of major late Cenozoic rhyolitic eruptions from New Zealand. New Zealand Journal of Geology and Geophysics 47, 481-500.

Eggins, S.M., Kinsley, L..P.J., Shelley, J.M.G., 1998. Deposition and element fractionation processes during atmospheric pressure laser sampling for analysis by ICP-MS. Applied Surface Science $129,278-286$.

Fenner, J., Stefano, A.D., 2004. Late Quaternary oceanic fronts along Chatham Rise indicated by phytoplankton assemblages, and refined calcareous nannofossil stratigraphy for the midlatitude SW Pacific. Marine Geology 205, 59-86. 
Fierstein, J., Nathenson, M., 1992. Another look at the calculation of fallout tephra volumes. Bulletin of Volcanology 54, 156-167.

Froggatt, P.C., 1982. Review of methods of estimating rhyolitic tephra volumes; applications to the Taupo Volcanic Zone, New Zealand. Journal of Volcanology and Geothermal Research 14, 301-318.

Froggatt, P.C., Nelson, C.S., Carter, L., Griggs, G., Black, K.P., 1986. An exceptionally large late Quaternary eruption from New Zealand. Nature 319, 578-582.

Guillong, M., Günther, D., 2002. Effect of particle size distribution on ICP-induced elemental fractionation in laser ablation - inductively coupled plasma - mass spectrometry. Journal of Analytical Atomic Spectrometry 17, 831-837.

Hall, I.R., McCave, I.N., Shackleton, N.J., Weedon,G.P., Harris, S.E., 2001. Intensified deep Pacific inflow and ventilation in Pleistocene glacial times. Nature 412, 809-812.

Harangi, S., Mason, P., Lukács, R., 2005. Correlation and petrogenesis of silicic pyroclastic rocks in the Northern Pannonian Basin, Eastern-Central Europe: In situ trace element data of glass shards and mineral chemical constraints. Journal of Volcanology and Geothermal Research $143,237-257$.

Harris, S.E., 2002. Data report: Late Pliocene-Pleistocene carbon and oxygen stable isotopes from benthic foraminifers at Ocean Drilling Program Site 1123 in the Southwest Pacific. In Richter, C. (Ed.) Proc. ODP, Scientific Results, 181, 1-20. Available from World Wide Web: http://www-odp.tamu.edu/publications/181_SR/volume/chapters/203.pdf.

Hildreth, W., 1979. The Bishop Tuff: Evidence for the origin of compositional zonation in silicic magma chambers. In Chapin, C.E., and Elston, W.E., (eds) Ash Flow Tuffs, Geological Society of America Special Paper 180, 43-75.

Horn, I., Günther, D., 2003. The influence of ablation carrier gases Ar, He and Ne on the particle size distribution and transport efficiencies of laser ablation-induced aerosols: implications for LAICP-MS. Applied Surface Science 207, 144-157.

Houghton, B.F., Wilson, C.J.N., McWilliams, M.O., Lanphere, M.A., Weaver, S.D., Briggs, R.M., Pringle, M.S., 1995. Chronology and dynamics of a large silicic magmatic system: Central Taupo Volcanic Zone, New Zealand. Geology 23, 13-16.

Jarosewich, E., Nelen, J.A., Norberg, J.A., 1979. Electron microprobe reference samples for mineral analysis. Smithsonian Contributions to the Earth Sciences 22, 68-72.

Jochum, K.P., Stoll, B., Herwig, K., Willbold, W., Hofmann, A.W., Amini, M., Aarburg, S., Abouchami, W., Hellebrand, E., Mocek, B., Raczek, I., Stracke, A., Alard, O., Bouman, C., Becker, S., Dücking, M., Brätz, H., Klemd, R., de Bruin, D., Canil, D., Cornell, D., de Hoog, C.J., Dalpé, C., Danyushevsky, L., Eisenhauer, A., Gao, Y., Snow, J.E., Groschopf, N., Günther, D., Latkocsy, C., Guillong, M., Hauri, E.H., Höfer, H,E., Lahaye, Y., Horz, K., Jacob, D.E., Kasemann, S.A., Kent, A.J.R., Ludwig, T., Zack, T., Mason, P.R.D., Meixner, A., Rosner, M., Misawa, K., Nash, B.P., Pfänder, J., Premo, W.R., Sun, W.D., Tiepolo, M., Vannucci, R., Vennemann, T., Wayne, D., Woodhead, J.D., 2006. MPI-DING reference glasses for in situ microanalysis: New reference values for element concentrations and isotope ratios. Geochemistry Geophysics Geosystems 7, Q02008, doi:10.1029/2005GC001060.

King, P.R., 2000. Tectonic reconstructions of New Zealand: 40 Ma to the present. New Zealand Journal of Geology and Geophysics 43, 611-638. 
Kroslakova, I., Günther, D., 2007. Elemental fractionation in laser ablation-inductively coupled plasma-mass spectrometry: evidence for mass load induced matrix effects in the ICP during ablation of a silicate glass. Journal of Analytical Atomic Spectrometry 22, 51-62.

Le Maitre, R.W., 1984. A proposal by the IUGS subcommission on the systematics of igneous rocks for a chemical classification of volcanic rocks based on total alkali silica (TAS) diagram. Australian Journal of Earth Sciences 31, 243-255.

Lean, C.M.B., McCave, I.N., 1998. Glacial to interglacial mineral magnetic and palaeoceanographic changes at Chatham Rise, SW Pacific Ocean. Earth and Planetary Science Letters 163, 247260.

Lian, O.B., Shane, P.A., 2000. Optical dating of paleosols bracketing the widespread Rotoehu tephra, North Island, New Zealand. Quaternary Science Reviews 19, 1649-1662.

Lowe, D.J., Shane, P.A.R., Alloway, B.V., Newnham, R.M., 2008. Fingerprints and age models for widespread New Zealand tephra marker beds erupted since 30,000 years ago: a framework for NZ-INTIMATE. Quaternary Science Reviews 27, 95-126.

Mahood, G., Hildreth, W., 1983. Large partition coefficients for trace elements in high-silica rhyolites. Geochimica et Cosmochimica Acta 47, 11-30.

Manville, V., Wilson, C.J.N., 2004. Vertical density currents: a review of their potential role in the deposition and interpretation of deep-sea ash layers. Journal of the Geological Society, London 161, 947-958.

Mason, B.G., Pyle, D.M., Dade, W.B., Jupp, T., 2004. Seasonality of volcanic eruptions. Journal of Geophysical Research 109, BO4206, doi:10.1029/2002JB002293.

McGuire, W.J., Howarth, R.J., Firth, C.R., Solow, A.R., Pullen, A.D., Saunders, S.J., Stewart, I.S., Vita-Finzi, C., 1997. Correlation between rate of sea-level change and frequency of explosive volcanism in the Mediterranean. Nature 389, 473-476.

McNutt, S.R., Beavan, R.J., 1987. Eruptions of Pavlof Volcano and their possible modulation by ocean load and tectonic stresses. Journal of Geophysical Research 92, 11,509-11,523.

Mildenhall, D.C., Hollis, C.J., Naish, T.R., 2004. Orbitally-influenced vegetation record of the MidPleistocene Transition, offshore eastern New Zealand (ODP Leg 181, Site 1123). Marine Geology 205, 87-111.

Mix, A.C., Pisias, N.G., Rugh, W., Wilson, J., Morey, A., Hagelberg, T.K., 1995. Benthic foraminifer stable isotope record from Site 849 (0-5 Ma); local and global climate changes. Proceedings of the Ocean Drilling Program, Scientific Results 138, 371-412.

Nakada, M., Yokose, H., 1992. Ice age as a trigger of active Quaternary volcanism and tectonism. Tectonophysics 212, 321-329.

Nelson, C.S., Froggatt, P.C., Gosson, G.J., 1986. Nature, chemistry, and origin of Late Cenozoic megascopic tephras in Leg 90 cores from the Southwest Pacific. Initial Reports of Deep Sea Drilling Project, Volume XC, Part 2, 1161-1171.

Newnham, R.M., Vandergoes, M.J., Hendy, C.H., Lowe, D.J., Preusser, F., 2007. A terrestrial palynological record for the last two glacial cycles from southwestern New Zealand. Quaternary Science Reviews 26, 517-535.

Paterne, M., Labeyrie, J., Guichard, F., Mazaud, A., Maitre, F., 1990. Fluctuations of the Campanian explosive volcanic activity (South Italy) during the past 190,000 years, as determined by marine tephrochronology. Earth and Planetary Science Letters 98, 166-174. 
Pearce, N.J.G., Westgate, J.A., Perkins, W.T., 1996. Developments in the analysis of volcanic glass shards by laser ablation ICP-MS: Quantitative and single internal standard-multi-element methods. Quaternary International 34-36, 213-227.

Pearce, N.J.G., Perkins, W.T., Westgate, J.A., Gorton, M.P., Jackson, S.E., Neal, C.R., Chenery, S.P., 1997. A compilation of new and published major and trace element data for NIST SRM 610 and NIST SRM 612 glass reference materials. Geostandards Newsletter 21, 115-144.

Pearce, N.J.G., Westgate, J.A., Perkins, W.T., Eastwood, W.J., Shane, P., 1999. The application of laser ablation ICP-MS to the analysis of volcanic glass shards from tephra deposits: bulk glass and single shard analysis. Global and Planetary Change 21, 151-171.

Pearce, N.J.G, Eastwood, W.J, Westgate, J.A., Perkins, W.T, 2002. Trace element composition of single glass shards in distal Minoan tephra from SW Turkey. Journal of the Geological Society, London 159, 545-556.

Pearce, N.J.G, Westgate, J.A., Perkins, W.T., Preece, S.J., 2004. The application of ICP-MS methods to tephrochronological problems. Applied Geochemistry 19, 289-322.

Pearce, N.J.G., Denton, J.S., Perkins, W.T., Westgate, J.A., Alloway, B.V., 2007. Correlation and characterisation of individual glass shards from tephra deposits using trace element laser ablation ICP-MS analyses: current status and future potential. Journal of Quaternary Science $22,721-736$.

Pearce, N.J.G., Westgate, J.A., Alloway, B.V., 2008. Mid-Pleistocene silicic tephra beds in the Auckland region, New Zealand: their correlation and origins based on trace element analyses of single shards. Quaternary International 178, 16-43.

Pillans, B., Wright, I., 1992. Late Quaternary tephrostratigraphy from the southern Havre Trough, Bay of Plenty, northeast New Zealand. New Zealand Journal of Geology and Geophysics 35, 129143.

Pillans, B., Alloway, B., Naish, T., Westgate, J., Abbott, S., Palmer, A., 2005. Silicic tephras in Pleistocene shallow-marine sediments of Wanganui Basin, New Zealand. Journal of the Royal Society of New Zealand 35, 43-90.

Pyle, D.M., 1989. The thickness, volume and grainsize of tephra fall deposits. Bulletin of Volcanology 51, 1-15.

Pyle, D.M., 1995. Assessment of the minimum volume of tephra fall deposits. Journal of Volcanology and Geothermal Research 69, 379-382.

Rampino, M.R., Self, S., Fairbridge, R.W., 1979. Can rapid climate change cause volcanic eruptions? Science 206, 826-829.

Rodushkin, I., Axelsson, M.D., Malinkovsky, D., Baxter, D.C., 2002. Analyte- and matrix-dependent elemental response variations under laser ablation inductively coupled plasma mass spectrometry. Part 1. The roles of plasma and ion sampling conditions. Journal of Analytical Atomic Spectrometry 17, 1223-1230.

Shane, P.A.R., 1994. A widespread, early Pleistocene tephra (Potaka Tephra $1 \mathrm{Ma}$ ) in New Zealand; characteristics, distribution, and implications. New Zealand Journal of Geology and Geophysics 37, 25-35.

Shane, P.A.R., Froggatt, P.C., 1991. Glass chemistry, paleomagnetism, and correlation of middle Pleistocene tuffs in southern North Island, New Zealand, and Western Pacific. New Zealand Journal of Geology and Geophysics 34, 203-211.

Shane, P., Sandiford, A., 2003. Paleovegetation of Marine Isotope Stages 4 and 3 in northern New Zealand and the age of the widespread Rotoehu tephra. Quaternary Research 59, 420-429. 
Shane, P.A.R., Black, T.M., Alloway, B.V., Westgate, J.A., 1996. Early to middle Pleistocene tephrochronology of North Island, New Zealand; implications for volcanism, tectonism and paleoenvironments. Geological Society of America Bulletin 108, 915-925.

Shane, P., Sikes, E.L.., Guilderson, T.P., 2006. Tephra beds in deep-sea cores off northern New Zealand: implications for the history of Taupo Volcanic Zone, Mayor Island and White Island volcanoes. Journal of Volcanology and Geothermal Research 154, 276-290.

Shipboard Scientific Party, 1999. Site 1123: North Chatham Drift - a 20 Ma record of the Pacific Deep Western Boundary Current. Proceedings ODP Initial Report Leg 181, 1-84 (CD-ROM).

Shulmeister, J., Shane, P., Lian, O.B., Okuda, M., Carter, J.A., Harper, M., Dickinson, W.W., Augustinus, P., Heijnis, H., 2001. A long, late-Quaternary record from Lake Poukawa, Hawkes Bay, New Zealand. Palaeogeography, Palaeoclimatology, Palaeoecology 176, 81107.

Smith, V.C., Shane, P., Nairn, I.A., 2005. Trends in rhyolite geochemistry, mineralogy, and magma storage during the last $50 \mathrm{kyr}$ at Okataina and Taupo volcanic centres, Taupo Volcanic Zone, New Zealand. Journal of Volcanology and Geothermal Research 148, 372-406.

Ukstins Peate, I., Baker, J.A., Kent, A.J.R., Al-Kadasi, M., Al-Subbary, A., Ayalew, D., Menzies, M., 2003. Correlation of Indian Ocean tephra to individual Oligocene silicic eruptions from AfroArabian flood volcanism. Earth and Planetary Science Letters 211, 311-327.

Ukstins Peate, I., Kent, A.J.R., Baker, J.A., Menzies, M.A., 2008. Extreme geochemical heterogeneity in Afro-Arabian Oligocene tephras: Preserving fractional crystallization and mafic recharge processes in silicic magma chambers. Lithos 102, 260-278.

Weedon, G.P., Hall, I.R., 2004. Neogene palaeoceanography of Chatham Rise (Southwest Pacific) based on sediment geochemistry. Marine Geology 205, 207-225.

Weisner, M.G., Wang, Y., Zheng, I., 1995. Fallout of volcanic ash to the deep South China Sea induced by the 1991 eruption of Mount Pinatubo (Philippines). Geology 23, 885-888.

Wilson, C.J.N., 1986. Reconnaisance stratigraphy and volcanology of ignimbrites from Mangakino volcano. In Smith, I.E.M (Editor), Late Cenozoic Volcanism in New Zealand. Royal Society of New Zealand Bulletin 23, 179-193.

Wilson, C.J.N., Switsur, V.R., Ward, A.P., 1988. A new ${ }^{14} \mathrm{C}$ age for the Oruanui (Wairakei) eruption, New Zealand. Geological Magazine 125, 297-300.

Wilson, C.J.N., Houghton, B.F., Lanphere, M.O., Weaver, S.D., 1992. A new radiometric age estimate for the Rotoehu Ash from Mayor Island volcano, New Zealand. New Zealand Journal of Geology and Geophysics 35, 371-374.

Wilson, C.J.N., Houghton, B.F., McWilliams, M.O., Lanphere, M.A., Weaver, S.D., Briggs, R.M., 1995a. Volcanic and structural evolution of Taupo Volcanic Zone, New Zealand: a review. Journal of Volcanology and Geothermal Research 68, 1-28.

Wilson, C.J.N., Houghton, B.F., Kamp, P.J.J., McWilliams, M.O., 1995b. An exceptionally widespread ignimbrite with implications for pyroclastic flow emplacement. Nature 378, 605607.

Wilson, C.J.N., Rhoades, D.A., Lanphere, M.O., Calvert, A.T., Houghton, B.F., Weaver, S.D., Cole, J.W., 2007. A multi-approach radiometric age estimate for the Rotoiti and Earthquake Flat eruptions, New Zealand, with implications for the MIS 4/3 boundary. Quaternary Science Reviews 26, 1861-1870. 


\title{
Chapter Three: Petrogenetic $\underline{\text { APPLICATIONS }}$
}

\author{
Re-examining the petrogenesis of silicic magmas from the world's most active \\ silicic volcanic system: an elemental and $\mathrm{Sr}-\mathrm{Nd}-\mathrm{Pb}$ isotopic study of an 1.65 Ma \\ deep ocean tephra record sourced from Taupo Volcanic Zone, New Zealand
}

\begin{abstract}

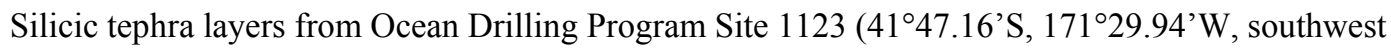
Pacific Ocean) are a well-dated $\sim 1.65$ Ma record of explosive silicic volcanism from the Taupo Volcanic Zone (TVZ), New Zealand. In this study major and trace element data from the $\sim 37$ Site 1123 tephra units are combined with new high precision $\mathrm{Sr}, \mathrm{Nd}$ and $\mathrm{Pb}$ isotope data for representative tephra units to investigate the generation of Quaternary silicic magmas in the TVZ.

Four broad silicic melt types (Types 1-4) are identified on the basis of age and chemistry. The youngest tephras $\left(<0.83 \mathrm{Ma}\right.$, Type 1) are generally more evolved (higher $\mathrm{SiO}_{2}$, lower $\mathrm{FeO}$, lower $\mathrm{Zr}$ ) than the oldest tephras $(1.50-1.65 \mathrm{Ma}$, Type 3$)$. Tephras with intermediate ages $(0.89-1.40 \mathrm{Ma})$ have considerable compositional overlap with Types 1 and 3 but also encompass some compositions (Type 2) with high concentrations of $\mathrm{Mg}$, Ti and $\mathrm{V}$. A single tephra unit (1.603 Ma) comprises melt Type 4 which has the lowest abundances of $\mathrm{Nb}, \mathrm{Zr}, \mathrm{Hf}, \mathrm{Ti}, \mathrm{Mg}, \mathrm{Ba}$ and HREEs, and highest abundances of $\mathrm{K}_{2} \mathrm{O}, \mathrm{Cs}, \mathrm{Rb}, \mathrm{Th}, \mathrm{U}$. Indices of fractional crystallisation and crustal contamination indicate that differential fractional crystallisation of accessory zircon, hydrous mineral phases and FeTi oxides is the primary cause for the development of these four melt types.
\end{abstract}

Trace element heterogeneity in glass shards from individual tephra units is commonplace, although such heterogeneity is not always preserved in the form of coherent linear or curvilinear trends on bivariate plots and instead often appears as diffuse clouds of data. The potential for preserving coherent trace element variations in the melt is likely to be dependent upon a number of physical (temperature, melt viscocity, crystallinity) and chemical (differential diffusivities of trace elements) parameters in the pre-eruptive magma bodies, as well as the number of compositional end-members.

Glass separates from 13 representative Site 1123 tephra units yielded the following ranges in isotopic compositions: ${ }^{87} \mathrm{Sr} /{ }^{86} \mathrm{Sr}=0.70535$ to $0.70643 ; \varepsilon_{\mathrm{Nd}}=-0.63$ to $1.35 ;{ }^{206} \mathrm{~Pb} /{ }^{204} \mathrm{~Pb}=18.835$ to 18.858 ; ${ }^{207} \mathrm{~Pb} /{ }^{204} \mathrm{~Pb}=15.625$ to $15.644 ;{ }^{208} \mathrm{~Pb} /{ }^{204} \mathrm{~Pb}=38.717$ to 38.774 . Sr-Nd isotopic compositions are largely consistent with that of previously reported whole rock isotopic data, but the $\mathrm{Pb}$ isotopic compositions of tephras reported here are almost exclusively offset more radiogenic $\mathrm{Pb}$ than any previously reported whole rock $\mathrm{Pb}$ isotopic data. This observation may reflect either incomplete removal of surface $\mathrm{Pb}$ contamination from pumiceous samples in earlier studies or the existence of significant crystal-melt isotopic heterogeneity in silicic TVZ magmas.

Most of the isotopic compositions of Site 1123 tephras cannot be explained by models in which Torlesse meta-sedimentary rocks are invoked as the sole crustal contaminant of mafic TVZ magmas. We propose a two-stage crustal contamination model in which ascending TVZ basalts are contaminated first at depth by Waipapa meta-greywacke crust (up to $15 \%$ ) followed by the assimilation of Torlesse meta-greywacke crust (20 to $45 \%$ ) at shallower levels. Bulk mixing models suggest the majority of the Site 1123 tephra samples require a total crustal component of $\sim 35 \%$ with the most chemically and isotopically evolved sample requiring a total of $\sim 45 \%$ crust. Extensive fractional crystallisation ( 55 to $85 \%$ ) is also required to have accompanied crustal assimilation in order to drive the melt compositions to the observed high $\mathrm{SiO}_{2}$ rhyolite compositions. The isotopic characteristics of plutonic xenoliths found in some TVZ ignimbrites, which are interpreted to represent the crystallised margins of zoned silicic magma chambers, are also broadly consistent with this model. 


\subsection{INTRODUCTION}

While it is generally accepted that all types of terrestrial magmatism ultimately derives its heat from the mantle (Hildreth, 1981), identifying the source(s) of magmas remains contentious in some settings. In particular, the origins of voluminous and catastrophically erupted silicic magmas is perhaps one of the longest standing controversies in igneous petrology. Fundamental to understanding of the generation of silicic magmas is whether they represent predominantly new additions to the crust as the result of extensive fractional crystallisation of mafic mantlederived melts or large scale recycling of existing continental crust by assimilation and melting of existing crustal protoliths.

Geochemical and isotopic studies of silicic volcanic rocks are the most commonly employed techniques when addressing the question of magma sources. The coupled effects of incompatible trace element partitioning during mantle melting and the time dependent in-growth of radiogenic daughter isotopes over geological timescales has resulted in a spectrum of isotopically distinctive source reservoirs in the mantle and crust (of different ages) from which magmas are ultimately sourced (Davidson et al., 2007). Radiogenic isotope ratios of volcanic rocks and their components can therefore be used to fingerprint the various source contributions involved in their genesis, and ultimately provide first order constraints on the dominance of either mantle or crustal contributions to silicic magmatism (Riley et al., 2001; Davidson et al., 2007; Charlier et al., 2008).

The recent development of novel in situ chemical and isotopic techniques allows the products of individual eruptions to be investigated at the crystal to sub-crystal scale (e.g. Charlier et al. 2005, 2008; Davidson et al., 2005, 2007; Morgan et al., 2007; Bindeman et al., 2008). Such studies have shown that many igneous crystals are inherited (antecrysts) and are not in chemical and isotopic equilibrium with the melts in which they were erupted. Therefore, the assumption of whole rock geochemical studies that powdered whole rock samples are isotopically homogeneous does not necessarily hold true (Davidson et al., 2007). In situ chemical and isotopic studies such as those mentioned above, in combination with petrographic observations (e.g. Kontak et al., 2002; Molloy et al., 2008), have demonstrated that silicic magma generation is appreciably more complex than previously realised. Remelting and 
remobilisation of crystalline mush material, crystal inheritance from much older crustal lithologies and the mixing of discrete magma batches are all 'averaged out' by powdered whole rock analytical methods, masking the complex pathways by which silicic magma evolve (Wilson et al., 2006; Hildreth and Wilson, 2007; Charlier et al., 2008; McDonald et al., 2008).

The Taupo Volcanic Zone (TVZ), New Zealand, is a young $(<2 \mathrm{Ma})$ continental arc related to the westward subduction of the Pacific Plate beneath the Australian Plate (Fig. 3-1). The central ( $125 \mathrm{~km}$ x $50 \mathrm{~km})$ segment of the TVZ is characterised by uniquely high rates of rhyolite magma generation and $\geq 90 \%\left(\geq 15000 \mathrm{~km}^{3}\right.$; Wilson et al., 1995a) of the exposed volcanic rocks are of rhyolitic composition, which characterises the TVZ as a silicic large igneous province according to Bryan et al. (2002). At least 34 large silicic eruptions associated with caldera collapse from eight identified volcanic centres have occurred in the last $\sim 1.65 \mathrm{Ma}$ (Houghton et al., 1995). Three main phases of caldera forming activity are suggested by the terrestrial ignimbrite stratigraphy, broadly occurring between ca. 1.60 to $1.53 \mathrm{Ma}, 1.21$ to 0.68 Ma, and 0.34 Ma to present (Houghton et al., 1995). High resolution distal tephra records indicate additional extensive (presumably extra-caldera) silicic activity has occurred outside of these times (Shane et al., 1996a; Carter et al., 2003, 2004; Allan et al., 2008).

Silicic magmas may in principle represent the products of one of two end-member petrogenetic models i.e., extensive fractional crystallisation of mafic mantle-derived melts or large-scale melting of continental crust. These possibilities have been evaluated for TVZ silicic magmas by chemical and isotopic study of primitive TVZ basalts to represent a 'least crustally contaminated' mantle melt and the two broadly Mesozoic-aged meta-greywacke terranes that outcrop to the east (Torlesse) and west (Waipapa) of the TVZ (Fig. 3-1b) to represent the continental crust presumed to underlie the TVZ (Graham et al., 1995). These end-member models can be discounted as the sole processes responsible for the generation of silicic TVZ magmas on the basis of geochemical and isotopic data. While theoretical models of extreme fractional crystallisation (up to 90\%) of high alumina TVZ basalts and andesites can generate rhyolitic magmas in terms of major element, the modelled compositions are irreconcilable with the observed trace element compositions of TVZ rhyolites (Reid, 1983). Bulk melting of meta-greywacke continental crust is 

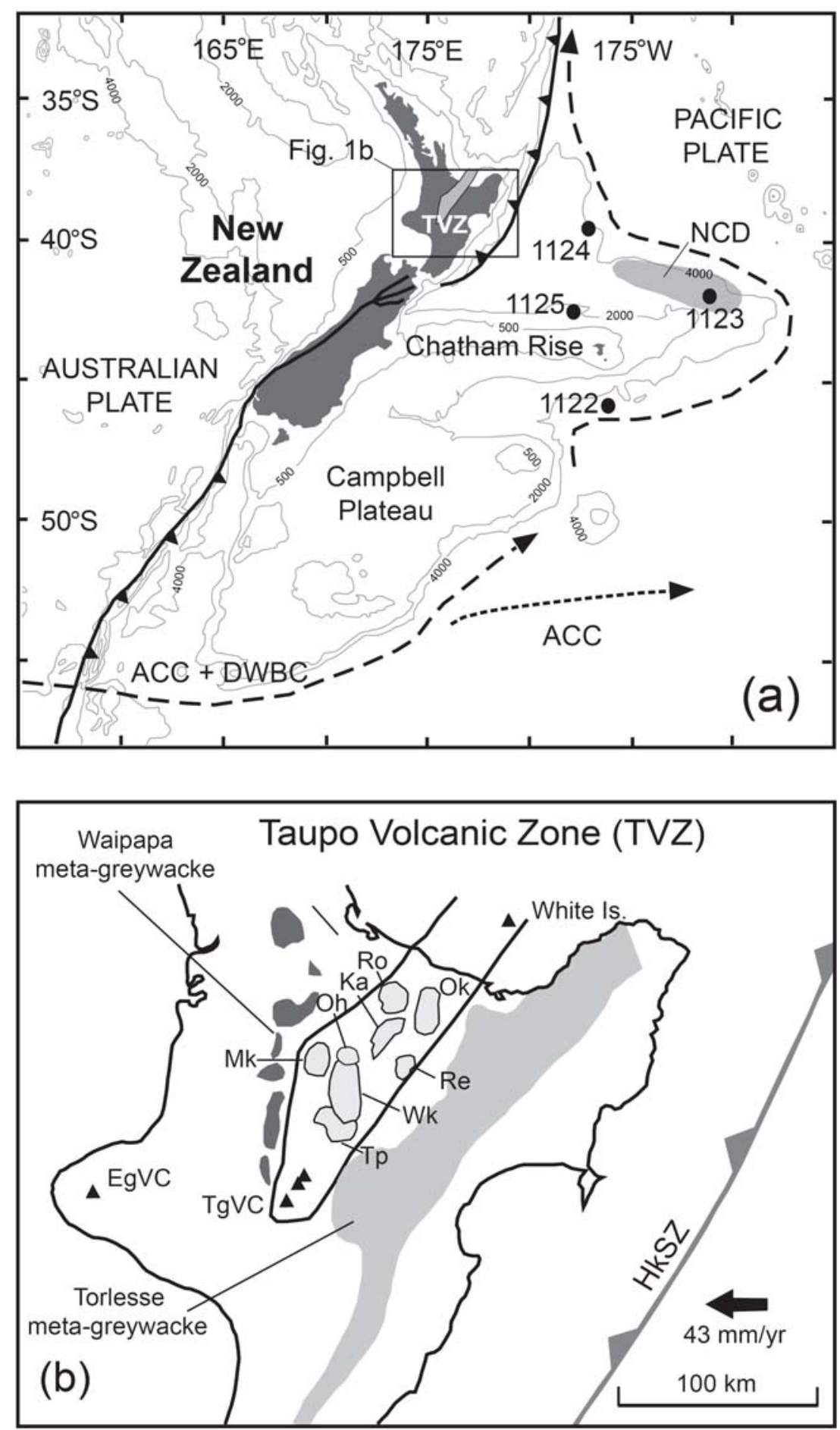

Figure 3-1. (a) Map showing the onshore-offshore New Zealand plate boundary, and the position of the Taupo Volcanic Zone (TVZ) in the central North Island, New Zealand. All tephras analysed in this study (and Allan et al., 2008) were recovered from deep marine sediment cores from Site 1123 located $\sim 1000 \mathrm{~km}$ east of the TVZ. Also shown are Sites 1122, 1124 and 1125 which also record a significant number of TVZ tephras (Carter et al., 2003 \& 2004; Alloway et al., 2005), and the significant deep ocean currents and bathymetric features. ACC - Antarctic Circumpolar Current; DWBC - Deep Western Boundary Current; NCD - North Chatham Drift sediment mass. Isobaths are in metres. Modified from Allan et al. (2008). (b) Close-up of TVZ showing identified caldera centres. Tp - Taupo; Wk - Whakamaru; Mk - Mangakino; Oh - Ohakuri; Re - Reporoa; Ka - Kapenga; Ok - Okataina; Ro Rotorua. The Waipapa and Torlesse meta-greywacke terranes which outcrop to the west and east of the TVZ, respectively, are considered the most likely crustal contaminants involved during the genesis of silicic magmas in the TVZ. Greywacke terrane boundaries from Graham et al. (1995) and the caldera boundaries are based upon Wilson et al. (1995a) and Gravley et al. (2007). 
also inconsistent with the generation of silicic TVZ rocks by this mechanism as both Torlesse and Waipapa meta-greywackes are isotopically $(\mathrm{Sr}, \mathrm{Nd}, \mathrm{Pb}, \mathrm{O})$ distinct from the rhyolites (Blattner and Reid, 1982; Graham et al., 1992, 1995; McCulloch et al., 1994; Blattner et al., 1996). The isotopic compositions of silicic TVZ magmas are, in fact, broadly intermediate between the commonly invoked end-member mantle and crustal compositions (primitive TVZ basalts and the two Mesozoic metagreywackes), and have been explained by either bulk mixing (McCulloch et al., 1994) or combined assimilation fractional crystallisation (AFC) models (Graham et al., 1992, 1995) involving primitive high-alumina TVZ basalts and 10-25\% Torlesse meta-greywacke crustal rocks. These models are apparently inconsistent with the absence of large volumes ( $>100000 \mathrm{~km}^{3}$ ) of fractionated mafic material (cumulates) required to produce the $\sim 15000 \mathrm{~km} 3$ of rhyolite magma observed at the surface (Graham et al., 1995). However, a recent interpretation of the crustal and upper mantle seismic velocity structure beneath the TVZ by Harrison and White (2006) suggests that these cumulates may reside at a depth of 16 to $30 \mathrm{~km}$ in a region of heavily intruded or under plated lower crust.

Most of the chemical and isotopic data that underpin these previous studies of silicic magma generation in the TVZ are based primarily on whole rock chemical and isotopic data. If whole rock analyses average out the seemly pervasive mineral scale isotopic heterogeneity in these magma systems that has been identified in most in situ chemical and isotopic studies of igneous rocks, then a different approach to studying their genesis is desirable.

Here we investigate the petrogenesis of silicic TVZ magmas by determining the elemental and radiogenic isotope ( $\mathrm{Sr}-\mathrm{Nd}-\mathrm{Pb})$ composition of a suite of well-dated TVZ-sourced tephras preserved in distal deep marine sediment cores $\sim 1000 \mathrm{~km}$ east of the TVZ (ODP Site 1123). Our previous investigation into the TVZ-sourced tephras recovered from ODP Site 1123 (Allan et al., 2008) focused on their use as chronostratigraphic marker horizons and their potential to provide a tephrochronological framework for the correlation and synchronisation of high resolution palaeoclimatic records in the New Zealand region. This study revealed that the 70 macroscopic tephra layers from these three Site 1123 sediment cores corresponded to $\sim 37$ individual silicic TVZ eruptions ranging in age from $\sim 1.665$ Ma to $0.027 \mathrm{Ma}$ (Fig. 3-2). 


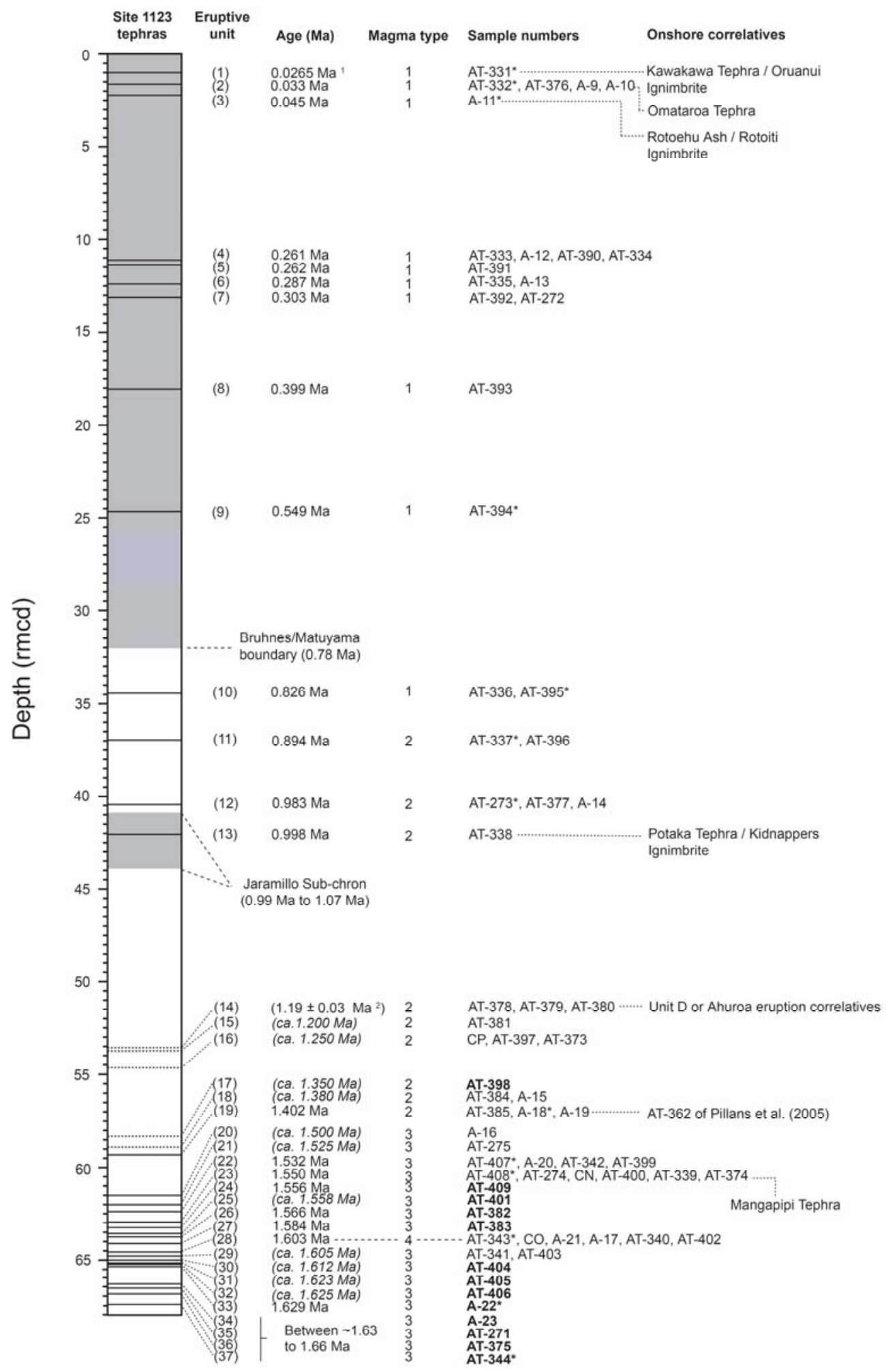

Figure 3-2. Summary of the revised Quaternary Site 1123 composite tephrostratigraphy (after Allan et al., 2008). Allan et al. (2008) used trace element fingerprinting to correlate Quaternary $(<1.81 \mathrm{Ma})$ TVZ tephra layers between the three Site 1123 sediment cores (1123A, B and C). The 70 Quaternary tephra layers (when correlated between cores) were shown to correspond to $~ 37$ eruptive events (referred to here as units 1 to 37 ). Each unit is allocated a 'melt type' (1 to 4) to reflect time-resolved differences in glass chemistry observed by Allan et al. (2008) (See text for further discussion). Sample numbers with asterixis denote tephras that were analysed for their $\mathrm{Sr}-\mathrm{Nd}-\mathrm{Pb}$ isotopic compositions in this study. Ages of the tephras have been derived from the orbitally tuned stable isotope age model (Hall et al. 2001; Harris, 2004) unless indicated otherwise. ${ }^{1}$ Calibrated radiocarbon age (Lowe et al., 2008).

${ }^{2}$ Bracketing radiometric age estimate (Wilson et al., 2007). ${ }^{340} \mathrm{Ar} /{ }^{39} \mathrm{Ar}$ age for Unit D Ignimbrite (Houghton et al., 1995). 
In this study, we combine our previously acquired major and trace element data (Allan et al., 2008) with new high precision $\mathrm{Sr}, \mathrm{Nd}$ and $\mathrm{Pb}$ isotopic data determined on high purity glass separates of selected Quaternary Site 1123 tephras. This approach allows us to: (1) sample from a high resolution tephra record that spans almost the entire $\sim 1.65$ Ma history of silicic volcanism from the TVZ, and extends the exposed onland record of volcanism that is obscured by erosion and burial by younger volcanic units, (2) place changes in the chemical and isotopic composition (and hence petrogenesis) of silicic TVZ melts within a precise temporal framework underpinned by the Site 1123 orbitally tuned stable isotope chronology, and (3) explore the generation of a pure petrological end-member (melt/glass) contributing to TVZ silicic magmas, which is not compromised by the incorporation of antecrystic and/or xenocrystic material as is the case for bulk analyses of TVZ silicic volcanic rocks.

\subsection{ANALYTICAL TECHNIQUES}

High purity glass separates of 13 Site 1123 tephra units (units 1, 2, 3, 9, 10, 11, 12, 19, 22, 23, 28, 33, and 37; Fig. 3-2) were characterised their for Sr-Nd-Pb isotopic compositions using a Nu Plasma multiple collector - ICP-MS at Victoria University of Wellington, New Zealand. These units were selected because they span the range of chemical compositions identified by major and trace element analysis (Allan et al., 2008) and eruption age. Full description of the analytical techniques used for major and trace element analysis was presented in Allan et al. (2008).

\subsection{Sample preparation}

Volcanic glass was initially separated from bulk sediment using the wet sieving method outlined in Allan et al. (2008) which produced a separate comprising 95$99 \%$ glass shards with the remainder comprising carbonate microfossils and igneous

minerals. Here, the samples selected for isotopic analysis were additionally treated to several stages of ultrasonic cleaning in $>18.2 \mathrm{M} \Omega$ water and analytical grade methanol. The liquids were decanted off after each ultrasonic cycle to remove any remaining detrital sediment and the cleaned glass separates were left to dry at $50^{\circ} \mathrm{C}$ 
for 2-3 days. All samples were visually inspected under transmitted and reflected light microscopy to ensure all detrital sediment had been removed.

Carbonate microfossils (foraminifera) were preferentially dissolved in a solution of $\sim$ $4 \mathrm{M} \mathrm{HNO}_{3}$. To prevent preferential leaching of trace elements from the glass shards this solution was promptly removed following dissolution of all carbonate material $(<2 \mathrm{~min})$ and the purified glass separates rinsed several times in $>18.2 \mathrm{M} \Omega$ water. All acids used during sample acid washing, sample digestion and during $\mathrm{Pb}$ separation were Seastar grade acids with sub-ppt concentrations of $\mathrm{Sr}, \mathrm{Nd}$ and $\mathrm{Pb}$. At the end of this cleaning and acid washing procedure most samples comprised $>99 \%$ pure glass shard material with the remainder of each sample comprising igneous minerals. The exception to this was unit 28 which comprised $\sim 97 \%$ glass shard material and $\sim 3 \%$ crystals made up of (in order of decreasing abundance) biotite, feldspar, pyroxene, amphibole and quartz. The purified glass separates $(30-80 \mathrm{mg})$ were dissolved using standard $\mathrm{HF}-\mathrm{HNO}_{3}$ digestion methods in Savillex capsules on a hotplate at $120^{\circ} \mathrm{C}$ preparation for chemical separation of $\mathrm{Sr}, \mathrm{Nd}$ and $\mathrm{Pb}$.

\subsection{Chemical separation of $\mathrm{Pb}, \mathrm{Sr}$ and $\mathrm{Nd}$}

Lead was separated on AG1-X8 anion exchange resin using standard anion exchange techniques by elution of the sample matrix in $1 \mathrm{M} \mathrm{HBr}$ and $\mathrm{Pb}$ collection in $7 \mathrm{M} \mathrm{HCl}$. Strontium separation was achieved by a double pass through Eichrom $\mathrm{Sr} \mathrm{Spec}$ chromatographic resin, with the sample matrix eluted in $3 \mathrm{M} \mathrm{HNO}_{3}$ followed by $\mathrm{Sr}$ collection in $>18.2 \mathrm{M} \Omega$ water. The $\mathrm{Nd}$ chemistry consisted of three stages of chemical separation. Firstly, Fe and most major elements were removed by eluting $1.5 \mathrm{M} \mathrm{HCl}$ through AG50W-X8 cation exchange resin, with the rare earth elements (REE) eluted in $7 \mathrm{M} \mathrm{HNO}_{3}$. Ba and any remaining $\mathrm{Ca}$ were then removed by eluting $3 \mathrm{M} \mathrm{HNO}_{3}$ through TRU Spec resin, and collecting REEs were collected in $>18.2$ $\mathrm{M} \Omega$ water. Finally, Ln Spec chemistry was used to separate the sample Nd from the other REEs. The light REEs were sequentially eluted in order of increasing atomic mass by elution ( $1 \mathrm{~mL}$ at a time) of $0.25 \mathrm{M} \mathrm{HCl}$. La and Ce were eluted during the 5 $\mathrm{mL}$ and $\mathrm{Nd}$ was collected in the $5-8 \mathrm{~mL}$ of $0.25 \mathrm{M} \mathrm{HCl}$ eluted whilst $\mathrm{Sm}$ was retained on the $\mathrm{Ln} \mathrm{Spec}$ resin. Prior to $\mathrm{Nd}$ isotopic analysis the $\mathrm{Nd}$ cut from each sample was 
measured by ICP-MS to ensure that the separation of $\mathrm{Ce}$ and $\mathrm{Sm}$ was sufficient to render potential mass interferences on the $\mathrm{Nd}$ isotopes negligible.

\section{3 $\mathrm{Pb}, \mathrm{Sr}$ and $\mathrm{Nd}$ isotopic analyses}

All isotopic analyses were performed on a Nu Plasma multiple collector (MC-) ICPMS at Victoria University of Wellington, New Zealand. Immediately prior to analysis the samples were brought into solution in $0.5 \% \mathrm{HNO}_{3} . \mathrm{Pb}$ and $\mathrm{Nd}$ samples were introduced into the MC-ICP-MS via a DSN-100 desolvating nebuliser system whereas Sr samples were analysed in 'wet plasma' mode following methods modified after Waight et al. (2002).

$\mathrm{Pb}$ isotope data were corrected for instrumental mass bias by external normalisation using the mass bias observed in bracketing analyses of SRM 981. Measured values were normalised to the Baker et al. (2004) values for SRM 981 i.e., ${ }^{206} \mathrm{~Pb} /{ }^{204} \mathrm{~Pb}=$ $16.9418,{ }^{207} \mathrm{~Pb} /{ }^{204} \mathrm{~Pb}=15.5000$, and ${ }^{208} \mathrm{~Pb} /{ }^{204} \mathrm{~Pb}=36.7265$. Analyses of the basaltic standard JB-2 were conducted to allow an assessment of the accuracy and precision of the $\mathrm{Pb}$ isotopic data obtained for the Site 1123 tephra melt compositions. Four analyses of JB-2 yielded the following mean values and 2 sd uncertainties: ${ }^{206} \mathrm{~Pb} /{ }^{204} \mathrm{~Pb}=18.3424 \pm 0.0018,{ }^{207} \mathrm{~Pb} /{ }^{204} \mathrm{~Pb}=15.5619 \pm 0.0017$, and ${ }^{208} \mathrm{~Pb} /{ }^{204} \mathrm{~Pb}=$ $38.2774 \pm 0.0049$. These values are indistinguishable from and have external reproducibilities comparable to those reported by Baker et al. (2004) who used highly precise $\mathrm{Pb}$ double-spike techniques to correct for instrumental mass bias. $\mathrm{Sr}-\mathrm{Nd}$ isotope data were corrected for instrumental mass fractionation bias by internal normalisation to ${ }^{86} \mathrm{Sr} /{ }^{88} \mathrm{Sr}=0.1194$ and ${ }^{146} \mathrm{Nd} /{ }^{144} \mathrm{Nd}=0.7219$, respectively. All ${ }^{87} \mathrm{Sr} /{ }^{86} \mathrm{Sr}$ ratios are reported relative to a value of 0.710248 for the SRM 987 standard and the external reproducibility of ${ }^{87} \mathrm{Sr} /{ }^{86} \mathrm{Sr}$ ratios are $\pm 0.000012(2 \mathrm{sd}) . \mathrm{Nd}$ isotopic data are normalised to the standard Alfa Aesar $\mathrm{Nd}\left({ }^{143} \mathrm{Nd} /{ }^{144} \mathrm{Nd}=0.512260\right)$ and repeated analyses of this standard yielded an external reproducibility on ${ }^{143} \mathrm{Nd} /{ }^{144} \mathrm{Nd}$ of \pm 0.000006 (2 sd). The chondritic value of ${ }^{143} \mathrm{Nd} /{ }^{144} \mathrm{Nd}=0.512638$ (Hofmann, 2003) has been used to convert ${ }^{143} \mathrm{Nd} /{ }^{144} \mathrm{Nd}$ values into $\varepsilon_{\mathrm{Nd}}$ notion. The relatively young ages $(<1.7 \mathrm{Ma})$ of the tephras analysed in this study obviate the need to apply age corrections to any of the measured isotopic compositions for radiogenic in-growth of $\mathrm{Pb}-\mathrm{Sr}-\mathrm{Nd}$ isotopes. 


\subsection{RESULTS}

\subsection{Major and trace element glass chemistry of Site 1123 tephras}

All Site 1123 tephras have rhyolitic compositions using the classification scheme of Le Maitre (1984) (Fig. 3-3a). However, the inference that Site 1123 tephras were erupted from rhyolitic magma bodies is not necessarily justified given that many crystal-rich ignimbrites are characterised by dacitic bulk rock compositions with rhyolitic interstitial glass (e.g. Fish Canyon Tuff, western USA; Bachmann and Dungan, 2002). Thus, any discussions regarding the parental magma bodies of the Site 1123 tephras throughout this paper refer to silicic rather than rhyolitic magma bodies.

Four broad silicic melt types amongst the Site 1123 tephras were identified by Allan et al. (2008) (Figs. 3-3 to 3-5) and the mean major and trace element compositions of glass shards from tephras representative of each melt type are summarised in Tables 3-1 and 3-2. The full major and trace element dataset for Site 1123 tephras is available as supplementary information (Appendix 6).

Type 1 melt compositions represent tephras with ages $<0.83 \mathrm{Ma}$ and are almost exclusively more evolved (higher $\mathrm{SiO}_{2}$; lower $\mathrm{FeO}$ and $\mathrm{Zr}$ ) than Type 3 melt compositions (tephras with ages $\sim 1.50-1.66 \mathrm{Ma}$ ). Type 1 and 3 melt types are readily distinguished on most bivariate major and trace element plots (Figs. 3-3, 3-4 \& 3-5). In general, tephras with ages $\sim 0.89-1.40$ Ma show some compositional overlap with the tephras that pre- and post-date their eruption (i.e., Types 1 and 3). However, 0.89-1.40 Ma tephras have compositions (Type 2) that are generally distinctive on the basis of their higher $\mathrm{CaO}$ at a given $\mathrm{FeO}$, higher $\mathrm{Ti}$ at a given $\mathrm{Zr}$, and noticeably higher $\mathrm{V}$ abundances (Figs. 3-3, 3-4 \& 3-5). Type 2 melts are also distinguished from Types 1 and 3 by their higher $\mathrm{CaO}$ and $\mathrm{TiO}_{2}$ at a given $\mathrm{SiO}_{2}$, and higher $\mathrm{MgO}$ at a given $\mathrm{FeO}_{\mathrm{t}}$ (not shown). A single unit (unit 28) erupted at $1.603 \mathrm{Ma}$ comprises the fourth melt type (Type 4) identified by Allan et al. (2008). This unit was erupted at the same time as the tephras that comprise the Type 3 melts (1.501.66 Ma; Fig. 3-2) but its distinctive composition (lowest abundances of Nb, Zr, Hf, $\mathrm{Ti}, \mathrm{Mg}, \mathrm{Ba}$ and HREEs, and highest abundances of $\left.\mathrm{K}_{2} \mathrm{O}, \mathrm{Cs}, \mathrm{Rb}, \mathrm{Th}, \mathrm{U}\right)$ led Allan et al. (2008) to group it separately. These four melt types are broadly defined and it is 

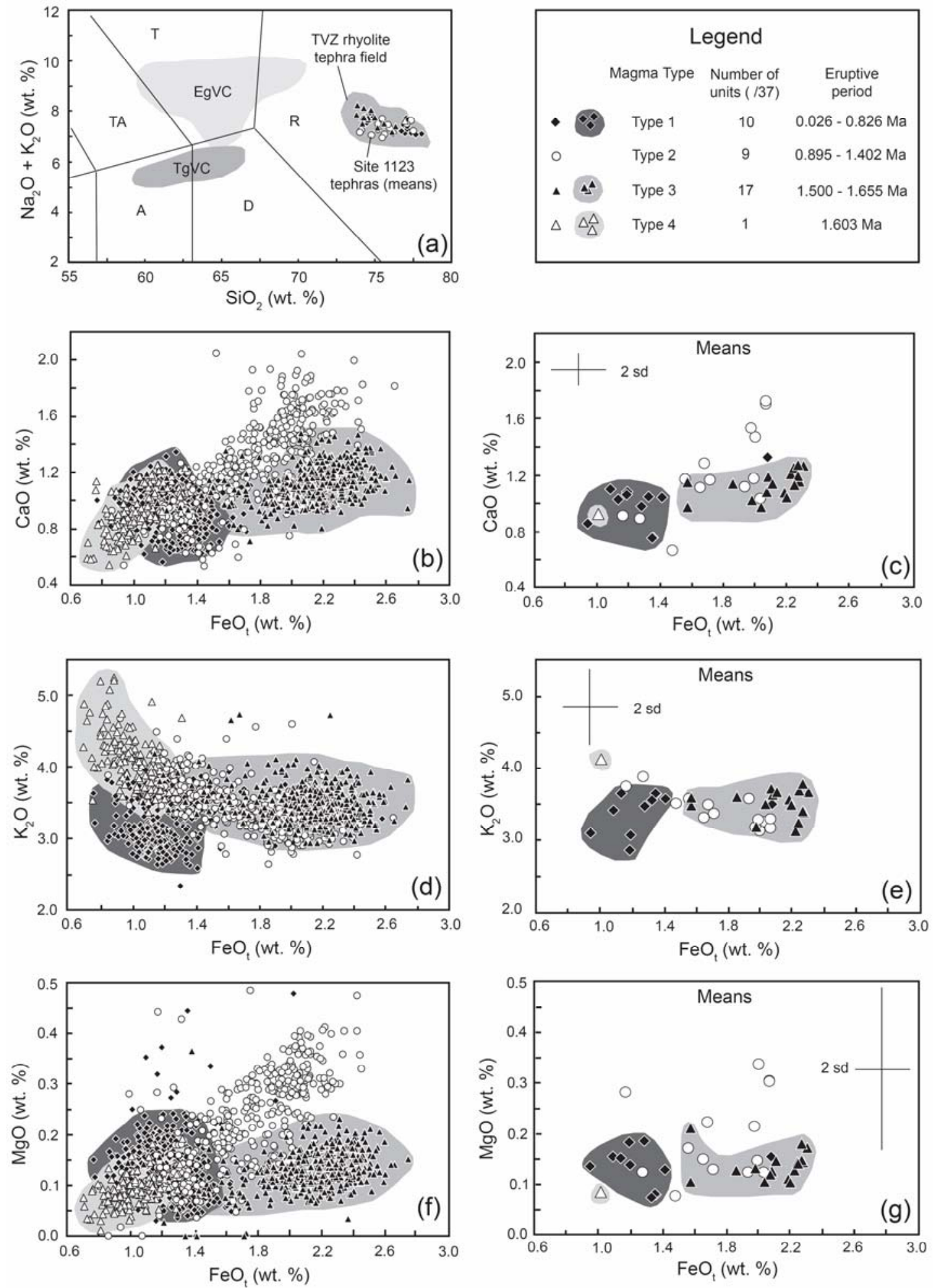

Figure 3-3. Summary of the major element characteristics of Site 1123 tephras (after Allan et al., 2008). See legend for explanation of symbols. (a) All Site 1123 tephras have rhyolitic glass (melt) compositions following the compositional scheme of Le Maitre (1984). Here bivariate major element oxide plots of individual glass shards (b, $d$, f) and the mean glass compositions of Site 1123 tephra units (c, e, g) demonstrate that melts erupted during particular time periods cluster into distinctive compositional groups. 
Table 3-1. Electron probe microanalysis (EPMA) major element data for representative Site 1123 tephras

\begin{tabular}{|c|c|c|c|c|c|c|c|}
\hline Tephra unit & 1 & 2 & 3 & 9 & 10 & 11 & 12 \\
\hline Melt type & 1 & 1 & 1 & 1 & 1 & 2 & 2 \\
\hline Age & $27.1 \mathrm{ka}$ & $33.0 \mathrm{ka}$ & $\sim 60.0 \mathrm{ka}$ & $0.549 \mathrm{Ma}$ & $0.826 \mathrm{Ma}$ & $0.894 \mathrm{Ma}$ & $0.983 \mathrm{Ma}$ \\
\hline $\mathrm{SiO}_{2}(\mathrm{wt} \%)$ & $77.5(1.08)$ & $77.0(0.98)$ & $78.2(0.57)$ & $77.7(0.51)$ & $77.1(1.14)$ & $74.9(2.61)$ & $75.6(2.13)$ \\
\hline $\mathrm{TiO}_{2}$ & $\mathbf{0 . 1 6}(0.09)$ & $\mathbf{0 . 1 9}(0.08)$ & $\mathbf{0 . 1 5}(0.08)$ & $\mathbf{0 . 1 6}(0.11)$ & $\mathbf{0 . 1 8}(0.08)$ & $\mathbf{0 . 3 5}(0.19)$ & $\mathbf{0 . 2 5}(0.85)$ \\
\hline $\mathrm{Al}_{2} \mathbf{O}_{3}$ & $12.6(0.56)$ & $12.9(0.65)$ & $12.2(0.40)$ & $12.4(0.23)$ & $12.6(0.83)$ & $13.6(1.00)$ & $13.5(0.14)$ \\
\hline FeO & $\mathbf{1 . 2 0}(0.23)$ & $\mathbf{1 . 1 9}(0.21)$ & $\mathbf{0 . 9 3}(0.17)$ & $\mathbf{1 . 0 8}(0.20)$ & $1.13(0.25)$ & $1.94(0.77)$ & $1.68(0.45)$ \\
\hline MnO & $\mathbf{0 . 1 0}(0.12)$ & $\mathbf{0 . 1 5}(0.13)$ & $\mathbf{0 . 1 3}(0.14)$ & $\mathbf{0 . 0 9}(0.11)$ & $\mathbf{0 . 1 0}(0.12)$ & $\mathbf{0 . 1 1}(0.12)$ & $\mathbf{0 . 1 0}(0.12)$ \\
\hline MgO & $\mathbf{0 . 1 4}(0.05)$ & $\mathbf{0 . 1 9}(0.06)$ & $\mathbf{0 . 1 4}(0.06)$ & $\mathbf{0 . 1 6}(0.07)$ & $\mathbf{0 . 1 5}(0.05)$ & $\mathbf{0 . 3 1}(0.23)$ & $\mathbf{0 . 2 2}(0.12)$ \\
\hline $\mathrm{CaO}$ & $\mathbf{1 . 0 8}(0.19)$ & $1.06(0.13)$ & $\mathbf{0 . 8 7}(0.13)$ & $1.10(0.26)$ & $1.03(0.14)$ & $1.41(0.51)$ & $1.28(0.46)$ \\
\hline $\mathrm{Na}_{2} \mathrm{O}$ & $\mathbf{3 . 9 5}(0.68)$ & $4.26(0.35)$ & $4.06(0.40)$ & $3.66(0.23)$ & $3.74(0.29)$ & $\mathbf{3 . 9 3}(1.17)$ & $\mathbf{3 . 6 0}(0.84)$ \\
\hline $\mathbf{K}_{2} \mathbf{O}$ & $\mathbf{3 . 0 6}(0.36)$ & $2.87(0.29)$ & $\mathbf{3 . 1 2}(0.29)$ & $\mathbf{3 . 4 2}(0.39)$ & $\mathbf{3 . 6 5}(0.28)$ & $3.15(0.62)$ & $3.49(0.50)$ \\
\hline Cl & $\mathbf{0 . 2 0}(0.07)$ & $\mathbf{0 . 2 0}(0.07)$ & $0.22(0.08)$ & $\mathbf{0 . 2 2}(0.07)$ & $\mathbf{0 . 2 6}(0.09)$ & $\mathbf{0 . 2 1}(0.08)$ & $\mathbf{0 . 2 1}(0.22)$ \\
\hline TOTAL & $94.81(3.40)$ & $\mathbf{9 5 . 5 4}(1.40)$ & $\mathbf{9 6 . 3 2}(3.40)$ & $\mathbf{9 4 . 8 9}(1.95)$ & $94.31(3.44)$ & $95.92(3.24)$ & $96.72(3.57)$ \\
\hline$n=$ & 103 & 81 & 35 & 15 & 45 & 94 & 78 \\
\hline
\end{tabular}

Table 3-1 continued.

\begin{tabular}{|c|c|c|c|c|c|c|}
\hline Tephra unit & 19 & 22 & 23 & 33 & 37 & 28 \\
\hline Melt type & 2 & 3 & 3 & 3 & 3 & 4 \\
\hline Age (Ma) & $1.402 \mathrm{Ma}$ & $1.532 \mathrm{Ma}$ & $1.550 \mathrm{Ma}$ & $1.629 \mathrm{Ma}$ & $1.660 \mathrm{Ma}$ & $1.603 \mathrm{Ma}$ \\
\hline $\mathrm{SiO}_{2}(w \mathrm{t} \%)$ & $77.1(0.78)$ & $74.9(0.96)$ & $\mathbf{7 4 . 2}(1.09)$ & $\mathbf{7 4 . 3}(0.63)$ & $73.8(0.77)$ & $77.0(0.75)$ \\
\hline $\mathrm{TiO}_{2}$ & $\mathbf{0 . 1 5}(0.09)$ & $\mathbf{0 . 1 8}(0.07)$ & $\mathbf{0 . 2 1}(0.09)$ & $\mathbf{0 . 2 0}(0.09)$ & $\mathbf{0 . 2 2}(0.08$ & $\mathbf{0 . 0 7}(0.07)$ \\
\hline $\mathbf{A l}_{2} \mathbf{O}_{3}$ & $12.6(0.51)$ & $13.4(0.56)$ & $13.9(0.52)$ & $13.7(0.34)$ & $\mathbf{1 4 . 0}(0.59)$ & $13.0(0.44)$ \\
\hline $\mathrm{FeO}$ & $1.27(0.19)$ & $2.19(0.38)$ & $2.27(0.41)$ & $\mathbf{2 . 2 6}(0.32)$ & $\mathbf{2 . 2 7}(0.26)$ & $\mathbf{1 . 0 1}(0.28)$ \\
\hline MnO & $\mathbf{0 . 0 9}(0.13)$ & $\mathbf{0 . 1 3}(0.12)$ & $\mathbf{0 . 1 4}(0.12)$ & $\mathbf{0 . 1 4}(0.10)$ & $\mathbf{0 . 1 0}(0.09)$ & $\mathbf{0 . 1 0}(0.11)$ \\
\hline MgO & $\mathbf{0 . 1 3}(0.09)$ & $\mathbf{0 . 1 1}(0.05)$ & $\mathbf{0 . 1 5}(0.06)$ & $\mathbf{0 . 1 5}(0.06)$ & $\mathbf{0 . 1 8}(0.05)$ & $\mathbf{0 . 0 9}(0.06)$ \\
\hline $\mathrm{CaO}$ & $\mathbf{0 . 8 9}(0.16)$ & $\mathbf{1 . 0 4}(0.15)$ & $1.15(0.17)$ & $1.19(0.17)$ & $\mathbf{1 . 2 7}(0.19)$ & $\mathbf{0 . 9 2}(0.35)$ \\
\hline $\mathrm{Na}_{2} \mathrm{O}$ & $3.61(0.40)$ & $4.34(0.76)$ & $4.36(0.81)$ & $4.37(0.15)$ & $\mathbf{4 . 0 9}(0.26)$ & $\mathbf{3 . 4 9}(0.37)$ \\
\hline $\mathbf{K}_{2} \mathbf{O}$ & $\mathbf{3 . 8 8}(0.42)$ & $\mathbf{3 . 5 0}(0.80)$ & $\mathbf{3 . 3 9}(0.61)$ & $3.41(0.24)$ & $\mathbf{3 . 7 8}(0.33)$ & $4.13(0.75)$ \\
\hline Cl & $\mathbf{0 . 2 8}(0.07)$ & $\mathbf{0 . 2 0}(0.08)$ & $\mathbf{0 . 2 2}(0.08)$ & $\mathbf{0 . 2 1}(0.06)$ & $\mathbf{0 . 2 3}(0.12)$ & $\mathbf{0 . 1 6}(0.07)$ \\
\hline TOTAL & $\mathbf{9 6 . 1 5}(1.76)$ & $95.71(3.95)$ & $\mathbf{9 5 . 7 3}(3.37)$ & $\mathbf{9 4 . 8 8}(1.95)$ & $\mathbf{9 4 . 8 1}(2.12)$ & $\mathbf{9 4 . 5 2}(2.35)$ \\
\hline$n=$ & 46 & 66 & 98 & 15 & 15 & 136 \\
\hline
\end{tabular}

important to note that additional complexity may exist within each melt type, a possibility illustrated by the three sub-groups of the Type 1 melts evident in Figs. 3$4 \mathrm{~b}$ and $3-5 \mathrm{~b}$.

When trace element data are plotted on primitive-mantle-normalised multi-element diagrams, all Site 1123 TVZ tephras have enrichments in large ion lithophile elements (LILE) relative to high field strength elements (HFSE) typical of arc magmas (Fig. 3-6). Distinction of the four melt types on these multi-element 
Table 3-2. Laser ablation inductively coupled plasma mass spectrometry (LA-ICP-MS) trace element data

\begin{tabular}{|c|c|c|c|c|c|c|c|}
\hline Tephra unit & 1 & 2 & 3 & 9 & 10 & 11 & 12 \\
\hline Melt type & 1 & 1 & 1 & 1 & 1 & 2 & 2 \\
\hline Age (Ma) & $27.1 \mathrm{ka}$ & $33.0 \mathrm{ka}$ & $\sim 60.0 \mathrm{ka}$ & $0.549 \mathrm{Ma}$ & $0.826 \mathrm{Ma}$ & $0.894 \mathrm{Ma}$ & $0.983 \mathrm{Ma}$ \\
\hline Mg (ppm) & 959 (217) & $1439(356)$ & $1102(285)$ & $1169(403)$ & $1063(253)$ & 2163 (1522) & 1754 (933) \\
\hline $\mathbf{T i}$ & 914 (194) & $1153(284)$ & 962 (342) & 918 (292) & 969 (329) & 2103 (1194) & $1589(863$ \\
\hline V & $\mathbf{1 . 3 6}(1.27)$ & $1.42(0.80)$ & $2.34(0.71)$ & $2.36(1.73)$ & $\mathbf{3 . 1 2}(1.01)$ & $\mathbf{7 . 0 9}(12.9)$ & $\mathbf{5 . 8 9}(3.95)$ \\
\hline $\mathrm{Cr}$ & $\mathbf{2 . 7 3}(5.09)$ & $\mathbf{5 . 1 7}(9.19)$ & $\mathbf{6 . 0 5}(12.6)$ & $\mathbf{0 . 6 2}(1.93)$ & $\mathbf{2 . 3 4}(6.19)$ & $\mathbf{2 . 3 7}(7.52)$ & $1.41(3.42)$ \\
\hline Mn & $407(78.5)$ & $591(108)$ & 447 (133) & $\mathbf{3 5 9}(56.3)$ & 363 (105) & $502(149)$ & 393 (143) \\
\hline Co & $\mathbf{0 . 6 2}(0.48)$ & $\mathbf{0 . 4 6}(0.48)$ & $\mathbf{0 . 7 8}(0.68)$ & $\mathbf{0 . 5 3}(0.68)$ & $\mathbf{0 . 6 2}(0.75)$ & $\mathbf{1 . 1 9}(1.48)$ & $1.41(0.78)$ \\
\hline $\mathbf{N i}$ & $0.75(2.67)$ & $\mathbf{1 . 0 8}(1.86)$ & $\mathbf{1 . 1 6}(2.22)$ & $\mathbf{0 . 0 7}(0.30)$ & $\mathbf{0 . 8 8}(2.17)$ & $1.01(2.61)$ & $1.40(3.51)$ \\
\hline $\mathrm{Cu}$ & $\mathbf{2 . 5 6}(1.96)$ & $\mathbf{2 . 3 1}(2.57)$ & $\mathbf{2 . 9 8}(1.83)$ & $\mathbf{2 . 0 4}(1.23)$ & $\mathbf{4 . 5 0}(2.97)$ & $\mathbf{2 . 8 5}(2.93)$ & $4.60(6.19)$ \\
\hline $\mathbf{Z n}$ & $42.4(19.2)$ & $44.2(26.8)$ & $32.6(17.4)$ & 28.4 (18.9) & $28.8(20.8)$ & $\mathbf{3 6 . 9}(34.5)$ & $\mathbf{3 9 . 8}(22.3)$ \\
\hline Ga & $14.5(3.71)$ & $14.3(2.16)$ & $12.9(3.60)$ & $12.0(2.07)$ & $\mathbf{1 3 . 5}(5.11)$ & $14.7(4.33)$ & $16.4(4.98)$ \\
\hline $\mathbf{R b}$ & $126(29.9)$ & $\mathbf{9 1 . 8}(20.0)$ & $102(26.3)$ & $129(21.8)$ & $142(47.9)$ & $107(37.2)$ & $136(47.7)$ \\
\hline $\mathrm{Sr}$ & $82.3(18.1)$ & $97.7(17.9)$ & $63.9(12.4)$ & $89.9(21.5)$ & $70.6(13.4)$ & $101(30.7)$ & $100(45.6)$ \\
\hline $\mathbf{Y}$ & $22.7(4.12)$ & $33.2(7.27)$ & $22.6(4.95)$ & $17.1(2.34)$ & $17.1(5.20)$ & $\mathbf{3 2 . 8}(9.80)$ & $29.1(9.80)$ \\
\hline $\mathbf{Z r}$ & $122(24.9)$ & 154 & $\mathbf{9 7 . 3}(16.0$ & $110(30.9)$ & $110(34.6)$ & $270(92.0)$ & 249 (125) \\
\hline $\mathbf{N b}$ & $7.74(1.79)$ & $\mathbf{9 . 9 2}(1.76)$ & $\mathbf{8 . 8 4}(2.54)$ & $\mathbf{6 . 7 0}(1.38)$ & $7.38(2.58)$ & $\mathbf{1 0 . 5}(2.42)$ & $\mathbf{1 0 . 3}(3.34)$ \\
\hline Mo & $\mathbf{1 . 5 6}(1.05)$ & $1.54(0.94)$ & $\mathbf{1 . 6 0}(1.00)$ & $1.79(0.39)$ & $\mathbf{2 . 1 1}(1.11)$ & $1.49(0.99)$ & $2.64(3.84)$ \\
\hline Cs & $\mathbf{6 . 3 0}(1.55)$ & $\mathbf{3 . 4 0}(0.69)$ & $\mathbf{3 . 8 6}(0.90)$ & $\mathbf{6 . 0 0}(1.18)$ & $\mathbf{6 . 8 9}(2.45)$ & $\mathbf{5 . 0 7}(1.86)$ & $6.25(2.20)$ \\
\hline Ba & $\mathbf{6 8 1}(151)$ & 806 (118) & 1023 & $860(128)$ & 773 (234) & 727 (175) & $824(267)$ \\
\hline La & $22.2(4.37)$ & $\mathbf{2 5 . 0}(4.35)$ & $24.2(4.62)$ & $21.2(3.36)$ & $20.8(6.32)$ & $25.5(6.17)$ & $27.7(8.87)$ \\
\hline $\mathrm{Ce}$ & $48.0(10.8)$ & $\mathbf{5 3 . 8}(8.20)$ & 49.3 (13.6) & $\mathbf{4 0 . 6}(9.21)$ & 43.5 (13.9) & $\mathbf{5 1 . 6}(13.2)$ & $\mathbf{6 0 . 6}(19.5)$ \\
\hline Pr & $\mathbf{4 . 8 1}(0.91)$ & $\mathbf{6 . 1 1}(0.80)$ & $4.95(1.03)$ & $4.21(0.59)$ & $4.32(1.23)$ & $\mathbf{5 . 9 5}(1.32)$ & $\mathbf{6 . 5 1}(2.01)$ \\
\hline Nd & $\mathbf{1 8 . 7}(4.21)$ & $25.4(3.81)$ & 18.5 & $15.1(2.30)$ & $15.2(4.61)$ & $\mathbf{2 4 . 6}(5.19)$ & $25.3(8.51)$ \\
\hline Sm & $\mathbf{3 . 6 9}(1.02)$ & $\mathbf{5 . 4 1}(1.11)$ & $\mathbf{3 . 6 1}(0.69)$ & $2.75(0.79)$ & $\mathbf{2 . 8 3}(1.00)$ & $\mathbf{5 . 2 6}(1.67)$ & $\mathbf{5 . 1 5}(1.67)$ \\
\hline $\mathbf{E u}$ & $\mathbf{0 . 6 5}(0.21)$ & $\mathbf{1 . 0 2}(0.18)$ & $\mathbf{0 . 5 4}(0.16)$ & $\mathbf{0 . 5 1}(0.09)$ & $\mathbf{0 . 4 3}(0.20)$ & $\mathbf{0 . 9 8}(0.32)$ & $\mathbf{0 . 8 6}(0.37)$ \\
\hline Gd & $\mathbf{3 . 3 3}(1.22)$ & $\mathbf{5 . 0 5}(1.23)$ & $\mathbf{3 . 1 9}(0.69)$ & $\mathbf{2 . 4 3}(0.82)$ & $2.54(1.11)$ & $\mathbf{5 . 1 4}(1.62)$ & $4.62(1.71)$ \\
\hline Tb & $\mathbf{0 . 5 7}(0.15)$ & $\mathbf{0 . 8 3}(0.17)$ & $\mathbf{0 . 5 2}(0.13)$ & $\mathbf{0 . 4 2}(0.10)$ & $\mathbf{0 . 4 3}(0.19)$ & $\mathbf{0 . 8 8}(0.26)$ & $\mathbf{0 . 7 0}(0.13)$ \\
\hline Dy & $3.75(0.88)$ & $\mathbf{5 . 6 1}(1.22)$ & $\mathbf{3 . 4 7}(0.82)$ & $2.55(0.54)$ & $2.68(0.80)$ & $\mathbf{5 . 6 6}(1.76)$ & $5.14(1.90)$ \\
\hline Ho & $\mathbf{0 . 8 4}(0.23)$ & $1.16(0.18)$ & $\mathbf{0 . 7 5}(0.20)$ & $\mathbf{0 . 5 5}(0.11)$ & $\mathbf{0 . 6 0}(0.25)$ & $1.26(0.28)$ & $\mathbf{0 . 9 9}(0.23)$ \\
\hline $\mathbf{E r}$ & $2.37(0.65)$ & $\mathbf{3 . 6 0}(1.02)$ & $\mathbf{2 . 3 0}(0.60)$ & $1.81(0.35)$ & $1.81(0.71)$ & $\mathbf{3 . 5 1}(1.11)$ & $\mathbf{3 . 0 7}(1.18)$ \\
\hline Tm & $\mathbf{0 . 3 8}(0.12)$ & $\mathbf{0 . 5 5}(0.12)$ & $\mathbf{0 . 4 0}(0.10)$ & $\mathbf{0 . 3 0}(0.05)$ & $\mathbf{0 . 3 7}(0.16)$ & $\mathbf{0 . 5 7}(0.16)$ & $\mathbf{0 . 4 6}(0.09)$ \\
\hline $\mathbf{Y b}$ & $2.69(0.67)$ & $\mathbf{3 . 8 5}(1.00)$ & $2.74(0.57)$ & $\mathbf{2 . 0 4}(0.37)$ & $\mathbf{2 . 1 9}(0.86)$ & $\mathbf{3 . 7 3}(0.98)$ & $3.41(1.28)$ \\
\hline Lu & $\mathbf{0 . 4 1}(0.12)$ & $\mathbf{0 . 5 8}(0.16)$ & $\mathbf{0 . 4 3}(0.10)$ & $\mathbf{0 . 3 5}(0.09)$ & $\mathbf{0 . 3 5}(0.19)$ & $\mathbf{0 . 5 7}(0.19)$ & $\mathbf{0 . 5 0}(0.19)$ \\
\hline Hf & $\mathbf{3 . 5 6}(1.05)$ & $4.45(1.05)$ & $\mathbf{3 . 0 5}(0.57)$ & $3.21(0.65)$ & $3.25(1.28)$ & $\mathbf{6 . 7 0}(2.43)$ & $\mathbf{6 . 3 9}(2.59)$ \\
\hline Ta & $\mathbf{0 . 7 2}(0.20)$ & $\mathbf{0 . 7 3}(0.16)$ & $\mathbf{0 . 8 5}(0.21)$ & $\mathbf{0 . 7 0}(0.10)$ & $\mathbf{0 . 7 1}(0.28)$ & $\mathbf{0 . 7 9}(0.24)$ & $\mathbf{0 . 8 2}(0.36)$ \\
\hline W & $1.63(0.52)$ & $1.36(0.50)$ & $1.36(0.54)$ & $1.55(0.39)$ & $1.81(0.56)$ & $1.24(0.72)$ & $\mathbf{1 . 7 8}(0.82)$ \\
\hline $\mathbf{P b}$ & $15.4(3.99)$ & $15.4(3.53)$ & $12.4(2.96)$ & $14.7(2.30)$ & $17.7(6.70)$ & $\mathbf{1 6 . 0}(5.44)$ & $20.3(7.20)$ \\
\hline Th & $11.8(2.28)$ & $\mathbf{9 . 5 8}(1.57)$ & $\mathbf{1 0 . 5}(1.98)$ & $13.5(2.02)$ & $12.5(3.70)$ & $11.8(3.09)$ & $13.6(4.76)$ \\
\hline $\mathbf{U}$ & $2.91(0.70)$ & $\mathbf{2 . 1 9}(0.44)$ & $2.45(0.66)$ & $\mathbf{2 . 8 4}(0.80)$ & $3.24(1.11)$ & $\mathbf{2 . 4 7}(0.87)$ & $3.25(1.10)$ \\
\hline $\mathbf{Z r} / \mathbf{H f}$ & 34.9 (13.9) & 34.7 (5.94) & $\mathbf{3 1 . 3}(5.59)$ & $34.4(7.14)$ & $\mathbf{3 4 . 3}(8.05)$ & $\mathbf{4 0 . 1}(6.31)$ & $38.7(6.65)$ \\
\hline $\mathrm{Nb} / \mathrm{Ta}$ & $\mathbf{1 0 . 6}(3.91)$ & $13.7(3.52)$ & $10.1(2.13)$ & $9.60(1.43)$ & $10.7(3.57)$ & $\mathbf{1 3 . 3}(3.42)$ & $12.8(2.65)$ \\
\hline $\mathbf{B a} / \mathbf{T h}$ & $\mathbf{5 8 . 2}(15.9)$ & 84.5 (13.9) & $90.1(29.5)$ & $63.8(5.10)$ & $62.0(14.0)$ & $\mathbf{6 2 . 7}(17.4)$ & $61.0(10.9)$ \\
\hline $\mathbf{E u} / \mathbf{E u}$ * & $\mathbf{0 . 5 8}(0.20)$ & $\mathbf{0 . 6 0}(0.14)$ & $\mathbf{0 . 4 6}(0.14)$ & $\mathbf{0 . 6 1}(0.16)$ & $\mathbf{0 . 5 1}(0.22)$ & $\mathbf{0 . 5 8}(0.16)$ & $\mathbf{0 . 5 4}(0.18)$ \\
\hline $\mathbf{n}=$ & 31 & 37 & 14 & 10 & 18 & 38 & 32 \\
\hline
\end{tabular}


Table 3-2 continued.

\begin{tabular}{|c|c|c|c|c|c|c|}
\hline Tephra unit & 19 & 22 & 23 & 33 & 37 & 28 \\
\hline Melt type & 2 & 3 & 3 & 3 & 3 & 4 \\
\hline Age & $1.402 \mathrm{Ma}$ & $1.532 \mathrm{Ma}$ & $1.550 \mathrm{Ma}$ & $1.629 \mathrm{Ma}$ & $1.660 \mathrm{Ma}$ & $1.603 \mathrm{Ma}$ \\
\hline Mg (ppm) & 777 (233) & 744 (134) & 1091 (439) & 1055 & $1594(668)$ & $\mathbf{5 3 8}(403)$ \\
\hline $\mathbf{T i}$ & 878 (224) & $1165(213)$ & 1344 (298) & $1112(237)$ & 1503 & $316(261)$ \\
\hline V & $\mathbf{1 . 8 4}(0.98)$ & $\mathbf{0 . 4 5}(1.09)$ & $\mathbf{0 . 6 4}(1.24)$ & $\mathbf{0 . 8 6}(0.81)$ & 2.48 & $1.29(1.17)$ \\
\hline $\mathrm{Cr}$ & $1.86(4.66)$ & $4.76(8.70)$ & $2.94(5.78)$ & $1.33(2.56)$ & $\mathbf{3 . 3 1}(7.42)$ & $4.63(11.0)$ \\
\hline Mn & 318 (78.3) & $\mathbf{5 8 2}(121)$ & 649 & $531(98.0)$ & $544(119)$ & 345 \\
\hline Co & $\mathbf{0 . 8 1}(0.72)$ & $\mathbf{0 . 6 6}(1.17)$ & $\mathbf{0 . 7 0}(1.07)$ & $\mathbf{0 . 7 8}(0.60)$ & $\mathbf{2 . 1 1}(2.32)$ & $\mathbf{0 . 7 7}(1.68)$ \\
\hline $\mathbf{N i}$ & $1.39(5.58)$ & $1.58(4.75)$ & $\mathbf{2 . 5 3}(8.69)$ & $\mathbf{2 . 8 2}(4.08)$ & $\mathbf{8 . 0 9}(12.9)$ & $2.11(5.46)$ \\
\hline $\mathbf{C u}$ & $4.71(5.18)$ & $\mathbf{3 . 8 3}(2.34)$ & $\mathbf{3 . 5 5}(3.14)$ & $13.7(15.1)$ & $\mathbf{3 . 3 8}(4.01)$ & $4.43(6.77)$ \\
\hline Zn & $42.6(22.9)$ & $71.4(36.7)$ & $\mathbf{6 2 . 7}(40.3)$ & $45.6(26.2)$ & $43.6(12.6)$ & $24.7(19.6)$ \\
\hline Ga & $14.7(5.00)$ & $18.0(3.77)$ & $17.3(3.45)$ & $\mathbf{1 6 . 4}(2.69)$ & $17.4(3.58)$ & 12.3 \\
\hline $\mathbf{R b}$ & $144(41.3)$ & $128(27.8)$ & $118(25.3)$ & 131 (25.6) & 144 & $151(55.0)$ \\
\hline $\mathrm{Sr}$ & $54.1(10.7)$ & $71.3(13.1)$ & $\mathbf{8 8 . 3}(14.2)$ & $95.3(25.1)$ & 108 & $56.1(34.9)$ \\
\hline $\mathbf{Y}$ & $\mathbf{3 4 . 0}(5.98)$ & $\mathbf{3 8 . 8}(8.76)$ & $42.7(8.34)$ & $\mathbf{3 8 . 2}(8.30)$ & $41.0(7.68)$ & $18.9(6.89)$ \\
\hline $\mathbf{Z r}$ & $137(25.8)$ & $\mathbf{3 0 7}(61.3)$ & $\mathbf{3 3 3}(61.4)$ & 288 & 348 & $66.8(24.8)$ \\
\hline $\mathbf{N b}$ & $10.1(2.95)$ & 13.1 & $12.8(2.61)$ & $11.8(2.14)$ & 12.8 & $\mathbf{5 . 4 2}(1.99)$ \\
\hline Mo & $1.78(0.78)$ & $\mathbf{2 . 0 0}(1.03)$ & $\mathbf{1 . 8 6}(1.02)$ & $1.90(0.67)$ & $\mathbf{1 . 8 4}(1.25)$ & $1.30(1.06)$ \\
\hline Cs & $7.61(2.07)$ & $6.49(1.26)$ & $6.15(1.26)$ & $\mathbf{6 . 7 5}(1.29)$ & $\mathbf{8 . 0 7}(1.92)$ & $9.08(3.70)$ \\
\hline $\mathbf{B a}$ & $\mathbf{8 5 3}(212)$ & 857 (169) & 811 (127) & 827 (152) & 853 (155) & $680(323)$ \\
\hline La & 29.8 (5.71) & $\mathbf{3 0 . 2}(5.69)$ & $\mathbf{3 1 . 3}(4.91)$ & $31.6(6.54)$ & $32.6(5.72)$ & 22.6 \\
\hline $\mathrm{Ce}$ & $\mathbf{6 2 . 5}(16.6)$ & $\mathbf{6 8 . 3}(12.6)$ & $\mathbf{6 5 . 3}(11.5)$ & $\mathbf{6 6 . 1}(12.9)$ & $\mathbf{6 9 . 0}(14.0)$ & $\mathbf{4 5 . 3}(18.2)$ \\
\hline $\operatorname{Pr}$ & $\mathbf{6 . 6 7}(1.36)$ & 7.45 (1.49) & $7.66(1.15)$ & $7.24(1.28)$ & $7.33(1.66)$ & $4.46(1.62)$ \\
\hline Nd & $26.4(5.24)$ & $\mathbf{3 0 . 8}(6.16)$ & $32.4(5.17)$ & $\mathbf{3 0 . 2}(5.92)$ & $\mathbf{3 0 . 8}(4.56)$ & $16.5(5.58)$ \\
\hline Sm & $\mathbf{5 . 3 7}(1.03)$ & $\mathbf{6 . 6 4}(1.38)$ & $7.12(1.44)$ & $\mathbf{6 . 5 6}(1.41)$ & $\mathbf{6 . 8 7}(1.54)$ & $\mathbf{3 . 0 7}(1.25)$ \\
\hline Eu & $\mathbf{0 . 5 0}(0.19)$ & $\mathbf{1 . 0 6}(0.27)$ & $1.15(0.20)$ & $\mathbf{1 . 0 5}(0.32)$ & $\mathbf{1 . 0 6}(0.23)$ & $\mathbf{0 . 3 4}(0.28)$ \\
\hline Gd & $4.92(1.38)$ & $\mathbf{6 . 0 8}(1.44)$ & $\mathbf{6 . 8 4}(1.46)$ & $\mathbf{6 . 3 7}(1.18)$ & $\mathbf{6 . 4 3}(1.34)$ & $\mathbf{2 . 7 8}(1.18)$ \\
\hline $\mathbf{T b}$ & $\mathbf{0 . 8 0}(0.15)$ & $\mathbf{0 . 9 9}(0.26)$ & $\mathbf{1 . 1 0}(0.21)$ & $\mathbf{1 . 0 1}(0.22)$ & $\mathbf{1 . 0 5}(0.31)$ & $\mathbf{0 . 4 4}(0.21)$ \\
\hline Dy & $\mathbf{5 . 5 2}(1.40)$ & $\mathbf{6 . 8 4}(1.67)$ & 7.54 (1.59) & $\mathbf{6 . 5 2}(1.57)$ & $\mathbf{6 . 6 9}(1.11)$ & $2.99(1.32)$ \\
\hline Ho & $1.20(0.24)$ & $1.40(0.36)$ & $\mathbf{1 . 5 4}(0.30)$ & $\mathbf{1 . 3 8}(0.33)$ & $\mathbf{1 . 4 8}(0.35)$ & $\mathbf{0 . 6 2}(0.29)$ \\
\hline $\mathbf{E r}$ & $\mathbf{3 . 5 7}(0.69)$ & $4.23(1.04)$ & $4.74(1.10)$ & $\mathbf{4 . 0 9}(0.84)$ & $4.23(1.24)$ & $1.96(0.84)$ \\
\hline Tm & $\mathbf{0 . 5 6}(0.15)$ & $\mathbf{0 . 6 4}(0.16)$ & $0.71(0.19)$ & $\mathbf{0 . 6 3}(0.14)$ & $\mathbf{0 . 6 2}(0.23)$ & $\mathbf{0 . 3 2}(0.18)$ \\
\hline $\mathbf{Y b}$ & $\mathbf{3 . 7 9}(0.92)$ & $\mathbf{4 . 3 4}(1.19)$ & $4.83(1.05)$ & $\mathbf{4 . 0 2}(0.98)$ & $4.88(1.66)$ & $\mathbf{2 . 2 8}(1.11)$ \\
\hline Lu & $\mathbf{0 . 5 9}(0.16)$ & $\mathbf{0 . 6 5}(0.19)$ & $\mathbf{0 . 7 2}(0.20)$ & $\mathbf{0 . 6 5}(0.14)$ & $\mathbf{0 . 7 0}(0.19)$ & $\mathbf{0 . 3 6}(0.18)$ \\
\hline Hf & $4.25(1.21)$ & 7.54 (1.67) & $8.36(1.59)$ & $7.30(1.50)$ & $8.68(2.55)$ & $2.49(0.95)$ \\
\hline $\mathbf{T a}$ & $\mathbf{0 . 9 6}(0.33)$ & $\mathbf{0 . 9 4}(0.25)$ & $\mathbf{0 . 9 7}(0.20)$ & $\mathbf{0 . 8 7}(0.16)$ & $\mathbf{0 . 9 9}(0.32)$ & $\mathbf{0 . 8 0}(0.39)$ \\
\hline $\mathbf{W}$ & $\mathbf{1 . 7 0}(0.59)$ & $\mathbf{1 . 5 5}(0.35)$ & $1.52(0.47)$ & $1.46(0.25)$ & $1.96(0.77)$ & $\mathbf{2 . 1 7}(1.21)$ \\
\hline $\mathbf{P b}$ & $19.9(5.68)$ & 22.5 & $20.2(4.35)$ & $20.6(2.85)$ & $\mathbf{2 5 . 0}(6.79)$ & $20.4(6.94)$ \\
\hline Th & $15.9(3.17)$ & $13.9(2.68)$ & $14.5(2.70)$ & $14.6(2.33)$ & $17.2(3.73)$ & $16.5(5.49)$ \\
\hline $\mathbf{U}$ & $3.44(1.25)$ & $\mathbf{3 . 2 8}(0.73)$ & $\mathbf{3 . 0 0}(0.65)$ & $3.22(0.56)$ & $\mathbf{3 . 7 3}(0.87)$ & $3.78(1.60)$ \\
\hline $\mathbf{Z r} / \mathbf{H f}$ & $\mathbf{3 2 . 6}(7.45)$ & $\mathbf{4 0 . 8}(4.92)$ & $39.8(3.76)$ & $39.4(4.41)$ & $\mathbf{4 0 . 5}(8.24)$ & 27.1 (8.99) \\
\hline $\mathrm{Nb} / \mathrm{Ta}$ & $\mathbf{1 0 . 7}(2.70)$ & $14.0(2.65)$ & $13.1(1.79)$ & $13.7(1.56)$ & 13.1 & $6.90(2.14)$ \\
\hline $\mathrm{Ba} / \mathrm{Th}$ & $\mathbf{5 3 . 8}(7.39)$ & $\mathbf{6 2 . 0}(11.4)$ & $\mathbf{5 6 . 0}(10.0)$ & $\mathbf{5 6 . 6}(8.20)$ & $49.6(6.10)$ & $41.4(16.9)$ \\
\hline $\mathbf{E u} / \mathbf{E u}$ * & $\mathbf{0 . 3 0}(0.13)$ & $\mathbf{0 . 5 1}(0.13)$ & $\mathbf{0 . 5 1}(0.09)$ & $\mathbf{0 . 4 9}(0.10)$ & $\mathbf{0 . 4 9}(0.09)$ & $\mathbf{0 . 3 5}(0.23)$ \\
\hline$n=$ & 29 & 35 & 53 & 11 & 9 & 57 \\
\hline
\end{tabular}



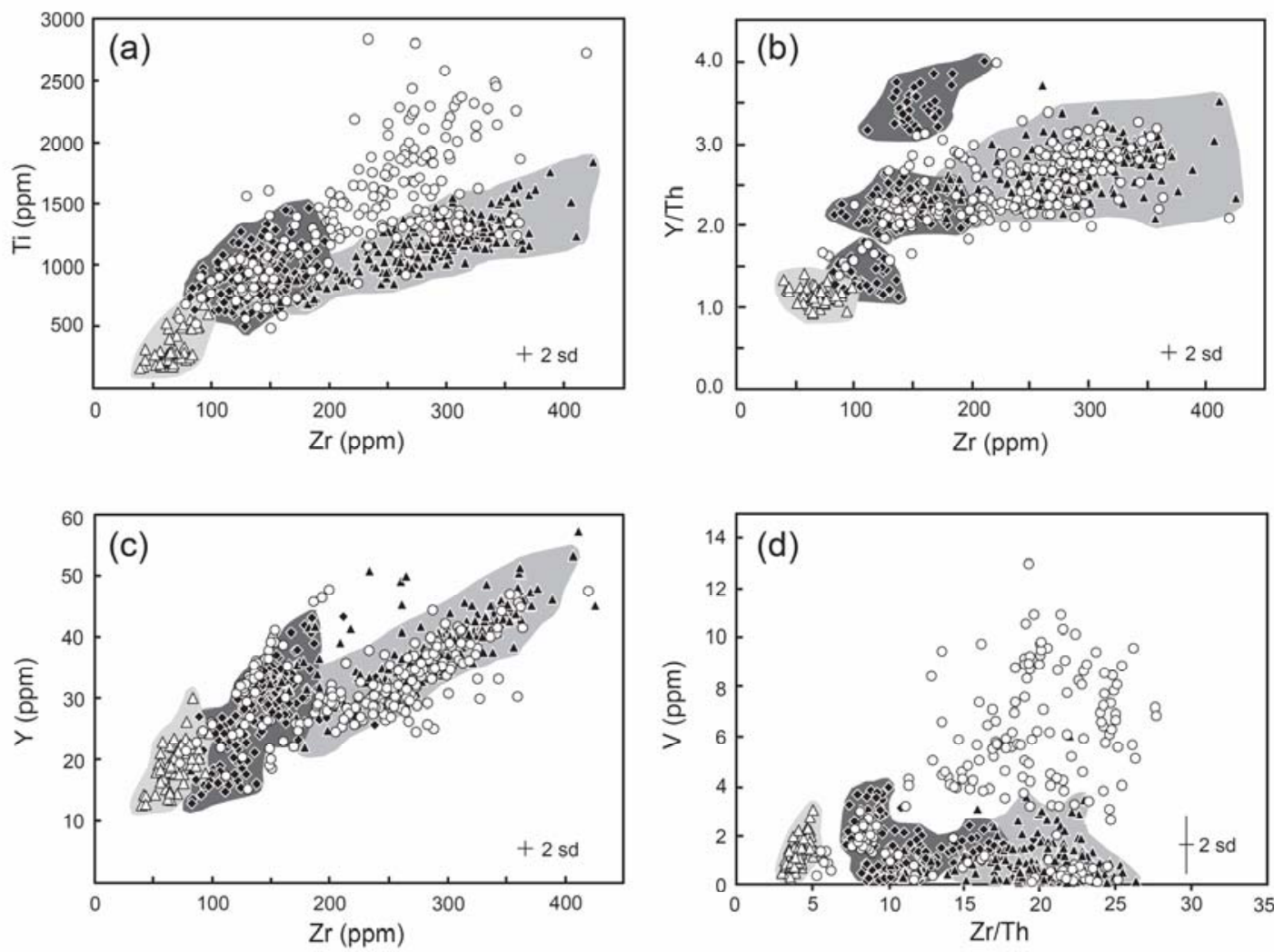

Figure 3-4. Bivariate plots of selected trace element data demonstrating the four broad silicic melt types identified by chemical characterisation of the Site 1123 tephras. Each symbol represents an individual LA-ICP-MS analysis of a single glass shard. Type 2 melt compositions again show considerable overlap with types 1 and 3 on some plots (e.g. $Y / T h$ versus $Z$ r; $Y$ versus $Z r$ ), yet show distinctive trace element characteristics on some plots (e.g. $Y$ versus $\mathrm{Zr}$; $V$ versus $\mathrm{Zr} / \mathrm{Th}$ ). See legend of Fig. 3-3 for explanation of symbols and groupings.

diagrams is difficult (e.g. Types 2 and 3) given the subtle compositional differences between the melt types and the logarithmic scale of the plots. Elements that are compatible (e.g. Ti, Sr and $\mathrm{Eu}$ ) in commonly observed fractionating mineral phases show the largest depletions on these multi-element diagrams (Fig. 3-6). The main feature that can be gleaned from these plots is that the various melt types have either a positive (Types 2 and 3) or negative (Types 1 and 4) anomalies of $\mathrm{Zr}$ with respect to $\mathrm{Nd}$ and Hf. Type 1 and 4 melts are also depleted in heavy REEs compared to Type 2 and 3 melts. All tephra units, with the exception of units 2 and 3, are depleted in $\mathrm{Ba}$ relative to $\mathrm{Rb}$ and Th (Fig. 3-6). These units are the only Site 1123 tephra units that are sourced from eruptions from Okataina caldera (unit 2 - Omataroa Tephra; unit 3 - Rotoehu/Rotoiti eruption). 

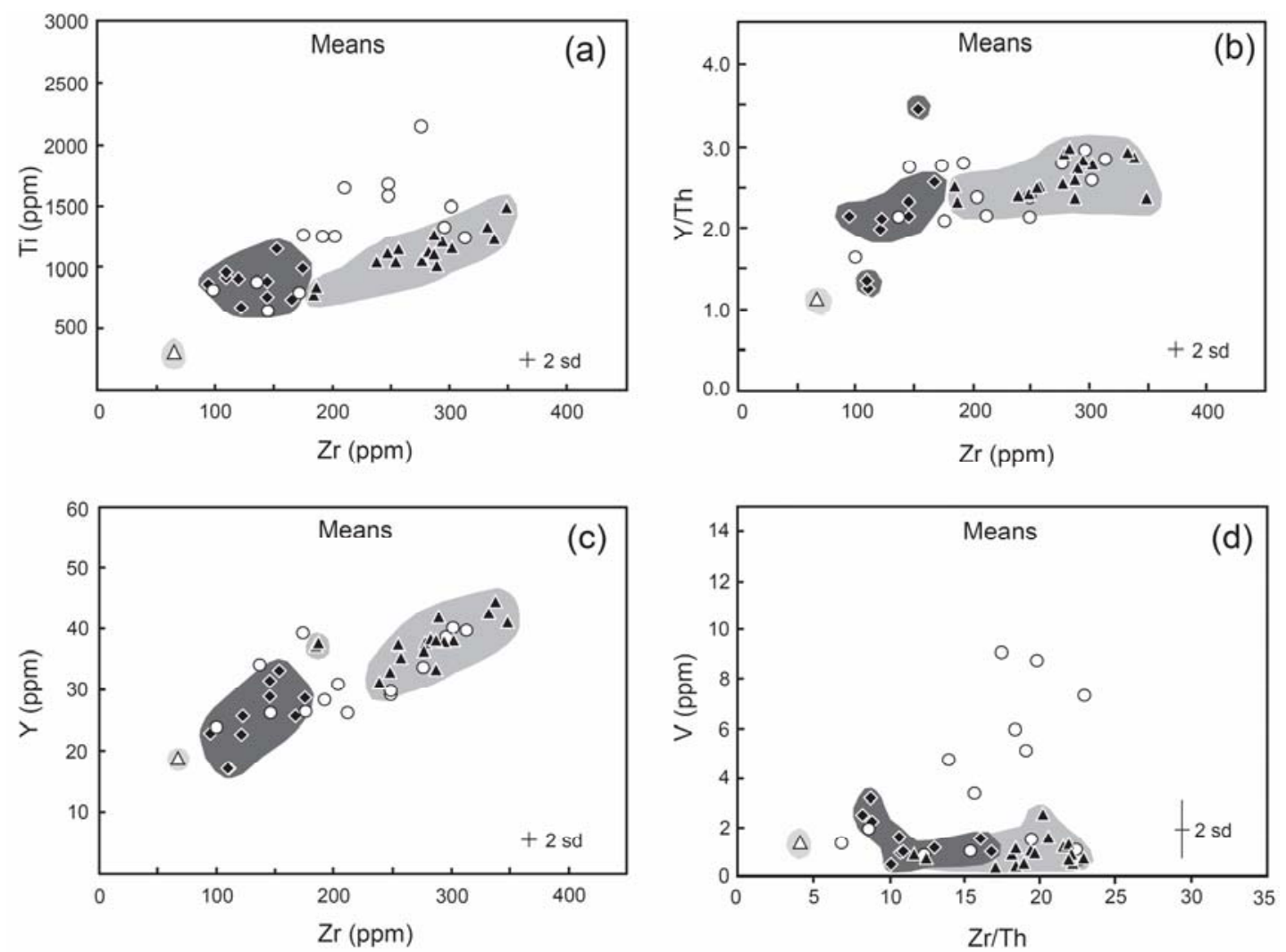

Figure 3-5. Mean glass shard compositions corresponding to the data shown in Fig. 3-4. For instances where major and trace element chemistry identified multiple glass populations within an individual tephra unit (e.g. units 14, 16, 17 and 18), a separate mean has been calculated and plotted for each population. See legend of Fig. 3-3 for explanation of symbols and groupings.

\subsection{Pb-Sr-Nd isotopic data for Site 1123 tephras}

$\mathrm{Pb}, \mathrm{Sr}$ and $\mathrm{Nd}$ isotopic data for 13 representative Site 1123 tephras determined in this study are presented in Table 3-3. The following ranges in $\mathrm{Sr}, \mathrm{Nd}$ and $\mathrm{Pb}$ isotopic compositions are observed: ${ }^{87} \mathrm{Sr} /{ }^{86} \mathrm{Sr}=0.70535$ to $0.70643 ; \varepsilon_{\mathrm{Nd}}=-0.63$ to 1.35 ; ${ }^{206} \mathrm{~Pb} /{ }^{204} \mathrm{~Pb}=18.835$ to $18.858 ;{ }^{207} \mathrm{~Pb} /{ }^{204} \mathrm{~Pb}=15.625$ to $15.644 ;{ }^{208} \mathrm{~Pb} /{ }^{204} \mathrm{~Pb}=38.717$ to 38.774. These ranges in isotopic composition and, in particular, the observed variations in $\mathrm{Pb}$ isotopic composition, are relatively small compared to that of previously reported isotope data for silicic TVZ rocks (Fig. 3-7).

$\mathrm{Sr}-\mathrm{Nd}$ isotopic data are broadly negatively correlated with the samples with the lowest ${ }^{87} \mathrm{Sr} /{ }^{86} \mathrm{Sr}$ defined by samples representative of Type 1,2 and 3 melt compositions and the highest ${ }^{87} \mathrm{Sr} /{ }^{86} \mathrm{Sr}$ end of the array defined by the tephra sample 

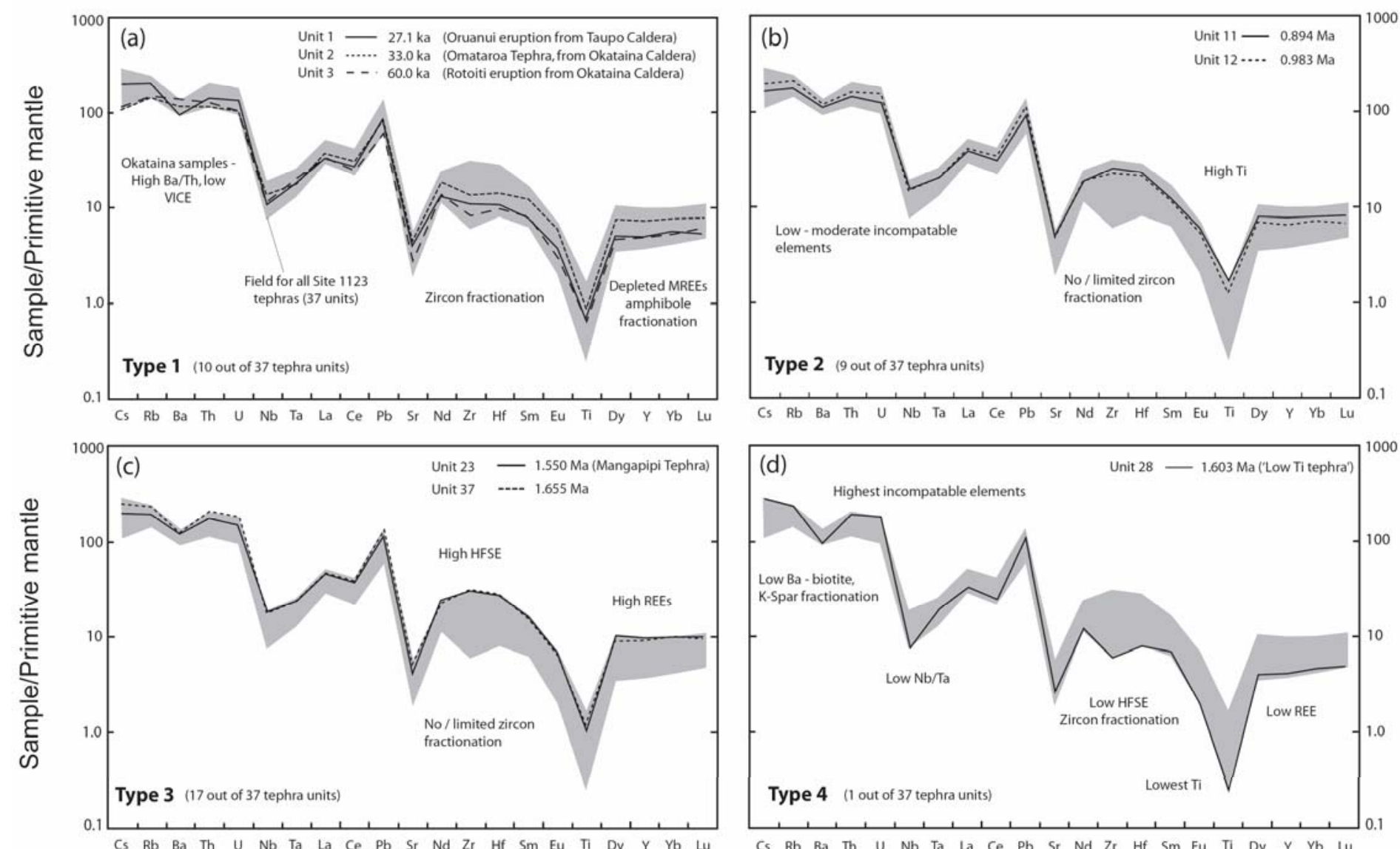

CS Rb Ba Th U N Nb Ta La Ce Pb Sr Nd Zr Hf Sm Eu Ti Dy Y Yb Lu

Figure 3-6. Multi-element diagrams illustrating the range of trace element variation for all Site 1123 glass (melt) compositions (grey shaded field) and representative tephra units from each of the four melt types (see text for discussion). (a) Type 1 melts. (b) Type 2 melts. (c) Type 3 melts. (d) Type 4 melts. Trace element data are normalised to the primitive mantle values of Sun and McDonough (1989). All melt compositions are characterised by enrichments in LILE relative to HFSE and show strong depletions in compatible elements (Sr and Ti). 

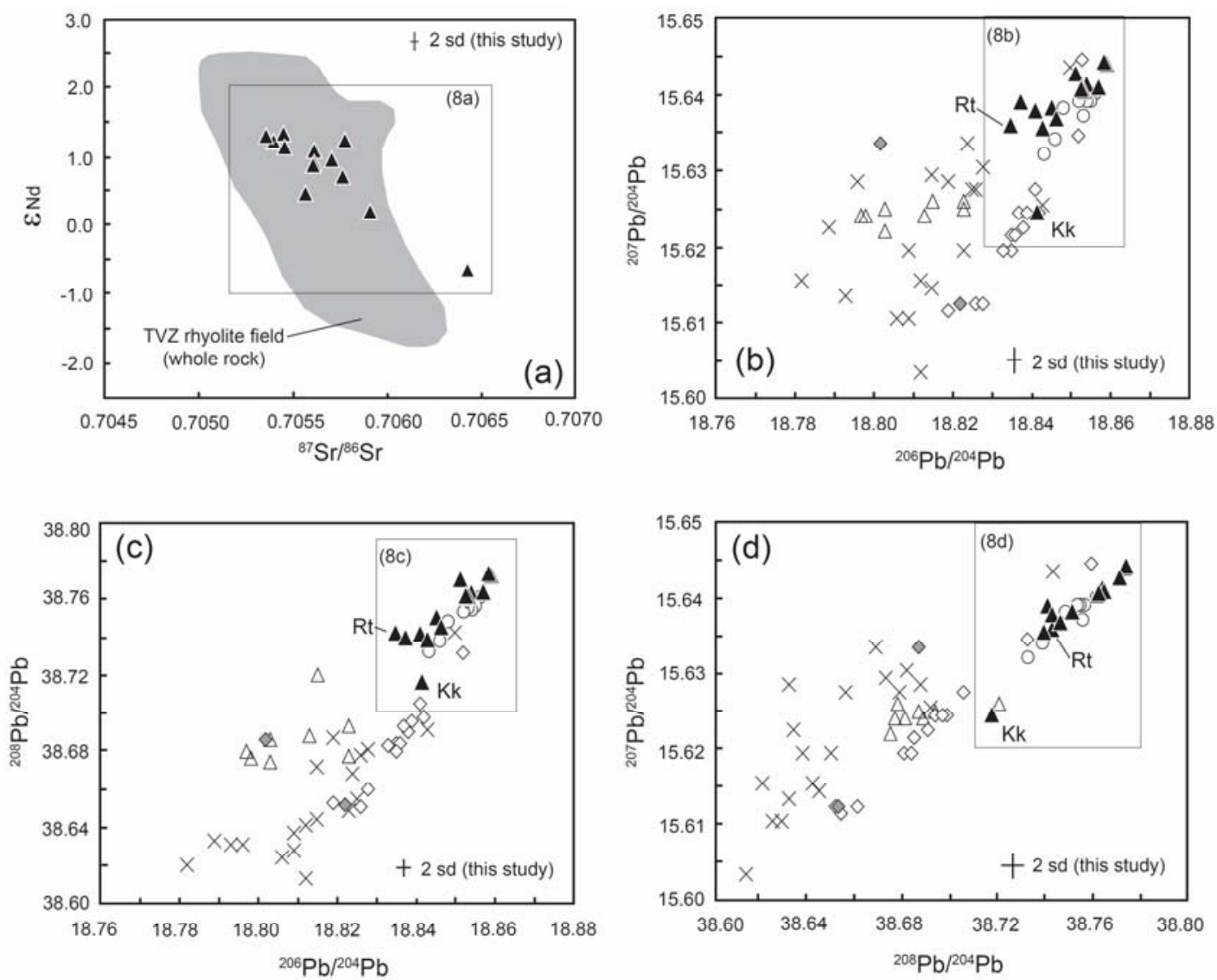

This study - high purity glass separates from Site 1123 tephras $(0.027$ to $1.66 \mathrm{Ma})$

$\times$ Graham et al. (1992) powdered whole rock gnimbrites and rhyolites $\left(0.0\right.$ to $\left.0.74 \mathrm{Ma}^{*}\right)$ maxium
McCulloch et al. (1994) - high purity plagioclase separates from Maroa volcanic centre rhyolites (ca. 0.23 to $0.25 \mathrm{Ma}$ \#)
$\diamond$ Brown et al. (1998) - whole rock pumice on Whakamaru eruption deposits ( $340 \mathrm{ka})$

$\triangle$ Schmitz \& Smith (2004) - whole rock on deposits from the Rotoiti eruption ( $60 \mathrm{ka}$ )

$\diamond$ Brown et al. (1998) glass separates on Whakamaru eruption deposits $(\sim 340 \mathrm{ka})$

Figure 3-7. A comparison of the $\mathrm{Sr}, \mathrm{Nd}$ and $\mathrm{Pb}$ isotopic data for Site 1123 tephras (high purity glass separates) to existing data for TVZ rhyolites. (a) $\varepsilon_{\mathrm{Nd}}$ versus ${ }^{87} \mathrm{Sr} /{ }^{86} \mathrm{Sr}$. Grey shaded field encompasses whole rock isotopic data reported by Briggs et al. (1993), McCulloch et al. (1994), Sutton et al. (1995 \& 2000) Beresford et al. (2000), Schmitz and Smith (2004) and Wilson et al. (2006). (b) ${ }^{207} \mathrm{~Pb} /{ }^{204} \mathrm{~Pb}$ versus ${ }^{206} \mathrm{~Pb} /{ }^{204} \mathrm{~Pb}$. (c) ${ }^{208} \mathrm{~Pb} /{ }^{204} \mathrm{~Pb}$ versus ${ }^{206} \mathrm{~Pb} /{ }^{204} \mathrm{~Pb}$. (d) ${ }^{207} \mathrm{~Pb} /{ }^{204} \mathrm{~Pb}$ versus ${ }^{208} \mathrm{~Pb} /{ }^{204} \mathrm{~Pb}$. The data sources for previously published $\mathrm{Pb}$ isotope data for TVZ rhyolites, the types of material analysed and the approximate age range for the samples in each of these studies, are indicated in the figure legend. All $\mathrm{Sr}$ and $\mathrm{Pb}$ isotope data shown here (and in subsequent figures) have been normalised (or renormalised) to the standards SRM987 $(\mathrm{Sr})$ and SRM981 $(\mathrm{Pb})$ using the following values: ${ }^{87} \mathrm{Sr} /{ }^{86} \mathrm{Sr}$ $=0.710248 ;{ }^{206} \mathrm{~Pb} /{ }^{204} \mathrm{~Pb}=16.9418 ;{ }^{207} \mathrm{~Pb} /{ }^{204} \mathrm{~Pb}=15.5000 ;{ }^{208} \mathrm{~Pb} /{ }^{204} \mathrm{~Pb} 36.7265$. Kk = Kawakawa Tephra from Site 1123, associated with the $\sim 27.1$ Oruanui eruption (Unit 1); Rt = Rotoehu Tephra from Site 1123, associated with the $\sim 60$ ka Rotoiti eruption (Unit 3). Inset boxes show the fields of view for the plots in Fig. 3-8.

that represents the Type 4 melt. Sr and Nd isotopic data reported here are largely consistent with previously published whole rock data for silicic TVZ rocks.

However, the Site 1123 tephra melt compositions in general occupy a more restricted range in ${ }^{87} \mathrm{Sr} /{ }^{86} \mathrm{Sr}$ versus $\varepsilon_{\mathrm{Nd}}$ isotope space. For example, 12 of 13 samples have ${ }^{87} \mathrm{Sr} /{ }^{86} \mathrm{Sr}=0.70535$ to 0.70591 and $\varepsilon_{\mathrm{Nd}}=0.22$ to 1.35 , with only a single unit (Unit 28) extending to more radiogenic $\mathrm{Sr}\left({ }^{87} \mathrm{Sr} /{ }^{86} \mathrm{Sr}=0.70643\right)$ than that defined by previous studies (Fig. 3-7a). 

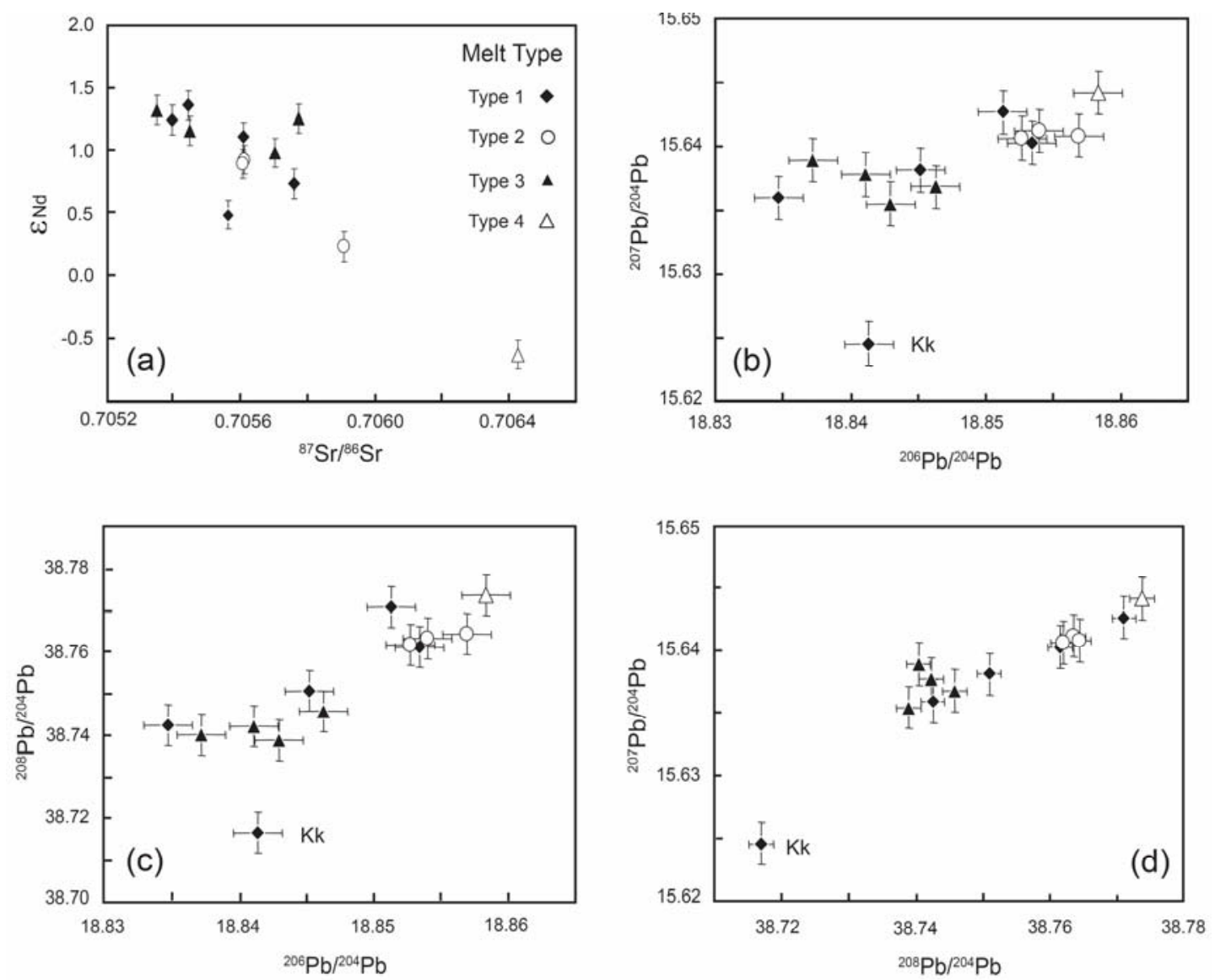

Figure 3-8. $\mathrm{Sr}, \mathrm{Nd}$ and $\mathrm{Pb}$ isotopic data for Site 1123 tephras. (a) $\varepsilon_{\mathrm{Nd}}$ versus ${ }^{87} \mathrm{Sr} /{ }^{86} \mathrm{Sr}(\mathrm{b}){ }^{207} \mathrm{~Pb} /{ }^{204} \mathrm{~Pb}$ versus ${ }^{206} \mathrm{~Pb} /{ }^{204} \mathrm{~Pb}$. (c) ${ }^{208} \mathrm{~Pb} /{ }^{204} \mathrm{~Pb}$ versus ${ }^{206} \mathrm{~Pb} /{ }^{204} \mathrm{~Pb}$. (d) ${ }^{207} \mathrm{~Pb} /{ }^{204} \mathrm{~Pb}$ versus ${ }^{208} \mathrm{~Pb} /{ }^{204} \mathrm{~Pb}$. Symbols are as described in the legend of Fig. 3-3. All error bars represent $2 \sigma$ uncertainties. The $2 \sigma$ uncertainties for ${ }^{87} \mathrm{Sr} /{ }^{86} \mathrm{Sr}$ measurements are comparable to the size of the symbols. Although the overall variation in the isotopic compositions is small, the precision of the measurements identifies broad linear trends. Interestingly, unit 1 (from the $\sim 27.1 \mathrm{ka}$

Oruanui/Kawakawa eruption) is compositionally offset from these trends in all $\mathrm{Pb}$ isotope plots (annotated here by $\mathrm{Kk})$.

$\mathrm{Pb}$ isotopic data for the Site 1123 tephras exhibit small variations that would be unresolvable with conventional thermal ionisation mass spectrometric techniques for $\mathrm{Pb}$ isotopic analysis, as has been typically used in previous studies of TVZ silicic volcanic rocks. However, the variations observed in this study are an order of magnitude than our analytical uncertainties and define broad linear positive covariations between ${ }^{206} \mathrm{~Pb} /{ }^{204} \mathrm{~Pb}$ and ${ }^{207} \mathrm{~Pb} /{ }^{204} \mathrm{~Pb}$ and ${ }^{208} \mathrm{~Pb} /{ }^{204} \mathrm{~Pb}$ (Fig. 3-8). One sample lies off the main array defined by the Site 1123 tephras - the 27.1 ka Kawakawa tephra correlative - that has lower ${ }^{207} \mathrm{~Pb} /{ }^{204} \mathrm{~Pb}$ and ${ }^{208} \mathrm{~Pb} /{ }^{204} \mathrm{~Pb}$ at a given ${ }^{206} \mathrm{~Pb} /{ }^{204} \mathrm{~Pb}$ as compared to the main array.

Most of the previously published $\mathrm{Pb}$ isotope compositions for silicic TVZ rocks, which have been almost exclusively determined on powdered whole rock samples (pumice and ignimbrite units), are offset to different and less radiogenic $\mathrm{Pb}$ isotope 
Table 3-3. Multi-collector inductively coupled plasma mass spectrometry (MC-ICP-MS) isotope data

\begin{tabular}{|c|c|c|c|c|c|c|c|}
\hline Tephra unit & 1 & 2 & 3 & 9 & 10 & 11 & 12 \\
\hline Melt type & 1 & 1 & 1 & 1 & 1 & 2 & 2 \\
\hline Age & $27.1 \mathrm{ka}$ & $33.0 \mathrm{ka}$ & $\sim 60.0 \mathrm{ka}$ & $0.549 \mathrm{Ma}$ & $0.826 \mathrm{Ma}$ & $0.894 \mathrm{Ma}$ & $0.983 \mathrm{Ma}$ \\
\hline${ }^{87} \mathrm{Sr} /{ }^{86} \mathrm{Sr}$ & 0.705563 & 0.705397 & 0.705443 & 0.705759 & 0.705608 & 0.705611 & 0.705908 \\
\hline${ }^{143} \mathrm{Nd} /{ }^{144} \mathrm{Nd}$ & 0.512662 & 0.512701 & 0.512707 & 0.512675 & 0.512694 & 0.512685 & 0.512650 \\
\hline$\varepsilon_{\mathrm{Nd}}$ & 0.48 & 1.24 & 1.35 & 0.73 & 1.10 & 0.92 & 0.22 \\
\hline${ }^{206} \mathrm{~Pb} /{ }^{204} \mathrm{~Pb}$ & 18.8414 & 18.8452 & 18.8347 & 18.8513 & 18.8534 & 18.8540 & 18.8569 \\
\hline${ }^{207} \mathrm{~Pb} /{ }^{204} \mathrm{~Pb}$ & 15.6246 & 15.6382 & 15.6360 & 15.6427 & 15.6404 & 15.6413 & 15.6409 \\
\hline${ }^{208} \mathrm{~Pb} /{ }^{204} \mathrm{~Pb}$ & 38.7169 & 38.7509 & 38.7425 & 38.7710 & 38.7615 & 38.7635 & 38.7644 \\
\hline
\end{tabular}

Table 3-3 continued.

\begin{tabular}{ccccccc}
\hline Tephra unit & 19 & 22 & 23 & 33 & 37 & 28 \\
Melt type & 2 & 3 & 3 & 3 & 3 & 4 \\
Age & $1.402 \mathrm{Ma}$ & $1.532 \mathrm{Ma}$ & $1.550 \mathrm{Ma}$ & $1.629 \mathrm{Ma}$ & $1.660 \mathrm{Ma}$ & $1.603 \mathrm{Ma}$ \\
\hline \hline & & & & & & \\
${ }^{\mathbf{8 7}} \mathbf{S r} /{ }^{\mathbf{8 6}} \mathbf{S r}$ & 0.705607 & 0.705703 & 0.705774 & 0.705450 & 0.705351 & 0.706427 \\
${ }^{\mathbf{1 4 3}} \mathbf{N d} /{ }^{\mathbf{1 4 4}} \mathbf{N d}$ & 0.512683 & 0.512688 & 0.512702 & 0.512697 & 0.512705 & 0.512605 \\
$\mathbf{E}_{\mathbf{N d}}$ & 0.89 & 0.98 & 1.25 & 1.15 & 1.32 & -0.63 \\
${ }^{{ }^{006}} \mathbf{P b} /{ }^{\mathbf{2 0 4}} \mathbf{P b}$ & 18.8527 & 18.8430 & 18.8463 & 18.8411 & 18.8372 & 18.8583 \\
${ }^{{ }^{007}} \mathbf{P b} /{ }^{\mathbf{2 0 4}} \mathbf{P b}$ & 15.6407 & 15.6355 & 15.6369 & 15.6378 & 15.6390 & 15.6442 \\
${ }^{{ }^{008}} \mathbf{P b} /{ }^{\mathbf{2 0 4}} \mathbf{P b}$ & 38.7619 & 38.7389 & 38.7458 & 38.7422 & 38.7403 & 38.7737 \\
\hline
\end{tabular}

compositions than data for the Site 1123 glasses reported here (Figs. 3-7b-d). For example, Schmitz and Smith (2004) reported $\mathrm{Pb}$ isotope data for powdered pyroclastic rocks from the $\sim 60$ ka Rotoiti eruption from Okataina caldera (open triangles in Figs. 3-7b-d) that are offset to significantly less radiogenic $\mathrm{Pb}$ than data obtained on a pure glass separate from the Site 1123 tephra associated with the same eruption (Allan et al., 2008). Although Schmitz and Smith (2004) give no information about the relative analytical uncertainties of their $\mathrm{Pb}$ isotope data, the magnitude of these differences make it seem unlikely that these differences are solely analytical. Moreover, all the $\mathrm{Pb}$ isotope data shown on Fig. $7 \mathrm{~b}-\mathrm{d}$ have been normalised (or re-normalised) to the same reference values for the SRM981 standard (Baker et al., 2004).

However, the $\mathrm{Pb}$ isotope data reported by McCulloch et al. (1994) for feldspar separates from Maroa centre rhyolites (open circles in Figs. 3-7b-d) overlap the $\mathrm{Pb}$ isotope data for the Site 1123 tephras reported here. Three observations about the McCulloch et al. (1994) dataset are worthy of note: (1) these Pb isotope data were determined on high purity, late crystallising, plagioclase separates as opposed to 
powdered whole rock analyses, (2) the Maroa samples were restricted in both time and space, coming from a single volcanic centre active during ca. $240 \mathrm{ka}$, and (3) these data were acquired using highly precise double-spike methodologies to correct for instrumental mass fractionation and are the only data with comparable precisions and accuracy to the data presented here.

One important feature of the radiogenic isotope data is that the four silicic melt types identified by major and trace element chemistry are not generally revealed in the isotope data. The principal exception to this is the Type 4 melt composition which has the most crustal-like $\mathrm{Sr}-\mathrm{Nd}$ isotopic signature and is also characterised by major and trace element features that mark it as having the most evolved melt composition (e.g., lowest $\mathrm{MgO}$ and highest $\mathrm{Rb} / \mathrm{Sr}$ ) and most extreme crustal-like incompatible trace element ratios (e.g., high $\mathrm{La} / \mathrm{Nb}$ ) (Tables 3-1 and 3-2).

\subsection{DISCUSSION}

4.1 Nature, origins and preservation of trace element heterogeneity in the melt phase of pre-eruptive silicic melt bodies

Single glass shard major and trace element data for the TVZ-sourced Site 1123 tephras makes it possible to determine to what extent chemical zonation existed in pre-eruptive TVZ silicic melt bodies or magma chambers. If variations in the trace element composition of single glass shards from an individual tephra deposit exceeds analytical uncertainties, then the glass shard chemistries provide snapshots of heterogeneity in the melt bodies or magma chambers immediately prior to eruption.

For example, Ukstins Peate et al. $(2003,2008)$ reported single glass shard major and trace element data for four tephras recovered from Indian Ocean marine sediment cores that were correlated to individual pyroclastic units found in the Oligocene Afro-Arabian flood volcanic province in Yemen and Ethiopia. Glass shards from these individual tephra layers revealed extreme major and trace element heterogeneity (e.g. $\mathrm{SiO}_{2}=43$ to $75 \mathrm{wt} . \%$; $\mathrm{Nb}=35$ to $190 \mathrm{ppm}$ ) providing strong evidence for the existence of extensive chemical zonation in the pre-eruptive silicic magma chambers. The curvilinear trends revealed on bivariate element-element plots enabled Ukstins Peate et al. $(2003,2008)$ to determine that the intermediate to silicic 
melt component of these tephras was generated by extreme fractional crystallisation $(\mathrm{F}=\sim 60 \%)$ of the observed phenocryst assemblages from a basaltic parental magma.

Major and trace element variability of the magnitude reported by Ukstins Peate et al. $(2003,2008)$ is not observed in individual Site 1123 tephras. However, unit 28 preserves a significant record of chemical heterogeneity in the pre-eruptive melt body. For example, the composition of single glass shards from this unit shows a wide range in trace element concentrations e.g., $\mathrm{Sr}=17-90 \mathrm{ppm} ; \mathrm{Mg}=210-1430$ ppm; $\mathrm{Ba}=144-999 \mathrm{ppm} ; \mathrm{Eu}=0.13-0.76 \mathrm{ppm}$. However, the magnitude of the trace element variability in unit 28 is unique to this unit, and most Site 1123 tephra units exhibit only modest trace element variability e.g. a factor of 2-4 variation for most compatible and incompatible trace elements.

Trace element data identifies the existence of small scale chemical heterogeneity in the melt phase for all of the Site 1123 tephra units that exceeds the analytical uncertainties of the LA-ICP-MS method as determined by repeated analyses of the rhyolite glass standard, ATHO-G (Allan et al., 2008; Fig. 3-9). However, it is rare for this trace element variability to be preserved in the form of coherent linear or curvilinear trends. Almost all tephra units have positive correlations between pairs of compatible or incompatible trace elements (e.g. $\mathrm{Mg}$ versus $\mathrm{Ti}, \mathrm{Pb}$ versus $\mathrm{U}$ ), but these features provide limited insights because they are not particularly unique to any petrogenetic process (i.e. they are consistent with either fractional crystallisation or magma mixing).

Figure 3-9 illustrates some of the trace element variability exhibited by individual Site 1123 tephra units. Plots illustrating co-variations between elements of strongly contrasting compatibility (e.g. Sr versus Th or Rb, Figs. 3-9a-d) are useful because progressive fractional crystallisation results in rapidly decreasing abundances of compatible trace elements ( $\mathrm{Sr}$ ) and at the same time modestly increasing abundances of incompatible trace elements (Th, Rb). While some Site 1123 tephra units do show negative correlations between compatible and incompatible trace element concentrations (e.g. Fig. 3-9b; unit 11), many show significant variations in these trace elements beyond analytical uncertainties that appears in the form of diffuse clouds of data (Fig. 3-9a; unit 4). Single shard trace element data for units 2 and 3 

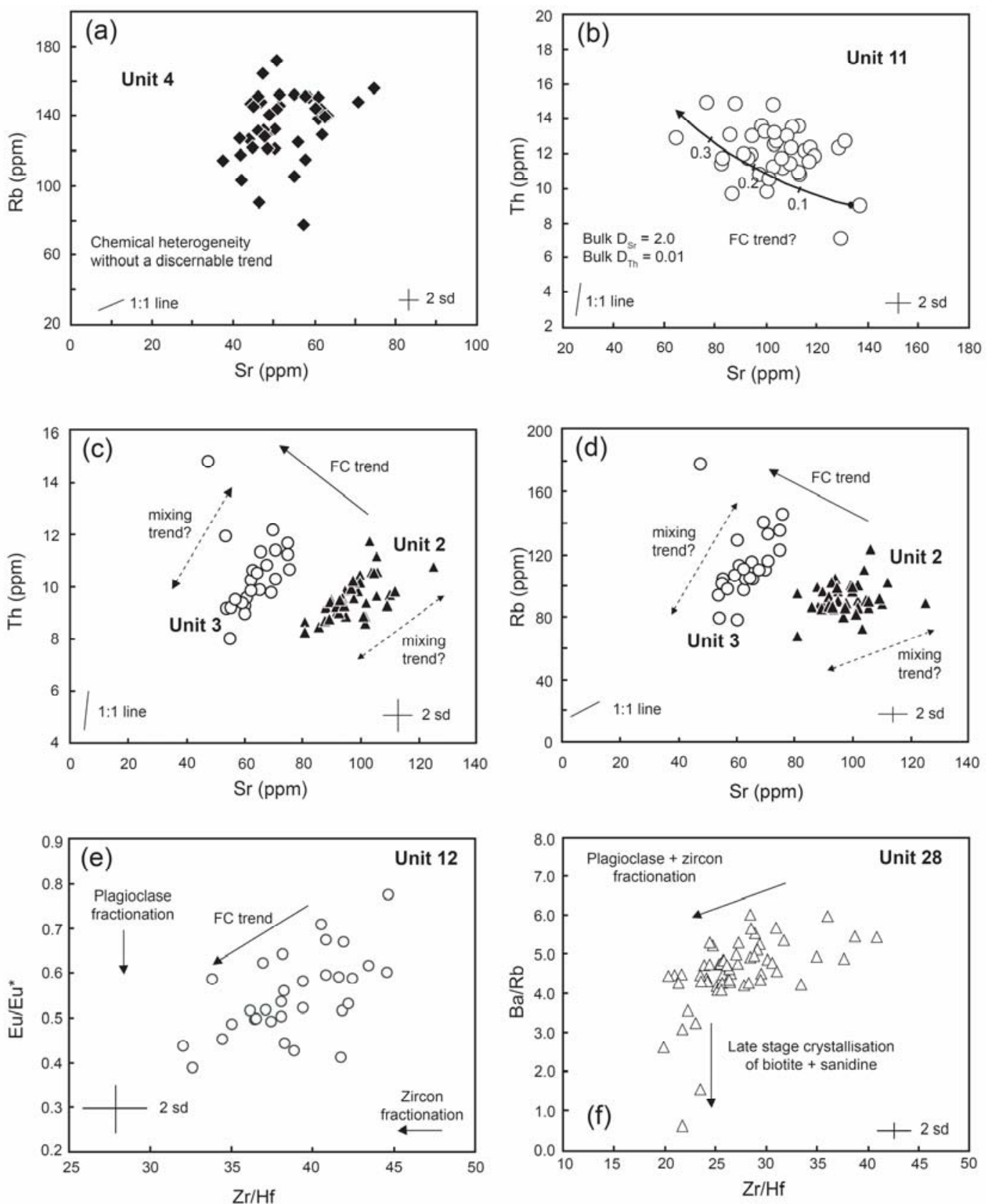

Figure 3-9. Single shard trace element data for selected individual tephra units demonstrating the variable interpretations of chemical heterogeneity. The 1:1 lines shown in (a to d) show the trend/analytical artefact that would be introduced by the $\mathrm{CaO}$ normalisation process if significant (see Allan et al., 2008). (a) Rb versus $\mathrm{Sr}$ for unit 4. The spread of the data is much larger than can be attributed to analytical uncertainty with the absence of a discernible trend (related to fractionation, melting or mixing processes). This sort of diffuse trace element variation is typical of many Site 1123 tephras. (b) Th versus Sr for unit 11. A negative correlation between a strongly compatible and incompatible trace element is consistent with fractional crystallisation. (c \& d) Positive correlations between compatible ( $\mathrm{Sr}$ ) and incompatible trace elements (Th and $\mathrm{Rb}$ ) cannot be generated by either fractional crystallisation or melting processes and most likely are relicts of mixing between two discrete batches of magma. (e) Trace element ratios provide more reliable indices of fractionation. The lowering of $\mathrm{Eu}^{\mathrm{E}} \mathrm{Eu}^{*}$ and $\mathrm{Zr} / \mathrm{Hf}$ can only be appreciably generated by the fractionation of plagioclase and zircon, respectively. (f) A dramatic decrease in the $\mathrm{Ba} / \mathrm{Rb}$ ratio of the melt documents the late stage crystallisation of biotite and sanidine in the unit 28 magma chamber. 
exhibit positive correlations between compatible and incompatible trace elements that cannot be readily generated by fractional crystallisation or partial melting processes (Figs. 3-9c-d). These units are interpreted to document mixing of discrete magma batches prior to eruption and provide a key to explaining the less coherent trace element variations described above which we attribute to the mixing of two variably fractionated magma batches.

Trace element ratios provide more sensitive indices of petrogenetic processes than abundances as ratios are less sensitive to some sources of analytical error e.g., the secondary normalisation of trace element abundances to the electron microprobe $\mathrm{CaO}$ content. Plagioclase fractionation is considered to be the major fractionating phase in TVZ silicic magmas (Graham et al., 1995). The significant negative Eu anomalies $\left(\mathrm{Eu} / \mathrm{Eu}^{*}<1\right.$; Table 3-2) of the Site 1123 tephras confirms this, yet the single shard trace element data for individual tephra units rarely reveals the preservation of such a process in the form of negative correlations between $\mathrm{Sr}$ and incompatible trace elements implying that the history of plagioclase fractionation has not been preserved in zoned silicic melt bodies due to mixing processes.

The propensity for chemical variations to be preserved in the tephra units and the melt bodies or magma chambers they were erupted from may reflect a range of factors including; (a) the physical properties of the melt with the most evolved lowest temperature and lowest viscosity melts most likely to be inefficiently mixed in a magma chamber; (b) crystal-poor magma bodies being more efficiently mixed than crystal-rich magma bodies; (c) the mechanisms of crystal-melt separation and the timing of this with respect to eruption; (d) that diffusivities of different trace element species in silicic melts vary by several orders of magnitude with diffusion being slowest for elements with large ionic radii and charge (e.g., Zr) (Koepke and Behrens, 2001).

\subsection{Origins of the four broad silicic melt types represented by Site 1123 tephras}

Four broad silicic melt types amongst the Site 1123 tephra units have been identified (e.g., Figs. 3-3 to 3-6, 3-10) on the basis of major and trace element chemistry. With the exception of the most evolved tephra unit (unit 28) which has the highest ${ }^{87} \mathrm{Sr} /{ }^{86} \mathrm{Sr}$ and lowest ${ }^{143} \mathrm{Nd} /{ }^{144} \mathrm{Nd}$ ratios of the analysed Site 1123 tephras, isotopic 
data for the Site 1123 tephras are decoupled from these chemical data. This observation constrains most of the differences in the major and trace element chemistry of the four broad silicic melt types amongst the Site 1123 tephra units to be controlled by fractional crystallisation processes rather than variable source inputs e.g., incorporation of significantly different amounts of continental crust into the silicic magmas.

Trace element ratios yield particularly useful insights into fractionation crystallisation processes. For example, higher $\mathrm{Rb} / \mathrm{Sr}$ ratios and lower values of $\mathrm{Eu} / \mathrm{Eu}^{*}$ in magmas (Fig. 3-10) tracks feldspar fractional crystallisation. Similarly, because $\mathrm{Rb}$ is highly incompatible in almost every common mineral phase and $\mathrm{Zr}$ and Hf are major constituents of the mineral zircon, progressive fractional crystallisation of zircon results in melts with higher $\mathrm{Rb} / \mathrm{Zr}$ ratios and lower abundances of $\mathrm{Zr}$ and $\mathrm{Hf}$.

The ratio of pairs of normally incompatible trace elements with near identical geochemical behaviour (e.g. $\mathrm{Nb} / \mathrm{Ta}$ or $\mathrm{Zr} / \mathrm{Hf}$ ) can be a sensitive indicator of
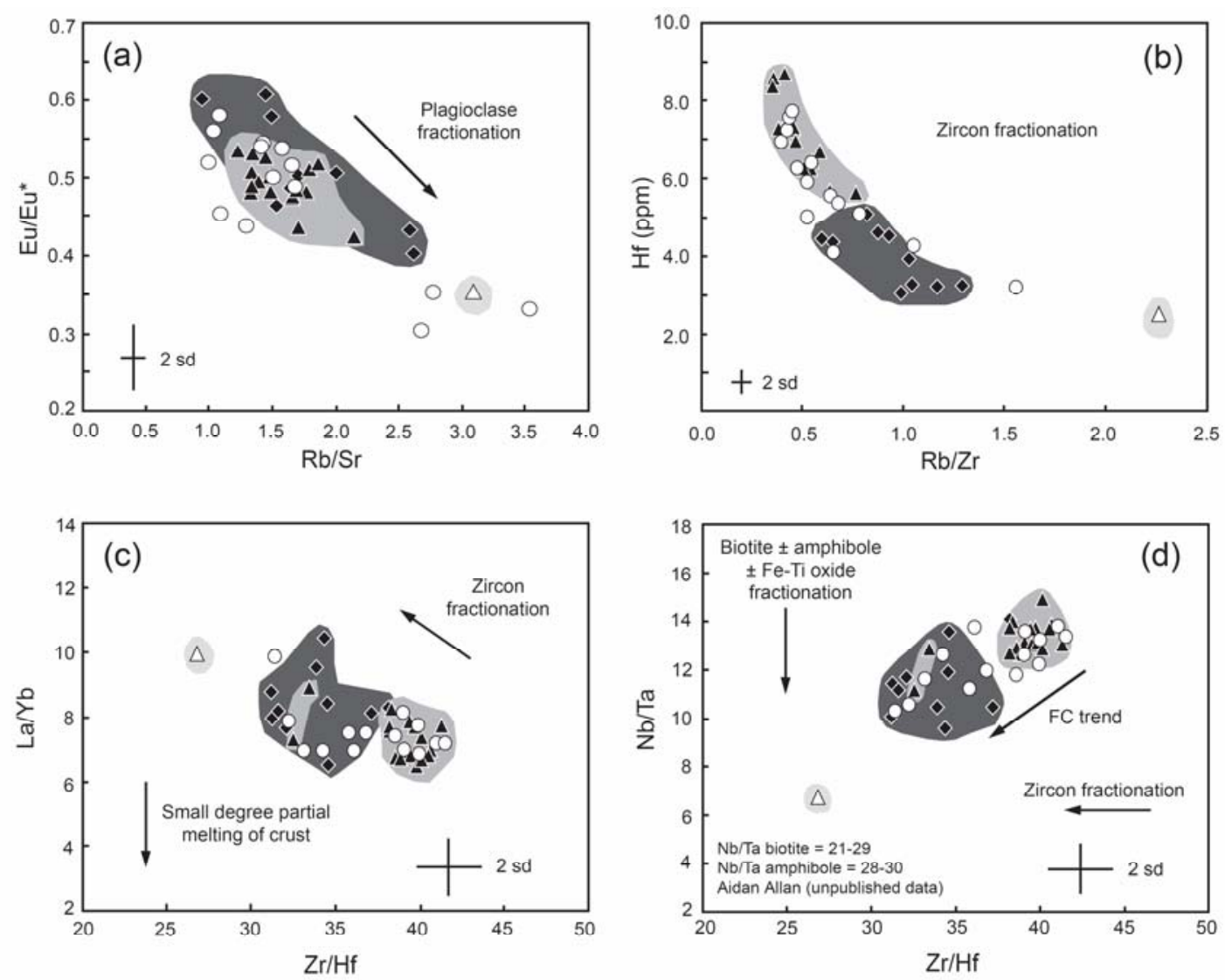

Figure 3-10. Trace element indices of fractional crystallisation demonstrate that the origin of the four silicic melt types is largely due to the differential fractionation of feldspar, accessory zircon, hydrous minerals and Fe-Ti oxides. 
fractional crystallisation for particular minerals. As a result of the near identical geochemical behaviour of $\mathrm{Zr}$ and $\mathrm{Hf}$, most rocks on Earth have near chondritic $\mathrm{Zr} / \mathrm{Hf}$ ratios $(\mathrm{Zr} / \mathrm{Hf}=35-40$, Lowery-Claiborne et al., 2006). However, zircon preferentially incorporates $\mathrm{Zr}$ over $\mathrm{Hf}$ and even modest degrees of zircon fractional crystallisation can dramatically reduce the $\mathrm{Zr} / \mathrm{Hf}$ ratio of the residual melt phase (Lowery Claiborne et al., 2006).

Examination of the systematics of such trace element ratios indicates that much of the major and trace element chemistry variations between the four silicic melt types represented by the Site 1123 tephras primarily reflect differing degrees of fractional crystallisation of minerals such as plagioclase, amphibole, biotite, zircon and Fe-Ti oxides. For example, the young Type 1 silicic melts appear to have experienced more fractional crystallisation in general and, in particular of accessory zircon, than the Type 3 silicic melts, which has resulted in them having higher $\mathrm{SiO}_{2}$, lower $\mathrm{CaO}$ and FeO (Fig. 3-3), and lower Zr, Zr/Hf and Rb/Zr (Fig. 3-10). However, Type 1 and 3 melts have comparable $\mathrm{Rb} / \mathrm{Sr}$ ratios and $\mathrm{Eu}$ anomalies implying that plagioclase fractionation was less important in generating the distinctive trace element characteristics of the Type 1 and 3 silicic melts. Some of the Type 2 silicic melt compositions overlap those of Types 1 and 3, but five Type 2 silicic melts have distinctly higher $\mathrm{MgO}, \mathrm{CaO}, \mathrm{TiO}_{2}$ and $\mathrm{V}$ that appear to require a rather different fractional crystallisation history to most of the other Site 1123 tephra units.

Silicic melt Type 4 as represented by unit 28 has unique composition marked by the highest abundances of $\mathrm{K}_{2} \mathrm{O}, \mathrm{Cs}, \mathrm{Rb}$, Th, $\mathrm{U}$ and lowest abundances of, for example, $\mathrm{MgO}, \mathrm{TiO}_{2}, \mathrm{Nb}, \mathrm{Zr}$, Hf. Unit 28 also has a significantly lower $\mathrm{Nb} / \mathrm{Ta}$ ratio $(\mathrm{Nb} / \mathrm{Ta}$ chondrites 17-18; Jochum et al., 2000) than all the other Site 1123 tephras. Unit 28 melt has experienced the greatest degree of fractional crystallisation of all the Site 1123 tephras which has imparted this unique major and trace element fingerprint. The low $\mathrm{Nb} / \mathrm{Ta}$ ratios are most likely a function of fractionation of hydrous mineral phases from this melt as LA-ICP-MS trace element analysis of biotite and amphibole crystals from unit 28 indicated they have significantly super-chondritic $\mathrm{Nb} / \mathrm{Ta}$ ratios of 20 and 30 (Allan, unpublished data). 
4.3 Isotopic constraints on the origins of silicic melts from the Taupo Volcanic Zone

The radiogenic isotope data presented here is for rapidly quenched melt preserved as tephra glass shards in the Site 1123 tephra record and represents a compositional end-member of TVZ silicic volcanic rocks that cannot be readily extracted by analysis of bulk rock samples of onland silicic volcanic samples. Before discussing the implications of these isotope data, it is important to first consider why our $\mathrm{Pb}$ isotope data obtained on glass separates by highly accurate and precise MC-ICPMS techniques is different to comparable $\mathrm{Pb}$ isotopic data for silicic TVZ rocks acquired by whole rock methods.

Two explanations can potentially explain the discrepancy between the $\mathrm{Pb}$ isotope data presented in this study with previous $\mathrm{Pb}$ isotopic studies of TVZ silicic volcanics (with the exception of the study of McCulloch et al., 1994). Firstly, bulk rock samples incorporate the melt component as well as crystals and exotic lithic material. It is likely that crystal-melt isotopic disequilibrium exists (Davidson et al., 2007) in what are essentially hybrid magmas. Silicic magmas are generated by the variable interaction of mafic magmas and continental crust and incorporation of variable amounts of different crystal populations (antecrysts and xenocyrsts) generated at various times during these processes. Thus, it is not improbable that bulk rock $\mathrm{Pb}$ isotope analyses may yield different results to analyses of a silicic glass end-member. However, the data of McCulloch et al. (2004) suggests that this is unlikely to be the explanation for the discrepancy of the $\mathrm{Pb}$ isotope presented here with most previously published isotopic studies of TVZ silicic volcanic rocks. McCulloch et al. (2004) presented high precision $\mathrm{Pb}$ isotope data on high purity feldspar separates from Maroa centre rhyolites which had a considerable range in ${ }^{87} \mathrm{Sr} /{ }^{86} \mathrm{Sr}(0.7052-0.7062)$. These feldspar separates have a very restricted range in $\mathrm{Pb}$ isotopic composition that overlap with the data presented here. As such we consider it unlikely that incorporation of crystal antecrysts in isotopic disequilibrium with host melt is the explanation for the less radiogenic $\mathrm{Pb}$ generally documented by previous $\mathrm{Pb}$ isotopic studies of bulk samples of TVZ silicic volcanic rocks.

We speculate that many of the previously published $\mathrm{Pb}$ isotopic studies (e.g., Graham et al., 1992) have inadequately removed anthropogenic $\mathrm{Pb}$ with $l o w{ }^{206} \mathrm{~Pb} /{ }^{204} \mathrm{~Pb}$ and 
high $\Delta 7 / 4$ and $\Delta 8 / 4$ and that these data need to be viewed with considerable caution when developing models for the origins of TVZ silicic magmas. This anthropogenic $\mathrm{Pb}$ may have been introduced to the sample either in the field prior to sampling through environmental $\mathrm{Pb}$ contamination or during subsequent powdering of samples in the laboratory. We note that removal of any surficial anthropogenic $\mathrm{Pb}$ may be more difficult when the contaminated material is pumice with a large surface area. Conversely, the mineral separates analysed by McCulloch et al. (1994) would be easier to remove any anthropogenic $\mathrm{Pb}$ contamination from by acid washing.

Neither the assimilation-fractional crystallisation model of Graham et al. (1992) nor the bulk mixing model of McCulloch et al. (1994) can generate compositions with low values of ${ }^{206} \mathrm{~Pb} /{ }^{204} \mathrm{~Pb}$ relative to ${ }^{87} \mathrm{Sr} /{ }^{86} \mathrm{Sr}$ and $\varepsilon_{\mathrm{Nd}}$ that are observed for units 1,2 , 3, 22, 23, 33 and 37 of the Site 1123 tephra record. In particular, plots of $\mathrm{Pb}$ isotope ratios versus ${ }^{87} \mathrm{Sr} /{ }^{86} \mathrm{Sr}$ or $\varepsilon_{\mathrm{Nd}}$ yield a mixing hyperbola that at low ${ }^{206} \mathrm{~Pb} /{ }^{204} \mathrm{~Pb}$ has an asymptote that projects to much higher ${ }^{87} \mathrm{Sr} /{ }^{86} \mathrm{Sr}$ and lower $\varepsilon_{\mathrm{Nd}}$ than the isotopic composition of primitive TVZ basalts (Fig. 3-11).

To explain the isotopic compositions of the Site 1123 tephras, we invoke a two-stage crustal contamination process whereby primitive TVZ basalts are variably contaminated first by Waipapa crust, followed by significant assimilation of Torlesse crust (Fig. 3-11). This model explains some of the features that cannot be generated using the models of Graham et al. (1992) or McCulloch et al. (1994). For example, in ${ }^{87} \mathrm{Sr} /{ }^{86} \mathrm{Sr}$ versus ${ }^{206} \mathrm{~Pb} /{ }^{204} \mathrm{~Pb}$ and $\varepsilon_{\mathrm{Nd}}$ versus ${ }^{206} \mathrm{~Pb} /{ }^{204} \mathrm{~Pb}$ isotopic space (Figs. $3-11 \mathrm{c}$ and e) many of the Site 1123 tephra melt compositions vector away from theoretical bulk mixing or AFC trajectories (not shown) between primitive TVZ basalts and Torlesse crust and trend instead towards a composition intermediate between primitive TVZ basalt and Waipapa crust. Many of these compositions cannot be reached unless both Waipapa and Torlesse crust are incorporated in the melt of individual eruptive units. Using this two-stage bulk mixing model, the majority of the Site 1123 tephra melt compositions can be explained by ascending hot primitive TVZ basalts assimilating $0-15 \%$ Waipapa crust followed by assimilation of $\sim 45$ to $20 \%$ Torlesse crust. Ten of the thirteen Site 1123 tephra units require a significant, but remarkably uniform, total amount $(\sim 35 \%)$ of assimilated crustal rocks. Almost all of the isotopic differences between these ten units are then explained solely by the different amounts of each crustal lithology incorporated into the magmas (i.e. 15\% Waipapa $+25 \%$ Torlesse or 

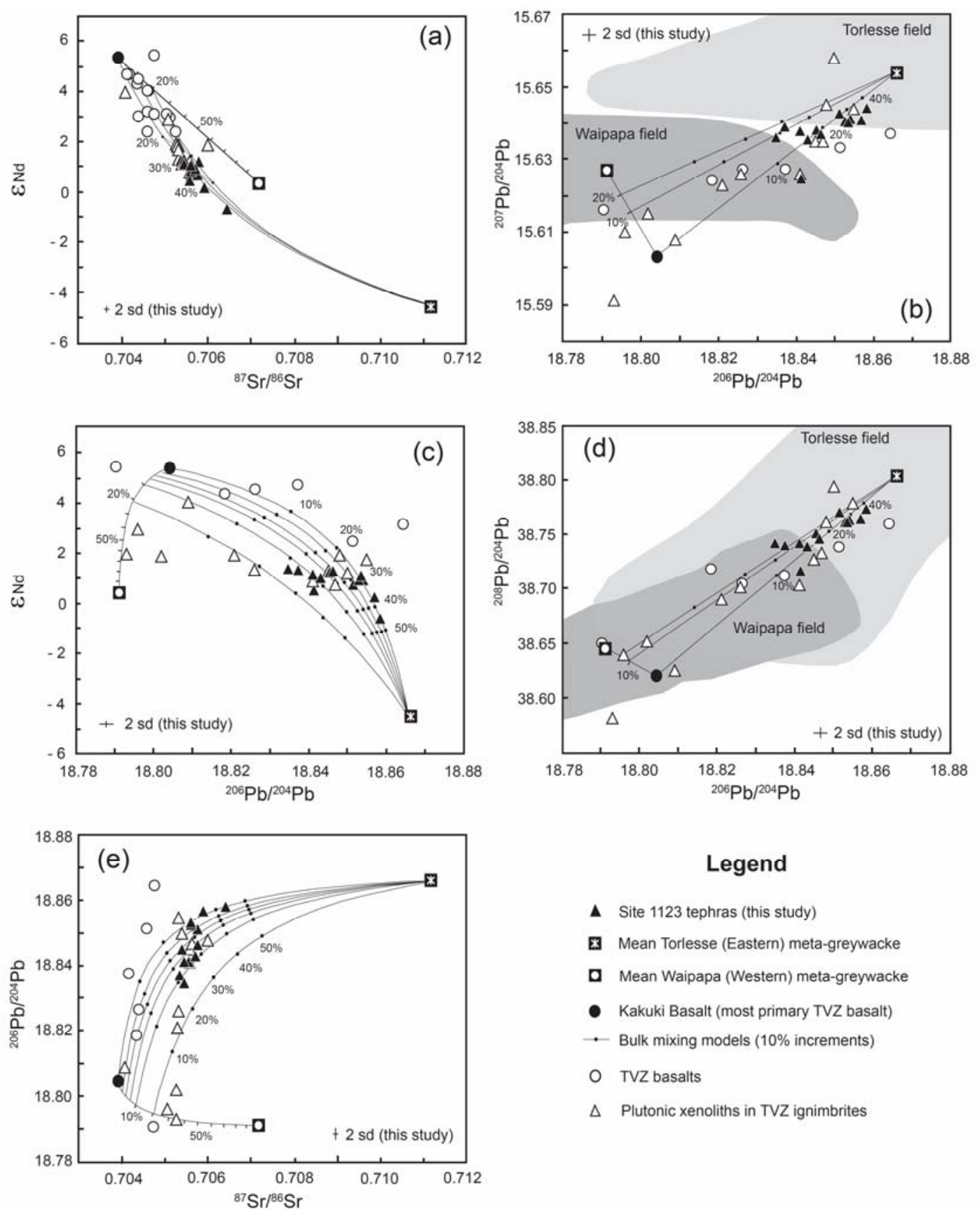

\section{Legend}
A Site 1123 tephras (this study)
\. Mean Torlesse (Eastern) meta-greywacke
d Mean Waipapa (Western) meta-greywacke
- Kakuki Basalt (most primary TVZ basalt)
- Bulk mixing models ( $10 \%$ increments)
O TVZ basalts
$\Delta$ Plutonic xenoliths in TVZ ignimbrites

Figure 3-11. Bulk mixing models demonstrating a two-stage crustal contamination process to explain the observed isotopic composition of Site 1123 tephras. Contamination of primitive TVZ basalt occurs first by assimilation of Waipapa meta-greywacke crust (0 to $15 \%$ ), followed by assimilation of the more radiogenic Torlesse metagreywacke crust (20 to $45 \%$ ). Most of the melt compositions (10/13) require a significant, but uniform, amount of crust $(\sim 35 \%)$ and almost all of the isotopic variability between these units is due to the differing amounts of each crustal lithology incorporated into these magmas. Isotopic data is also shown for TVZ basalts (from Gamble et al., 1994 \& 1996) and rare plutonic xenoliths found in some TVZ ignimbrites (from Brown et al., 1998). Grey shaded fields mark the range of $\mathrm{Pb}$ isotopic compositions reported for the greywacke crustal lithologies. The large variation in $\mathrm{Pb}$ isotope data for the greywackes introduces additional uncertainty into this model. Model parameters: Kakuki basalt (most primary TVZ basalt) $-{ }^{87} \mathrm{Sr} /{ }^{86} \mathrm{Sr}=0.703931, \varepsilon_{\mathrm{Nd}}=5.36,{ }^{206} \mathrm{~Pb} /{ }^{204} \mathrm{~Pb}=18.804 ;{ }^{207} \mathrm{~Pb} /{ }^{204} \mathrm{~Pb}=15.603$; ${ }^{208} \mathrm{~Pb} / 204 \mathrm{~Pb} 38.621, \mathrm{Sr}=350 \mathrm{ppm}, \mathrm{Nd}=12.6 \mathrm{ppm}, \mathrm{Pb}=2.0 \mathrm{ppm}$; Waipapa crust (mean) $-{ }^{87} \mathrm{Sr} /{ }^{86} \mathrm{Sr}=0.70718, \varepsilon_{\mathrm{Nd}}=$ $0.41,{ }^{206} \mathrm{~Pb} /{ }^{204} \mathrm{~Pb}=18.791 ;{ }^{207} \mathrm{~Pb} /{ }^{204} \mathrm{~Pb}=15.627 ;{ }^{208} \mathrm{~Pb} /{ }^{204} \mathrm{~Pb} 38.646, \mathrm{Sr}=470 \mathrm{ppm}, \mathrm{Nd}=17.6 \mathrm{ppm}, \mathrm{Pb}=19.5 \mathrm{ppm}$; Torlesse crust (mean) $-{ }^{87} \mathrm{Sr} /{ }^{86} \mathrm{Sr}=0.71120, \varepsilon_{\mathrm{Nd}}=-4.51,{ }^{206} \mathrm{~Pb} /{ }^{204} \mathrm{~Pb}=18.866 ;{ }^{207} \mathrm{~Pb} /{ }^{204} \mathrm{~Pb}=15.654 ;{ }^{208} \mathrm{~Pb} /{ }^{204} \mathrm{~Pb}$ $38.804, \mathrm{Sr}=240 \mathrm{ppm}, \mathrm{Nd}=24.0 \mathrm{ppm}, \mathrm{Pb}=18.4 \mathrm{ppm}$. Data sources for these model parameters include: Reid (1982 \& 1983), Graham et al. (1992); Gamble et al. (1994 \& 1996) McCulloch et al. (1994), Charlier et al. (2008). 
5\% Waipapa $+30 \%$ Torlesse). In contrast, units 12 (0.983 Ma) and $28(1.603 \mathrm{Ma})$ apparently incorporated principally Torlesse crust in their genesis but in greater amounts ( $\sim 38 \%$ and $45 \%$, respectively) than the other units. Unit 1 which has been identified as representing the $\sim 27.1 \mathrm{ka}$ Oruanui eruption from Taupo caldera, is consistently offset from the $\mathrm{Pb}$ isotope trends revealed by the other units, and its melt composition cannot be readily explained using this model described above.

The bulk mixing models shown in Figure 3-11 demonstrate that the crustal isotopic signature imparted on the basalt by this initial contamination $(\leq 15 \%)$ from Waipapa crust is subtle and is not readily identified on conventional ${ }^{87} \mathrm{Sr} /{ }^{86} \mathrm{Sr}$ versus $\varepsilon_{\mathrm{Nd}}$ or $\mathrm{Pb}$ $\mathrm{Pb}$ isotope plots.

The various basalt-Waipapa-Torlesse mixtures that are used to explain the $\mathrm{Sr}-\mathrm{Nd}-\mathrm{Pb}$ isotopic compositions of the Site 1123 tephras would result in melt $\delta^{18} \mathrm{O}_{\text {melt }}$ values ranging from $8.0 \pm 0.6 \%$ (calculated using the following end-member compositions from McCulloch et al., 1994 and Blattner et al., 1996: Kakuki Basalt, 5.7 \%o; mean Torlesse, $12.5 \%$; mean Waipapa, $9.4 \%$ o). These values are generally consistent with $\delta^{18} \mathrm{O}_{\text {magma }}$ compositions estimated for TVZ rhyolites and ignimbrites $\left(\delta^{18} \mathrm{O}=7.6 \pm\right.$ $1.0 \%$; Blattner et al., 1996).

One important point about the modelling presented in Fig. 3-11 is that the incorporation of the crustal components is modelled using bulk mixing models, and as such, represents a simplification of the full range of petrogenetic possibilities that operated during silicic melt generation. For example, in the simplified bulk mixing scenario discussed above the initial primitive TVZ basalt, despite having acquired the isotopic characteristics of the rhyolites, would only have experienced a modest increase in $\mathrm{SiO}_{2}$ from an initial value of $\sim 48 \mathrm{wt} . \%$ to between 53 to $58 \mathrm{wt} . \%$. Therefore, a substantial amount of fractional crystallisation is required to take part during or after crustal contamination to generate melts of rhyolitic composition as is indicated by the major and trace element variations discussed earlier. Modelling the elemental effects of this fractional crystallisation stage is made complicated due to the large changes in elemental partition coefficients likely to occur as the melt evolves from a basaltic-andesite to rhyolite composition. However, Fig. 3-12 


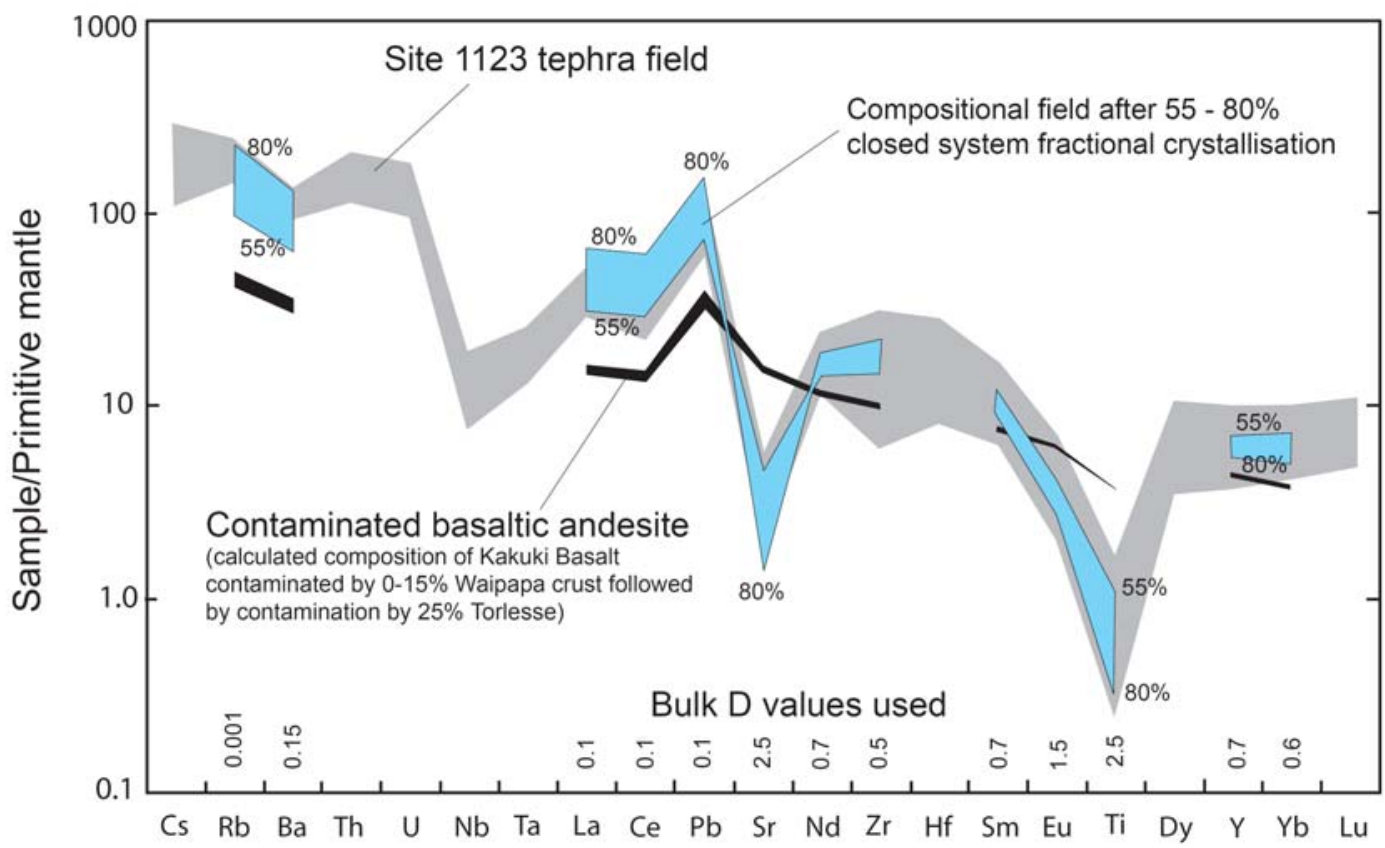

Figure 3-12. Primitive mantle normalised trace element diagram demonstrating how the main trace element characteristics of the Site 1123 tephras can be attained after 55-85\% fractional crystallisation of mafic magmas that have been variably contaminated by Waipapa and Torlesse meta-greywacke crustal rocks. Trace element compositional field for the 'contaminated basaltic andesite' was calculated by the same two-stage bulk mixing model used to explain the isotopic compositions of the Site 1123 tephras. Trace element data for end-member compositions are from Gamble et al. (1994) (Kakuki Basalt) and Reid (1982) (Waipapa and Torlesse metagreywackes).

illustrates that the trace element characteristics of the Site 1123 tephras can be broadly modelled by $55-85 \%$ fractional crystallisation.

Rare plutonic xenoliths entrained in some TVZ ignimbrites have been interpreted to represent the crystallised portion of zoned silicic magma chambers (Brown et al., 1998b). The isotopic compositions of many of these plutonic xenoliths are very similar to that of the Site 1123 tephra melt compositions (open triangles on Fig. 311). As such the formation of many of these xenoliths can be explained by a similar model in which ascending mafic magmas assimilate and mix with Waipapa and Torlesse crust before stagnating and evolving to higher $\mathrm{SiO}_{2}$ compositions by prolonged fractional crystallisation. As is evident from the plots in Fig 3-11c and e, some of these xenoliths indicate a much greater contribution from Waipapa (as opposed to Torlesse) crust.

The geodynamic consequence of our model to explain the isotopic characteristics of the Site 1123 tephras is illustrated in Fig. 3-13. Most of the TVZ-sourced Site 1123 tephras contain evidence for contributions from both Waipapa and Torlesse metagreywacke terranes that crop out to the west and east of the TVZ, respectively. This 
feature implies that a low angle contact between the Waipapa and Torlesse metagreywacke terranes extends beneath the TVZ. Fig. 3-13 illustrates (in a highly schematic fashion) how silicic melts with low ${ }^{206} \mathrm{~Pb} /{ }^{204} \mathrm{~Pb}$ at a given ${ }^{87} \mathrm{Sr} /{ }^{86} \mathrm{Sr}$, perhaps sourced from western parts of the TVZ, contain the greatest amount of Waipapa crust. We note, however, that the crustal basement beneath the TVZ may be a more complex melange of blocks of Waipapa and Torlesse terranes, although the $\mathrm{Sr}-\mathrm{Pb}$ and $\mathrm{Nd}-\mathrm{Pb}$ isotopic mixing trends (Fig. 3-11) imply that in general the Waipapa rocks underlie the Torlesse rocks beneath the TVZ.
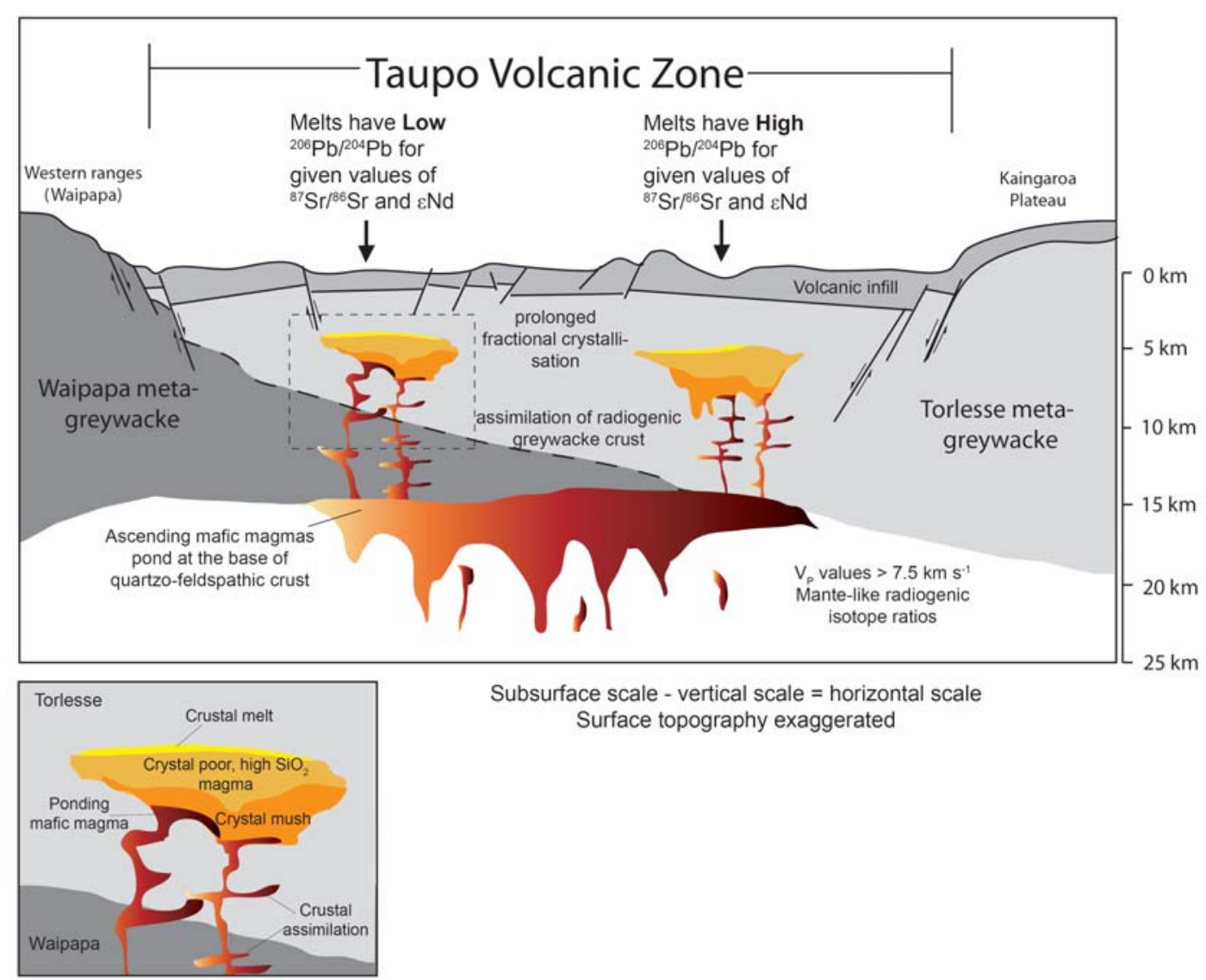

Subsurface scale - vertical scale $=$ horizontal scale Surface topography exaggerated

Figure 3-13. A schematic cross-section of the crustal structure beneath the TVZ demonstrating how the subtle differences in the radiogenic isotope compositions of the Site 1123 tephras could have been generated. Mafic magmas ascend from the mantle and pond at the base of a quartz-feldspathic crust at a depth of $\sim 15 \mathrm{~km}$. This boundary is seismically observed by a significant change in $V p$ velocities $\left(V p>7.5 \mathrm{~km} \mathrm{~s}^{-1}\right.$ below $15 \mathrm{~km}$ depth; $V p=$ $6.0-6.5 \mathrm{~km} \mathrm{~s}^{-1}$ above $15 \mathrm{~km}$ depth [Stratford and Stern, 2004]). Mafic magmas assimilate significant volumes of greywacke crust en route to magma chambers. Isotopic data reported here shows that most melt compositions from individual eruptions are generated by assimilation of both Waipapa and Torlesse meta-greywacke crust. By implication, a sub-parallel contact between the two crustal lithologies must occur at depth beneath the TVZ. Crustally contaminated mafic magmas are periodically injected into large crystal rich magma reservoirs (crustal mushes) where fractional crystallisation is the dominant mechanism of magma differentiation. Mafic recharge provides heat to rejuvenate the system by promoting mixing, remelting and mobilisation of the crystal pile. Evolved interstitial melts are extracted (by compaction) from the crystal mush zone to mix with melts in upper melt-rich (crystal-poor) regions of the magma chamber. Further crustal melting/assimilation may occur along the roof and/or walls of the chamber. 


\subsection{Petrogenesis of the TVZ silicic large igneous province in a global context}

Silicic magmas of the TVZ appear to represent the product of incorporation of ca. $35 \%$ (and up to $\sim 45 \%$ ) continental crust from different crustal levels into primitive arc basalts that subsequently undergo significant fractional crystallisation. This model for formation of silicic magmas can be compared with two other well studied silicic large igneous provinces; large-volume rhyolitic pyroclastic units emplaced in Yemen and Ethiopia (Baker et al., 1996, 2000; Ukstins Peate et al., 2003, 2008) during the Oligocene in association with the arrival of the Afar plume at the base of Afro-Arabian lithosphere and rifting of Arabia away from Africa, and the large rhyolitic pyroclastic volcanism from the Long Valley caldera system, western USA (Hildreth, 2004; Hildreth and Wilson, 2007).

Oligocene rhyolitic pyroclastic units emplaced in Yemen and Ethiopia have much smaller crustal contributions than those in the TVZ. Oxygen and radiogenic isotope data constrain the crustal contribution to Yemen-Ethiopian large-volume silicic magmas to be generally $\leq 10 \%$ and these magmas are interpreted to be the product of extensive fractional crystallisation (90\%) from large volumes of basaltic magmas produced by decompression melting of the Afar plume (Baker et al., 1996; Ukstins Peate et al., 2003, 2008).

The $\mathrm{Nd}$ isotopic compositions of early erupted rhyolites (between 2.1 and $1.2 \mathrm{Ma}$ ) at Glass Mountain, Long Valley indicate an origin for these rhyolites by extensive fractional crystallisation of basaltic magmas from an enriched lithospheric mantle source with very little contribution from radiogenic crustal rocks (Knesel and Davidson, 1997). However, the chemical and isotopic compositions of younger Quaternary mafic magmas from Long Valley, which are generally accepted to be parental source for the large volume silicic magmas (e.g. Bishop Tuff), suggest a maximum crustal component of $30 \%$ (Cousens, 1996). This is consistent with the findings of Knesel and Davidson (1997) who suggested the later erupted rhyolites from Long Valley (1.2 to 0.76 Ma), including the Bishop Tuff, incorporated more continental crust during their generation. The initial $\mathrm{Sr}, \mathrm{Nd}$ and $\mathrm{O}$ isotope compositions of pumices indicate that this crustal contamination took place relatively early in the evolution of the Bishop Tuff magma system and that it did not receive significant influxes of melt sourced from radiogenic country rock, presumably due to thermal and mechanical buffering from the extensive crystalline mush zone in the 
lower chamber (Halliday et al., 1984; Bindeman and Valley, 2001; Hildreth and Wilson, 2007).

It is unclear why large volumes of silicic magmas could be produced in a continental flood volcanic setting like that of Yemen with such limited crustal input as compared to the TVZ. Some authors have considered that silicic magmas with the largest crustal contributions occur in regions with a low basaltic flux and thick crust, and, particularly where hot, dry basalts interact with fertile (e.g. pelitic) crustal compositions (Bachmann et al., 2007). However, many of these features are inconsistent with the Yemen-Ethiopia and TVZ settings. For example, extension and thinning of continental crust in Yemen-Ethiopia largely post-dated continental flood volcanism (i.e. thick crust accompanied by a large basaltic flux, yet little crustal contribution; Baker et al., 1996) and crustal thinning in the central North Island of New Zealand has been concomitant with silicic volcanism in the TVZ for at least the last $\sim 0.9 \mathrm{Ma}$ (Wilson et al., 1995a). In addition, TVZ basalts, like most subduction zone basalts, are cool and wet compared to Mid Ocean Ridge and Ocean Island basalts (Sisson and Grove, 1993; Gamble et al., 1995; Roggensack et al., 1997), rather than the hot, dry basalts that Bachmann et al. (2007) suggest are necessary for melting large amounts of crust.

The cause of the large crustal contributions to silicic TVZ magmas is likely a reflection of the high thermal flux, seven times that of a typically arc setting (Hochstein, 1995), associated with rifting and thinning of the crust. Seismic velocity surveys of the crust and mantle beneath the TVZ suggest the crust beneath the TVZ has been thinned to $\sim 15 \mathrm{~km}, \sim 60 \%$ of its original thickness (Wilson et al., 1995a). Although some debate persists as to the nature of a prominent seismic boundary at $15 \mathrm{~km}$ depth beneath the TVZ (e.g. Stratford and Stern, 2004; Harrison and White, 2006), Stratford and Stern (2004) interpret this boundary as being the crust-mantle interface. We suggest therefore that crustal rifting and thinning has created an enhanced heat flow in the TVZ that facilitates much greater amounts of crustal melting during silicic magma generation. 


\subsection{CONCLUSIONS}

Silicic tephras erupted from New Zealand's TVZ and recovered from ODP Site 1123 provide a continuous record of explosive silicic volcanism that complements and extends the fragmentary onshore record of silicic TVZ magmatism. Single glass shard major and trace element data and $\mathrm{Sr}-\mathrm{Nd}$ and high precision $\mathrm{Pb}$ isotope data for glass separates of 13 representative tephra units has shown that:

(1) Significant small-scale trace element heterogeneity between glass shards from individual tephra units is identified in all Site 1123 tephras. In some tephra units this trace element variability defines curvilinear or linear trends on bivariate plots that are consistent with documenting fractional crystallisation and magma mixing in silicic magma chambers and tapping of chemically zoned magma chambers. However, many tephra units exhibit trace element heterogeneity in the form of diffuse clouds of data from which no discernable trends can be recognised that may reflect a combination of both fractional crystallisation and magma mixing and/or variable diffusion rates of different elements in silicic magmas.

(2) Four broad silicic melt types that are identified on the basis of both age and major and trace element chemistry are not clearly identified by isotopic data. This observation, coupled with evidence from trace element fractionation indices, indicates that these broad melt types largely reflect differences in the amount and nature of fractional crystallisation processes.

(3) Sr-Nd-Pb isotopic compositions of the Site 1123 tephras require a two-stage contamination process whereby primitive TVZ basalts are contaminated first by Waipapa meta-greywacke crust at depth (0-15\%), followed by assimilation of Torlesse meta-greywacke crust (45-20\%), accompanied by extensive fractional crystallisation. The implication of this model is that a low angle contact between these two crustal terranes occurs at depth below the TVZ. The isotopically less extreme composition of Waipapa (compared to Torlesse) crust allows for the cryptic assimilation of significant volumes of Waipapa crust (up to 15\%) without imparting as strong a crustal isotopic signature $(\mathrm{Sr}, \mathrm{Nd}, \mathrm{Pb}, \mathrm{O})$ on the initial basaltic magma as assimilation of Torlesse meta-greywacke achieves. In this model most of the tephra units for which radiogenic isotope compositions were determined (10/13) require a significant, but uniform, amount of crust $(\sim 35 \%)$ and almost all of the isotopic 
variability observed between the units is due to the differing amounts of each crustal lithology incorporated into the magmas. Two units require $~ 38 \%$ and $45 \%$ contribution from Torlesse crust but very little contribution from Waipapa crust. Unit 1 which has been identified as the Kawakawa Tephra associated with the $\sim 27.1 \mathrm{ka}$ Oruanui eruption has an isotopic composition that cannot readily be explained by this model. The isotopic composition of the Site 1123 tephras are similar to that of (rare) plutonic xenoliths found in TVZ some ignimbrites. These plutonic xenoliths may represent the lower parts of crystal-rich (mush) regions of the magma chamber from which evolved interstitial silicic melts are expelled by compaction into the melt-rich upper magma chamber from where they are subsequently explosively erupted. 


\section{CHAPTER FOUR: SYNTHESIS AND CONCLUSIONS}

\subsection{Synthesis and conclusions}

This thesis has presented a chemical and isotopic investigation of a suite of silicic TVZ tephra layers preserved in deep ocean sediment cores recovered from ODP Site 1123 located $\sim 1000 \mathrm{~km}$ east of New Zealand. The onshore record of TVZ volcanism is fragmented by the preferential erosion of non-consolidated volcanic deposits and the deep burial of older units by younger volcanism. The relative quiescence of the deep ocean sedimentary setting, the continuous supply of pelagic and terrigenous sediment, and the favourable location downwind of the main TVZ ash dispersal path to Site 1123 are all factors that have contributed to the preservation of a remarkably continuous TVZ tephra record at Site 1123. The tephras at Site 1123 span almost the entire $\sim 1.65 \mathrm{Ma}$ Quaternary history of rhyolitic volcanism in the TVZ, and the majority are precisely dated by the Site 1123 orbitally tuned oxygen isotope age model meaning the age control for these tephras is generally greater than is currently possible by radiometric dating methods. The orbitally tuned age control on these tephra layers also provides the unique opportunity for the timing of large silicic eruptions from the TVZ to be placed within the context of high resolution paleoclimate and paleo-oceanographic records.

With these defining features of the Site 1123 tephra record in mind, this thesis set out with two main research objectives: (1) to refine and establish the Site 1123 tephra record as a type section for Quaternary tephrochronologic studies in the New Zealand region, and (2) to investigate the petrogenesis of silicic magmas in the TVZ throughout the $\sim 1.65 \mathrm{Ma}$ of rhyolitic volcanism. Some of the salient points that have emerged from this research are summarised below.

\section{Trace element fingerprinting of glass shards can be used to distinguish} between tephras with essentially identical major element chemistries. The 


\section{Trace element fingerprinting and correlation of Site 1123 tephras has}

enabled an independent re-evaulation of the Site 1123 composite stratigraphy and (< 1.7 Ma) age model. The precise correlation of tephra layers between the three Site 1123 sediment cores (1123A, B and C) enabled a critical re-evaluation of the 'splice' used to create the original Site 1123 composite stratigraphy and age model. The trace element fingerprints of several Site 1123 tephras were integral in identifying sections of repeated sediment in the $1123 \mathrm{~A}$ and $1123 \mathrm{C}$ cores. These previously unidentified repeated sections had introduced a significant error into the stable isotope stratigraphy and are the cause of poor correspondence between the $\delta^{18} \mathrm{O}$ profiles for Site 1123 and Site 849 (equatorial Pacific) during the 1.1 to 1.4 Ma interval.

3. The ODP Site 1123 tephra record provides new insights into the oldest period ( 1.50 - 1.65 Ma) of silicic TVZ volcanism. An intense period of silicic volcanic activity was identified between $\sim 1.50$ to $1.65 \mathrm{Ma}$. During this time at least 17 tephra units are recorded at Site 1123, corresponding to an eruptive frequency of 1 event every $7 \mathrm{ka}$. It is notable that approximately $50 \%$ of the tephra volume (cumulative tephra thickness) at Site 1123 was generated during this brief period of intense activity when rhyolitic volcanism in the TVZ had only just initiated. The onland TVZ record, which over time has been obscured by erosion and burial from younger eruptions, does not preserve clear evidence for this period of hyperactivity.

4. The isopach technique for estimating eruption volumes based on tephra thickness is unreliable when applied to deep ocean tephras. Tephra layers that are reliably correlated between all three sediment cores (1123A, B and C) show considerable variations in thickness. This observation is consistent with the findings of Manville and Wilson (2004) who demonstrated that the vigorous nature of tephra deposition in deep marine settings does not permit 


\section{All Site 1123 tephras exhibit significant small-scale trace element}

heterogeneity that reflects compositional gradients in the melt immediately prior to eruption. Trace element data for some units reveal compositional variations consistent with fractional crystallisation (e.g., a negative correlation between $\mathrm{Rb} / \mathrm{Sr}$ and $\left.\mathrm{Eu} / \mathrm{Eu}^{*}\right)$. However, analytically significant variations between compatible - incompatible trace element pairs (e.g., Sr versus Rb) for most Site 1123 tephras are not manifest in the form of coherent linear or curvilinear trends that would be consistent with either fractional crystallisation or two component mixing. Factors effecting the preservation of chemical gradients in the melt bodies of silicic TVZ magma chambers are likely to include: (a) the (in)efficiency with which low temperature, high viscosity melts can be physically mixed; (b) the proportion of crystals to melt in a magma with mixing of different melt batches likely to be more efficient in crystal-poor magmas than in crystal-rich magmas; (c) the mechanisms of crystal-melt separation and the timing of this with respect to eruption; and (d) the diffusivities of different trace element species in silicic melts which can vary by several orders of magnitude with diffusion being slowest for elements with large ionic radii and charge (e.g., Zr) (Koepe and Behrens, 2001).

\section{A two-stage crustal contamination model is invoked to explain the} isotopic characteristics of most Site 1123 tephras. In this model hot mafic magmas ascending from the mantle beneath the TVZ assimilate up to $\sim 15 \%$ Waipapa meta-greywacke crust, followed by the incorporation of $\sim 20 \%$ to $45 \%$ Torlesse meta-greywacke crust. Implicit in this model is that a sub- 
7. Most of the Site 1123 tephra melt compositions require a remarkably uniform amount of crustal contamination. Ten out of the thirteen tephras characterised for $\mathrm{Sr}, \mathrm{Nd}$ and $\mathrm{Pb}$ isotopic compositions required a total of $\sim$ $35 \%$ crust in their genesis. The small isotopic differences between these particular tephras were due simply to the varying amounts of each crustal lithology incorporated into the magmas. The isotopic compositions of two Site 1123 tephra units indicate a greater amount of (only Torlesse) crust (38\% and $45 \%$ ) was consumed during their genesis.

8. The broad picture of silicic magma generation in the TVZ is generally consistent with currently popular 'crystal mush' models. The prolonged fractional crystallisation invoked in this petrogenetic model is envisaged to occur largely within the lower crystal-rich portions (crystal mush zones) of the parental magma chambers. During magma evolution liquid is extracted (through compaction) from the crystal mush zone and injected and subsequently mixed into an upper melt-rich zone. Here, it is envisaged that chemical heterogeneity in the melt is generated partially as a result of fractional crystallisation, but predominantly by the episodic injection of discrete batches of evolved rhyolitic melt originating from the lower mush zone. It is suggested that convection within the melt-rich upper portions of the magma chambers may act to efficiently overprint or re-homogenise chemical gradients within the melt.

9. Alternatively active rifting within the TVZ may provide a mechanism to generate large volumes of melt-rich (high $\mathrm{SiO}_{2}$ ) magma, with broadly consistent isotopic and chemical characteristics extremely rapidly. Rare 


\subsection{Suggestions for further study}

The data acquired and ideas proposed in this thesis lend themselves to further study and/or analytical data so that they can be properly tested. Some specific recommendations for further study are summarised below:

1. Trace element fingerprinting of Quaternary tephras preserved at ODP Site 1124. Due to its closer proximity to the TVZ ( $\sim 600 \mathrm{~km}$ east $)$ and its more favourable location along the main TVZ ash dispersal path, Site 1124 has received a greater influx of Quaternary tephras from TVZ eruptions compared to Site 1123 (Carter et al., 2003). Trace element fingerprinting of the Quaternary $(<1.7 \mathrm{Ma})$ TVZ tephra record from Site 1124 would be useful to assess a number of the ideas put forward in this thesis (e.g., the timing of eruptions with respect to glacial-interglacial periods, the preservation potential of deep marine tephra layers, and periods of intensified eruptive activity).

2. As is discussed in Appendix Two (Analytical Techniques), there is significant potential for ambiguity when comparing LA-ICP-MS trace element data acquired from different laboratories, particularly when different 
3. The development of methods for analysing single glass shards by solution ICP-MS. All Site 1123 tephras have variability in the trace element composition of single glass shards that is significantly greater than the analytical uncertainties of the LA-ICP-MS method. The validity and petrogenetic significance of this apparent trace element heterogeneity could be more rigorously assessed with superior analytical precision if a single glass shard solution ICP-MS method can be developed. For example, the greater signal stability during solution ICP-MS analyses, and the sensitivity of modern ICP-MS instruments should enable trace element ratios such as $\mathrm{Rb} / \mathrm{Sr}$ and $\mathrm{Zr} / \mathrm{Y}$ be measured with precisions of $< \pm 1-2 \%$ ( 2 sd relative).

4. The petrogenetic model for magma generation in the TVZ proposed in this thesis requires additional $\mathrm{Sr}, \mathrm{Nd}$ and $\mathrm{Pb}$ isotopic data for Site 1123 tephras to be fully tested. In addition, oxygen isotope data for the Site 1123 tephras would be particularly useful to scrutinise the degree of crustal contamination implied by this research provided the glass shards have not been too hydrated.

5. One of the major limitations in unravelling the petrogenesis of silicic TVZ magmas is the relatively poor constraints we have on the nature and composition of the meta-greywacke crustal lithologies that are assumed to make major contributions to TVZ magmas. Future studies of TVZ magma petrogenesis would benefit significantly from a new set of chemical and isotopic data for the central North Island greywackes measured by modern analytical techniques and methodologies.

6. Hafnium isotope studies of TVZ volcanic rocks and meta-greywacke basement rocks. The accuracy and precision of petrogenetic models for TVZ magmas are hindered by the small $\mathrm{Sr}, \mathrm{Nd}$ and $\mathrm{Pb}$ isotopic differences between 
7. In Chapter Three it was highlighted that $\mathrm{Pb}$ isotope data reported here for the pure glass material of Site 1123 tephras were almost exclusively offset to more radiogenic values than that of previously reported $\mathrm{Pb}$ isotope data acquired from whole-rock isotopic methods. It remains to be tested whether this offset is an analytical artefact (i.e. a result of incomplete and/or differential leaching of sample $\mathrm{Pb}$ contamination) or a real feature that reflects a difference between whole rock and glass isotopic analyses (i.e. the crystal cargo of TVZ magmas may have a $\mathrm{Pb}$ isotope signature of an earlier, less contaminated melt in which the crystals grew). These hypotheses could be tested in two ways. Firstly, some of the samples for which $\mathrm{Pb}$ isotope compositions have been previously reported (e.g. Rototiti pyroclastic rocks, Schmitz and Smith, 2005; Whakamaru Ignimbrite, Brown et al., 1998) could be re-analyse in the Victoria University Geochemistry Laboratory using the same sample preparation and modern mass spectrometry methods employed in this thesis. Secondly, a single pumice clast from any well characterised volcanic deposit could be broken in two and one piece analysed as a powdered whole rock sample and the other as a pure glass separate. If the whole rock - glass pairs returned significantly different $\mathrm{Pb}$ isotope compositions then this would be considered evidence for significant crystal melt heterogeneity. 


\section{REFERENCES}

Allan, A.S.R., Baker, J.A., Carter, L., Wysoczanski, R.J., 2008. Reconstructing the Quaternary evolution of the world's most active silicic volcanic system: insights from an $\sim 1.65$ Ma deep ocean tephra record sourced from Taupo Volcanic Zone, New Zealand. Quaternary Science Reviews. doi: 10.1016/j.quascirev.2008.09.003

Alloway, B.V., Pillans, B.J., Sandhu, A.S., Westgate, J.A., 1993. Revision of marine chronology in Wanganui Basin, New Zealand, based on isothermal plateau fission-track dating of tephra horizons. Sedimentary Geology 82, 299-310.

Alloway, B., Westgate, J., Pillans, B., Pearce, N., Newnham, R., Byrami, M., Aarburg, S., 2004. Stratigraphy, age and correlation of middle Pleistocene silicic tephras in the Auckland region, New Zealand - a prolific distal record of Taupo Volcanic Zone volcanism. New Zealand Journal of Geology and Geophysics 47, 447-479.

Alloway, B.V., Pillans, B.J., Carter, L., Naish, T.R., Westgate, J.A., 2005. Onshore-offshore correlation of Pleistocene rhyolitic eruptions from New Zealand: implications for TVZ eruptive history and paleoenvironmental construction. Quaternary Science Reviews 24, $1601-1622$.

Alloway, B.V., Larsen, G., Lowe, D.J., Shane, P.A.R., Westgate, J.A., 2006. Tephrochronology. In: Elias, S.A. (Editor-in-chief), Encyclopaedia of Quaternary Science. Elsevier, London, pp 2869-2898.

Almond, P.C., Shanhun, F.L., Rieser, U., Shulmeister, J., 2007. An OSL, radiocarbon and tephraisochron based chronology for Birdlings Flat loess at Ahuriri Quarry, Banks Peninsula, Canterbury, New Zealand. Quaternary Geochronology 2, 4-8.

Bachmann, O., Dungan, M.A., 2002. Temperature-induced Al-zoning in hornblendes of the Fish Canyon magma, Colorado. American Mineralogist 87, 1062-1076.

Bachmann, O., Miller, C.F., de Silva, S.L., 2007. The volcanic - plutonic connection as a stage for understanding crustal magmatism. Journal of Volcanology and Geothermal Research 167, 123.

Baker, J.A., Thirwall, M.F., Menzies, M.A., 1996. Sr-Nd-Pb isotopic and trace element evidence for crustal contamination of plume-derived flood basalts; Oligocene flood volcanism in Western Yemen. Geochimica et Cosmochimica Acta 60, 2559-2581. 
Baker, J.A., Macpherson, C.G., Menzies, M.A., Thirwall, M.F., Al-Kadasi, M., Mattey, D.P., 2000. Resolving crustal and mantle contributions to continental flood volcanism, Yemen; constraints from mineral oxygen isotope data. Journal of Petrology 41, 1805-1820.

Baker, J., Peate, D., Waight, T., Meyzen, C., 2004. Pb isotopic analysis of standards and samples using a ${ }^{207} \mathrm{~Pb}-{ }^{204} \mathrm{~Pb}$ double spike and thallium to correct for mass bias with a double-focusing MC-ICP-MS. Chemical Geology 211, 275-303.

Beresford, S.W., Cole, J.W., Weaver, S.D., 2000. Weak chemical and mineralogical zonation in the Kaingaroa Ignimbrite, Taupo Volcanic Zone, New Zealand. New Zealand Journal of Geology and Geophysics 43, 639-650.

Bindeman, I.N., Valley, J.W., 2001. Low $\delta^{18}$ O rhyolites from Yellowstone: magmatic evolution based on analysis of zircons and individual phenocrysts. Journal of Petrology 42, 1491-1517.

Bindeman, I.N., Fu, B., Kita, N.T., Valley, J.W., 2008. Origin and evolution of silicic magmatism at Yellowstone based on ion microprobe analysis of isotopically zoned zircons. Journal of Petrology 49, 163-193.

Black, T.M., 1992. Chronology of the Middle Pleistocene Kidnappers Group, New Zealand and correlation to global oxygen isotope stratigraphy. Earth and Planetary Science Letters 109, 573-584.

Black, T.M., Shane, P.A.R., Westgate, J.A., 1996. Chronological and paleomagnetic constraints on widespread ignimbrites of the Taupo Volcanic Zone, New Zealand. Bulletin of Volcanology $58,226-238$.

Blattner, P., Reid, F., 1982. The origins of lavas and ignimbrites of the Taupo Volcanic Zone, New Zealand, in the light of oxygen isotope data. Geochimica et Cosmochimica Acta 46, 1417 1429.

Blattner, P., Rui-Zhong, H., Graham, I.J., Houston-Eleftheriadis, C., 1996. Temperatures and isotopic evolution of silicic magmas, Taupo Volcanic Zone and Coromandel, New Zealand. New Zealand Journal of Geology and Geophysics 39, 353-362.

Briggs, R.M., Gifford, M.G., Moyle, A.R., Taylor, S.R., Norman, M.D., Houghton, B.F., Wilson, C.J.N., 1993. Geochemical zoning and eruptive mixing in ignimbrites from Mangakino volcano, Taupo Volcanic Zone, New Zealand. Journal of Volcanology and Geothermal Research 56, 175-203. 
Brown, S.J.A., Wilson, C.J.N., Cole, J.W., Wooden, J., 1998a. The Whakamaru group ignimbrites, Taupo Volcanic Zone, New Zealand: evidence for reverse tapping of a zoned silicic magmatic system. Journal of Volcanology and Geothermal Research 84, 1-37.

Brown, S.J.A., Burt, R.M., Cole, J.W., Krippner, S.J.P., Price, R.C., Cartwright, I., 1998b. Plutonic lithics in ignimbrites of Taupo Volcanic Zone, New Zealand; sources and conditions of crystallisation. Chemical Geology 148, 21-41.

Brown, S.J.A., Smith, R.T., 2004. Crystallisation history and crustal inheritance in a large silicic magma system: $206 \mathrm{~Pb} / 238 \mathrm{U}$ ion probe dating of zircons from the $1.2 \mathrm{Ma}$ Ongatiti ignimbrite, Taupo Volcanic Zone. Journal of Volcanology and Geothermal Research 135, 247-257.

Browne, P.R.L., Graham, I.J., Parker, R.J., Wood, C.P., 1992. Subsurface andesite lavas and plutonic rocks in the Rotokawa and Ngatamariki geothermal systems, Taupo Volcanic Zone, New Zealand. Journal of Volcanology and Geothermal Research 51, 199-215.

Bryan, S.E., Riley, T.R., Jerram, D.A., Stephens, C.J., Leat, P.T., 2002. Silicic volcanism: An undervalued component of large igneous provinces and volcanic rifted margins. In Menzies, M.A., Klemperer, S.L., Ebinger, C.J., Baker, J (Editiors), Volcanic Rifted Margins, Geological Society of America Special Paper 362, 97-118.

Bryant, C.J., Arculus, R.J., Eggins, S.M., 1999. Laser ablation-inductively coupled plasma-mass spectrometry and tephras: A new approach to understanding arc-magma genesis. Geology 27, 1119-1122.

Carter, L., Carter, R.M., McCave, I.N., Gamble, J., 1996. Regional sediment recycling in the abyssal Southwest Pacific Ocean. Geology 24, 735-738.

Carter, L., Alloway, B., Shane, P., Hall, I.R., Harris, S.E., Westgate, J.A., 2003. Demise of one volcanic zone and birth of another - A 12 m.y. marine record of major rhyolitic eruptions from New Zealand. Geology 31, 493-496.

Carter, L., Alloway, B., Shane, P., Westgate, J., 2004. Deep-ocean record of major late Cenozoic rhyolitic eruptions from New Zealand. New Zealand Journal of Geology and Geophysics 47, 481-500.

Charlier, B.L.A., Wilson, C.J.N., Lowenstern, J.B., Blake, S., Van Calsteren, P.W., Davidson, J.P., 2005. Magma generation at a large, hyperactive silicic volcano (Taupo, New Zealand) revealed by $\mathrm{U}-\mathrm{Th}$ and $\mathrm{U}-\mathrm{Pb}$ systematics in zircons. Journal of Petrology 46, 3-32. 
Charlier, B.L.A., Bachmann, O., Davidson, J.P., Dungan, M.A., Morgan, D.J., 2007. The upper crustal evolution of a large silicic magma body: evidence from crystal-scale $\mathrm{Rb}$-Sr isotopic heterogeneities in the Fish Canyon magmatic system. Journal of Petrology 48, 1875-1894.

Charlier, B.L.A., Wilson, C.J.N., Davidson, J.P., 2008. Rapid open-system assembly of a large silicic magma body: time-resolved evidence from cored plagioclase crystals in the Oruanui eruption deposits, New Zealand. Contributions to Mineralogy and Petrology, DOI 10.1007/s00410008

Christiansen, E.H., 2005. Contrasting processes in silicic magma chambers: evidence from very large volume ignimbrites. Geological Magazine 142, 669-681.

Conrad, W.K., Nicholls, I.A., Wall, V.J., 1988. Water-saturated and-under-saturated melting of metaluminous and peraluminous crustal compositions at $10 \mathrm{~kb}$ : Evidence for the origin of silicic magmas in the Taupo Volcanic Zone, New Zealand, and other occurrences. Journal of Petrology 29, 765-803.

Cousens, B., 1996. Magmatic evolution of Quaternary mafic magmas at Long Valley Caldera and the Devil's Postpile, California: Effects of crustal contamination on lithospheric mantle-derived magmas. Journal of Geosphysical Research 101 (B12), 27673-27689.

Davidson, J.P., Tepley, F.J III., Palacz, Z., Main, S., 2001. Magma recharge, contamination and residence times revealed by in situ laser ablation isotopic analysis of feldspar in volcanic rocks. Earth and Planetary Science Letters 182, 427-442.

Davidson, J.P., Hora, J.M., Garrison, J.M., Dungan, M.A., 2005. Crustal forensics in arc magmas. Journal of Volcanology and Geothermal Research 140, 157-170.

Davidson, J.P., Morgan, D.J., Charlier, B.L.A., Harlou, R., Hora, J.M., 2007. Microsampling and isotopic analysis of igneous rocks: implications for the study of magmatic systems. Annual Reviews of Earth and Planetary Science Letters 35, 273-311.

De Paolo, D.J., 1981. Trace element and isotopic effects of combined wallrock assimilation and fractional crystallisation. Earth and Planetary Science Letters 53, 189-202.

Dicken, A.P., 2005. Radiogenic Isotope Geology. Cambridge, UK. Cambridge University Press, $2^{\text {nd }}$ edition. 
Dunbar, N.W., Kyle, P.R., Wilson, C.J.N., 1989. Evidence for limited zonation in silicic magma systems, Taupo Volcanic zone, New Zealand. Geology 17, 234-236

Eastwood, W.J., Pearce, N.J.G., Westgate, J.A., Perkins, W.T., 1998. Recognition of the Santorini (Minoan) Tephra in Lake Sediments from Gölhisar, Southwest Turkey by Laser Ablation ICP-MS. Journal of Archaeological Science 25, 677-687.

Eggins, S.M., Kinsley, L..P.J., Shelley, J.M.G., 1998. Deposition and element fractionation processes during atmospheric pressure laser sampling for analysis by ICP-MS. Applied Surface Science 129, 278-286.

Faure, G., 1986. Principles of Isotope Geology, New York: Wiley.

Fenner, J., Stefano, A.D., 2004. Late Quaternary oceanic fronts along Chatham Rise indicated by phytoplankton assemblages, and refined calcareous nannofossil stratigraphy for the midlatitude SW Pacific. Marine Geology 205, 59-86.

Fierstein, J., Nathenson, M., 1992. Another look at the calculation of fallout tephra volumes. Bulletin of Volcanology 54, 156-167.

Froggatt, P.C., 1982. Review of methods of estimating rhyolitic tephra volumes; applications to the Taupo Volcanic Zone, New Zealand. Journal of Volcanology and Geothermal Research 14, $301-318$

Froggatt, P.C., Lowe, D.J., 1990. A review of late Quaternary silicic and some other tephra formations from New Zealand: their stratigraphy, nomenclature, distribution, volume and ages. New Zealand Journal of Geology and Geophysics 33, 89-109.

Froggatt, P.C., Nelson, C.S., Carter, L., Griggs, G., Black, K.P., 1986. An exceptionally large late Quaternary eruption from New Zealand. Nature 319, 578-582.

Gamble, J.A., Smith, I.E.M., McCulloch, M.T., Graham, I.J., Kokelaar, B.P., 1994. The geochemistry and petrogenesis of basalts from the Taupo Volcanic Zone and Kermadec Island Arc, S.W. Pacific. Journal of Volcanology and Geothermal Research 54, 265-290.

Gamble, J.A., Wright, I.C., Woodhead, J.D., McCulloch, M.T., 1995. Arc and back-arc geochemistry in the southern Kermadec arc - Ngatoro Basin and offshore Taupo Volcanic Zone, SW Pacific. In Smellie, J.L. (Editor), Volcanism Associated with Extension at Consuming Plate Margins. Geological Society Special Publication No. 81, 199-212. 
Gamble, J., Woodhead, J., Wright, I., Smith, I., 1996. Basalt and sediment geochemistry and magma petrogenesis in a transect from ocean island arc to rifted continental margin arc: the Kermadec - Hikurangi Margin, SW Pacific. Journal of Petrology 37, 1523-1546.

Graham, I.J., Gulson, B.L., Hedenquist, J.W., Mizon, K., 1992. Petrogenesis of Late Cenozoic volcanic rocks from the Taupo Volcanic Zone, New Zealand, in the light of new lead isotope data. Geochimica et Cosmochimica Acta 56, 2797-2819.

Graham, I.J., Cole, J.W., Briggs, R.M., Gamble, J.A., Smith, I.E.M., 1995. Petrology and petrogenesis of volcanic rocks from Taupo Volcanic Zone: a review. Journal of Volcanology and Geothermal Research 68, 59-87.

Gravley, D.M., Wilson, C.J.N., Leonard, G.S., Cole, J.W., 2007. Double trouble: paired ignimbrite eruptions and collateral subsidence in the Taupo Volcanic Zone, New Zealand. Geological Society of America Bulletin 119, 18-30.

Guillong, M., Günther, D., 2002. Effect of particle size distribution on ICP-induced elemental fractionation in laser ablation - inductively coupled plasma - mass spectrometry. Journal of Analytical Atomic Spectrometry 17, 831-837.

Hall, I.R., McCave, I.N., Shackleton, N.J., Weedon,G.P., Harris, S.E., 2001. Intensified deep Pacific inflow and ventilation in Pleistocene glacial times. Nature 412, 809-812.

Hall, I.R., Carter, L., Harris, S.E., 2002. Major depositional events under the deep Pacific inflow. Geology 30, 487-490.

Halliday, A.N., Fallick, A.E., Hutchinson, J., Hildreth, W., 1984. A nd, Sr and O isotopic investigation into the causes of chemical and isotopic zonation in the Bishop Tuff, California. Earth and Planetary Science Letters 68, 379-391.

Harangi, S., Mason, P., Lukács, R., 2005. Correlation and petrogenesis of silicic pyroclastic rocks in the Northern Pannonian Basin, Eastern-Central Europe: In situ trace element data of glass shards and mineral chemical constraints. Journal of Volcanology and Geothermal Research $143,237-257$.

Harris, S.E., 2002. Data report: Late Pliocene-Pleistocene carbon and oxygen stable isotopes from benthic foraminifers at Ocean Drilling Program Site 1123 in the Southwest Pacific. In Richter, C. (Ed.) Proc. ODP, Scientific Results, 181, 1-20. Available from World Wide Web: http://www-odp.tamu.edu/publications/181_SR/volume/chapters/203.pdf. 
Harrison, A., White, R.S., 2006. Lithospheric structure of an active backarc basin: the Taupo Volcanic Zone, New Zealand. Geophysics Journal International 167, 968-990.

Hildreth, W., 1979. The Bishop Tuff: Evidence for the origin of compositional zonation in silicic magma chambers. In Chapin, C.E., and Elston, W.E., (eds) Ash Flow Tuffs, Geological Society of America Special Paper 180, 43-75.

Hildreth, W., 1981. Gradients in silicic magma chambers: implications for lithospheric magmatism. Journal of Geophysical Research B 86, 10152-10192

Hildreth, W., 2004. Volcanological perspectives on Long Valley, Mammoth Mountain, and Mono Craters: several contiguous but discrete systems. Journal of Volcanology and Geothermal Research 136, 169-198.

Hildreth, W., Wilson, C.J.N., 2007. Compositional zoning of the Bishop Tuff. Journal of Petrology 48, 951-999.

Hochstein, M., 1995. Crustal heat transfer in the Taupo Volcanic Zone (NZ): comparison with other volcanic arcs and explanatory heat source models. Journal of Volcanology and Geothermal Research 68, 117-151.

Hofmann, A.W., 2003. Sampling mantle heterogeneity through oceanic basalts: isotopes and trace elements. In Turekian, K.K., Holland, H.D., (Editors), Treatise on Geochemistry, Elsevier, Chapter 2.03, 61-101.

Horn, I., Günther, D., 2003. The influence of ablation carrier gases Ar, He and Ne on the particle size distribution and transport efficiencies of laser ablation-induced aerosols: implications for LAICP-MS. Applied Surface Science 207, 144-157.

Houghton, B.F., Wilson, C.J.N., McWilliams, M.O., Lanphere, M.A., Weaver, S.D., Briggs, R.M., Pringle, M.S., 1995. Chronology and dynamics of a large silicic magmatic system: Central Taupo Volcanic Zone, New Zealand. Geology 23, 13-16.

Hunt, J.B., Hill, P.G., 2001. Tephrological implications of beam size - sample-size effects in electron microprobe analysis of glass shards. Journal of Quaternary Science 16, 105-117.

Jarosewich, E., Nelen, J.A., Norberg, J.A., 1979. Electron microprobe reference samples for mineral analysis. Smithsonian Contributions to the Earth Sciences 22, 68-72. 
Jochum, K.P., Stolz, A.J., McOrist, G., 2000. Niobium and tantalum in carbonaceous chondrites: Constraints on the solar system and primitive mantle niobium/tantalum, and niobium/uranium ratios. Meteoritics and Planetary Science 35, 229-235.

Jochum, K.P., Willbold, M., Raczek, I., Stoll, B., Herwig, H., 2005. Chemical characterisation of the USGS reference glasses GSA-1G, GSC-1G, GSD-1G, GSE-1G, BCR-2G, BHVO-2G and BIR-1G using EPMA, ID-TIMS, ID-ICP-MS and LA-ICP-MS. Geostandards and Geoanalytical Research 29, 285-302.

Jochum, K.P., Stoll, B., Herwig, K., Willbold, W., Hofmann, A.W., Amini, M., Aarburg, S., Abouchami, W., Hellebrand, E., Mocek, B., Raczek, I., Stracke, A., Alard, O., Bouman, C., Becker, S., Dücking, M., Brätz, H., Klemd, R., de Bruin, D., Canil, D., Cornell, D., de Hoog, C.J., Dalpé, C., Danyushevsky, L., Eisenhauer, A., Gao, Y., Snow, J.E., Groschopf, N., Günther, D., Latkocsy, C., Guillong, M., Hauri, E.H., Höfer, H,E., Lahaye, Y., Horz, K., Jacob, D.E., Kasemann, S.A., Kent, A.J.R., Ludwig, T., Zack, T., Mason, P.R.D., Meixner, A., Rosner, M., Misawa, K., Nash, B.P., Pfänder, J., Premo, W.R., Sun, W.D., Tiepolo, M., Vannucci, R., Vennemann, T., Wayne, D., Woodhead, J.D., 2006. MPI-DING reference glasses for in situ microanalysis: New reference values for element concentrations and isotope ratios. Geochemistry Geophysics Geosystems 7, Q02008, doi:10.1029/2005GC001060.

Jurado-Chichay, Z., Walker, G.P.L., 2000. Stratigraphy and dispersal of the Mangaone Subgroup pyroclastic deposits, Okataina Volcanic Centre, New Zealand. Journal of Volcanology and Geothermal Research 104, 319-383.

Kent A.J.R., Jacobsen B., Peate D.W., Waight T., Baker J.A., 2004. Isotope dilution MC-ICP-MS rare earth element analysis of geochemical reference materials NIST SRM 610, NIST SRM 612, NIST SRM 614, BHVO-2G, BHVO-2, BCR-2G, JB-2, WS-E, W-2, AGV-1 and AGV-2. Geostandards and Geoanalytical Research 28, 417-429

King, P.R., 2000. Tectonic reconstructions of New Zealand: 40 Ma to the present. New Zealand Journal of Geology and Geophysics 43, 611-638.

Koepke, J., Behrens, H., 2001. Trace element diffusion in andesitic melts: An application of synchrotron X-ray fluorescence analysis. Geochimica et Cosmochimica Acta 65, 1481-1498.

Kontak, D.J., De Young, M.Y., Dostal, J., 2002. Late-stage crystallisation history of the Jurassic North Mountain Basalt, Nova Scotia, Canada. I. Textural and chemical evidence for pervasive development of silicate-liquid immiscibility. The Canadian Mineralogist 40, $1287-$ 1311. 
Knesel, K.M., Davidson, J.P., 1997. The origin and evolution of large-volume silicic magma systems: Long Valley Caldera. International Geology Review 39, 1033-1052.

Kroslakova, I., Günther, D., 2007. Elemental fractionation in laser ablation-inductively coupled plasma-mass spectrometry: evidence for mass load induced matrix effects in the ICP during ablation of a silicate glass. Journal of Analytical Atomic Spectrometry 22, 51-62.

Le Maitre, R.W., 1984. A proposal by the IUGS subcommission on the systematics of igneous rocks for a chemical classification of volcanic rocks based on total alkali silica (TAS) diagram. Australian Journal of Earth Sciences 31, 243-255.

Lean, C.M.B., McCave, I.N., 1998. Glacial to interglacial mineral magnetic and palaeoceanographic changes at Chatham Rise, SW Pacific Ocean. Earth and Planetary Science Letters 163, 247260.

Lian, O.B., Shane, P.A., 2000. Optical dating of paleosols bracketing the widespread Rotoehu tephra, North Island, New Zealand. Quaternary Science Reviews 19, 1649-1662.

Liu, Y., Anderson, A.T., Wilson, C.J.N., Davis, A.M., Steele, I.M., 2006. Mixing and differentiation in the Oruanui rhyolitic magma, Taupo, New Zealand: evidence from volatiles and trace elements in melt inclusion. Contributions to Mineralogy and Petrology 151, 71-87.

Longerich, H., Diegor, W., 2001. Introduction to mass spectrometry. In: Laser-Ablation-ICPMS in the Earth Sciences, Short Course Series 29, Editor Sylvester, P., Mineralogical Association of Canada, pp 243.

Lowe, D.J., Shane, P.A.R., Alloway, B.V., Newnham, R.M., 2008. Fingerprints and age models for widespread New Zealand tephra marker beds erupted since 30,000 years ago: a framework for NZ-INTIMATE. Quaternary Science Reviews 27, 95-126.

Lowery Claiborne, L., Miller, C.F., Walker, B.A., Wooden, J.L., Mazdab, F.K., Bea, F., 2006. Tracking magmatic processes through $\mathrm{Zr} / \mathrm{Hf}$ ratios in rocks and $\mathrm{Hf}$ and Ti zoning in zircons: An example from the Spirit Mountain batholith, Nevada. Mineralogical Magazine 70, 517543.

Mahood, G., Hildreth, W., 1983. Large partition coefficients for trace elements in high-silica rhyolites. Geochimica et Cosmochimica Acta 47, 11-30. 
Manville, V., Wilson, C.J.N., 2004. Vertical density currents: a review of their potential role in the deposition and interpretation of deep-sea ash layers. Journal of the Geological Society, London 161, 947-958.

Mason, B.G., Pyle, D.M., Dade, W.B., Jupp, T., 2004. Seasonality of volcanic eruptions. Journal of Geophysical Research 109, BO4206, doi:10.1029/2002JB002293.

McCulloch, M.T., Kyser, T.K., Woodhead, J.D., Kinsley, L., 1994. Pb-Sr-Nd-O isotopic constraints on the origin of rhyolites from the Taupo Volcanic Zone of New Zealand: evidence for assimilation followed by fractionation from basalt. Contributions to Mineralogy and Petrology 115, 303-312.

McDonald, R., Belkin, H.E., Fitton, J.G., Rogers, N.W., Nejbert, K., Tindle, A.G., Marshall, A.S., 2008. The roles of fractional crystallisation, magma mixing, crystal mush rejuvenation and volitle-melt interactions in the genesis of a young basalt - peralkaline rhyolite suite, the Greater Olkaria Volcanic Complex, Kenya Rift Valley. Journal of Petrology 49, 1515-1547.

McGuire, W.J., Howarth, R.J., Firth, C.R., Solow, A.R., Pullen, A.D., Saunders, S.J., Stewart, I.S., Vita-Finzi, C., 1997. Correlation between rate of sea-level change and frequency of explosive volcanism in the Mediterranean. Nature 389, 473-476.

McNutt, S.R., Beavan, R.J., 1987. Eruptions of Pavlof Volcano and their possible modulation by ocean load and tectonic stresses. Journal of Geophysical Research 92, 11,509-11,523.

Mildenhall, D.C., Hollis, C.J., Naish, T.R., 2004. Orbitally-influenced vegetation record of the MidPleistocene Transition, offshore eastern New Zealand (ODP Leg 181, Site 1123). Marine Geology 205, 87-111.

Mix, A.C., Pisias, N.G., Rugh, W., Wilson, J., Morey, A., Hagelberg, T.K., 1995. Benthic foraminifer stable isotope record from Site 849 (0-5 Ma); local and global climate changes. Proceedings of the Ocean Drilling Program, Scientific Results 138, 371-412.

Molloy, C., Shane, P., Nairn, I., 2008. Pre-eruption thermal rejuvenation and stirring of a partly crystalline rhyolite pluton revealed by the Earthquake Flat Pyroclastics deposits, New Zealand. Journal of the Geological Society 165, 435-447.

Morgan, D.J., Jerram, D.A., Chertkoff, D.G., Davidson, J.P., Pearson, D.G., Kronz, A., Nowell, G.M., 2007. Combining CSD and isotopic microanalysis: Magma supply and mixing processes at Stromboli Volcano, Aeolian Islands, Italy. Earth and Planetary Science Letters 260, 419-431. 
Nakada, M., Yokose, H., 1992. Ice age as a trigger of active Quaternary volcanism and tectonism. Tectonophysics 212, 321-329.

Nelson, C.S., Froggatt, P.C., Gosson, G.J., 1986. Nature, chemistry, and origin of Late Cenozoic megascopic tephras in Leg 90 cores from the Southwest Pacific. Initial Reports of Deep Sea Drilling Project, Volume XC, Part 2, 1161-1171.

Newnham, R.M., Vandergoes, M.J., Hendy, C.H., Lowe, D.J., Preusser, F., 2007. A terrestrial palynological record for the last two glacial cycles from southwestern New Zealand. Quaternary Science Reviews 26, 517-535.

Paterne, M., Labeyrie, J., Guichard, F., Mazaud, A., Maitre, F., 1990. Fluctuations of the Campanian explosive volcanic activity (South Italy) during the past 190,000 years, as determined by marine tephrochronology. Earth and Planetary Science Letters 98, 166-174.

Pearce, N.J.G., Westgate, J.A., Perkins, W.T., 1996. Developments in the analysis of volcanic glass shards by laser ablation ICP-MS: Quantitative and single internal standard-multi-element methods. Quaternary International 34-36, 213-227.

Pearce, N.J.G., Perkins, W.T., Westgate, J.A., Gorton, M.P., Jackson, S.E., Neal, C.R., Chenery, S.P., 1997. A compilation of new and published major and trace element data for NIST SRM 610 and NIST SRM 612 glass reference materials. Geostandards Newsletter 21, 115-144.

Pearce, N.J.G., Westgate, J.A., Perkins, W.T., Eastwood, W.J., Shane, P., 1999. The application of laser ablation ICP-MS to the analysis of volcanic glass shards from tephra deposits: bulk glass and single shard analysis. Global and Planetary Change 21, 151-171.

Pearce, N.J.G, Eastwood, W.J, Westgate, J.A., Perkins, W.T, 2002. Trace element composition of single glass shards in distal Minoan tephra from SW Turkey. Journal of the Geological Society, London 159, 545-556.

Pearce, N.J.G, Westgate, J.A., Perkins, W.T., Preece, S.J., 2004. The application of ICP-MS methods to tephrochronological problems. Applied Geochemistry 19, 289-322.

Pearce, N.J.G., Denton, J.S., Perkins, W.T., Westgate, J.A., Alloway, B.V., 2007. Correlation and characterisation of individual glass shards from tephra deposits using trace element laser ablation ICP-MS analyses: current status and future potential. Journal of Quaternary Science $22,721-736$. 
Pearce, N.J.G., Westgate, J.A., Alloway, B.V., 2008. Mid-Pleistocene silicic tephra beds in the Auckland region, New Zealand: their correlation and origins based on trace element analyses of single shards. Quaternary International 178, 16-43.

Pillans, B., Wright, I., 1992. Late Quaternary tephrostratigraphy from the southern Havre Trough, Bay of Plenty, northeast New Zealand. New Zealand Journal of Geology and Geophysics 35, 129143 .

Pillans, B., Alloway, B., Naish, T., Westgate, J., Abbott, S., Palmer, A., 2005. Silicic tephras in Pleistocene shallow-marine sediments of Wanganui Basin, New Zealand. Journal of the Royal Society of New Zealand 35, 43-90.

Price, R.C., Gamble, J.A., Smith, I.E.M., Stewart, R.B., Eggins, S., Wright, I.C., 2005. An integrated model for the temporal evolution of andesites and rhyolites and crustal development in New Zealand's North Island. Journal of Volcanology and Geothermal Research 140,1-24.

Pyle, D.M., 1989. The thickness, volume and grainsize of tephra fall deposits. Bulletin of Volcanology 51, 1-15.

Pyle, D.M., 1995. Assessment of the minimum volume of tephra fall deposits. Journal of Volcanology and Geothermal Research 69, 379-382.

Rampino, M.R., Self, S., Fairbridge, R.W., 1979. Can rapid climate change cause volcanic eruptions? Science 206, 826-829.

Reagan, M.K., Sims, K.W.W., Erich, J., Thomas, R.B., Cheng, H., Edwards, R.L., Layne, G., Ball, L., 2003. Time-scales of differentiation from mafic parents to rhyolite in North American continental arcs. Journal of Petrology 44, 1703-1726.

Reed, W.P., 1992. Certificate of Analysis, Standard Reference Materials 612, 613.

Reid, F.W., 1982. Geochemistry of central North Island greywackes and genesis of silicic magmas. $\mathrm{PhD}$ thesis, Victoria University of Wellington, New Zealand (unpublished)

Reid, F.W., 1983. Origin of the rhyolitic rocks of the Taupo Volcanic Zone, New Zealand. Journal of Volcanology and Geothermal Research 15, 315-338.

Riley, T.R., Leat., P.T., Pankhurst, R.J., Harris, C., 2001. Origins of large volume rhyolitic volcanism in the Antarctic Peninsula and Patagonia by crustal melting. Journal of Petrology 42, 1043 1065 . 
Rodushkin, I., Axelsson, M.D., Malinkovsky, D., Baxter, D.C., 2002. Analyte- and matrix-dependent elemental response variations under laser ablation inductively coupled plasma mass spectrometry. Part 1. The roles of plasma and ion sampling conditions. Journal of Analytical Atomic Spectrometry 17, 1223-1230.

Roggensack, K., Hervig, R.L., McKnight, S.B., Williams, S.N., 1997. Explosive basaltic volcanism from Cerro Negro volcano: influence of volatiles on eruptive style. Science 277, 1639-1642.

Seward, D., 1974. Age of New Zealand Pleistocene substages by fission-track dating of glass shards from tephra horizons. Earth and Planetary Science Letters 24, 242-248.

Schmitz, M.D., Smith, I.E.M., 2004. The petrology of the Rotoiti eruption sequence, Taupo Volcanic Zone: an example of fractionation and mixing in a rhyolitic system. Journal of Petrology 45, 2045-2066.

Shane, P.A.R., 1994. A widespread, early Pleistocene tephra (Potaka Tephra $1 \mathrm{Ma}$ ) in New Zealand; characteristics, distribution, and implications. New Zealand Journal of Geology and Geophysics 37, 25-35.

Shane, P., 2000. Tephrochronology: a New Zealand case study. Earth-Science Reviews 49, 223-259

Shane, P.A.R., Froggatt, P.C., 1991. Glass chemistry, paleomagnetism, and correlation of middle Pleistocene tuffs in southern North Island, New Zealand, and Western Pacific. New Zealand Journal of Geology and Geophysics 34, 203-211.

Shane, P., Sandiford, A., 2003. Paleovegetation of Marine Isotope Stages 4 and 3 in northern New Zealand and the age of the widespread Rotoehu tephra. Quaternary Research 59, 420-429.

Shane, P., Froggatt, P., Black, T., Westgate, J., 1995. Chronology of Pliocene and Quaternary bioevents and climatic events from fission-track ages on tephra beds, Wairarapa, New Zealand. Earth and Planetary Science Letters 130, 141-154.

Shane, P.A.R., Black, T.M., Alloway, B.V., Westgate, J.A., 1996a. Early to middle Pleistocene tephrochronology of North Island, New Zealand; implications for volcanism, tectonism and paleoenvironments. Geological Society of America Bulletin 108, 915-925.

Shane, P., Alloway, B., Black, T., Westgate, J., 1996b. Isothermal plateau fission-track ages of tephra beds in an early-middle Pleistocene marine and terrestrial sequence, Cape Kidnappers, New Zealand. Quaternary International 34-36, 49-53. 
Shane, P., Black, T., Eggins, S., Westgate, J., 1998. Late Miocene marine tephra beds: recorders of rhyolitic volcanism in North Island, New Zealand. New Zealand Journal of Geology and Geophysics 41, 165-178.

Shane, P., Smith, V., Nairn, I., 2003. Biotite composition as a tool for the identification of Quaternary tephra beds. Quaternary Research 59, 262-270.

Shane, P., Sikes, E.L.., Guilderson, T.P., 2006. Tephra beds in deep-sea cores off northern New Zealand: implications for the history of Taupo Volcanic Zone, Mayor Island and White Island volcanoes. Journal of Volcanology and Geothermal Research 154, 276-290.

Shipboard Scientific Party, 1999. Site 1123: North Chatham Drift - a 20 Ma record of the Pacific Deep Western Boundary Current. Proceedings ODP Initial Report Leg 181, 1-84 (CD-ROM).

Shulmeister, J., Shane, P., Lian, O.B., Okuda, M., Carter, J.A., Harper, M., Dickinson, W.W., Augustinus, P., Heijnis, H., 2001. A long, late-Quaternary record from Lake Poukawa, Hawkes Bay, New Zealand. Palaeogeography, Palaeoclimatology, Palaeoecology 176, 81107.

Sisson, T.W., Grove, T.L., 1993. Temperatures and $\mathrm{H}_{2} \mathrm{O}$ contents of low-Mg high-alumina basalts. Contributions to Mineralogy and Petrology 113, 167-184.

Stratford, W.R., Stern, T.A., 2004. Strong seismic reflections and melts in the mantle of a continental back-arc basin. Geophysical Research Letters 31, doi:10.1029/2003GL019232

Sun,S.S., McDonough, W.F., 1989. Chemical and isotopic systematics of oceanic basalts; implications for mantle composition and processes. Geological Society Special Publications $42,313-345$.

Sutton, A.N., Blake, S., Wilson, C.J.N., 1995. An outline geochemistry of rhyolite eruptives from Taupo volcanic centre, New Zealand. Journal of Volcanology and Geothermal Research 68, $153-175$.

Sutton, A.N., Blake, S., Wilson, C.J.N., Charlier, B.L.A., 2000. Late Quaternary evolution of a hyperactive rhyolite magma system: Taupo volcanic centre, New Zealand. Journal of the Geological Society of London 157, 537-552.

Ukstins Peate, I., Baker, J.A., Kent, A.J.R., Al-Kadasi, M., Al-Subbary, A., Ayalew, D., Menzies, M., 2003. Correlation of Indian Ocean tephra to individual Oligocene silicic eruptions from AfroArabian flood volcanism. Earth and Planetary Science Letters 211, 311-327. 
Ukstins Peate, I., Kent, A.J.R., Baker, J.A., Menzies, M.A., 2008. Extreme geochemical heterogeneity in Afro-Arabian Oligocene tephras: Preserving fractional crystallization and mafic recharge processes in silicic magma chambers. Lithos 102, 260-278.

Waight, T., Baker, J., Peate, D., 2002. Sr isotope ratio measurements by double-focusing MC-ICPMS: techniques, observations and pitfalls. International Journal of Mass Spectrometry 221, 229-244.

Weedon, G.P., Hall, I.R., 2004. Neogene palaeoceanography of Chatham Rise (Southwest Pacific) based on sediment geochemistry. Marine Geology 205, 207-225.

Weisner, M.G., Wang, Y., Zheng, I., 1995. Fallout of volcanic ash to the deep South China Sea induced by the 1991 eruption of Mount Pinatubo (Philippines). Geology 23, 885-888.

Westgate, J. A., 1989. Isothermal plateau fission-track ages of hydrated glass shards from silicic tephra beds. Earth and Planetary Science Letters 95, 226-234.

Wilson, C.J.N., 1986. Reconnaisance stratigraphy and volcanology of ignimbrites from Mangakino volcano. In Smith, I.E.M (Editor), Late Cenozoic Volcanism in New Zealand. Royal Society of New Zealand Bulletin 23, 179-193.

Wilson, C.J.N., 1991. Ignimbrite morphology and the effects of erosion: a New Zealand case study. Bulletin of Volcanology 53, 635-644.

Wilson, C.J.N., 2001. The 26.5 ka Oruanui eruption, New Zealand: an introduction and overview. Journal of Volcanology and Geothermal Research 1123, 133-174.

Wilson, C.J.N., Rogan, A.M., Smith, I.E.M., 1984. Caldera volcanoes of the Taupo Volcanic Zone, New Zealand. Journal of Geophysical Research 89 (B10), 8463-8484.

Wilson, C.J.N., Switsur, V.R., Ward, A.P., 1988. A new ${ }^{14} \mathrm{C}$ age for the Oruanui (Wairakei) eruption, New Zealand. Geological Magazine 125, 297-300.

Wilson, C.J.N., Houghton, B.F., Lanphere, M.O., Weaver, S.D., 1992. A new radiometric age estimate for the Rotoehu Ash from Mayor Island volcano, New Zealand. New Zealand Journal of Geology and Geophysics 35, 371-374.

Wilson, C.J.N., Houghton, B.F., McWilliams, M.O., Lanphere, M.A., Weaver, S.D., Briggs, R.M., 1995a. Volcanic and structural evolution of Taupo Volcanic Zone, New Zealand: a review. Journal of Volcanology and Geothermal Research 68, 1-28. 
Wilson, C.J.N., Houghton, B.F., Kamp, P.J.J., McWilliams, M.O., 1995b. An exceptionally widespread ignimbrite with implications for pyroclastic flow emplacement. Nature 378, 605607.

Wilson, C.J.N., Blake, S., Charlier, B.L.A., Sutton, A.N., 2006. The 26.5 ka Oruanui eruption, Taupo volcano, New Zealand: development, characteristics and evacuation of a large rhyolitic magma body. Journal of Petrology 47, 35-69.

Wilson, C.J.N., Rhoades, D.A., Lanphere, M.O., Calvert, A.T., Houghton, B.F., Weaver, S.D., Cole, J.W., 2007. A multi-approach radiometric age estimate for the Rotoiti and Earthquake Flat eruptions, New Zealand, with implications for the MIS 4/3 boundary. Quaternary Science Reviews 26, 1861-1870. 


\section{SUPPLEMENTARY INFORMATION}




\section{APPENDIX ONE}

Table A1-1. Sample list

Table A1-2. Original Site 1123 composite record tie-points 
Table A1-1. Sampling details for Site 1123 tephra layers analysed in this study

\begin{tabular}{|c|c|c|c|c|c|c|c|c|c|}
\hline $\begin{array}{c}\text { Sample } \\
\text { numbers }\end{array}$ & Site & Hole & Core & Type & Sect & $\begin{array}{c}\text { Base of } \\
\text { ash }(\mathrm{cm})\end{array}$ & mbsf & $\begin{array}{l}\text { Thickness } \\
\text { (cm) }\end{array}$ & Age (Ma) \\
\hline 331 & 1123 & A & 1 & $\mathrm{H}$ & 1 & 101 & 1.01 & $?$ & 0.0212 \\
\hline 332 & 1123 & A & 1 & $\mathrm{H}$ & 2 & 10 & 1.6 & 5 & 0.033 \\
\hline 333 & 1123 & A & 2 & $\mathrm{H}$ & 5 & 65 & 12.75 & 5 & 0.2584 \\
\hline 334 & 1123 & A & 2 & $\mathrm{H}$ & 5 & 138 & 13.48 & 0.8 & 0.2728 \\
\hline 335 & 1123 & A & 2 & $\mathrm{H}$ & 6 & 20 & 13.8 & 1.8 & 0.2791 \\
\hline 272 & 1123 & A & 2 & $\mathrm{H}$ & 6 & 70 & 14.3 & 5.5 & 0.289 \\
\hline 336 & 1123 & A & 4 & $\mathrm{H}$ & 4 & 62 & 30.22 & 1.5 & 0.6397 \\
\hline 337 & 1123 & A & 4 & $\mathrm{H}$ & 6 & 130 & 33.9 & 5 & 0.7479 \\
\hline 273 & 1123 & A & 5 & $\mathrm{H}$ & 2 & 100 & 37.1 & 9 & 0.968 \\
\hline 338 & 1123 & A & 5 & $\mathrm{H}$ & 3 & 68 & 38.28 & 0.5 & 0.9977 \\
\hline 373 & 1123 & A & 6 & $\mathrm{H}$ & 2 & 109 & 46.69 & 0.2 & 1.2684 \\
\hline A-15 & 1123 & A & 6 & $\mathrm{H}$ & 3 & 140 & 48.5 & 1 & 1.3322 \\
\hline 275 & 1123 & A & 6 & $\mathrm{H}$ & 4 & 134 & 49.94 & 5 & 1.3658 \\
\hline 339 & 1123 & A & 6 & $\mathrm{H}$ & 5 & 21 & 50.31 & 3.5 & 1.38 \\
\hline 374 & 1123 & A & 6 & $\mathrm{H}$ & 6 & 66 & 52.26 & 0.3 & 1.3434 \\
\hline 340 & 1123 & A & 6 & $\mathrm{H}$ & 6 & 127 & 52.87 & 1 & 1.3584 \\
\hline A-17 & 1123 & A & 6 & $\mathrm{H}$ & 7 & 16 & 53.26 & 0.5 & 1.3704 \\
\hline 341 & 1123 & A & 6 & $\mathrm{H}$ & 7 & 42 & 53.52 & 0.5 & 1.3804 \\
\hline A-19 & 1123 & A & 7 & $\mathrm{H}$ & 1 & 55 & 54.15 & 3 & 1.4098 \\
\hline 342 & 1123 & A & 7 & $\mathrm{H}$ & 3 & 51.5 & 57.12 & 5 & 1.5377 \\
\hline 274 & 1123 & A & 7 & $\mathrm{H}$ & 3 & 112 & 57.72 & 8.5 & 1.5543 \\
\hline 343 & 1123 & A & 7 & $\mathrm{H}$ & 4 & 112 & 59.22 & 2.5 & 1.6055 \\
\hline 271 & 1123 & A & 7 & $\mathrm{H}$ & 5 & 36 & 59.96 & 6 & 1.6306 \\
\hline 375 & 1123 & A & 7 & $\mathrm{H}$ & 5 & 60 & 60.2 & 1 & 1.6389 \\
\hline 344 & 1123 & A & 7 & $\mathrm{H}$ & 5 & 128 & 60.88 & 3 & 1.6554 \\
\hline 376 & 1123 & B & 1 & $\mathrm{H}$ & 2 & 9 & 1.59 & 4 & 0.0328 \\
\hline A-12 & 1123 & B & 2 & $\mathrm{H}$ & 6 & 95 & 11.85 & 5.5 & 0.2614 \\
\hline 377 & 1123 & B & 5 & $\mathrm{H}$ & 3 & 6 & 34.96 & 5 & 0.9907 \\
\hline 378 & 1123 & B & 6 & $\mathrm{H}$ & 6 & 11 & 49.01 & 1 & 1.3166 \\
\hline 379 & 1123 & B & 6 & $\mathrm{H}$ & 6 & 24.5 & 49.15 & 2 & 1.3235 \\
\hline 380 & 1123 & B & 6 & $\mathrm{H}$ & 6 & 32 & 49.22 & 0.3 & 1.3265 \\
\hline 381 & 1123 & B & 6 & $\mathrm{H}$ & 6 & 47 & 49.37 & 1 & 1.33 \\
\hline $\mathrm{CP}$ & 1123 & B & 6 & $\mathrm{H}$ & 6 & 143 & 50.33 & 10 & 1.3509 \\
\hline 384 & 1123 & B & 7 & $\mathrm{H}$ & 2 & 40 & 52.8 & 6 & 1.3823 \\
\hline 385 & 1123 & B & 7 & $\mathrm{H}$ & 2 & 92 & 53.32 & 2 & 1.4018 \\
\hline A-20 & 1123 & B & 7 & $\mathrm{H}$ & 4 & 94 & 56.34 & 0.5 & 1.5322 \\
\hline $\mathrm{CN}$ & 1123 & B & 7 & $\mathrm{H}$ & 4 & 148 & 56.88 & 5 & 1.5499 \\
\hline 382 & 1123 & B & 7 & $\mathrm{H}$ & 5 & 75.5 & 57.66 & 0.5 & 1.5655 \\
\hline 383 & 1123 & B & 7 & $\mathrm{H}$ & 5 & 117 & 58.07 & 1.5 & 1.584 \\
\hline $\mathrm{CO}$ & 1123 & B & 7 & $\mathrm{H}$ & 6 & 15.5 & 58.56 & 4 & 1.6025 \\
\hline A-9 & 1123 & C & 1 & $\mathrm{H}$ & 1 & 135 & 1.35 & 10 & 0.028 \\
\hline A-10 & 1123 & C & 1 & $\mathrm{H}$ & 2 & 3 & 1.53 & 3 & 0.0316 \\
\hline A-11 & 1123 & C & 1 & $\mathrm{H}$ & 2 & 70 & 2.2 & 5 & 0,0451 \\
\hline 390 & 1123 & C & 2 & $\mathrm{H}$ & 2 & 94 & 11.44 & 6 & 0.2625 \\
\hline 391 & 1123 & C & 2 & $\mathrm{H}$ & 2 & 109 & 11.59 & 5 & 0.2623 \\
\hline A-13 & 1123 & C & 2 & $\mathrm{H}$ & 3 & 70 & 12.7 & 1 & 0.2874 \\
\hline 392 & 1123 & C & 2 & $\mathrm{H}$ & 3 & 139 & 13.39 & 7 & 0.3025 \\
\hline 393 & 1123 & C & 2 & $\mathrm{H}$ & 7 & 35 & 18.35 & 4 & 0.3993 \\
\hline 394 & 1123 & C & 3 & $\mathrm{H}$ & 4 & 86 & 23.86 & 2 & 0.5489 \\
\hline 395 & 1123 & C & 4 & $\mathrm{H}$ & 4 & 120 & 33.7 & 2 & $\begin{array}{c}0.8256 \\
\text { contimued }\end{array}$ \\
\hline
\end{tabular}


Table A1-1 continued

\begin{tabular}{cccccccccc}
$\begin{array}{c}\text { Sample } \\
\text { numbers }\end{array}$ & Site & Hole & Core & Type & Sect & $\begin{array}{c}\text { Base of } \\
\text { ash }(\mathbf{c m})\end{array}$ & mbsf & $\begin{array}{c}\text { Thickness } \\
\text { (cm) }\end{array}$ & $\begin{array}{c}\text { Age (Ma) } \\
\mathbf{3 9 6}\end{array}$ \\
\hline A-14 & 1123 & C & 4 & H & 6 & 73 & 36.23 & 5 & 0.8936 \\
$\mathbf{3 9 7}$ & 1123 & C & 5 & H & 1 & 93 & 38.43 & 8 & 0.9833 \\
$\mathbf{3 9 8}$ & 1123 & C & 5 & H & 5 & 123 & 44.73 & 3 & 1.167 \\
A-16 & 1123 & C & 6 & H & 1 & 78 & 47.78 & 1 & 1.2338 \\
$\mathbf{3 9 9}$ & 1123 & C & 6 & H & 4 & 130 & 51.3 & 1 & 1.3346 \\
$\mathbf{4 0 0}$ & 1123 & C & 6 & H & 4 & 97 & 52.15 & 9 & 1.3529 \\
$\mathbf{4 0 1}$ & 1123 & C & 6 & H & 5 & 11 & 53.11 & 1 & 1.3609 \\
$\mathbf{4 0 2}$ & 1123 & C & 6 & H & 5 & 92 & 53.92 & 2 & 1.3838 \\
$\mathbf{4 0 3}$ & 1123 & C & 6 & H & 5 & 113 & 54.13 & 3 & 1.4139 \\
$\mathbf{4 0 4}$ & 1123 & C & 6 & H & 6 & 10 & 54.6 & 3 & 1.4204 \\
$\mathbf{4 0 5}$ & 1123 & C & 6 & H & 6 & 120 & 55.7 & 4 & 1.3367 \\
$\mathbf{4 0 6}$ & 1123 & C & 6 & H & 6 & 124 & 55.74 & 1 & 1.3627 \\
A-18 & 1123 & C & 6 & H & 7 & 67 & 56.67 & 8 & 1.3976 \\
$\mathbf{4 0 7}$ & 1123 & C & 7 & H & 2 & 67 & 58.67 & 7 & 1.5318 \\
$\mathbf{4 0 8}$ & 1123 & C & 7 & H & 2 & 127 & 59.27 & 8 & 1.5509 \\
$\mathbf{4 0 9}$ & 1123 & C & 7 & H & 3 & 4 & 59.54 & 4 & 1.5563 \\
A-21 & 1123 & C & 7 & H & 3 & 135 & 60.85 & 2 & 1.6022 \\
A-22 & 1123 & C & 7 & H & 4 & 63 & 61.63 & 7 & 1.629 \\
A-23 & 1123 & C & 7 & H & 5 & 13 & 62.63 & 2 & 1.656
\end{tabular}

Samples prefixed “AT-” were provided by Brent Alloway and those with the prefix “A-” were order from the Integrated Ocean Drilling Program's Gulf Coast Core Repository (Texas, USA). Ages had previously been assigned (Alloway et al., 2005; Brent Alloway, unpublished data) based on a tephra layer's stratigraphic position within the orbitally tuned stable isotope age model of Hall et al. (2001) and Harris (2002). Note that some of the assigned ages in this list are inconsistent with stratigraphic constraints. For example, AT-404 occurs stratigraphically below sample AT-403 (1123C) yet AT-404 paradoxically has been assigned a younger age. These inconsistencies are addressed during re-evaluation of the composite stratigraphy and age model in Chapter Two. 
Table A1-2. Original tie-points used in the construction of the ( $<1.7 \mathrm{Ma})$ composite stratigraphy and age model

\begin{tabular}{ccccccccc}
\hline $\begin{array}{c}\text { Site/Hole/Core/ } \\
\text { Section }\end{array}$ & $\begin{array}{c}\text { Depth in } \\
\text { section } \\
(\mathrm{cm})\end{array}$ & $\begin{array}{c}\text { Depth } \\
\text { (mbsf) }\end{array}$ & $\begin{array}{c}\text { Depth } \\
\text { (mcd) }\end{array}$ & $\begin{array}{c}\text { Site/Hole/Core/ } \\
\text { Section }\end{array}$ & $\begin{array}{c}\text { Depth in } \\
\text { section } \\
\text { (cm) }\end{array}$ & $\begin{array}{c}\text { Depth } \\
\text { (mbsf) }\end{array}$ & $\begin{array}{c}\text { Depth } \\
\text { (mcd) }\end{array}$ \\
\hline $1123 \mathrm{C}-1 \mathrm{H}-5$ & 112 & 7.12 & 7.12 & Tied to & $1123 \mathrm{~B}-2 \mathrm{H}-3$ & 146 & 7.86 & 7.12 \\
$1123 \mathrm{~B}-2 \mathrm{H}-6$ & 92 & 11.82 & 11.08 & Tied to & $1123 \mathrm{C}-2 \mathrm{H}-2$ & 86 & 11.36 & 11.08 \\
$1123 \mathrm{C}-2 \mathrm{H}-5$ & 100 & 16.00 & 15.72 & Tied to & $1123 \mathrm{~B}-3 \mathrm{H}-1$ & 109 & 14.00 & 15.72 \\
$1123 \mathrm{~B}-3 \mathrm{H}-6$ & 88 & 21.28 & 23.00 & Tied to & $1123 \mathrm{C}-3 \mathrm{H}-3$ & 70 & 22.20 & 23.00 \\
$1123 \mathrm{C}-3 \mathrm{H}-6$ & 36 & 26.36 & 27.16 & Tied to & $1123 \mathrm{~B}-4 \mathrm{H}-3$ & 104 & 26.44 & 27.16 \\
$1123 \mathrm{~B}-4 \mathrm{H}-5$ & 132 & 29.72 & 30.44 & Tied to & $1123 \mathrm{C}-4 \mathrm{H}-2$ & 22 & 29.72 & 30.44 \\
$1123 \mathrm{C}-4 \mathrm{H}-6$ & 120 & 36.70 & 37.42 & Tied to & $1123 \mathrm{~B}-5 \mathrm{H}-1$ & 144 & 33.34 & 37.42 \\
$1123 \mathrm{~B}-5 \mathrm{H}-4$ & 140 & 37.80 & 40.70 & Tied to & $1123 \mathrm{C}-5 \mathrm{H}-3$ & 106 & 41.56 & 40.70 \\
$1123 \mathrm{C}-5 \mathrm{H}-6$ & 20 & 45.20 & 44.34 & Tied to & $1123 \mathrm{~B}-6 \mathrm{H}-1$ & 134 & 42.74 & 44.34 \\
$1123 \mathrm{~B}-6 \mathrm{H}-4$ & 60 & 46.50 & 48.10 & Tied to & $1123 \mathrm{C}-6 \mathrm{H}-1$ & 124 & 48.24 & 48.10 \\
$1123 \mathrm{C}-6 \mathrm{H}-6$ & 144 & 55.94 & 55.80 & Tied to & $1123 \mathrm{~B}-7 \mathrm{H}-2$ & 8 & 52.48 & 55.80 \\
$1123 \mathrm{~B}-7 \mathrm{H}-5$ & 96 & 57.86 & 61.18 & Tied to & $1123 \mathrm{C}-7 \mathrm{H}-3$ & 70 & 60.20 \\
\hline
\end{tabular}

Source: Shipboard Scientific Party (1999). 


\section{APPENDIX TWO:}

Analytical TechniQues 


\subsection{Introduction}

The 'Analytical Techniques' section from Chapter Two forms the basis of this appendix. However, this appendix contains additional detail about sample preparation and analytical methods, a comparison of LA-ICP-MS trace element data for a single tephra sample that has also been analysed in another study (Pearce et al., 2008), and step-by-step accounts of the separation of $\mathrm{Sr}, \mathrm{Nd}$, and $\mathrm{Pb}$ from selected Site 1123 tephras for isotopic analysis. These additional details were necessarily omitted from Chapters 2 and 3 to accommodate space restrictions necessary for these chapters to be submitted to the journals Quaternary Science Reviews and the Journal of Petrology, respectively.

\subsection{Microanalytical Techniques}

\subsubsection{Sample preparation}

Volcanic glass was separated from bulk tephra samples and mounted in 'half moon' epoxy resin blocks (Plate 1) for geochemical characterisation by EPMA (major elements) and LA-ICP-MS (trace elements). About 50 tephra samples analysed in this study were provided by Brent Alloway and are allocated the same sample numbers as in Alloway et al. (2005). All other samples analysed in this study were obtained from the Integrated Ocean Drilling Program's Gulf Coast Repository (Texas, USA). These samples were rinsed through a $33 \mu \mathrm{m}$ nylon mesh to remove excess mud. This produced a residue of $80-95 \%$ volcanic glass shards with the remainder comprising variable proportions of feldspar, mafic igneous minerals and carbonate microfossils. The separated glass was then rinsed and decanted several times in ultra-clean water $\left(>18.2 \mathrm{M} \Omega\right.$ ) and left to dry at $50^{\circ} \mathrm{C}$ for $2-3$ days. Only one tephra sample was mounted in each epoxy block to avoid the possibility of intersample contamination during preparation (Plate 1). The epoxy blocks were ground down using 400 - 4000 grit silicon carbide paper to expose the glass shards and then polished using $1 \mu \mathrm{m}$ liquid diamond suspension. A $25 \mathrm{~nm}$ carbon coating was then applied to each sample prior to major element characterisation by EPMA. This carbon coating was removed prior to LA-ICP-MS analysis. 
(a)

Tephra sample In-house obsidian

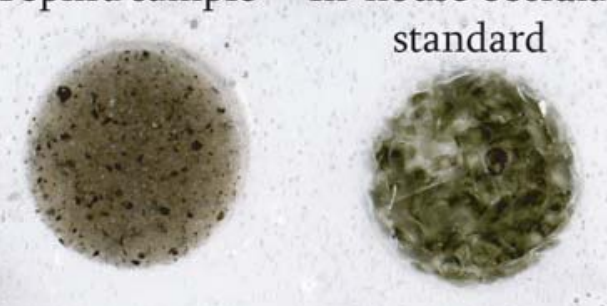

\section{$25 \mathrm{~mm}$}

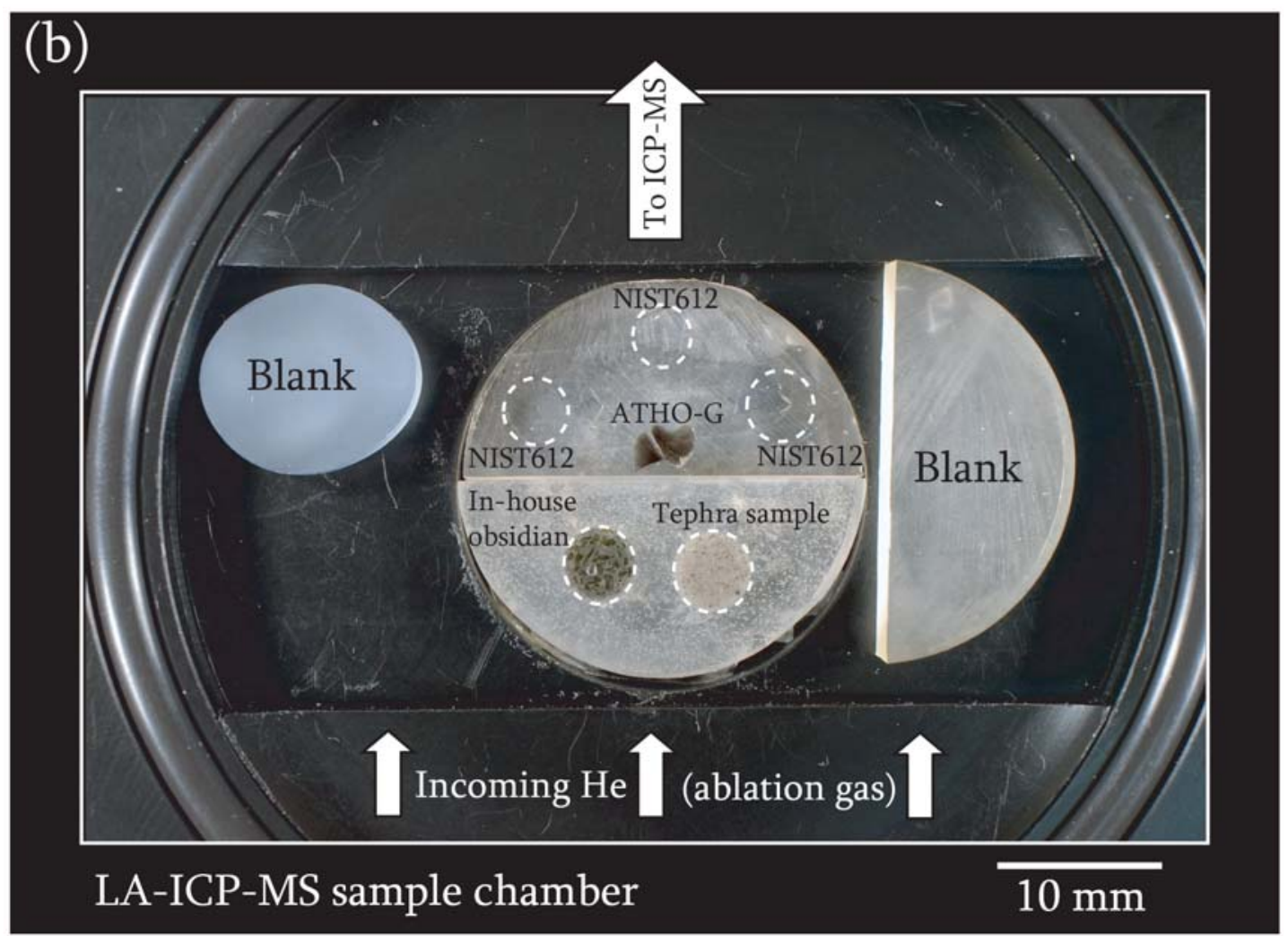

Plate 1(a) Photo of separated volcanic glass shards from a Site 1123 tephra layer mounted in a 'half-moon' epoxy resin block. (Note: the 'in-house obsidian' was initially investigated to be used as a secondary standard to monitor spectrometer drift and the accuracy and precision of EPMA data. Small scale heterogeneity and low elemental concentrations [e.g. $\mathrm{CaO} \sim 0.2 \mathrm{wt}$ \%] in the obsidian meant that it was not suitable for this purpose and thus was not routinely analysed.) (b) Photo demonstrating the positioning of sample and standard blocks in the laser ablation chamber. Placing the 'blank' blocks in the ablation chamber as demonstrated resulted in greater signal stability during tuning of the ICP-MS. 


\subsubsection{Electron probe microanalysis (EPMA)}

The major element composition $\left(\mathrm{SiO}_{2}, \mathrm{TiO}_{2}, \mathrm{Al}_{2} \mathrm{O}_{3}, \mathrm{FeO}, \mathrm{MnO}, \mathrm{MgO}, \mathrm{CaO}, \mathrm{Na}_{2} \mathrm{O}\right.$, $\mathrm{K}_{2} \mathrm{O}$ and $\mathrm{Cl}$ ) of glass shards was determined using a JEOL 733 Superprobe equipped with three wavelength dispersive spectrometers at Victoria University of Wellington, New Zealand. Major element concentrations were determined using the ZAF correction method. Analyses were performed using an accelerating voltage of $15 \mathrm{kV}$ under a static electron beam operating at $8 \mathrm{nA}$. The electron beam was defocused to $20 \mu \mathrm{m}$ and $\mathrm{Na}_{2} \mathrm{O}$ and $\mathrm{K}_{2} \mathrm{O}$ were determined first during each run to minimise the effects of alkali loss that result from analysis under a focused electron beam (Fig. A2-1). All analyses were normalised to $100 \%$ to enable comparison of tephras that may have experienced varying degrees of secondary hydration. The instrument was calibrated daily using a series of natural and synthetic standards: Al, Ti, Fe, Mn and $\mathrm{Mg}$ - synthetic element oxides; $\mathrm{Si}$ and $\mathrm{Ca}$ - wollastonite; $\mathrm{Na}$ - jadeite; $\mathrm{K}$ orthoclase; $\mathrm{Cl}$ - sodalite. The homogeneous reference glasses VG-A99 (basaltic) and ATHO-G (rhyolitic) were analysed between samples to monitor any spectrometer drift and the precision and accuracy of the major element data. Table A2-1 summarises the precision and accuracy of the EPMA data reported in this study. The major element reference values adopted for these standards, and their associated uncertainties, are shown in Table A2-2. A back-scattered electron image of each sample was taken during major element characterisation so that each individual glass shard measured by EPMA could later be analysed for trace elements by LA-ICP-MS (Chapter 1, Fig. 1-7).

\subsubsection{Laser ablation inductively coupled plasma mass spectrometry}

The trace element composition of single shards of volcanic glass was determined using a New Wave deep UV (193 nm solid state) laser ablation system coupled to an Agilent 7500CS ICP-MS at Victoria University of Wellington, New Zealand. Typically thirty-eight minor and trace elements were determined by LA-ICP-MS: Mg, Ti, V, Cr, Mn, Ni, Co, Cu, Zn, Ga, Rb, Sr, Y, Zr, Nb, Mo, Cs, Ba, La, Ce, Pr, $\mathrm{Nd}, \mathrm{Sm}, \mathrm{Eu}, \mathrm{Gd}, \mathrm{Tb}, \mathrm{Dy}, \mathrm{Ho}, \mathrm{Er}, \mathrm{Tm}, \mathrm{Yb}, \mathrm{Lu}, \mathrm{Hf}, \mathrm{Ta}, \mathrm{W}, \mathrm{Pb}$, Th and U. Some of the trace element data acquired in the early stages of this research did not include $\mathrm{Tb}$, Ho 


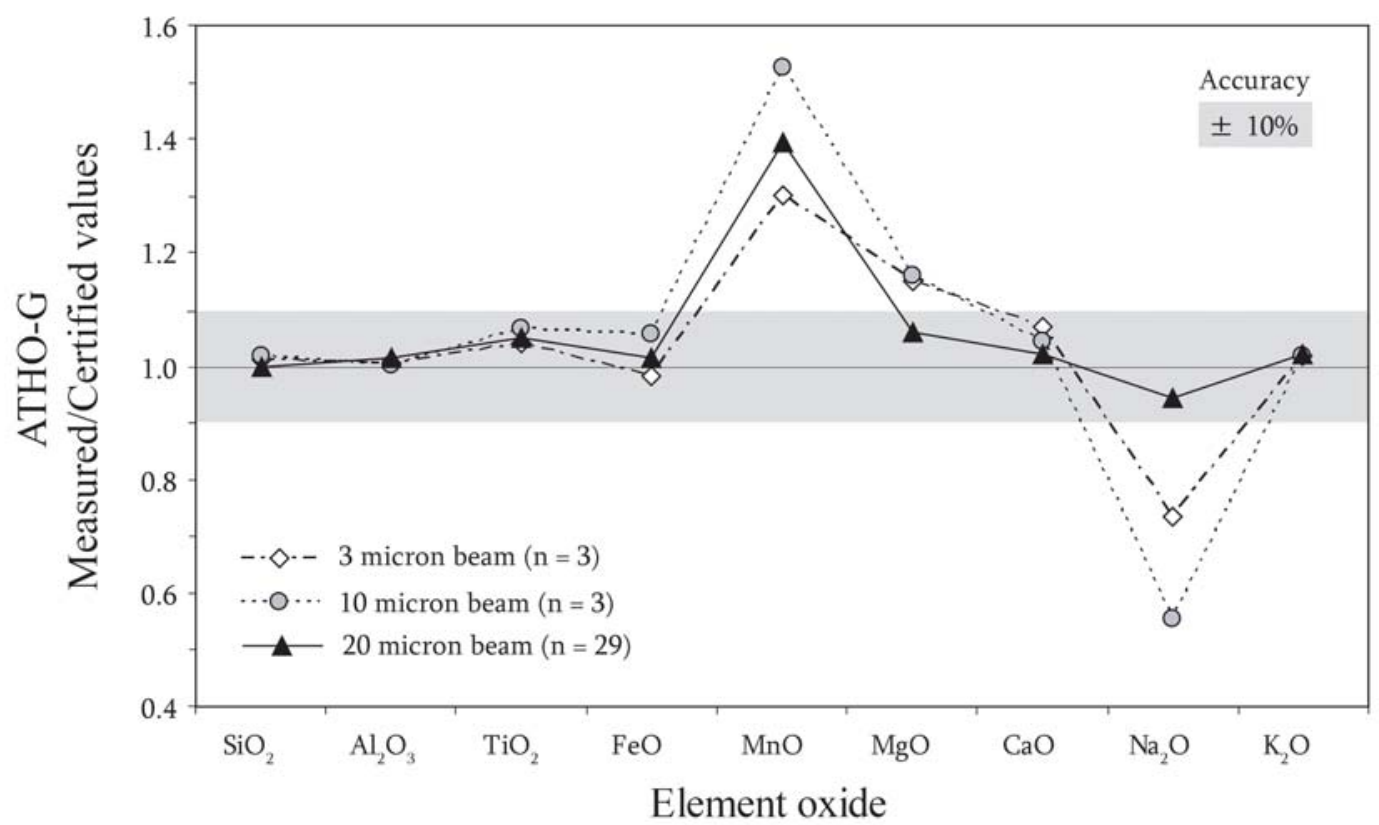

Figure A2-1. An assessment of the severity of alkali loss ( $\mathrm{Na}$ and $\mathrm{K}$ ) caused by different electron beam diameters during EPMA of the Icelandic rhyolite glass standard, ATHO-G. Y-axis represents the mean measured values for ATHO-G normalised to the certified values of Jochum et al. (2006). Analysis under a $3 \mu \mathrm{m}$ or $10 \mu \mathrm{m}$ beam resulted in significant sodium loss. Analysis under a $20 \mu \mathrm{m}$ electron beam resulted in $\mathrm{Na}_{2} \mathrm{O}$ values within $\sim 5 \%$ of the certified value. All tephras investigated in this study were analysed under a $20 \mu \mathrm{m}$ electron beam. Note that while the $\mathrm{MnO}$ abundances determined by EPMA in this study are too high, the Mn (ppm) abundances of glass shards were determined with superior accuracy $(\sim 3 \%)$ and precision $(\sim 3 \%)$ by LA-ICP-MS.

Table A2-1. Electron probe microanalysis data for glass standards

\begin{tabular}{|c|c|c|c|c|c|c|c|c|c|c|}
\hline & \multicolumn{5}{|c|}{ ATHO-G (rhyolitic glass) } & \multicolumn{5}{|c|}{ VG-A99 (basaltic glass) } \\
\hline & Mean $^{2}$ & $2 \mathrm{sd}$ & $\begin{array}{l}\% 2 \text { sd }^{b} \\
\text { precision }\end{array}$ & $\begin{array}{l}\% \text { diff. }^{c} \\
\text { accuracy }\end{array}$ & Recomm $^{d}$ & Mean " & $2 \mathrm{sd}$ & $\begin{array}{l}\% 2 \mathrm{sd}^{\mathrm{b}} \\
\text { precision }\end{array}$ & $\begin{array}{l}\% \text { diff. }^{c} \\
\text { accuracy }\end{array}$ & Recomm ${ }^{d}$ \\
\hline $\mathrm{SiO}_{2}(\mathrm{wt} \%)$ & 75.6 & 1.18 & 1.6 & 0.0 & 75.6 & 50.5 & 1.79 & 3.5 & -0.8 & 50.9 \\
\hline $\mathrm{TiO}_{2}$ & 0.27 & 0.08 & 30 & 3.9 & 0.26 & 4.06 & 0.27 & 6.7 & 0.0 & 4.06 \\
\hline $\mathrm{Al}_{2} \mathrm{O}_{3}$ & 12.4 & 0.45 & 3.6 & 1.6 & 12.2 & 12.5 & 0.51 & 4.1 & 0.0 & 12.5 \\
\hline $\mathrm{FeO}_{t}{ }^{e}$ & 3.32 & 0.34 & 10 & 1.5 & 3.27 & 13.2 & 0.78 & 5.9 & -0.8 & 13.3 \\
\hline $\mathrm{MnO}$ & 0.14 & 0.13 & 93 & 27 & 0.11 & 0.23 & 0.14 & 61 & 53 & 0.15 \\
\hline $\mathrm{MgO}$ & 0.12 & 0.07 & 58 & 20 & 0.10 & 5.19 & 0.26 & 5.0 & 2.2 & 5.08 \\
\hline $\mathrm{CaO}$ & 1.74 & 0.13 & 7.5 & 2.4 & 1.70 & 9.10 & 0.41 & 4.5 & -2.2 & 9.30 \\
\hline $\mathrm{Na}_{2} \mathrm{O}$ & 3.56 & 0.50 & 14 & -5.1 & 3.75 & 2.75 & 0.20 & 7.3 & 3.4 & 2.66 \\
\hline $\mathrm{K}_{2} \mathrm{O}$ & 2.71 & 0.35 & 13 & 2.7 & 2.64 & 0.82 & 0.09 & 11 & 0 & 0.82 \\
\hline $\mathrm{Cl}$ & 0.06 & 0.06 & 98 & 50 & 0.04 & 0.04 & 0.04 & 125 & 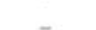 & \\
\hline TOTAL & 99.88 & & & & 99.86 & 98.34 & & & & 98.77 \\
\hline (n) & 29 & & & & & 102 & & & & \\
\hline
\end{tabular}

"Mean of $\mathrm{n}$ analyses (data were not normalised so as to allow comparison with recommended values)

b $\% 2$ sd precision $=(2$ sd $/$ Mean $) \times 100$

$\%$ diff. $=(($ Mean - Recommended $) /$ Recommended $) \times 100$

Recommended values: ATHO-G - Jochum et al. (2006) G-Cubed 7, doi:10.1029/2005GC001060 .: VG-A99 -

Jarosewich et al. (1979) Smithsonian Contributions to the Earth Sciences 22, 68-72.

e All iron calculated as $\mathrm{FeO}$ 
Table A2-2. Reference values for major element glass standards

\begin{tabular}{|c|c|c|c|}
\hline & \multicolumn{2}{|c|}{$\begin{array}{l}\text { Rhyolitic glass } \\
\text { ATHO-G }\end{array}$} & \multirow{2}{*}{$\begin{array}{c}\text { Basaltic glass } \\
\text { VG-A99 } \\
\text { Value* }^{*}\end{array}$} \\
\hline & Value & $\pm 2 \mathrm{SD}$ & \\
\hline $\mathrm{SiO}_{2}$ (wt. \%) & 75.6 & 0.70 & 50.9 \\
\hline $\mathrm{TiO}_{2}$ & 0.255 & 0.016 & 4.06 \\
\hline $\mathrm{Al}_{2} \mathrm{O}_{3}$ & 12.2 & 0.20 & 12.5 \\
\hline $\mathrm{FeO}_{(t)}$ & 3.27 & 0.10 & 13.3 \\
\hline $\mathrm{MnO}$ & 0.106 & 0.005 & 0.15 \\
\hline MgO & 0.103 & 0.01 & 5.08 \\
\hline $\mathrm{CaO}$ & 1.70 & 0.03 & 9.30 \\
\hline $\mathrm{K}_{2} \mathrm{O}$ & 2.64 & 0.09 & 2.66 \\
\hline $\mathrm{Na}_{2} \mathrm{O}$ & 3.75 & 0.31 & 0.82 \\
\hline $\mathrm{Cl}$ & $0.043^{\#}$ & . & \\
\hline Total & 99.624 & & 98.77 \\
\hline \multicolumn{4}{|c|}{ * No uncertainties given for VG-A99 } \\
\hline \multicolumn{4}{|c|}{$\begin{array}{l}\text { Print error in original publication - now considered an information value onl } \\
\text { ATHO-G values from Jochum et al. (2006) }\end{array}$} \\
\hline G-A99 values & & 979) & \\
\hline
\end{tabular}

and Tm. All data were acquired as static spot analyses using a laser beam diameter of 25 or $35 \mu \mathrm{m}$. Helium was used as an ablation gas to more efficiently transfer the sample aerosol from the ablation chamber to the ICP-MS and this provided a 2-3 fold increase in signal intensity and a reduction in background intensity across the entire mass range (c.f. Eggins et al., 1998) as compared to using argon as the ablation gas. The carbon coating from EPMA characterisation was removed prior to LA-ICP-MS analysis by cleaning in AR grade methanol and ultra-clean water ( $>18.2 \mathrm{M} \Omega$ ). Placing the cleaned sample blocks in an oven at $80^{\circ} \mathrm{C}$ for $\sim 15$ minutes ensured any moisture filled voids in the epoxy resin and/or vesicular glass shards were evaporated prior to analysis and resulted in a noticeable reduction of background signal intensities (particularly for ${ }^{43} \mathrm{Ca}$ ) and a further decrease in oxide productivity (monitored by $\mathrm{ThO}+/ \mathrm{Th}+$ ) during LA-ICP-MS analysis. The sample and standard mounts were loaded into the laser ablation sample chamber as shown in Plate 1. This configuration, with two 'blank' mounts positioned as shown, resulted in greater signal stability during tuning of the ICP-MS. This is probably due to a reduction in the volume of the ablation chamber which enhances the efficiency of flow of the ablation gas $(\mathrm{He})$ through the cell. A summary of LA-ICP-MS analytical parameters is presented in Chapter 2, Table 2-1.

The LA-ICP-MS data acquisition technique employed here follows that of Pearce et al. (1996) where a minor isotope of a major element (here ${ }^{43} \mathrm{Ca}$ ), previously 
determined by EPMA, is included in the ICP-MS analysis and used as an internal standard. Analyses of the sample are bracketed by analyses of a homogeneous reference material (NIST 612) so that (after corrections for backgrounds) the trace element concentration of element $\mathrm{x}$ in a tephra glass shard is determined by the relationships:

$$
\begin{aligned}
& \mathrm{C}_{\text {tephra }}^{\mathrm{CaO}, \text { ICP-MS }}=\mathrm{C}_{\text {std }}^{\mathrm{CaO}} \times\left(\mathrm{CPS}_{\text {tephra }}^{\mathrm{Ca}} / \mathrm{CPS}_{\text {sdd }}^{\mathrm{Ca}}\right) \\
& \mathrm{C}_{\text {tephra }}^{\mathrm{x} \text { ICP-MS }}=\mathrm{C}_{\text {std }}^{\mathrm{x}} \times\left(\mathrm{C}_{\text {tephra }}^{\mathrm{CaO}, \mathrm{EPMA}} / \mathrm{C}_{\text {tephra }}^{\mathrm{C} a \mathrm{I}, \mathrm{ICP}-\mathrm{MS}}\right) \times\left(\mathrm{CPS}_{\text {tephra }}^{\mathrm{x}} / \mathrm{CPS}_{\text {std }}^{\mathrm{x}}\right)
\end{aligned}
$$

$\mathrm{C}_{\text {tephra }}^{\text {Cao,ICP-MS }}, \mathrm{C}_{\text {tephra }}^{\text {Caa,EPMA }}=$ concentration of Ca determined by LA-ICP-MS or EPMA $\mathrm{C}_{\text {std }}^{\mathrm{caO}}=$ reference $\mathrm{CaO}$ concentration of the NIST612 standard $\mathrm{CPS}_{\text {tpphra }}^{\mathrm{Ca}}, \mathrm{CPS}_{\text {std }}^{\mathrm{Ca}}=$ counts per second obtained on ${ }^{43} \mathrm{Ca}$ whilst ablating the tephra glass shard (tephra) or standard (std)

$\mathrm{C}_{\mathrm{tephra}}^{\mathrm{x}, \mathrm{CP}-\mathrm{MS}}=$ concentration of element $\mathrm{x}$ determined by LA-ICP-MS

$\mathrm{C}_{\mathrm{std}}^{\mathrm{x}}=$ reference concentration of element $\mathrm{x}$ in the standard NIST612

$\mathrm{CPS}_{\text {tephra }}^{\mathrm{x}}, \mathrm{CPS}_{\mathrm{std}}^{\mathrm{x}}=$ counts per second obtained on an isotope of element $\mathrm{x}$ whilst ablating the tephra glass shard (tephra) or standard (std)

In order for this method to accurately determine the trace element abundances in the sample, it is ideal for the calibration standard (reference material) to have a matrix composition similar to that of the sample. A poor choice of calibration standard may produce differential elemental fractionation in the standard and sample (matrix effects) during the analysis resulting in inaccurate data. The exact causes of elemental fractionation during LA-ICP-MS analyses and the location at which this occurs have been widely studied and variously attributed to either the laser ablation process itself, aerosol transport processes and incomplete ionisation of large particles within the plasma, or various combinations thereof (e.g. Eggins et al., 1998; Guillong and Günther, 2002; Rodushkin et al., 2002; Horn and Günther, 2003; Kroslakova and Günther, 2007).

Tests conducted in the early stages of this research have shown that the synthetic NIST612 glass standard is suitably matrix-matched for the analysis rhyolite glasses. When NIST612 is used was a calibration standard for analyses the rhyolite standard ATHO-G the certified values of ATHO-G were typically reproduced with an accuracy of $< \pm 5 \%$ (Fig. A2-2). In contrast when the basaltic glass standard BCR- 
$2 \mathrm{G}$ was used as a calibration standard the accuracy was noticeably poorer $(\sim \pm 5$ 10\%) (Fig. A2-2). Following the results of these experiments we use NIST612 as the calibration standard for calculating all trace element abundances of the rhyolitic glasses analysed in this study. Between 3 and 5 spot analyses of the MPI-DING rhyolite glass standard (ATHO-G) were performed at least once a day during sample data acquisition to monitor the precision and accuracy of the trace element data for the Site 1123 tephra samples (Table A2-3). All analyte isotopes (Chapter 2, Table 21) were chosen so that they were least affected by potential direct, oxide and doublycharged mass interferences, and $\mathrm{ThO}+/ \mathrm{Th}+$ was maintained at $<2 \%$ for all analyses (typically $<1 \%$ ). Data acquired for every element from all LA-ICP-MS analyses in this dataset have been screened to remove analyses that were compromised by the accidental ablation of micro-phenocrysts below the glass surface (e.g. Harangi et al., 2005 ) to ensure that only data corresponding to pure glass shard material was integrated when calculating trace element abundances.

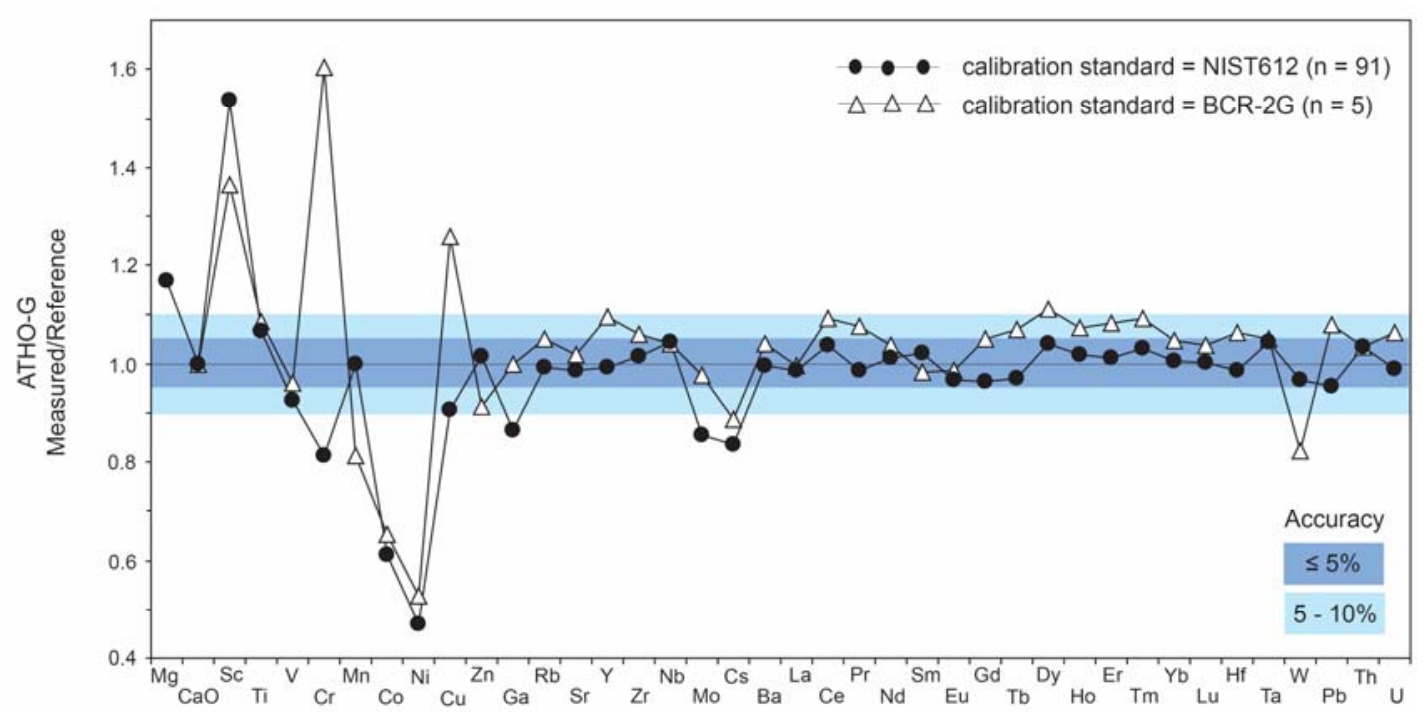

Figure A2-2. An example of the accuracy of LA-ICP-MS trace element data when well suited (NIST612; synthetic calcium-aluminium-silicate glass) and poorly suited (BCR-2G; basaltic glass) calibration standards are employed. Yaxis represents the mean measured values for ATHO-G normalised to the certified values of Jochum et al. (2006). This figure demonstrates that successful matrix-matching of the calibration standard and 'sample' (here ATHO-G) results in superior accuracy of LA-ICP-MS trace element data. When a suitably matrix-matched calibration standard is used, i.e. NIST612 for ATHO-G, the majority of elements are reproduced to within $\pm 5 \%$ of the certified values. When a poorly matrix-matched calibration standard is used, i.e. BCR-2G for ATHO-G, the accuracy is considerably poorer (e.g., $\sim 5 \%$ to $>10 \%$ for $\mathrm{Ce}$ to $U$ ). 
Table A2-3. Day-to-day accuracy and precision of laser ablation inductively coupled plasma mass spectrometry data

\begin{tabular}{|c|c|c|c|c|c|}
\hline & $\begin{array}{l}\text { ATHO-G }{ }^{a} \\
\text { Recomm. }\end{array}$ & $\begin{array}{c}\text { Mean }^{b} \\
n=5\end{array}$ & $2 \mathrm{sd}$ & $\begin{array}{c}\% 2 \mathrm{sd} \\
\text { precision }^{\mathrm{e}}\end{array}$ & $\begin{array}{c}\% \text { difference } \\
\text { accuracy }\end{array}$ \\
\hline $\mathrm{Mg}$ (ppm) & 621 & 761 & 14.4 & 1.9 & 22 \\
\hline $\mathrm{Ti}$ & 1529 & 1864 & 24.0 & 1.3 & 22 \\
\hline v & 3.91 & 4.00 & 0.29 & 7.1 & 2.2 \\
\hline $\mathrm{Cr}$ & 6.10 & 4.84 & 4.75 & 98 & -21 \\
\hline Mn & 821 & 857 & 26.4 & 3.1 & 4.4 \\
\hline Co & 2.13 & 1.29 & 0.21 & 16 & -39 \\
\hline $\mathrm{Ni}$ & 13.0 & 5.63 & 1.12 & 20 & -57 \\
\hline $\mathrm{Cu}$ & 18.6 & 17.7 & 0.50 & 2.8 & -4.7 \\
\hline $\mathrm{Zn}$ & 141 & 154 & 7.42 & 4.8 & 9.4 \\
\hline $\mathrm{Ga}$ & 25.3 & $\mathrm{n} / \mathrm{a}$ & & & \\
\hline $\mathbf{R b}$ & 65.3 & 69.5 & 4.15 & 6.0 & 6.4 \\
\hline $\mathrm{Sr}$ & 94.1 & 93.9 & 3.96 & 4.2 & -0.2 \\
\hline $\mathrm{Y}$ & 94.5 & 94.2 & 3.93 & 4.2 & -0.3 \\
\hline $\mathrm{Zr}$ & 512 & 512 & 21.0 & 4.1 & 0.1 \\
\hline Nb & 62.4 & 71.1 & 2.31 & 3.2 & 14 \\
\hline Mo & 4.80 & 4.95 & 1.39 & 28 & 3.1 \\
\hline Cs & 1.08 & 0.94 & 0.14 & 15 & -13 \\
\hline $\mathrm{Ba}$ & 559 & 553 & 26.1 & 4.7 & -1.0 \\
\hline La & 55.6 & 54.0 & 2.02 & 3.7 & -2.8 \\
\hline $\mathrm{Ce}$ & 121 & 128 & 6.82 & 5.3 & 5.9 \\
\hline $\mathrm{Pr}$ & 14.6 & 14.5 & 0.66 & 4.5 & -0.8 \\
\hline Nd & 60.9 & 62.1 & 3.64 & 5.9 & 1.9 \\
\hline Sm & 14.2 & 14.3 & 1.30 & 9.1 & 1.0 \\
\hline Eu & 2.76 & 2.75 & 0.16 & 6.0 & -0.4 \\
\hline Gd & 15.3 & 14.5 & 0.69 & 4.7 & -5.3 \\
\hline $\mathrm{Tb}$ & 2.51 & 2.37 & 0.17 & 7.3 & -5.4 \\
\hline Dy & 16.2 & 16.9 & 0.60 & 3.5 & 4.3 \\
\hline Ho & 3.43 & 3.52 & 0.20 & 5.6 & 2.5 \\
\hline Er & 10.3 & 10.5 & 0.58 & 5.5 & 2.0 \\
\hline $\mathrm{Tm}$ & 1.52 & 1.55 & 0.15 & 9.6 & 2.1 \\
\hline $\mathrm{Yb}$ & 10.5 & 11.0 & 0.36 & 3.3 & 4.9 \\
\hline Lu & 1.54 & 1.54 & 0.21 & 14 & -0.2 \\
\hline $\mathrm{Hf}$ & 13.7 & 13.7 & 0.86 & 6.3 & 0.0 \\
\hline $\mathrm{Ta}$ & 3.90 & 4.13 & 0.19 & 4.7 & 5.9 \\
\hline w & 9.30 & 9.09 & 0.62 & 6.8 & -2.3 \\
\hline $\mathbf{P b}$ & 5.67 & 5.78 & 0.59 & 10 & 1.9 \\
\hline Th & 7.40 & 7.68 & 0.40 & 5.2 & 3.7 \\
\hline $\mathbf{U}$ & 2.37 & 2.53 & 0.12 & 4.8 & 6.7 \\
\hline $\mathrm{Rb} / \mathrm{Sr}$ & 0.69 & 0.74 & 0.04 & 5.7 & 6.7 \\
\hline $\mathrm{Sr} / \mathrm{Y}$ & 1.00 & 1.00 & 0.03 & 3.2 & 0.1 \\
\hline $\mathrm{Zr} / \mathrm{Th}$ & 69.2 & 66.8 & 1.97 & 2.9 & -3.5 \\
\hline $\mathbf{E} \mathbf{u} / \mathbf{E} \mathbf{u}^{*}$ & 0.57 & 0.58 & 0.05 & 8.1 & 2.0 \\
\hline $\mathrm{Rb} / \mathrm{Sm}$ & 4.60 & 4.85 & 0.28 & 5.8 & 5.5 \\
\hline $\mathbf{Z r} / \mathbf{Y}$ & 5.42 & 5.44 & 0.17 & 3.1 & 0.4 \\
\hline $\mathrm{Ba} / \mathrm{Sr}$ & 5.94 & 5.90 & 0.26 & 4.3 & -0.8 \\
\hline $\mathrm{Nb} / \mathrm{Pb}$ & 11.0 & 12.3 & 1.03 & 8.4 & 12 \\
\hline $\mathbf{L a} / \mathbf{Y b}$ & 5.30 & 4.91 & 0.16 & 3.3 & -7.3 \\
\hline Dy/Yb & 1.54 & 1.53 & 0.06 & 4.0 & -0.5 \\
\hline $\mathrm{Ba} / \mathrm{Th}$ & 75.5 & 72.1 & 4.32 & 6.0 & -4.5 \\
\hline
\end{tabular}


Table A2-3 continued

\begin{tabular}{|c|c|c|c|c|c|}
\hline & $\begin{array}{l}\text { ATHO-G a } \\
\text { Recomm. }\end{array}$ & $\begin{array}{c}\text { Mean }^{c} \\
n=3\end{array}$ & $2 \mathrm{sd}$ & $\begin{array}{c}\% 2 \mathrm{sd} \\
\text { precision }^{2}\end{array}$ & $\begin{array}{c}\% \text { difference } \\
\text { accuracy }\end{array}$ \\
\hline $\mathrm{Mg}(\mathrm{ppm})$ & 621 & 741 & 9.73 & 1.3 & 19 \\
\hline $\mathrm{Ti}$ & 1529 & 1759 & 70.2 & 4.0 & 15 \\
\hline V & 3.91 & 3.74 & 0.49 & 13 & -4.3 \\
\hline $\mathrm{Cr}$ & 6.10 & 5.13 & 4.69 & 91 & -16 \\
\hline Mn & 821 & 843 & 17.3 & 2.1 & 2.7 \\
\hline Co & 2.13 & 1.23 & 0.45 & 36 & -42 \\
\hline $\mathrm{Ni}$ & 13.0 & 5.62 & 0.45 & 8.0 & -57 \\
\hline $\mathrm{Cu}$ & 18.6 & 17.6 & 1.65 & 9.4 & -5.2 \\
\hline $\mathrm{Zn}$ & 141 & 133 & 7.58 & 5.7 & -5.6 \\
\hline Ga & 25.3 & 21.7 & 1.00 & 4.6 & -14 \\
\hline $\mathbf{R b}$ & 65.3 & 65.4 & 2.71 & 4.1 & 0.2 \\
\hline $\mathrm{Sr}$ & 94.1 & 92.3 & 1.70 & 1.8 & -1.9 \\
\hline $\mathbf{Y}$ & 94.5 & 95.7 & 3.89 & 4.1 & 1.2 \\
\hline $\mathrm{Zr}$ & 512 & 540 & 18.7 & 3.5 & 5.4 \\
\hline $\mathrm{Nb}$ & 62.4 & 70.0 & 0.37 & 0.5 & 12 \\
\hline Mo & 4.80 & 4.17 & 0.59 & 14 & -13 \\
\hline Cs & 1.08 & 0.92 & 0.02 & 2.4 & -15 \\
\hline $\mathrm{Ba}$ & 559 & 560 & 9.40 & 1.7 & 0.1 \\
\hline La & 55.6 & 56.2 & 2.24 & 4.0 & 1.1 \\
\hline $\mathrm{Ce}$ & 121 & 126 & 3.99 & 3.2 & 3.9 \\
\hline $\mathrm{Pr}$ & 14.6 & 14.5 & 0.74 & 5.1 & -0.8 \\
\hline Nd & 60.9 & 63.3 & 2.15 & 3.4 & 3.9 \\
\hline $\mathrm{Sm}$ & 14.2 & 14.6 & 1.12 & 7.7 & 2.6 \\
\hline Eu & 2.76 & 2.85 & 0.11 & 4.0 & 3.4 \\
\hline Gd & 15.3 & 15.3 & 1.18 & 7.7 & 0.3 \\
\hline Tb & 2.51 & 2.50 & 0.25 & 10 & -0.6 \\
\hline Dy & 16.2 & 17.6 & 0.88 & 5.0 & 8.8 \\
\hline Ho & 3.43 & 3.54 & 0.37 & 11 & 3.1 \\
\hline Er & 10.3 & 10.9 & 0.64 & 5.8 & 5.7 \\
\hline $\mathrm{Tm}$ & 1.52 & 1.60 & 0.08 & 5.0 & 5.1 \\
\hline $\mathrm{Yb}$ & 10.5 & 11.0 & 0.44 & 4.0 & 5.2 \\
\hline $\mathbf{L u}$ & 1.54 & 1.65 & 0.12 & 7.1 & 7.3 \\
\hline Hf & 13.7 & 14.2 & 1.14 & 8.1 & 3.3 \\
\hline $\mathrm{Ta}$ & 3.90 & 4.24 & 0.35 & 8.3 & 8.6 \\
\hline w & 9.30 & 8.87 & 0.23 & 2.6 & -4.6 \\
\hline $\mathbf{P b}$ & 5.67 & 5.61 & 0.04 & 0.7 & -1.0 \\
\hline Th & 7.40 & 7.88 & 0.41 & 5.2 & 6.5 \\
\hline $\mathbf{U}$ & 2.37 & 2.40 & 0.14 & 5.8 & 1.4 \\
\hline $\mathrm{Rb} / \mathrm{Sr}$ & 0.69 & 0.71 & 0.02 & 2.4 & 2.1 \\
\hline $\mathrm{Sr} / \mathrm{Y}$ & 1.00 & 0.97 & 0.05 & 4.9 & -3.0 \\
\hline $\mathrm{Zr} / \mathrm{Th}$ & 69.2 & 68.5 & 3.88 & 5.7 & -1.0 \\
\hline $\mathbf{E u} / \mathbf{E} \mathbf{u}^{*}$ & 0.57 & 0.58 & 0.06 & 11 & 2.1 \\
\hline $\mathrm{Rb} / \mathrm{Sm}$ & 4.60 & 4.50 & 0.44 & 9.9 & -2.2 \\
\hline $\mathrm{Zr} / \mathrm{Y}$ & 5.42 & 5.64 & 0.16 & 2.9 & 4.1 \\
\hline $\mathrm{Ba} / \mathrm{Sr}$ & 5.94 & 6.06 & 0.08 & 1.4 & 2.1 \\
\hline $\mathrm{Nb} / \mathrm{Pb}$ & 11.0 & 12.5 & 0.09 & 0.7 & 13 \\
\hline $\mathrm{La} / \mathrm{Yb}$ & 5.30 & 5.09 & 0.16 & 3.2 & -3.9 \\
\hline Dy/Yb & 1.54 & 1.60 & 0.07 & 4.7 & 3.5 \\
\hline $\mathrm{Ba} / \mathrm{Th}$ & 75.5 & 71.1 & 3.26 & 4.6 & -5.9 \\
\hline
\end{tabular}


Table A2-3 continued

\begin{tabular}{|c|c|c|c|c|c|}
\hline & $\begin{array}{l}\text { ATHO-G }{ }^{a} \\
\text { Recomm. }\end{array}$ & $\begin{array}{c}\text { Mean }^{d} \\
n=4\end{array}$ & $2 \mathrm{sd}$ & $\begin{array}{c}\% 2 \mathrm{sd} \\
\text { precision }^{\mathrm{e}}\end{array}$ & $\begin{array}{c}\% \text { difference } \\
\text { accuracy }^{\mathrm{f}}\end{array}$ \\
\hline $\mathrm{Mg}(\mathrm{ppm})$ & 621 & 709 & 7.41 & 1.0 & 14 \\
\hline $\mathrm{Ti}$ & 1529 & 1576 & 35.5 & 2.3 & 3.1 \\
\hline V & 3.91 & 3.67 & 0.19 & 5.3 & -6.1 \\
\hline $\mathrm{Cr}$ & 6.10 & 3.38 & 2.35 & 70 & -45 \\
\hline Mn & 821 & 821 & 29.4 & 3.6 & 0.0 \\
\hline Co & 2.13 & 1.29 & 0.15 & 12 & -40 \\
\hline $\mathrm{Ni}$ & 13.0 & 5.81 & 0.42 & 7.2 & -55 \\
\hline $\mathrm{Cu}$ & 18.6 & 17.3 & 0.62 & 3.6 & -6.8 \\
\hline $\mathrm{Zn}$ & 141 & 150 & 4.13 & 2.7 & 6.7 \\
\hline $\mathrm{Ga}$ & 25.3 & 22.6 & 0.60 & 2.7 & -11 \\
\hline $\mathbf{R b}$ & 65.3 & 65.5 & 2.72 & 4.2 & 0.2 \\
\hline $\mathrm{Sr}$ & 94.1 & 91.4 & 2.55 & 2.8 & -2.9 \\
\hline $\mathbf{Y}$ & 94.5 & 87.2 & 2.25 & 2.6 & -7.8 \\
\hline $\mathrm{Zr}$ & 512 & 495 & 18.5 & 3.7 & -3.3 \\
\hline $\mathrm{Nb}$ & 62.4 & 64.8 & 2.28 & 3.5 & 3.8 \\
\hline Mo & 4.80 & 4.23 & 0.42 & 9.9 & -12 \\
\hline Cs & 1.08 & 0.88 & 0.10 & 12 & -18 \\
\hline $\mathbf{B a}$ & 559 & 552 & 17.1 & 3.1 & -1.3 \\
\hline $\mathbf{L a}$ & 55.6 & 53.1 & 1.97 & 3.7 & -4.5 \\
\hline $\mathrm{Ce}$ & 121 & 124 & 3.68 & 3.0 & 2.6 \\
\hline $\mathrm{Pr}$ & 14.6 & 14.2 & 0.10 & 0.7 & -3.0 \\
\hline Nd & 60.9 & 60.1 & 0.33 & 0.5 & -1.3 \\
\hline Sm & 14.2 & 13.9 & 0.30 & 2.2 & -2.4 \\
\hline Eu & 2.76 & 2.61 & 0.18 & 6.9 & -5.5 \\
\hline Gd & 15.3 & 14.1 & 1.06 & 7.5 & -7.7 \\
\hline $\mathbf{T b}$ & 2.51 & 2.29 & 0.09 & 3.8 & -8.7 \\
\hline Dy & 16.2 & 15.5 & 0.67 & 4.3 & -4.3 \\
\hline Ho & 3.43 & 3.32 & 0.10 & 3.1 & -3.3 \\
\hline Er & 10.3 & 9.87 & 0.56 & 5.7 & -4.1 \\
\hline $\mathrm{Tm}$ & 1.52 & 1.48 & 0.08 & 5.4 & -2.8 \\
\hline $\mathrm{Yb}$ & 10.5 & 10.1 & 0.46 & 4.6 & -4.0 \\
\hline Lu & 1.54 & 1.46 & 0.05 & 3.1 & -5.2 \\
\hline Hf & 13.7 & 12.5 & 0.44 & 3.5 & -8.9 \\
\hline Ta & 3.90 & 3.98 & 0.02 & 0.5 & 1.9 \\
\hline w & 9.30 & 9.52 & 0.46 & 4.9 & 2.4 \\
\hline $\mathrm{Pb}$ & 5.67 & 5.58 & 0.14 & 2.5 & -1.5 \\
\hline Th & 7.40 & 7.26 & 0.24 & 3.3 & -2.0 \\
\hline $\mathbf{U}$ & 2.37 & 2.38 & 0.12 & 5.0 & 0.6 \\
\hline $\mathrm{Rb} / \mathrm{Sr}$ & 0.69 & 0.72 & 0.02 & 2.1 & 3.2 \\
\hline $\mathrm{Sr} / \mathrm{Y}$ & 1.00 & 1.05 & 0.02 & 1.5 & 5.3 \\
\hline $\mathrm{Zr} / \mathrm{Th}$ & 69.2 & 68.2 & 3.98 & 5.8 & -1.4 \\
\hline $\mathbf{E u} / \mathbf{E} \mathbf{u}^{*}$ & 0.57 & 0.57 & 0.02 & 3.8 & -0.4 \\
\hline $\mathrm{Rb} / \mathrm{Sm}$ & 4.60 & 4.72 & 0.14 & 2.9 & 2.7 \\
\hline $\mathrm{Zr} / \mathrm{Y}$ & 5.42 & 5.68 & 0.07 & 1.3 & 4.8 \\
\hline $\mathrm{Ba} / \mathrm{Sr}$ & 5.94 & 6.04 & 0.14 & 2.3 & 1.6 \\
\hline $\mathrm{Nb} / \mathrm{Pb}$ & 11.0 & 11.6 & 0.33 & 2.8 & 5.4 \\
\hline $\mathrm{La} / \mathrm{Yb}$ & 5.30 & 5.27 & 0.23 & 4.3 & -0.5 \\
\hline Dy/Yb & 1.54 & 1.54 & 0.06 & 3.8 & -0.3 \\
\hline $\mathrm{Ba} / \mathrm{Th}$ & 75.5 & 76.1 & 3.15 & 4.1 & 0.7 \\
\hline
\end{tabular}


Table A2-3.

${ }^{a}$ Recommended values for ATHO-G from Jochum et al. (2006) Geochemistry Geophysics Geosystems 7, Q02008, doi:10.1029/2005GC001060.

${ }^{\mathrm{b}}$ Analyses performed on $9 / 09 / 07$

${ }^{\mathrm{c}}$ Analyses performed on 3/12/07

${ }^{\mathrm{d}}$ Analyses performed on 29/10/07

${ }^{\mathrm{e}}$ Precision $=(2 \mathrm{sd} /$ Mean $) \times 100$

${ }^{\mathrm{f}}$ Accuracy $=(($ Mean $/$ Recomm. $) /$ Recomm. $) \times 100$

\subsubsection{Precision and accuracy of major and trace element data}

The precision and accuracy of both analytical techniques is discussed here by reference to the glass standards analysed in this study (Tables A2-1 and A2-3). The basaltic glass VG-A99 yielded major element concentrations that, with the exception of $\mathrm{MnO}$, agreed to within $\pm 4 \%$ of the recommended reference values (Jarosewich et al., 1979). The rhyolitic glass ATHO-G reproduced to within $\pm 6 \%$ of the certified values (Jochum et al., 2006) with the exception of the low concentration elements $\mathrm{MgO}(+12 \%), \mathrm{MnO}(+35 \%)$ and $\mathrm{Cl}(-50 \%)$. However, Mn concentrations of the glasses were also determined by LA-ICP-MS at much greater precision and accuracy than the EPMA measurements. The day-to-day precision of EPMA measurements based on repeated analyses $(\mathrm{n}=29)$ of ATHO-G were: $\mathrm{SiO}_{2}, \pm 1.6 \% ; \mathrm{Al}_{2} \mathrm{O}_{3}, \pm 3.6 \%$; $\mathrm{CaO}, \mathrm{FeO}, \mathrm{K}_{2} \mathrm{O}$ and $\mathrm{Na}_{2} \mathrm{O}, \pm 8-15 \% ; \mathrm{TiO}_{2} \pm 30 \% ; \mathrm{MgO}, \mathrm{MnO}$, and $\mathrm{Cl} \pm 50-90 \%$ (2 sd relative).

The rhyolitic glass standard ATHO-G was also repeatedly measured by LA-ICP-MS to monitor the accuracy and precision of the trace element data acquired throughout this study. ATHO-G and chips of NIST612 (calibration standard) were mounted in the same epoxy block midway through this study so that data from the secondary standard (ATHO-G) could be acquired under the exact same conditions as the sample. The mean ( $\mathrm{n}=91)$ abundances of Ti, Mn, Zn, Rb, Sr, Y, Zr, Nb, Ba, La, Ce, Pr, Nd, Sm, Eu, Gd, Tb, Dy, Ho, Er, Tm, Yb, Lu, Hf, Ta, W, Pb, Th and U are within \pm ca. $5 \%$ of the certified values (Jochum et al., 2006) (Chapter 2, Fig. 2-2). The mean values determined for $\mathrm{V}$ and $\mathrm{Cu}$ are ca. 10\% lower than the Jochum et al. (2006) values, whereas $\mathrm{Cr}, \mathrm{Ga}$, Mo and $\mathrm{Cs}$ are lower by ca. $15-20 \%$, and $\mathrm{Mg}$ is higher by ca. $15 \%$. The values of $\mathrm{Co}$ and $\mathrm{Ni}$ were significantly lower than certified values (Jochum et al., 2006) by ca. 40-50\% respectively. The deviations from the recommended values for these relatively low concentration elements $(\mathrm{Mg}, \mathrm{V}, \mathrm{Cr}, \mathrm{Co}, \mathrm{Ni}, \mathrm{Cu}, \mathrm{Ga}$, 
Mo, Cs) may be due to a number of factors: (a) the reference values for these elements in either ATHO-G or NIST612 (calibration standard) may be incorrect and poorly constrained; (b) mass interferences on the analyte isotopes in the NIST612 standard may be resulting in inaccurate data, (c) the signal intensity for an element may be small compared to background intensity (e.g. Co, Ni). For example, a significant part of the discrepancy $(\sim 17 \%)$ between the mean $\mathrm{Mg}$ concentration determined for ATHO-G and the recommended value (Jochum et al., 2006) is likely to be due to the utilised reference concentration of $\mathrm{Mg}$ in NIST612, which has a large uncertainty (77 \pm 60 ppm, 2 sd; Pearce et al., 1997), being 10-20\% too high. Also note that both $\mathrm{Co}$ and $\mathrm{Ni}$ values for ATHO-G were routinely determined to be $\sim 40 \%$ lower and $\sim 50 \%$ lower, respectively, than the reference values regardless of whether NIST612 or BCR-2G was used as the calibration standard. This suggests that the reference values for Co and Ni in ATHO-G may be $\sim 40 \%$ to $50 \%$ too high. The dayto-day precision of LA-ICP-MS trace element data was typically \pm ca. $6 \%$ ( $\% 2 \mathrm{sd}$ relative) for most elements of interest ( $\mathrm{Mg}, \mathrm{Ti}, \mathrm{Mn}, \mathrm{Ga}, \mathrm{Rb}, \mathrm{Sr}, \mathrm{Y}, \mathrm{Zr}, \mathrm{Nb}, \mathrm{Ba}$, rare earth elements [REE], Hf, Ta, $\mathrm{Pb}, \mathrm{Th}, \mathrm{U})$. The reproducibility of low concentration elements (e.g. V, Ni, Cr, Co, Cu, Cs, Mo, W) and volatile elements (e.g. Zn) varied more widely (V, Cs and W typically $10-15 \%$; Ni, Cu, Co, and Mo typically 15-30\%; Cr typically $\sim 80 \%$ ) from day-to-day and these elements were generally not used for the correlation of the tephra layers.

\subsubsection{Comparison to existing LA-ICP-MS trace element data of TVZ tephras}

At the time of writing this thesis there are only two examples of published single glass shard LA-ICP-MS trace element data for New Zealand tephras; Shane et al. (1998) and Pearce et al. (2008). Shane et al. (1998) analysed a number of 7-9 Myr old tephras sourced from the now extinct Coromandel Volcanic Zone and thus does not allow for a comparison to data from this study. However, a single tephra sample analysed by Pearce et al. (2008) was also collected and characterised by EPMA and LA-ICP-MS here, allowing a direct comparison of the Pearce et al. (2008) data to that of this study.

The tephra analysed both here and by Pearce et al. (2008) is informally known as the Lower Te Muna (LTM) tephra and is preserved in the Huangarua River Section in the Te Muna field area, Southern Wairarapa (Shane et al., 1996). The LTM tephra 
has been demonstrated to be a correlative to the widespread ( $\sim 1.0 \mathrm{Ma})$ Potaka

Tephra (Shane et al., 1996), the pyroclastic fall deposit corresponding to the eruption of the Kidnappers Ignimbrite from Mangakino Caldera (Wilson et al., 1995b). The major and trace element data for the LTM tephra from this study and that of Pearce et al. (2008) are summarised in Tables A2-4 and A2-5, respectively. Data acquired for sample AT-338 from Site 1123, which is correlated to the Potaka/LTM tephra in this study, is also shown.

Table A2-4. A comparison of the major element glass composition of the Potaka Tephra

\begin{tabular}{|c|c|c|c|c|c|c|}
\hline & $\begin{array}{l}\Gamma-338 \text { ( } \\
\text { his stud }\end{array}$ & 1123) & $\begin{array}{l}\text { Lower T } \\
\text { (This stud }\end{array}$ & a tephra & $\begin{array}{l}\text { Lower Te } \\
\text { (Pearce et }\end{array}$ & $\begin{array}{l}\text { a tephra } \\
\text { 08) }\end{array}$ \\
\hline & Mean & $2 S D$ & Mean & $2 S D$ & Mean & $2 S D$ \\
\hline $\mathrm{SiO}_{2}($ wt. \%) & 77.5 & 0.68 & 77.5 & 0.48 & 77.9 & 0.36 \\
\hline $\mathrm{Al}_{2} \mathrm{O}_{3}$ & 12.4 & 0.44 & 12.6 & 0.27 & 12.3 & 0.22 \\
\hline $\mathrm{TiO}_{2}$ & 0.13 & 0.05 & 0.13 & 0.07 & 0.11 & 0.06 \\
\hline $\mathrm{FeO}$ & 1.17 & 0.42 & 1.18 & 0.30 & 1.09 & 0.22 \\
\hline $\mathrm{MnO}$ & 0.08 & 0.10 & 0.09 & 0.10 & - & _ \\
\hline MgO & 0.28 & 0.51 & 0.10 & 0.04 & 0.08 & 0.04 \\
\hline $\mathrm{CaO}$ & 0.91 & 0.22 & 0.91 & 0.25 & 0.84 & 0.18 \\
\hline $\mathrm{Na}_{2} \mathrm{O}$ & 3.47 & 0.60 & 3.44 & 0.23 & 3.67 & 0.26 \\
\hline $\mathrm{K}_{2} \mathrm{O}$ & 3.75 & 0.49 & 3.80 & 0.53 & 3.69 & 0.44 \\
\hline Cl & 0.24 & 0.07 & 0.23 & 0.06 & 0.23 & 0.04 \\
\hline & 94.18 & 2.27 & 96.60 & 1.40 & 93.70 & 0.94 \\
\hline & $n=13$ & & $n=15$ & & $n=22$ & \\
\hline
\end{tabular}

The EPMA major element data from both studies is in good agreement, with one exception; the mean $\mathrm{MgO}$ concentration of AT-338 from Site 1123 is much higher than either of the LTM analyses. This discrepancy is believed to have resulted from a poor $\mathrm{MgO}$ calibration during EPMA characterisation of this sample. The similar $\mathrm{Mg}$ (ppm) concentrations for AT-338 and LTM (Table A2-5) that were determined by LA-ICP-MS support this view. There are, however, many significant discrepancies in the LA-ICP-MS trace element data of both studies (Table A2-5 and Fig. A2-3). For example, Pearce et al. (2008) report significantly different values for Y ( 40\% lower), $\mathrm{Zr}(\sim 30 \%$ lower), $\mathrm{Ba}(\sim 30 \%$ lower $)$, Ce ( $\sim 25 \%$ lower $), \operatorname{Sm}(\sim 30 \%$ lower $)$ and Th ( $\sim 25 \%$ lower) compared to LA-ICP-MS trace element data from this study ( 2 sd relative). Both LTM tephra samples were collected from the same locality and 
Table A2-5. A comparison of the trace element glass composition of the Potaka Tephra

\begin{tabular}{|c|c|c|c|c|c|c|}
\hline & $\begin{array}{l}\Gamma-338( \\
\text { his stuc }\end{array}$ & 1123) & $\begin{array}{l}\text { Lower Te } \\
\text { (This stuc }\end{array}$ & tephra & $\begin{array}{l}\text { Lower Te } \\
\text { (Pearce e }\end{array}$ & $\begin{array}{l}\text { tephre } \\
08)\end{array}$ \\
\hline & Mean & $2 \mathrm{SD}$ & Mean & $2 \mathrm{SD}$ & Mean & $2 \mathrm{SD}$ \\
\hline Mg (ppm) & 775 & 337 & 830 & 253 & - & _ \\
\hline Sc & 7.34 & 2.43 & 6.73 & 2.70 & 7.5 & 4.64 \\
\hline $\mathbf{T i}$ & 809 & 399 & 894 & 230 & - & _- \\
\hline $\mathbf{V}$ & 1.26 & 1.09 & 2.21 & 2.54 & _- & _ \\
\hline $\mathrm{Cr}$ & 1.73 & 2.02 & 1.60 & 3.74 & - & _- \\
\hline Mn & 335 & 70.0 & 339 & 83.3 & - & _- \\
\hline Co & 0.55 & 0.30 & 0.64 & 0.67 & - & - \\
\hline $\mathrm{Ni}$ & 0.27 & 0.38 & 0.63 & 1.01 & - & - \\
\hline $\mathrm{Cu}$ & 2.53 & 1.82 & 4.04 & 1.67 & - & - \\
\hline $\mathrm{Zn}$ & 34.1 & 21.2 & 41.2 & 28.7 & _ & - \\
\hline Ga & 14.9 & 4.9 & 14.9 & 2.73 & - & _ \\
\hline $\mathbf{R b}$ & 156 & 34.0 & 160 & 57.3 & 145 & 36.6 \\
\hline $\mathrm{Sr}$ & 58.2 & 25.1 & 59.4 & 27.9 & 49.5 & 15.4 \\
\hline $\mathbf{Y}$ & 23.9 & 4.8 & 27.6 & 11.2 & 16.4 & 8.00 \\
\hline $\mathbf{Z r}$ & 100 & 42.8 & 117 & 45.1 & 76 & 30.0 \\
\hline $\mathrm{Nb}$ & 9.05 & 2.48 & 10.1 & 3.00 & 7.3 & 1.64 \\
\hline Мo & 1.95 & 0.45 & 1.69 & 0.88 & _ & _ \\
\hline Cs & 7.81 & 2.34 & 7.70 & 1.97 & 8.16 & 5.08 \\
\hline $\mathbf{B a}$ & 911 & 237 & 882 & 165 & 626 & 120 \\
\hline La & 27.0 & 5.06 & 28.1 & 5.35 & 26.2 & 19.8 \\
\hline $\mathrm{Ce}$ & 57.6 & 15.1 & 60.8 & 17.8 & 45.4 & 28.4 \\
\hline Pr & 5.65 & 1.65 & 6.19 & 1.69 & 4.57 & 4.00 \\
\hline Nd & 21.0 & 5.97 & 23.3 & 7.48 & 19.8 & 19.6 \\
\hline Sm & 4.00 & 1.52 & 4.28 & 1.72 & 3.15 & 4.12 \\
\hline Eu & 0.44 & 0.25 & 0.53 & 0.23 & 0.43 & 0.66 \\
\hline Gd & 3.74 & 0.92 & 4.02 & 1.87 & 3.23 & 2.64 \\
\hline $\mathbf{T b}$ & - & - & 0.66 & 0.28 & 0.62 & 0.50 \\
\hline Dy & 3.72 & 1.13 & 4.40 & 1.76 & 3.83 & 2.44 \\
\hline Но & _ & _ & 0.94 & 0.51 & 0.79 & 0.38 \\
\hline Er & 2.47 & 0.52 & 2.91 & 1.40 & 2.32 & 1.26 \\
\hline Tm & - & _- & 0.44 & 0.20 & 0.30 & 0.26 \\
\hline Yb & 2.74 & 0.82 & 3.26 & 1.18 & 2.68 & 1.52 \\
\hline Lu & 0.45 & 0.11 & 0.48 & 0.15 & 0.47 & 0.26 \\
\hline Hf & 3.18 & 1.18 & 3.93 & 1.21 & 2.76 & 1.40 \\
\hline $\mathbf{T a}$ & 0.88 & 0.26 & 1.00 & 0.26 & 0.62 & 0.72 \\
\hline W & 1.90 & 0.46 & 1.77 & 0.32 & - & - \\
\hline $\mathrm{Pb}$ & 20.1 & 6.51 & 21.0 & 4.61 & _- & - \\
\hline Th & 14.6 & 3.67 & 15.5 & 3.27 & 11.4 & 4.04 \\
\hline $\mathbf{U}$ & 3.45 & 0.98 & 3.63 & 1.10 & 4.07 & 1.46 \\
\hline & $\mathrm{n}=9$ & & $\mathrm{n}=7$ & & $\mathrm{n}=17$ & \\
\hline
\end{tabular}


represent the same eruptive event, which suggests that the differences in trace element abundances between the two datasets are almost certainly the result of different analytical conditions and/or instrumentation.

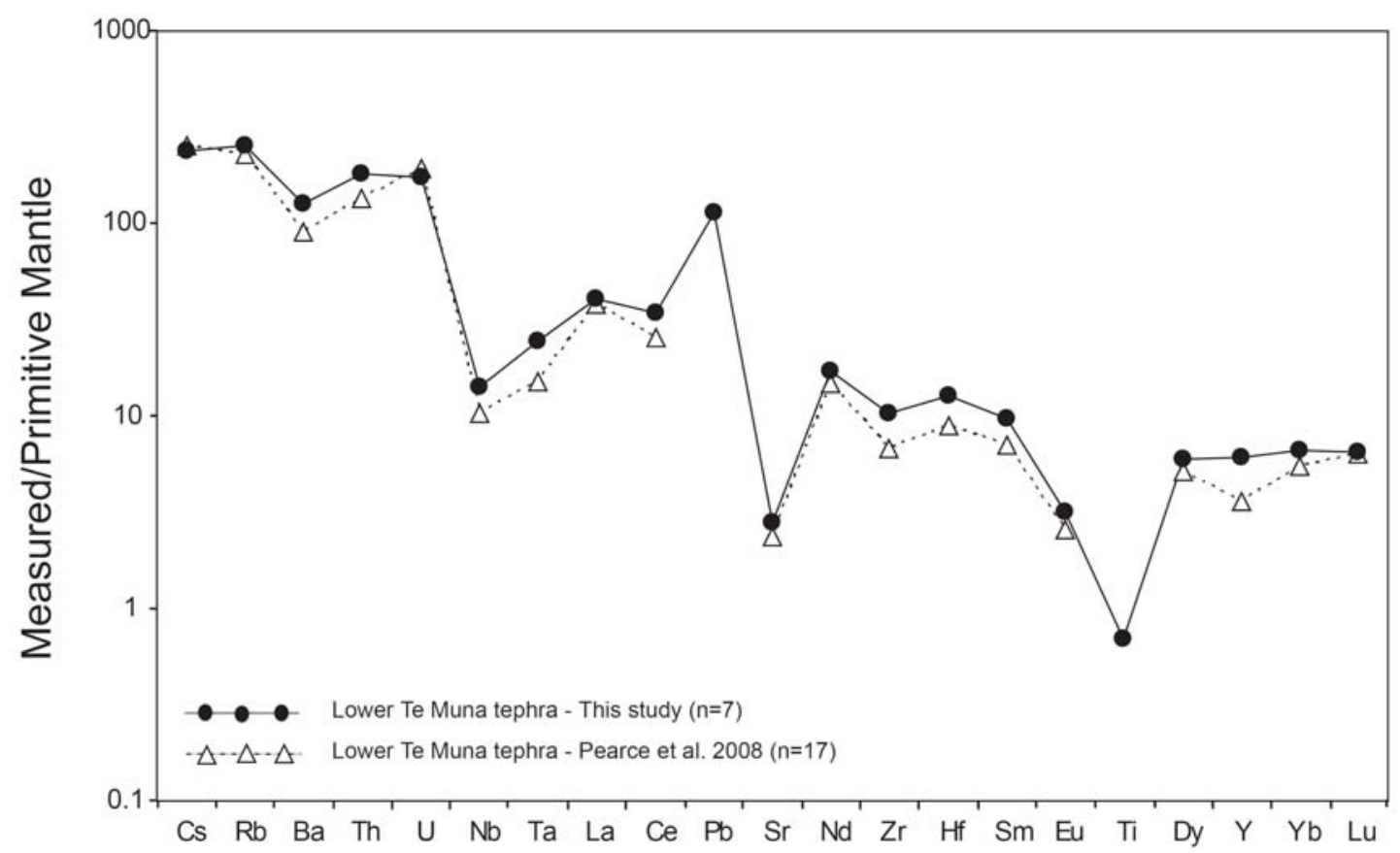

Figure A2-3. Selected LA-ICP-MS trace element data normalised to primitive mantle abundances for the Lower Te Muna (=Potaka) tephra as measured in this study (black circles) and by Pearce et al. (2008) (white triangles). Between the two datasets there are significant differences in the $\mathrm{Ba}, \mathrm{Th}, \mathrm{U}, \mathrm{Nb}, \mathrm{Ce}, \mathrm{Zr}, \mathrm{Hf}, \mathrm{Sm}$ and $\mathrm{Y}$. In all cases (except Cs and U) the Pearce et al. (2008) values are lower than those determined in this study. Primitive mantle values used for normalisation are from Sun and McDonough (1989).

There are several possibilities that may have resulted in these discrepancies, each of which is briefly addressed below.

\section{Elemental fractionation may have been more severe on one of the} instruments used to make the measurements. Elemental fractionation effects (matrix effects), which compromise the accuracy of LA-ICP-MS data, are less severe for lasers ablation systems operating at shorter (deep UV) wavelengths and when analyses are made in static mode (spot analyses) rather than raster mode (Guillong and Gunther, 2002). This is (mostly) a function of the greater ablation efficiency of deep UV radiation which yields more controllable ablation of glass shards and an even particle size distribution allowing for more efficient ionisation of the sample aerosol in the ICP (Guillong and Gunther, 2002). Data from this study was acquired using a $193 \mathrm{~nm}$ laser ablation system and all analyses were made in static mode, 


\section{The use of different calibration standards.}

Both studies utilised different calibration standards: Pearce et al. (2008) used NIST610 with nominal trace element abundances of ca. 500 ppm, whereas NIST612 with nominal trace element abundances of ca. 50 ppm was used here. In this study the accurate determinations of the trace element composition of ATHO-G from repeated analyses demonstrate that NIST612 is a suitably matrix-matched reference material for the analysis of rhyolite glasses. No such data exists for NIST610 to demonstrate its suitability for the analysis of rhyolite glasses.

\section{The use of different internal standards may have caused the} discrepancies in the trace element data. Both studies used a different internal standard for secondary normalisation of LA-ICP-MS trace element data: Pearce et al. (2008) used ${ }^{29} \mathrm{Si}$, whereas ${ }^{43} \mathrm{Ca}$ was used here. Three factors determine the effective use of an internal standard in LA-ICP-MS: (1) the internal standard isotope must be minimally affected by direct, oxide and doubly-charged mass interferences, (2) the elemental concentration of the internal standard must be precisely measured by EPMA, and (3) the isotope used for internal standardisation must occur in low enough abundance to prevent saturation of the ICP-MS detector. Mass interferences on both ${ }^{29} \mathrm{Si}$ and ${ }^{43} \mathrm{Ca}$ are considered negligible. (The oxide interference on ${ }^{43} \mathrm{Ca}\left({ }^{27} \mathrm{Al}+\right.$ ${ }^{16} \mathrm{O}$ ) was made negligible here by constantly maintaining a $\mathrm{ThO}+/ \mathrm{Th}+$ of $<$ $2 \%$, and typically was $<1 \%$ ). In electron microprobe characterisation of rhyolitic glasses, $\mathrm{SiO}_{2}$ is able to be measured with superior precision $( \pm 2 \%$; 2 sd relative) compared to $\mathrm{CaO}( \pm 8 \% ; 2$ sd relative), making $\mathrm{Si}$ an attractive choice as an internal standard for LA-ICP-MS. However, the high concentration of $\mathrm{SiO}_{2}$ in $\mathrm{TVZ}$ rhyolitic tephras (typically 74-79 wt.\%) and comparatively high abundance of ${ }^{29} \mathrm{Si}\left(4.67 \%\right.$ of all $\mathrm{Si}$, compared to ${ }^{43} \mathrm{Ca}$ 


\section{The values used for normalisation of LA-ICP-MS trace element data}

may be incorrect. If the trace element values of the calibration standard that were used for normalisation of the data were incorrect, this would result in incorrect determination of trace element abundances in the LTM tephra. The trace element abundances for NIST612 used for normalisation in this study are presented in Table A2-6. These values include certified values (Reed, 1992) and values determined by high precision isotope dilution (ID) TIMS and/or ID-MC-ICP-MS methods (Jochum et al., 2005). Pearce et al. (2008) used NIST610 as a calibration standard and adopted the values of Pearce et al. (1997). The Pearce et al. (1997) values for NIST610 (none of which have been certified) were compiled from repeat analyses of NIST610 at 3 laboratories (University of Wales, University of Notre Dame, Memorial University of Newfoundland) using ICP-MS, ICP-AES and INAA methods. The REE abundances for NIST610 have more recently been determined by high precision isotope dilution MC-ICP-MS methods by Kent et al. (2004). While there are differences in the ID values for NIST610 and the compiled values of Pearce et al. (1997) they are not of significant magnitude (typically 
5. Poor reproducibility of the Pearce et al. (2008) data. Some of the discrepancy of trace element data for the LTM tephra may be due to the poor reproducibility of the Pearce et al. (2008) data, particularly for low concentration trace elements. For example, the mean abundance of some trace elements determined by Pearce et al. (2008) for the LTM tephra, particularly the REEs, are comparable to the 2 sd variability (e.g., $\mathrm{Nd}=19.8 \mathrm{ppm}, \pm 19.6$ ppm; $2 \mathrm{sd})$. While some of this variation is probably attributable to 'real' trace element heterogeneity in the LTM tephra (see Chapter 2), this possibility can not be accessed for the Pearce et al. (2008) dataset because they do not present data for a well characterised secondary standard. In this study the homogeneous Icelandic rhyolite glass standard ATHO-G, which has been extensively characterised by Jochum et al. (2006; Table A2-7), was repeatedly analysed during trace element data acquisition. The $\mathrm{Nd}$ concentration of ATHO-G was routinely determined with an accuracy of ca. $5 \%$ and a precision of ca. $\pm 6 \%$ (2 sd relative; Table A2-3). By referring to data obtained for the homogenous ATHO-G glass standard, and the reproducibility of $\mathrm{Nd}$ measurements thereof, it can be determined that only $6 \%$ of the inter-shard variation in Nd abundance in LTM tephra glass shards analysed here can be attributed to analytical uncertainty (Table A2-3). The remaining inter-shard $\mathrm{Nd}$ variability $(\sim 25 \%$; 2 sd relative) can be attributed to real chemical variability in the LTM tephra. Pearce et al. (2008) also present single glass shard trace element data for 13 additional samples of the Potaka Tephra (or related ignimbrite deposits). A comparison of the trace element data for these additional samples (Pearce et al., 2008, pp. 28-29) demonstrates that the Pearce et al. (2008) LA-ICP-MS data is not reproducible. For example, between these samples the mean abundance of Eu varies from $0.31-0.70 \mathrm{ppm}, \mathrm{Zr}$ varies from $52-98 \mathrm{ppm}$, Y varies from 14.0 -22.7 ppm, Gd varies from $1.94-4.57$ ppm and Th varies from $7.88-14.6$ ppm.

Regardless of the cause(s) of the discrepancies between the LA-ICP-MS trace element data of Pearce et al. (2008) and that of this study it is evident that the 
accuracy and precision of LA-ICP-MS trace element data is strongly influenced by the analytical methods employed, the choice of internal and calibration standards and the reference values adopted for data normalisation. Thus, LA-ICP-MS trace element data must be accompanied by detailed and transparent accounts of these analytical methods and reference materials. Based on the experiences I have had while developing the LA-ICP-MS method employed in this thesis the following approaches are recommended.

1. Presentation of LA-ICP-MS sample data should be accompanied by data for a world-wide available homogenous reference material acquired under the same conditions. The rhyolite glass standard (MPI-DING) ATHO-G is recommended when presenting data for rhyolitic tephras.

2. The 'matrix-matched suitability' of the calibration standard must be rigorously investigated before sample data acquisition. In this study NIST612 has been demonstrated to have a matrix composition that allows the accurate analysis of rhyolite glasses.

3. Careful monitoring of the pulse-analogue counting settings is necessary to prevent saturation of the detector that may arise from using internal standards or calibration standards with high elemental abundances. A threshold of $\sim 1$ million counts per second (cps) was employed in this study and was found to be sufficiently high to prevent saturation.

4. The trace element values adopted for all reference materials analysed in the study must be clearly documented. Where possible values determined by high precision techniques (such as isotope dilution methods) should be used.

5. A comprehensive account of the analytical instruments and conditions used during data acquisition should be presented (e.g. spot size, use of ablation gases, whether data was acquired under in static or raster mode). 
Table A2-6. Trace element values for the synthetic glass standard NIST 612 utilised in this study

\begin{tabular}{|c|c|c|c|c|c|}
\hline & Value & \pm 2 SD & Unit & Origin/Method & Referenc \\
\hline Mg & 77.0 & 60 & ppm & compiled value & $\mathrm{a}$ \\
\hline $\mathrm{CaO}$ & 11.9 & 0.4 & wt. $\%$ & compiled value & $\mathrm{a}$ \\
\hline Sc & 41.0 & 8.0 & ppm & compiled value & $\mathrm{a}$ \\
\hline $\mathbf{T i}$ & 44.0 & 10 & ppm & mean of new data & $\mathrm{d}$ \\
\hline $\mathbf{V}$ & 39.0 & 8.0 & ppm & compiled value & $\mathrm{a}$ \\
\hline $\mathrm{Cr}$ & 36.0 & 6.0 & ppm & mean of new data & $\mathrm{d}$ \\
\hline Mn & 38.0 & 2.0 & ppm & compiled value & $\mathrm{a}$ \\
\hline Co & 35.0 & 4.0 & ppm & compiled value & $\mathrm{a}$ \\
\hline $\mathbf{N i}$ & 38.8 & 0.2 & ppm & certified value & $\mathrm{b}$ \\
\hline $\mathbf{C u}$ & 37.0 & 6.0 & ppm & compiled value & $\mathrm{a}$ \\
\hline Zn & 38.0 & 8.0 & ppm & compiled value & $\mathrm{a}$ \\
\hline Ga & 36.0 & 4.0 & ppm & compiled value & $\mathrm{a}$ \\
\hline $\mathbf{R b}$ & 31.4 & 0.4 & ppm & certified value & $\mathrm{b}$ \\
\hline Sr & 78.4 & 0.2 & ppm & certified value & $\mathrm{b}$ \\
\hline $\mathbf{Y}$ & 38.0 & 4.0 & ppm & compiled value & $\mathrm{a}$ \\
\hline $\mathrm{Zr}$ & 38.0 & 4.0 & ppm & mean of new data & $\mathrm{d}$ \\
\hline $\mathbf{N b}$ & 40.0 & 6.0 & ppm & mean of new data & $\mathrm{d}$ \\
\hline Mo & 38.0 & 4.0 & ppm & compiled value & $\mathrm{a}$ \\
\hline Cs & 42.0 & 6.0 & ppm & compiled value & $\mathrm{a}$ \\
\hline Ba & 39.7 & 0.8 & ppm & ID-TIMS & $\mathrm{c}$ \\
\hline La & 35.8 & 0.8 & ppm & ID-TIMS & $\mathrm{c}$ \\
\hline Ce & 38.7 & 0.8 & ppm & ID-TIMS & $\mathrm{c}$ \\
\hline Pr & 37.2 & 1.8 & ppm & compiled value & $\mathrm{a}$ \\
\hline Nd & 35.9 & 0.8 & ppm & ID-TIMS & $\mathrm{c}$ \\
\hline Sm & 38.1 & 0.8 & ppm & ID-TIMS & $\mathrm{c}$ \\
\hline Eu & 35.0 & 2.0 & ppm & ID-ICPMS & $\mathrm{c}$ \\
\hline Gd & 36.7 & 0.8 & ppm & ID-TIMS & $\mathrm{c}$ \\
\hline $\mathbf{T b}$ & 36.0 & 6.0 & ppm & compiled value & $\mathrm{a}$ \\
\hline Dy & 36.0 & 0.8 & ppm & ID-TIMS, ID-ICPMS & $\mathrm{c}$ \\
\hline Но & 38.0 & 2.0 & ppm & compiled value & $\mathrm{a}$ \\
\hline Er & 38.0 & 1.8 & ppm & ID-TIMS, ID-ICPMS & $\mathrm{c}$ \\
\hline Tm & 38.0 & 2.0 & ppm & compiled value & $\mathrm{a}$ \\
\hline $\mathbf{Y b}$ & 39.2 & 0.8 & ppm & ID-TIMS & $\mathrm{c}$ \\
\hline Lu & 36.9 & 0.8 & ppm & ID-TIMS & $\mathrm{c}$ \\
\hline Hf & 35.0 & 8.0 & ppm & compiled value & $\mathrm{a}$ \\
\hline Ta & 40.0 & 4.0 & ppm & compiled value & $\mathrm{a}$ \\
\hline $\mathbf{W}$ & 40.0 & 2.0 & ppm & compiled value & $\mathrm{a}$ \\
\hline $\mathbf{P b}$ & 38.57 & 0.2 & ppm & certified value & $\mathrm{b}$ \\
\hline Th & 37.79 & 0.08 & ppm & certified value & $\mathrm{b}$ \\
\hline $\mathbf{U}$ & 37.38 & 0.08 & ppm & certified value & $\mathrm{b}$ \\
\hline
\end{tabular}

References

$\mathrm{a}=$ Pearce et al., 1997 - Journal of Geostandards and Geoanalysis 21 (1), 115-144

$\mathrm{b}=$ Reed, W.P., 1992 - Certificate of Analysis, Standards and Reference Materials, 612, 613

$c=$ Jochum et al., 2005 - Journal of Geostandards and Geoanalysis Research 29 (3) 285-302

$\mathrm{d}=$ values from the GeoReM database 11/2006 (http://georem.mpch-mainz.gwdg.de) 
Table A2-7. Trace element values for the rhyolite glass standard ATHO-G utilised in this study

\begin{tabular}{|c|c|c|c|}
\hline & Value & \pm 2 SD & Unit \\
\hline Mg & 621 & 60.3 & ppm \\
\hline $\mathrm{CaO}$ & 1.70 & 0.03 & wt. \% \\
\hline Sc & 7.00 & 0.90 & ppm \\
\hline $\mathbf{T i}$ & 1529 & 95.9 & ppm \\
\hline $\mathbf{V}$ & 3.91 & 0.34 & ppm \\
\hline $\mathrm{Cr}$ & 6.10 & 1.40 & ppm \\
\hline Mn & 821 & 38.7 & ppm \\
\hline Co & 2.13 & 0.47 & ppm \\
\hline $\mathrm{Ni}$ & 13.0 & 5.00 & ppm \\
\hline $\mathrm{Cu}$ & 18.6 & 2.20 & ppm \\
\hline Zn & 141 & 15.0 & ppm \\
\hline Ga & 25.3 & 2.40 & ppm \\
\hline $\mathbf{R b}$ & 65.3 & 3.00 & ppm \\
\hline Sr & 94.1 & 2.70 & ppm \\
\hline $\mathbf{Y}$ & 94.5 & 3.50 & ppm \\
\hline $\mathrm{Zr}$ & 512 & 20.0 & ppm \\
\hline Nb & 62.4 & 2.60 & ppm \\
\hline Mo & 4.80 & 1.00 & ppm \\
\hline Cs & 1.08 & 0.11 & ppm \\
\hline Ba & 547 & 16.0 & ppm \\
\hline La & 55.6 & 1.50 & ppm \\
\hline Ce & 121 & 4.00 & ppm \\
\hline Pr & 14.6 & 0.40 & ppm \\
\hline Nd & 60.9 & 2.00 & ppm \\
\hline Sm & 14.2 & 0.40 & ppm \\
\hline Eu & 2.76 & 0.10 & ppm \\
\hline Gd & 15.3 & 0.70 & ppm \\
\hline $\mathbf{T b}$ & 2.51 & 0.08 & ppm \\
\hline Dy & 16.2 & 0.70 & ppm \\
\hline Ho & 3.43 & 0.11 & ppm \\
\hline Er & 10.3 & 0.50 & ppm \\
\hline Tm & 1.52 & 0.07 & ppm \\
\hline $\mathbf{Y b}$ & 10.5 & 0.40 & ppm \\
\hline Lu & 1.54 & 0.05 & ppm \\
\hline Hf & 13.7 & 0.50 & ppm \\
\hline Ta & 3.90 & 0.20 & ppm \\
\hline $\mathbf{W}$ & 9.30 & 1.20 & ppm \\
\hline $\mathbf{P b}$ & 5.67 & 0.62 & ppm \\
\hline Th & 7.40 & 0.27 & ppm \\
\hline $\mathbf{U}$ & 2.37 & 0.12 & ppm \\
\hline
\end{tabular}

All values from Jochum et al. (2006) - Geochemistry Geophysics Geosystems 7, Q02008, doi: 10.1029/2005GC001060 


\subsection{Isotopic analysis by multi-collector (MC-) ICP-MS}

Thirteen Site 1123 tephras representative of the four main magma types identified by major and trace element chemistry (see Chapter 2) were selected for $\mathrm{Sr}, \mathrm{Nd}$ and $\mathrm{Pb}$ isotopic characterisation by MC-ICP-MS at Victoria University of Wellington: AT331, AT-332, A-11, AT-394, AT-395, AT-337, AT-273, A-18, AT-407, AT-408, AT-343, A-22, AT-344. Where possible tephras that were almost purely glass shards were selected to minimise the effects of incorporating crystals with multi-stage histories. All acids used during $\mathrm{Sr}, \mathrm{Nd}$ and $\mathrm{Pb}$ separation are distilled from $\mathrm{AR}$ grade acids, unless specified otherwise.

\subsection{Sample preparation}

Between 30 - $100 \mathrm{mg}$ of separated glass shards (see Appendix 2, section 1) for isotopic analysis were treated to an additional stage of purification. Each of the 13 tephra samples were transferred to a separate glass beaker and soaked in ultraclean water (or milli-Q [MQ]; > 18.2 M 2 ) for $2-3$ minutes. The beakers were then placed in an ultrasonic tank for $2-3$ minutes to ensure complete sample disaggregation and any suspended detrital sediment (silt and mud) was decanted off. This process was repeated numerous times until there was no visible suspended sediment generated during ultrasonic treatment. The samples were then treated to ultrasonic treatment in AR grade methanol and decanted a further 3 times. The glass beakers containing the purified samples were covered with Kimwipe tissue and placed in an oven to dry at $50^{\circ} \mathrm{C}$ for $2-3$ days. Once dried each sample was inspected under plane light microscopy to confirm all detrital material had been removed and to assess the abundance of igneous minerals and carbonate microfossils present. In all cases igneous minerals comprised a only minor proportion $(<0.5-3 \%)$ of the cleaned tephra residue meaning the isotopic analyses are not significantly affected by the incorporation of phenocrysts with more primitive multi-stage histories (see Chapter 1). Sample AT-343 contained approximately 3\% biotite, a late crystallising phase, and trace amounts of pyroxene and feldspar. Almost all tephra samples contained $\sim 2$ $-10 \%$ carbonate microfossils (dominantly benthic foraminifers). Each sample was leached in and 1 drop of conc. Seastar grade (SS) $\mathrm{HNO}_{3}$ diluted in $1 \mathrm{~mL}$ of MQ to remove carbonate. As soon as the samples stopped effervescing (all carbonates 
dissolved) the liquid was pipetted off and each sample was rinsed 3 times in MQ to remove all traces of the acid.

Forty-two $7 \mathrm{~mL}$ Teflon beakers were required to collect and store the separated $\mathrm{Sr}$, $\mathrm{Nd}$ and $\mathrm{Pb}$ (13 samples and 1 'blank' for each element). These pre-cleaned beakers were refluxed in 6-7 $\mathrm{M} \mathrm{HNO}_{3}$ ( $\mathrm{Sr}$ and $\mathrm{Nd}$ beakers) or $\mathrm{SS} \mathrm{HCl}$ ( $\mathrm{Pb}$ beakers) and rinsed 3 times with MQ prior to use.

\subsection{Sample digestion}

The cleaned and leached tephra samples were transferred into the $\mathrm{Pb}$ sample beakers. Samples were digested by adding 30 drops of conc. SS hydrofluoric acid (HF) and 10 drops of conc. $\mathrm{SS}_{\mathrm{HNO}_{3}}$ and placing the closed beakers on to a hotplate $\left(120^{\circ} \mathrm{C}\right)$. After $\sim 3$ hours the beakers were opened and left on the hotplate to evaporate. Once dried, 10 drops of conc. $\mathrm{SS} \mathrm{HNO}_{3}$ was added to the samples and they were placed back on the hotplate to evaporate. Once evaporated, $1 \mathrm{~mL}$ of conc. $\mathrm{SS} \mathrm{HCl}$ was added to each sample and the beakers were again placed on to the hotplate for evaporation. Once dried, the beakers were capped and stored, ready for the $\mathrm{Pb}$ chemistry.

\subsection{Pb chemistry}

Lead was separated on AG1-X8 anion exchange resin using standard anion exchange techniques by elution of the sample matrix in $1 \mathrm{M} \mathrm{HBr}$ and $\mathrm{Pb}$ collection in $7 \mathrm{M} \mathrm{HCl}$. A step-by-step account of the $\mathrm{Pb}$ chemistry is given below.

1. Rinse 14 × $2 \mathrm{~mL}$ pipette tip columns (for 13 samples and 1 'blank') inside and outside 3 times with MQ.

2. Add $\mathrm{Pb}$ resin (AG1-X8 anion exchange resin) to columns to form $\mathrm{a} \sim 1 \mathrm{~cm}$ thick bed of resin.

3. Wash, 1 full column load of 7M SS HCl. Discard.

4. Wash, 1 full column load of MQ. Discard.

5. Wash, 1 full column load of 7M SS HCl. Discard.

6. Wash, 1 full column load of MQ. Discard.

7. To dry sample (glass shards), add $1.5 \mathrm{~mL}$ of $1 \mathrm{M} \mathrm{SS} \mathrm{HBr}$, close lids and place on hotplate for $\sim 30$ minutes to bring samples into solution.

8. Remove beakers from hotplate and allow to cool. 
9. Centrifuge each beaker for 3 minutes at $1000 \mathrm{rpm}$ (to ensure any residual solids are not loaded onto the columns).

10. Pre-treat columns with 1 full column load of 1M SS HBr. Discard.

11. Load samples onto columns, collecting this cut in Sr sample beakers.

12. Meanwhile, rinse the $\mathrm{Pb}$ sample beakers 3 times with MQ and reflux in 6-7M SS $\mathrm{HNO}_{3}$.

13. Elute, $2 \mathrm{~mL} 1 \mathrm{M}$ SS HBr. Collect in Sr sample beakers.

14. Elute, $1 \mathrm{~mL} 1 \mathrm{M}$ SS HBr. Collect in Sr sample beakers.

15. Elute, $1 \mathrm{~mL} 1 \mathrm{M}$ SS HBr. Collect in Sr sample beakers.

16. Meanwhile, rinse $\mathrm{Pb}$ sample beakers $3 \times \mathrm{MQ}$

17. Collect $2 \mathrm{~mL}$ of conc. $\mathrm{SS} \mathrm{HCl}$ in $\mathrm{Pb}$ sample beakers. This cut contains the $\mathrm{Pb}$.

16. Add 3 drops of conc. $\mathrm{SS}_{\mathrm{HNO}_{3}}$ to the $\mathrm{Pb}$ cuts and place on hotplate to evaporate.

17. Once dried add a further 3 drops of conc. $\mathrm{SS} \mathrm{HNO}_{3}$ and place on hotplate to evaporate.

18. Once dried, cap and store safely.

19. Immediately prior to analysis by MC-ICP-MS add $\sim 1 \mathrm{~mL}$ of $0.5 \% \mathrm{SS}^{\mathrm{HNO}} 3$ to sample beaker, cap and place on hotplate for $\sim 30$ minutes to bring samples into solution.

\subsection{Sr chemistry}

Strontium separation was achieved by a double pass through Eichrom Sr Spec chromatographic resin, with the sample matrix eluted in $3 \mathrm{M} \mathrm{HNO}_{3}$ followed by $\mathrm{Sr}$ collection in $>18.2 \mathrm{M} \Omega$ water. A step-by-step account of the Sr chemistry is given below.

1. Evaporate the sample cut in the Sr sample beakers. (This was collected during stages 11-15 of the Pb chemistry.)

2. Once dried, add 10 drops conc. $\mathrm{HNO}_{3}$ to each $\mathrm{Sr}$ sample beaker and place on hotplate to evaporate.

3. Once dried, add $1 \mathrm{~mL} 3 \mathrm{M} \mathrm{HNO}_{3}$, replace lids and place on hotplate for $\sim 30$ minutes to bring samples into solution.

4. Rinse 14 × 2 mL Eichrom columns (for 13 samples +1 'blank') inside and outside with MQ. 
5. Add Sr Spec resin in a slurry of MQ to each column forming a $\sim 5 \mathrm{~mm}$ thick resin bed.

6. Wash, 3 x column loads of $3 \mathrm{M} \mathrm{HNO}_{3}$. Discard.

7. Wash, 3 column loads of MQ. Discard.

8. Load samples onto columns, collecting in the $7 \mathrm{~mL} \mathrm{Nd}$ sample beakers.

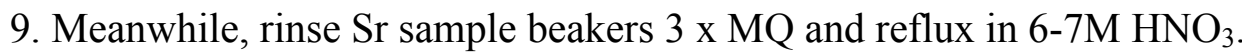

10. Elute 2 full column loads of $3 \mathrm{M} \mathrm{HNO}_{3}$, collecting in the $\mathrm{Nd}$ sample beakers.

11. Rinse the refluxed Sr sample beakers 3 times with MQ.

12. Collect 2 x column loads of MQ in Sr sample beakers. This cut contains the Sr.

13. Add 3 drops of conc. $\mathrm{HNO}_{3}$ to $\mathrm{Sr}$ cuts, cap and place on hotplate to evaporate.

14. Once dried, bring samples into solution in $1 \mathrm{~mL} 3 \mathrm{M} \mathrm{HNO}_{3}$ and repeat steps 6-13 (second column pass).

15. Once dried, add 3 drops conc. $\mathrm{HNO}_{3}$ to the Sr cuts. Evaporate.

16. Once dried, add 3 drops conc. HCl. Evaporate.

17. Once dried, add 3 drops conc. $\mathrm{HNO}_{3}$. Evaporate.

18. Once dried, cap and store safely.

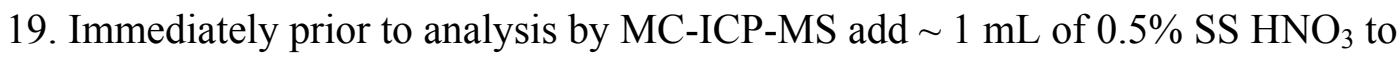
sample beaker, cap and place on hotplate for $\sim 30$ minutes to bring samples into solution.

\subsection{Nd chemistry}

The Nd chemistry consisted of three stages of chemical separation. Firstly, Fe and most major elements were removed by eluting $1.5 \mathrm{M} \mathrm{HCl}$ through AG50W-X8 cation exchange resin, with the rare earth elements (REE) eluted in $7 \mathrm{M} \mathrm{HNO}_{3}$. Ba and any remaining $\mathrm{Ca}$ were then removed by eluting $3 \mathrm{M} \mathrm{HNO}_{3}$ through TRU Spec resin, and collecting REEs were collected in > 18.2 M $\Omega$ water. Finally, Ln Spec chemistry was used to separate the sample $\mathrm{Nd}$ from the other REEs. The light REEs were sequentially eluted in order of increasing atomic mass by elution ( $1 \mathrm{~mL}$ at a time) of $0.25 \mathrm{M} \mathrm{HCl}$. La and Ce were eluted during the $5 \mathrm{~mL}$ and $\mathrm{Nd}$ was collected in the 5-8 $\mathrm{mL}$ of $0.25 \mathrm{M} \mathrm{HCl}$ eluted whilst Sm was retained on the Ln Spec resin.A step-by-step account of the $\mathrm{Nd}$ chemistry is outlined below. 


\section{Cation chemistry}

1. Add $0.5 \mathrm{~mL}$ of $1.5 \mathrm{M} \mathrm{HCl}$ to each $\mathrm{Nd}$ sample beaker, cap and place on hotplate to bring the samples into solution.

2. Rinse 14 × $2 \mathrm{~mL}$ pipette tip columns (13 samples +1 'blank') inside and outside 3 times with MQ.

3. Add cation resin (AG50W-X8) to each column forming a $\sim 1 \mathrm{~cm}$ thick resin bed.

4. Clean, 1 full column load of $6 \mathrm{M} \mathrm{HCl}$.

5. Rinse, 1 full column load of MQ.

6. Pre-treat columns with $1 / 2$ a column load of $1.5 \mathrm{M} \mathrm{HCl}$.

7. Load samples onto columns.

8. Elute 1 full column load of 1.5M HCl. Discard.

9. Collect $15 \mathrm{~mL}$ of $7 \mathrm{M} \mathrm{HNO}_{3}$ in $\mathrm{MQ}$ cleaned shotglasses. This cut is to be dried down and used for TRU Spec chemistry.

10. Transfer $5 \mathrm{~mL}$ of collected sample into cleaned $7 \mathrm{~mL} \mathrm{Nd}$ sample beakers. Evaporate.

11. Transfer a further $5 \mathrm{~mL}$ of collected sample into cleaned $7 \mathrm{~mL} \mathrm{Nd}$ sample beakers. Evaporate.

12. Transfer the remaining $\sim 5 \mathrm{~mL}$ of collected sample into cleaned $7 \mathrm{~mL} \mathrm{Nd}$ sample beakers. Evaporate.

\section{TRU Spec chemistry}

1. Evaporate the sample cut collected in the Nd sample beakers. (This was collected during step 9 of the cation column chemistry.)

2. Once dried, add $\sim 1 \mathrm{~mL}$ of $3 \mathrm{M} \mathrm{HNO}_{3}$ to each $\mathrm{Nd}$ sample beaker, cap and place on hotplate to bring sample into solution.

3. Rinse 14 columns (13 samples + 1 'blank') inside and outside 3 times with MQ.

4. Add TRU Spec resin to each column forming a $\sim 1 \mathrm{~cm}$ thick resin.

5. Wash 1 full column load MQ. Discard.

6. Wash 1 full column load $3 \mathrm{M} \mathrm{HNO}_{3}$. Discard.

7. Wash 1 full column load MQ. Discard.

8. Wash 1 full column load $3 \mathrm{M} \mathrm{HNO}_{3}$. Discard.

9. Load samples onto columns.

10. Wash, 1 full column load of $3 \mathrm{M} \mathrm{HNO}_{3}$. Discard. 
11. Wash, $2 \times 1 / 2$ column loads of $3 \mathrm{M} \mathrm{HNO}_{3}$. Discard.

12. Meanwhile, rinse $\mathrm{Nd}$ sample beakers 3 times with $\mathrm{MQ}$, reflux in 6-7M $\mathrm{HNO}_{3}$, and rinse 3 times with MQ.

12. Collect 2 x column loads of MQ in Nd sample beakers. This cut contains the REEs.

13. Evaporate.

\section{Ln Spec chemistry}

1. Add $0.5 \mathrm{~mL} 0.25 \mathrm{M} \mathrm{HCl}$ to each $\mathrm{Nd}$ sample beaker, cap and place on hotplate to bring samples into solution.

2. Wash, 1 x column load of 6M HCl. Discard.

3. Wash, 1 x column load of MQ. Discard.

4. Pre-treat columns with $1 \mathrm{~mL}$ of $0.25 \mathrm{M} \mathrm{HCl}$. Discard.

5. Load samples onto columns, and collect in $1.5 \mathrm{~mL}$ microcentrifuge tubes.

6. Collect $1 \mathrm{~mL} 0.25 \mathrm{M} \mathrm{HCl}$ in new microcentrifuge tubes.

7. Repeat step 6 so that $9 \mathrm{~mL}$ of $0.25 \mathrm{M} \mathrm{HCl}$ in total is collected for each sample, with each $1 \mathrm{~mL}$ collected in a separate microcentrifuge tube. The LREEs (La, Ce, Pr, $\mathrm{Nd}$ ) are progressively removed during this process.

8. Collect $2 \mathrm{~mL}$ of $0.75 \mathrm{M} \mathrm{HCl}$ from each column in shotglasses. This cut should contain the Sm of the sample.

9. Rinse $\mathrm{Nd}$ sample beakers 3 times with $\mathrm{MQ}$, reflux in 6-7M $\mathrm{HNO}_{3}$, and rinse again 3 times with MQ.

10. Check the separation of the LREEs (the $1 \mathrm{~mL}$ collections in the microcentrifuge tubes) using solution ICP-MS. Nd isotopic analysis will only be successful if the $\mathrm{Ce} / \mathrm{Nd}$ of the sample is $<1$, and $\mathrm{Sm}$ has been effectively separated from the $\mathrm{Nd}$.

11. Combine the sample cuts for which $\mathrm{Ce} / \mathrm{Nd}$ is $<<1$ and evaporate in the refluxed Nd sample beakers. Evaporate.

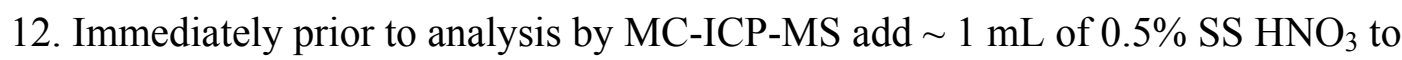
sample beaker, replace lid and place on hotplate for $\sim 30$ minutes to bring samples into solution. 


\subsection{Isotopic analyses and standards}

All isotopic analyses were performed on a Nu Plasma multiple collector (MC-) ICPMS at Victoria University of Wellington, New Zealand. Immediately prior to analysis the samples were brought into solution in $0.5 \% \mathrm{HNO}_{3} . \mathrm{Pb}$ and $\mathrm{Nd}$ samples were introduced into the MC-ICP-MS via a DSN-100 desolvating nebuliser system whereas Sr samples were analysed in 'wet plasma' mode following methods modified after Waight et al. (2002).

$\mathrm{Pb}$ isotope data were corrected for instrumental mass bias by external normalisation using the mass bias observed in bracketing analyses of SRM 981. Measured values were normalised to the Baker et al. (2004) values for SRM 981 i.e., ${ }^{206} \mathrm{~Pb} /{ }^{204} \mathrm{~Pb}=$ $16.9418,{ }^{207} \mathrm{~Pb} /{ }^{204} \mathrm{~Pb}=15.5000$, and ${ }^{208} \mathrm{~Pb} /{ }^{204} \mathrm{~Pb}=36.7265$. Analyses of the basaltic standard JB-2 were conducted to allow an assessment of the accuracy and precision of the $\mathrm{Pb}$ isotopic data obtained for the Site 1123 tephra melt compositions. Four analyses of JB-2 yielded the following mean values and 2 sd uncertainties: ${ }^{206} \mathrm{~Pb} /{ }^{204} \mathrm{~Pb}=18.3424 \pm 0.0018,{ }^{207} \mathrm{~Pb} /{ }^{204} \mathrm{~Pb}=15.5619 \pm 0.0017$, and ${ }^{208} \mathrm{~Pb} /{ }^{204} \mathrm{~Pb}=$ $38.2774 \pm 0.0049$. These values are indistinguishable from and have external reproducibilities comparable to those reported by Baker et al. (2004) who used highly precise $\mathrm{Pb}$ double-spike techniques to correct for instrumental mass bias.

$\mathrm{Sr}-\mathrm{Nd}$ isotope data were corrected for instrumental mass fractionation bias by internal normalisation to ${ }^{86} \mathrm{Sr} /{ }^{88} \mathrm{Sr}=0.1194$ and ${ }^{146} \mathrm{Nd} /{ }^{144} \mathrm{Nd}=0.7219$, respectively. All ${ }^{87} \mathrm{Sr} /{ }^{86} \mathrm{Sr}$ ratios are reported relative to a value of 0.710248 for the SRM 987 standard and the external reproducibility of ${ }^{87} \mathrm{Sr} /{ }^{86} \mathrm{Sr}$ ratios are $\pm 0.000012(2 \mathrm{sd}) . \mathrm{Nd}$ isotopic data are normalised to the standard Alfa Aesar $\mathrm{Nd}\left({ }^{143} \mathrm{Nd} /{ }^{144} \mathrm{Nd}=0.512260\right)$ and repeated analyses of this standard yielded an external reproducibility on ${ }^{143} \mathrm{Nd} /{ }^{144} \mathrm{Nd}$ of \pm 0.000006 (2 sd). The chondritic value of ${ }^{143} \mathrm{Nd} /{ }^{144} \mathrm{Nd}=0.512638$ (Hofmann, 2003) has been used to convert ${ }^{143} \mathrm{Nd} /{ }^{144} \mathrm{Nd}$ values into $\varepsilon_{\mathrm{Nd}}$ notion. The relatively young ages $(<1.7 \mathrm{Ma})$ of the tephras analysed in this study obviate the need to apply age corrections to any of the measured isotopic compositions for radiogenic in-growth of $\mathrm{Pb}-\mathrm{Sr}-\mathrm{Nd}$ isotopes. 


\section{APPENDIX THREE:}

\section{MAJOR ElEMENT DATA}

Table A3-1. Mean major element composition of glass shards from tephra layers analysed in this study as measured by electron probe microanalysis (EPMA) 
Table A3-1. Mean major element composition of glass shards from tephra layers analysed in this study as measured by electron probe microanalysis (EPMA)

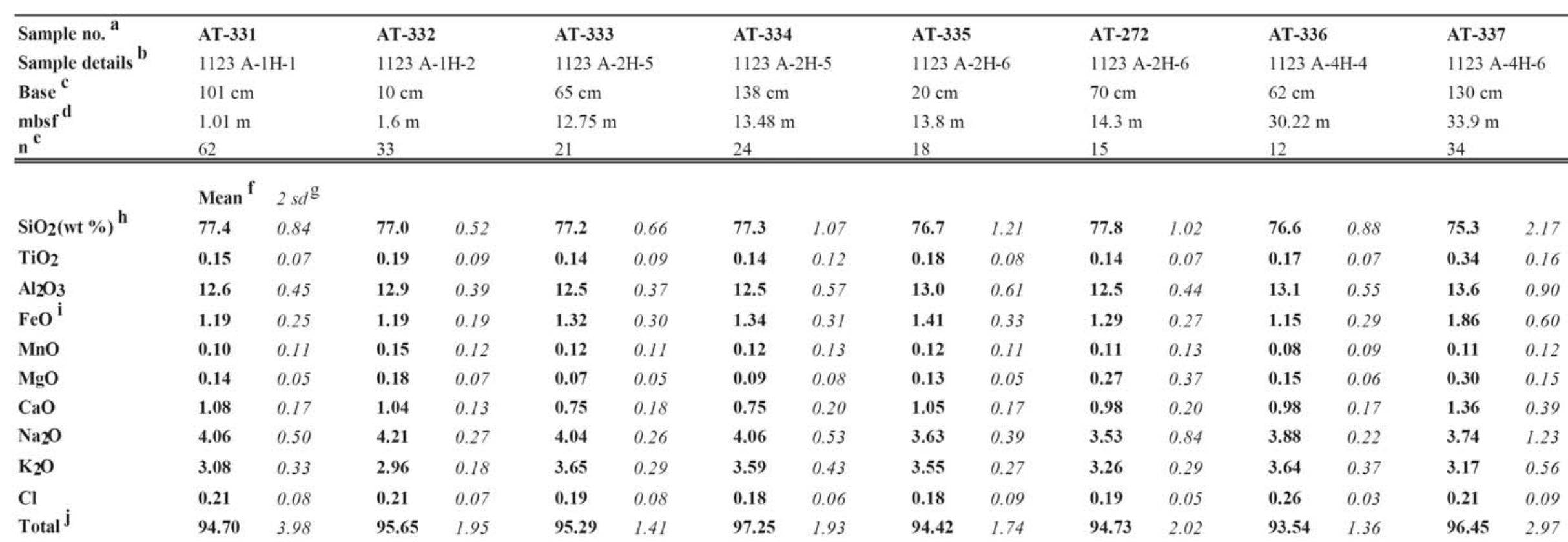


Table A3-1 continued

\begin{tabular}{|c|c|c|c|c|c|c|c|c|c|c|c|c|c|c|c|c|}
\hline Sample no. & \multirow{2}{*}{\multicolumn{2}{|c|}{$\begin{array}{l}\text { AT-273 } \\
1123 \mathrm{~A}-5 \mathrm{H}-2\end{array}$}} & \multicolumn{2}{|c|}{ AT-338 } & \multicolumn{2}{|c|}{ AT-373 (1) } & \multicolumn{2}{|c|}{ AT-373 (2) } & \multicolumn{2}{|c|}{ AT-373 (3) } & \multicolumn{2}{|c|}{ AT-373 (4) } & \multicolumn{2}{|c|}{ A-15 (1) } & \multicolumn{2}{|c|}{ A-15 (2) } \\
\hline Sample details & & & $1123 \mathrm{~A}$ & $\mathrm{H}-3$ & $1123 \mathrm{~A}$ & $\mathrm{H}-2$ & $1123 \mathrm{~A}$ & $\mathrm{H}-2$ & $1123 \mathrm{~A}$ & $\mathrm{H}-2$ & $1123 \mathrm{~A}$ & H-2 & $1123 \mathrm{~A}$ & $\mathrm{H}-3$ & $1123 \mathrm{~A}$ & $\mathrm{H}-3$ \\
\hline Base & $100 \mathrm{~cm}$ & & $68 \mathrm{~cm}$ & & $109 \mathrm{~cm}$ & & $109 \mathrm{~cm}$ & & $109 \mathrm{~cm}$ & & $109 \mathrm{~cm}$ & & $140 \mathrm{~cm}$ & & $140 \mathrm{~cm}$ & \\
\hline mbsf & $37.1 \mathrm{~m}$ & & 38.28 & & $46.69 \mathrm{n}$ & & $46.69 \mathrm{n}$ & & $46.69 \mathrm{r}$ & & 46.69 & & $48.5 \mathrm{~m}$ & & $48.5 \mathrm{~m}$ & \\
\hline $\mathrm{n}$ & 38 & & 12 & & 15 & & 4 & & 3 & & 3 & & 8 & & & \\
\hline $\mathrm{SiO}_{2}(\mathrm{wt} \%$ ) & 76.1 & 2.04 & 77.5 & 0.68 & 74.2 & 0.70 & 75.7 & 0.21 & 76.1 & 0.48 & 77.4 & 0.43 & 75.1 & 1.50 & 74.4 & 0.46 \\
\hline $\mathrm{TiO}_{2}$ & 0.25 & 0.11 & 0.13 & 0.05 & 0.26 & 0.08 & 0.20 & 0.09 & 0.18 & 0.04 & 0.17 & 0.15 & 0.19 & 0.09 & 0.29 & 0.12 \\
\hline $\mathrm{Al}_{2} \mathrm{O}_{3}$ & 13.3 & 0.74 & 12.4 & 0.44 & 14.0 & 0.37 & 13.6 & 0.10 & 13.4 & 0.21 & 12.6 & 0.18 & 13.6 & 0.61 & 13.9 & 0.27 \\
\hline $\mathrm{FeO}$ & 1.62 & 0.46 & 1.17 & 0.42 & 2.04 & 0.20 & 1.55 & 0.27 & 1.97 & 0.11 & 1.32 & 0.50 & 2.01 & 0.63 & 2.05 & 0.38 \\
\hline MnO & 0.10 & 0.15 & 0.08 & 0.10 & 0.07 & 0.11 & 0.10 & 0.08 & 0.14 & 0.08 & 0.04 & 0.07 & 0.13 & 0.10 & 0.06 & 0.08 \\
\hline MgO & 0.21 & 0.11 & 0.28 & 0.51 & 0.31 & 0.07 & 0.15 & 0.11 & 0.12 & 0.04 & 0.10 & 0.02 & 0.14 & 0.06 & 0.29 & 0.04 \\
\hline $\mathrm{CaO}$ & 1.27 & 0.37 & 0.91 & 0.22 & 1.68 & 0.29 & 1.23 & 0.20 & 1.01 & 0.01 & 0.79 & 0.22 & 1.21 & 0.25 & 1.73 & 0.13 \\
\hline $\mathrm{Na}_{2} \mathrm{O}$ & 3.32 & 0.81 & 3.47 & 0.60 & 4.01 & 0.28 & 3.96 & 0.22 & 3.85 & 0.44 & 3.76 & 0.07 & 4.02 & 0.40 & 3.90 & 0.22 \\
\hline $\mathrm{K}_{2} \mathrm{O}$ & 3.55 & 0.48 & 3.75 & 0.49 & 3.13 & 0.31 & 3.32 & 0.40 & 3.05 & 0.05 & 3.57 & 0.55 & 3.37 & 0.55 & 3.17 & 0.12 \\
\hline $\mathrm{Cl}$ & 0.19 & 0.05 & 0.24 & 0.07 & 0.21 & 0.07 & 0.23 & 0.07 & 0.22 & 0.11 & 0.28 & 0.10 & 0.20 & 0.04 & 0.20 & 0.04 \\
\hline Total & 97.66 & 2.59 & 94.18 & 2.27 & 96.31 & 1.87 & 95.78 & 1.15 & 95.94 & 1.93 & 96.15 & 3.22 & 94.32 & 1.32 & 94.52 & 1.13 \\
\hline
\end{tabular}


Table A3-1 continued

\begin{tabular}{|c|c|c|c|c|c|c|c|c|c|c|c|c|c|c|c|c|}
\hline Sample no. & \multirow{2}{*}{\multicolumn{2}{|c|}{$\begin{array}{l}\text { A-15 (3) } \\
1123 \text { A-6H-3 }\end{array}$}} & \multicolumn{2}{|c|}{ AT-275 } & \multicolumn{2}{|c|}{ AT-339 } & \multicolumn{2}{|c|}{ AT-374 } & \multicolumn{2}{|c|}{ AT-340 } & \multicolumn{2}{|l|}{ A-17 } & \multicolumn{2}{|c|}{ AT-341 } & \multicolumn{2}{|l|}{ A-19 } \\
\hline Sample details & & & $1123 \mathrm{~A}$ & $\mathrm{H}-4$ & $1123 \mathrm{~A}$ & $\mathrm{H}-5$ & $1123 \mathrm{~A}$ & H-6 & $1123 \mathrm{~A}$ & H-6 & $1123 \mathrm{~A}$ & $\mathrm{H}-7$ & $1123 \mathrm{~A}$ & $\mathrm{H}-7$ & $1123 \mathrm{~A}$ & $\mathrm{H}-\mathrm{l}$ \\
\hline Base & $140 \mathrm{~cm}$ & & $134 \mathrm{~cm}$ & & $21 \mathrm{~cm}$ & & $66 \mathrm{~cm}$ & & $127 \mathrm{~cm}$ & & $16 \mathrm{~cm}$ & & $42 \mathrm{~cm}$ & & $55 \mathrm{~cm}$ & \\
\hline mbsf & $48.5 \mathrm{~m}$ & & 49.94 & & $50.31 \mathrm{n}$ & & $52.26 \mathrm{n}$ & & $52.87 \mathrm{n}$ & & $53.26 \mathrm{r}$ & & $53.52 \mathrm{r}$ & & 54.15 & \\
\hline $\mathrm{n}$ & 2 & & 18 & & 17 & & 18 & & 13 & & 33 & & 13 & & 17 & \\
\hline $\mathrm{SiO}_{2}(\mathrm{wt} \%)$ & 77.4 & 0.26 & 74.3 & 0.59 & 74.4 & 0.63 & 74.5 & 1.97 & 77.2 & 0.49 & 77.1 & 0.78 & 74.7 & 0.99 & 77.1 & 0.54 \\
\hline $\mathrm{TiO}_{2}$ & 0.15 & 0.00 & 0.20 & 0.08 & 0.20 & 0.07 & 0.20 & 0.10 & 0.06 & 0.08 & 0.08 & 0.09 & 0.20 & 0.09 & 0.16 & 0.10 \\
\hline $\mathrm{Al}_{2} \mathrm{O}_{3}$ & 12.5 & 0.38 & 13.7 & 0.64 & 13.8 & 0.46 & 13.9 & 0.76 & 13.1 & 0.41 & 13.0 & 0.34 & 13.9 & 0.34 & 12.6 & 0.30 \\
\hline $\mathrm{FeO}$ & 1.41 & 0.00 & 2.18 & 0.30 & 2.33 & 0.27 & 2.20 & 0.75 & 1.00 & 0.19 & 1.03 & 0.29 & 2.09 & 0.47 & 1.26 & 0.20 \\
\hline $\mathrm{MnO}$ & 0.07 & 0.18 & 0.13 & 0.14 & 0.13 & 0.16 & 0.14 & 0.08 & 0.07 & 0.10 & 0.10 & 0.12 & 0.10 & 0.10 & 0.10 & 0.10 \\
\hline $\mathrm{MgO}$ & 0.08 & 0.04 & 0.11 & 0.05 & 0.14 & 0.05 & 0.14 & 0.09 & 0.11 & 0.05 & 0.10 & 0.05 & 0.14 & 0.07 & 0.12 & 0.03 \\
\hline $\mathrm{CaO}$ & 0.93 & 0.01 & 1.08 & 0.13 & 1.11 & 0.11 & 1.19 & 0.24 & 0.98 & 0.31 & 1.06 & 0.28 & 1.16 & 0.27 & 0.94 & 0.11 \\
\hline $\mathrm{Na}_{2} \mathrm{O}$ & 3.47 & 0.23 & 4.56 & 0.27 & 4.22 & 0.46 & 4.14 & 0.88 & 3.41 & 0.37 & 3.44 & 0.27 & 3.92 & 0.28 & 3.60 & 0.42 \\
\hline $\mathrm{K}_{2} \mathrm{O}$ & 3.76 & 0.02 & 3.57 & 0.44 & 3.44 & 0.37 & 3.39 & 0.47 & 3.99 & 0.52 & 4.01 & 0.57 & 3.61 & 0.37 & 3.82 & 0.35 \\
\hline $\mathrm{Cl}$ & 0.28 & 0.09 & 0.23 & 0.11 & 0.24 & 0.07 & 0.22 & 0.09 & 0.15 & 0.04 & 0.17 & 0.07 & 0.21 & 0.05 & 0.29 & 0.06 \\
\hline Total & 94.93 & 1.18 & 94.79 & 1.56 & 95.01 & 1.83 & 95.12 & 1.75 & 93.02 & 1.75 & 92.89 & 1.47 & 94.76 & 1.82 & 93.04 & 1.66 \\
\hline
\end{tabular}

contimued 
Table A3-1 continued

\begin{tabular}{|c|c|c|c|c|c|c|c|c|c|c|c|c|c|c|c|c|}
\hline Sample no. & \multicolumn{2}{|c|}{ AT-342 } & \multicolumn{2}{|c|}{ AT-274 } & \multicolumn{2}{|c|}{ AT-343 } & \multicolumn{2}{|c|}{ AT-271 } & \multicolumn{2}{|c|}{ AT-375 (1) } & \multicolumn{2}{|c|}{ AT-375 (2) } & \multicolumn{2}{|c|}{ AT-375 (3) } & \multicolumn{2}{|c|}{ AT-344 } \\
\hline Sample details & \multicolumn{2}{|c|}{$1123 \mathrm{~A}-7 \mathrm{H}-3$} & \multicolumn{2}{|c|}{$1123 \mathrm{~A}-7 \mathrm{H}-3$} & \multicolumn{2}{|c|}{$1123 \mathrm{~A}-7 \mathrm{H}-4$} & \multicolumn{2}{|c|}{$1123 \mathrm{~A}-7 \mathrm{H}-5$} & \multicolumn{2}{|c|}{$1123 \mathrm{~A}-7 \mathrm{H}-5$} & \multicolumn{2}{|c|}{$1123 \mathrm{~A}-7 \mathrm{H}-5$} & \multicolumn{2}{|c|}{1123 A-7H-5 } & \multicolumn{2}{|c|}{$1123 \mathrm{~A}-7 \mathrm{H}-5$} \\
\hline Base & $51.5 \mathrm{~cm}$ & & $112 \mathrm{~cm}$ & & $112 \mathrm{cn}$ & & $36 \mathrm{~cm}$ & & $60 \mathrm{~cm}$ & & $60 \mathrm{~cm}$ & & $60 \mathrm{~cm}$ & & $128 \mathrm{~cm}$ & \\
\hline mbsf & $57.12 \mathrm{n}$ & & $57.72 \mathrm{n}$ & & 59.22 & & $59.96 \mathrm{n}$ & & $60.2 \mathrm{~m}$ & & $60.2 \mathrm{~m}$ & & $60.2 \mathrm{~m}$ & & $60.88 \mathrm{n}$ & \\
\hline $\mathrm{n}$ & 15 & & 17 & & 31 & & 20 & & 8 & & 4 & & 2 & & 14 & \\
\hline $\mathrm{SiO}_{2}(\mathrm{wt} \%)$ & 74.6 & 0.75 & 74.0 & 0.68 & 76.9 & 0.78 & 73.9 & 1.07 & 74.2 & 0.60 & 76.1 & 1.74 & 75.8 & 0.24 & 73.8 & 0.97 \\
\hline $\mathrm{TiO}_{2}$ & 0.19 & 0.09 & 0.22 & 0.11 & 0.08 & 0.08 & 0.18 & 0.10 & 0.22 & 0.10 & 0.18 & 0.11 & 0.14 & 0.09 & 0.25 & 0.17 \\
\hline $\mathrm{Al}_{2} \mathrm{O}_{3}$ & 13.7 & 0.42 & 13.9 & 0.30 & 13.1 & 0.57 & 13.9 & 0.39 & 13.8 & 0.16 & 13.1 & 1.02 & 13.2 & 0.08 & 14.0 & 0.57 \\
\hline $\mathrm{FeO}$ & 2.15 & 0.22 & 2.23 & 0.29 & 0.99 & 0.25 & 2.24 & 0.80 & 2.14 & 0.18 & 1.33 & 0.31 & 1.79 & 0.16 & 2.22 & 0.37 \\
\hline MnO & 0.15 & 0.10 & 0.14 & 0.11 & 0.10 & 0.10 & 0.12 & 0.12 & 0.17 & 0.18 & 0.09 & 0.09 & 0.17 & 0.19 & 0.11 & 0.09 \\
\hline $\mathrm{MgO}$ & 0.11 & 0.07 & 0.14 & 0.03 & 0.09 & 0.06 & 0.14 & 0.07 & 0.14 & 0.04 & 0.13 & 0.10 & 0.08 & 0.03 & 0.18 & 0.05 \\
\hline $\mathrm{CaO}$ & 1.04 & 0.11 & 1.13 & 0.16 & 0.87 & 0.34 & 1.13 & 0.23 & 1.27 & 0.31 & 1.07 & 0.14 & 0.77 & 0.16 & 1.32 & 0.34 \\
\hline $\mathrm{Na}_{2} \mathrm{O}$ & 4.33 & 0.53 & 4.66 & 0.35 & 3.46 & 0.40 & 4.55 & 0.23 & 4.29 & 0.41 & 3.94 & 0.52 & 4.06 & 0.52 & 4.10 & 0.38 \\
\hline $\mathrm{K}_{2} \mathrm{O}$ & 3.49 & 0.31 & 3.36 & 0.44 & 4.28 & 0.93 & 3.70 & 0.31 & 3.50 & 0.50 & 3.75 & 0.90 & 3.81 & 0.66 & 3.85 & 0.56 \\
\hline $\mathrm{Cl}$ & 0.19 & 0.06 & 0.22 & 0.08 & 0.14 & 0.05 & 0.22 & 0.06 & 0.22 & 0.07 & 0.26 & 0.06 & 0.22 & 0.06 & 0.21 & 0.15 \\
\hline Total & 93.12 & 1.07 & 94.57 & 1.60 & 94.05 & 2.73 & 96.00 & 1.71 & 94.89 & 0.79 & 95.06 & 2.30 & 94.92 & 1.04 & 94.98 & 2.27 \\
\hline
\end{tabular}

continued 
Table A3-1 continued

\begin{tabular}{|c|c|c|c|c|c|c|c|c|c|c|c|c|c|c|c|c|}
\hline Sample no. & \multicolumn{2}{|l|}{ AT-376 } & \multicolumn{2}{|l|}{$A-12$} & \multicolumn{2}{|c|}{ AT-377 } & \multicolumn{2}{|c|}{ AT-378 (1) } & \multicolumn{2}{|c|}{ AT-378 (2) } & \multicolumn{2}{|c|}{ AT-379 (1) } & \multicolumn{2}{|c|}{ AT-379 (2) } & \multicolumn{2}{|c|}{ AT-380 (1) } \\
\hline Sample details & \multicolumn{2}{|c|}{1123 B-1H-2 } & \multicolumn{2}{|c|}{1123 B-2H-6 } & \multicolumn{2}{|c|}{1123 B-5H-3 } & \multicolumn{2}{|c|}{1123 B-6H-6 } & \multicolumn{2}{|c|}{1123 B-6H-6 } & \multicolumn{2}{|c|}{1123 B-6H-6 } & \multicolumn{2}{|c|}{1123 B-6H-6 } & \multicolumn{2}{|c|}{1123 B-6H-6 } \\
\hline Base & \multicolumn{2}{|l|}{$9 \mathrm{~cm}$} & \multicolumn{2}{|l|}{$95 \mathrm{~cm}$} & \multicolumn{2}{|l|}{$6 \mathrm{~cm}$} & \multicolumn{2}{|l|}{$11 \mathrm{~cm}$} & \multicolumn{2}{|l|}{$11 \mathrm{~cm}$} & \multicolumn{2}{|l|}{$24.5 \mathrm{~cm}$} & \multicolumn{2}{|c|}{$24.5 \mathrm{~cm}$} & \multicolumn{2}{|l|}{$32 \mathrm{~cm}$} \\
\hline mbsf & \multirow{2}{*}{\multicolumn{2}{|c|}{$\begin{array}{l}1.59 \mathrm{~m} \\
14 \\
\end{array}$}} & \multirow{2}{*}{\multicolumn{2}{|c|}{$\begin{array}{l}11.85 \mathrm{~m} \\
14\end{array}$}} & \multirow{2}{*}{\multicolumn{2}{|c|}{$\begin{array}{l}34.96 \mathrm{~m} \\
19\end{array}$}} & \multirow{2}{*}{\multicolumn{2}{|c|}{$\begin{array}{l}49.01 \mathrm{~m} \\
13\end{array}$}} & \multirow{2}{*}{\multicolumn{2}{|c|}{$\begin{array}{l}49.01 \mathrm{~m} \\
3\end{array}$}} & \multirow{2}{*}{\multicolumn{2}{|c|}{$\begin{array}{l}49.15 \mathrm{~m} \\
18\end{array}$}} & \multirow{2}{*}{\multicolumn{2}{|c|}{$\begin{array}{l}49.15 \mathrm{~m} \\
5\end{array}$}} & $49.22 \mathrm{~m}$ & \\
\hline \multirow[t]{2}{*}{$\mathrm{n}$} & & & & & & & & & & & & & & & 17 & \\
\hline & Mean & $2 s d$ & & & & & & & & & & & & & & \\
\hline $\mathrm{SiO}_{2}(\mathrm{wt} \%)$ & 76.8 & 0.35 & 77.0 & 0.71 & 75.2 & 1.68 & 75.6 & 0.78 & 77.5 & 0.20 & 75.6 & 0.58 & 77.5 & 0.48 & 75.5 & 0.53 \\
\hline $\mathrm{TiO}_{2}$ & 0.18 & 0.07 & 0.14 & 0.04 & 0.29 & 0.20 & 0.21 & 0.06 & 0.12 & 0.10 & 0.20 & 0.08 & 0.11 & 0.03 & 0.20 & 0.07 \\
\hline $\mathrm{Al}_{2} \mathrm{O}_{3}$ & 13.0 & 0.19 & 12.7 & 0.32 & 13.6 & 0.68 & 13.3 & 0.42 & 12.6 & 0.35 & 12.9 & 0.36 & 12.2 & 0.25 & 13.0 & 0.24 \\
\hline $\mathrm{FeO}$ & 1.17 & 0.22 & 1.36 & 0.20 & 1.76 & 0.35 & 2.03 & 0.23 & 1.34 & 0.13 & 2.02 & 0.22 & 1.52 & 0.23 & 2.03 & 0.24 \\
\hline $\mathrm{MnO}$ & 0.17 & 0.21 & 0.09 & 0.07 & 0.11 & 0.13 & 0.11 & 0.12 & 0.07 & 0.14 & 0.16 & 0.11 & 0.11 & 0.12 & 0.14 & 0.15 \\
\hline $\mathrm{MgO}$ & 0.19 & 0.04 & 0.08 & 0.05 & 0.23 & 0.11 & 0.12 & 0.05 & 0.09 & 0.05 & 0.12 & 0.04 & 0.07 & 0.03 & 0.13 & 0.05 \\
\hline $\mathrm{CaO}$ & 1.04 & 0.09 & 0.78 & 0.16 & 1.29 & 0.67 & 1.03 & 0.13 & 0.72 & 0.31 & 1.03 & 0.12 & 0.61 & 0.13 & 1.06 & 0.17 \\
\hline $\mathrm{Na}_{2} \mathrm{O}$ & 4.41 & 0.36 & 4.02 & 0.25 & 3.67 & 0.38 & 4.14 & 0.25 & 3.74 & 0.52 & 4.53 & 0.39 & 4.19 & 0.51 & 4.48 & 0.48 \\
\hline $\mathrm{K}_{2} \mathrm{O}$ & 2.86 & 0.39 & 3.62 & 0.29 & 3.46 & 0.66 & 3.31 & 0.31 & 3.61 & 0.36 & 3.27 & 0.30 & 3.48 & 0.21 & 3.20 & 0.33 \\
\hline $\mathrm{Cl}$ & 0.19 & 0.06 & 0.19 & 0.06 & 0.28 & 0.43 & 0.20 & 0.07 & 0.24 & 0.07 & 0.19 & 0.05 & 0.22 & 0.06 & 0.21 & 0.06 \\
\hline Total & 96.08 & 2.50 & 93.27 & 1.57 & 95.01 & 2.41 & 96.42 & 1.72 & 94.68 & 2.28 & 96.09 & 2.40 & 94.86 & 2.42 & 95.20 & 2.06 \\
\hline
\end{tabular}


Table A3-1 continued

\begin{tabular}{|c|c|c|c|c|c|c|c|c|c|c|c|c|c|c|c|c|}
\hline Sample no. & \multirow{2}{*}{\multicolumn{2}{|c|}{$\begin{array}{l}\text { AT-380 (2) } \\
1123 \text { B-6H-6 }\end{array}$}} & \multicolumn{2}{|c|}{ AT-381 } & \multicolumn{2}{|l|}{$\mathrm{CP}$} & \multicolumn{2}{|c|}{ AT-384 (1) } & \multicolumn{2}{|c|}{ AT-384 (2) } & \multicolumn{2}{|c|}{ AT-385 } & \multicolumn{2}{|l|}{$A-20$} & \multicolumn{2}{|l|}{$\mathrm{CN}$} \\
\hline Sample details & & & $1123 \mathrm{~B}$ & & $1123 \mathrm{~B}-$ & & $1123 \mathrm{~B}$ & & $1123 \mathrm{~B}$ & $\mathrm{H}-2$ & $1123 \mathrm{~B}$ & $\mathrm{H}-2$ & $1123 \mathrm{~B}$ & $\mathrm{H}-4$ & $1123 \mathrm{~B}$ & H-4 \\
\hline Base & $32 \mathrm{~cm}$ & & $47 \mathrm{~cm}$ & & $143 \mathrm{~cm}$ & & $40 \mathrm{~cm}$ & & $40 \mathrm{~cm}$ & & $92 \mathrm{~cm}$ & & $94 \mathrm{~cm}$ & & $148 \mathrm{~cm}$ & \\
\hline mbsf & $49.22 \mathrm{~m}$ & & $49.37 n$ & & $50.33 \mathrm{~m}$ & & $52.8 \mathrm{~m}$ & & $52.8 \mathrm{~m}$ & & $53.32 \mathrm{r}$ & & $56.34 \mathrm{I}$ & & $56.88 \mathrm{n}$ & \\
\hline $\mathrm{n}$ & 3 & & 16 & & 20 & & 10 & & 7 & & 12 & & 18 & & 16 & \\
\hline $\mathrm{SiO}_{2}(\mathrm{wt} \%)$ & 77.2 & 0.84 & 75.0 & 1.12 & 74.1 & 0.86 & 73.9 & 0.80 & 75.6 & 0.44 & 77.2 & 1.25 & 75.2 & 0.54 & 73.9 & 0.84 \\
\hline $\mathrm{TiO}_{2}$ & 0.15 & 0.13 & 0.21 & 0.07 & 0.28 & 0.10 & 0.27 & 0.07 & 0.18 & 0.10 & 0.13 & 0.07 & 0.19 & 0.05 & 0.24 & 0.10 \\
\hline $\mathrm{Al}_{2} \mathrm{O}_{3}$ & 12.4 & 0.34 & 13.7 & 0.70 & 13.9 & 0.45 & 14.1 & 0.51 & 13.5 & 0.45 & 12.8 & 0.75 & 13.4 & 0.37 & 14.0 & 0.44 \\
\hline $\mathrm{FeO}$ & 1.52 & 0.33 & 2.06 & 0.38 & 2.12 & 0.30 & 2.07 & 0.47 & 1.57 & 0.11 & 1.27 & 0.23 & 2.21 & 0.34 & 2.29 & 0.24 \\
\hline $\mathrm{MnO}$ & 0.08 & 0.14 & 0.12 & 0.12 & 0.11 & 0.13 & 0.14 & 0.17 & 0.10 & 0.10 & 0.11 & 0.20 & 0.11 & 0.12 & 0.14 & 0.12 \\
\hline MgO & 0.08 & 0.02 & 0.13 & 0.07 & 0.32 & 0.08 & 0.31 & 0.15 & 0.21 & 0.03 & 0.14 & 0.16 & 0.11 & 0.04 & 0.16 & 0.06 \\
\hline $\mathrm{CaO}$ & 0.71 & 0.17 & 1.14 & 0.13 & 1.70 & 0.20 & 1.71 & 0.31 & 1.23 & 0.10 & 0.83 & 0.18 & 1.07 & 0.13 & 1.15 & 0.21 \\
\hline $\mathrm{Na}_{2} \mathrm{O}$ & 4.26 & 0.34 & 3.96 & 0.73 & 4.16 & 0.28 & 3.87 & 0.70 & 3.97 & 0.20 & 3.46 & 0.42 & 4.07 & 0.57 & 4.33 & 1.20 \\
\hline $\mathrm{K}_{2} \mathrm{O}$ & 3.45 & 0.21 & 3.49 & 0.44 & 3.12 & 0.26 & 3.35 & 0.45 & 3.50 & 0.22 & 3.78 & 0.46 & 3.45 & 0.98 & 3.59 & 1.25 \\
\hline $\mathrm{Cl}$ & 0.20 & 0.16 & 0.19 & 0.04 & 0.22 & 0.09 & 0.23 & 0.09 & 0.25 & 0.06 & 0.26 & 0.08 & 0.19 & 0.06 & 0.22 & 0.08 \\
\hline Total & 94.65 & 1.89 & 95.13 & 2.58 & 94.49 & 2.29 & 94.19 & 3.36 & 94.13 & 2.31 & 98.01 & 3.53 & 94.76 & 1.96 & 93.53 & 2.51 \\
\hline
\end{tabular}

continued 
Table A3-1 continued

\begin{tabular}{|c|c|c|c|c|c|c|c|c|c|c|c|c|c|c|c|c|}
\hline Sample no. & \multicolumn{2}{|c|}{ AT-382 } & \multicolumn{2}{|c|}{ AT-383 } & \multicolumn{2}{|l|}{$\mathrm{CO}$} & \multicolumn{2}{|l|}{ A-9 } & \multicolumn{2}{|l|}{ A-10 } & \multicolumn{2}{|l|}{ A-11 } & \multicolumn{2}{|c|}{ AT-390 } & \multicolumn{2}{|l|}{ AT-391 } \\
\hline Sample details & \multicolumn{2}{|c|}{1123 B-7H-5 } & \multicolumn{2}{|c|}{1123 B-7H-5 } & \multicolumn{2}{|c|}{1123 B-7H-6 } & \multicolumn{2}{|c|}{$1123 \mathrm{C}-1 \mathrm{H}-1$} & \multicolumn{2}{|c|}{$1123 \mathrm{C}-1 \mathrm{H}-2$} & \multicolumn{2}{|c|}{$1123 \mathrm{C}-1 \mathrm{H}-2$} & \multicolumn{2}{|c|}{$1123 \mathrm{C}-2 \mathrm{H}-2$} & \multicolumn{2}{|c|}{$1123 \mathrm{C}-2 \mathrm{H}-2$} \\
\hline Base & $75.7 \mathrm{~cm}$ & & $117 \mathrm{cr}$ & & $15.5 \mathrm{cn}$ & & $135 \mathrm{~cm}$ & & $3 \mathrm{~cm}$ & & $70 \mathrm{~cm}$ & & $94 \mathrm{~cm}$ & & $109 \mathrm{~cm}$ & \\
\hline mbsf & $57.66 \mathrm{~m}$ & & 58.07 & & $58.56 \mathrm{n}$ & & $1.35 \mathrm{~m}$ & & $1.53 \mathrm{~m}$ & & $2.2 \mathrm{~m}$ & & 11.44 & & 11.59 & \\
\hline$\underline{\mathrm{n}}$ & 17 & & 18 & & 26 & & 18 & & 16 & & 15 & & 18 & & 24 & \\
\hline $\mathrm{SiO}_{2}(\mathrm{wt} \%)$ & 74.6 & 0.64 & 74.8 & 0.53 & 77.1 & 0.76 & 77.6 & 0.59 & 76.4 & 0.85 & 78.1 & 0.54 & 76.7 & 0.89 & 77.1 & 0.56 \\
\hline $\mathrm{TiO}_{2}$ & 0.20 & 0.07 & 0.19 & 0.08 & 0.08 & 0.08 & 0.19 & 0.04 & 0.20 & 0.11 & 0.14 & 0.06 & 0.14 & 0.09 & 0.15 & 0.06 \\
\hline $\mathrm{Al}_{2} \mathrm{O}_{3}$ & 13.6 & 0.35 & 13.6 & 0.43 & 13.0 & 0.33 & 12.6 & 0.47 & 13.3 & 0.52 & 12.4 & 0.24 & 12.7 & 0.47 & 12.5 & 0.45 \\
\hline $\mathrm{FeO}$ & 2.07 & 0.27 & 2.03 & 0.28 & 1.04 & 0.28 & 1.16 & 0.19 & 1.23 & 0.22 & 0.94 & 0.16 & 1.40 & 0.32 & 1.34 & 0.27 \\
\hline $\mathrm{MnO}$ & 0.11 & 0.12 & 0.12 & 0.16 & 0.09 & 0.11 & 0.12 & 0.06 & 0.15 & 0.13 & 0.12 & 0.05 & 0.11 & 0.15 & 0.11 & 0.09 \\
\hline $\mathrm{MgO}$ & 0.12 & 0.05 & 0.11 & 0.04 & 0.08 & 0.05 & 0.18 & 0.05 & 0.20 & 0.04 & 0.14 & 0.05 & 0.08 & 0.05 & 0.08 & 0.05 \\
\hline $\mathrm{CaO}$ & 1.08 & 0.15 & 0.97 & 0.16 & 0.92 & 0.31 & 1.06 & 0.12 & 1.11 & 0.14 & 0.86 & 0.12 & 0.78 & 0.17 & 0.75 & 0.15 \\
\hline $\mathrm{Na}_{2} \mathrm{O}$ & 4.25 & 0.50 & 4.56 & 0.39 & 3.58 & 0.37 & 4.14 & 0.30 & 4.36 & 0.25 & 4.01 & 0.44 & 4.15 & 0.24 & 4.07 & 0.46 \\
\hline $\mathrm{K}_{2} \mathrm{O}$ & 3.73 & 0.32 & 3.50 & 0.20 & 4.04 & 0.73 & 2.79 & 0.24 & 2.78 & 0.24 & 3.10 & 0.22 & 3.74 & 0.31 & 3.67 & 0.30 \\
\hline $\mathrm{Cl}$ & 0.19 & 0.09 & 0.20 & 0.08 & 0.16 & 0.06 & 0.18 & 0.07 & 0.20 & 0.05 & 0.22 & 0.08 & 0.19 & 0.08 & 0.20 & 0.08 \\
\hline Total & 91.16 & 2.31 & 94.96 & 2.09 & 95.29 & 1.52 & 96.57 & 1.97 & 96.53 & 3.10 & 97.54 & 2.62 & 93.49 & 1.56 & 92.47 & 1.43 \\
\hline
\end{tabular}


Table A3-1 continued

\begin{tabular}{|c|c|c|c|c|c|c|c|c|c|c|c|c|c|c|c|c|}
\hline Sample no. & \multicolumn{2}{|l|}{ A-13 } & \multicolumn{2}{|c|}{ AT-392 } & \multicolumn{2}{|c|}{ AT-393 (1) } & \multicolumn{2}{|c|}{ AT-393 (2) } & \multicolumn{2}{|c|}{ AT-394 } & \multicolumn{2}{|c|}{ AT-395 } & \multicolumn{2}{|c|}{ AT-396 } & \multicolumn{2}{|l|}{ A-14 } \\
\hline Sample details & \multicolumn{2}{|c|}{$1123 \mathrm{C}-2 \mathrm{H}-3$} & \multicolumn{2}{|c|}{$1123 \mathrm{C}-2 \mathrm{H}-3$} & \multicolumn{2}{|c|}{$1123 \mathrm{C}-2 \mathrm{H}-7$} & \multicolumn{2}{|c|}{$1123 \mathrm{C}-2 \mathrm{H}-7$} & \multicolumn{2}{|c|}{$1123 \mathrm{C}-3 \mathrm{H}-4$} & \multicolumn{2}{|c|}{$1123 \mathrm{C}-4 \mathrm{H}-4$} & \multicolumn{2}{|c|}{1123 C-4H-6 } & \multicolumn{2}{|c|}{$1123 \mathrm{C}-5 \mathrm{H}-1$} \\
\hline Base & $70 \mathrm{~cm}$ & & $139 \mathrm{~cm}$ & & $35 \mathrm{~cm}$ & & $35 \mathrm{~cm}$ & & $86 \mathrm{~cm}$ & & $120 \mathrm{~cm}$ & & $73 \mathrm{~cm}$ & & $93 \mathrm{~cm}$ & \\
\hline mbsf & $12.7 \mathrm{~m}$ & & $13.39 \mathrm{n}$ & & $18.35 \mathrm{n}$ & & $18.35 \mathrm{n}$ & & $23.86 \mathrm{n}$ & & $33.7 \mathrm{~m}$ & & $36.23 \mathrm{n}$ & & $38.43 \mathrm{n}$ & \\
\hline$\underline{\mathrm{n}}$ & 16 & & 18 & & 8 & & 2 & & 16 & & 20 & & 36 & & 24 & \\
\hline $\mathrm{SiO}_{2}(\mathrm{wt} \%)$ & 76.8 & 0.95 & 76.6 & 0.86 & 75.7 & 2.63 & 67.5 & 3.40 & 77.7 & 0.51 & 77.3 & 1.01 & 74.5 & 2.51 & 75.1 & 1.92 \\
\hline $\mathrm{TiO}_{2}$ & 0.17 & 0.07 & 0.15 & 0.09 & 0.20 & 0.11 & 0.40 & 0.26 & 0.16 & 0.11 & 0.19 & 0.08 & 0.36 & 0.21 & 0.24 & 0.10 \\
\hline $\mathrm{Al}_{2} \mathrm{O}_{3}$ & 12.9 & 0.33 & 12.8 & 0.61 & 13.3 & 1.13 & 17.3 & 0.29 & 12.4 & 0.23 & 12.5 & 0.67 & 13.7 & 0.99 & 13.7 & 0.96 \\
\hline $\mathrm{FeO}$ & 1.41 & 0.45 & 1.27 & 0.29 & 1.70 & 0.87 & 2.30 & 0.79 & 1.08 & 0.20 & 1.12 & 0.23 & 2.03 & 0.81 & 1.71 & 0.48 \\
\hline $\mathrm{MnO}$ & 0.12 & 0.16 & 0.10 & 0.11 & 0.10 & 0.14 & 0.19 & 0.07 & 0.09 & 0.11 & 0.11 & 0.12 & 0.12 & 0.12 & 0.10 & 0.08 \\
\hline $\mathrm{MgO}$ & 0.14 & 0.05 & 0.12 & 0.05 & 0.12 & 0.14 & 0.65 & 0.49 & 0.16 & 0.07 & 0.15 & 0.05 & 0.33 & 0.28 & 0.24 & 0.13 \\
\hline $\mathrm{CaO}$ & 1.03 & 0.14 & 0.98 & 0.17 & 1.18 & 0.42 & 3.21 & 0.57 & 1.10 & 0.26 & 1.04 & 0.12 & 1.46 & 0.51 & 1.29 & 0.42 \\
\hline $\mathrm{Na}_{2} \mathrm{O}$ & 3.66 & 0.40 & 4.05 & 0.20 & 3.97 & 0.30 & 5.03 & 0.66 & 3.66 & 0.23 & 3.70 & 0.24 & 4.21 & 0.79 & 3.97 & 0.37 \\
\hline $\mathrm{K}_{2} \mathrm{O}$ & 3.61 & 0.24 & 3.65 & 0.41 & 3.53 & 0.56 & 3.10 & 0.48 & 3.42 & 0.29 & 3.65 & 0.24 & 3.14 & 0.64 & 3.42 & 0.35 \\
\hline $\mathrm{Cl}$ & 0.17 & 0.06 & 0.19 & 0.07 & 0.19 & 0.10 & 0.30 & 0.06 & 0.22 & 0.07 & 0.26 & 0.10 & 0.20 & 0.06 & 0.20 & 0.08 \\
\hline Total & 92.58 & 1.46 & 95.05 & 1.85 & 94.08 & 2.04 & 93.36 & 5.31 & 94.89 & 1.95 & 94.59 & 3.80 & 94.98 & 2.48 & 96.47 & 3.68 \\
\hline
\end{tabular}


Table A3-1 continued

\begin{tabular}{|c|c|c|c|c|c|c|c|c|c|c|c|c|c|c|c|c|}
\hline Sample no. & \multicolumn{2}{|c|}{ AT-397 (1) } & \multicolumn{2}{|c|}{ AT-397 (2) } & \multicolumn{2}{|c|}{ AT-398 (1) } & \multicolumn{2}{|c|}{ AT-398 (2) } & \multicolumn{2}{|l|}{ A-16 } & \multicolumn{2}{|c|}{ AT-399 } & \multicolumn{2}{|c|}{ AT- -400} & \multicolumn{2}{|l|}{ AT- 401} \\
\hline Sample details & \multicolumn{2}{|c|}{$1123 \mathrm{C}-5 \mathrm{H}-5$} & \multicolumn{2}{|c|}{$1123 \mathrm{C}-5 \mathrm{H}-5$} & \multicolumn{2}{|c|}{$1123 \mathrm{C}-6 \mathrm{H}-1$} & \multicolumn{2}{|c|}{$1123 \mathrm{C}-6 \mathrm{H}-1$} & \multicolumn{2}{|c|}{$1123 \mathrm{C}-6 \mathrm{H}-3$} & \multicolumn{2}{|c|}{$1123 \mathrm{C}-6 \mathrm{H}-4$} & \multicolumn{2}{|c|}{$1123 \mathrm{C}-6 \mathrm{H}-4$} & \multicolumn{2}{|c|}{$1123 \mathrm{C}-6 \mathrm{H}-5$} \\
\hline Base & $123 \mathrm{~cm}$ & & $123 \mathrm{~cm}$ & & $78 \mathrm{~cm}$ & & $78 \mathrm{~cm}$ & & $130 \mathrm{~cm}$ & & $65 \mathrm{~cm}$ & & $97 \mathrm{~cm}$ & & $11 \mathrm{~cm}$ & \\
\hline mbsf & $44.73 \mathrm{~m}$ & & $44.73 n$ & & $47.78 n$ & & $47.78 n$ & & $51.3 \mathrm{~m}$ & & $52.15 \mathrm{n}$ & & $52.47 \mathrm{n}$ & & $53.11 \mathrm{n}$ & \\
\hline $\mathrm{n}$ & 10 & & 6 & & 12 & & 6 & & 17 & & 16 & & 14 & & 15 & \\
\hline $\mathrm{SiO}_{2}(\mathrm{wt} \%$ ) & 74.3 & 1.35 & 76.1 & 1.75 & 75.5 & 0.42 & 76.0 & 0.33 & 75.2 & 0.77 & 74.5 & 0.89 & 74.1 & 0.67 & 74.6 & 1.27 \\
\hline $\mathrm{TiO}_{2}$ & 0.28 & 0.06 & 0.21 & 0.08 & 0.24 & 0.13 & 0.18 & 0.06 & 0.19 & 0.09 & 0.18 & 0.08 & 0.21 & 0.07 & 0.19 & 0.09 \\
\hline $\mathrm{Al}_{2} \mathrm{O}_{3}$ & 13.9 & 0.34 & 13.2 & 0.39 & 13.2 & 0.31 & 13.1 & 0.26 & 13.4 & 0.27 & 13.2 & 0.44 & 13.7 & 0.61 & 13.9 & 0.42 \\
\hline $\mathrm{FeO}$ & 2.07 & 0.23 & 1.67 & 0.30 & 1.97 & 0.24 & 1.72 & 0.24 & 2.22 & 0.29 & 2.31 & 0.40 & 2.28 & 0.33 & 2.08 & 0.43 \\
\hline MnO & 0.09 & 0.12 & 0.11 & 0.13 & 0.12 & 0.12 & 0.13 & 0.06 & 0.12 & 0.06 & 0.14 & 0.16 & 0.14 & 0.16 & 0.10 & 0.10 \\
\hline MgO & 0.30 & 0.08 & 0.19 & 0.06 & 0.22 & 0.07 & 0.13 & 0.04 & 0.13 & 0.05 & 0.10 & 0.05 & 0.17 & 0.06 & 0.13 & 0.08 \\
\hline $\mathrm{CaO}$ & 1.71 & 0.24 & 1.21 & 0.12 & 1.53 & 0.19 & 1.16 & 0.11 & 1.21 & 0.22 & 1.06 & 0.15 & 1.18 & 0.17 & 1.19 & 0.22 \\
\hline $\mathrm{Na}_{2} \mathrm{O}$ & 3.95 & 0.90 & 3.77 & 0.92 & 3.78 & 0.32 & 3.96 & 0.15 & 4.22 & 0.44 & 4.77 & 0.32 & 4.69 & 0.29 & 4.03 & 0.47 \\
\hline $\mathrm{K}_{2} \mathrm{O}$ & 3.20 & 0.28 & 3.32 & 0.42 & 3.18 & 0.49 & 3.37 & 0.20 & 3.14 & 0.28 & 3.50 & 0.50 & 3.31 & 0.32 & 3.64 & 0.67 \\
\hline $\mathrm{Cl}$ & 0.22 & 0.07 & 0.22 & 0.07 & 0.23 & 0.18 & 0.20 & 0.10 & 0.21 & 0.04 & 0.21 & 0.11 & 0.22 & 0.07 & 0.22 & 0.11 \\
\hline Total & 94.54 & 3.35 & 95.42 & 3.27 & 95.93 & 2.44 & 95.92 & 1.18 & 96.38 & 2.22 & 95.71 & 3.35 & 94.81 & 3.37 & 94.03 & 2.37 \\
\hline
\end{tabular}


Table A3-1 continued

\begin{tabular}{|c|c|c|c|c|c|c|c|c|c|c|c|c|c|c|c|c|}
\hline Sample no. & \multicolumn{2}{|c|}{ AT-402 } & \multicolumn{2}{|c|}{ AT-403 } & \multicolumn{2}{|c|}{ AT-404 } & \multicolumn{2}{|c|}{ AT- 405} & \multicolumn{2}{|c|}{ AT-406 } & \multicolumn{2}{|l|}{ A-18 } & \multicolumn{2}{|c|}{ AT-407 } & \multicolumn{2}{|c|}{ AT- -408} \\
\hline Sample details & \multicolumn{2}{|c|}{$1123 \mathrm{C}-6 \mathrm{H}-5$} & \multicolumn{2}{|c|}{$1123 \mathrm{C}-6 \mathrm{H}-5$} & \multicolumn{2}{|c|}{1123 C- $6 \mathrm{H}-6$} & \multicolumn{2}{|c|}{$1123 \mathrm{C}-6 \mathrm{H}-6$} & \multicolumn{2}{|c|}{$1123 \mathrm{C}-6 \mathrm{H}-6$} & \multicolumn{2}{|c|}{$1123 \mathrm{C}-6 \mathrm{H}-7$} & \multicolumn{2}{|c|}{$1123 \mathrm{C}-7 \mathrm{H}-2$} & \multicolumn{2}{|c|}{$1123 \mathrm{C}-7 \mathrm{H}-2$} \\
\hline Base & $92 \mathrm{~cm}$ & & $113 \mathrm{~cm}$ & & $10 \mathrm{~cm}$ & & $120 \mathrm{~cm}$ & & $124 \mathrm{~cm}$ & & $67 \mathrm{~cm}$ & & $67 \mathrm{~cm}$ & & $127 \mathrm{~cm}$ & \\
\hline mbsf & $53.92 \mathrm{n}$ & & $54.13 \mathrm{~m}$ & & $54.6 \mathrm{~m}$ & & $55.7 \mathrm{~m}$ & & $55.74 \mathrm{~m}$ & & $56.67 \mathrm{n}$ & & $58.67 \mathrm{~m}$ & & $59.27 \mathrm{~m}$ & \\
\hline n & 26 & & 15 & & 18 & & 11 & & 15 & & 18 & & 17 & & 18 & \\
\hline $\mathrm{SiO}_{2}(\mathrm{wt} \%)$ & 76.9 & 0.69 & 74.5 & 1.21 & 76.2 & 0.79 & 75.6 & 1.34 & 76.4 & 1.28 & 77.1 & 0.59 & 75.2 & 0.85 & 74.4 & 0.66 \\
\hline $\mathrm{TiO}_{2}$ & 0.07 & 0.06 & 0.19 & 0.07 & 0.21 & 0.11 & 0.15 & 0.13 & 0.15 & 0.09 & 0.15 & 0.09 & 0.17 & 0.08 & 0.20 & 0.09 \\
\hline $\mathrm{Al}_{2} \mathrm{O}_{3}$ & 13.1 & 0.44 & 13.6 & 0.64 & 13.0 & 0.51 & 13.7 & 0.91 & 13.0 & 0.61 & 12.5 & 0.28 & 13.4 & 0.53 & 14.0 & 0.32 \\
\hline $\mathrm{FeO}$ & 0.97 & 0.30 & 2.12 & 0.47 & 1.97 & 0.30 & 1.57 & 0.30 & 1.57 & 0.56 & 1.30 & 0.16 & 2.11 & 0.43 & 2.34 & 0.29 \\
\hline MnO & 0.11 & 0.12 & 0.12 & 0.12 & 0.14 & 0.14 & 0.08 & 0.14 & 0.15 & 0.15 & 0.06 & 0.08 & 0.12 & 0.10 & 0.13 & 0.08 \\
\hline $\mathrm{MgO}$ & 0.08 & 0.05 & 0.16 & 0.06 & 0.13 & 0.06 & 0.21 & 0.61 & 0.11 & 0.05 & 0.12 & 0.06 & 0.11 & 0.04 & 0.13 & 0.04 \\
\hline $\mathrm{CaO}$ & 0.86 & 0.34 & 1.13 & 0.30 & 1.02 & 0.14 & 0.97 & 0.11 & 1.15 & 0.26 & 0.87 & 0.13 & 1.01 & 0.18 & 1.18 & 0.14 \\
\hline $\mathrm{Na}_{2} \mathrm{O}$ & 3.51 & 0.33 & 4.22 & 0.60 & 3.99 & 0.21 & 4.02 & 1.11 & 3.82 & 0.27 & 3.74 & 0.21 & 4.22 & 0.72 & 4.17 & 0.53 \\
\hline $\mathrm{K}_{2} \mathrm{O}$ & 4.20 & 0.68 & 3.73 & 0.59 & 3.20 & 0.26 & 3.49 & 0.26 & 3.60 & 0.49 & 3.93 & 0.36 & 3.55 & 1.11 & 3.29 & 0.32 \\
\hline $\mathrm{Cl}$ & 0.17 & 0.08 & 0.23 & 0.08 & 0.18 & 0.08 & 0.19 & 0.07 & 0.20 & 0.09 & 0.27 & 0.08 & 0.20 & 0.06 & 0.21 & 0.08 \\
\hline Total & 94.52 & 2.35 & 95.31 & 2.84 & 95.23 & 1.62 & 97.35 & 2.30 & 94.57 & 4.21 & 96.15 & 1.76 & 93.88 & 2.24 & 93.88 & 2.45 \\
\hline
\end{tabular}




\section{Table A3-1 continued}

Onshore TVZ tephra samples

\begin{tabular}{|c|c|c|c|c|c|c|c|c|c|c|c|c|c|c|}
\hline Sample no. & \multicolumn{2}{|c|}{ AT-409 } & \multicolumn{2}{|l|}{ A-21 } & \multicolumn{2}{|l|}{ A-22 } & \multicolumn{2}{|l|}{ A-23 } & \multicolumn{2}{|c|}{ Kawakawa Tephra } & \multicolumn{2}{|c|}{ Rotoehu Tephra } & \multicolumn{2}{|c|}{ Potaka Tephra } \\
\hline Sample details & \multicolumn{2}{|c|}{$1123 \mathrm{C}-7 \mathrm{H}-3$} & \multicolumn{2}{|c|}{$1123 \mathrm{C}-7 \mathrm{H}-3$} & \multicolumn{2}{|c|}{$1123 \mathrm{C}-7 \mathrm{H}-4$} & \multicolumn{2}{|c|}{$1123 \mathrm{C}-7 \mathrm{H}-5$} & \multicolumn{2}{|c|}{ Irirangi Section, } & \multirow{3}{*}{\multicolumn{2}{|c|}{$\begin{array}{l}63.86 \mathrm{~m} \text {, Pukaki } \\
\text { drill core, Lake } \\
\text { Pukaki }\end{array}$}} & \multirow{3}{*}{\multicolumn{2}{|c|}{$\begin{array}{l}\text { Huangarua River, } \\
\text { Te Muna Formation } \\
\text { Wairarapa }\end{array}$}} \\
\hline Base & $4 \mathrm{~cm}$ & & $135 \mathrm{cn}$ & & $63 \mathrm{~cm}$ & & $13 \mathrm{~cm}$ & & $10 \mathrm{~km}$ & uth of & & & & \\
\hline mbsf & $59.54 \mathrm{n}$ & & 60.851 & & $61.63 \mathrm{r}$ & & $62.63 \mathrm{r}$ & & Waiou & & & & & \\
\hline$\underline{n}$ & 17 & & 18 & & 17 & & 19 & & 26 & & 20 & & 15 & \\
\hline $\mathrm{SiO}_{2}(\mathrm{wt} \%)$ & 74.2 & 0.79 & 77.0 & 0.55 & 74.3 & 0.63 & 74.3 & 0.47 & 77.2 & 1.04 & 78.2 & 0.29 & 77.5 & 0.48 \\
\hline $\mathrm{TiO}_{2}$ & 0.21 & 0.09 & 0.08 & 0.06 & 0.20 & 0.09 & 0.22 & 0.06 & 0.16 & 0.11 & 0.16 & 0.05 & 0.13 & 0.07 \\
\hline $\mathrm{Al}_{2} \mathrm{O}_{3}$ & 14.1 & 0.29 & 12.9 & 0.23 & 13.7 & 0.34 & 13.6 & 0.28 & 12.8 & 0.77 & 12.1 & 0.13 & 12.6 & 0.27 \\
\hline $\mathrm{FeO}$ & 2.24 & 0.32 & 0.98 & 0.32 & 2.26 & 0.32 & 2.30 & 0.25 & 1.25 & 0.18 & 0.91 & 0.09 & 1.18 & 0.30 \\
\hline $\mathrm{MnO}$ & 0.14 & 0.10 & 0.09 & 0.09 & 0.14 & 0.10 & 0.11 & 0.11 & 0.12 & 0.15 & 0.13 & 0.09 & 0.09 & 0.10 \\
\hline MgO & 0.15 & 0.07 & 0.08 & 0.07 & 0.15 & 0.06 & 0.17 & 0.04 & 0.14 & 0.06 & 0.15 & 0.03 & 0.10 & 0.04 \\
\hline $\mathrm{CaO}$ & 1.25 & 0.19 & 0.87 & 0.29 & 1.19 & 0.17 & 1.26 & 0.20 & 1.10 & 0.22 & 0.87 & 0.06 & 0.91 & 0.25 \\
\hline $\mathrm{Na}_{2} \mathrm{O}$ & 4.27 & 0.30 & 3.57 & 0.27 & 4.37 & 0.15 & 4.07 & 0.55 & 4.06 & 0.38 & 4.10 & 0.18 & 3.44 & 0.23 \\
\hline $\mathrm{K}_{2} \mathrm{O}$ & 3.25 & 0.19 & 4.19 & 0.69 & 3.41 & 0.24 & 3.68 & 0.55 & 2.97 & 0.27 & 3.14 & 0.17 & 3.80 & 0.53 \\
\hline $\mathrm{Cl}$ & 0.22 & 0.06 & 0.16 & 0.07 & 0.21 & 0.06 & 0.23 & 0.06 & 0.20 & 0.06 & 0.23 & 0.04 & 0.23 & 0.06 \\
\hline Total & 96.18 & 1.18 & 96.09 & 2.06 & 94.88 & 1.95 & 95.47 & 2.02 & 94.98 & 2.29 & 95.41 & 2.75 & 96.60 & 1.40 \\
\hline
\end{tabular}

Analyses performed on a WDS Jeol Superprobe 733 at VUW, NZ ( $20 \mu \mathrm{m}$ beam, $15 \mathrm{kV}, 8 \mathrm{nA})$. ${ }^{\mathrm{a}}$ Data for samples with multiple glass populations are presented separately - e.g. AT-380(2), AT-380 second population. ${ }^{b} 1123 \mathrm{~A}-1 \mathrm{H}-1=$ Site 1123 , hole A, core 1 , core type $\left(\mathrm{H}=\right.$ hydraulic piston), section $1 .{ }^{\mathrm{c}}$ Depth to base of tephra $(\mathrm{cm})$ in relevant section. ${ }^{\mathrm{d}}$ Depth to base of tephra in metres below seafloor in the corresponding hole. ${ }^{\mathrm{e}}$ number of analyses. ${ }^{\mathrm{f}}$ Mean of $\mathrm{n}$ analyses. ${ }^{\mathrm{g}} \pm 2$ standard deviations in weight $\% .{ }^{\mathrm{h}}$ Mean composition in wt. \%, recalcuated to $100 \%$. ${ }^{i}$ All Fe reported as $\mathrm{FeO} .{ }^{j}$ Mean total of original EPMA analyses. 


\section{APPENDIX FOUR:}

\section{TRACE ELEMENT DATA}

Table A4-1. Mean trace element glass composition of tephras analysed in this study as measured by laser ablation inductively coupled plasma mass spectrometry (LAICP-MS). 
Table A4-1. Mean trace element glass composition of tephras analysed in this study

\begin{tabular}{|c|c|c|c|c|c|c|c|c|}
\hline Sample no. " & \multicolumn{2}{|l|}{ AT-331 } & \multicolumn{2}{|c|}{ AT-332 } & \multicolumn{2}{|c|}{ AT-333 } & \multicolumn{2}{|c|}{ AT-334 } \\
\hline Sample details ${ }^{\text {b }}$ & \multicolumn{2}{|c|}{$1123 \mathrm{~A}-1 \mathrm{H}-1$} & \multicolumn{2}{|c|}{$1123 \mathrm{~A}-1 \mathrm{H}-2$} & \multicolumn{2}{|c|}{$1123 \mathrm{~A}-2 \mathrm{H}-5$} & \multicolumn{2}{|c|}{$1123 \mathrm{~A}-2 \mathrm{H}-5$} \\
\hline Base $^{c}$ & \multicolumn{2}{|l|}{$101 \mathrm{~cm}$} & \multicolumn{2}{|l|}{$10 \mathrm{~cm}$} & \multicolumn{2}{|c|}{$65 \mathrm{~cm}$} & \multicolumn{2}{|c|}{$138 \mathrm{~cm}$} \\
\hline mbsf $^{d}$ & \multicolumn{2}{|l|}{$1.01 \mathrm{~m}$} & \multirow{2}{*}{\multicolumn{2}{|c|}{$\begin{array}{l}1.6 \mathrm{~m} \\
9\end{array}$}} & \multicolumn{2}{|c|}{$12.75 \mathrm{~m}$} & \multirow{2}{*}{\multicolumn{2}{|c|}{$\begin{array}{l}13.48 \mathrm{~m} \\
13\end{array}$}} \\
\hline & 8 & & & & 7 & & & \\
\hline & Mean ${ }^{r}$ & $2 s d^{g}$ & & & & & & \\
\hline Mg (ppm) & 991 & 142 & 1305 & 298 & 637 & 189 & 533 & 253 \\
\hline $\mathbf{T i}$ & 911 & 171 & 1104 & 328 & 760 & 243 & 756 & 242 \\
\hline V & 1.51 & 1.12 & 1.24 & 0.53 & 1.13 & 1.76 & 0.71 & 1.04 \\
\hline $\mathrm{Cr}$ & 3.18 & 7.25 & 1.73 & 3.77 & 1.37 & 3.34 & 1.11 & 1.95 \\
\hline Mn & 419 & 86.3 & 592 & 110 & 405 & 90.1 & 344 & 76.5 \\
\hline Co & 0.65 & 0.34 & 0.30 & 0.18 & 0.49 & 0.57 & 0.38 & 0.43 \\
\hline $\mathrm{Ni}$ & 0.41 & 0.74 & 0.31 & 0.73 & 3.51 & 5.39 & 1.10 & 2.31 \\
\hline $\mathrm{Cu}$ & 2.64 & 1.88 & 0.34 & 0.93 & 2.78 & 2.48 & 2.27 & 1.04 \\
\hline $\mathrm{Zn}$ & 45.5 & 23.8 & 50.4 & 18.9 & 40.2 & 27.9 & 36.8 & 25.1 \\
\hline $\mathrm{Ga}$ & 14.7 & 5.89 & 14.0 & 1.96 & 14.9 & 2.85 & 12.8 & 3.75 \\
\hline $\mathbf{R b}$ & 126 & 41.8 & 90.1 & 25.7 & 144 & 30.8 & 121 & 37.3 \\
\hline $\mathrm{Sr}$ & 84.5 & 14.7 & 91.4 & 17.1 & 54.9 & 19.6 & 48.5 & 14.7 \\
\hline $\mathbf{Y}$ & 22.7 & 3.65 & 33.2 & 8.63 & 30.1 & 5.34 & 30.2 & 6.67 \\
\hline $\mathrm{Zr}$ & 121 & 15.0 & 147 & 40.4 & 138 & 21.2 & 138 & 29.7 \\
\hline Nb & 7.62 & 2.15 & 10.2 & 1.84 & 10.0 & 2.46 & 9.62 & 2.79 \\
\hline Mo & 1.74 & 1.97 & 1.80 & 1.47 & 1.92 & 0.70 & 1.44 & 0.59 \\
\hline Cs & 6.37 & 2.06 & 3.40 & 0.82 & 6.07 & 1.54 & 5.02 & 1.62 \\
\hline $\mathrm{Ba}$ & 663 & 202 & 796 & 127 & 784 & 205 & 659 & 161 \\
\hline La & 21.8 & 5.09 & 24.6 & 6.16 & 27.2 & 4.08 & 24.9 & 4.96 \\
\hline $\mathrm{Ce}$ & 46.9 & 15.3 & 52.9 & 8.84 & 60.6 & 17.4 & 51.8 & 14.6 \\
\hline $\mathrm{Pr}$ & 4.80 & 1.04 & 6.08 & 1.25 & 6.34 & 1.19 & 5.69 & 1.17 \\
\hline Nd & 17.6 & 4.78 & 25.0 & 4.73 & 25.2 & 6.56 & 23.4 & 5.31 \\
\hline $\mathrm{Sm}$ & 3.46 & 0.64 & 5.44 & 1.54 & 5.03 & 1.63 & 5.10 & 1.04 \\
\hline Eu & 0.63 & 0.22 & 0.99 & 0.25 & 0.66 & 0.17 & 0.63 & 0.13 \\
\hline Gd & 3.22 & 1.51 & 5.08 & 1.70 & 4.88 & 0.70 & 4.74 & 0.82 \\
\hline Tb & 0.56 & 0.19 & & & 0.75 & 0.19 & 0.75 & 0.16 \\
\hline Dy & 3.70 & 0.90 & 5.54 & 1.17 & 4.96 & 1.04 & 5.27 & 1.19 \\
\hline Ho & 0.79 & 0.28 & & & 1.06 & 0.29 & 1.09 & 0.26 \\
\hline $\mathrm{Er}$ & 2.25 & 0.60 & 3.45 & 1.16 & 3.19 & 0.81 & 3.21 & 0.74 \\
\hline Tm & 0.38 & 0.16 & & & 0.47 & 0.11 & 0.49 & 0.13 \\
\hline $\mathrm{Yb}$ & 2.69 & 0.47 & 3.74 & 1.49 & 3.35 & 0.58 & 3.40 & 0.81 \\
\hline Lu & 0.39 & 0.14 & 0.55 & 0.18 & 0.49 & 0.08 & 0.50 & 0.12 \\
\hline Hf & 3.26 & 1.17 & 4.33 & 1.08 & 4.20 & 0.89 & 4.38 & 0.95 \\
\hline Ta & 0.73 & 0.19 & 0.68 & 0.21 & 0.79 & 0.18 & 0.84 & 0.21 \\
\hline W & 1.64 & 0.76 & 1.44 & 0.75 & 1.95 & 0.59 & 1.6 & 0.62 \\
\hline $\mathrm{Pb}$ & 15.2 & 4.56 & 15.9 & 3.88 & 23.0 & 5.75 & 19.7 & 6.75 \\
\hline Th & 11.4 & 2.32 & 9.49 & 2.15 & 12.9 & 2.72 & 13.0 & 3.01 \\
\hline $\mathbf{U}$ & 2.77 & 0.75 & 2.10 & 0.36 & 3.17 & 0.87 & 2.80 & 0.94 \\
\hline $\mathrm{Rb} / \mathrm{Sr}$ & 1.50 & 0.44 & 0.99 & 0.27 & 2.67 & 0.84 & 2.56 & 1.12 \\
\hline $\mathrm{Sr} / \mathbf{Y}$ & 3.74 & 0.83 & 2.77 & 0.33 & 1.83 & 0.69 & 1.63 & 0.73 \\
\hline $\mathrm{Zr} / \mathrm{Th}$ & 10.7 & 1.73 & 15.5 & 2.14 & 10.8 & 1.72 & 10.6 & 1.57 \\
\hline $\mathbf{E u} / \mathbf{E} \mathbf{u}^{* h}$ & 0.58 & 0.20 & 0.59 & 0.18 & 0.41 & 0.07 & 0.39 & 0.06 \\
\hline $\mathrm{Rb} / \mathrm{Sm}$ & 36.5 & 8.78 & 16.7 & 4.65 & 29.0 & 6.45 & 23.8 & 6.49 \\
\hline $\mathrm{Zr} / \mathbf{Y}$ & 5.35 & 0.69 & 4.43 & 0.40 & 4.61 & 0.64 & 4.58 & 0.76 \\
\hline $\mathrm{Ba} / \mathrm{Sr}$ & 7.83 & 1.77 & 8.75 & 1.62 & 14.5 & 4.88 & 13.9 & 5.44 \\
\hline $\mathrm{Nb} / \mathrm{Pb}$ & 0.50 & 0.07 & 0.65 & 0.18 & 0.44 & 0.05 & 0.49 & 0.07 \\
\hline $\mathrm{La} / \mathrm{Yb}$ & 8.11 & 1.37 & 6.78 & 2.52 & 8.13 & 0.97 & 7.35 & 0.78 \\
\hline Dy/Yb & 1.38 & 0.24 & 1.54 & 0.71 & 1.48 & 0.23 & 1.56 & 0.26 \\
\hline $\mathrm{Ba} / \mathrm{Th}$ & 58.2 & 15.9 & 84.6 & 18.2 & 60.9 & 7.43 & 50.8 & 7.35 \\
\hline
\end{tabular}


Table A4-1 continued

\begin{tabular}{|c|c|c|c|c|c|c|c|c|}
\hline Sample no. ${ }^{\text {a }}$ & \multicolumn{2}{|c|}{ AT-335 } & \multicolumn{2}{|c|}{ AT-272 } & \multicolumn{2}{|c|}{ AT-336 } & \multicolumn{2}{|c|}{ AT-337 } \\
\hline Sample details ${ }^{b}$ & \multicolumn{2}{|c|}{$1123 \mathrm{~A}-2 \mathrm{H}-6$} & \multicolumn{2}{|c|}{$1123 \mathrm{~A}-2 \mathrm{H}-6$} & \multicolumn{2}{|c|}{$1123 \mathrm{~A}-4 \mathrm{H}-4$} & \multicolumn{2}{|c|}{$1123 \mathrm{~A}-4 \mathrm{H}-6$} \\
\hline Base $^{c}$ & \multicolumn{2}{|l|}{$20 \mathrm{~cm}$} & \multicolumn{2}{|l|}{$70 \mathrm{~cm}$} & \multicolumn{2}{|c|}{$62 \mathrm{~cm}$} & \multicolumn{2}{|l|}{$130 \mathrm{~cm}$} \\
\hline mbsf $^{d}$ & $13.8 \mathrm{~m}$ & & $14.3 \mathrm{~m}$ & & 30.22 & & $33.9 \mathrm{~m}$ & \\
\hline $\mathrm{n}^{\mathrm{e}}$ & 9 & & 13 & & 7 & & 11 & \\
\hline $\mathrm{Mg}(\mathrm{ppm})$ & 911 & 173 & 798 & 253 & 1031 & 260 & 2094 & 1529 \\
\hline $\mathrm{Ti}$ & 1016 & 162 & 916 & 260 & 968 & 384 & 2076 & 1133 \\
\hline v & 1.00 & 0.78 & 0.77 & 0.40 & 2.91 & 0.73 & 6.69 & 9.34 \\
\hline $\mathrm{Cr}$ & 1.41 & 7.43 & 1.57 & 2.77 & 1.60 & 4.03 & 5.29 & 4.81 \\
\hline Mn & 395 & 87.5 & 367 & 92.3 & 353 & 112 & 501 & 174 \\
\hline Co & 1.07 & 1.28 & 0.53 & 0.33 & 0.62 & 0.75 & 1.21 & 1.03 \\
\hline $\mathrm{Ni}$ & 1.03 & 2.35 & 0.39 & 0.63 & 0.80 & 1.89 & 1.74 & 2.45 \\
\hline $\mathrm{Cu}$ & 2.65 & 1.58 & 2.32 & 0.50 & 4.73 & 1.95 & 3.18 & 2.05 \\
\hline $\mathrm{Zn}$ & 51.9 & 16.7 & 40.1 & 27.0 & 25.0 & 20.0 & 41.5 & 27.7 \\
\hline $\mathrm{Ga}$ & 15.5 & 3.45 & 14.0 & 4.33 & 12.5 & 4.59 & 15.9 & 2.77 \\
\hline $\mathbf{R b}$ & 150 & 33.1 & 123 & 38.3 & 138 & 55.4 & 121 & 32.3 \\
\hline $\mathrm{Sr}$ & 81.1 & 10.5 & 77.7 & 18.8 & 72.6 & 12.3 & 102 & 40.1 \\
\hline $\mathbf{Y}$ & 30.3 & 5.32 & 30.3 & 6.15 & 17.8 & 4.96 & 33.9 & 10.9 \\
\hline $\mathrm{Zr}$ & 168 & 25.1 & 155 & 44.1 & 114 & 35.4 & 263 & 108 \\
\hline $\mathrm{Nb}$ & 9.7 & 1.17 & 10.1 & 3.12 & 7.30 & 2.94 & 10.8 & 2.05 \\
\hline Mo & 1.78 & 0.84 & 1.49 & 0.42 & 2.08 & 1.24 & 1.80 & 1.09 \\
\hline Cs & 5.95 & 1.19 & 5.04 & 1.65 & 6.48 & 2.74 & 5.68 & 1.66 \\
\hline Ba & 823 & 147 & 791 & 195 & 744 & 251 & 804 & 167 \\
\hline La & 27.7 & 5.16 & 27.5 & 5.77 & 21.1 & 7.98 & 26.9 & 6.82 \\
\hline $\mathrm{Ce}$ & 61.3 & 12.1 & 53.3 & 16.2 & 41.7 & 14.9 & 56.9 & 10.1 \\
\hline Pr & 6.44 & 1.36 & 5.98 & 1.48 & 4.25 & 1.44 & 6.29 & 1.23 \\
\hline Nd & 25.6 & 4.64 & 24.0 & 5.45 & 15.7 & 6.07 & 25.9 & 5.82 \\
\hline $\mathrm{Sm}$ & 5.25 & 0.97 & 4.82 & 1.33 & 2.84 & 1.25 & 5.42 & 1.73 \\
\hline Eu & 0.78 & 0.20 & 0.76 & 0.21 & 0.42 & 0.21 & 0.96 & 0.33 \\
\hline Gd & 4.66 & 1.42 & 4.89 & 1.37 & 2.69 & 0.85 & 5.05 & 1.59 \\
\hline Tb & 0.71 & 0.10 & 0.76 & 0.16 & 0.43 & 0.19 & & \\
\hline Dy & 5.16 & 1.11 & 5.25 & 1.22 & 2.77 & 0.84 & 5.66 & 1.28 \\
\hline Но & 1.04 & 0.24 & 1.08 & 0.27 & 0.60 & 0.25 & & \\
\hline Er & 3.31 & 0.43 & 3.31 & 0.77 & 1.75 & 0.30 & 3.63 & 1.19 \\
\hline $\mathrm{Tm}$ & 0.45 & 0.04 & 0.48 & 0.09 & 0.37 & 0.16 & & \\
\hline $\mathrm{Yb}$ & 3.41 & 0.68 & 3.38 & 0.60 & 2.29 & 1.01 & 3.76 & 0.90 \\
\hline Lu & 0.51 & 0.12 & 0.52 & 0.14 & 0.39 & 0.19 & 0.58 & 0.18 \\
\hline Hf & 4.98 & 0.78 & 4.87 & 0.73 & 3.34 & 1.25 & 6.62 & 2.37 \\
\hline $\mathbf{T a}$ & 0.87 & 0.24 & 0.93 & 0.23 & 0.69 & 0.24 & 0.82 & 0.17 \\
\hline w & 2.08 & 0.64 & 1.68 & 0.58 & 1.89 & 0.68 & 1.54 & 0.65 \\
\hline $\mathrm{Pb}$ & 23.5 & 5.30 & 18.9 & 6.47 & 16.0 & 6.98 & 17.5 & 4.85 \\
\hline Th & 14.4 & 2.40 & 14.1 & 2.96 & 13.0 & 4.92 & 12.2 & 3.03 \\
\hline $\mathbf{U}$ & 3.52 & 0.93 & 2.94 & 0.93 & 2.92 & 1.20 & 2.71 & 0.67 \\
\hline $\mathrm{Rb} / \mathrm{Sr}$ & 1.86 & 0.40 & 1.60 & 0.66 & 1.89 & 0.51 & 1.25 & 0.81 \\
\hline $\mathrm{Sr} / \mathrm{Y}$ & 2.69 & 0.49 & 2.59 & 0.84 & 4.13 & 1.24 & 3.06 & 1.36 \\
\hline $\mathrm{Zr} / \mathrm{Th}$ & 11.7 & 1.92 & 11.2 & 4.34 & 8.78 & 0.96 & 21.9 & 10.1 \\
\hline $\mathbf{E} \mathbf{u} / \mathbf{E} \mathbf{u}^{*{ }^{h}}$ & 0.48 & 0.09 & 0.48 & 0.11 & 0.47 & 0.16 & 0.56 & 0.14 \\
\hline $\mathrm{Rb} / \mathrm{Sm}$ & 28.8 & 6.52 & 25.5 & 6.15 & 48.9 & 9.10 & 22.7 & 7.85 \\
\hline $\mathbf{Z r} / \mathbf{Y}$ & 5.56 & 0.95 & 5.17 & 1.96 & 6.39 & 1.55 & 7.73 & 2.26 \\
\hline $\mathrm{Ba} / \mathrm{Sr}$ & 10.2 & 1.76 & 10.3 & 3.47 & 10.2 & 2.45 & 8.29 & 4.72 \\
\hline $\mathrm{Nb} / \mathrm{Pb}$ & 0.42 & 0.08 & 0.54 & 0.06 & 0.46 & 0.10 & 0.63 & 0.18 \\
\hline $\mathrm{La} / \mathrm{Yb}$ & 8.15 & 1.23 & 8.12 & 1.17 & 9.38 & 2.89 & 7.21 & 1.88 \\
\hline Dy/Yb & 1.52 & 0.28 & 1.55 & 0.21 & 1.24 & 0.43 & 1.51 & 0.20 \\
\hline $\mathrm{Ba} / \mathrm{Th}$ & 57.4 & 6.99 & 56.3 & 8.33 & 57.6 & 13.8 & 66.4 & 7.90 \\
\hline
\end{tabular}


Table A4-1 continued

\begin{tabular}{|c|c|c|c|c|c|c|c|c|}
\hline Sample no. ${ }^{\mathrm{a}}$ & \multicolumn{2}{|c|}{ AT-273 } & \multicolumn{2}{|c|}{ AT-338 } & \multicolumn{2}{|c|}{ AT-373 (1) } & \multicolumn{2}{|c|}{ AT-373 (2) } \\
\hline Sample details ${ }^{b}$ & \multicolumn{2}{|c|}{$1123 \mathrm{~A}-5 \mathrm{H}-2$} & \multicolumn{2}{|c|}{$1123 \mathrm{~A}-5 \mathrm{H}-3$} & \multicolumn{2}{|c|}{$1123 \mathrm{~A}-6 \mathrm{H}-2$} & \multicolumn{2}{|c|}{$1123 \mathrm{~A}-6 \mathrm{H}-2$} \\
\hline Base ${ }^{c}$ & \multicolumn{2}{|c|}{$100 \mathrm{~cm}$} & \multicolumn{2}{|c|}{$68 \mathrm{~cm}$} & \multicolumn{2}{|c|}{$109 \mathrm{~cm}$} & \multicolumn{2}{|c|}{$109 \mathrm{~cm}$} \\
\hline mbsf $^{d}$ & \multicolumn{2}{|c|}{$37.1 \mathrm{~m}$} & \multicolumn{2}{|c|}{$38.28 \mathrm{~m}$} & \multicolumn{2}{|c|}{$46.69 \mathrm{~m}$} & \multicolumn{2}{|c|}{$46.69 \mathrm{~m}$} \\
\hline$n^{e}$ & 12 & & 10 & & 5 & & 3 & \\
\hline $\mathrm{Mg}(\mathrm{ppm})$ & 1720 & 729 & 775 & 337 & 2006 & 401 & 838 & 29.5 \\
\hline $\mathrm{Ti}$ & 1550 & 547 & 809 & 399 & 1574 & 247 & 1254 & 91.0 \\
\hline V & 5.73 & 3.06 & 1.26 & 1.09 & 8.25 & 2.39 & 0.27 & 0.23 \\
\hline $\mathrm{Cr}$ & 7.54 & 5.27 & 1.73 & 2.02 & 1.62 & 0.82 & 5.97 & 12.8 \\
\hline Mn & 396 & 116 & 335 & 70.0 & 380 & 72.3 & 635 & 52.4 \\
\hline Co & 1.34 & 0.41 & 0.55 & 0.30 & 1.64 & 0.16 & 0.36 & 0.33 \\
\hline $\mathrm{Ni}$ & 1.62 & 0.98 & 0.27 & 0.38 & 0.84 & 1.32 & 1.03 & 1.16 \\
\hline $\mathrm{Cu}$ & 3.73 & 1.69 & 2.53 & 1.82 & 4.56 & 0.96 & 2.84 & 0.95 \\
\hline $\mathbf{Z n}$ & 33.4 & 20.2 & 34.1 & 21.2 & 42.2 & 28.1 & 82.5 & 26.3 \\
\hline Ga & 17.2 & 5.06 & 14.9 & 4.87 & 16.4 & 4.21 & 17.8 & 1.55 \\
\hline $\mathbf{R b}$ & 143 & 47.6 & 156 & 34.0 & 124 & 37.6 & 120 & 12.6 \\
\hline $\mathrm{Sr}$ & 96.9 & 34.5 & 58.2 & 25.1 & 113 & 20.8 & 75.7 & 1.76 \\
\hline Y & 30.1 & 6.56 & 23.9 & 4.79 & 30.1 & 10.1 & 33.4 & 2.53 \\
\hline $\mathrm{Zr}$ & 246 & 90.4 & 100 & 42.8 & 239 & 50.0 & 253 & 28.0 \\
\hline $\mathrm{Nb}$ & 10.4 & 2.05 & 9.05 & 2.48 & 8.93 & 2.00 & 12.0 & 0.77 \\
\hline Mo & 1.95 & 0.82 & 1.95 & 0.45 & 1.32 & 0.66 & 1.80 & 0.88 \\
\hline Cs & 6.59 & 2.32 & 7.81 & 2.34 & 6.43 & 2.17 & 5.91 & 0.61 \\
\hline $\mathrm{Ba}$ & 855 & 239 & 911 & 237 & 835 & 246 & 801 & 62.1 \\
\hline La & 28.2 & 6.57 & 27.0 & 5.06 & 26.3 & 8.47 & 26.6 & 2.72 \\
\hline $\mathrm{Ce}$ & 62.5 & 18.0 & 57.6 & 15.1 & $\mathbf{5 7 . 3}$ & 18.8 & 64.4 & 5.82 \\
\hline $\operatorname{Pr}$ & 6.64 & 1.34 & 5.65 & 1.65 & 6.20 & 1.71 & 6.75 & 0.46 \\
\hline Nd & 25.8 & 6.75 & 21.0 & 5.97 & 24.9 & 5.91 & 27.8 & 0.24 \\
\hline $\mathrm{Sm}$ & 5.06 & 1.55 & 4.00 & 1.52 & 5.36 & 1.45 & 6.08 & 0.12 \\
\hline Eu & 0.86 & 0.41 & 0.44 & 0.25 & 0.82 & 0.20 & 1.04 & 0.04 \\
\hline Gd & 4.62 & 1.49 & 3.74 & 0.92 & 4.79 & 1.10 & 5.50 & 0.79 \\
\hline $\mathrm{Tb}$ & & & & & 0.74 & 0.16 & 0.89 & 0.04 \\
\hline Dy & 5.28 & 1.78 & 3.72 & 1.13 & 5.04 & 1.26 & 5.79 & 0.92 \\
\hline Ho & & & & & 1.06 & 0.29 & 1.23 & 0.15 \\
\hline Er & 3.11 & 0.91 & 2.47 & 0.52 & 3.25 & 1.04 & 3.71 & 0.25 \\
\hline $\mathrm{Tm}$ & & & & & 0.49 & 0.15 & 0.52 & 0.03 \\
\hline $\mathbf{Y b}$ & 3.43 & 1.08 & 2.74 & 0.82 & 3.27 & 0.86 & 3.91 & 0.51 \\
\hline Lu & 0.50 & 0.19 & 0.45 & 0.11 & 0.50 & 0.17 & 0.57 & 0.06 \\
\hline Hf & 6.40 & 1.92 & 3.18 & 1.18 & 5.97 & 1.28 & 6.51 & 1.00 \\
\hline Ta & 0.81 & 0.26 & 0.88 & 0.26 & 0.70 & 0.15 & 0.86 & 0.09 \\
\hline $\mathbf{W}$ & 2.05 & 0.76 & 1.90 & 0.46 & 1.55 & 0.38 & 1.48 & 0.18 \\
\hline $\mathrm{Pb}$ & 21.7 & 6.88 & 20.1 & 6.51 & 19.5 & 4.80 & 21.2 & 2.89 \\
\hline Th & 14.1 & 3.27 & 14.6 & 3.67 & 12.6 & 3.96 & 11.6 & 0.89 \\
\hline $\mathbf{U}$ & 3.35 & 1.18 & 3.45 & 0.98 & 3.05 & 0.92 & 3.01 & 0.31 \\
\hline $\mathrm{Rb} / \mathrm{Sr}$ & 1.52 & 0.95 & 2.77 & 1.13 & 1.09 & 0.24 & 1.59 & 0.17 \\
\hline $\mathrm{Sr} / \mathbf{Y}$ & 3.23 & 0.99 & 2.42 & 0.75 & 3.81 & 0.66 & 2.27 & 0.21 \\
\hline $\mathrm{Zr} / \mathrm{Th}$ & 17.6 & 6.41 & 6.98 & 3.73 & 19.0 & 2.86 & 21.8 & 0.84 \\
\hline $\mathbf{E u} / \mathbf{E} \mathbf{u}^{* \mathrm{~h}}$ & 0.54 & 0.19 & 0.35 & 0.18 & 0.50 & 0.05 & 0.49 & 0.10 \\
\hline $\mathrm{Rb} / \mathrm{Sm}$ & 28.4 & 7.42 & 39.6 & 8.68 & 23.1 & 2.97 & 19.8 & 2.43 \\
\hline $\mathbf{Z r} / \mathbf{Y}$ & 8.21 & 2.57 & 4.16 & 1.17 & 8.01 & 1.32 & 7.56 & 0.43 \\
\hline $\mathrm{Ba} / \mathrm{Sr}$ & 9.04 & 4.04 & 16.1 & 5.61 & 7.35 & 1.30 & 10.6 & 0.80 \\
\hline $\mathrm{Nb} / \mathrm{Pb}$ & 0.48 & 0.10 & 0.45 & 0.11 & 0.46 & 0.03 & 0.57 & 0.05 \\
\hline $\mathrm{La} / \mathbf{Y b}$ & 8.33 & 2.35 & 10.0 & 3.25 & 8.10 & 2.31 & 6.82 & 0.68 \\
\hline Dy/Yb & 1.57 & 0.69 & 1.39 & 0.66 & 1.56 & 0.39 & 1.48 & 0.21 \\
\hline $\mathrm{Ba} / \mathrm{Th}$ & 60.7 & 10.4 & 62.8 & 11.9 & 66.1 & 4.36 & 69.1 & 2.92 \\
\hline
\end{tabular}


Table A4-1 continued

\begin{tabular}{|c|c|c|c|c|c|c|c|c|}
\hline Sample no. ${ }^{a}$ & \multicolumn{2}{|c|}{ AT-373 (3) } & \multicolumn{2}{|c|}{ A-15 (1) } & \multicolumn{2}{|c|}{ A-15 (2) } & \multicolumn{2}{|c|}{ AT-275 } \\
\hline Sample details ${ }^{\text {b }}$ & \multicolumn{2}{|c|}{$1123 \mathrm{~A}-6 \mathrm{H}-2$} & \multicolumn{2}{|c|}{$1123 \mathrm{~A}-6 \mathrm{H}-3$} & \multicolumn{2}{|c|}{$1123 \mathrm{~A}-6 \mathrm{H}-3$} & \multicolumn{2}{|c|}{$1123 \mathrm{~A}-6 \mathrm{H}-4$} \\
\hline Base c & \multicolumn{2}{|c|}{$109 \mathrm{~cm}$} & \multicolumn{2}{|c|}{$140 \mathrm{~cm}$} & \multicolumn{2}{|c|}{$140 \mathrm{~cm}$} & \multicolumn{2}{|c|}{$134 \mathrm{~cm}$} \\
\hline $\operatorname{mbsf}^{d}$ & \multicolumn{2}{|c|}{$46.69 \mathrm{~m}$} & \multicolumn{2}{|l|}{$48.5 \mathrm{~m}$} & \multicolumn{2}{|c|}{$48.5 \mathrm{~m}$} & \multicolumn{2}{|c|}{$49.94 \mathrm{~m}$} \\
\hline$n^{e}$ & 2 & & 5 & & 3 & & 9 & \\
\hline Mg (ppm) & 1440 & 236 & 1263 & 497 & 2091 & 507 & 997 & 403 \\
\hline $\mathrm{Ti}$ & 1349 & 6.39 & 1520 & 528 & 1780 & 679 & 1244 & 158 \\
\hline $\mathbf{v}$ & 5.07 & 2.30 & 2.01 & 3.62 & 8.97 & 2.77 & 1.21 & 1.85 \\
\hline $\mathrm{Cr}$ & 4.74 & 0.98 & 4.03 & 17.4 & 0.19 & 16.4 & 0.85 & 1.92 \\
\hline Mn & 357 & 41.7 & 560 & 280 & 375 & 153 & 630 & 98.5 \\
\hline Co & 1.52 & 0.37 & 0.84 & 1.85 & 1.18 & 1.67 & 0.52 & 0.36 \\
\hline $\mathrm{Ni}$ & 0.68 & 1.71 & 0.01 & 1.05 & 0.98 & 0.37 & 4.18 & 4.94 \\
\hline $\mathrm{Cu}$ & 4.92 & 1.27 & 4.29 & 5.97 & 6.83 & 2.30 & 3.07 & 0.97 \\
\hline $\mathrm{Zn}$ & 49.8 & 7.65 & 52.0 & 41.8 & 43.3 & 12.8 & 55.7 & 43.3 \\
\hline $\mathrm{Ga}$ & 16.7 & 1.71 & 18.1 & 5.19 & 16.0 & 6.78 & 17.0 & 3.95 \\
\hline $\mathbf{R b}$ & 139 & 11.4 & 138 & 44.9 & 113 & 51.9 & 120 & 20.9 \\
\hline $\mathrm{Sr}$ & 88.5 & 3.06 & 99.4 & 26.3 & 118 & 21.1 & 73.7 & 12.9 \\
\hline $\mathbf{Y}$ & 30.2 & 1.75 & 38.0 & 9.38 & 27.4 & 15.4 & 44.5 & 7.01 \\
\hline $\mathrm{Zr}$ & 199 & 3.30 & 282 & 129 & 218 & 117 & 338 & 44.6 \\
\hline $\mathrm{Nb}$ & 9.00 & 0.19 & 12.4 & 6.40 & 8.17 & 4.60 & 13.5 & 2.18 \\
\hline Mo & 1.51 & 0.00 & 1.59 & 0.58 & 1.15 & 0.64 & 2.54 & 1.95 \\
\hline Cs & 7.14 & 0.14 & 6.75 & 1.56 & 5.88 & 3.38 & 6.11 & 1.18 \\
\hline $\mathrm{Ba}$ & 889 & 37.6 & 857 & 150 & 715 & 343 & 840 & 139 \\
\hline La & 27.2 & 0.50 & 30.9 & 8.29 & 24.1 & 12.1 & 33.5 & 4.09 \\
\hline $\mathrm{Ce}$ & 61.8 & 0.03 & 67.0 & 15.6 & 53.4 & 27.6 & 67.2 & 10.4 \\
\hline Pr & 6.38 & 0.22 & 7.49 & 1.18 & 5.47 & 2.68 & 8.00 & 1.27 \\
\hline Nd & 25.0 & 1.59 & 30.4 & 7.45 & 22.0 & 12.7 & 33.8 & 5.60 \\
\hline $\mathrm{Sm}$ & 5.46 & 0.45 & 6.21 & 1.89 & 4.96 & 2.18 & 7.42 & 1.30 \\
\hline Eu & 0.77 & 0.01 & 1.03 & 0.35 & 0.82 & 0.26 & 1.11 & 0.16 \\
\hline Gd & 4.71 & 0.26 & 5.50 & 2.41 & 4.42 & 2.58 & 6.96 & 1.06 \\
\hline Tb & 0.84 & 0.14 & 1.02 & 0.32 & 0.70 & 0.45 & 1.17 & 0.22 \\
\hline Dy & 5.20 & 0.25 & 7.02 & 2.57 & 5.14 & 2.31 & 7.67 & 1.16 \\
\hline Но & 1.13 & 0.07 & 1.50 & 0.55 & 1.05 & 0.92 & 1.58 & 0.30 \\
\hline Er & 3.19 & 0.04 & 4.33 & 1.53 & 3.20 & 1.58 & 4.84 & 1.06 \\
\hline $\mathrm{Tm}$ & 0.48 & 0.05 & 0.64 & 0.29 & 0.49 & 0.12 & 0.74 & 0.09 \\
\hline $\mathbf{Y b}$ & 3.26 & 0.18 & 4.40 & 1.61 & 3.21 & 1.87 & 4.93 & 0.68 \\
\hline Lu & 0.50 & 0.13 & 0.60 & 0.09 & 0.54 & 0.46 & 0.81 & 0.18 \\
\hline Hf & 5.14 & 1.97 & 7.30 & 2.85 & 5.90 & 2.89 & 8.58 & 1.49 \\
\hline Ta & 0.82 & 0.04 & 0.95 & 0.34 & 0.48 & 0.34 & 1.04 & 0.28 \\
\hline W & 1.78 & 0.39 & 1.74 & 1.01 & 1.11 & 0.99 & 1.45 & 0.34 \\
\hline $\mathbf{P b}$ & 21.4 & 2.63 & 24.0 & 8.11 & 19.7 & 8.87 & 20.4 & 4.84 \\
\hline Th & 13.5 & 0.08 & 15.3 & 2.74 & 12.5 & 6.21 & 15.4 & 2.07 \\
\hline $\mathbf{U}$ & 3.45 & 0.06 & 3.46 & 0.78 & 2.82 & 1.47 & 3.08 & 0.64 \\
\hline $\mathrm{Rb} / \mathrm{Sr}$ & 1.57 & 0.07 & 1.39 & 0.37 & 0.95 & 0.29 & 1.65 & 0.48 \\
\hline $\mathrm{Sr} / \mathrm{Y}$ & 2.93 & 0.27 & 2.66 & 1.19 & 4.47 & 1.75 & 1.66 & 0.26 \\
\hline $\mathrm{Zr} / \mathrm{Th}$ & 14.8 & 0.33 & 18.3 & 6.29 & 17.5 & 4.64 & 21.9 & 1.99 \\
\hline $\mathbf{E u} / \mathbf{E} \mathbf{u}^{*}$ & 0.47 & 0.01 & 0.54 & 0.10 & 0.55 & 0.13 & 0.47 & 0.08 \\
\hline $\mathrm{Rb} / \mathrm{Sm}$ & 25.5 & 0.02 & 22.5 & 8.40 & 22.8 & 2.70 & 16.3 & 3.07 \\
\hline $\mathrm{Zr} / \mathbf{Y}$ & 6.60 & 0.27 & 7.36 & 2.09 & 8.01 & 2.44 & 7.61 & 0.59 \\
\hline $\mathrm{Ba} / \mathrm{Sr}$ & 10.0 & 0.08 & 8.70 & 1.78 & 6.02 & 2.02 & 11.5 & 2.84 \\
\hline $\mathrm{Nb} / \mathrm{Pb}$ & 0.42 & 0.04 & 0.52 & 0.20 & 0.41 & 0.08 & 0.67 & 0.07 \\
\hline $\mathrm{La} / \mathrm{Yb}$ & 8.34 & 0.32 & 7.11 & 1.69 & 7.55 & 1.21 & 6.82 & 0.92 \\
\hline Dy/Yb & 1.59 & 0.01 & 1.60 & 0.23 & 1.63 & 0.56 & 1.56 & 0.31 \\
\hline $\mathrm{Ba} / \mathrm{Th}$ & 66.0 & 2.42 & 56.0 & 3.52 & 57.6 & 14.2 & 54.5 & 9.43 \\
\hline
\end{tabular}


Table A4-1 continued

\begin{tabular}{|c|c|c|c|c|c|c|c|c|}
\hline Sample no. ${ }^{a}$ & \multicolumn{2}{|c|}{ AT-339 } & \multicolumn{2}{|c|}{ AT-374 } & \multicolumn{2}{|c|}{ AT-340 } & \multicolumn{2}{|l|}{ A-17 } \\
\hline Sample details ${ }^{b}$ & \multicolumn{2}{|c|}{$1123 \mathrm{~A}-6 \mathrm{H}-5$} & \multicolumn{2}{|c|}{$1123 \mathrm{~A}-6 \mathrm{H}-6$} & \multicolumn{2}{|c|}{$1123 \mathrm{~A}-6 \mathrm{H}-6$} & \multicolumn{2}{|c|}{$1123 \mathrm{~A}-6 \mathrm{H}-7$} \\
\hline Base ${ }^{c}$ & \multicolumn{2}{|l|}{$21 \mathrm{~cm}$} & \multicolumn{2}{|l|}{$66 \mathrm{~cm}$} & \multicolumn{2}{|c|}{$127 \mathrm{~cm}$} & \multicolumn{2}{|c|}{$16 \mathrm{~cm}$} \\
\hline $\operatorname{mbsf}^{d}$ & \multicolumn{2}{|c|}{$50.31 \mathrm{~m}$} & \multicolumn{2}{|c|}{$52.26 \mathrm{~m}$} & \multicolumn{2}{|c|}{$52.87 \mathrm{~m}$} & \multicolumn{2}{|c|}{$53.26 \mathrm{~m}$} \\
\hline$n^{e}$ & 7 & & 10 & & 5 & & 6 & \\
\hline Mg (ppm) & 1087 & 262 & 1061 & 173 & 651 & 248 & 517 & 248 \\
\hline $\mathrm{Ti}$ & 1282 & 162 & 1383 & 220 & 457 & 287 & 304 & 186 \\
\hline $\mathrm{v}$ & 1.04 & 1.85 & 0.48 & 0.66 & 1.88 & 0.77 & 1.24 & 1.14 \\
\hline $\mathrm{Cr}$ & 2.38 & 3.00 & 1.11 & 3.44 & 4.06 & 10.1 & 0.71 & 2.01 \\
\hline Mn & 636 & 105 & 660 & 95.6 & 285 & 93.3 & 379 & 122 \\
\hline Co & 0.41 & 0.65 & 0.38 & 0.44 & 1.97 & 4.72 & 0.38 & 0.25 \\
\hline $\mathrm{Ni}$ & 4.76 & 13.3 & 0.55 & 1.20 & 0.66 & 1.25 & 0.41 & 0.81 \\
\hline $\mathrm{Cu}$ & 4.66 & 3.75 & 3.36 & 1.79 & 2.32 & 1.71 & 5.96 & 8.15 \\
\hline $\mathrm{Zn}$ & 56.9 & 31.6 & 51.0 & 46.3 & 23.5 & 19.4 & 33.4 & 17.6 \\
\hline $\mathrm{Ga}$ & 15.9 & 3.02 & 18.0 & 3.89 & 12.4 & 8.55 & 12.9 & 3.59 \\
\hline $\mathbf{R b}$ & 110 & 20.7 & 119 & 22.4 & 127 & 44.7 & 163 & 56.5 \\
\hline $\mathrm{Sr}$ & 87 & 11.7 & 90.5 & 16.0 & 75.4 & 34.7 & 61.5 & 24.2 \\
\hline $\mathbf{Y}$ & 43.6 & 4.66 & 44.4 & 12.2 & 15.2 & 4.60 & 17.5 & 4.65 \\
\hline $\mathrm{Zr}$ & 342 & 50.3 & 335 & 76.7 & 63.4 & 24.7 & 61.4 & 12.2 \\
\hline $\mathbf{N b}$ & 12.1 & 1.87 & 12.9 & 2.49 & 5.18 & 2.44 & 5.62 & 1.40 \\
\hline Mo & 2.02 & 0.62 & 1.44 & 0.57 & 1.39 & 1.13 & 1.21 & 0.61 \\
\hline Cs & 5.89 & 0.94 & 6.15 & 1.29 & 7.60 & 2.63 & 9.55 & 3.33 \\
\hline $\mathrm{Ba}$ & 782 & 101 & 821 & 131 & 679 & 351 & 785 & 172 \\
\hline La & 32.4 & 3.58 & 31.8 & 5.08 & 22.1 & 9.97 & 24.7 & 3.32 \\
\hline $\mathrm{Ce}$ & 62.6 & 6.83 & 66.1 & 12.5 & 46.4 & 24.1 & 51.9 & 11.5 \\
\hline $\mathrm{Pr}$ & 7.68 & 0.80 & 7.99 & 1.27 & 4.31 & 1.81 & 4.92 & 1.28 \\
\hline Nd & 33.5 & 3.73 & 33.3 & 6.87 & 14.6 & 5.06 & 17.7 & 3.12 \\
\hline $\mathrm{Sm}$ & 7.33 & 0.50 & 7.67 & 2.14 & 2.21 & 1.62 & 3.32 & 0.88 \\
\hline Eu & 1.14 & 0.17 & 1.19 & 0.18 & 0.33 & 0.23 & 0.34 & 0.12 \\
\hline Gd & 6.81 & 1.08 & 7.11 & 1.89 & 2.41 & 1.24 & 2.67 & 0.68 \\
\hline $\mathbf{T b}$ & 1.16 & 0.17 & 1.12 & 0.28 & 0.36 & 0.08 & 0.43 & 0.18 \\
\hline Dy & 7.82 & 1.15 & 7.71 & 2.07 & 2.36 & 0.70 & 2.88 & 0.86 \\
\hline Но & 1.59 & 0.17 & 1.58 & 0.31 & 0.53 & 0.31 & 0.60 & 0.17 \\
\hline Er & 4.98 & 0.67 & 4.83 & 1.78 & 1.52 & 0.66 & 1.82 & 0.58 \\
\hline $\mathrm{Tm}$ & 0.73 & 0.12 & 0.75 & 0.26 & 0.20 & 0.11 & 0.29 & 0.11 \\
\hline $\mathbf{Y b}$ & 4.95 & 0.47 & 5.04 & 1.59 & 1.64 & 1.06 & 2.23 & 1.00 \\
\hline Lu & 0.75 & 0.19 & 0.73 & 0.26 & 0.27 & 0.12 & 0.34 & 0.10 \\
\hline Hf & 8.45 & 0.99 & 8.63 & 1.97 & 2.27 & 0.49 & 2.27 & 0.57 \\
\hline $\mathrm{Ta}$ & 0.96 & 0.09 & 0.94 & 0.23 & 0.63 & 0.20 & 0.73 & 0.30 \\
\hline W & 1.83 & 0.51 & 1.49 & 0.46 & 1.76 & 1.17 & 2.3 & 1.02 \\
\hline $\mathrm{Pb}$ & 18.4 & 3.31 & 20.3 & 4.33 & 18.5 & 5.72 & 22.2 & 6.33 \\
\hline Th & 15.0 & 2.18 & 14.4 & 3.46 & 14.1 & 4.72 & 16.5 & 4.60 \\
\hline $\mathbf{U}$ & 2.78 & 0.69 & 2.93 & 0.56 & 3.03 & 0.67 & 4.26 & 1.64 \\
\hline $\mathrm{Rb} / \mathrm{Sr}$ & 1.27 & 0.28 & 1.32 & 0.26 & 1.72 & 0.46 & 2.78 & 1.68 \\
\hline $\mathrm{Sr} / \mathbf{Y}$ & 2.00 & 0.34 & 2.05 & 0.28 & 4.99 & 2.44 & 3.61 & 2.19 \\
\hline $\mathrm{Zr} / \mathrm{Th}$ & 22.8 & 3.62 & 23.4 & 3.27 & 4.48 & 0.60 & 3.77 & 0.97 \\
\hline $\mathbf{E} \mathbf{u} / \mathbf{E} \mathbf{u}^{*}{ }^{h}$ & 0.49 & 0.06 & 0.50 & 0.11 & 0.44 & 0.25 & 0.36 & 0.17 \\
\hline $\mathrm{Rb} / \mathrm{Sm}$ & 15.0 & 2.78 & 15.7 & 3.42 & 62.9 & 42.1 & 49.2 & 12.8 \\
\hline $\mathbf{Z r} / \mathbf{Y}$ & 7.85 & 0.93 & 7.57 & 0.62 & 4.15 & 0.86 & 3.53 & 0.78 \\
\hline $\mathrm{Ba} / \mathrm{Sr}$ & 9.02 & 1.66 & 9.11 & 1.53 & 9.08 & 3.48 & 13.2 & 5.49 \\
\hline $\mathrm{Nb} / \mathrm{Pb}$ & 0.66 & 0.06 & 0.64 & 0.07 & 0.28 & 0.08 & 0.25 & 0.02 \\
\hline $\mathrm{La} / \mathrm{Yb}$ & 6.55 & 0.40 & 6.38 & 1.12 & 14.2 & 6.64 & 11.5 & 4.64 \\
\hline Dy/Yb & 1.58 & 0.11 & 1.54 & 0.25 & 1.60 & 1.32 & 1.31 & 0.25 \\
\hline $\mathrm{Ba} / \mathrm{Th}$ & 52.2 & 7.12 & $\mathbf{5 7 . 8}$ & 17.8 & 47.7 & 14.8 & 48.1 & 9.29 \\
\hline
\end{tabular}


Table A4-1 continued

\begin{tabular}{|c|c|c|c|c|c|c|c|c|}
\hline Sample no. ${ }^{a}$ & \multicolumn{2}{|c|}{$\Delta T-341$} & \multicolumn{2}{|l|}{ A-19 } & \multicolumn{2}{|c|}{$\Delta T-342$} & \multicolumn{2}{|c|}{$\Delta T-274$} \\
\hline Sample details ${ }^{b}$ & \multicolumn{2}{|c|}{$1123 \mathrm{~A}-6 \mathrm{H}-7$} & \multicolumn{2}{|c|}{$1123 \mathrm{~A}-7 \mathrm{H}-1$} & \multicolumn{2}{|c|}{$1123 \mathrm{~A}-7 \mathrm{H}-3$} & \multicolumn{2}{|c|}{$1123 \mathrm{~A}-7 \mathrm{H}-3$} \\
\hline Base ${ }^{c}$ & \multicolumn{2}{|l|}{$42 \mathrm{~cm}$} & \multicolumn{2}{|l|}{$55 \mathrm{~cm}$} & \multicolumn{2}{|c|}{$51.5 \mathrm{~cm}$} & \multicolumn{2}{|c|}{$112 \mathrm{~cm}$} \\
\hline mbsf $^{d}$ & \multicolumn{2}{|c|}{$53.52 \mathrm{~m}$} & \multicolumn{2}{|l|}{54.15} & \multicolumn{2}{|c|}{$57.12 \mathrm{~m}$} & \multicolumn{2}{|c|}{$57.72 \mathrm{~m}$} \\
\hline $\mathrm{n}^{\mathrm{e}}$ & 7 & & 11 & & 7 & & 8 & \\
\hline Mg (ppm) & 985 & 158 & 855 & 116 & 754 & 197 & 1241 & 394 \\
\hline $\mathrm{Ti}$ & 1070 & 291 & 964 & 145 & 1176 & 208 & 1381 & 343 \\
\hline V & 0.94 & 1.77 & 2.09 & 0.61 & 0.39 & 0.67 & 0.58 & 0.70 \\
\hline $\mathrm{Cr}$ & 3.53 & 9.53 & 0.65 & 1.95 & 1.03 & 3.54 & 0.91 & 2.11 \\
\hline Mn & 476 & 215 & 341 & 59.7 & 587 & 169 & 632 & 65.3 \\
\hline Co & 0.68 & 0.65 & 0.85 & 0.42 & 0.54 & 1.41 & 0.94 & 1.04 \\
\hline $\mathrm{Ni}$ & 0.73 & 2.91 & 0.43 & 0.97 & 1.25 & 3.75 & 2.58 & 5.74 \\
\hline $\mathrm{Cu}$ & 4.43 & 3.74 & 4.75 & 2.10 & 4.72 & 2.83 & 2.94 & 1.66 \\
\hline $\mathbf{Z n}$ & 49.8 & 53.2 & 48.9 & 21.5 & 76.1 & 32.6 & 62.1 & 24.6 \\
\hline Ga & 15.9 & 6.87 & 16.9 & 2.94 & 17.9 & 3.74 & 17.4 & 1.75 \\
\hline $\mathbf{R b}$ & 125 & 62.6 & 159 & 34.2 & 127 & 36.5 & 122 & 22.2 \\
\hline $\mathrm{Sr}$ & 82.7 & 13.2 & 55.3 & 6.37 & 71.3 & 16.9 & 86.5 & 6.01 \\
\hline Y & 32.2 & 11.3 & 34.3 & 4.32 & 35.6 & 9.19 & 43.0 & 4.49 \\
\hline $\mathrm{Zr}$ & 250 & 75.7 & 137 & 15.1 & 290 & 66.9 & 340 & 49.4 \\
\hline Nb & 11.1 & 6.38 & 11.2 & 1.86 & 12.3 & 3.27 & 13.2 & 2.55 \\
\hline Mo & 1.65 & 1.48 & 1.78 & 0.67 & 2.49 & 0.56 & 2.10 & 1.09 \\
\hline Cs & 6.51 & 3.19 & 8.41 & 1.52 & 6.62 & 1.39 & 6.21 & 1.47 \\
\hline $\mathrm{Ba}$ & 778 & 260 & 903 & 143 & 866 & 267 & 826 & 103 \\
\hline La & 27.4 & 10.4 & 29.8 & 3.49 & 30.1 & 7.32 & 31.2 & 3.97 \\
\hline $\mathrm{Ce}$ & 62.2 & 31.4 & 67.1 & 12.3 & 67.6 & 16.1 & 64.5 & 13.2 \\
\hline $\mathrm{Pr}$ & 6.65 & 2.68 & 6.99 & 1.05 & 7.44 & 2.19 & 7.58 & 1.07 \\
\hline Nd & 26.9 & 9.31 & 27.1 & 2.99 & 30.3 & 8.58 & 31.7 & 3.91 \\
\hline $\mathrm{Sm}$ & 5.68 & 2.07 & 5.52 & 0.59 & 6.63 & 1.68 & 7.01 & 0.89 \\
\hline Eu & 0.87 & 0.36 & 0.52 & 0.06 & 1.10 & 0.22 & 1.12 & 0.15 \\
\hline Gd & 5.02 & 2.41 & 5.10 & 0.97 & 5.67 & 1.43 & 6.75 & 0.72 \\
\hline Tb & 0.83 & 0.38 & 0.81 & 0.10 & 0.91 & 0.27 & 1.11 & 0.13 \\
\hline Dy & 5.39 & 2.21 & 5.74 & 0.74 & 6.5 & 2.11 & 7.61 & 1.01 \\
\hline Ho & 1.15 & 0.44 & 1.20 & 0.15 & 1.34 & 0.43 & 1.52 & 0.15 \\
\hline Er & 3.55 & 1.78 & 3.63 & 0.48 & 3.96 & 1.17 & 4.73 & 0.82 \\
\hline $\mathrm{Tm}$ & 0.54 & 0.21 & 0.57 & 0.12 & 0.6 & 0.08 & 0.72 & 0.18 \\
\hline $\mathbf{Y b}$ & 3.62 & 1.55 & 3.93 & 0.63 & 4.10 & 1.49 & 4.74 & 0.86 \\
\hline Lu & 0.55 & 0.30 & 0.56 & 0.10 & 0.59 & 0.14 & 0.76 & 0.19 \\
\hline $\mathrm{Hf}$ & 6.47 & 2.34 & 4.16 & 0.77 & 6.87 & 0.75 & 8.44 & 1.50 \\
\hline Ta & 0.83 & 0.48 & 1.04 & 0.29 & 0.90 & 0.27 & 1.03 & 0.15 \\
\hline W & 1.41 & 0.56 & 1.82 & 0.62 & 1.57 & 0.25 & 1.45 & 0.41 \\
\hline $\mathrm{Pb}$ & 20.3 & 9.60 & 22.2 & 3.97 & 23.3 & 4.60 & 20.7 & 4.34 \\
\hline Th & 13.4 & 4.76 & 16.3 & 2.24 & 13.2 & 1.82 & 14.9 & 2.41 \\
\hline $\mathbf{U}$ & 3.14 & 1.36 & 3.93 & 0.82 & 3.27 & 0.94 & 3.10 & 0.57 \\
\hline $\mathrm{Rb} / \mathrm{Sr}$ & 1.52 & 0.80 & 2.87 & 0.65 & 1.78 & 0.26 & 1.41 & 0.28 \\
\hline $\mathrm{Sr} / \mathrm{Y}$ & 2.65 & 1.02 & 1.62 & 0.25 & 2.01 & 0.41 & 2.01 & 0.19 \\
\hline $\mathrm{Zr} / \mathrm{Th}$ & 18.8 & 4.05 & 8.39 & 0.80 & 22.0 & 4.05 & 22.8 & 2.01 \\
\hline $\mathbf{E} \mathbf{u} / \mathbf{E} \mathbf{u}^{* h}$ & 0.50 & 0.10 & 0.30 & 0.04 & 0.56 & 0.16 & 0.50 & 0.07 \\
\hline $\mathrm{Rb} / \mathrm{Sm}$ & 22.0 & 7.34 & 28.7 & 5.42 & 19.2 & 2.49 & 17.4 & 3.45 \\
\hline $\mathrm{Zr} / \mathbf{Y}$ & 7.82 & 0.75 & 3.99 & 0.22 & 8.16 & 1.12 & 7.90 & 0.50 \\
\hline $\mathrm{Ba} / \mathrm{Sr}$ & 9.47 & 3.65 & 16.4 & 2.87 & 12.1 & 2.37 & 9.54 & 1.09 \\
\hline $\mathrm{Nb} / \mathrm{Pb}$ & 0.54 & 0.11 & 0.51 & 0.06 & 0.53 & 0.12 & 0.64 & 0.09 \\
\hline $\mathbf{L a} / \mathbf{Y b}$ & 7.62 & 1.32 & 7.61 & 0.94 & 7.46 & 2.10 & 6.62 & 1.13 \\
\hline Dy $/ \mathbf{Y b}$ & 1.50 & 0.29 & 1.46 & 0.17 & 1.6 & 0.37 & 1.61 & 0.23 \\
\hline $\mathrm{Ba} / \mathrm{Th}$ & 58.6 & 13.7 & 55.3 & 4.64 & 65.8 & 16.7 & 55.5 & 6.39 \\
\hline
\end{tabular}


Table A4-1 continued

\begin{tabular}{|c|c|c|c|c|c|c|c|c|}
\hline \multirow{5}{*}{$\begin{array}{l}\text { Sample no. } \\
\text { Sample details } \\
\text { Base }^{\text {b }} \\
\text { mbsf }^{\text {d }} \\
n^{{ }^{e}}\end{array}$} & \multicolumn{2}{|c|}{$\Delta T-343$} & \multicolumn{2}{|c|}{ AT-271 } & \multicolumn{2}{|c|}{$\Delta \mathrm{T}-375(1)$} & \multicolumn{2}{|c|}{$\Delta T-375(2)$} \\
\hline & \multicolumn{2}{|c|}{$1123 \mathrm{~A}-7 \mathrm{H}-4$} & \multicolumn{2}{|c|}{$1123 \mathrm{~A}-7 \mathrm{H}-5$} & \multicolumn{2}{|c|}{$1123 \mathrm{~A}-7 \mathrm{H}-5$} & \multicolumn{2}{|c|}{$1123 \mathrm{~A}-7 \mathrm{H}-5$} \\
\hline & \multicolumn{2}{|c|}{$112 \mathrm{~cm}$} & \multicolumn{2}{|c|}{$36 \mathrm{~cm}$} & \multicolumn{2}{|c|}{$60 \mathrm{~cm}$} & \multicolumn{2}{|l|}{$60 \mathrm{~cm}$} \\
\hline & \multicolumn{2}{|l|}{59.22} & \multicolumn{2}{|c|}{$59.96 \mathrm{~m}$} & \multicolumn{2}{|c|}{$60.2 \mathrm{~m}$} & \multicolumn{2}{|l|}{$60.2 \mathrm{~m}$} \\
\hline & \multicolumn{2}{|l|}{9} & 11 & & 4 & & 2 & \\
\hline Mg (ppm) & 516 & 365 & 1036 & 202 & 899 & 441 & 616 & 332 \\
\hline $\mathrm{Ti}$ & 279 & 255 & 1055 & 268 & 1119 & 558 & 934 & 658 \\
\hline V & 1.25 & 1.50 & 0.98 & 0.84 & 0.15 & 0.07 & 0.46 & 0.31 \\
\hline $\mathrm{Cr}$ & 0.68 & 1.69 & 1.94 & 2.37 & 4.12 & 5.89 & 5.34 & 15.1 \\
\hline Mn & 311 & 86.6 & 501 & 139 & 586 & 307 & 500 & 313 \\
\hline Co & 0.48 & 0.42 & 1.12 & 0.99 & 0.94 & 1.29 & 0.49 & 1.39 \\
\hline $\mathrm{Ni}$ & 2.27 & 4.19 & 7.68 & 10.4 & 0.75 & 1.72 & 0.18 & 0.50 \\
\hline $\mathrm{Cu}$ & 3.26 & 2.55 & 9.02 & 10.3 & 2.68 & 2.31 & 3.67 & 2.70 \\
\hline $\mathrm{Zn}$ & 17.9 & 12.7 & 46.2 & 29.1 & 66.9 & 43.2 & 71.2 & 38.0 \\
\hline $\mathrm{Ga}$ & 11.1 & 3.32 & 16.4 & 3.75 & 18.7 & 9.85 & 21.6 & 21.5 \\
\hline $\mathbf{R b}$ & 139 & 48.0 & 121 & 33.6 & 127 & 56.2 & 190 & 154 \\
\hline $\mathrm{Sr}$ & 55.2 & 33.2 & 84.6 & 20.5 & 87.0 & 18.3 & 58.5 & 40.4 \\
\hline $\mathbf{Y}$ & 17.3 & 4.70 & 31.4 & 4.85 & 34.6 & 14.6 & 41.4 & 24.2 \\
\hline $\mathrm{Zr}$ & 60.6 & 21.8 & 239 & 54.5 & 275 & 147 & 212 & 149 \\
\hline $\mathrm{Nb}$ & 4.85 & 2.19 & 11.0 & 2.60 & 11.7 & 5.70 & 14.0 & 6.76 \\
\hline Mo & 0.98 & 0.42 & 2.05 & 0.80 & 1.37 & 1.23 & 2.22 & 1.03 \\
\hline Cs & 8.44 & 3.72 & 6.49 & 1.28 & 6.41 & 4.17 & 10.4 & 8.22 \\
\hline $\mathrm{Ba}$ & 636 & 219 & 728 & 153 & 766 & 405 & 1057 & 786 \\
\hline La & 20.8 & 7.17 & 26.2 & 4.83 & 29.7 & 17.2 & 35.5 & 21.8 \\
\hline $\mathrm{Ce}$ & 41.8 & 13.1 & 59.3 & 12.4 & 64.1 & 34.1 & 86.0 & 57.3 \\
\hline $\operatorname{Pr}$ & 4.12 & 1.27 & 6.47 & 1.28 & 6.66 & 3.26 & 8.42 & 5.74 \\
\hline Nd & 15.1 & 5.24 & 26.8 & 5.13 & 29.0 & 15.2 & 38.0 & 25.5 \\
\hline $\mathrm{Sm}$ & 2.83 & 0.70 & 5.40 & 0.85 & 6.61 & 3.25 & 8.23 & 6.95 \\
\hline Eu & 0.28 & 0.13 & 0.90 & 0.13 & 0.92 & 0.45 & 0.85 & 0.78 \\
\hline Gd & 2.47 & 0.89 & 5.16 & 1.22 & 5.00 & 3.03 & 6.59 & 5.37 \\
\hline Tb & 0.40 & 0.11 & 0.80 & 0.17 & 0.91 & 0.51 & 1.07 & 0.78 \\
\hline Dy & 2.68 & 0.81 & 5.43 & 0.94 & 6.18 & 3.08 & 7.53 & 5.34 \\
\hline Но & 0.58 & 0.19 & 1.09 & 0.15 & 1.14 & 0.53 & 1.59 & 1.17 \\
\hline Er & 1.85 & 0.57 & 3.37 & 0.47 & 3.71 & 1.89 & 4.32 & 3.05 \\
\hline $\mathrm{Tm}$ & 0.28 & 0.12 & 0.51 & 0.10 & 0.60 & 0.37 & 0.51 & 0.08 \\
\hline Yb & 2.16 & 0.68 & 3.45 & 0.55 & 3.76 & 2.42 & 4.55 & 4.32 \\
\hline Lu & 0.32 & 0.11 & 0.53 & 0.11 & 0.57 & 0.28 & 0.55 & 0.11 \\
\hline $\mathrm{Hf}$ & 2.31 & 0.62 & 6.25 & 1.34 & 7.06 & 3.89 & 5.87 & 4.81 \\
\hline Ta & 0.71 & 0.38 & 0.80 & 0.20 & 0.87 & 0.50 & 1.15 & 1.00 \\
\hline W & 2.09 & 0.85 & 2.65 & 1.73 & 1.46 & 0.91 & 2.66 & 2.75 \\
\hline $\mathrm{Pb}$ & 17.9 & 4.96 & 20.9 & 4.14 & 21.6 & 8.13 & 26.6 & 18.2 \\
\hline Th & 15.2 & 4.69 & 13.0 & 2.53 & 13.1 & 5.92 & 18.2 & 10.6 \\
\hline $\mathbf{U}$ & 3.46 & 1.44 & 3.20 & 0.76 & 3.13 & 1.63 & 4.68 & 3.34 \\
\hline $\mathrm{Rb} / \mathrm{Sr}$ & 2.81 & 2.84 & 1.45 & 0.47 & 1.47 & 0.76 & 3.21 & 0.41 \\
\hline $\mathrm{Sr} / \mathrm{Y}$ & 3.28 & 2.26 & 2.70 & 0.41 & 2.58 & 0.96 & 1.40 & 0.15 \\
\hline $\mathrm{Zr} / \mathrm{Th}$ & 4.03 & 1.47 & 18.4 & 2.25 & 21.1 & 8.17 & 11.5 & 1.48 \\
\hline $\mathbf{E u} / \mathbf{E} \mathbf{u}^{*{ }^{h}}$ & 0.33 & 0.12 & 0.53 & 0.09 & 0.50 & 0.10 & 0.35 & 0.03 \\
\hline $\mathrm{Rb} / \mathrm{Sm}$ & 49.1 & 13.0 & 22.5 & 6.51 & 19.6 & 9.37 & 23.2 & 0.93 \\
\hline $\mathrm{Zr} / \mathrm{Y}$ & 3.54 & 1.46 & 7.61 & 1.13 & 7.89 & 1.81 & 5.08 & 0.64 \\
\hline $\mathrm{Ba} / \mathrm{Sr}$ & 12.3 & 7.90 & 8.67 & 2.05 & 8.78 & 4.15 & 18.0 & 1.04 \\
\hline $\mathrm{Nb} / \mathrm{Pb}$ & 0.27 & 0.07 & 0.52 & 0.06 & 0.54 & 0.11 & 0.54 & 0.11 \\
\hline $\mathrm{La} / \mathrm{Yb}$ & 9.77 & 3.27 & 7.58 & 0.90 & 8.04 & 1.45 & 8.17 & 2.97 \\
\hline Dy/Yb & 1.25 & 0.18 & 1.58 & 0.22 & 1.69 & 0.40 & 1.71 & 0.45 \\
\hline $\mathrm{Ba} / \mathrm{Th}$ & 42.0 & 10.0 & 56.3 & 11.7 & 57.9 & 8.48 & $\mathbf{5 7 . 3}$ & 9.70 \\
\hline
\end{tabular}


Table A4-1 continued

\begin{tabular}{|c|c|c|c|c|c|c|c|c|}
\hline Sample no. ${ }^{a}$ & \multicolumn{2}{|c|}{ AT-344 } & \multicolumn{2}{|c|}{ AT -376} & \multicolumn{2}{|l|}{ A-12 } & \multicolumn{2}{|c|}{ AT-377 } \\
\hline Sample details ${ }^{\text {b }}$ & \multicolumn{2}{|c|}{$1123 \mathrm{~A}-7 \mathrm{H}-5$} & \multicolumn{2}{|c|}{$1123 \mathrm{~B}-1 \mathrm{H}-2$} & \multicolumn{2}{|c|}{$1123 \mathrm{~B}-2 \mathrm{H}-6$} & \multicolumn{2}{|c|}{$1123 \mathrm{~B}-5 \mathrm{H}-3$} \\
\hline Base $^{c}$ & \multicolumn{2}{|c|}{$128 \mathrm{~cm}$} & \multicolumn{2}{|l|}{$9 \mathrm{~cm}$} & \multicolumn{2}{|c|}{$95 \mathrm{~cm}$} & \multicolumn{2}{|l|}{$6 \mathrm{~cm}$} \\
\hline mbsf $^{d}$ & \multicolumn{2}{|c|}{$60.88 \mathrm{~m}$} & \multicolumn{2}{|l|}{$1.59 \mathrm{~m}$} & \multicolumn{2}{|c|}{$11.85 \mathrm{~m}$} & \multicolumn{2}{|c|}{$34.96 \mathrm{~m}$} \\
\hline $\mathrm{n}^{\mathrm{e}}$ & 9 & & 9 & & 9 & & 7 & \\
\hline Mg (ppm) & 1594 & 668 & 1559 & 453 & 572 & 224 & 1809 & 1170 \\
\hline $\mathrm{Ti}$ & 1503 & 327 & 1141 & 259 & 690 & 182 & 1732 & 1400 \\
\hline V & 2.48 & 3.37 & 1.49 & 0.68 & 0.75 & 1.24 & 6.32 & 4.45 \\
\hline $\mathrm{Cr}$ & 3.31 & 7.42 & 0.99 & 1.89 & 1.29 & 2.20 & 0.56 & 1.91 \\
\hline Mn & 544 & 119 & 597 & 114 & 394 & 73.3 & 399 & 230 \\
\hline Co & 2.11 & 2.32 & 0.24 & 0.13 & 0.46 & 0.48 & 1.42 & 0.87 \\
\hline $\mathrm{Ni}$ & 8.09 & 12.9 & 0.52 & 0.95 & 0.71 & 1.47 & 0.51 & 1.00 \\
\hline $\mathrm{Cu}$ & 3.38 & 4.01 & 1.71 & 0.71 & 3.61 & 4.01 & 2.40 & 1.49 \\
\hline $\mathrm{Zn}$ & 43.6 & 12.6 & 43.6 & 30.5 & 49.5 & 32.9 & 40.8 & 22.1 \\
\hline $\mathrm{Ga}$ & 17.4 & 3.58 & 15.1 & 1.89 & 14.7 & 3.93 & 15.5 & 7.11 \\
\hline $\mathbf{R b}$ & 144 & 33.1 & 99.5 & 20.5 & 135 & 26.6 & 128 & 82.5 \\
\hline $\mathrm{Sr}$ & 108 & 26.4 & 96.9 & 11.1 & 54.9 & 17.8 & 99.2 & 61.0 \\
\hline $\mathbf{Y}$ & 41.0 & 7.68 & 32.2 & 5.04 & 32.6 & 7.44 & 30.7 & 18.2 \\
\hline $\mathrm{Zr}$ & 348 & 74.1 & 152 & 29.3 & 153 & 34.1 & 280 & 182 \\
\hline $\mathrm{Nb}$ & 12.8 & 3.31 & 9.57 & 1.83 & 10.3 & 2.11 & 11.1 & 6.07 \\
\hline Mo & 1.84 & 1.25 & 1.67 & 0.35 & 1.47 & 0.46 & 1.70 & 1.27 \\
\hline Cs & 8.07 & 1.92 & 3.63 & 0.86 & 5.81 & 1.16 & 5.79 & 3.42 \\
\hline $\mathrm{Ba}$ & 853 & 155 & 824 & 156 & 756 & 150 & 785 & 496 \\
\hline La & 32.6 & 5.72 & 24.9 & 2.77 & 27.9 & 4.46 & 27.7 & 17.40 \\
\hline $\mathrm{Ce}$ & 69.0 & 14.0 & 55.3 & 11.5 & 60.5 & 12.4 & 57.9 & 34.8 \\
\hline $\mathrm{Pr}$ & 7.33 & 1.66 & 6.06 & 0.76 & 6.42 & 1.18 & 6.33 & 3.92 \\
\hline Nd & 30.8 & 4.56 & 25.3 & 3.36 & 25.6 & 4.50 & 25.2 & 16.10 \\
\hline $\mathrm{Sm}$ & 6.87 & 1.54 & 5.23 & 0.84 & 5.52 & 1.14 & 5.33 & 2.91 \\
\hline Eu & 1.06 & 0.23 & 1.03 & 0.24 & 0.74 & 0.16 & 0.82 & 0.40 \\
\hline Gd & 6.43 & 1.34 & 4.75 & 1.02 & 5.15 & 0.96 & 4.92 & 3.19 \\
\hline $\mathrm{Tb}$ & 1.05 & 0.31 & 0.84 & 0.15 & 0.83 & 0.18 & & \\
\hline Dy & 6.69 & 1.11 & 5.49 & 1.01 & 5.45 & 1.12 & 5.33 & 3.24 \\
\hline Но & 1.48 & 0.35 & 1.12 & 0.09 & 1.15 & 0.26 & & \\
\hline Er & 4.23 & 1.24 & 3.58 & 0.71 & 3.50 & 0.76 & 3.23 & 2.10 \\
\hline $\mathrm{Tm}$ & 0.62 & 0.23 & 0.52 & 0.13 & 0.52 & 0.11 & & \\
\hline $\mathbf{Y b}$ & 4.88 & 1.66 & 3.94 & 0.95 & 3.52 & 0.83 & 3.75 & 2.19 \\
\hline Lu & 0.70 & 0.19 & 0.58 & 0.10 & 0.56 & 0.10 & 0.51 & 0.32 \\
\hline Hf & 8.68 & 2.55 & 4.17 & 0.90 & 4.69 & 1.10 & 7.28 & 3.82 \\
\hline Ta & 0.99 & 0.32 & 0.73 & 0.11 & 0.89 & 0.21 & 0.93 & 0.65 \\
\hline w & 1.96 & 0.77 & 1.38 & 0.40 & 1.80 & 0.59 & 1.44 & 1.00 \\
\hline $\mathrm{Pb}$ & 25.0 & 6.79 & 16.7 & 3.39 & 22.9 & 6.28 & 18.3 & 10.40 \\
\hline Th & 17.2 & 3.73 & 9.45 & 1.29 & 13.5 & 2.41 & 14.4 & 8.83 \\
\hline $\mathbf{U}$ & 3.73 & 0.87 & 2.38 & 0.53 & 3.14 & 0.91 & 3.01 & 1.62 \\
\hline $\mathrm{Rb} / \mathrm{Sr}$ & 1.34 & 0.21 & 1.03 & 0.18 & 2.50 & 0.63 & 1.33 & 0.58 \\
\hline $\mathrm{Sr} / \mathbf{Y}$ & 2.62 & 0.36 & 3.03 & 0.51 & 1.70 & 0.65 & 3.26 & 1.26 \\
\hline $\mathrm{Zr} / \mathrm{Th}$ & 20.3 & 2.95 & 16.2 & 3.10 & 11.3 & 1.95 & 19.7 & 8.73 \\
\hline $\mathbf{E u} / \mathbf{E} \mathbf{u}^{*}{ }^{h}$ & 0.49 & 0.09 & 0.63 & 0.16 & 0.43 & 0.08 & 0.50 & 0.20 \\
\hline $\mathrm{Rb} / \mathrm{Sm}$ & 21.0 & 4.01 & 19.1 & 5.13 & 24.6 & 5.38 & 24.1 & 6.92 \\
\hline $\mathrm{Zr} / \mathrm{Y}$ & 8.50 & 1.14 & 4.74 & 0.69 & 4.70 & 0.68 & 9.16 & 3.47 \\
\hline $\mathrm{Ba} / \mathrm{Sr}$ & 7.96 & 1.25 & 8.50 & 1.23 & 13.9 & 2.98 & 8.07 & 3.04 \\
\hline $\mathrm{Nb} / \mathrm{Pb}$ & 0.51 & 0.10 & 0.57 & 0.08 & 0.45 & 0.07 & 0.61 & 0.09 \\
\hline $\mathrm{La} / \mathrm{Yb}$ & 6.77 & 1.46 & 6.39 & 1.16 & 7.96 & 0.91 & 7.35 & 0.91 \\
\hline Dy/Yb & 1.40 & 0.48 & 1.40 & 0.18 & 1.55 & 0.14 & 1.41 & 0.27 \\
\hline $\mathrm{Ba} / \mathrm{Th}$ & 49.6 & 6.10 & 87.2 & 13.1 & 56.1 & 10.3 & 54.6 & 4.95 \\
\hline
\end{tabular}


Table A4-1 continued

\begin{tabular}{|c|c|c|c|c|c|c|c|c|}
\hline Sample no. " & \multicolumn{2}{|c|}{ AT-378 (1) } & \multicolumn{2}{|c|}{ AT-378 (2) } & \multicolumn{2}{|c|}{ AT-379 (1) } & \multicolumn{2}{|c|}{ AT-379 (2) } \\
\hline Sample details ${ }^{\text {b }}$ & $1123 \mathrm{~B}-$ & & $1123 \mathrm{~B}$ & & $1123 \mathrm{~B}$ & & $1123 \mathrm{~B}$ & \\
\hline Base $^{c}$ & $11 \mathrm{~cm}$ & & $11 \mathrm{~cm}$ & & $24.5 \mathrm{cl}$ & & $24.5 \mathrm{cr}$ & \\
\hline $\operatorname{mbsf}^{\mathrm{d}}$ & $49.01 \mathrm{n}$ & & 49.011 & & 49.151 & & 49.151 & \\
\hline $\mathrm{n}^{\mathrm{e}}$ & 3 & & 2 & & 6 & & 4 & \\
\hline $\mathrm{Mg}(\mathrm{ppm})$ & 913 & 187 & 644 & 766 & 878 & 134 & 343 & 96.9 \\
\hline $\mathrm{Ti}$ & 1399 & 71.3 & 860 & 80.5 & 1385 & 108 & 811 & 422 \\
\hline V & 0.58 & 0.91 & 1.48 & 4.17 & 0.37 & 0.63 & 0.28 & 0.87 \\
\hline $\mathrm{Cr}$ & 0.98 & 2.46 & 0.29 & 0.54 & 4.67 & 9.63 & 1.80 & 1.29 \\
\hline Mn & 656 & 67.9 & 402 & 283 & 691 & 49.4 & 510 & 234 \\
\hline Co & 0.46 & 0.11 & 0.60 & 0.94 & 0.52 & 0.49 & 0.57 & 1.26 \\
\hline $\mathrm{Ni}$ & 1.32 & 2.26 & n.d & n.d & 0.62 & 1.96 & 1.84 & 3.72 \\
\hline $\mathrm{Cu}$ & 4.05 & 3.65 & 3.53 & 2.36 & 2.62 & 2.20 & 2.33 & 1.94 \\
\hline $\mathrm{Zn}$ & 72.6 & 28.0 & 54.9 & 79.5 & 71.9 & 41.5 & 73.8 & 28.8 \\
\hline Ga & 18.6 & 1.36 & 17.0 & 7.43 & 18.2 & 2.18 & 17.4 & 7.05 \\
\hline $\mathbf{R b}$ & 126 & 14.4 & 148 & 29.2 & 128 & 8.68 & 149 & 69.3 \\
\hline $\mathrm{Sr}$ & 80.6 & 6.05 & 43.2 & 25.7 & 79.9 & 6.98 & 36.6 & 7.60 \\
\hline $\mathbf{Y}$ & 41.4 & 10.5 & 43.2 & 9.25 & 36.8 & 6.26 & 40.4 & 16.5 \\
\hline $\mathrm{Zr}$ & 318 & 75.5 & 173 & 58.4 & 287 & 29.8 & 167 & 63.5 \\
\hline $\mathrm{Nb}$ & 13.3 & 0.97 & 13.7 & 7.91 & 12.5 & 1.12 & 13.5 & 4.83 \\
\hline Mo & 1.55 & 0.89 & 1.83 & 1.15 & 1.60 & 0.63 & 1.75 & 0.87 \\
\hline Cs & 6.17 & 0.06 & 7.61 & 1.45 & 6.21 & 0.36 & 7.15 & 3.41 \\
\hline Ba & 836 & 44.3 & 866 & 238 & 868 & 51.8 & 874 & 379 \\
\hline La & 31.0 & 4.09 & 33.4 & 5.00 & 28.5 & 2.77 & 30.4 & 12.1 \\
\hline $\mathrm{Ce}$ & 65.5 & 3.92 & 67.5 & 31.1 & 68.0 & 7.27 & 74.6 & 36.7 \\
\hline $\operatorname{Pr}$ & 7.35 & 0.28 & 7.79 & 2.66 & 7.31 & 0.32 & 7.97 & 3.14 \\
\hline Nd & 31.4 & 6.80 & 31.9 & 6.32 & 31.6 & 3.31 & 32.6 & 16.7 \\
\hline $\mathrm{Sm}$ & 7.18 & 1.18 & 7.28 & 0.57 & 6.71 & 0.86 & 6.26 & 2.41 \\
\hline Eu & 1.19 & 0.12 & 0.63 & 0.61 & 1.11 & 0.31 & 0.60 & 0.12 \\
\hline Gd & 7.21 & 1.32 & 6.46 & 5.81 & 5.82 & 0.89 & 6.00 & 2.66 \\
\hline Tb & & & & & 0.93 & 0.10 & 1.02 & 0.42 \\
\hline Dy & 7.40 & 3.43 & 7.59 & 1.13 & 6.39 & 1.50 & 6.56 & 1.80 \\
\hline Ho & & & & & 1.29 & 0.17 & 1.34 & 0.49 \\
\hline Er & 4.31 & 0.48 & 4.22 & 1.31 & 3.96 & 1.06 & 4.38 & 1.24 \\
\hline $\mathrm{Tm}$ & & & & & 0.61 & 0.12 & 0.60 & 0.31 \\
\hline $\mathrm{Yb}$ & 4.93 & 1.52 & 4.72 & 0.01 & 3.99 & 0.83 & 4.38 & 2.74 \\
\hline Lu & 0.70 & 0.23 & 0.68 & 0.03 & 0.61 & 0.16 & 0.66 & 0.48 \\
\hline Hf & 7.84 & 1.23 & 5.14 & 1.89 & 6.64 & 1.56 & 4.95 & 1.81 \\
\hline Ta & 0.99 & 0.31 & 1.16 & 0.13 & 0.89 & 0.13 & 0.98 & 0.51 \\
\hline w & 1.38 & 0.27 & 1.67 & 0.35 & 1.52 & 0.30 & 1.88 & 1.32 \\
\hline $\mathrm{Pb}$ & 21.7 & 1.82 & 21.9 & 12.0 & 22.8 & 2.32 & 26.5 & 13.7 \\
\hline Th & 13.5 & 1.96 & 17.5 & 2.98 & 12.7 & 1.04 & 14.1 & 5.55 \\
\hline $\mathbf{U}$ & 3.15 & 0.64 & 3.32 & 0.50 & 3.05 & 0.64 & 3.56 & 1.44 \\
\hline $\mathrm{Rb} / \mathrm{Sr}$ & 1.57 & 0.25 & 3.64 & 2.84 & 1.61 & 0.15 & 4.08 & 1.58 \\
\hline $\mathrm{Sr} / \mathbf{Y}$ & 1.97 & 0.37 & 1.02 & 0.81 & 2.18 & 0.21 & 0.93 & 0.41 \\
\hline $\mathrm{Zr} / \mathrm{Th}$ & 23.5 & 3.32 & 9.99 & 5.05 & 22.5 & 0.98 & 11.9 & 0.41 \\
\hline $\mathbf{E} \mathbf{u} / \mathbf{E} \mathbf{u}^{*{ }^{h}}$ & 0.51 & 0.11 & 0.28 & 0.16 & 0.54 & 0.15 & 0.31 & 0.12 \\
\hline $\mathrm{Rb} / \mathrm{Sm}$ & 17.7 & 4.82 & 20.4 & 5.62 & 19.2 & 2.41 & 24.1 & 10.9 \\
\hline $\mathbf{Z r} / \mathbf{Y}$ & 7.69 & 0.29 & 3.99 & 0.50 & 7.81 & 0.66 & 4.16 & 0.43 \\
\hline $\mathrm{Ba} / \mathrm{Sr}$ & 10.4 & 1.13 & 21.4 & 18.2 & 10.9 & 0.89 & 23.9 & 8.64 \\
\hline $\mathrm{Nb} / \mathrm{Pb}$ & 0.61 & 0.01 & 0.62 & 0.02 & 0.55 & 0.07 & 0.52 & 0.09 \\
\hline $\mathrm{La} / \mathrm{Yb}$ & 6.36 & 1.44 & 7.08 & 1.04 & 7.21 & 1.46 & 7.14 & 1.82 \\
\hline Dy/Yb & 1.50 & 0.40 & 1.61 & 0.24 & 1.61 & 0.36 & 1.57 & 0.61 \\
\hline $\mathrm{Ba} / \mathrm{Th}$ & 62.1 & 11.9 & 50.1 & 22.2 & 68.2 & 5.08 & 61.8 & 4.29 \\
\hline
\end{tabular}


Table A4-1 continued

\begin{tabular}{|c|c|c|c|c|c|c|c|c|}
\hline Sample no. ${ }^{\text {a }}$ & \multirow{2}{*}{\multicolumn{2}{|c|}{$\begin{array}{l}\text { AT-380 (1) } \\
\end{array}$}} & \multicolumn{2}{|c|}{ AT-380 (2) } & \multicolumn{2}{|c|}{ AT-381 } & \multicolumn{2}{|l|}{$\mathrm{CP}$} \\
\hline Sample details ${ }^{b}$ & & & $1123 \mathrm{~B}-\mathrm{C}$ & & $1123 \mathrm{~B}$ & & $1123 \mathrm{~B}-$ & \\
\hline Base $^{c}$ & $32 \mathrm{~cm}$ & & $32 \mathrm{~cm}$ & & $47 \mathrm{~cm}$ & & $143 \mathrm{~cm}$ & \\
\hline $\operatorname{mbsf}^{d}$ & $49.22 \mathrm{r}$ & & $49.22 \mathrm{~m}$ & & 49.37 & & $50.33 \mathrm{n}$ & \\
\hline$n^{e}$ & 10 & & 2 & & 10 & & 9 & \\
\hline Mg (ppm) & 878 & 293 & 342 & 70.6 & 935 & 357 & 2258 & 294 \\
\hline $\mathrm{Ti}$ & 1224 & 345 & 644 & 166 & 1243 & 242 & 1728 & 221 \\
\hline V & 0.82 & 2.12 & 0.23 & 0.46 & 0.95 & 2.34 & 9.13 & 2.15 \\
\hline $\mathrm{Cr}$ & 1.34 & 3.85 & 1.27 & 3.59 & 0.98 & 3.34 & 0.53 & 4.43 \\
\hline Mn & 632 & 150.7 & 436 & 90.7 & 662 & 129 & 410 & 69.0 \\
\hline Co & 0.48 & 0.69 & 0.18 & 0.07 & 1.18 & 2.83 & 1.68 & 0.42 \\
\hline $\mathrm{Ni}$ & 1.03 & 4.19 & 0.09 & 0.18 & 0.92 & 2.03 & 0.18 & 0.41 \\
\hline $\mathrm{Cu}$ & 2.80 & 1.06 & 2.28 & 1.45 & 3.20 & 2.98 & 10.3 & 19.7 \\
\hline $\mathrm{Zn}$ & 71.8 & 38.0 & 57.5 & 48.6 & 84.2 & 45.0 & 43.4 & 29.1 \\
\hline $\mathrm{Ga}$ & 17.3 & 3.59 & 14.1 & 4.02 & 19.7 & 4.93 & 15.8 & 4.76 \\
\hline $\mathbf{R b}$ & 122 & 30.8 & 117 & 14.9 & 136 & 40.5 & 118 & 32.7 \\
\hline $\mathrm{Sr}$ & 78.0 & 22.0 & 36.9 & 17.3 & 82.5 & 15.2 & 120 & 15.5 \\
\hline Y & 37.9 & 9.63 & 36.9 & 4.93 & 39.6 & 7.67 & 30.2 & 6.57 \\
\hline $\mathrm{Zr}$ & 288 & 68.8 & 162 & 4.61 & 313 & 67.2 & 259 & 64.4 \\
\hline Nb & 12.5 & 2.83 & 10.7 & 2.06 & 13.3 & 3.43 & 9.03 & 1.80 \\
\hline Mo & 1.36 & 0.84 & 1.17 & 0.28 & 1.72 & 0.92 & 1.34 & 0.37 \\
\hline Cs & 6.16 & 1.27 & 5.95 & 0.45 & 6.96 & 1.87 & 6.10 & 1.66 \\
\hline $\mathrm{Ba}$ & 823 & 194 & 731 & 119 & 888 & 190 & 797 & 180 \\
\hline La & 29.5 & 6.94 & 27.2 & 1.21 & 30.9 & 5.18 & 26.6 & 5.25 \\
\hline $\mathrm{Ce}$ & 66.1 & 16.4 & 62.7 & 7.53 & 73.3 & 17.1 & 56.4 & 13.6 \\
\hline $\operatorname{Pr}$ & 7.41 & 1.75 & 6.84 & 0.97 & 7.75 & 1.34 & 6.23 & 1.11 \\
\hline Nd & 29.9 & 6.61 & 27.8 & 1.58 & 31.1 & 6.80 & 24.7 & 4.01 \\
\hline $\mathrm{Sm}$ & 6.48 & 1.90 & 6.37 & 0.47 & 6.74 & 2.13 & 5.23 & 0.88 \\
\hline Eu & 1.13 & 0.35 & 0.72 & 0.11 & 1.12 & 0.34 & 0.85 & 0.14 \\
\hline Gd & 6.48 & 1.71 & 5.82 & 0.74 & 6.58 & 1.15 & 4.80 & 1.20 \\
\hline Tb & 1.00 & 0.29 & 0.92 & 0.00 & 0.99 & 0.26 & 0.78 & 0.14 \\
\hline Dy & 6.69 & 1.42 & 6.52 & 0.16 & 6.81 & 1.70 & 5.19 & 1.04 \\
\hline Ho & 1.37 & 0.39 & 1.27 & 0.01 & 1.45 & 0.35 & 1.09 & 0.22 \\
\hline Er & 4.22 & 1.21 & 3.95 & 0.61 & 4.15 & 1.13 & 3.23 & 0.60 \\
\hline $\mathrm{Tm}$ & 0.62 & 0.16 & 0.63 & 0.30 & 0.69 & 0.13 & 0.50 & 0.13 \\
\hline $\mathbf{Y b}$ & 3.91 & 1.12 & 4.22 & 0.36 & 4.32 & 1.18 & 3.42 & 0.58 \\
\hline Lu & 0.66 & 0.29 & 0.58 & 0.03 & 0.64 & 0.14 & 0.53 & 0.15 \\
\hline Hf & 7.26 & 2.24 & 4.80 & 0.28 & 7.54 & 1.51 & 6.45 & 1.51 \\
\hline Ta & 0.92 & 0.23 & 0.93 & 0.10 & 1.00 & 0.26 & 0.74 & 0.15 \\
\hline W & 1.50 & 0.67 & 1.54 & 0.22 & 1.55 & 0.75 & 1.46 & 0.40 \\
\hline $\mathrm{Pb}$ & 21.6 & 4.68 & 20.7 & 6.03 & 24.4 & 8.26 & 23.0 & 8.56 \\
\hline Th & 12.8 & 3.07 & 12.5 & 0.38 & 14.0 & 3.30 & 12.6 & 1.92 \\
\hline $\mathbf{U}$ & 3.07 & 0.82 & 2.70 & 0.52 & 3.48 & 1.01 & 2.97 & 0.94 \\
\hline $\mathrm{Rb} / \mathrm{Sr}$ & 1.57 & 0.26 & 3.25 & 1.11 & 1.66 & 0.57 & 0.98 & 0.28 \\
\hline $\mathrm{Sr} / \mathrm{Y}$ & 2.05 & 0.23 & 1.01 & 0.60 & 2.10 & 0.67 & 4.01 & 0.72 \\
\hline $\mathrm{Zr} / \mathrm{Th}$ & 22.5 & 2.52 & 13.0 & 0.03 & 22.5 & 3.12 & 20.6 & 5.56 \\
\hline $\mathbf{E u} / \mathbf{E} \mathbf{u}^{* \mathrm{~h}}$ & 0.54 & 0.10 & 0.36 & 0.09 & 0.52 & 0.11 & 0.52 & 0.11 \\
\hline $\mathrm{Rb} / \mathrm{Sm}$ & 19.0 & 3.66 & 18.5 & 3.69 & 20.3 & 5.02 & 22.5 & 5.00 \\
\hline $\mathrm{Zr} / \mathrm{Y}$ & 7.61 & 0.41 & 4.41 & 0.71 & 7.91 & 1.02 & 8.61 & 1.86 \\
\hline $\mathrm{Ba} / \mathrm{Sr}$ & 10.6 & 1.31 & 20.2 & 6.19 & 10.8 & 3.08 & 6.62 & 1.34 \\
\hline $\mathrm{Nb} / \mathrm{Pb}$ & 0.58 & 0.06 & 0.52 & 0.05 & 0.55 & 0.10 & 0.40 & 0.14 \\
\hline $\mathrm{La} / \mathrm{Yb}$ & 7.58 & 0.79 & 6.45 & 0.84 & 7.24 & 1.61 & 7.77 & 1.02 \\
\hline Dy/Yb & 1.73 & 0.29 & 1.55 & 0.10 & 1.59 & 0.28 & 1.52 & 0.18 \\
\hline $\mathrm{Ba} / \mathrm{Th}$ & 64.2 & 8.63 & 58.5 & 7.78 & 63.8 & 8.48 & 63.0 & 7.49 \\
\hline
\end{tabular}


Table A4-1 continued

\begin{tabular}{|c|c|c|c|c|c|c|c|c|}
\hline Sample no. ${ }^{a}$ & \multicolumn{2}{|c|}{ AT-384 (1) } & \multicolumn{2}{|c|}{ AT-384 (2) } & \multicolumn{2}{|c|}{ AT-385 } & \multicolumn{2}{|l|}{ A-20 } \\
\hline Sample details ${ }^{b}$ & \multicolumn{2}{|c|}{$1123 \mathrm{~B}-7 \mathrm{H}-2$} & \multicolumn{2}{|c|}{$1123 \mathrm{~B}-7 \mathrm{H}-2$} & \multicolumn{2}{|c|}{$1123 \mathrm{~B}-7 \mathrm{H}-2$} & \multicolumn{2}{|c|}{$1123 \mathrm{~B}-7 \mathrm{H}-4$} \\
\hline Base $^{c}$ & \multicolumn{2}{|c|}{$40 \mathrm{~cm}$} & \multicolumn{2}{|l|}{$40 \mathrm{~cm}$} & \multicolumn{2}{|c|}{$92 \mathrm{~cm}$} & \multicolumn{2}{|c|}{$94 \mathrm{~cm}$} \\
\hline mbsf $^{d}$ & \multicolumn{2}{|c|}{$52.8 \mathrm{~m}$} & \multicolumn{2}{|l|}{$52.8 \mathrm{~m}$} & \multicolumn{2}{|c|}{$53.32 \mathrm{~m}$} & \multicolumn{2}{|c|}{$56.34 \mathrm{~m}$} \\
\hline $\mathrm{n}^{\mathrm{e}}$ & 5 & & 4 & & 9 & & 10 & \\
\hline Mg (ppm) & 2641 & 744 & 1623 & 562 & 662 & 254 & 735 & 95.5 \\
\hline $\mathrm{Ti}$ & 1592 & 573 & 1205 & 337 & 826 & 269 & 1129 & 168 \\
\hline$v$ & 9.05 & 5.20 & 4.70 & 2.06 & 1.41 & 1.27 & 0.11 & 0.13 \\
\hline $\mathrm{Cr}$ & 1.55 & 4.80 & 2.33 & 3.97 & 0.31 & 0.73 & 0.73 & 2.16 \\
\hline Mn & 369 & 116 & 324 & 110 & 289 & 84.1 & 601 & 94.4 \\
\hline Co & 1.87 & 1.66 & 1.21 & 0.41 & 0.56 & 0.34 & 0.25 & 0.20 \\
\hline $\mathrm{Ni}$ & 1.92 & 4.29 & 1.40 & 1.95 & 0.75 & 2.35 & 0.16 & 0.31 \\
\hline $\mathrm{Cu}$ & 4.49 & 1.91 & 3.52 & 1.50 & 3.36 & 1.95 & 3.53 & 1.71 \\
\hline Zn & 48.7 & 35.7 & 36.4 & 29.7 & 39.3 & 23.2 & 75.7 & 22.4 \\
\hline Ga & 17.0 & 5.73 & 15.1 & 4.15 & 13.7 & 4.79 & 18.9 & 2.67 \\
\hline $\mathbf{R b}$ & 111 & 40.1 & 116 & 50 & 130 & 31.3 & 129 & 20.1 \\
\hline $\mathrm{Sr}$ & 105 & 48.7 & 74.1 & 27.7 & 48.4 & 11.1 & 73.9 & 10.1 \\
\hline $\mathbf{Y}$ & 25.5 & 16.0 & 25.7 & 15.6 & 34.0 & 4.26 & 41.1 & 5.39 \\
\hline $\mathrm{Zr}$ & 209 & 147 & 172 & 110 & 142 & 28.6 & 318 & 41.2 \\
\hline $\mathrm{Nb}$ & 7.53 & 4.51 & 7.26 & 4.86 & 10.1 & 2.45 & 13.8 & 2.40 \\
\hline Mo & 1.11 & 0.65 & 1.02 & 0.58 & 1.62 & 0.36 & 1.46 & 0.33 \\
\hline Cs & 5.50 & 2.47 & 5.76 & 2.52 & 6.86 & 1.56 & 6.60 & 1.07 \\
\hline Ba & 667 & 332 & 689 & 335 & 770 & 152 & 883 & 127 \\
\hline La & 21.2 & 14.9 & 22.2 & 14.5 & 28.8 & 4.76 & 31.5 & 4.26 \\
\hline $\mathrm{Ce}$ & 47.1 & 26.5 & 49.3 & 29.5 & 56.6 & 11.6 & 70.7 & 11.6 \\
\hline $\operatorname{Pr}$ & 5.20 & 2.91 & 5.71 & 3.15 & 6.31 & 1.18 & 7.74 & 1.30 \\
\hline Nd & 21.1 & 11.8 & 22.0 & 11.57 & 25.7 & 6.22 & 32.2 & 4.10 \\
\hline $\mathrm{Sm}$ & 4.75 & 2.34 & 4.75 & 2.46 & 5.20 & 1.34 & 7.08 & 1.00 \\
\hline Eu & 0.82 & 0.33 & 0.70 & 0.39 & 0.57 & 0.28 & 1.12 & 0.18 \\
\hline Gd & 4.26 & 2.44 & 4.10 & 2.45 & 4.78 & 1.86 & 6.66 & 1.05 \\
\hline Tb & 0.67 & 0.35 & 0.65 & 0.35 & & & 1.11 & 0.18 \\
\hline Dy & 4.60 & 2.40 & 4.66 & 2.66 & 5.19 & 2.02 & 7.27 & 0.87 \\
\hline Нo & 0.89 & 0.49 & 0.91 & 0.56 & & & 1.51 & 0.22 \\
\hline Er & 2.87 & 1.44 & 2.95 & 1.88 & 3.56 & 0.73 & 4.50 & 0.66 \\
\hline $\mathrm{Tm}$ & 0.44 & 0.18 & 0.46 & 0.20 & & & 0.70 & 0.13 \\
\hline Yb & 3.18 & 1.59 & 3.23 & 1.72 & 3.50 & 1.09 & 4.71 & 0.68 \\
\hline Lu & 0.49 & 0.32 & 0.49 & 0.29 & 0.64 & 0.23 & 0.71 & 0.15 \\
\hline $\mathrm{Hf}$ & 5.87 & 2.95 & 5.28 & 2.92 & 4.32 & 1.96 & 8.12 & 1.49 \\
\hline Ta & 0.60 & 0.30 & 0.61 & 0.31 & 0.97 & 0.35 & 1.04 & 0.19 \\
\hline W & 1.30 & 0.62 & 1.29 & 0.53 & 1.66 & 0.68 & 1.52 & 0.38 \\
\hline $\mathrm{Pb}$ & 19.5 & 6.10 & 18.7 & 5.62 & 18.4 & 4.97 & 23.2 & 3.77 \\
\hline Th & 12.0 & 3.59 & 12.2 & 4.28 & 15.7 & 3.04 & 14.6 & 2.09 \\
\hline $\mathbf{U}$ & 2.93 & 0.97 & 2.89 & 0.65 & 2.88 & 1.20 & 3.34 & 0.64 \\
\hline $\mathrm{Rb} / \mathrm{Sr}$ & 1.07 & 0.15 & 1.55 & 0.25 & 2.70 & 0.56 & 1.75 & 0.18 \\
\hline $\mathrm{Sr} / \mathrm{Y}$ & 4.23 & 1.14 & 2.96 & 0.67 & 1.42 & 0.16 & 1.80 & 0.09 \\
\hline $\mathrm{Zr} / \mathrm{Th}$ & 17.1 & 8.40 & 13.8 & 4.67 & 9.16 & 2.40 & 21.8 & 1.10 \\
\hline $\mathbf{E} \mathbf{u} / \mathbf{E} \mathbf{u}^{\text {th }^{\mathrm{h}}}$ & 0.57 & 0.11 & 0.49 & 0.05 & 0.36 & 0.20 & 0.50 & 0.05 \\
\hline $\mathrm{Rb} / \mathrm{Sm}$ & 23.8 & 4.79 & 24.6 & 5.59 & 25.3 & 7.16 & 18.2 & 1.96 \\
\hline $\mathbf{Z r} / \mathbf{Y}$ & 8.16 & 1.54 & 6.66 & 0.67 & 4.20 & 0.90 & 7.75 & 0.44 \\
\hline $\mathrm{Ba} / \mathrm{Sr}$ & 6.38 & 1.37 & 9.22 & 1.81 & 15.9 & 1.76 & 12.0 & 0.96 \\
\hline $\mathrm{Nb} / \mathrm{Pb}$ & 0.38 & 0.18 & 0.38 & 0.17 & 0.55 & 0.06 & 0.60 & 0.08 \\
\hline $\mathrm{La} / \mathrm{Yb}$ & 6.59 & 2.24 & 6.79 & 1.36 & 8.42 & 3.18 & 6.71 & 0.91 \\
\hline Dy/Yb & 1.44 & 0.16 & 1.44 & 0.17 & 1.53 & 0.93 & 1.55 & 0.15 \\
\hline $\mathrm{Ba} / \mathrm{Th}$ & 55.2 & 16.2 & 56.0 & 15.5 & 49.2 & 5.17 & 60.6 & 3.65 \\
\hline
\end{tabular}


Table A4-1 continued

\begin{tabular}{|c|c|c|c|c|c|c|c|c|}
\hline Sample no. ${ }^{a}$ & \multicolumn{2}{|l|}{$\mathrm{CN}$} & \multicolumn{2}{|c|}{ AT-382 } & \multicolumn{2}{|c|}{ AT-383 } & \multicolumn{2}{|l|}{$\mathrm{CO}$} \\
\hline Sample details ${ }^{b}$ & \multicolumn{2}{|c|}{$1123 \mathrm{~B}-7 \mathrm{H}-4$} & \multicolumn{2}{|c|}{ 1123B-7H-5 } & \multicolumn{2}{|c|}{ 1123B-7H-5 } & \multicolumn{2}{|c|}{$1123 \mathrm{~B}-7 \mathrm{H}-6$} \\
\hline Base ${ }^{c}$ & \multicolumn{2}{|c|}{$148 \mathrm{~cm}$} & \multicolumn{2}{|c|}{$75.7 \mathrm{~cm}$} & \multicolumn{2}{|c|}{$117 \mathrm{~cm}$} & \multicolumn{2}{|c|}{$15.5 \mathrm{~cm}$} \\
\hline $\operatorname{mbsf}^{d}$ & \multicolumn{2}{|c|}{$56.88 \mathrm{~m}$} & \multicolumn{2}{|c|}{$57.66 \mathrm{~m}$} & \multicolumn{2}{|c|}{$58.07 \mathrm{~m}$} & \multicolumn{2}{|c|}{$58.56 \mathrm{~m}$} \\
\hline$n^{e}$ & 9 & & 9 & & 11 & & 13 & \\
\hline Mg (ppm) & 1166 & 878 & 812 & 112 & 753 & 228 & 690 & 559 \\
\hline $\mathrm{Ti}$ & 1173 & 175 & 1162 & 253 & 1016 & 350 & 365 & 270 \\
\hline V & 0.87 & 2.11 & 0.30 & 0.23 & 0.45 & 0.88 & 1.38 & 1.40 \\
\hline $\mathrm{Cr}$ & 0.93 & 3.31 & 1.80 & 5.29 & 2.64 & 5.05 & 4.25 & 9.64 \\
\hline Mn & 609 & 117 & 589 & 108 & 544 & 178 & 352 & 67.5 \\
\hline Co & 0.83 & 1.46 & 0.31 & 0.26 & 0.32 & 0.25 & 0.85 & 1.22 \\
\hline $\mathrm{Ni}$ & 4.80 & 15.1 & 0.34 & 0.84 & 0.70 & 1.21 & 4.23 & 8.33 \\
\hline $\mathrm{Cu}$ & 3.79 & 6.31 & 2.64 & 0.95 & 2.45 & 1.04 & 5.42 & 8.23 \\
\hline $\mathrm{Zn}$ & 68.2 & 37.4 & $\mathbf{5 7 . 7}$ & 54.6 & 42.7 & 29.9 & 23.9 & 16.4 \\
\hline $\mathrm{Ga}$ & 16.6 & 2.70 & 17.7 & 4.96 & 16.3 & 5.51 & 13.3 & 3.35 \\
\hline $\mathbf{R b}$ & 116 & 31.1 & 141 & 29.5 & 125 & 34.8 & 154 & 30.3 \\
\hline $\mathrm{Sr}$ & 86.3 & 20.1 & 75.5 & 10.8 & 70.2 & 17.8 & 60.8 & 37.3 \\
\hline $\mathbf{Y}$ & 40.0 & 7.31 & 35.3 & 4.78 & 42.0 & 12.5 & 21.5 & 4.54 \\
\hline $\mathrm{Zr}$ & 307 & 47.1 & 258 & 44.2 & 290 & 101 & 79.3 & 19.0 \\
\hline Nb & 11.8 & 1.89 & 12.7 & 2.50 & 12.1 & 4.16 & 5.95 & 1.23 \\
\hline Mo & 1.40 & 0.86 & 1.56 & 0.46 & 1.43 & 0.64 & 1.27 & 0.87 \\
\hline Cs & 6.00 & 1.42 & 7.50 & 2.00 & 6.57 & 1.91 & 9.23 & 2.00 \\
\hline $\mathrm{Ba}$ & 785 & 137 & 891 & 194 & 809 & 206 & 695 & 301 \\
\hline La & 29.6 & 3.66 & 29.9 & 3.05 & 32.0 & 8.46 & 25.1 & 8.43 \\
\hline $\mathrm{Ce}$ & 62.8 & 9.74 & 70.8 & 16.0 & 64.0 & 19.1 & 47.6 & 14.4 \\
\hline $\operatorname{Pr}$ & 7.42 & 1.05 & 7.61 & 1.43 & 7.42 & 2.22 & 4.80 & 1.10 \\
\hline Nd & 31.1 & 3.86 & 29.8 & 3.43 & 31.1 & 9.68 & 17.9 & 4.35 \\
\hline $\mathrm{Sm}$ & 6.59 & 0.90 & 6.34 & 0.58 & 6.81 & 2.11 & 3.29 & 0.77 \\
\hline Eu & 1.12 & 0.17 & 1.02 & 0.17 & 1.03 & 0.31 & 0.33 & 0.22 \\
\hline Gd & 6.46 & 1.06 & 5.70 & 0.57 & 6.63 & 2.30 & 2.95 & 0.92 \\
\hline Tb & 1.05 & 0.21 & 0.95 & 0.13 & 1.02 & 0.36 & 0.47 & 0.13 \\
\hline Dy & 7.03 & 1.35 & 6.34 & 0.84 & 7.28 & 2.37 & 3.26 & 0.71 \\
\hline Но & 1.47 & 0.36 & 1.29 & 0.16 & 1.54 & 0.41 & 0.67 & 0.22 \\
\hline Er & 4.46 & 0.85 & 3.83 & 0.53 & 4.47 & 1.36 & 2.16 & 0.54 \\
\hline $\mathrm{Tm}$ & 0.65 & 0.14 & 0.57 & 0.09 & 0.69 & 0.19 & 0.34 & 0.15 \\
\hline $\mathrm{Yb}$ & 4.51 & 0.73 & 4.05 & 0.69 & 4.75 & 1.37 & 2.36 & 0.71 \\
\hline Lu & 0.66 & 0.18 & 0.59 & 0.15 & 0.71 & 0.22 & 0.38 & 0.15 \\
\hline Hf & 7.99 & 1.33 & 6.42 & 0.73 & 7.51 & 2.25 & 2.82 & 0.73 \\
\hline $\mathbf{T a}$ & 0.91 & 0.21 & 0.85 & 0.16 & 0.94 & 0.34 & 0.86 & 0.17 \\
\hline w & 1.42 & 0.41 & 1.73 & 0.45 & 1.51 & 0.47 & 2.05 & 0.55 \\
\hline $\mathbf{P b}$ & 20.5 & 4.43 & 23.0 & 7.94 & 20.3 & 5.83 & 20.6 & 3.83 \\
\hline Th & 14.0 & 2.32 & 14.0 & 1.47 & 15.3 & 3.46 & 18.0 & 2.18 \\
\hline $\mathbf{U}$ & 2.97 & 0.57 & 3.67 & 1.05 & 3.04 & 0.95 & 3.65 & 0.83 \\
\hline $\mathrm{Rb} / \mathrm{Sr}$ & 1.36 & 0.49 & 1.86 & 0.27 & 1.78 & 0.16 & 2.86 & 2.65 \\
\hline $\mathrm{Sr} / \mathrm{Y}$ & 2.16 & 0.28 & 2.14 & 0.32 & 1.68 & 0.30 & 2.88 & 1.95 \\
\hline $\mathrm{Zr} / \mathrm{Th}$ & 22.1 & 3.16 & 18.4 & 2.83 & 18.9 & 3.12 & 4.41 & 1.02 \\
\hline $\mathbf{E} \mathbf{u} / \mathbf{E} \mathbf{u}^{*^{h}}$ & 0.53 & 0.06 & 0.52 & 0.09 & 0.47 & 0.07 & 0.33 & 0.20 \\
\hline $\mathrm{Rb} / \mathrm{Sm}$ & 17.7 & 4.62 & 22.2 & 3.96 & 18.5 & 3.40 & 47.5 & 13.7 \\
\hline $\mathrm{Zr} / \mathbf{Y}$ & 7.69 & 0.41 & 7.30 & 0.62 & 6.88 & 0.83 & 3.71 & 1.01 \\
\hline $\mathrm{Ba} / \mathrm{Sr}$ & 9.18 & 2.27 & 11.8 & 1.75 & 11.5 & 0.98 & 11.8 & 4.71 \\
\hline $\mathrm{Nb} / \mathrm{Pb}$ & 0.58 & 0.07 & 0.56 & 0.11 & 0.60 & 0.08 & 0.29 & 0.06 \\
\hline $\mathrm{La} / \mathrm{Yb}$ & 6.57 & 0.74 & 7.40 & 0.82 & 6.76 & 0.78 & 10.8 & 4.32 \\
\hline Dy/Yb & 1.56 & 0.15 & 1.57 & 0.30 & 1.53 & 0.16 & 1.39 & 0.25 \\
\hline $\mathrm{Ba} / \mathrm{Th}$ & 56.3 & 6.47 & 63.6 & 10.2 & 53.0 & 6.44 & 38.7 & 16.7 \\
\hline
\end{tabular}


Table A4-1 continued

\begin{tabular}{|c|c|c|c|c|c|c|c|c|}
\hline Sample no. ${ }^{a}$ & \multicolumn{2}{|l|}{ A-9 } & \multicolumn{2}{|l|}{ A-10 } & \multicolumn{2}{|l|}{ A-11 } & \multicolumn{2}{|c|}{ AT-390 } \\
\hline Sample details ${ }^{\text {b }}$ & \multicolumn{2}{|c|}{$1123 \mathrm{C}-1 \mathrm{H}-1$} & \multicolumn{2}{|c|}{$1123 \mathrm{C}-1 \mathrm{H}-2$} & \multicolumn{2}{|c|}{$1123 \mathrm{C}-1 \mathrm{H}-2$} & \multicolumn{2}{|c|}{$1123 \mathrm{C}-2 \mathrm{H}-2$} \\
\hline Base $^{c}$ & \multicolumn{2}{|c|}{$135 \mathrm{~cm}$} & \multicolumn{2}{|l|}{$3 \mathrm{~cm}$} & \multicolumn{2}{|c|}{$70 \mathrm{~cm}$} & \multicolumn{2}{|c|}{$94 \mathrm{~cm}$} \\
\hline $\operatorname{mbsf}^{d}$ & \multicolumn{2}{|c|}{$1.35 \mathrm{~m}$} & \multicolumn{2}{|l|}{$1.53 \mathrm{~m}$} & \multicolumn{2}{|c|}{$2.2 \mathrm{~m}$} & \multicolumn{2}{|c|}{$11.44 \mathrm{~m}$} \\
\hline$n^{e}$ & 8 & & 10 & & 6 & & 11 & \\
\hline Mg (ppm) & 1384 & 118 & 1509 & 233 & 1026 & 342 & 554 & 137 \\
\hline $\mathrm{Ti}$ & 1094 & 160 & 1262 & 244 & 867 & 438 & 825 & 193 \\
\hline $\mathrm{v}$ & 1.64 & 0.87 & 1.49 & 0.90 & 2.14 & 0.72 & 0.45 & 0.29 \\
\hline $\mathrm{Cr}$ & 3.10 & 4.62 & 1.11 & 2.68 & 0.55 & 1.94 & 2.05 & 2.99 \\
\hline Mn & 592 & 96.2 & 606 & 80.6 & 414 & 178 & 419 & 84.2 \\
\hline Co & 0.33 & 0.46 & 0.35 & 0.32 & 0.50 & 0.28 & 0.45 & 0.74 \\
\hline $\mathrm{Ni}$ & 0.42 & 0.89 & 0.25 & 0.75 & 0.31 & 0.85 & 0.60 & 1.01 \\
\hline $\mathrm{Cu}$ & 3.39 & 2.96 & 1.73 & 1.40 & 2.70 & 1.03 & 2.53 & 0.98 \\
\hline $\mathrm{Zn}$ & 31.8 & 19.1 & 48.6 & 24.4 & 27.2 & 16.3 & 46.9 & 30.1 \\
\hline Ga & 13.9 & 1.91 & 14.1 & 2.28 & 12.1 & 4.07 & 16.0 & 3.62 \\
\hline $\mathrm{Rb}$ & 90.1 & 11.4 & 88.0 & 12.1 & 93.5 & 25.7 & 144 & 37.8 \\
\hline $\mathrm{Sr}$ & 97.2 & 11.8 & 105 & 18.7 & 61.1 & 12.9 & 53.2 & 14.5 \\
\hline Y & 34.1 & 6.90 & 33.4 & 8.39 & 22.9 & 6.36 & 33.0 & 10.2 \\
\hline $\mathrm{Zr}$ & 151 & 27.1 & 165 & 37.7 & 94.8 & 21.0 & 152 & 36.7 \\
\hline $\mathrm{Nb}$ & 9.54 & 1.27 & 10.3 & 1.72 & 8.30 & 3.09 & 11.2 & 2.90 \\
\hline Mo & 1.22 & 0.49 & 1.44 & 0.57 & 1.20 & 0.68 & 1.64 & 0.49 \\
\hline Cs & 3.36 & 0.35 & 3.23 & 0.38 & 3.67 & 1.03 & 6.33 & 1.42 \\
\hline $\mathrm{Ba}$ & 788 & 66.5 & 815 & 105 & 954 & 302 & 805 & 181 \\
\hline La & 25.4 & 3.94 & 25.2 & 4.20 & 23.4 & 5.21 & 28.6 & 7.28 \\
\hline $\mathrm{Ce}$ & 53.0 & 4.70 & 53.9 & 6.39 & 44.5 & 15.1 & 64.6 & 13.6 \\
\hline $\mathrm{Pr}$ & 6.13 & 0.47 & 6.16 & 0.52 & 4.83 & 1.44 & 6.98 & 1.64 \\
\hline Nd & 25.4 & 3.21 & 25.8 & 4.02 & 18.8 & 4.61 & 27.1 & 7.70 \\
\hline Sm & 5.62 & 0.88 & 5.36 & 1.02 & 3.64 & 0.75 & 5.80 & 2.30 \\
\hline Eu & 1.02 & 0.08 & 1.05 & 0.10 & 0.51 & 0.20 & 0.72 & 0.16 \\
\hline Gd & 5.22 & 1.07 & 5.15 & 0.93 & 3.13 & 0.97 & 5.41 & 1.94 \\
\hline Tb & 0.82 & 0.17 & 0.82 & 0.21 & 0.54 & 0.17 & 0.88 & 0.29 \\
\hline Dy & 5.74 & 1.01 & 5.69 & 1.64 & 3.46 & 1.08 & 5.93 & 2.26 \\
\hline Ho & 1.21 & 0.23 & 1.14 & 0.18 & 0.78 & 0.25 & 1.22 & 0.38 \\
\hline Er & 3.76 & 0.69 & 3.66 & 1.35 & 2.47 & 0.79 & 3.56 & 1.39 \\
\hline $\mathrm{Tm}$ & 0.57 & 0.12 & 0.56 & 0.09 & 0.40 & 0.11 & 0.53 & 0.17 \\
\hline $\mathrm{Yb}$ & 3.82 & 0.70 & 3.89 & 0.71 & 2.67 & 0.68 & 3.78 & 1.24 \\
\hline Lu & 0.58 & 0.15 & 0.62 & 0.16 & 0.45 & 0.11 & 0.56 & 0.22 \\
\hline Hf & 4.56 & 0.84 & 4.73 & 1.11 & 3.04 & 0.72 & 4.78 & 1.33 \\
\hline Ta & 0.74 & 0.09 & 0.78 & 0.15 & 0.82 & 0.31 & 0.98 & 0.33 \\
\hline W & 1.31 & 0.39 & 1.29 & 0.31 & 1.19 & 0.42 & 1.98 & 0.60 \\
\hline $\mathrm{Pb}$ & 15.0 & 2.34 & 14.1 & 2.13 & 11.3 & 3.20 & 25.3 & 6.20 \\
\hline Th & 9.79 & 1.57 & 9.64 & 1.26 & 10.7 & 2.67 & 14.4 & 3.77 \\
\hline $\mathbf{U}$ & 2.10 & 0.28 & 2.17 & 0.34 & 2.21 & 0.63 & 3.62 & 1.09 \\
\hline $\mathrm{Rb} / \mathrm{Sr}$ & 0.93 & 0.14 & 0.84 & 0.12 & 1.53 & 0.29 & 2.75 & 0.99 \\
\hline $\mathrm{Sr} / \mathrm{Y}$ & 2.86 & 0.33 & 3.18 & 0.64 & 2.70 & 0.73 & 1.64 & 0.61 \\
\hline $\mathrm{Zr} / \mathrm{Th}$ & 15.4 & 1.01 & 17.0 & 2.41 & 8.93 & 1.53 & 10.6 & 2.10 \\
\hline $\mathbf{E u} / \mathbf{E} u^{*}$ & 0.58 & 0.10 & 0.61 & 0.08 & 0.46 & 0.14 & 0.40 & 0.12 \\
\hline $\mathrm{Rb} / \mathrm{Sm}$ & 16.1 & 3.94 & 16.5 & 3.43 & 25.7 & 4.77 & 25.4 & 9.31 \\
\hline $\mathrm{Zr} / \mathbf{Y}$ & 4.43 & 0.33 & 4.95 & 0.61 & 4.17 & 0.91 & 4.65 & 0.86 \\
\hline $\mathrm{Ba} / \mathrm{Sr}$ & 8.12 & 0.62 & 7.77 & 0.90 & 15.5 & 2.22 & 15.3 & 4.34 \\
\hline $\mathrm{Nb} / \mathrm{Pb}$ & 0.64 & 0.07 & 0.73 & 0.10 & 0.74 & 0.19 & 0.44 & 0.05 \\
\hline $\mathrm{La} / \mathrm{Yb}$ & 6.66 & 0.57 & 6.49 & 0.67 & 8.83 & 2.14 & 7.61 & 0.97 \\
\hline $\mathrm{Dy} / \mathrm{Yb}$ & 1.51 & 0.22 & 1.46 & 0.21 & 1.30 & 0.36 & 1.57 & 0.25 \\
\hline $\mathrm{Ba} / \mathrm{Th}$ & 80.8 & 9.27 & 84.8 & 12.0 & 90.1 & 29.5 & 56.0 & 5.50 \\
\hline
\end{tabular}


Table A4-1 continued

\begin{tabular}{|c|c|c|c|c|c|c|c|c|}
\hline Sample no. " & \multicolumn{2}{|c|}{ AT-391 } & \multicolumn{2}{|l|}{ A-13 } & \multicolumn{2}{|c|}{ AT-392 } & \multicolumn{2}{|c|}{ AT-393 } \\
\hline Sample details ${ }^{b}$ & \multicolumn{2}{|c|}{$1123 \mathrm{C}-2 \mathrm{H}-2$} & \multicolumn{2}{|c|}{$1123 \mathrm{C}-2 \mathrm{H}-3$} & \multicolumn{2}{|c|}{$1123 \mathrm{C}-2 \mathrm{H}-3$} & \multicolumn{2}{|c|}{$1123 \mathrm{C}-2 \mathrm{H}-7$} \\
\hline Base $^{c}$ & \multicolumn{2}{|c|}{$109 \mathrm{~cm}$} & \multicolumn{2}{|l|}{$70 \mathrm{~cm}$} & \multicolumn{2}{|c|}{$139 \mathrm{~cm}$} & \multicolumn{2}{|l|}{$35 \mathrm{~cm}$} \\
\hline $\operatorname{mbsf}^{d}$ & \multicolumn{2}{|c|}{11.59} & \multicolumn{2}{|c|}{$12.7 \mathrm{~m}$} & \multicolumn{2}{|c|}{$13.39 \mathrm{~m}$} & \multicolumn{2}{|c|}{$18.35 \mathrm{~m}$} \\
\hline $\mathrm{n}^{\mathrm{e}}$ & 8 & & 9 & & 9 & & 4 & \\
\hline $\mathbf{M g}(\mathrm{ppm})$ & 495 & 129 & 904 & 235 & 836 & 179 & 750 & 287 \\
\hline $\mathrm{Ti}$ & 671 & 102 & 969 & 205 & 851 & 235 & 734 & 397 \\
\hline V & 0.37 & 0.58 & 1.18 & 0.98 & 0.91 & 0.29 & 0.91 & 1.33 \\
\hline $\mathrm{Cr}$ & 1.19 & 2.15 & 0.30 & 0.90 & 2.33 & 7.87 & 5.88 & 9.23 \\
\hline Mn & 369 & 65.7 & 379 & 83.8 & 381 & 80.6 & 399 & 211 \\
\hline Co & 0.31 & 0.24 & 0.59 & 0.50 & 0.57 & 0.49 & 0.78 & 1.76 \\
\hline $\mathrm{Ni}$ & 0.18 & 0.56 & 0.30 & 0.91 & 0.37 & 0.88 & 1.81 & 1.39 \\
\hline $\mathrm{Cu}$ & 2.67 & 0.61 & 3.05 & 2.70 & 2.51 & 0.57 & 5.03 & 3.91 \\
\hline $\mathrm{Zn}$ & 38.1 & 12.3 & 47.2 & 18.8 & 39.7 & 28.6 & 37.0 & 16.5 \\
\hline $\mathrm{Ga}$ & 13.0 & 2.15 & 14.8 & 3.68 & 14.4 & 3.28 & 12.7 & 8.26 \\
\hline $\mathbf{R b}$ & 126 & 11.0 & 137 & 35.3 & 133 & 43.6 & 108 & 60.2 \\
\hline $\mathrm{Sr}$ & 49.8 & 17.5 & 88.6 & 15.8 & 79.1 & 15.0 & 79.2 & 14.8 \\
\hline $\mathbf{Y}$ & 25.8 & 5.26 & 27.0 & 5.26 & 26.8 & 3.83 & 25.7 & 13.6 \\
\hline $\mathrm{Zr}$ & 123 & 57.0 & 183 & 67.9 & 132 & 27.6 & 167 & 105 \\
\hline $\mathrm{Nb}$ & 8.71 & 0.92 & 9.05 & 2.17 & 9.19 & 2.69 & 8.24 & 4.62 \\
\hline Mo & 1.37 & 0.36 & 1.57 & 0.77 & 1.70 & 0.70 & 1.49 & 1.12 \\
\hline Cs & 5.33 & 0.63 & 5.80 & 1.39 & 5.51 & 1.97 & 5.35 & 2.89 \\
\hline $\mathrm{Ba}$ & 717 & 66.5 & 784 & 174 & 814 & 210 & 661 & 378 \\
\hline La & 24.2 & 3.37 & 26.6 & 5.28 & 24.8 & 4.32 & 22.8 & 11.7 \\
\hline $\mathrm{Ce}$ & 57.5 & 8.58 & 59.9 & 14.5 & 55.4 & 14.0 & 48.9 & 22.2 \\
\hline $\operatorname{Pr}$ & 6.20 & 1.02 & 6.26 & 1.39 & 5.74 & 1.14 & 5.69 & 3.37 \\
\hline Nd & 23.6 & 4.06 & 24.1 & 4.90 & 22.1 & 4.62 & 20.9 & 11.3 \\
\hline $\mathrm{Sm}$ & 4.79 & 0.91 & 4.78 & 0.74 & 4.66 & 0.80 & 4.33 & 3.19 \\
\hline Eu & 0.62 & 0.19 & 0.78 & 0.22 & 0.73 & 0.20 & 0.66 & 0.48 \\
\hline Gd & 4.09 & 1.26 & 4.35 & 1.25 & 4.45 & 1.16 & 4.00 & 2.77 \\
\hline Tb & 0.65 & 0.13 & 0.71 & 0.14 & 0.67 & 0.14 & 0.70 & 0.33 \\
\hline Dy & 4.64 & 1.28 & 4.71 & 1.00 & 4.47 & 0.97 & 4.36 & 2.70 \\
\hline Ho & 0.91 & 0.18 & 0.95 & 0.21 & 0.92 & 0.24 & 0.90 & 0.42 \\
\hline Er & 2.82 & 0.68 & 2.86 & 0.50 & 2.84 & 0.52 & 2.62 & 1.26 \\
\hline $\mathrm{Tm}$ & 0.42 & 0.12 & 0.45 & 0.11 & 0.43 & 0.14 & 0.41 & 0.18 \\
\hline $\mathbf{Y b}$ & 3.05 & 0.76 & 3.05 & 0.71 & 3.00 & 0.63 & 2.75 & 2.00 \\
\hline Lu & 0.45 & 0.10 & 0.44 & 0.10 & 0.46 & 0.15 & 0.38 & 0.14 \\
\hline Hf & 3.93 & 1.31 & 5.16 & 1.75 & 4.21 & 1.13 & 4.37 & 2.48 \\
\hline Ta & 0.76 & 0.10 & 0.71 & 0.19 & 0.79 & 0.24 & 0.59 & 0.28 \\
\hline W & 1.75 & 0.35 & 1.79 & 0.37 & 1.71 & 0.56 & 1.22 & 0.44 \\
\hline $\mathrm{Pb}$ & 22.3 & 3.04 & 22.9 & 4.81 & 22.0 & 6.02 & 16.6 & 8.67 \\
\hline Th & 12.2 & 1.09 & 12.7 & 2.02 & 12.3 & 2.24 & 9.96 & 4.85 \\
\hline $\mathbf{U}$ & 3.24 & 0.45 & 3.19 & 0.79 & 3.09 & 1.35 & 2.51 & 1.10 \\
\hline $\mathrm{Rb} / \mathrm{Sr}$ & 2.59 & 0.73 & 1.55 & 0.37 & 1.70 & 0.61 & 1.37 & 0.70 \\
\hline $\mathrm{Sr} / \mathbf{Y}$ & 1.93 & 0.53 & 3.29 & 0.38 & 2.96 & 0.64 & 3.26 & 2.01 \\
\hline $\mathrm{Zr} / \mathrm{Th}$ & 10.0 & 3.78 & 14.5 & 6.18 & 10.7 & 2.87 & 16.8 & 6.63 \\
\hline $\mathbf{E u} / \mathbf{E} \mathbf{u}^{*}$ h & 0.43 & 0.09 & 0.52 & 0.09 & 0.49 & 0.10 & 0.49 & 0.14 \\
\hline $\mathrm{Rb} / \mathrm{Sm}$ & 26.5 & 5.52 & 28.7 & 6.44 & 28.5 & 7.27 & 26.0 & 8.53 \\
\hline $\mathbf{Z r} / \mathbf{Y}$ & 4.72 & 1.22 & 6.77 & 2.32 & 4.92 & 1.19 & 6.59 & 2.81 \\
\hline $\mathrm{Ba} / \mathrm{Sr}$ & 14.7 & 4.34 & 8.87 & 1.70 & 10.3 & 2.72 & 8.35 & 4.32 \\
\hline $\mathrm{Nb} / \mathrm{Pb}$ & 0.39 & 0.02 & 0.40 & 0.06 & 0.42 & 0.07 & 0.50 & 0.09 \\
\hline $\mathrm{La} / \mathbf{Y b}$ & 8.02 & 1.46 & 8.79 & 1.65 & 8.34 & 1.55 & 8.60 & 2.77 \\
\hline Dy/Yb & 1.52 & 0.18 & 1.55 & 0.19 & 1.50 & 0.29 & 1.63 & 0.45 \\
\hline $\mathrm{Ba} / \mathrm{Th}$ & 58.9 & 5.88 & 61.9 & 6.29 & 66.0 & 12.0 & 66.1 & 17.2 \\
\hline
\end{tabular}


Table A4-1 continued

\begin{tabular}{|c|c|c|c|c|c|c|c|c|}
\hline Sample no. ${ }^{a}$ & \multicolumn{2}{|c|}{ AT-394 } & \multicolumn{2}{|c|}{ AT-395 } & \multicolumn{2}{|c|}{ AT-396 } & \multicolumn{2}{|l|}{ A-14 } \\
\hline Sample details ${ }^{b}$ & \multicolumn{2}{|c|}{$1123 \mathrm{C}-3 \mathrm{H}-4$} & \multicolumn{2}{|c|}{$1123 \mathrm{C}-4 \mathrm{H}-4$} & \multicolumn{2}{|c|}{$1123 \mathrm{C}-4 \mathrm{H}-6$} & \multicolumn{2}{|c|}{$1123 \mathrm{C}-5 \mathrm{H}-1$} \\
\hline Base $^{c}$ & \multicolumn{2}{|l|}{$86 \mathrm{~cm}$} & \multicolumn{2}{|c|}{$120 \mathrm{~cm}$} & \multicolumn{2}{|l|}{$73 \mathrm{~cm}$} & \multicolumn{2}{|l|}{$93 \mathrm{~cm}$} \\
\hline mbsf $^{d}$ & \multicolumn{2}{|c|}{$23.86 \mathrm{~m}$} & \multicolumn{2}{|c|}{$33.7 \mathrm{~m}$} & \multicolumn{2}{|c|}{$36.23 \mathrm{~m}$} & \multicolumn{2}{|c|}{$38.43 \mathrm{~m}$} \\
\hline $\mathrm{n}^{\mathrm{e}}$ & 10 & & 11 & & 23 & & 13 & \\
\hline Mg (ppm) & 1169 & 403 & 1083 & 252 & 2264 & 1582 & 1739 & 1010 \\
\hline $\mathrm{Ti}$ & 918 & 292 & 970 & 309 & 2164 & 1270 & 1529 & 696 \\
\hline V & 2.36 & 1.73 & 3.25 & 1.10 & 7.55 & 15.1 & 5.71 & 4.35 \\
\hline $\mathrm{Cr}$ & 0.62 & 1.93 & 2.80 & 7.27 & 3.06 & 9.24 & 1.67 & 4.35 \\
\hline Mn & 359 & 56.3 & 369 & 103 & 511 & 139 & 383 & 111 \\
\hline Co & 0.53 & 0.68 & & & 1.23 & 1.74 & 1.49 & 0.97 \\
\hline $\mathrm{Ni}$ & 0.07 & 0.30 & 0.93 & 2.42 & 0.99 & 1.72 & 2.49 & 4.63 \\
\hline $\mathrm{Cu}$ & 2.04 & 1.23 & 4.35 & 3.54 & 2.73 & 1.87 & 6.60 & 8.00 \\
\hline $\mathrm{Zn}$ & 28.4 & 18.9 & 31.2 & 20.7 & 33.5 & 35.9 & 44.5 & 18.5 \\
\hline $\mathrm{Ga}$ & 12.0 & 2.07 & 14.2 & 5.20 & 14.3 & 4.90 & 16.0 & 3.08 \\
\hline $\mathbf{R b}$ & 129 & 21.8 & 144 & 44.5 & 100 & 36.7 & 133 & 24.4 \\
\hline $\mathrm{Sr}$ & 89.9 & 21.5 & 69.3 & 14.1 & 103 & 23.9 & 102 & 48.2 \\
\hline $\mathrm{Y}$ & 17.1 & 2.34 & 16.7 & 5.37 & 33.1 & 9.16 & 27.2 & 6.30 \\
\hline $\mathrm{Zr}$ & 110 & 30.9 & 108 & 34.9 & 282 & 71.4 & 233 & 113 \\
\hline Nb & 6.70 & 1.38 & 7.43 & 2.47 & 10.6 & 2.74 & 9.62 & 1.94 \\
\hline Mo & 1.79 & 0.39 & 2.13 & 1.07 & 1.34 & 0.76 & 3.89 & 5.07 \\
\hline Cs & 6.00 & 1.18 & 7.16 & 2.22 & 4.79 & 1.84 & 6.15 & 1.23 \\
\hline Ba & 860 & 128 & 791 & 227 & 698 & 172 & 812 & 132 \\
\hline La & 21.2 & 3.36 & 20.7 & 5.41 & 25.3 & 6.22 & 27.1 & 5.49 \\
\hline $\mathrm{Ce}$ & 40.6 & 9.21 & 44.6 & 13.5 & 49.2 & 13.7 & 59.9 & 11.2 \\
\hline $\operatorname{Pr}$ & 4.21 & 0.59 & 4.36 & 1.14 & 5.84 & 1.37 & 6.46 & 1.25 \\
\hline Nd & 15.1 & 2.30 & 14.9 & 3.58 & 24.4 & 5.34 & 24.7 & 5.64 \\
\hline $\mathrm{Sm}$ & 2.75 & 0.79 & 2.83 & 0.89 & 5.32 & 1.75 & 5.12 & 1.18 \\
\hline Eu & 0.51 & 0.09 & 0.44 & 0.19 & 1.02 & 0.30 & 0.89 & 0.38 \\
\hline Gd & 2.43 & 0.82 & 2.44 & 1.25 & 5.34 & 1.61 & 4.44 & 0.86 \\
\hline Tb & 0.42 & 0.10 & & & 0.88 & 0.26 & 0.70 & 0.13 \\
\hline Dy & 2.55 & 0.54 & 2.62 & 0.78 & 5.83 & 1.92 & 4.90 & 1.35 \\
\hline Но & 0.55 & 0.11 & & & 1.26 & 0.28 & 0.99 & 0.23 \\
\hline Er & 1.81 & 0.35 & 1.84 & 0.89 & 3.54 & 1.09 & 2.92 & 0.80 \\
\hline $\mathrm{Tm}$ & 0.30 & 0.05 & & & 0.57 & 0.16 & 0.46 & 0.09 \\
\hline $\mathrm{Yb}$ & 2.04 & 0.37 & 2.13 & 0.78 & 3.82 & 1.00 & 3.20 & 0.73 \\
\hline Lu & 0.35 & 0.09 & 0.33 & 0.18 & 0.59 & 0.20 & 0.48 & 0.12 \\
\hline Hf & 3.21 & 0.65 & 3.19 & 1.34 & 7.01 & 2.28 & 5.85 & 1.99 \\
\hline $\mathbf{T a}$ & 0.70 & 0.10 & 0.72 & 0.32 & 0.80 & 0.27 & 0.75 & 0.15 \\
\hline w & 1.55 & 0.39 & 1.76 & 0.47 & 1.13 & 0.70 & 1.64 & 0.40 \\
\hline $\mathrm{Pb}$ & 14.7 & 2.30 & 18.8 & 5.75 & 15.3 & 5.74 & 20.0 & 4.67 \\
\hline Th & 13.5 & 2.02 & 12.2 & 2.80 & 11.8 & 3.35 & 12.6 & 2.71 \\
\hline $\mathbf{U}$ & 2.84 & 0.80 & 3.44 & 0.88 & 2.34 & 0.92 & 3.25 & 0.65 \\
\hline $\mathrm{Rb} / \mathrm{Sr}$ & 1.45 & 0.43 & 2.08 & 0.38 & 0.98 & 0.38 & 1.39 & 0.88 \\
\hline $\mathrm{Sr} / \mathrm{Y}$ & 5.30 & 1.88 & 4.21 & 0.97 & 3.17 & 1.04 & 3.75 & 1.66 \\
\hline $\mathrm{Zr} / \mathrm{Th}$ & 8.18 & 2.03 & 8.81 & 1.67 & 24.1 & 4.03 & 18.7 & 9.44 \\
\hline $\mathbf{E u} / \mathbf{E} \mathbf{u}^{* h}$ & 0.61 & 0.16 & 0.53 & 0.24 & 0.59 & 0.17 & 0.57 & 0.17 \\
\hline $\mathrm{Rb} / \mathrm{Sm}$ & 47.2 & 8.88 & 51.8 & 18.6 & 19.3 & 9.16 & 26.1 & 5.25 \\
\hline $\mathbf{Z r} / \mathbf{Y}$ & 6.50 & 2.51 & 6.47 & 0.78 & 8.54 & 0.93 & 8.58 & 3.75 \\
\hline $\mathrm{Ba} / \mathrm{Sr}$ & 9.66 & 2.24 & 11.4 & 1.50 & 6.81 & 1.73 & 8.46 & 4.83 \\
\hline $\mathrm{Nb} / \mathrm{Pb}$ & 0.45 & 0.07 & 0.39 & 0.07 & 0.70 & 0.18 & 0.48 & 0.07 \\
\hline $\mathrm{La} / \mathrm{Yb}$ & 10.5 & 2.22 & 9.82 & 2.02 & 6.65 & 1.47 & 8.49 & 0.75 \\
\hline Dy/Yb & 1.26 & 0.35 & 1.26 & 0.48 & 1.53 & 0.36 & 1.53 & 0.19 \\
\hline $\mathrm{Ba} / \mathrm{Th}$ & 63.8 & 5.10 & 64.8 & 11.4 & 60.2 & 20.2 & 64.7 & 6.65 \\
\hline
\end{tabular}


Table A4-1 continued

\begin{tabular}{|c|c|c|c|c|c|c|c|c|}
\hline \multirow{5}{*}{$\begin{array}{l}\text { Sample no. }{ }^{a} \\
\text { Sample details } \\
{ }^{b} \\
\text { Base }^{\mathrm{c}} \\
\text { mbsf }^{\mathrm{d}} \\
\mathrm{n}^{\mathrm{e}}\end{array}$} & \multicolumn{2}{|c|}{ AT-397 (1) } & \multicolumn{2}{|c|}{ AT-397 (2) } & \multicolumn{2}{|c|}{ AT-398 (1) } & \multicolumn{2}{|c|}{ AT-398 (2) } \\
\hline & \multicolumn{2}{|c|}{$1123 \mathrm{C}-5 \mathrm{H}-5$} & \multicolumn{2}{|c|}{$1123 \mathrm{C}-5 \mathrm{H}-5$} & \multicolumn{2}{|c|}{$1123 \mathrm{C}-6 \mathrm{H}-1$} & \multicolumn{2}{|c|}{$1123 \mathrm{C}-6 \mathrm{H}-1$} \\
\hline & $123 \mathrm{~cm}$ & & $123 \mathrm{~cm}$ & & $78 \mathrm{~cm}$ & & $78 \mathrm{~cm}$ & \\
\hline & $44.73 \mathrm{n}$ & & $44.73 \mathrm{n}$ & & $47.78 \mathrm{r}$ & & $47.78 \mathrm{n}$ & \\
\hline & 7 & & 5 & & 9 & & 3 & \\
\hline $\mathrm{Mg}(\mathrm{ppm})$ & 2119 & 807 & 1376 & 146 & 1506 & 267 & 686 & 39.0 \\
\hline $\mathrm{Ti}$ & 1690 & 625 & 1288 & 237 & 1248 & 244 & 642 & 2.18 \\
\hline V & 8.60 & 3.52 & 4.62 & 1.43 & 5.04 & 1.87 & 0.90 & 0.34 \\
\hline $\mathrm{Cr}$ & 1.32 & 3.62 & 1.22 & 2.59 & 2.71 & 5.82 & 1.27 & 1.46 \\
\hline Mn & 396 & 98.3 & 346 & 95.1 & 322 & 82.9 & 263 & 15.9 \\
\hline Co & 2.07 & 0.96 & 1.24 & 0.28 & 1.31 & 0.60 & 0.61 & 0.30 \\
\hline $\mathrm{Ni}$ & 5.17 & 9.02 & 5.33 & 17.0 & 2.81 & 4.38 & 1.10 & 0.85 \\
\hline $\mathrm{Cu}$ & 4.71 & 2.52 & 4.63 & 0.91 & 8.26 & 7.19 & 5.25 & 2.07 \\
\hline $\mathrm{Zn}$ & 40.1 & 30.8 & 40.8 & 29.1 & 22.2 & 15.9 & 20.4 & 4.32 \\
\hline $\mathrm{Ga}$ & 15.2 & 5.03 & 15.9 & 4.59 & 12.6 & 2.84 & 11.5 & 1.59 \\
\hline Rb & 116 & 34.0 & 128 & 17.9 & 101 & 17.7 & 95.8 & 10.2 \\
\hline $\mathrm{Sr}$ & 120 & 23.0 & 84.9 & 11.7 & 92.9 & 14.2 & 73.8 & 8.74 \\
\hline Y & 29.0 & 5.79 & 29.3 & 5.11 & 28.2 & 5.81 & 26.1 & 0.99 \\
\hline $\mathrm{Zr}$ & 242 & 37.4 & 192 & 29.0 & 193 & 38.1 & 147 & 6.98 \\
\hline Nb & 7.72 & 2.69 & 8.18 & 2.10 & 6.20 & 1.47 & 5.89 & 0.42 \\
\hline Mo & 2.99 & 2.89 & 2.96 & 3.41 & 1.26 & 0.77 & 0.91 & 0.48 \\
\hline Cs & 5.94 & 1.72 & 6.67 & 1.30 & 5.02 & 0.97 & 4.94 & 0.99 \\
\hline $\mathrm{Ba}$ & 764 & 159 & 830 & 93.6 & 658 & 112 & 637 & 48.8 \\
\hline $\mathbf{L a}$ & 24.6 & 3.32 & 25.8 & 3.45 & 20.7 & 3.83 & 20.0 & 1.02 \\
\hline $\mathrm{Ce}$ & 53.1 & 10.7 & 58.6 & 6.76 & 40.6 & 7.31 & 38.7 & 1.70 \\
\hline Pr & 5.88 & 0.87 & 6.33 & 1.08 & 4.63 & 0.90 & 4.57 & 0.08 \\
\hline Nd & 24.3 & 4.67 & 24.9 & 3.43 & 18.7 & 3.69 & 18.3 & 0.84 \\
\hline $\mathrm{Sm}$ & 4.96 & 0.98 & 5.02 & 0.33 & 4.10 & 0.78 & 3.97 & 0.23 \\
\hline Eu & 0.82 & 0.24 & 0.77 & 0.19 & 0.61 & 0.12 & 0.57 & 0.11 \\
\hline Gd & 4.44 & 1.04 & 4.48 & 1.24 & 4.14 & 0.84 & 4.01 & 0.71 \\
\hline Tb & 0.74 & 0.24 & 0.71 & 0.19 & 0.64 & 0.21 & 0.61 & 0.03 \\
\hline Dy & 4.98 & 0.77 & 5.14 & 1.02 & 4.60 & 0.87 & 4.37 & 0.70 \\
\hline Ho & 1.01 & 0.22 & 1.08 & 0.23 & 0.96 & 0.21 & 0.90 & 0.10 \\
\hline Er & 3.11 & 0.42 & 3.25 & 0.86 & 2.88 & 0.64 & 2.70 & 0.30 \\
\hline $\mathrm{Tm}$ & 0.48 & 0.15 & 0.48 & 0.15 & 0.43 & 0.08 & 0.40 & 0.05 \\
\hline $\mathrm{Yb}$ & 3.31 & 0.72 & 3.38 & 0.59 & 2.80 & 0.67 & 2.66 & 0.12 \\
\hline Lu & 0.53 & 0.15 & 0.51 & 0.10 & 0.43 & 0.14 & 0.41 & 0.03 \\
\hline Hf & 6.13 & 1.38 & 5.45 & 0.96 & 4.99 & 0.95 & 4.10 & 0.47 \\
\hline Ta & 0.65 & 0.18 & 0.70 & 0.09 & 0.53 & 0.12 & 0.53 & 0.04 \\
\hline w & 1.50 & 0.43 & 1.70 & 0.59 & 1.10 & 0.28 & 1.04 & 0.22 \\
\hline $\mathrm{Pb}$ & 18.7 & 6.20 & 20.6 & 8.13 & 15.2 & 5.38 & 13.8 & 1.89 \\
\hline Th & 12.3 & 1.81 & 13.0 & 2.13 & 10.1 & 1.94 & 9.50 & 0.42 \\
\hline $\mathbf{U}$ & 2.77 & 0.82 & 3.17 & 1.12 & 2.12 & 0.50 & 1.96 & 0.05 \\
\hline $\mathrm{Rb} / \mathrm{Sr}$ & 0.96 & 0.20 & 1.52 & 0.23 & 1.10 & 0.20 & 1.30 & 0.09 \\
\hline $\mathrm{Sr} / \mathrm{Y}$ & 4.18 & 1.11 & 2.90 & 0.23 & 3.32 & 0.72 & 2.83 & 0.37 \\
\hline $\mathrm{Zr} / \mathrm{Th}$ & 19.8 & 2.54 & 14.8 & 2.17 & 19.1 & 1.71 & 15.5 & 1.29 \\
\hline $\mathbf{E u} / \mathbf{E} u^{* h}$ & 0.54 & 0.17 & 0.50 & 0.10 & 0.45 & 0.08 & 0.44 & 0.13 \\
\hline $\mathrm{Rb} / \mathrm{Sm}$ & 23.4 & 5.94 & 25.6 & 4.52 & 24.8 & 2.89 & 24.2 & 3.54 \\
\hline $\mathrm{Zr} / \mathrm{Y}$ & 8.36 & 0.83 & 6.57 & 0.47 & 6.83 & 0.46 & 5.63 & 0.09 \\
\hline $\mathrm{Ba} / \mathrm{Sr}$ & 6.35 & 1.13 & 9.80 & 1.12 & 7.11 & 1.49 & 8.64 & 0.40 \\
\hline $\mathrm{Nb} / \mathrm{Pb}$ & 0.42 & 0.08 & 0.40 & 0.06 & 0.41 & 0.11 & 0.43 & 0.06 \\
\hline $\mathrm{La} / \mathrm{Yb}$ & 7.49 & 1.54 & 7.69 & 1.61 & 7.41 & 1.00 & 7.51 & 0.07 \\
\hline Dy/Yb & 1.51 & 0.28 & 1.53 & 0.43 & 1.65 & 0.24 & 1.65 & 0.33 \\
\hline $\mathrm{Ba} / \mathrm{Th}$ & 62.6 & 14.2 & 64.0 & 5.94 & 65.3 & 4.07 & 67.2 & 7.97 \\
\hline
\end{tabular}


Table A4-1 continued

\begin{tabular}{|c|c|c|c|c|c|c|c|c|}
\hline Sample no. ${ }^{a}$ & \multicolumn{2}{|l|}{ A-16 } & \multicolumn{2}{|c|}{ AT-399 } & \multicolumn{2}{|c|}{ AT-400 } & \multicolumn{2}{|c|}{ AT-401 } \\
\hline Sample details ${ }^{b}$ & \multicolumn{2}{|c|}{$1123 \mathrm{C}-6 \mathrm{H}-3$} & \multicolumn{2}{|c|}{$1123 \mathrm{C}-6 \mathrm{H}-4$} & \multicolumn{2}{|c|}{$1123 \mathrm{C}-6 \mathrm{H}-4$} & \multicolumn{2}{|c|}{$1123 \mathrm{C}-6 \mathrm{H}-5$} \\
\hline Base ${ }^{c}$ & \multicolumn{2}{|c|}{$130 \mathrm{~cm}$} & \multicolumn{2}{|l|}{$65 \mathrm{~cm}$} & \multicolumn{2}{|l|}{$97 \mathrm{~cm}$} & \multicolumn{2}{|l|}{$11 \mathrm{~cm}$} \\
\hline $\operatorname{mbsf}^{d}$ & \multicolumn{2}{|c|}{$51.3 \mathrm{~m}$} & \multicolumn{2}{|c|}{$52.15 \mathrm{~m}$} & \multicolumn{2}{|c|}{$52.47 \mathrm{~m}$} & \multicolumn{2}{|c|}{$53.11 \mathrm{~m}$} \\
\hline$n^{e}$ & 6 & & 8 & & 9 & & 6 & \\
\hline Mg (ppm) & 986 & 292 & 737 & 153 & 1007 & 165 & 900 & 393 \\
\hline $\mathrm{Ti}$ & 1065 & 239 & 1166 & 174 & 1433 & 304 & 1064 & 301 \\
\hline V & 1.13 & 1.78 & 0.47 & 1.43 & 0.27 & 0.20 & 0.99 & 1.69 \\
\hline $\mathrm{Cr}$ & 3.43 & 6.68 & 1.48 & 2.54 & 0.71 & 2.16 & 1.57 & 2.39 \\
\hline Mn & 560 & 158 & 563 & 123 & 671 & 126 & 540 & 149 \\
\hline Co & 0.49 & 0.58 & 0.28 & 0.25 & 0.33 & 0.27 & 0.57 & 0.54 \\
\hline $\mathrm{Ni}$ & 0.72 & 1.41 & 1.48 & 5.51 & 0.30 & 0.67 & 2.98 & 6.93 \\
\hline $\mathrm{Cu}$ & 5.45 & 5.49 & 2.98 & 1.76 & 2.96 & 0.59 & 4.64 & 4.11 \\
\hline $\mathrm{Zn}$ & 40.9 & 31.6 & 70.2 & 40.6 & 67.4 & 46.8 & 42.7 & 41.6 \\
\hline $\mathrm{Ga}$ & 14.6 & 4.22 & 17.5 & 3.13 & 17.7 & 4.39 & 15.1 & 4.15 \\
\hline $\mathbf{R b}$ & 111 & 28.8 & 126 & 27.4 & 121 & 32.5 & 126 & 27.9 \\
\hline $\mathrm{Sr}$ & 84.2 & 18.2 & 69.0 & 14.2 & 88.7 & 17.6 & 85.9 & 23.8 \\
\hline Y & 37.8 & 10.4 & 41.3 & 8.61 & 42.4 & 9.89 & 36.5 & 7.72 \\
\hline $\mathrm{Zr}$ & 278 & 72.5 & 323 & 64.3 & 341 & 68.6 & 277 & 73.8 \\
\hline Nb & 9.90 & 2.84 & 13.6 & 2.35 & 13.4 & 3.21 & 11.4 & 2.65 \\
\hline Mo & 1.37 & 0.91 & 1.86 & 0.93 & 2.10 & 0.80 & 3.63 & 7.18 \\
\hline Cs & 5.50 & 1.79 & 6.45 & 0.98 & 6.28 & 1.49 & 6.92 & 1.45 \\
\hline $\mathrm{Ba}$ & 753 & 169 & 846 & 91.4 & 833 & 166 & 856 & 193 \\
\hline La & 28.3 & 6.02 & 31.0 & 5.01 & 31.5 & 6.90 & 32.2 & 5.79 \\
\hline $\mathrm{Ce}$ & 58.1 & 16.3 & 66.7 & 7.52 & 67.4 & 13.3 & 64.7 & 12.8 \\
\hline $\mathrm{Pr}$ & 6.88 & 1.43 & 7.51 & 1.21 & 7.60 & 1.26 & 7.41 & 1.20 \\
\hline Nd & 27.7 & 5.81 & 31.6 & 4.73 & 32.0 & 5.64 & 29.0 & 5.81 \\
\hline $\mathrm{Sm}$ & 6.38 & 1.96 & 6.58 & 1.42 & 7.08 & 1.36 & 6.15 & 0.83 \\
\hline Eu & 1.00 & 0.31 & 1.07 & 0.36 & 1.16 & 0.33 & 0.95 & 0.19 \\
\hline Gd & 6.31 & 1.72 & 6.29 & 1.17 & 6.91 & 1.83 & 5.88 & 1.13 \\
\hline Tb & 0.93 & 0.27 & 1.01 & 0.16 & 1.06 & 0.22 & 0.95 & 0.19 \\
\hline Dy & 6.53 & 2.07 & 7.31 & 1.53 & 7.39 & 1.84 & 6.15 & 1.31 \\
\hline Но & 1.34 & 0.44 & 1.47 & 0.32 & 1.55 & 0.40 & 1.42 & 0.34 \\
\hline Er & 4.06 & 1.12 & 4.47 & 1.11 & 4.76 & 1.04 & 3.97 & 0.83 \\
\hline $\mathrm{Tm}$ & 0.63 & 0.16 & 0.66 & 0.15 & 0.70 & 0.20 & 0.59 & 0.16 \\
\hline $\mathbf{Y b}$ & 4.14 & 1.26 & 4.47 & 1.11 & 4.82 & 0.99 & 3.90 & 0.85 \\
\hline Lu & 0.63 & 0.13 & 0.70 & 0.23 & 0.72 & 0.19 & 0.58 & 0.18 \\
\hline Hf & 7.11 & 2.09 & 7.94 & 1.80 & 8.30 & 1.98 & 7.24 & 1.50 \\
\hline Ta & 0.76 & 0.23 & 0.98 & 0.16 & 1.03 & 0.25 & 0.81 & 0.23 \\
\hline W & 1.36 & 0.28 & 1.65 & 0.37 & 1.47 & 0.37 & 1.40 & 0.52 \\
\hline $\mathbf{P b}$ & 18.6 & 4.87 & 21.7 & 3.76 & 20.4 & 5.53 & 20.5 & 5.65 \\
\hline Th & 12.9 & 3.42 & 14.8 & 2.27 & 14.7 & 3.24 & 14.3 & 2.63 \\
\hline $\mathbf{U}$ & 2.70 & 0.74 & 3.25 & 0.43 & 3.11 & 0.89 & 3.26 & 0.90 \\
\hline $\mathrm{Rb} / \mathrm{Sr}$ & 1.33 & 0.42 & 1.84 & 0.47 & 1.37 & 0.26 & 1.48 & 0.46 \\
\hline $\mathrm{Sr} / \mathrm{Y}$ & 2.24 & 0.33 & 1.67 & 0.23 & 2.10 & 0.23 & 2.37 & 0.75 \\
\hline $\mathrm{Zr} / \mathrm{Th}$ & 21.6 & 3.57 & 21.8 & 2.08 & 23.1 & 1.67 & 19.4 & 2.79 \\
\hline $\mathbf{E u} / \mathbf{E} \mathbf{u}^{* h}$ & 0.48 & 0.05 & 0.51 & 0.19 & 0.51 & 0.11 & 0.48 & 0.06 \\
\hline $\mathrm{Rb} / \mathrm{Sm}$ & 17.6 & 3.62 & 19.2 & 4.71 & 17.2 & 4.33 & 20.4 & 2.39 \\
\hline $\mathrm{Zr} / \mathrm{Y}$ & 7.36 & 0.73 & 7.83 & 0.62 & 8.06 & 0.68 & 7.59 & 0.75 \\
\hline $\mathrm{Ba} / \mathrm{Sr}$ & 9.03 & 2.86 & 12.3 & 2.14 & 9.40 & 0.76 & 10.1 & 3.36 \\
\hline $\mathrm{Nb} / \mathrm{Pb}$ & 0.53 & 0.09 & 0.63 & 0.09 & 0.66 & 0.06 & 0.56 & 0.06 \\
\hline $\mathrm{La} / \mathrm{Yb}$ & 6.89 & 1.46 & 6.99 & 1.11 & 6.53 & 0.83 & 8.28 & 1.07 \\
\hline Dy/Yb & 1.58 & 0.16 & 1.64 & 0.26 & 1.53 & 0.18 & 1.58 & 0.19 \\
\hline $\mathrm{Ba} / \mathrm{Th}$ & 58.9 & 14.5 & 57.5 & 8.61 & 56.6 & 7.27 & 60.0 & 7.20 \\
\hline
\end{tabular}


Table A4-1 continued

\begin{tabular}{|c|c|c|c|c|c|c|c|c|}
\hline Sample no. ${ }^{a}$ & \multicolumn{2}{|c|}{ AT-402 } & \multicolumn{2}{|c|}{ AT-403 } & \multicolumn{2}{|c|}{ AT-404 } & \multicolumn{2}{|c|}{ AT -405} \\
\hline Sample details ${ }^{\text {b }}$ & \multicolumn{2}{|c|}{$1123 \mathrm{C}-6 \mathrm{H}-5$} & \multicolumn{2}{|c|}{$1123 \mathrm{C}-6 \mathrm{H}-5$} & \multicolumn{2}{|c|}{$1123 \mathrm{C}-6 \mathrm{H}-6$} & \multicolumn{2}{|c|}{$1123 \mathrm{C}-6 \mathrm{H}-6$} \\
\hline Base $^{c}$ & \multicolumn{2}{|l|}{$92 \mathrm{~cm}$} & \multicolumn{2}{|c|}{$113 \mathrm{~cm}$} & \multicolumn{2}{|c|}{$10 \mathrm{~cm}$} & \multicolumn{2}{|c|}{$120 \mathrm{~cm}$} \\
\hline $\operatorname{mbsf}^{d}$ & \multicolumn{2}{|c|}{$53.92 \mathrm{~m}$} & \multicolumn{2}{|c|}{$54.13 \mathrm{~m}$} & \multicolumn{2}{|c|}{$54.6 \mathrm{~m}$} & \multicolumn{2}{|c|}{$55.7 \mathrm{~m}$} \\
\hline $\mathrm{n}^{\mathrm{e}}$ & 17 & & 8 & & 10 & & 7 & \\
\hline Mg (ppm) & 446 & 260 & 1011 & 527 & 838 & 169 & 601 & 96.7 \\
\hline $\mathrm{Ti}$ & 292 & 257 & 1167 & 404 & 1140 & 265 & 787 & 165 \\
\hline V & 1.10 & 0.80 & 0.69 & 0.96 & 0.59 & 1.89 & 0.63 & 0.75 \\
\hline $\mathrm{Cr}$ & 10.0 & 10.9 & 1.20 & 4.53 & 2.18 & 9.20 & 1.47 & 2.99 \\
\hline Mn & 359 & 116 & 556 & 141 & 562 & 250 & 349 & 59.6 \\
\hline Co & 0.79 & 0.80 & 0.67 & 0.59 & 0.50 & 0.62 & 0.75 & 0.81 \\
\hline $\mathrm{Ni}$ & 2.21 & 3.12 & 1.54 & 2.73 & 0.40 & 1.30 & 1.40 & 4.31 \\
\hline $\mathrm{Cu}$ & 3.13 & 1.96 & 3.57 & 1.76 & 2.66 & 0.77 & 4.16 & 3.16 \\
\hline $\mathrm{Zn}$ & 28.4 & 21.7 & 52.5 & 24.4 & 62.0 & 44.4 & 41.2 & 20.0 \\
\hline $\mathrm{Ga}$ & 12.2 & 4.04 & 17.5 & 1.70 & 14.9 & 5.10 & 15.0 & 2.03 \\
\hline Rb & 156 & 58.2 & 142 & 27.9 & 107 & 26.9 & 117 & 17.2 \\
\hline $\mathrm{Sr}$ & 48.7 & 34.4 & 83.6 & 32.1 & 72.5 & 11.6 & 69.2 & 11.8 \\
\hline Y & 19.1 & 5.52 & 33.8 & 7.04 & 38.4 & 9.47 & 37.3 & 8.50 \\
\hline $\mathrm{Zr}$ & 66.8 & 18.8 & 246 & 93.2 & 282 & 86.2 & 184 & 33.4 \\
\hline $\mathrm{Nb}$ & 5.53 & 1.82 & 12.4 & 1.38 & 11.2 & 4.26 & 10.2 & 2.90 \\
\hline Mo & 1.60 & 1.41 & 2.52 & 1.71 & 1.46 & 0.52 & 1.61 & 0.65 \\
\hline Cs & 9.43 & 3.96 & 7.71 & 1.73 & 5.31 & 1.28 & 6.15 & 1.28 \\
\hline $\mathrm{Ba}$ & 656 & 387 & 849 & 101 & 747 & 187 & 804 & 109 \\
\hline La & 22.3 & 7.57 & 28.9 & 3.63 & 28.0 & 7.17 & 30.9 & 5.91 \\
\hline $\mathrm{Ce}$ & 44.8 & 20.4 & 69.1 & 9.78 & 58.4 & 19.4 & 59.7 & 7.92 \\
\hline Pr & 4.46 & 1.68 & 7.15 & 1.14 & 6.75 & 2.06 & 6.96 & 1.34 \\
\hline Nd & 16.8 & 5.17 & 28.2 & 3.55 & 28.5 & 8.60 & 29.9 & 5.81 \\
\hline $\mathrm{Sm}$ & 3.25 & 1.06 & 5.99 & 0.94 & 6.15 & 1.98 & 5.97 & 1.05 \\
\hline Eu & 0.41 & 0.39 & 0.85 & 0.20 & 1.01 & 0.39 & 0.82 & 0.18 \\
\hline Gd & 3.06 & 1.08 & 5.50 & 0.88 & 6.13 & 1.39 & 5.65 & 1.56 \\
\hline Tb & 0.52 & 0.21 & 0.86 & 0.09 & 0.93 & 0.32 & & \\
\hline Dy & 3.28 & 1.41 & 6.01 & 0.95 & 6.81 & 2.22 & 6.59 & 0.96 \\
\hline Но & 0.69 & 0.35 & 1.17 & 0.21 & 1.38 & 0.36 & & \\
\hline Er & 2.08 & 0.81 & 3.59 & 0.88 & 4.07 & 1.16 & 3.89 & 0.66 \\
\hline $\mathrm{Tm}$ & 0.41 & 0.17 & 0.51 & 0.11 & 0.62 & 0.15 & & \\
\hline $\mathbf{Y b}$ & 2.51 & 1.10 & 3.70 & 0.38 & 4.17 & 1.21 & 4.24 & 0.98 \\
\hline Lu & 0.41 & 0.15 & 0.54 & 0.16 & 0.65 & 0.19 & 0.65 & 0.26 \\
\hline Hf & 2.51 & 0.92 & 6.04 & 1.74 & 7.26 & 2.12 & 5.67 & 1.02 \\
\hline Ta & 0.91 & 0.38 & 0.88 & 0.08 & 0.89 & 0.34 & 0.92 & 0.31 \\
\hline W & 2.40 & 1.60 & 1.71 & 0.55 & 1.24 & 0.46 & 1.48 & 0.59 \\
\hline $\mathbf{P b}$ & 21.7 & 6.81 & 23.7 & 3.78 & 18.1 & 5.06 & 20.8 & 4.46 \\
\hline Th & 17.0 & 4.10 & 13.9 & 1.56 & 12.9 & 2.18 & 14.8 & 2.92 \\
\hline $\mathbf{U}$ & 4.01 & 1.56 & 3.62 & 0.83 & 2.65 & 0.71 & 2.85 & 0.58 \\
\hline $\mathrm{Rb} / \mathrm{Sr}$ & 3.87 & 5.49 & 1.79 & 1.11 & 1.47 & 0.23 & 1.71 & 0.40 \\
\hline $\mathrm{Sr} / \mathbf{Y}$ & 2.66 & 2.28 & 2.48 & 0.91 & 1.91 & 0.42 & 1.87 & 0.43 \\
\hline $\mathrm{Zr} / \mathrm{Th}$ & 3.96 & 0.98 & 17.8 & 6.82 & 21.8 & 4.26 & 12.6 & 3.66 \\
\hline $\mathbf{E u} / \mathbf{E u}^{*{ }^{h}}$ & 0.39 & 0.32 & 0.45 & 0.11 & 0.50 & 0.10 & 0.44 & 0.13 \\
\hline $\mathrm{Rb} / \mathrm{Sm}$ & 49.4 & 27.8 & 23.9 & 6.21 & 17.6 & 3.38 & 19.7 & 3.65 \\
\hline $\mathrm{Zr} / \mathrm{Y}$ & 3.57 & 1.43 & 7.27 & 2.39 & 7.32 & 0.80 & 4.97 & 0.87 \\
\hline $\mathrm{Ba} / \mathrm{Sr}$ & 13.7 & 5.31 & 10.6 & 5.26 & 10.3 & 1.56 & 11.7 & 1.26 \\
\hline $\mathrm{Nb} / \mathrm{Pb}$ & 0.26 & 0.05 & 0.52 & 0.06 & 0.61 & 0.10 & 0.49 & 0.13 \\
\hline $\mathrm{La} / \mathrm{Yb}$ & 9.27 & 5.18 & 7.83 & 1.18 & 6.76 & 1.07 & 7.33 & 1.45 \\
\hline Dy/Yb & 1.34 & 0.61 & 1.63 & 0.31 & 1.64 & 0.31 & 1.57 & 0.32 \\
\hline $\mathrm{Ba} / \mathrm{Th}$ & 38.8 & 21.5 & 61.3 & 4.07 & 57.9 & 7.26 & 54.7 & 13.6 \\
\hline
\end{tabular}


Table A4-1 continued

\begin{tabular}{|c|c|c|c|c|c|c|c|c|}
\hline Sample no. ${ }^{\mathrm{a}}$ & \multicolumn{2}{|c|}{ AT-406 } & \multicolumn{2}{|l|}{ A-18 } & \multicolumn{2}{|c|}{ AT -407} & \multicolumn{2}{|c|}{ AT-408 } \\
\hline Sample details ${ }^{\mathrm{b}}$ & \multicolumn{2}{|c|}{$1123 \mathrm{C}-6 \mathrm{H}-6$} & \multicolumn{2}{|c|}{$1123 \mathrm{C}-6 \mathrm{H}-7$} & \multicolumn{2}{|c|}{$1123 \mathrm{C}-7 \mathrm{H}-2$} & \multicolumn{2}{|c|}{$1123 \mathrm{C}-7 \mathrm{H}-2$} \\
\hline Base ${ }^{c}$ & \multicolumn{2}{|c|}{$124 \mathrm{~cm}$} & \multicolumn{2}{|c|}{$67 \mathrm{~cm}$} & \multicolumn{2}{|c|}{$67 \mathrm{~cm}$} & \multicolumn{2}{|c|}{$127 \mathrm{~cm}$} \\
\hline $\operatorname{mbsf}^{d}$ & \multicolumn{2}{|c|}{$55.74 \mathrm{~m}$} & \multicolumn{2}{|c|}{$56.67 \mathrm{~m}$} & \multicolumn{2}{|c|}{$58.67 \mathrm{~m}$} & \multicolumn{2}{|c|}{$59.27 \mathrm{~m}$} \\
\hline $\mathrm{n}^{\mathrm{e}}$ & 6 & & 10 & & 10 & & 10 & \\
\hline $\mathrm{Mg}(\mathrm{ppm})$ & 773 & 91.1 & 783 & 163 & 752 & 116 & 1014 & 210 \\
\hline $\mathrm{Ti}$ & 847 & 339 & 824 & 131 & 1194 & 284 & 1394 & 251 \\
\hline V & 0.83 & 0.90 & 1.92 & 0.75 & 0.17 & 0.26 & 0.36 & 0.53 \\
\hline $\mathrm{Cr}$ & 5.21 & 11.1 & 0.73 & 3.01 & 0.89 & 1.94 & 1.02 & 1.66 \\
\hline Mn & 438 & 167 & 314 & 62.6 & 576 & 110 & 678 & 102 \\
\hline Co & 0.70 & 0.58 & 0.96 & 1.02 & 0.35 & 0.40 & 0.62 & 0.61 \\
\hline $\mathrm{Ni}$ & 1.33 & 4.91 & 2.70 & 8.82 & 0.33 & 0.84 & 0.63 & 2.09 \\
\hline $\mathrm{Cu}$ & 3.44 & 2.09 & 5.67 & 8.10 & 3.55 & 1.15 & 2.89 & 1.11 \\
\hline $\mathrm{Zn}$ & 50.7 & 29.5 & 38.4 & 19.8 & 64.8 & 47.3 & 70.1 & 42.0 \\
\hline $\mathrm{Ga}$ & 17.8 & 5.62 & 13.2 & 3.53 & 17.6 & 4.92 & 18.0 & 2.88 \\
\hline $\mathbf{R b}$ & 143 & 35.1 & 139 & 37.7 & 128 & 31.9 & 116 & 20.0 \\
\hline $\mathrm{Sr}$ & 86.3 & 27.4 & $\mathbf{5 7 . 2}$ & 7.06 & 70.7 & 12.2 & 89.7 & 8.98 \\
\hline $\mathbf{Y}$ & 37.7 & 23.8 & 33.7 & 8.71 & 36.7 & 6.98 & 42.9 & 6.48 \\
\hline $\mathrm{Zr}$ & 187 & 128 & 133 & 31.6 & 294 & 55.7 & 334 & 53.3 \\
\hline $\mathrm{Nb}$ & 10.9 & 6.05 & 8.86 & 2.38 & 12.4 & 2.92 & 13.0 & 2.29 \\
\hline Mo & 1.53 & 0.91 & 1.89 & 1.08 & 2.30 & 0.71 & 2.17 & 0.84 \\
\hline Cs & 7.15 & 2.78 & 7.34 & 1.85 & 6.32 & 1.62 & 6.30 & 1.03 \\
\hline $\mathrm{Ba}$ & 888 & 277 & 865 & 248 & 832 & 177 & 814 & 104 \\
\hline La & 35.1 & 11.0 & 30.5 & 8.06 & 28.4 & 4.97 & 31.4 & 4.63 \\
\hline $\mathrm{Ce}$ & 72.2 & 30.3 & 62.3 & 18.8 & 67.5 & 14.4 & 67.6 & 10.4 \\
\hline $\mathrm{Pr}$ & 8.16 & 3.67 & 6.61 & 1.58 & 7.14 & 1.24 & 7.65 & 1.24 \\
\hline Nd & 32.5 & 19.3 & 26.2 & 6.42 & 29.0 & 5.7 & 32.9 & 5.16 \\
\hline $\mathrm{Sm}$ & 6.84 & 4.86 & 5.35 & 1.16 & 6.24 & 1.06 & 7.02 & 1.22 \\
\hline Eu & 1.04 & 0.75 & 0.44 & 0.14 & 0.95 & 0.20 & 1.17 & 0.19 \\
\hline Gd & 6.39 & 5.43 & 4.83 & 1.36 & 5.63 & 1.10 & 6.97 & 1.62 \\
\hline Tb & 0.98 & 0.68 & 0.79 & 0.20 & 0.92 & 0.25 & 1.09 & 0.18 \\
\hline Dy & 6.66 & 4.84 & 5.54 & 1.29 & 6.26 & 1.26 & 7.69 & 1.53 \\
\hline Ho & 1.32 & 0.88 & 1.20 & 0.32 & 1.27 & 0.29 & 1.55 & 0.32 \\
\hline Er & 3.96 & 2.33 & 3.51 & 0.89 & 3.95 & 0.85 & 4.73 & 0.96 \\
\hline $\mathrm{Tm}$ & 0.59 & 0.41 & 0.56 & 0.18 & 0.58 & 0.14 & 0.69 & 0.15 \\
\hline $\mathbf{Y b}$ & 3.95 & 2.30 & 3.86 & 0.92 & 4.02 & 1.08 & 4.92 & 1.05 \\
\hline Lu & 0.66 & 0.36 & 0.59 & 0.14 & 0.61 & 0.11 & 0.73 & 0.15 \\
\hline Hf & 5.61 & 3.66 & 4.30 & 0.92 & 7.12 & 1.09 & 8.37 & 1.54 \\
\hline Ta & 0.85 & 0.50 & 0.85 & 0.27 & 0.84 & 0.16 & 0.98 & 0.14 \\
\hline W & 1.81 & 0.53 & 1.61 & 0.44 & 1.48 & 0.33 & 1.52 & 0.38 \\
\hline $\mathrm{Pb}$ & 25.1 & 8.70 & 18.5 & 4.70 & 21.9 & 6.14 & 20.7 & 3.37 \\
\hline Th & 16.2 & 5.37 & 15.5 & 4.07 & 12.9 & 2.37 & 14.4 & 2.33 \\
\hline $\mathbf{U}$ & 3.40 & 1.01 & 3.36 & 0.82 & 3.24 & 0.91 & 3.08 & 0.54 \\
\hline $\mathrm{Rb} / \mathrm{Sr}$ & 1.69 & 0.58 & 2.45 & 0.77 & 1.81 & 0.31 & 1.29 & 0.17 \\
\hline $\mathrm{Sr} / \mathrm{Y}$ & 2.51 & 2.02 & 1.73 & 0.57 & 1.93 & 0.17 & 2.10 & 0.22 \\
\hline $\mathrm{Zr} / \mathrm{Th}$ & 11.9 & 9.60 & 8.60 & 0.50 & 22.8 & 1.13 & 23.2 & 1.52 \\
\hline $\mathbf{E u} / \mathbf{E} \mathbf{u}^{*{ }^{h}}$ & 0.48 & 0.10 & 0.27 & 0.04 & 0.49 & 0.08 & 0.51 & 0.12 \\
\hline $\mathrm{Rb} / \mathrm{Sm}$ & 23.9 & 22.0 & 26.0 & 2.84 & 20.6 & 3.84 & 16.6 & 2.56 \\
\hline $\mathbf{Z r} / \mathbf{Y}$ & 4.93 & 0.80 & 3.95 & 0.19 & 8.03 & 0.48 & 7.80 & 0.53 \\
\hline $\mathrm{Ba} / \mathrm{Sr}$ & 10.5 & 3.97 & 15.2 & 4.96 & 11.8 & 1.28 & 9.08 & 0.75 \\
\hline $\mathrm{Nb} / \mathrm{Pb}$ & 0.43 & 0.15 & 0.48 & 0.05 & 0.57 & 0.06 & 0.63 & 0.07 \\
\hline $\mathrm{La} / \mathrm{Yb}$ & 9.36 & 4.62 & 7.91 & 1.26 & 7.13 & 1.07 & 6.41 & 0.68 \\
\hline Dy/Yb & 1.67 & 0.78 & 1.44 & 0.21 & 1.57 & 0.24 & 1.57 & 0.14 \\
\hline $\mathrm{Ba} / \mathrm{Th}$ & 55.2 & 9.91 & 55.8 & 4.67 & 64.5 & 9.08 & 56.7 & 6.85 \\
\hline
\end{tabular}


Table A4-1 continued

\begin{tabular}{|c|c|c|c|c|c|c|c|c|}
\hline Sample no. ${ }^{a}$ & \multicolumn{2}{|c|}{ AT-409 } & \multicolumn{2}{|l|}{ A-21 } & \multicolumn{2}{|l|}{ A-22 } & \multicolumn{2}{|l|}{ A-23 } \\
\hline Sample details ${ }^{\text {b }}$ & \multicolumn{2}{|c|}{$1123 \mathrm{C}-7 \mathrm{H}-3$} & \multicolumn{2}{|c|}{$1123 \mathrm{C}-7 \mathrm{H}-3$} & \multicolumn{2}{|c|}{$1123 \mathrm{C}-7 \mathrm{H}-4$} & \multicolumn{2}{|c|}{$1123 \mathrm{C}-7 \mathrm{H}-5$} \\
\hline Base $^{c}$ & \multicolumn{2}{|l|}{$4 \mathrm{~cm}$} & \multicolumn{2}{|c|}{$135 \mathrm{~cm}$} & \multicolumn{2}{|l|}{$63 \mathrm{~cm}$} & \multicolumn{2}{|c|}{$13 \mathrm{~cm}$} \\
\hline $\operatorname{mbsf}^{d}$ & \multicolumn{2}{|c|}{$59.54 \mathrm{~m}^{\prime}$} & \multicolumn{2}{|c|}{$60.85 \mathrm{~m}$} & \multicolumn{2}{|c|}{$61.63 \mathrm{~m}$} & \multicolumn{2}{|c|}{$62.63 \mathrm{~m}$} \\
\hline$n^{e}$ & 10 & & 7 & & 11 & & 10 & \\
\hline Mg (ppm) & 1062 & 268 & 443 & 235 & 1055 & 329 & 1340 & 211 \\
\hline $\mathrm{Ti}$ & 1222 & 277 & 241 & 107 & 1112 & 237 & 1272 & 214 \\
\hline $\mathbf{v}$ & 0.78 & 2.20 & 1.25 & 1.05 & 0.86 & 0.81 & 1.50 & 1.02 \\
\hline $\mathrm{Cr}$ & 2.11 & 4.83 & 1.47 & 3.35 & 1.38 & 2.43 & 1.24 & 2.20 \\
\hline Mn & 631 & 167 & 356 & 192 & 531 & 98.0 & 500 & 68.9 \\
\hline Co & 0.52 & 0.79 & 0.45 & 0.39 & 0.78 & 0.60 & 1.49 & 0.77 \\
\hline $\mathrm{Ni}$ & 0.29 & 0.99 & 0.80 & 1.80 & 2.82 & 4.08 & 1.78 & 1.90 \\
\hline $\mathrm{Cu}$ & 3.75 & 2.71 & 7.46 & 10.6 & 13.7 & 15.1 & 9.07 & 12.3 \\
\hline $\mathrm{Zn}$ & 65.1 & 40.5 & 19.1 & 12.9 & 45.6 & 26.2 & 44.3 & 19.1 \\
\hline Ga & 17.2 & 4.28 & 11.7 & 6.24 & 16.4 & 2.69 & 16.4 & 2.47 \\
\hline $\mathbf{R b}$ & 118 & 26.0 & 155 & 80.1 & 131 & 25.6 & 135 & 22.0 \\
\hline $\mathrm{Sr}$ & 96.2 & 17.5 & 48.4 & 14.9 & 95.3 & 25.1 & 101 & 13.0 \\
\hline Y & 37.9 & 9.69 & 19.2 & 11.5 & 38.2 & 8.30 & 33.4 & 4.99 \\
\hline $\mathrm{Zr}$ & 295 & 74.1 & 58.8 & 29.6 & 288 & 60.7 & 288 & 39.3 \\
\hline Nb & 11.1 & 2.85 & 4.87 & 2.63 & 11.8 & 2.14 & 10.7 & 1.67 \\
\hline Mo & 1.31 & 0.58 & 1.08 & 0.64 & 1.90 & 0.67 & 1.69 & 0.49 \\
\hline Cs & 6.26 & 1.35 & 9.42 & 5.74 & 6.75 & 1.29 & 7.46 & 1.32 \\
\hline $\mathrm{Ba}$ & 832 & 174 & 675 & 398 & 827 & 152 & 815 & 107 \\
\hline La & 29.7 & 7.07 & 20.0 & 9.79 & 31.6 & 6.54 & 28.7 & 3.94 \\
\hline $\mathrm{Ce}$ & 65.6 & 14.9 & 40.6 & 21.1 & 66.1 & 12.9 & 63.9 & 8.48 \\
\hline $\mathrm{Pr}$ & 7.33 & 1.59 & 4.00 & 2.27 & 7.24 & 1.28 & 7.10 & 0.91 \\
\hline Nd & 30.4 & 6.70 & 15.0 & 7.90 & 30.2 & 5.92 & 28.2 & 4.16 \\
\hline Sm & 6.92 & 1.70 & 2.96 & 1.87 & 6.56 & 1.41 & 6.03 & 1.14 \\
\hline Eu & 1.15 & 0.38 & 0.25 & 0.20 & 1.05 & 0.32 & 0.96 & 0.18 \\
\hline Gd & 6.21 & 1.89 & 2.56 & 1.85 & 6.37 & 1.18 & 5.08 & 0.87 \\
\hline Tb & 0.98 & 0.24 & 0.44 & 0.35 & 1.01 & 0.22 & 0.85 & 0.10 \\
\hline Dy & 6.64 & 1.77 & 2.75 & 2.09 & 6.52 & 1.57 & 5.73 & 0.84 \\
\hline Но & 1.39 & 0.36 & 0.61 & 0.46 & 1.38 & 0.33 & 1.20 & 0.14 \\
\hline Er & 4.22 & 1.37 & 1.88 & 1.39 & 4.09 & 0.84 & 3.51 & 0.60 \\
\hline $\mathrm{Tm}$ & 0.66 & 0.23 & 0.31 & 0.19 & 0.63 & 0.14 & 0.53 & 0.10 \\
\hline $\mathbf{Y b}$ & 4.36 & 1.24 & 2.22 & 1.69 & 4.02 & 0.98 & 3.72 & 0.52 \\
\hline Lu & 0.62 & 0.13 & 0.35 & 0.32 & 0.65 & 0.14 & 0.57 & 0.10 \\
\hline $\mathrm{Hf}$ & 7.27 & 1.55 & 2.43 & 1.61 & 7.30 & 1.50 & 6.96 & 1.15 \\
\hline Ta & 0.81 & 0.19 & 0.74 & 0.58 & 0.87 & 0.16 & 0.82 & 0.14 \\
\hline W & 1.46 & 0.36 & 2.10 & 1.45 & 1.46 & 0.25 & 1.88 & 0.48 \\
\hline $\mathrm{Pb}$ & 20.1 & 4.43 & 20.1 & 11.2 & 20.6 & 2.85 & 22.4 & 4.02 \\
\hline Th & 13.4 & 3.28 & 16.1 & 10.6 & 14.6 & 2.33 & 14.0 & 2.05 \\
\hline $\mathbf{U}$ & 3.05 & 0.69 & 4.03 & 2.52 & 3.22 & 0.56 & 3.51 & 0.55 \\
\hline $\mathrm{Rb} / \mathrm{Sr}$ & 1.23 & 0.26 & 3.23 & 1.59 & 1.39 & 0.42 & 1.34 & 0.23 \\
\hline $\mathrm{Sr} / \mathrm{Y}$ & 2.57 & 0.63 & 2.67 & 1.37 & 2.51 & 0.66 & 3.02 & 0.40 \\
\hline $\mathrm{Zr} / \mathrm{Th}$ & 22.1 & 2.30 & 3.72 & 0.77 & 19.7 & 3.52 & 20.6 & 1.72 \\
\hline $\mathbf{E} u / \mathbf{E} u^{* h}$ & 0.53 & 0.10 & 0.28 & 0.07 & 0.49 & 0.10 & 0.53 & 0.10 \\
\hline $\mathrm{Rb} / \mathrm{Sm}$ & 17.1 & 1.66 & 53.7 & 13.0 & 20.1 & 3.16 & 22.4 & 2.12 \\
\hline $\mathbf{Z r} / \mathbf{Y}$ & 7.78 & 0.47 & 3.11 & 0.63 & 7.56 & 1.32 & 8.62 & 0.48 \\
\hline $\mathrm{Ba} / \mathrm{Sr}$ & 8.69 & 1.98 & 14.0 & 7.90 & 8.78 & 2.32 & 8.11 & 1.04 \\
\hline $\mathrm{Nb} / \mathrm{Pb}$ & 0.55 & 0.08 & 0.24 & 0.04 & 0.57 & 0.07 & 0.48 & 0.05 \\
\hline $\mathrm{La} / \mathrm{Yb}$ & 6.84 & 0.62 & 9.43 & 2.77 & 7.88 & 0.92 & 7.72 & 0.77 \\
\hline Dy/Yb & 1.53 & 0.12 & 1.24 & 0.39 & 1.63 & 0.24 & 1.54 & 0.12 \\
\hline $\mathrm{Ba} / \mathrm{Th}$ & 62.5 & 6.68 & 42.2 & 7.83 & 56.6 & 8.20 & 58.3 & 5.43 \\
\hline
\end{tabular}


Table A4-1 continued

\begin{tabular}{|c|c|c|c|c|c|c|}
\hline \multirow{2}{*}{$\begin{array}{l}\text { Onshore TVZ } \\
\text { tephra samples } \\
\text { n LA-ICP-MS }\end{array}$} & \multicolumn{2}{|c|}{$\begin{array}{l}\text { Kawakawa Tephra } \\
\text { Irirangi Section, } \\
10 \mathrm{~km} \text { south of } \\
\text { Waiouru } \\
13\end{array}$} & \multicolumn{2}{|c|}{$\begin{array}{l}\text { Rotoehu Tephra } \\
63.86 \mathrm{~m} \text {, Pukaki } \\
\text { drill core, } \\
\text { Auckland } \\
8 \\
\end{array}$} & \multicolumn{2}{|c|}{$\begin{array}{l}\text { Potaka Tephra } \\
\text { Huangarua River } \\
\text { Te Muna Format } \\
\text { Wairarapa } \\
15 \\
\end{array}$} \\
\hline & Mean ${ }^{\mathrm{g}}$ & $2 s d^{h}$ & & & & \\
\hline $\mathrm{Mg}$ (ppm) & 963 & 197 & 1160 & 177 & 830 & 253 \\
\hline $\mathrm{Ti}$ & 954 & 177 & 1033 & 161 & 894 & 230 \\
\hline V & 1.25 & 0.51 & 1.87 & 1.08 & 2.21 & 2.54 \\
\hline $\mathrm{Cr}$ & 1.62 & 3.83 & 0.89 & 2.39 & 1.60 & 3.74 \\
\hline Mn & 422 & 68.7 & 472 & 61.1 & 339 & 83.3 \\
\hline Co & 0.58 & 0.55 & 1.00 & 0.55 & 0.64 & 0.67 \\
\hline $\mathrm{Ni}$ & 0.72 & 4.08 & 1.44 & 1.91 & 0.63 & 1.01 \\
\hline $\mathrm{Cu}$ & 2.51 & 1.69 & 3.20 & 2.22 & 4.04 & 1.67 \\
\hline $\mathrm{Zn}$ & 43.7 & 18.6 & 36.6 & 14.1 & 41.2 & 28.7 \\
\hline Ga & 15.1 & 2.78 & 13.6 & 2.80 & 14.9 & 2.73 \\
\hline $\mathbf{R b}$ & 131 & 26.5 & 108 & 19.5 & 160 & 57.3 \\
\hline $\mathrm{Sr}$ & 84.4 & 19.7 & 65.9 & 11.0 & 59.4 & 27.9 \\
\hline $\mathbf{Y}$ & 23.2 & 4.90 & 22.4 & 4.01 & 27.6 & 11.2 \\
\hline $\mathrm{Zr}$ & 125 & 30.1 & 99.1 & 11.2 & 117 & 45.1 \\
\hline $\mathrm{Nb}$ & 8.21 & 1.46 & 9.25 & 1.84 & 10.1 & 3.00 \\
\hline Mo & 1.39 & 0.40 & 1.90 & 0.77 & 1.69 & 0.88 \\
\hline Cs & 6.60 & 1.43 & 4.01 & 0.71 & 7.70 & 1.97 \\
\hline Ba & 692 & 122 & 1075 & 151 & 882 & 165 \\
\hline La & 22.7 & 4.46 & 24.8 & 4.00 & 28.1 & 5.35 \\
\hline $\mathrm{Ce}$ & 49.5 & 9.44 & 52.9 & 6.66 & 60.8 & 17.8 \\
\hline $\mathrm{Pr}$ & 4.90 & 0.94 & 5.03 & 0.67 & 6.19 & 1.69 \\
\hline Nd & 19.7 & 3.87 & 18.3 & 2.24 & 23.3 & 7.48 \\
\hline $\mathrm{Sm}$ & 3.89 & 0.77 & 3.59 & 0.69 & 4.28 & 1.72 \\
\hline $\mathbf{E u}$ & 0.67 & 0.16 & 0.57 & 0.12 & 0.53 & 0.23 \\
\hline Gd & 3.59 & 0.93 & 3.23 & 0.43 & 4.02 & 1.87 \\
\hline Tb & 0.57 & 0.14 & 0.50 & 0.09 & 0.66 & 0.28 \\
\hline Dy & 3.87 & 0.91 & 3.48 & 0.65 & 4.40 & 1.76 \\
\hline Но & 0.86 & 0.22 & 0.72 & 0.15 & 0.94 & 0.51 \\
\hline Er & 2.46 & 0.53 & 2.17 & 0.21 & 2.91 & 1.40 \\
\hline $\mathrm{Tm}$ & 0.38 & 0.11 & 0.40 & 0.11 & 0.44 & 0.20 \\
\hline $\mathrm{Yb}$ & 2.76 & 0.65 & 2.80 & 0.49 & 3.26 & 1.18 \\
\hline $\mathbf{L u}$ & 0.42 & 0.12 & 0.40 & 0.06 & 0.48 & 0.15 \\
\hline Hf & 3.72 & 0.88 & 3.06 & 0.49 & 3.93 & 1.21 \\
\hline Ta & 0.78 & 0.14 & 0.86 & 0.09 & 1.00 & 0.26 \\
\hline W & 1.66 & 0.46 & 1.49 & 0.49 & 1.77 & 0.32 \\
\hline $\mathrm{Pb}$ & 16.1 & 3.26 & 13.2 & 1.41 & 21.0 & 4.61 \\
\hline Th & 12.3 & 2.47 & 10.3 & 1.39 & 15.5 & 3.27 \\
\hline $\mathbf{U}$ & 3.08 & 0.57 & 2.64 & 0.41 & 3.63 & 1.10 \\
\hline $\mathrm{Rb} / \mathrm{Sr}$ & 1.57 & 0.42 & 1.64 & 0.21 & 2.90 & 2.40 \\
\hline $\mathrm{Sr} / \mathrm{Y}$ & 3.65 & 0.68 & 2.95 & 0.35 & 2.22 & 1.18 \\
\hline $\mathrm{Zr} / \mathrm{Th}$ & 10.2 & 1.45 & 9.64 & 1.38 & 7.62 & 3.54 \\
\hline $\mathbf{E u} / \mathbf{E} \mathbf{u}^{*}$ & 0.55 & 0.10 & 0.51 & 0.09 & 0.40 & 0.11 \\
\hline $\mathrm{Rb} / \mathrm{Sm}$ & 33.7 & 6.29 & 30.2 & 4.15 & 38.0 & 12.1 \\
\hline $\mathbf{Z r} / \mathbf{Y}$ & 5.40 & 0.64 & 4.44 & 0.62 & 4.27 & 1.39 \\
\hline $\mathrm{Ba} / \mathrm{Sr}$ & 8.27 & 1.74 & 16.3 & 1.39 & 15.6 & 7.76 \\
\hline $\mathrm{Nb} / \mathrm{Pb}$ & 0.51 & 0.03 & 0.70 & 0.10 & 0.48 & 0.14 \\
\hline $\mathrm{La} / \mathrm{Yb}$ & 8.25 & 0.80 & 8.89 & 1.33 & 8.72 & 1.52 \\
\hline Dy/Yb & 1.40 & 0.17 & 1.24 & 0.19 & 1.35 & 0.20 \\
\hline $\mathrm{Ba} / \mathrm{Th}$ & 56.3 & 6.96 & 104 & 11.3 & 57.0 & 8.51 \\
\hline
\end{tabular}




\section{Table A4-1}

${ }^{a}$ Data for samples with mutliple glass populations are presented separately - e.g. AT-380 (2), AT-380 second population

b 1123 A-1H-1 = Site 1123, hole A, core 1, core type (H = hydropiston), section 1

${ }^{\mathrm{c}}$ Depth to base of tephra $(\mathrm{cm})$ in relevant section

${ }^{\mathrm{d}}$ Depth to base of tephra in metres below seafloor in the corresponding hole

e number of analyses

${ }^{\mathrm{f}}$ Mean of $\mathrm{n}$ analyses

${ }^{\mathrm{g}} \pm 2$ standard deviatiations in $\mathrm{ppm}$

${ }^{\mathrm{h}} \mathrm{Eu} / \mathrm{Eu}^{*}=\left(\left(\mathrm{Eu}_{\mathrm{N}}{ }^{2} /\left(\mathrm{Sm}_{\mathrm{N}} \mathrm{x} \mathrm{Gd}_{\mathrm{N}}\right)\right)^{0.5}\right.$, where $\mathrm{Eu}_{\mathrm{N}}, \mathrm{Sm}_{\mathrm{N}}$ and $\mathrm{Gd}_{\mathrm{N}}$ are the measured values of Eu, Sm and Gd normalised to chondritic abundances 


\section{APPENDIX FIVE:}

\section{ISOTOPE DATA}

Table A5-1. Sr, $\mathrm{Nd}$ and $\mathrm{Pb}$ isotope data for Site 1123 tephras 
Table A5-1. Sr, Nd and Pb isotope data for Site 1123 tephras

\begin{tabular}{|c|c|c|c|c|c|c|c|}
\hline Tephra unit & 1 & 2 & 3 & 9 & 10 & 11 & 12 \\
\hline Melt type & 1 & 1 & 1 & 1 & 1 & 2 & 2 \\
\hline Age & $27.1 \mathrm{ka}$ & $33.0 \mathrm{ka}$ & $\sim 60.0 \mathrm{ka}$ & $0.549 \mathrm{Ma}$ & $0.826 \mathrm{Ma}$ & $0.894 \mathrm{Ma}$ & $0.983 \mathrm{Ma}$ \\
\hline${ }^{87} \mathrm{Sr} /{ }^{86} \mathrm{Sr}$ & 0.705563 & 0.705397 & 0.705443 & 0.705759 & 0.705608 & 0.705611 & 0.705908 \\
\hline${ }^{143} \mathrm{Nd} /{ }^{144} \mathrm{Nd}$ & 0.512662 & 0.512701 & 0.512707 & 0.512675 & 0.512694 & 0.512685 & 0.51265 \\
\hline$\varepsilon_{\mathrm{Nd}}$ & 0.48 & 1.24 & 1.35 & 0.73 & 1.1 & 0.92 & 0.22 \\
\hline${ }^{206} \mathrm{~Pb} /{ }^{204} \mathrm{~Pb}$ & 18.8414 & 18.8452 & 18.8347 & 18.8513 & 18.8534 & 18.854 & 18.8569 \\
\hline${ }^{207} \mathrm{~Pb} /{ }^{204} \mathrm{~Pb}$ & 15.6246 & 15.6382 & 15.636 & 15.6427 & 15.6404 & 15.6413 & 15.6409 \\
\hline${ }^{208} \mathrm{~Pb} /{ }^{204} \mathrm{~Pb}$ & 38.7169 & 38.7509 & 38.7425 & 38.771 & 38.7615 & 38.7635 & 38.7644 \\
\hline Tephra unit & 19 & 22 & 23 & 33 & 37 & 28 & \\
\hline Melt type & 2 & 3 & 3 & 3 & 3 & 4 & \\
\hline Age & $1.402 \mathrm{Ma}$ & $1.532 \mathrm{Ma}$ & $1.550 \mathrm{Ma}$ & $1.629 \mathrm{Ma}$ & $1.660 \mathrm{Ma}$ & $1.603 \mathrm{Ma}$ & \\
\hline${ }^{87} \mathrm{Sr} /{ }^{86} \mathrm{Sr}$ & 0.705607 & 0.705703 & 0.705774 & 0.70545 & 0.705351 & 0.706427 & \\
\hline${ }^{143} \mathrm{Nd} /{ }^{144} \mathrm{Nd}$ & 0.512683 & 0.512688 & 0.512702 & 0.512697 & 0.512705 & 0.512605 & \\
\hline$\varepsilon_{\mathrm{Nd}}$ & 0.89 & 0.98 & 1.25 & 1.15 & 1.32 & -0.63 & \\
\hline${ }^{206} \mathrm{~Pb} /{ }^{204} \mathrm{~Pb}$ & 18.8527 & 18.843 & 18.8463 & 18.8411 & 18.8372 & 18.8583 & \\
\hline${ }^{207} \mathrm{~Pb} /{ }^{204} \mathrm{~Pb}$ & 15.6407 & 15.6355 & 15.6369 & 15.6378 & 15.639 & 15.6442 & \\
\hline${ }^{208} \mathrm{~Pb} /{ }^{204} \mathrm{~Pb}$ & 38.7619 & 38.7389 & 38.7458 & 38.7422 & 38.7403 & 38.7737 & \\
\hline
\end{tabular}

Isotope data reported relative the following standards and values: SRM $987,{ }^{87} \mathrm{Sr} /{ }^{56} \mathrm{Sr}=0.710248$; Alfa Aesar Nd, ${ }^{43} \mathrm{Nd} /{ }^{144} \mathrm{Nd}=0.512260$; SRM 981, ${ }^{206} \mathrm{~Pb} /{ }^{204} \mathrm{~Pb}=16.9418,{ }^{207} \mathrm{~Pb} /{ }^{204} \mathrm{~Pb}=15.5000,{ }^{208} \mathrm{~Pb} /{ }^{204} \mathrm{~Pb}=36.7265 . \varepsilon_{\mathrm{Nd}}=$ $\left.\left({ }^{143} \mathrm{Nd} /{ }^{144} \mathrm{Nd}_{\text {sample }}-{ }^{143} \mathrm{Nd} /{ }^{144} \mathrm{Nd}_{\text {chondrite }}\right) /{ }^{143} \mathrm{Nd} / /^{144} \mathrm{Nd}_{\text {chondrite }}\right) \times 10^{4}$, where ${ }^{143} \mathrm{Nd} /{ }^{144} \mathrm{Nd}_{\text {chondrite }}=0.512638$. 